\title{
Zbawić się na ziemi O soteriologii immanentnej
}


盗 


\section{ANDRZEJ SEPKOWSKI}

\section{Zbawić się na ziemi O soteriologii immanentnej}


Andrzej Sepkowski - Uniwersytet Łódzki, Wydział Studiów Międzynarodowych i Politologicznych, Zakład Metodologii Badań Politologicznych i Prognozowania Politycznego, 90-127 Łódź, ul. Składowa 41/43

\title{
RECENZENT
}

Patrycja Jakóbczyk-Adamczyk

\author{
SKŁAD I ŁAMANIE
}

AGENT PR

\author{
PROJEKT OKEADKI \\ Barbara Grzejszczak
}

(C) Copyright by Uniwersytet Łódzki, Łódź 2014

Wydane przez Wydawnictwo Uniwersytetu Łódzkiego

Wydanie I. W.06478.14.0.M

ISBN (wersja drukowana) 978-83-7969-086-2

ISBN (ebook) 978-83-7969-201-9

\author{
Wydawnictwo Uniwersytetu Łódzkiego \\ 90-131 Łódź, ul. Lindleya 8 \\ www.wydawnictwo.uni.lodz.pl \\ e-mail: ksiegarnia@uni.lodz.pl \\ tel. (42) 6655863 , faks (42) 6655862
}




\section{SPIS TREŚCI}

$\begin{array}{ll}\text { WSTEP } & 7\end{array}$

1. CzŁowiek I Wiara 11

2. ZBaWienie 45

3. W STRONE NADZIEI 79

4. IdEOLOGIE 109

5. Demokracja 139

6. DUCH I PRAKTYKA UTOPII 167

7. ZBAWIENIE W POSTĘPIE 197

8. ZBAWIENIE W NARODZIE I EUROPIE 223

9. Polskie WiZje ZBawienia 253

10. ZBAWIENIE DLA WSZYSTKICH - GLOBALIZACJA 277

11. KROKI W PRZYSZŁOŚĆ 303

$\begin{array}{ll}\text { BIBLIOGRAFIA } & 329\end{array}$ 



\section{WSTĘP}

Poszukiwanie wiedzy prawdziwej, pewnej i przydatnej w życiu codziennym, jest odwiecznym zadaniem nauki i niekiedy wysiłki naukowych poszukiwaczy spełzają na niczym, niekiedy pojawiają się wyjaśnienia, które tylko przez pewien czas satysfakcjonuja i przestaja wtedy, kiedy zmienia się kulturowa homeostaza świata, a takie zmiany ukrywane bywają tak głęboko, że nie sposób ich dostrzec przez „okulary", o których wspomina filozof, gdyż to te kultury sa twórcami tych intelektualnych „okularów”, za pomoca których interpretujemy rzeczywistość ${ }^{1}$. Dziś patrzymy na naszą rzeczywistość przez szkiełka oświeceniowego racjonalizmu z wmontowanym weń mechanicznym strukturalizmem i teleologicznym indywidualizmem. Za ich sprawą chyba zbyt łatwo i często przechodzimy od konstruowanych ekstrakcji modeli do rzeczywistości i traktujemy te modele jako autonomiczne, samosterowne. Lubimy - zauważała B. Skarga - kreślić wielkie linie rozwoju pomijając wszystko to, co powstało poza nimi ${ }^{2}$. Ale lubimy także analizować to, co już analiz zdaje się nie wymagać i uważamy, że jest to potrzebne. „Racjonalne” nauki usypiaja nas i zniewalaja - konstatował L. Szestow - a rzekomo coraz doskonalsze myślenie przeobraża nas w bezwolne, pokorne istoty, potrafiace szukać w życiu wyłącznie „porządku” oraz widzieć i mieć zasady i normy ustanowione przez ów „porządek”3.

Rozum przenika rzeczywistość wedle kartezjanizmu, a wedle Pascala tylko nieco rozświetla otaczajacy nas mrok, bo rzeczywistość wciąż pozostaje niepojęta mimo takich wzlotów rozumu. Wciąż nie potrafimy

\footnotetext{
${ }^{1}$ R.M. Pirsig, Lila czyli rozprawa o moralności, Poznań 1995, s. 81.

${ }^{2}$ B. Skarga, Ktopoty intelektu, Warszawa 1975, s. 9.

${ }^{3}$ L. Szestow, Ateny $i$ Jerozolima, Kraków 1993, s. 21.
} 
przewidzieć przyszłości, mimo iż rzekomo poznano zasady rządzące tą rzeczywistościa, która rodzi przyszłość. Przez długi czas racjonalizm epistemologiczny łączył się z irracjonalizmem ontologicznym za przyczyną niepojętego człowieka - irracjonalnej części racjonalnego świata. Poszukując mądrości poza nim samym nader często poprzestawaliśmy na pozorach pewności, a owocami są rozpoznania, jakie nie przydają się w praktyce życiowej. Nietrudno zauważyć, że przez dekady jakościowe czynniki zmian były na planie trzecim zainteresowań ludzi nauki, a determinanty stamtąd wypływające traktowano jak mało znaczace korektory postaw i zachowań, choć kłóciło się to z indywidualnymi odczuciami, bo nigdy nie kwestionowaliśmy mocy naszych strachów i nadziei, pragnień, emocji. Nie zauważając poczęliśmy szukać remediów w metodach jakościowych, nie zawsze wykazując się umiejętnościami poszukiwaczy. Do takiego mniemania wiedzie nas choćby lektura pracy, w której przypisuje się ogromne role metodom jakościowym, jakimi sa wywiad pogłębiony, czy obserwacja uczestnicząca (Metody badań jakościowych pod redakcją N.K. Denzina i Y. Lincoln). Zdaje się to tylko nieporozumieniem, gdyż w obu „metodach” spotkamy czynniki jakościowe i ilościowe. Jakościowe jednak są częścią integralną praktycznie każdej metody, nawet takiej, jaka bywa uznawana za ilościowa i przekonamy się do tego analizując nasze metapoznanie. Być może nie wszystkie one nie sa tak ,racjonalne”, jak chcieliby tego niektórzy, ale skoro mają tak istotny wpływ na zachowania wielkich grup ludzkich, to interesować się nimi musimy pytając wpierw, czym są nadzieje, strachy, pragnienia zbawienia, spełnienia w doczesności i transcendencji.

Takich pytań zdaje się jednak brakować, trochę dlatego, że - jak zauważała ze sporym sarkazmem M. Janion - brak odkrywczości wypowiedzi został w naszym czasie uznany za pożądaną normę ${ }^{4}$. Swoista konsekwencją tego stanu w nauce jest to choćby, że wyżej cenione przez praktyków bywaja propozycje publicystów, ale tu zauważmy też, że owi „publicyści” to nader często przedstawiciele świata nauki. Na stare pytania niby udziela się nowych odpowiedzi, ale te bywaja zwykle reinterpretacjami dawno udzielonych i miast prowokować tylko usypiaja tymi pozorami pewności. Nie roszcząc sobie najmniejszych pretensji do odkrywczości chcieliśmy zaprezentować kilkanaście wymiarów soteriologii ziemskiej - wyobrażeń zbawienia w doczesności, choć, być może lepiej mówić o spełnieniu. Chcemy zaproponować próby zrozumienia i wyjaśnienia integralnego skupiając się nie na przyczynowym wyjaśnianiu skutków, ale wyjaśnieniu „racjonalnym” i pozaracjonalnym ze

${ }^{4}$ M. Janion, Niesamowita Stowiańszczyzna, Kraków 2007, s. 9. 
zwróceniem szczególnej uwagi na struktury motywacyjne działań ludzkich, tak często nieobecne w wysiłkach nauk społecznych.

Najczęściej spotykane strategie wyjaśniania zwykle opierają się na splocie determinant tworzących teorie czasstkowe, jednostronne, opierane zwykle na aspektach wydarzeniowych. Dowiadujemy się z nich tego, jak zrealizowała się jakaś alternatywa, zbyt często jednak nie odnajdując równie prawdziwych mocy sprawczych, jakich nie da się kwantyfikować na sposób taki, jakim mierzymy te policzalne. Takim sposobem nasze wysiłki, jak powiadał K. Popper, sa „historia niedopowiedzianych snów, uporu, błędów" . Prowadzący nieustanny dialog z historia rozumienia i wyjaśniania złożoności naszego świata badacze odkrywaja coraz to nowe rysy procesów, zjawisk, nowe determinacje, zwykle nie docierając do podskórnego nurtu „historii nieświadomej”, do afektów, motywacji, oczekiwań będących czymś pierwotnym dla świadomych myśli i wypływających z nich działań. Obiegową mądrościa nauk społecznych - utrzymywał nie bez racji M. Ridley - jest twierdzenie, że natura ludzka to rezultat wychowania i doświadczenia jednostki. Nasze kultury nie są jednak zbiorami arbitralnych nawyków, ale ukierunkowanym wyrazem naszych instynktów ${ }^{6}$.

Zdaniem wielu (Bourdieu, Popper) nauki społeczne muszą unikać pułapek redukcjonizmu zawierzając obiektywistycznym punktom widzenia, które kuszą do reifikacji struktur społecznych i uznawania ich za byty autonomiczne. Ci badacze proponują nawrót do romantyzmu epistemologicznego uznając, że winniśmy uznawać wizje i interpretacje podmiotów społecznych, od jednostek poczynajacc, za oczywisty komponent rzeczywistości świata społecznego. Nie kwestionując obiektywizmu wielkich struktur winniśmy mieć także na uwadze wolę, projekcje i emocje jednostek i zbiorowości. A także to, że jednak ludzkie postrzeganie i poznanie sa $\mathrm{w}$ nas elementami nieprzewidywalnymi, a one przesądzają o ukierunkowaniu działań mających kreować Nowe.

Zwłaszcza praca nad kształtami amerykańskiej religii obywatelskiej ${ }^{7}$ uczulała autora na problem determinant jakościowych, bez ich uwzględnienia próba analizy tego fenomenu musiałaby zakończyć się fiaskiem. W pracach wielu badaczy problem zbawienia tu, na ziemi, pojawił się nader często, acz najczęściej w charakterze ozdobnika. Zauważali, że ludzkie pragnienia i potrzeby spełnienia maja charakter generujący, ale poprzestawali na tym zauważając ogrom trudności

\footnotetext{
${ }^{5}$ K. Popper, Conjectures and Refutations. The Growth of Scientific Knowledge, New York 1966, s. 216.

${ }^{6}$ M. Ridley, O pochodzeniu cnoty, Poznań 2000, s. 16.

${ }^{7}$ A. Sepkowski, Poczatki misji. Narodziny amerykańskiej „religii obywatelskiej”, Toruń 2008
} 
w konceptualizacjach tyczących ich ról społecznych. Te trudności rzeczywiście są ogromne i wymagają zdecydowanie interdyscyplinarnego podejścia, także niełatwego choćby za sprawą nieprzystawalności metod wielu nauk. Kilka prób, uwzględnionych w jedenastu poniższych zbliżeniach, było wielką inspiracją do zmierzenia się z tą powikłaną materia. Te zbliżenia powstały z przekonania, że chyba powinniśmy spojrzeć inaczej na czynniki jakościowe pytając przede wszystkim o możliwości ich badania, a jesteśmy przekonani, że daja się badać, kwantyfikować, ale tylko przy wysiłku specjalistów wielu nauk humanistycznych. Taki wysiłek zdaje się konieczny, jeśli chcemy wiedzieć więcej o sobie samych przyjmując za punkt wyjścia tezy A.C. Clarke'a z Childchoods End, a ten naukowiec i pisarz twierdził, że nasze zadufanie w wiedzę jest zdecydowanie za duże, że dopiero wychodzimy z wczesnego dzieciństwa ucząc się chodzić. To samo spotkamy u Teilharda de Chardin, a wedle niego „energetycznie” ludzkość jest wciąż młoda, wciąż świeża8. Chciałoby się dodać, że wciąż zdarzają się jej błędy, jakie zwykle towarzyszą odważnej, bezkompromisowej, ale naiwnej, zbyt spontanicznej młodości człowieka.

Autor jest daleki od postawy konstruktywistycznej, utrzymywania, że wszystkie światopoglądy są arbitralne, wszystkie prawdy względne, ale też równie daleki od tych, którzy na siłę „obiektywizuja” poszukując przede wszystkim tej pewności Ricouera. Zgadza się natomiast z K. Popperem powiadającym, że cała nasza wiedza naukowa jest wiedza przypuszczeń, wiedzą hipotetyczną ${ }^{9}$ Stąd wiele sugestii ma charakter właśnie przypuszczeń wynikających z przeświadczenia, że w próbach zrozumienia i wyjaśniania istoty świata społecznego coś nam jednak umyka, a potrzeba zrozumienia tego świata staje się palaca właśnie w naszej ponowoczesności, w której nie porozstawiano drogowskazów, w której niemal wszystko staje się zamazane, nieczytelne. Mimo rosnącej liczby informacji „społeczeństwo jako całość wydaje się mniej czytelne, wręcz nieprzejrzyste", jak zauważał Z. Bokszański ${ }^{10}$, a to stanowić musi wyzwanie dla nauki, jeśli ta chce pomagać w rozumieniu i wyjaśnianiu złożoności świata.

Można spodziewać się reakcji tych, którzy hołdują innym sposobom poszukiwania prawd naukowych, oskarżeń o korzystanie z „metody kubłowej”, uprawiania pseudonauki, i tym podobnych, ale, zdaniem autora, każda droga jest dobra, jeśli pozwoli nam na uwzględnienie nowych przesłanek do nowych wniosków.

\footnotetext{
8 T. de Chardin, The Future of Man, New York 2004, s. 62.

${ }^{9}$ K. Popper, Wiedza obiektywna, Warszawa 2002, s. 3.

${ }^{10}$ Z. Bokszański, Tożsamości zbiorowe, Warszawa 2005, s. 25.
} 


\section{1}

\section{CzlowieK I WIARA}

Celem nauki jest poszukiwanie dobrych wyjaśnień dla wszystkiego, co według nas potrzebuje wyjaśnienia - pisał K. Popper ${ }^{1}$, a naszym zdaniem czynnik historii nieświadomej, jakim jest pragnienie zbawienia/spełnienia nie tylko w transcendencji, ale i w doczesności potrzebuje i zrozumienia i wyjaśnienia, jeśli już zauważamy jego niezwykłe, generujące role, a takie chyba nie dają się kwestionować. A zauważamy te role nie tylko w literaturze pięknej powtarzając czasami, że pragnąc spełnienia w wielu wymiarach chcemy stawiać Bogu świeczkę, a diabłu ogarek i wtedy nie zdajemy sobie sprawy z prawdziwości takiego powiedzenia potwierdzanego przecież codzienną praktyką każdego z nas. Można to interpretować tak, że myśląc o Bogu mamy na uwadze zbawienie poza tym światem, a o diable spełnienie tu i teraz, nawet wtedy, kiedy jesteśmy zadeklarowanymi ateistami, choć nietrudno zauważyć, że ateizm może być postawa równie dogmatyczna jak jej przeciwieństwo - zauważał R. Dawkins ${ }^{2}$. W tej żmudnej praktyce codzienności pragniemy także tego, co zwie się pewnością istnienia, ale nie możemy żyć bez jej przeciwieństwa - niepewności, która nieustannie otwiera nas na transcendencję i przywołuje to stare pytanie o to, czy po drugiej stronie życia istnieje inne, a jeśli istnieje, to jakie miejsce nas tam czeka i czy możemy już teraz jakoś zapewnić sobie w miarę wygodne. A kiedy pytamy, sama myśl o wszechobejmującej konieczności przejścia tej bariery mrozi przeczuciem zniewolenia.

Nie jesteśmy wystarczająco tchórzliwi - pisał Cioran - by nadać życiu pewność stałości i ostateczności ${ }^{3}$. Takie tchórzostwo odebrałoby

\footnotetext{
${ }^{1}$ K. Popper, Wiedza obiektywna. Ewolucyjna teoria epistemologiczna, Warszawa 2002, s. 231.

${ }^{2}$ R. Dawkins, Bóg urojony, Warszawa 2008, s. 11.

${ }^{3}$ E. Cioran, Księga złudzen, Warszawa 2004, s. 56.
} 
nam nadzieje, marzenia, strachy, uczyniłoby świat koszmarem pewności, a wbrew pozorom nie chcemy żyć w takim koszmarze, choć czasami powtarzamy, że jednak chcemy mieć pewność, bo niepewność jest dręcząca, niepokojąca, stale budzi uczucie niedosytu, bez którego tak trudno byłoby nam żyć. Miotając się między potrzebą pewności, a jej przeciwieństwem często dochodzimy do wniosków, że chyba jednak nie wiemy, jak i gdzie chcemy żyć ulegając tysiącom złudzeń przekładajacych się na działania, mniej czy bardziej „racjonalne”. Te złudzenia sa tak oczywiste, że czasami niektórych nawet nie zauważamy, nie zauważając także tego, że ci, którzy zaspokajają naszą potrzebę złudzeń, często chca nad nami zapanować - jak powiadał E. Topitsch ${ }^{4}$. Ale, tonąc w złudzeniach, wiemy, że chcemy wiedzieć także o nich, poznawać naturę tych złudzeń, a przez to samych siebie z poczuciem niedokończoności naszego poznania, choć nie wszyscy chca wiedzieć czym są owe złudzenia. Nurtują nas niejasne niepokoje o to, że nie jesteśmy jednak autentyczni, że nie potrafimy właściwie oceniać świata i siebie, że jesteśmy warunkowani wieloma nierozpoznanymi jeszcze determinantami, choć może nie do takiego stopnia jak sugerował to filozof ${ }^{5}$. Chcemy to czynić w poczuciu, że nic co ludzkie....

Nie wiedząc jak, mimo tylu drogowskazów, chcemy żyć, by godnie przejść naszą wędrówkę w czasie, nie zapominając przy tym nawet na chwilę o zbawieniu poza ziemia, czynimy wszystko, by zbawiać się tu, na ziemi, poszukiwać spełnienia materialnego i duchowego i czynia to nawet ci, którzy kwestionuja takie spełnienie, bo spełniać się można także w kontestacji, choć czasami to zdaje się ocierać o granice dewiacji. Przede wszystkim, co zauważamy na każdym kroku, poszukujemy spełnienia materialnego, zbawienia w rzeczach, dla rzeczy i przez rzeczy, bo to jest łatwiejsze wtedy, kiedy czujemy, że brak nam pełni duchowej, intelektualnej i chcemy potwierdzać postać naszej tożsamości właśnie tysiącami nowych rzeczy, potrzebnych i mniej potrzebnych. Wtedy, ponieważ odkrywamy, że życie, jakim żyjemy, jest puste - pisał O. Marquard - pragniemy, by ono i wszystko w nim było co najmniej podwojone: drugi telewizor, drugie auto, drugi dom 6 . Ale i takie podwojenie zbyt często nie daje satysfakcji, tego upragnionego poczucia spełnienia, choć czujemy, że osiagnięcie takiego stanu mogłoby okazać się dla nas katastrofalne, bo całkowite spełnienie, coś niewyobrażalnego, może oznaczać marazm. Czasami zdaje się nam, że przez rzeczy podwajamy się także duchowo przyjmując wobec innych postawy i za-

\footnotetext{
${ }^{4}$ Cyt. za: R. Baader, Śmiercionośne myśli. Dlaczego intelektualiści niszcza nasz świat, Wrocław 2009, s. 129.

${ }^{5}$ J. Ortega y Gasset, Bunt mas, Warszawa 2004, s. 141.

${ }^{6}$ O. Marquard, Apologia przypadkowości, Warszawa 1994, s. 38.
} 
chowania, jakie świadczyć mają o naszej inności, wyjątkowości. Boleśnie odczuwamy także przejściowość niemal wszystkiego, co nas otacza, zwłaszcza w ponowoczesności, kiedy tak wiele zmienia się z dnia na dzień zaskakując nas i budząc poczucie trwałego niedosytu? ${ }^{7} \mathrm{Tu}$ nie wystarcza nawet podwojenie czy potrojenie posiadanych dóbr, bo w epoce dekretowanego dobrobytu potrzebujemy już niezliczonej ilości przedmiotów, zdecydowanie więcej niż w epoce przemysłowej i bez nich ciężko nam budować własną tożsamość ${ }^{8}$. Dziś już nawet nie mówimy o reifikacji godzac się z tym, że wszyscy jesteśmy urzeczowieni bardziej lub mniej, ale pewnie będziemy bardziej. Godzimy się tylko z banalnymi w gruncie rzeczy twierdzeniami, że im bardziej staramy się osiagnąć szczęście, tym bardziej jest ono ulotne ${ }^{9}$.

Pustkę, mimo ogromu rzeczy martwych wokół nas, odczuwaną czasami przez każdego, pogłębia egzystencjalna samotność, jakiej doświadczamy wszyscy wgłębiający się w tajniki egzystencji i weryfikujący powiedzenie Lukrecjusza: „Życie nie jest własnością niczyja, lecz wszystkich dzierżawa”. Nawet podwojeni, potrojeni w rzeczach nie zawsze czujemy, że zbliżyliśmy się ku tej pełni i czasami, acz nie zawsze, otwieramy się na inne, zawsze otwarte wymiary spełnienia przez wiedzę, samodoskonalenie umysłu albo ciała, jak robią to asceci albo prawdziwi sportowcy. Choć czasami nie chcemy tego zauważać, to przecież bezustannie, bez względu na wiek, myślimy o spełnieniu emocjonalnym i intelektualnym, pragniemy go i zbyt często poddajemy się po małych porażkach. Każdy pragnie kochać i być kochanym, przeżywać wielka, oczywiście spełniona, miłość, każdy chce odczuwać swoistą ekstazę emocjonalną i chyba jednak każdy dąży do spełnienia intelektualnego na swój sposób, zależnie od możliwości. Nie oznacza to przecież, że każdy chce zostać mędrcem na wzór starożytnych, ale chce wyróżniać się na tle innych, choćby przez lepszą znajomość tajników jakiejś dziedziny, niekiedy bardzo wasskiej. Wszystko po to, by spełniać się przed innymi z wyższościa eksperta i budzić podziw innych taka, swoista postacią spełnienia. Zreszta, można godzić się z autorem twierdzącym, że większość ludzi nie wie, czego chce, dopóki nie zobaczy tego w określonym kontekście społecznym ${ }^{10}$. Natomiast dość trudno zgodzić się z E. Cioranem, powiadającym, że im bardziej się jest, tym mniej się chce $^{11}$. Tak mogą twierdzić ludzie czujący smak spełnienia material-

\footnotetext{
${ }^{7}$ A. Finkielkraut, Zagubione człowieczeństwo, Warszawa 1999, s. 114.

${ }^{8}$ J. Riffkin, Wiek dostepu, Wrocław 2003, s. 117.

${ }^{9}$ D. Icke, Wolność. Przewodnik dla robotów, Katowice 2009, s. 137.

${ }^{10}$ D. Ariely, Potega racjonalności. Ukryte sity, które wptywaja na nasze decyzje, Wrocław 2009, s. 21.

${ }^{11}$ E. Cioran, Upadek w czas, Warszawa 2008, s. 21.
} 
nego i duchowego, a filozof pisząc patrzył na to z ogromnym bagażem doświadczeń, ale nie ci, którzy jeszcze go nie doświadczyli i karmią się tylko złudzeniami spełnienia.

Poszukując wszystkich postaci spełnienia, tych ziemskich namiastek zbawienia na zawsze, cały czas myślimy o ciemnych zasłonach dzielących nas od niewiadomego, czasami bezkrytycznie przyjmujemy, a czasami kwestionujemy wizje teologów mówiących nam o tym, co poza tym ziemskim życiem, ale świadomość kresu sprawia, że myśli o życiu poza życiem nie opuszczają nas, zwłaszcza od linii, za która czekający na życie odkrywaja, że teraz pozostaje im czekanie na śmierć. Czynimy to i chyba rację miał C.G. Jung powiadając, że wszystko, co spoczywa w nieświadomości chce stać się zdarzeniem ${ }^{12}$, a w naszej nieświadomości mamy i piekła, i raje.

Tylko intuicyjnie rozpoznajemy naszą nieświadomość wypełniona tysiącami symboli, ale odczuwamy zakodowany w niej ogrom strachów i nadziei na trwanie, wtedy zwłaszcza, kiedy znajdujemy się w sytuacjach niezwykłych, ekstremalnych. Choć jeszcze zdaje się niepoznawalna, to powinniśmy próbować ja poznawać pomni nauk Kanta przekonującego do nieodzowności metafizyki, a taka nieodzowność kieruje nas w stronę nieistniejącego paradygmatu człowieka, paradygmatu, jakiego chyba nie stworzymy, choć próbujemy od wieków. Obezwładnieni przywiązaniem do innych paradygmatów powinniśmy powoli zbliżać się do „ostatecznych” problemów ludzkiego istnienia, choć te są pograżone w irracjonalności, nieuchwytnej dla naszego intelektu - powiadał G. Lukacs ${ }^{13}$. Musimy zacząć próbować je poznawać choć w części, bo przede wszystkim chcemy przeżyć to życie jak najpełniej poruszając się między byciem i posiadaniem, często uzależniając posiadanie od bycia, a bycie od posiadania, często nierozumiejąc tego starego dylematu „mieć” czy „być”, mimo iż ten istnieje cały czas w historii ludzkiej, nie od chwili takiego wyartykułowania go przez E. Fromma. Wydaje się, że taki dylemat, mający rzekomo być największym dylematem końca wieku XX, nie jest nim w ogóle, zwłaszcza dla tych, którzy nie sycili się posiadaniem, ale i nie jest nim dla tych, którzy posiadają wiele. Nie jest tak wielkim dylematem i nie będzie nim nigdy, co jest także prosta konsekwencją dualności człowieka.

Poszukiwanie przez autora wyjaśnień różnych zachowań wielkich zbiorowości, zwłaszcza amerykańskiej, inspirowało sięganie po determinanty jakościowe zachowań i postaw jednostek i zbiorowości, zwykle niedoceniane w nauce i metodach w niej stosowanych, między nimi

12 C.G. Jung, Wspomnienia, sny, myśli, Warszawa 1993, s. 15.

${ }^{13}$ G. Lukacs, Antynomia myśli mieszczańskiej, [w:] B. Jasiński, Lukacs, Warszawa 1985, s. 215. 
po wyrastające $\mathrm{z}$ wiary nadzieje, strachy zbiorowe i rozpinane między nimi pragnienia urzeczywistnienia się w treści człowieka i zbiorowości. Bez ich uwzględniania zarówno zrozumienie, jak i wyjaśnianie wielu zjawisk, procesów staje się coraz trudniejsze, a bez tego nauka traci swoje walory praktyczne. Nietrudno zauważyć to, jak zmalały jej możliwości predykcyjne, jak oddala się od nagiego życia zajmując się sama sobą i starając się przekonywać do tego, że jest nieodzowna. Nie potrafimy przewidywać nawet zdarzeń czy procesów, do których mamy niekiedy setki mocnych przesłanek, a, być może, uwzględnianie owych determinant mogłoby nam pomóc choćby tylko w zrozumieniu.

Wiemy dobrze, jak trudne jest przewidywanie, ale nie możemy jego braku w nauce tłumaczyć tym, iż jest niemożliwe, bo takim sposobem uniemożliwiamy wszelkie planowanie, kolonizację przyszłości, która jest przecież naszą codziennością i oczywistą koniecznością. Nadto, takie poszukiwania zdaja się niezbędne, zwłaszcza w naszym czasie, za sprawa nagłych, szybkich zmian, czasie coraz bardziej otwartym na atakująca nas przyszłość, pełnym nowych obietnic, o jakich nie mogli nawet myśleć nasi przodkowie przyjmujacy z nieznanym nam fatalizmem to, co przynosi los. To czas zmuszajacy do radykalnych reorientacji stylów myślenia, postaw, zachowań i zdaje się, że symptomy niektórych już zauważamy, bo chyba jednak z jednostek epimetejskich powoli, bardzo powoli zmieniamy się w prometejskie. A prometeizm, wedle M. Boxela, oznacza myślenie na zapas, gdy epimeteizm - myślenie poniewczasie, a takie zachowania cechowały bliźniaków-tytanów - Prometeusza i Epimeteusza ${ }^{14}$. Powoli, zdaniem wielu zbyt powoli, zaczynamy myśleć o jutrze i sobie samych w jutrze. Wciąż za mało, bo nietrudno dostrzec, że tak częste diagnozy nie pociagają za sobą nawet prób terapii, a takie byłyby możliwe, gdybyśmy śmielej tworzyli przemyślane projekty jutra i konsekwentnie zmierzali ku nim korygując je po drodze, nie zawierzając swoiście pojmowanemu determinizmowi. Powiada się, że skoro jutro jest nieprzewidywalne, to tworzenie takich projektów mogących uzdrawiać nasz świat jest bez sensu. Jest w tym sporo zdroworozsądkowych racji, ale zauważmy, że nie kwestionujemy takich projektów w odniesieniu do nas samych, bo przecież jako jednostki uparcie i konsekwentnie kolonizujemy to jutro wiedzac o tym, że jest nieodgadnione, a mimo to osiagajac wiele zawieszonych $\mathrm{w}$ nim celów. Ale wiemy także - zauważał F. Hayek - jak wiele uczymy się na zawiedzionych oczekiwaniach wtedy, kiedy te cele sa nieosiagalne ${ }^{15}$.

W takim sensie możemy stać się prometejscy, o ile jesteśmy skłonni zawierzyć A. Tofflerowi, który od lat utrzymuje, że: „Na naszych

${ }^{14}$ M. Von Boxel, Encyklopedia gtupoty, Warszawa 2005, s. 39.

${ }^{15}$ F.A. Hayek, Konstytucja wolności, Warszawa 2006, s. 43. 
oczach, w naszym życiu rodzi się nowa cywilizacja, a ślepcy usiłuja ją uśmiercić. Ta nowa cywilizacja niesie ze soba nowy styl życia rodzinnego, zmiany w sposobie pracy, odnoszenia się do siebie i życia, nowy kształt życia gospodarczego, nowe konflikty polityczne, a przede wszystkim nową świadomość"16. Zbyt wolno godzimy się na to, że jednak zmienia się wiele, o ile nie wszystko, ale jednak godzimy się z tym, że na naszych oczach staje się Nowe. W takim czasie powinniśmy wyraźniej określać granice wiedzy i wiary, odkrywać, do jakiego stopnia wiara tworzy przestrzenie obietnicy, aktywizuje, ale także winniśmy dostrzegać nowe przestrzenie przyzwolenia dla działania. I mamy tu na myśli wiarę $\mathrm{w}$ immanencję i w immanencji, na wiarę będąca przyzwoleniem na konkretne działania polityczne i inne, rzekomo zgodne z naszą wola. Możemy, a nawet może musimy poszukiwać postaci zbiorowego prometeizmu, jeśli chcemy, by szybkie zmiany nie wywoływały poczucia bolesnej straty, ciagłej tęsknoty w ogólnym nastroju depresji, powodującym uczucie ciagłego wyczerpania, a wedle Tofflera to one sa wielka przeszkoda na drodze ku prometeizmowi ${ }^{17}$. Możemy to potwierdzać przyglądając się choćby jakości naszego społeczeństwa.

W takim czasie jak nasz koniecznościa jest reorientacja jednostki i zbiorowości na nowe cele i sposoby ich osiagania, bo tym naturalnym dążeniem każdego z nas jest osiaganie spełnienia materialnego i duchowego, spełnienia bez granic, bo nigdy nie wiemy, co zaspokoi nasze pragnienia posiadania i bycia, czy one w ogóle są do zaspokojenia, czy te, które nas dręczą teraz, są ostatnie, najważniejsze. Nie wiemy nawet jak wygląda nasze zaspokojenie „bycia”, czym jest, czym być może. Ale myślimy o tym bezustannie nie pytając o to, dlaczego oczywiste pytanie o spełnienie i jego granice jest tak ciche mimo konsumpcyjnego zgiełku, permisywizmu obyczajowego, poczucia coraz większej zewnątrzsterowności i zagubienia w znakach i symbolach ponowoczesności. Pytający o to samo filozof odpowiedział po prostu, że pytanie człowieka o zbawienie w doczesności zbytnio go obciążało i dlatego zostało usunięte poza kwestionariusz pytań życiowych ${ }^{18}$. Próby odpowiedzi na te, codzienne przecież, pytania wymagały zbyt wiele wysiłku, były równoznaczne z koniecznością pełnej, krytycznej oceny siebie samego jako pragnącego „mieć”, a taka zdaje się niemożliwa $\mathrm{z}$ wielu względów. Wspominamy o spełnieniu już właśnie tu, bo jego pragnienie jest mocno bijącym źródłem tej „małej” wiary. Powrócimy do pytań o nie niżej.

Chyba jednak nie do końca potrafimy się pozbyć i pytań i odpowiedzi o spełnienie w jego wielu wymiarach, bo takie nieme pytanie prze-

\footnotetext{
${ }^{16}$ A i H. Toffler, Budowa nowej cywilizacji. Polityka trzeciej fali, Poznań 1996, s. 17.

${ }^{17}$ A. Toffler, Szok przyszłości, Warszawa 1974, s. 115.

${ }^{18}$ O. Marquard, Szczęście w nieszczęściu, Warszawa 2001, s. 78.
} 
jawia się na każdym kroku, w każdym zamiarze działania i działaniu samym. Jest przecież pytaniem o to, kim chcemy być, jak żyć i istnieje w nas, mimo że nie zostało wyraziście wyartykułowane, a także pytaniem o to, czy czyniąc to, co czynimy, czynimy to dla własnego dobra, o ile wiemy, czym jest to dobro, czy potrafimy dobrze czynić coś sami. To także nigdy nie jest proste, a czasami bywa tak skomplikowane, że nie chcemy wiedzieć czym jest. Doświadczenie podpowiada nam, że od takich pytań nie sposób się uwolnić, one pojawiają się znikąd, dręczą, nieustannie zmuszaja do udzielania praktycznych odpowiedzi czynami, zachowaniami, czasami sensownymi, czasami nie. Bywa, że one często rodzą działania chaotyczne, generowane przypadkowymi zdarzeniami, bodźcami, jakie często zwiemy okazjami życiowymi albo zwykłym pechem. Poszukując zbawienia, o którym będziemy mówić szerzej w rozdziale drugim, może powinniśmy, mając na myśli taką dozę chaosu w okazjonalnych działaniach ,może powinniśmy inaczej spojrzeć na dość kontrowersyjną sugestię: „Musimy zarządzać własnym życiem zupełnie tak, jakbyśmy prowadzili niewielkie przedsiębiorstwo"19. Możemy spojrzeć na nią inaczej tylko wtedy, kiedy czujemy się na siłach poprowadzić to „przedsiębiorstwo”, a wiemy przecież, że wielu ludzi uznaje to za zadanie ponad siły i poszukuje plenipotentów odnajdując ich często przypadkowo i zawierzając im z wiarą w to, że jednak dobrze wybrali. Niektóre reguły takiej przedsiębiorczości z pewnością byłyby przydatne, ale niektóre mogłyby prowadzić nawet do bankructwa, a mogłoby stać się tak w przypadku, gdybyśmy choćby regułę maksymalizacji zysku zamienili na regułę maksymalizacji przyjemności nie myśląc tu o ich wyrafinowanych formach, ale o zwykłych, codziennych przyjemnościach, jakich sobie odmawiamy $\mathrm{w}$ imię imaginowanego, większego dobra w przyszłości.

Nie trzeba przekonywać się do tego, iż nie można prowadzić takiej „firmy” nie powodując się ani wiedza, ani emocjami i impulsami, a to są siły sprawcze większości z nas dla N. Chomsky'ego i chyba trzeba się z nim zgodzićn ${ }^{20}$. Próbując czynić to samodzielnie zdobywamy się na wysiłek, który może dać nam poczucie pełni, ale także uczynić przegranym, a nawet życiowym bankrutem. Wydaje się, że określając status naszego „przedsiębiorstwa” musimy zadawać intensywne pytania o to, dlaczego jako jednostki tracimy swą indywidualność w masie, dlaczego tylko w niej możemy sublimować i desublimować emocje, kultywować wartości, a jeśli tak, to czy nie powinniśmy moderować struktur tej masy tak, aby były rozwiązaniem optymalnym dla jak największej czę-

${ }^{19}$ A. Aldridge, Konsumpcja, Warszawa 2006, s.
${ }^{20}$ N. Chomsky, Media Control, New York 2002, s. 20. 
ści tej masy $\mathrm{i}$ to nie $\mathrm{w}$ imię jej, ale naszego dobra, bo czynilibyśmy to $\mathrm{w}$ imię spełniania się $\mathrm{w}$ masie i przez masę. Pytając winniśmy pamiętać o tym, że wobec tej „masy” nie można określić się na długo i cały czas trzeba korygować, dopełniać więzy między nami a nią nie do końca zawierzając pośrednikom, jakich w życiu każdego z nas nie brakuje. Winniśmy pytać także o to, czy wiedza dostarczana nam choćby przez psychologów i socjologów wystarcza dla tworzenia siebie, a jeśli nie, to jak mamy zdobywać ją w sobie i czy jest to możliwe. Wiemy albo tylko wierzymy w to, że najważniejsze procesy społeczne zachodzą wewnątrz masy i sa konsekwencją indywidualnych jakości ${ }^{21}$. To czasami skutecznie zniechęca do poszukiwania siebie w sobie, a nikt nie przekonuje nas do tego, że mit „jednostki społecznej” jest tylko mitem, który nie wyjaśnia właściwie niczego. Wierząc weń nie musimy jednak domagać się pełnych wyjaśnień tyczących nas samych, bo takie są nieosiagalne, ale do takiej pełni winniśmy dażyć w imię siebie.

Jakasś barierą w próbach rozumienia i wyjaśniania naszego miejsca i ról sa dominujące w Europie koncepcje człowieka oświeconego, nieprzygotowujace do rozwiązywania takich problemów, jakie pojawiaja się w splątanej ponowoczesności, do śmiałego kolonizowania nieprzewidywalnej przyszłości, ergo, nieuczące nas wiary w siebie, innych, świat, w nasze moce sprawcze. To wcale nie kazuistyka, a wniosek płynacy z wielu prób analizy stosunku człowieka do tego nieustannie wyzywającego nas ,jutra”. Przy pomocy ułomnej wiedzy nie jesteśmy w stanie go rozpoznawać, co i tak jest niemożliwe, ale nie potrafimy zagospodarować przyszłości z myśla o własnym dobru, czego potwierdzeń nie musimy szukać przyglądając się tysiącom prób przewidzenia biegu spraw jutra, które bywają nie porażkami, a klęskami. Jeśli więc nie możemy z pozoru ufać ułomnej wiedzy, pozostaje nam wiara przyjmujacca wiele postaci, ale stale w nas obecna, nieustannie domagająca się potwierdzeń. Jednostka nieprzygotowana do formułowania jednostkowych kwestionariuszy pytań o wszystko, niepotrafiąca antycypować, jest szokowana na co dzień nowymi faktami, wydarzeniami, które ja przygniataja, tłamsza, kwestionuja jej miejsce, przynależność grupowa. Zdobycie wiedzy choćby o części tych faktów i zdarzeń nader często przekracza jej siły i dlatego odwołuje się do swoich pokładów wiary i to nie zależy od statusu społecznego ani wykształcenia. Zdaje się, że poza religia także powinniśmy stosować credo Tertuliana ${ }^{22}$, jak powiada N. Wiener, czyli wierzyć w to, co absurdalne.

Widząc, że nie może do końca zaufać ułomnej wiedzy, poszukujący człowiek poczyna sięgać do pokładów wiary, swoich „wierzeń bazo-

${ }^{21}$ E. Canetti, Masa i władza, Warszawa 1996, s. 18.

${ }^{22}$ N. Wiener, God \& Golem Inc., Cambridge 2007, s. 2. 
wych", które są także swoistymi postaciami projekcji w jutro, bo większość w nas jednak, mimo przesłanek do innego wniosku, wierzy w to, że będzie lepsze niż dziśs ${ }^{23}$. Jeśli nie ma rezerwuarów takiej wiary, wtedy ów człowiek przejawia frustrację, strach i życie przestaje być centrum spełnienia przez siebie, staje się koszmarem, i wtedy zdaje się, że z niego wybawić moga polityczni i społeczni soterzy, jakich zwykle nie brakuje, zwłaszcza w demokracjach. Samozbawienie poczyna wydawać się niemożnością i jednostki poszukują na zewnątrz sił, jakie pomagaja w tłumaczeniu świata, wskazuja na istotę egzystencji, ich rzeczywiste czy mniemane potrzeby, a poszukując ich tam, przejawiaja coraz większa podatność na sterowanie nimi z zewnątrz. A, co jest jeszcze ważniejsze, bez wiary nie sa w stanie kultywować systemów wartości, bo one wszystkie wyrastaja z niej. Wiara w wiarę, że coś ma jakieś znaczenie jest i mocna i szeroko rozpowszechniona - uważał D.C. Dennet i nie wypada się z nim nie zgodzićn ${ }^{24}$.

W okresie niepojętego przyspieszenia, eskalacji ryzyka, rosnącej „nieprzejrzystości” społeczeństwa i swoistego kryzysu podstaw nauki w ponowoczesności, musimy zaczacc intensywnie poszukiwać tych „dobrych wyjaśnień" dla setek zjawisk i procesów, które nas zaskakuja i które z nawyku odwzorowujemy na starych wzorach myląc się, popełniając błędy, wykazując coraz więcej symptomów tego, co uczony nazwał schizochronia. Schizochronia, choć samo określenie brzmi egzotycznie, to nic innego jak „choroba” utraconych szans będąca oczywista konsekwencją złego wyboru spośród wielu możliwości, jakie stawały przed nami w przeszłości i nieustannie pojawiaja się w płynnej teraźniejszości. Chyba wszyscy znamy ją z własnego doświadczenia, wiemy jak wiele niewykorzystanych możliwości pozostawiliśmy za sobą i często cierpimy przekonani, że nasz wybór mógł być lepszy, trafny, a często nasz rozum instrumentalny podpowiada, że tak ${ }^{25}$. Rozpamiętując zaś wybory, te przeszłe wybory, zwykle nie przyglądamy się bieżącym i popełniamy podobne błędy, których także będziemy żałować wedle starej zasady, że czego byśmy nie uczynili i tak będziemy żałować. Pamiętając o tym, że błądzić będziemy ciagle, starajmy się jednak unikać symptomów tej „choroby” wybierając ostrożnie spośród tysięcy możliwości, wykorzystując przy codziennych wyborach i wiarę i wiedzę. Niestety, na tę powszechną dolegliwość nie ma i nie będzie skutecznego lekarstwa, a wybory są tak często czystym ryzykiem. Twórca koncepcji „społeczeństwa ryzyka" U. Beck przekonuje, że powinniśmy je minimalizować, ale

${ }_{23}^{23}$ T.A. van Dijk, Ideology. An Interdisciplinary Approach, London 2000, s. 24.

${ }^{24}$ D.C. Dennet, Odczarowanie. Religia jako zjawisko naturalne, Warszawa 2008, s. 242.

${ }^{25}$ A. Demandt, Historia niebyta, Warszawa 1999, s. 46. 
takie przekonanie bez praktycznych wskazówek wystarczyć nie może ${ }^{26}$. Tu nie zawsze pomoże nam nawet krańcowa ostrożność i przezorność, one czasami mogą także maksymalizować ryzyko.

Powracanie ku tym wyborom i rozpamiętywanie ich, czasami ze szkodą dla siebie, zdaje się być pochodna recentywizmu, czyli stałego oglądania się na teraźniejszość i poszukiwania tylko w niej odpowiedzi na najbardziej palące pytania, a przecież każde pytanie o sprawy istotne ma także korzenie w przeszłości i przyszłości, o czym czasami nie chcemy pamiętać, choć dobrze wiemy, że każdy wybór służy tylko przyszłości. W jakiejś mierze sa to efekty wpływu nerwowej, chaotycznej, zrelatywizowanej ponowoczesności - epoki obrazu i dźwięku wypełniającego życie. Coraz większa liczba ludzi chce w niej przeżywać rzeczywistość, a nie wyjaśniać ja, szukać wygodnych miejsc w szeroko rozumianej przyszłości, a nie męczyć się jej kolonizowaniem, które przecież wymaga sporego wysiłku wiązanego ze zdobywaniem wiedzy, kwalifikacji. Sprzyja temu fragmentacja przekazów, pomijanie niektórych informacji, falsyfikowanie, produkowanie rzeczywistości i korzenienie wielu postaci wiary naprawdę „fałszywej” i oczywiście cały czas mamy tu na uwadze tą „zwykła” wiarę, nie transcendentna.

Animatorzy i kreatorzy wyobrażeń zbiorowych w krajach rozwiniętych zdają się wiedzieć o tym, że istotną właściwością umysłu ludzkiego jest ujmowanie oddzielnie tego, co doświadczenie podpowiada jako całość ${ }^{27}$. Korzystając z tej wiedzy oraz z naszych naturalnych pokładów wiary nieustannie przekonują nas także do tego, że żyjemy w czasach najlepszych z najlepszych starając się rytualizować sądy, że jesteśmy już zbawieni w doczesności, że jednak jest to swoisty koniec historii, choć zwykle nie pytają o to, jakiej historii. My zaś nie wiemy, czy zaufać (bo jedna z postaci wiary jest zaufanie) wiedząc za to, że zajmujemy tylko maleńką część świata, poruszamy się w zamkniętych kręgach, w każdym wydarzeniu widzimy tylko jakąś fazę, jakiś aspekt - tak widział zagubionego człowieka W. Lippman ${ }^{28}$. Poczucie małości sprawia, że minimalizujemy także naszą wiarę w wiedzę o świecie i o sobie samych godząc się często na to, iż jesteśmy tak mało ważni, że prawie niezauważalni. Do w miarę spokojnego życia wystarczają nam podstawy $\mathrm{w}$ rozumieniu świata zdobywane $\mathrm{w}$ trakcie wczesnej socjalizacji w szkole, w domu, na ulicy. Jesteśmy tacy, jacy jesteśmy dzięki setkom autorytetów, przed jakimi ostrzegał Kant w swoim traktacie o oświeceniu. Nie jesteśmy w stanie skutecznie przekonać się do tego, że jesteśmy niepowtarzalnym mikrokosmosem, całym światem pośród wielu

${ }^{26}$ U. Beck, Społeczeństwo ryzyka, Warszawa 2002, s. 28.

${ }^{27}$ P.L. Berger, Rewolucja kapitalistyczna, Warszawa 1995, s. 48.

${ }^{28}$ W. Lippman, Public Opinion, New York 1996, s. 53. 
innych światów i nie pytamy o to, czy taki świat winien stworzyć własne prawa nie zawsze zgodne z powszechnie przyjętymi. Nie jesteśmy, a powinniśmy powtarzać za $\mathrm{P}$. della Mirandola, że jesteśmy przede wszystkim zdeterminowani przez samych siebie. W wiedzy, w wierze i potem w czynach. Takich nauk nam trzeba, a dobrych nauczycieli nie brakuje w przeszłości i teraźniejszości.

Powinniśmy pamiętać o tym, że człowiek jako gatunek i nie tylko jako gatunek, istnieje dzięki stałemu definiowaniu siebie ${ }^{29}$, co wcale nie oznacza, że takie potrzeby stałego określania się na nowo wszyscy odczuwają jednakowo, ale nie sposób przyjąć, że są ludzie, którzy tego nie robia, bo codzienna transgresja, „przekraczanie siebie”, czyli takie definiowanie jest częścią życia, choć wiemy o tym, że wielu z nas ogranicza takie przekraczanie z przekonaniem, że wiedzą wszystko, co jest im potrzebne i chyba takich nie brakuje. Sama transgresja oznacza konieczność stałego zadawania pytań egzystencjalnych, tych bazowych pytań Kanta: co mogę wiedzieć?, co powinienem uczynić?, czego mogę się spodziewać?. Wydaje się, że wszyscy chcemy zadawać takie pytania wbrew temu, co mówią sceptycy widzący człowieka współczesnego jako zewnątrzsterowną kukłę, przy czym nie same pytania są ważne, ale próby odpowiedzi na nie, bo te pytania sa w nas. Jakimś poświadczeniem konieczności takiego pytania jest dla autora niedawny fenomen filmu Wachowskich „Matrix”, filmu, który zdobył niezwykłą i zasłużona popularność, zwłaszcza wśród młodych, co także znaczy wiele. Zasłużeni krytycy widzieli w nim tylko formy, nie treści, i opinie o nim, recenzje czasami śmieszyły, czasami przerażały. Nie pytano o to, dlaczego setki tysięcy młodych odebrały ten film jako adresowany właśnie do siebie czyniąc go „kultowym” (a nie bardzo wiemy co to znaczy). Pisano o tym, że magnesem były sceny walk, że muzyka, ale były to wydumane tłumaczenia wynikajace $\mathrm{z}$ bezradności interpretacyjnej.

Te ważkie treści zauważali za to młodzi odbiorcy, dla których te przesłania stały się „kultowe”. One nie były aż tak oryginalne, bo znamy je od dawna $\mathrm{z}$ antropologii filozoficznej, ale w tym filmie sa skondensowane do granic i w takim czasie przywoływane dla tych, którzy nie stykali się z nimi w szkołach i tych zwykłych i szkołach życia. Neo - bohater filmu, chyba nie znający Kanta - a wraz z nim miliony widzów zetknęły się z pytaniami zadanymi wprost, brutalnie, z niezwykła siła: kim jestem?, czy jestem sobą?, czy mogę być kim innym i za jaka cenę?, jak wyzwolić się od siebie?, jak narodzić się na nowo? Natłoku takich pytań młodzi, którzy na co dzień raczej nie stykaja się z filozofia, nie znajdowali w miałkiej pop-kulturze i zetknięcie z nimi było jakąś

${ }^{29}$ C. Castoriadis, The Imaginary Institution of Society, Cambridge 1987, s. 47. 
formą traumy, ozdrowieńczej traumy. Takie pytania, choć czasem niewypowiedziane, pozostają w nas na zawsze, nurtuja, zmuszaja do odpowiedzi, transgresji, zmieniania siebie, a potem świata. A sa o wiele aktualniejsze właśnie dziś, kiedy wchodząc w życie nie wiemy, jakie miejsce możemy zajać $\mathrm{w}$ hierarchii społecznej, jak było kiedyś, kiedy role życiowe pisano przed wejściem w dorosłość i przyszłość była już niejako „napisana”. Dziś nie da się ich określić bez zadawania setek nowych pytań o to, jak żyć i jak najlepiej przeżyć całe życie, a takich pytań w kulturze masowej brakuje.

Przekonuje się nas także do tego, że przeżycia, marzenia, tropizmy to nie nasza poszukująca istota, ale że sa wytwarzane niejako na zewnątrz i inni wiedzą najlepiej, co jest dla nas dobre, a nasze „życie nieprzeżyte" jest dla nich czymś naturalnym, że marzenia to zwykłe mrzonki. Często z biernościa godzimy się z tym, że inni wiedzą lepiej o tym, co jest dla nas dobre, uznajemy, że powinniśmy z pokora znosić los zaprojektowany przez społecznych kreatorów desublimując swoje pragnienia namiastkami albo przeżyciami innych, tłumiąc i przenosząc na innych swoje emocje, bo często uważamy, że nasze przeżycia sa zbyt zwyczajne, prozaiczne, niewarte uwagi nie innych, a samych siebie. Wtedy kradniemy przeżycia innych z wiara, że wzbogacamy siebie, a to sa jakby klasyczne symptomy tożsamości lustrzanej albo tego, co psychologowie nazywają dyfuzją tożsamości, w której ,ja” jest rozmyte, a człowiek nie potrafi odpowiedzieć nawet na proste pytanie o to, kim jest, a bardzo boi się pytania o to, po co istnieje, bo po nim jednak może pojawić się odpowiedź.

To pogłębia syndromy ,życia nieprzeżytego”, czyli tego, jakie chcemy przeżyć, ale wiemy, że nie uczynimy tego nigdy, choć z drugiej strony takie kradzieże, nawet z seriali południowoamerykańskich, pogłębiaja naszą emocjonalność, uczą transgresji, mają walory ozdrowieńcze jakby na zasadzie placebo. Potępianie „oglądaczy” takich seriali nie dość, że bywa wymogiem środowiska, to jest jeszcze potępianiem zubożonej formy emocjonalności milionów ludzi, którzy nie potrafią odnaleźć bardziej wyrafinowanej, bo w tym nie pomaga im kultura, w jakiej żyja. To potępienie, ze strony niby intelektualistów bierze się chyba stąd, że marzenia i same emocje długo były uważane za niekontrolowane i destrukcyjne w „porównaniu z konstruktywnymi płodami rozważnego umysłu" ${ }^{30}$. O tym, że znaczą więcej niż sądziliśmy, zaczynamy przekonywać się dopiero teraz, kiedy znowu zaczynamy poszukiwać społecznych więzów z innymi szukając nowych dróg, takich jak Internet. Poświadczaja to także coraz bardziej zdecydowane sądy badaczy, jak

${ }^{30}$ K. Oatley, J.M. Jenkins, Zrozumieć emocje, Warszawa 2003, s. 39. 
choćby R. Dahla, który przekonuje, że umysł nie może być oddzielony od uczuć i emocji ${ }^{31}$. Z kolei socjologowie, którzy od niedawna poczęli doceniać kreatywną siłę emocji, stwierdzaja, że emocje zdecydowanie sa konstrukcjami społecznym i jako takie wręcz muszą znaleźć się $\mathrm{w}$ kręgu zainteresowania nauki ${ }^{32}$. Przy ich uwzględnianiu w metodach badawczych możemy na wiele procesów i zjawisk spojrzeć na nowo. Problem w tym, że badania nad nimi znajduja się jeszcze w stadium prenatalnym, co potwierdza wielu ludzi nauki ${ }^{33}$.

Zbyt często nie chce się zauważać tego, że emocje są częścią regulacji homeostatycznej i maja zapobiegać utracie integralności naszej psychosomy i bez nich tracimy zbyt wiele, ale tracimy równie wiele, kiedy je trwonimy uważając, że ich rezerwuary nigdy się nie wyczerpia $^{34}$. A przecież to jednostki wytwarzaja to wszystko i ich emocje, marzenia i nadzieje wyrastające ze „zwykłej” wiary staja się społeczna kanwa. Nie doceniamy ich, choć rzeczywistość, nie tylko polityczna, rodzi się z fantazji - przekonywał autor zbliżający europejskich wizjonerów, których czasami podejrzewano o szaleństwo (jak Cedenhoueva Kalergiego ${ }^{35}$. Nie był zbyt oryginalny jak wieki temu de la Mettrie, dla którego wyobraźnie to główna władza duchowa ${ }^{36}$. Ich rezerwuar zdaje się nieprzebrany, może zrodzić nowe światy, choć - jak mówił Gandhi - świat jest w stanie zaspokoić wszystkie potrzeby człowieka, ale nie jego chciwość. Ta niesprecyzowana chciwość, żądza spełniania się $\mathrm{w}$ dobrach materialnych odebrała nam wiele $\mathrm{z}$ emocjonalności jeszcze $\mathrm{w}$ dobie nowoczesnej, czyniąc stosunki z innymi funkcjonalne, powierzchowne, z zasadą ograniczonego zaangażowania ${ }^{37}$.

Tej cechy, mającej służyć samozbawieniu jednostek, ale także całych zbiorowości, zakwestionować nie można, podobnie jak nie jesteśmy w stanie kwestionować prawdziwego altruizmu nie tyle jednostek, co całych grup, dualnych jak ich atomy, bo jednostki spodziewają się tego po innych i skłaniaja się ku takim postawom wtedy, kiedy widzą podobne $\mathrm{u}$ innych. Człowiek potrafi zmieścić w sobie wszystko, jest dualny, a nasze umysły - zauważał J. Gould - działają przez dychotomię, wyobrażaja złożone problemy w postaci alternatywy albo-albo, uznając tym samym wybór jednego z ekstremów ${ }^{38}$. Nie sposób godzić się z takimi stwierdze-

\footnotetext{
${ }^{31}$ R.A. Dahl, On Political Equality, Yale University 2006, s. 40.

32 J.H. Turner, J.E. Stets, Socjologia emocji, Warszawa 2009, s. 16.

${ }^{33}$ D. Norman, Kognitywne protezy, [w:] Prognozy. Trzydziestu myślicieli o przyszłości, ed. G. Griffith, Poznań 2006, s. 204.

${ }^{34}$ A.R. Damasio, Tajemnice świadomości, Poznań 2000, s. 63.

${ }^{35}$ G. Gross, Federacje i konfederacje europejskie, Warszawa 1994, s. 14.

${ }^{36}$ J.O. de la Mettrie, Człowiek-maszyna, Warszawa 1984, s. 39.

${ }^{37}$ U. Hannerz, Odkrywanie miasta, Warszawa 2008, s. 89.

${ }^{38}$ J. Gould, Skaty wieków, Poznań 2002, s. 40.
} 
niami, bo jednak chyba niewyobrażalne jest opowiadanie się tylko po jednej ze stron alternatywy i tu znowu odwołujemy się do naszych codziennych doświadczeń korygujących taki ogląd. One poświadczaja, że najczęściej poszukujemy jednak złotych środków, kompromisów, zdając sobie w jakiejś mierze sprawę z naszej dualności, choć nie zawsze biernie godząc się na nią. Wiemy, że nie możemy być skończenie dobrzy albo źli, mądrzy albo głupi, że wierzymy albo wiemy, choć nie mówimy, że jesteśmy trochę mądrzy, trochę głupi, bardziej lub mniej wierzący.

Stale jesteśmy rozpięci między tymi skrajnościami, ku którym zbliżamy się sterowani systemami wartości, spychani sytuacjami w ślepe zaułki, zmuszani do ogromu niechcianych niekiedy wyborów. Czasami nie poznajemy siebie samych i przyznajemy rację twórcy powiadającemu, że człowiek jest jedynym na ziemi stworzeniem, któremu nie starcza czasu na to, by nauczyć się żyćs ${ }^{39}$. W jakiejś mierze ta dualność jest pochodną naszej zwierzęcej natury, co zauważał D. Morris mówiąc, że wielokrotnie chyliliśmy głowę przed tą natura przyznając milcząco, że $\mathrm{w}$ tak doskonałej istocie żyje bestia i raz po raz daje o sobie znać ${ }^{40}$. Zauważając te antynomie chcielibyśmy wiedzieć, jacy jesteśmy naprawdę, choć chyba boimy się takich odpowiedzi. Niełatwo jest odkrywać w sobie mister Hyde'a. Być może rację ma autor powiadający, że ludzie od zawsze cierpieli z powodu braku spokoju ducha biorącego się z poczucia własnej nieadekwatności i „niepełnego” człowieczeństwa z racji swojej inności ${ }^{41}$.

Zdaje się, że doświadczanie świata społecznego-historycznego nie pozwala osiagnąć satysfakcjonującego badaczy i społeczności poziomu nauki na drodze przyrodoznawczej procedury indukcyjnej - tak utrzymywał H.G. Gadamer ${ }^{42}$. Oznaczało to dla filozofa, że poziom wiedzy o człowieku jest co najmniej niezadowalający, a to oznacza przecież niewielki poziom wiedzy o wielu postaciach zbiorowości. Wiedzac o tym możemy powtarzać za Kantem, że z drzewa tak rosochatego, jakim jest człowiek nie da się wyciosać niczego prostego ${ }^{43}$. Wiele razy próbowano odnaleźć jądro jego „natury” przyznając się nie do porażek, a klęsk. Skoro nie możemy wiedzieć wiele o człowieku, nie wiemy także wszystkiego o społeczeństwie. A nie wiemy i w dodatku niektórzy (jak M. Foucault) przyznaja, że upadła już wiara w możliwość odkrycia istoty człowieka ${ }^{44}$.

\footnotetext{
${ }^{39}$ W. Stróżewski, W kręgu wartości, Kraków 1992, s. 39.

${ }^{40}$ D. Morris, Naga matpa, Warszawa 2005, s. 33.

${ }^{41}$ M. Jacyno, Kultura indywidualizmu, Warszawa 2007, s. 21.

${ }^{42}$ H.G. Gadamer, Prawda i metoda, Warszawa 2004, s. 29.

${ }^{43}$ I. Kant, Pomysty do ujęcia historii powszechnej w aspekcie światowym, [w:] Filozofia niemieckiego Oświecenia, Warszawa 1973, s. 466.

${ }^{44}$ M. Foucault, Historia seksualności, Warszawa 1995, t. II, s. 419.
} 
Nie sposób przecież przyznawać się do przegranej przed batalia, jak zrobili to Foucault czy E. Morin. Jeśli zdamy sobie sprawę z tego, iż dopiero wychodzimy z okresu raczkowania, to musimy ufać w siebie, zakładając że dowiemy się o sobie więcej, na pewno nie wszystkiego, ale więcej, pod warunkiem, że przyznamy prawo obywatelstwa wysiłkom tych badaczy, którzy orientuja się na badania interdyscyplinarne nie poprzestając na powielaniu różnorakich opisów, nie bojąc się o to, że będąc narażonymi na sarkazm reprezentantów „czystej nauki”.

Człowiek, to zwierzę symboliczne, jest zawieszony między immanencja a transcendencja poszukując stale swego nowego miejsca, transgresyjny, egoistyczny i zdolny zarazem do wielkich poświęceń w imię zbiorowości, twórczy i destrukcyjny, tak często niegodzący się ze swoimi miejscami, społecznymi rolami. Niepojęty dla samego siebie i niepokojący się tą niewiedza. Jakimś potwierdzeniem tych jednostkowych i zbiorowych niepokojów sa tu „odkrycia” teoretyków osobowości, którzy zauważaja, że dzięki jaźni może być podmiotem własnych działań, może gniewać się na siebie, godzić ze soba, nienawidzić, a także zbawiać. A przez jaźń, za A. Adlerem, rozumiemy twórczy system świadomości, który interpretuje doświadczenia i nadaje im sens. Adlerowska jaźń poszukuje doświadczeń, a jeśli ich nie znajduje, wówczas próbuje je tworzyć przy pomocy dostępnego jej tworzywa. Tego nie potrafia zwierzęta, ale mimo wszystko człowiek jest zwierzęciem i winniśmy uznać tę naturę przyglądając się jego wielu instynktom. Wmawiamy sobie z całkiem dobrym skutkiem, że jesteśmy stworzeni do „wyższych” celów i pragnień niż zwierzęta, ale co to za cele i w jakim sensie są wyższe, to wciąż podlega dyskusji i bywało podawane w wątpliwość nie tylko przez K. Lorentza i S. Langer ${ }^{45}$. Bez wątpienia jesteśmy zwierzęciem wyjątkowym, stać nas na dobro niespotykane u zwierząt, ale także na zło, jakiego nie spotkamy nawet u drapieżców, do czego przekonywał Lorentz w Tak zwane zło.

Od wieków pytano o człowieczą naturę i granice samego człowieczeństwa udzielając tysięcy odpowiedzi, które niekiedy korygowały jednostkowe postawy i zachowania w sposób radykalny, o czym winniśmy pamiętać. Dla B. Pascala człowiek to sędzia wszechrzeczy - bezrozumny robak, piastun prawdy - zlew niepewności i błędu, chluba i zakała wszechświata ${ }^{46}$. Podobnie, choć jeszcze mocniej, oceniali go inni z E. Morinem na czele, nie zapominajac przy tym o powtarzaniu odwiecznego pytania o naszą wyjątkowość we wszechświecie, a ono rodziło inne, o celowość naszego istnienia, a raczej wyjątkami były sądy,

${ }_{45}$ S. Langer, Nowy sens filozofii, Warszawa 1976, s. 89.

${ }^{46}$ B. Pascal, Myśli, Warszawa 1960, s. 185. 
w których człowiek jest akcydensem, pomyłka natury. Nawet matka natura nie mogła się mylić aż tak stwarzając taką chodząca aporię.

Niektórzy powiadaja, że człowiek jest bardziej postulatem niż spełnieniem, ale zwykle dodaja, że sama istota człowieczeństwa zakłada transgresję, nieustanne przekraczanie siebie, zawsze „ku” i zawsze „dla”, że człowiek nieustannie zmierza do pełni, do tego, co B. Trentowski ponad wiek temu nazywał „bożoczłowieczeństwem” i nie był jedynym człowiekiem takiej wiary, bo te „anielskie” pierwiastki w człowieku jednak były zauważalne, istniały i istnieja. Nie wiemy jak mogła wyglądać taka wymarzona przez filozofa pełnia, i zdaje się, że te romantyczne marzenia o ,anieleniu” człowieka szły nieco zbyt daleko, co potwierdzały liczne i nieudane eksperymenty psychospołeczne okresu Romantyzmu mające na celu stworzenie człowieka bliskiego ideału. Ale inni, patrzący przez „mędrca szkiełko”, utrzymuja, że jeśli człowiek jako forma będzie uparcie, nieustannie poszukiwał swoich treści, to taki postulat musi się kiedyś spełnić - tak twierdziło wielu intelektualistów nieodmiennie wierzących w esencjonalne dobro człowieka i zrealizowanie się tego dobra w różnych postaciach. Według takich optymistów droga od postulatu do spełnienia wydaje się powoli skracać, ale zbyt powoli dla tych, dla których miara czasu jest niecierpliwość, którzy chcą ujrzeć ideał własnymi oczami. Oni chcieliby za życia zbliżyć się do swego „ja”, do ideału Człowieka ${ }^{47}$. Tymi sa altruistycznie nastawieni intelektualiści, w tym rozmaitych postaci gnostycy, dla których wiedza bywała środkiem zbawienia. ${ }^{48}$. Oni jednak niechętnie przyjmowali do wiadomości to, że ich wiedza jest postacią wiary. To samo zresztą możny wytykać wielu naukowcom.

Reprezentując naukę są nader często ludźmi głębokiej wiary, oni bodaj najlepiej potwierdzają siłę tego, także niedocenianego czynnika zmian. Wierza głęboko, niezmiennie optymistyczni mimo tak wielu klęsk tego Człowieka, którego wędrówka po wciąż obcym i szerokim świecie dopiero się zaczyna, który dopiero uczy się chodzić wychodząc z dzieciństwa. Oni, poszukujący pełni człowieczeństwa, bez ograniczeń krępujących nas, tworzyli idee Człowieka, nadczłowieka, supermana i tu w jednym rzędzie stawiamy M. Shelley, F. Nietzsche i E. van Voghta - twórcy wizji supermana z planety Krypton. Zdawać się może, że takie zestawienie, to nadużycie, ale jeśli zważymy, że superman wciąż zakreśla dalekie, niewidoczne granice marzeń milionów młodych ludzi, to winniśmy spojrzeć na niego inaczej, podobnie jak na wielu innych bohaterów komiksów.

\footnotetext{
${ }^{47}$ W. Jaeger, Paideia, Warszawa 1962, t. I, s. 27.
}

${ }^{48}$ H. Jonas, Religia gnozy, Warszawa 1994, s. 48 
Niewiele wiemy o początkach sięgania przez człowieka w transcendencję i narodzin wiary $\mathrm{w}$ nia, ale możemy mniemać, że wiara i odczucie boskości pojawiły się wcześnie z naturalnej potrzeby odnajdywania się w budzącym strachy i nadzieje świecie, zjednywania sobie przychylności sił wyższych, jak widział to G. Frazer ${ }^{49}$. Wiara, wywodzące się z niej wczesne religie i mity tworzyły zrozumiałe struktury ładu, pozwalały na zrozumienie i iluzyjne opanowanie tego, co dookoła, zapewniały iluzyjne bezpieczeństwo i pomagały w przeżyciu, bo konfirmowały przecież organizację pierwotnych społeczności. Wspomagała je niedoceniana w naukach społecznych magia i już dla B. Malinowskiego był to kompleks działań mających zmniejszyć obszary niepewności, a dla innych antropologów magia umożliwiała kontrolowanie świata przez człowieka na poziomie archaicznym i magicznym ${ }^{50}$. Chyba jednak nie tylko na takich poziomach, bo nietrudno zauważyć, że nie jest przymiotem tylko społeczeństw prymitywnych i choć się tego wypieramy, to stosujemy zabiegi magiczne niezwykle często, „uprawiamy te praktyki stare jak sam świat, uprawiać będziemy, ponieważ, niczym ludzie grający na loterii, chcemy wierzyć" ${ }^{51}$. Biernie godzimy się na takie zabiegi w polityce choćby, być może dlatego, że w każdym z nas istnieja te pokłady umysłowości pierwotnej, na jakie działają zabiegi magiczne.

Chcemy wierzyć przede wszystkim w skuteczność naszych codziennych działań i tu zachowujemy się niemal jak szamani uprawiając działania pozorowane, tą naszą magię codzienna, która niby ułatwia nam poruszanie się w codzienności, spełnianie się w niej. Myślenie magiczne i towarzyszące mu działania magiczne są integralnymi częściami życia i znaczy ono wiele nie tylko w odniesieniu do jednostek, ale także wielkich grup społecznych i znaczyć będzie jeszcze długo. Nie przesadzimy aż tak wiele, jeśli nazwiemy politykę magia, a samych polityków szamanami. Ona jednak nie zaginęła w tych „mrokach dziejów” jak twierdzą niektórzy. Niektórzy teoretycy twierdza, że zauważalny dziś zwrot ku magii, to część rewolty przeciw materialistyczno-racjonalistycznemu wyjaśnianiu sposobu funkcjonowania świata ${ }^{52}$. Takie wyjaśnienia nie do końca wystarczaja, a konieczność zrozumienia i uzgodnienia się ze światem zdaje się rosnać właśnie $\mathrm{w}$ takich okresach i podówczas wracamy do magii, obecnej i ukrytej za zasłonami rzekomej racjonalności, tej racjonalności, w jaką uparcie wierzymy. Magia zdaje się emanacja wiary i nie zaniknie dopóty, dopóki będziemy skłonni wierzyć

\footnotetext{
${ }^{49}$ J. G. Frazer, Złota gałaź, Warszawa 1969, s. 72.

${ }^{50}$ M. Kochan, Slogany $w$ reklamie i polityce, Warszawa 2003, s. 67.

${ }^{51}$ D.G. Landes, Bogactwo i nędza narodów, Warszawa 2007, s. 235.

${ }^{52}$ A. Aveni, Poza kryształowa kula, Poznań 2001, s. 303.
} 
w cokolwiek. Stosowaliśmy i stosujemy ją na co dzień i nader często służy nam w zaklinaniu rzeczywistości owocując ogromem działań pozornych, magicznych. Jeśli przyjrzymy się naszym zachowaniom bez trudu odnajdziemy jej ślady.

W rozpoznawaniu tych zjawisk nie wspomaga nas także filozofia, przez wieki pełniąca role swoistej „projektonauki”, „matki wszelkich pytań. Ona „była najpierw kompetentna we wszystkim, potem była kompetentna $\mathrm{w}$ pewnych sprawach, wreszcie stała się kompetentna w jednej, a mianowicie wyznawaniu własnej niekompetencji”"53. To zdanie filozofa poszukujacego siebie, sądzimy, że myślącego o spełnieniu w poszukiwaniach i nie jest to zdanie wyjątkowe w naszym czasie. Swoją droga moga zdumiewać tak częste i krytyczne sądy współczesnych filozofów o samych sobie i pozwolimy sobie przywołać jeszcze jedna gorzka opinię: „dopóki filozofowie wiodą filozoficzny dyskurs z innymi filozofami w oparciu o filozoficzne teksty, nie mogą uwierzyć w swoja misje" 54 . Oczywista, nigdy niekwestionowana misją filozofów jest poszukiwanie tego, co nazywamy „prawda”, ale dziś owe poszukiwania przybieraja postać hermetycznego dyskursu, w którym brak pytań o zwykłe życie zwykłych ludzi. Nie wattpimy w to, że chcąc bronić swojej tożsamości filozofia kiedyś zajmie się problemami zwykłego życia tych zwykłych ludzi, nie pozostanie tylko przysłuchiwaniem się echom z dalekiej przeszłości, choć tych słuchać trzeba, a ciagle do nas dochodzą. Przyglądając się dokonaniom wielu współczesnych filozofów można odnieść wrażenie, że spełniają się oni w wysublimowanej „mądrości” niedostępnej zwykłym śmiertelnikom i chyba uważaja, że tym gorzej dla tych ostatnich, że nie chca zrozumieć.

Chcąc zrozumieć i potem wyjaśniać świat winniśmy chyba przyjrzeć się bliżej, zaczać badać to, co z pozoru wydawało się niebadalne, czyli jakościowe determinanty życia zbiorowego, zaczynając od części, czyli jednostek, niemal niezauważalnych za wielkimi strukturami, jakie interesują ludzi nauki najbardziej z raczej prostego względu i nie mamy tu tylko na uwadze dominującego w myśleniu nowoczesnym (ale i ponowoczesnym) mechanicyzmu. Tam, w tych strukturach można znaleźć spore ilości kwantyfikatorów, tam czynniki ilościowe sa przesłankami do wniosków, w których tak często brakuje jednostki z jej niezbywalnymi cechami, zbyt kapryśnej i nieobliczalnej, o wiele trudniejszej w rozumieniu, a efektem bywa przystosowanie jednostek do tych struktur niekiedy w taki sposób, że w wielkich grupach społecznych brakuje dla niej miejsca, do czego przekonujemy się przy analizie generujących teo-

${ }_{53}$ O. Marquard, Rozstanie z filozofia pierwszych zasad, Warszawa 1994, s. 29.

${ }^{54}$ J. Lachs, The Relevance of Philosophy to Life, Nashville 1995, s. 15. 
rii społecznych, z marksizmem na czele. Z obserwacji wielkich struktur wyciaga się wnioski o właściwościach maleńkich składników czasami z katastrofalnymi dla nich skutkami, co potwierdza choćby praktyka socjalizmu. Od niedawna dopiero interdyscyplinarni badacze uznaja za konieczne badanie wszystkich możliwych wymiarów antropo i psychosfery i ich konstatacje raczej nie są budujace, choć za optymistyczne można uznawać przekonania, że badania istot społecznych dopiero się rozpoczęły ${ }^{55}$. Dopiero i jednak. Wedle wielu badaczy takie eksploracje są konieczne, bo nie odnajdując się w labiryntach świata człowiek tworzył i tworzy na oślep, często nie pojmując konsekwencji swoich czynów, po prostu epimetejski. A to sprawia, że staje się jeszcze bardziej niepewny siebie, co zdaje się owocować także tym, że coraz większe stają się grupy samotników z wyboru, że polityka staje się obca ${ }^{56}$.

Komentując takie postawy pielgrzymów czasu i przestrzeni dawno temu H. G. Mead mówił, że wreszcie powinniśmy odnaleźć w miarę trwałe, zrozumiałe podstawy egzystencji, bo „nie jesteśmy obcymi ani pielgrzymami w świecie, który jest naszym domem"57. Z pewnościa dom jest nasz i pewni tego chyba powinniśmy wreszcie określić nasz status gospodarzy, zwłaszcza w okresach tak niezwykłych, przełomowych, w jakich przyszło nam żyć. Tymczasem nie wiemy nawet tego, czy jesteśmy lepsi czy gorsi od przodków, mądrzejsi, czy bardziej od nich destrukcyjni, czy jesteśmy ludzka jednościa, czy jednak stanem naturalnym jest wrogość rodząca wiele podziałów. Sami nie wiemy, kim chcemy być, choć chcemy wiedzieć nie przestając pytać o to. Nie wiemy, czy możemy w pełni zgodzić się z Teilhardem de Chardin, który utrzymywał, że w każdym programie życia człowieka istnieje imperatyw „bycia czymś więcej”. Być czymś więcej to więcej wiedzieć po to, by więcej móc, dawać sobie i innym. To oznaczało dla Teilharda przyrost bytu $^{58}$. Wydaje się jednak, że obserwacje naszego czasu skłaniają do odwrotnego wniosku. Jest to bycie czymś więcej, ale inaczej, bycie dzięki rzeczom i imitacji zachowań innych.

Potrzeba nie pełnego, bo takie chyba jest niemożliwe, ale raczej doraźnego samookreślenia jest tym bardziej piląca, że - jak zauważają dziesiątki analityków - znajdujemy się pośrodku otwartej sytuacji historycznej po upadku wielkich, spajających zbiorowości ideologii, w okresie ogromnego przyspieszenia zmian, między nowoczesnościa a jej kontynuacją i „bez wątpienia istnieje realność słusznego wyboru,

\footnotetext{
${ }^{55}$ W. Wickler, Biologia dziesięciu przykazań, Poznań 2001, s. 26.

${ }_{56}$ T. Zeldin, Intymna historia ludzkości, Warszawa 1998, s. 415.

${ }^{57}$ Cyt. za: J. Campbell, The Community Reconstructs. The Meaning of Pragmatic Social

Thought, Chicago 1992, s. 23.

${ }^{58}$ P. Teilhard de Chardin, Pisma wybrane, Warszawa 1967, s. 15.
} 
lecz nasze błędy z przeszłości i obecne doświadczenia pokazują, że jak dotąd nie wykorzystaliśmy kompletnie naszych możliwości"59. Być może jest to konsekwencją tego, że kultury europejskie zupełnie lekceważyły podstawową naturę człowieka - zauważał E.T. Hall mając na myśli jakościowe czynniki zmian ${ }^{60}$. Zamiast zająć się w początku jednostka jako fundamentem wielkich dociekań społecznych, na plan pierwszy wysunięto owe wielkie struktury lekceważąc atomy tych struktur, a te jednak przesądzają o charakterze całości w stopniu, jakiego jeszcze nie znamy. Stworzono system wiary w takie struktury rytualizowany przez animatorów życia społeczno-gospodarczego usuwając jednostki w głęboki cień, co ułatwiało sterowanie tymi, którzy nie wierzyli we własna podmiotowość. Żyjemy w czasie, w którym wiemy więcej, poznajemy więcej szczegółów docierając do jednostek i tego, co ludzkie, nie społeczne, nie masowe, ale obrazy całości, jakich nie potrafimy ogarniać umysłem, zamazuja się coraz bardziej w jakiejś mierze za sprawą braku umiejętności rozumienia i wyjaśniania elementów gubionych tak często w bezrefleksyjnym opisywaniu. Naukowcy społeczni, cierpiący rzekomo na „syndrom zazdrości o fizykę”, jednak nie mieli zamiaru iść śladami fizyków i rozbijać nawet atomy na coraz mniejsze składowe.

Co do tego, iż wszelkie badania w naukach społecznych winniśmy zaczynać od człowieka nie miał złudzeń $R$. Conquest powiadając, że człowiek jest zarazem istotą społeczną i jednostka. Pomijanie go jako jednego lub drugiego prowadzi do naturalnych wynaturzeń ${ }^{61}$. Zdawało się przed niewielu jeszcze laty, że wiemy już wiele o prawach rządzących tymi wielkimi strukturami, że stworzone paradygmaty sa trwałe, pewne, że pomogą w konstrukcji innego, doskonalszego ładu społecznego, ale konwulsje społeczne, neurozy, nieprzewidywalne załamania tych struktur poczęły zmuszać do reorientacji i poszukiwań właśnie tych atomów, choć w większości przypadków tylko akcentuje się takie konieczności i Conquest nie jest tu wyjątkiem Niektóre z tych załamań to już symptomy gwałtownego i nieprzewidzianego ataku ponowoczesności, której istotę dopiero próbuje się wyjaśniać. Dotąd jednostka była nieustannie kierowana, prowadzona przez społeczeństwo, a jej bierność potęgowały standaryzacja i synchronizacja. Pozostawiona sama sobie $\mathrm{w}$ społeczeństwie ryzyka pozostała bierna jak uprzednio zaczynając gubić się w strachach, tracąc nadzieję, nie wiedząc nawet, że w najgorszym przypadku ryzyko można minimalizować, oswajać się z nim, choć postawą najbardziej pożądaną jest otwarta z nim konfrontacja. Okazało się, że te wielkie, z pozoru niewzruszone struktury, nie

${ }^{59}$ K.A. Wittfogei, Wtadza totalna, Toruń 2002, s. 513.

${ }^{60}$ E.T. Hall, Poza kultura, Warszawa 1984, s. 235.

${ }^{61}$ R. Conquest, Uwagi o spustoszonym stuleciu, Poznań 2002, s. 40. 
mają tak mocnych fundamentów, jak sądzono. A sądzono nie próbując oceniać trwałości tych fundamentów, nie badając ziaren piasku.

Zapominając o konieczności badania antroposfery czy psychosfery bezustannie projektujemy, tworzymy dziesiątki, reklamowanych jako rewolucyjne, wysublimowanych planów politycznych, ekonomicznych czy społecznych, rzadko pytając o to, co zdaje się ogromnie ważne, czyli o użytkowość, funkcjonalność tych wielkich budowli mających przecież służyć dobru i wygodzie samego twórcy. Czasami można odnieść wrażenie, że takie plany tworzy się po to, by dowodzić tylko umiejętności trwania systemów społeczno-politycznych. Ale nic w tym dziwnego, skoro sprawy „szarego człowieka” od wieków pozostawały na marginesie zainteresowań i nauki i tych, którzy posiedli nad nim władzę - zauważał D.C. Dennet ${ }^{62}$. Czasami, dopiero po skonstruowaniu nowego, wyrafinowanego modelu socjoekonomicznego czy politycznego zaczynamy pytać o miejsce $\mathrm{w}$ nim człowieka i zauważamy jak jest niefunkcjonalny - konstatował swego czasu prezes Klubu Rzymskiego A. Peccei. Dodawał, że po to, by zrozumieć świat trzeba wpierw zrozumieć samego człowieka będącego całością tak samo nieobjętą i skomplikowaną jak wszechświat, pamiętając także o tym, że ludzie zwykli redukować złożoność, a nie ją tworzyć, że ci zwykli ludzie oczekują tego zrozumienia i wyjaśnienia od tych, którzy winni to czynić, ale to nie znaczy, że twórcy wizji świata powinni dokonywać takich uproszczeń umożliwiających zrozumienie przez „szarego człowieka”, choć powinni starać się o to.

Taki swoisty redukcjonizm, przesądzał o tym, że tworzono także uproszczone obrazy zbyt skomplikowanego człowieka. Odsuwano go na trzeci plan, on zaś pozwalał na takie marginalizowanie daleki jednak od wiary, że jest tylko śrubka w maszynie, bo na to nigdy nie mógł wyrazić pełnej zgody, choćby przez konieczność obrony tego, co nazywamy godnością. Od niedawna dopiero, dzięki tym, których Boorstin nazywał „poszukiwaczami” poczęto zauważać, że by zrozumieć siebie powinniśmy sięgać w przeszłość, by poznawać siebie samych istniejących gatunkowo, ale nie tak, jak czyniliśmy i czynimy to od czasu początków „produkcji historii”. Musimy - twierdził z przekonaniem niekonwencjonalny historyk - wiedzieć jak myśleli ludzie. Jego zdaniem zbyt wiele historii to dzieje panujących i elit, nie zauważa się tam szarego człowieka i jego szarych problemów ${ }^{63}$. Nie do końca wiadomo, czym jest kreator dziejów, jakim w istocie był ten szary człowiek, co poprzedzało jego działania, historyków interesowały raczej symplifikacje ograniczane do tego, jak wyglądały same działania i skutki, czasami pojawiające się

${ }^{62}$ D.C. Dennet, Natura umystów, Warszawa 1997, s. 167.

${ }^{63}$ R. Takaki, Strangers from a Different Shore, New York 1989, s. 9. 
znikąd. Każda redukcja złożoności zaś oznacza uproszczenie, a te, tak często w historii, zwłaszcza „świętej” nie bywaja próbami zrozumienia ani wyjaśniania, ale swoistym credo. Wydaje się, że sięgając w przeszłość możemy inaczej, lepiej zrozumieć siebie w dynamice zmian, możemy przyrównywać siebie takimi, jakimi byliśmy z tymi, jakimi jesteśmy wedle starego pytania o to, skąd pochodzimy, bo tylko zadając je możemy odpowiedzieć na pytanie o to, dokąd zmierzamy, a to nie jest częste w naszym czasie. Tu sugerujemy raz jeszcze, że jeśli nie będziemy pamiętać o tym pytaniu nie wykształcimy wiary w przyszłość, nie będziemy potrafili jej kolonizować ani w wymiarze jednostkowym, ani grupowym.

Zawierzając bez reszty mityzowanemu mechanicyzmowi, stawiając na pierwszym miejscu te wielkie struktury, w jakich ginie jednostka, człowiek zatraca zdolność nie tylko definiowania siebie, ale i świata, w którym żyje, traci zdolność transgresji poprzez nowe iluzje posybilne, przez to, co jest tym „II światem” K. Poppera albo motorami „historii nieświadomej” F. Braudela, których podłożem jest wiara. Dominujące wizje człowieka-maszyny przysłoniły te popperowskie intencje, wartości, kalkulacje, uczucia, marzenia ${ }^{64}$, a stary paradygmat zakładał, że człowieka i społeczeństwo można konstruować jak trwałe maszyny, co owocowało tworzeniem struktur takich, jak totalitaryzmy, ale przekłada się także na konstrukcje demokratyczne. Zapominano jednak o tym, że człowiek i zbiorowość ludzka nie zużywają się jak maszyny, rosna, zmieniają się, a poza tym myśla, czuja, wartościuja. Mimo wszystko nieodgadniony człowiek jest aktorem na ogromnej scenie świata grającym wiele ról, poszukujacym ciagle nowych prawd o skomplikowanej rzeczywistości i sobie samym ${ }^{65}$. To dość zdumiewajacce, ale od niedawna dopiero w naukach społecznych zauważa się, że żyjemy, oddychamy wartościami, że żaden aspekt naszego życia nie jest wolny od wartościowania, a to jest jakby tworzenie „wiary w wierze" ${ }^{66}$. Po części dlatego, że poszukiwania etyków nie interesowały ani socjologów, ani historyków i politologów. Zapewne niewiele zmieni się w najbliższym czasie, choć tak mocno artykułuje się konieczność badań interdyscyplinarnych. Wiemy od lat o tym, że dobre intencje nie zawsze są początkami czynu.

Myśląc człowiek jest jakością niezwykle dynamiczna, z czego nie zawsze zdaje sobie sprawę, dokonuje setek tysięcy transgresji samo-

\footnotetext{
${ }^{64}$ M. Benedict, Cyberspasm. First Step, [w:] The Cyberculture Reader, ed. D. Bell, New York 2000, s. 31.

65 J.M. Charon, Ten Questions. A Sociological Perspective, Minnesota State University 2001, s. 117.

${ }^{66}$ B. Skeggs, Class, Self, Culture, London 2004, s. 13.
} 
rzutnych albo inspirowanych z zewnątrz, które zmieniaja go, zbliżają albo oddalają od siebie takiego, jakim mógłby, czy chciał być. Transgresje zaś dla psychologa to czynności innowacyjne i ekspansywne, wykraczające poza rutynowe działania i zachowania, czyniące człowieka innym $^{67}$. Jako takie są pochodną i wiedzy i wiary, a wydaje się, że to właśnie wiara jest tu bardziej znaczaca. Nieustannie przekraczając siebie sięgamy do świata po to, by coś zatrzymać, coś zmienić, zrobić coś możliwego, ale przez nas pożądanego, bo w takich metamorfozach myślimy o sobie, bliskich, społeczności, dla których pragniemy spełnienia $^{68}$. Według twórcy transgresyjnych koncepcji jednostki pragnie ona wyjść poza to, czym jest i co posiada, a niekiedy pragnie także obejść prawa natury i historii ${ }^{69}$, co poświadczaja choćby utopiści czynu. Jednostka jest z natury buntownicza, czujacca granice spełnienia, buntuje się przeciw wszelkim ograniczeniom, wszelkim połowicznościom swojej egzystencji, bo ze swojej istoty dąży do pełni i czuje wszelkie bariery, jakie stoja na drodze ku tej pełni. Często dokonuje tego przekroczenia siebie odchodzac od wszelkich modeli, wzorów, paradygmatów zachowania i myślenia i nie jest wtedy tak irracjonalna, jak się czasami sądzi ${ }^{70}$. Takie jednostki, uważane często za dziwaczne, ekscentryczne, kreując siebie, zmieniaja świat na lepszy lub na gorszy jeśli maja takie szanse. Są też tacy, którzy zamiast transgresji wybieraja regresję - eskapizm w jego wielu formach. Czasami stają się takimi tylko przez brak umiejętności wyboru i wiary w siebie, w społeczeństwo, lepszy świat.

Szukając prostych, zrozumiałych interpretacji istoty świata, zmian, pełni wiary w możliwość jego lepszego poznania, wciąż jesteśmy skłonni do zawierzania różnego rodzaju „racjonalnym” rozwiązaniom technicznym, „inżynierii społecznej”, choć one nie zawsze są racjonalne, bo nie dają się rozumowo tłumaczyć innowacje służące destrukcji albo takie, które, miast pomagać, tylko utrudniają nam życie, choć twierdzi się, że mają nam je ułatwiać. Wciąż na mechanistyczny sposób myślimy o zbawczych rolach wielkich struktur, od państwa i gospodarki poczynając, wierząc że zbawi nas wielki przemysł, nowe struktury polityczne albo fantomy globalizacji. Twierdzimy albo biernie zgadzamy się z twierdzeniami, że rozwój gospodarki jest rzeczą nadrzędną i nikt nawet nie pyta o to, czy ten rozwój w takiej postaci przekłada się to na dobro jednostkowe, nasze dobro. Nie pytano o to, bo ludzie wiary byli przekonani, że rozwój przemysłu jest remedium na wiele bolączek. A pytania odbiorców podobnych przesłań winny być proste jak enun-

\footnotetext{
67 J. Kozielecki, Transgresyjne koncepcje człowieka, Warszawa 1987, s. 10.

${ }^{68}$ K. Lynch, What Time is this Place?, Cambridge 1990, s. 1.

69 J. Kozielecki, O człowieku wielowymiarowym, Warszawa 1988, s. 15.

${ }^{70}$ V. Turner, Gry społeczne, pola, metafory, Kraków 2005, s. 10.
} 
cjacje zauroczonych nimi polityków: dlaczego, jeśli produkcja rośnie o tyle procent, o tyle dochód narodowy, to nasza sytuacja materialna pogarsza się? Czy powinniśmy się cieszyć, czy raczej martwić takimi przyrostami? Zbyt często nie zadajemy takich pytań nie potrafiąc się dekodować w próbach odpowiedzi, jako że zmiany raz zakodowanego sposoby myślenia i zachowania wymagaja podwójnego wysiłku i rezygnacji z czegoś, co już przyswoiliśmy, a także powtórnej nauki, a jest to zdecydowanie trudniejsze niż uczenie się po raz pierwszy ${ }^{71}$. Tu znowu pojawia się ta wiara $\mathrm{w}$ to, że raz zakodowane sposoby interpretacji sa dla nas najlepsze, czasami tylko dlatego, że są rzekomo nasze własne, bo już zapomnieliśmy o ich zewnętrznych źródłach. One codziennie służą poczuciu integralności, bezpieczeństwa, temu upragnionemu świętemu spokojowi.

Chyba stale winniśmy mieć na uwadze sentencję H.D. Thoreau, który powiadał, że świat nieustannie, posłusznie odpowiada na natrętne pytania o prawdziwość naszych koncepcji ${ }^{72}$, ale dodajmy, że po to, by oczekiwać jego mądrych odpowiedzi, które i tak nie rozwiążą naszych wszystkich problemów, musimy wpierw zaczaćc mądrze pytać, pomni tego, że „na mądre pytania świat daje mądre odpowiedzi, a na głupie - głupie"73. Jednym z paradoksów naszego czasu jest to, że takich mądrych pytań nie brakuje, ale rozziew między elitami intelektu, gdzie powstaje ich większość, a elitami władzy, które powinny odpowiadać, jest tak wielki, że te pytania nie dochodzą do tych, którzy różnymi drogami posiedli moce organizacji społeczności. A pytania zmieniają się przecież z każdym drgnieniem teraźniejszości.

Politycy zwykle zadają całkiem inne pytania i sami na nie odpowiadają odwołując się nie do potocznej racjonalności, ale do postaci wiary człowieka żyjącego w kręgach mitów i potrafia go mierzyć własnymi miarami, czemu często zawdzięczaja osobiste sukcesy. Podobna luka pytań i odpowiedzi pojawia się między generacjami. Młodzi, poszukujacy spójnego poglądu na spełnione życie, szukają znaczenia, celów, ideałów, a często, zmuszani przez starszych, nie zadają wielu pytań, przyjmuja to, co oferuje im kultura zwana dominująca w chaosie ponowoczesności. Uczeni wedle starych, przeżytych wzorów, korygowanych normami rodzonymi w ponowoczesności nie sa przekonani, że życie jest długą wędrówką do miejsca, gdzie czekamy na siebie sami, dla nich sa to skoki z dnia w następny dzień. Otoczenie nie potrafi wydobyć z nich i wykorzystać naturalnych przymiotów młodości, jakich brakuje

\footnotetext{
${ }^{71}$ G. Hofstede, Kultury i organizacje. Zaprogramowanie umystu, Warszawa 2000, s. 38.

${ }^{72}$ C. Cavell, The Sense of Walden, Chicago 1992, s. 125.

${ }^{73}$ C. F. Wieizsacker, Jedność przyrody, Warszawa 1978, s. 6.
} 
społecznościom, a do nich z pewnością należy odwaga, bezkompromisowość, umiejętność „oswajania” ponowoczesnych klimatów, radzenia sobie z urządzeniami, innowacjami. I w jakiejś mierze za sprawą nieumiejętności, ale także strachu przed ekspansją młodości dzieje się tak, że „przekleństwem przeważającej części ludzi jest bierność, bezwład, strach, a nie nadzieja i odwaga" ${ }^{4}$. Jednak jeszcze większym zdaje się to, że przez takie uczucia odkrywamy nasze anachroniczne punkty widzenia świata i nie widzimy w tym nic złego ${ }^{75}$.

Reasumując te uwagi zauważamy, że jednostka żyjaca w naszym świecie, obok niezbędnej wiedzy musi posiasść dynamiczny system wiary - uważał teoretyk ${ }^{76}$ - po to, by, móc określić w nim swoje miejsce, zdobyć tożsamość, czyli znajdować drogę do samego siebie. Wraz ze świadomościa człowiek sam dla siebie staje się pytaniem, jak mawiał święty Augustyn, a każde pytanie, nawet najgłupsze, domaga się odpowiedzi, bo inaczej niepokoi, nęka, nie pozwala zasnać. Tych pytań miewamy tysiące, bo otoczenie obliguje nas do zajęcia stanowiska w niemal każdej sprawie i są to już nowe pytania. Ale odpowiadając na nie najczęściej opieramy się na wyobrażeniach zbiorowych kodowanych w nas $\mathrm{w}$ procesie socjalizacji, często mających charakter teorii spisku albo spiskowych (co wedle nas jest różnicą bardzo istotna) i zdajemy się na wiarę wybierając to, co zdaje się nam najlepsze w określonej sytuacji. Odpowiadając, nieustannie poszukując, a potem potwierdzając swoje Ja podmiotowe przez wiarę i wiedzę, poszukująca jednostka odnajduje właściwe dla siebie formy aktywności i nie sa to tylko formy wzniosłe, szlachetne, ale moga być destrukcyjne, nawet patologiczne. Formy takich dewiacji biora się stąd, że zwykle nie potrafimy określić idealnego Ja - zauważał psycholog, choć taka próba wyjaśnienia znowu pozostawia spory niedosyt ${ }^{77}$, bo nie wiemy czym jest owo idealne Ja i zapewne wiedzieć nie będziemy. Można przyjąć, że jego formy zmieniają się wraz ze zmianami środowiska zewnętrznego i są to zwykle korekty wszystkich komponentów Ja: realnego, idealnego (nadzieje i marzenia i powinnościowego (poczucie praw i obowiązków) wobec zbiorowości. A ponieważ korygujemy nasze Ja stale, siła rzeczy nie potrafimy go dobrze określić, choć istnieją komponenty, jakie nie ulegaja tak radykalnym zmianom w procesach transgresji i tym powinniśmy się przyjrzeć.

Psychologowie społeczni sa zgodni, co do tego, że każdemu z nas trzeba koherentnego, uporządkowanego Ja. I niezbędnej wiary w moż-

\footnotetext{
${ }^{74}$ A. Rand, Powrót człowieka pierwotnego, Poznań 2003, s. 182.

${ }^{75}$ A. Russel-Hochschild, The Managed Heart. Communication of Human Feeling, Berkeley 1983, s. 17.

${ }^{76}$ D. Alger, The Media and the Politics, Belmont 1996, s. 21.

${ }^{77}$ H. Levinson, Psychologia przywództwa, Gliwice 2007, s. 18.
} 
liwość jego osiagnięcia. Dla psychologa Ja stanowi strukturę poznawcza, która pozwala człowiekowi świadomie myśleć o sobie samym ${ }^{78}$. Bez niego tracimy orientację $\mathrm{w}$ świecie, a brak poczucia swojego miejsca w nim zwykle owocuje anomia, zgubieniem, a tu przez anomię rozumiemy mertonowską rozbieżność między akceptowanymi społecznie wartościami, a postulowanymi w nim normami mającymi służyć osiagnięciu tych wartości. Integralną częścią tego Ja są jakości, które L. A. Pervin nazywa konstruktami osobistymi chronicznie dostępnymi, a sa to, nabywane w procesie akulturacji, automatyczne sposoby postrzegania świata, co znaczy, że potrzeba niewiele informacji, by je uruchomić, niekiedy wystarczy fizyczny bodziec, choćby pojawienie się wizerunku polityka w telewizji ${ }^{79}$.

Psycholog miał zapewne na myśli struktury mityczne przybierające postać symplifikacji służących bieżącemu uzgadnianiu się ze światem, co jest codzienną koniecznością każdego z nas, bo, czy chcemy, czy nie, codziennie zadajemy dziesiątki pytań egzystencjalnych i odpowiadamy na nie, nie zawsze świadomie. Odpowiadamy szybko wtedy, kiedy odpowiedzi ułatwiają nam równie szybką zgodę ze światem. Czynimy to na swoiste sposoby, których etologii jeszcze nie poznaliśmy. Chyba każdy z nas zauważał to, co filozof powiadający, że jeszcze przed rozpoznaniem sytuacji skłaniamy się bardziej ku pewnym rzeczom, ku tym, a nie innym wartościom i to już jakoś determinuje wybory, postawy ${ }^{80}$. Możemy też dostrzec, że reagujemy wielorako nawet na jednakowe bodźce zewnętrzne, doświadczamy samego siebie, stale odpowiadając na wyzwania w codziennym życiu społecznym - dodawał znany psycho$\log ^{81}$. Te odpowiedzi bywaja aktywne lub pasywne, oznaczają ekspansję albo wycofanie, sięgając niekiedy do coraz częściej zauważanego strachu przed społecznościa, przed innymi w ogóle. Ale na takie wyzwania musimy odpowiadać, bo one sa po prostu życiem. Niekiedy odpowiadamy na nie ze sporym wysiłkiem, niekiedy zaś używamy uproszczeń, które rażą nas samych. Ale bywa tak, że nie mamy czasu czy ochoty na to, by odpowiadać tak, jak powinniśmy, bo wszyscy jesteśmy na swój sposób eskapistyczni.

Ciagła aktywność pytającego i odpowiadającego wynika także z konieczności stałego potwierdzania własnej wartości i miejsca, jakie zajmujemy w grupie, większej zbiorowości, bo takie nie jest dane raz na zawsze. Wiadomo, że kontakty społeczne sa dynamiczne, wielorakie

\footnotetext{
${ }^{78}$ M. Leary, Wywieranie wrażenia na innych. O sztuce autoprezentacji, Gdańsk 2003, s. 175.

${ }^{79}$ L.A. Pervin, Psychologia osobowości, Gdańsk 2002, s. 229.

80 J. Ortega y Gasset, Szkice o miłości, Warszawa 1989, s. 75.

${ }^{81}$ A. Elliott, Koncepcje „ja”, Warszawa 2007, s. 61.
} 
i w naturalnej potrzebie samooceny rozglądamy się za szybkimi i kompetentnymi potwierdzeniami otoczenia, a czasami tylko za takimi, jakie wydaja się nam kompetentne. Człowiek penetrujący swoje otoczenie odnajduje w nim nie tylko informacje zwrotne, ale również sądy wartościujące jego działania, które stają się przedmiotem nie wiedzy, ale wiary, bo chyba tak przyjmujemy opinie innych o sobie, zwłaszcza te pochlebne. Poza wiarą w transcendencję, o której będziemy wspominać później, a od której próbujemy czasami uciekać w naszej dualności, mieści się $\mathrm{w}$ nas wielopostaciowa wiara $\mathrm{w}$ immanencję, jeszcze jeden z niepojęcie ważnych czynników zmian, niemal niezauważalny w nauce. Być może stało się tak za sprawą S. Kierkegaarda i M. Webera, którzy uwierzyli i przekonali innych wyznawców do tego, iz świat został odczarowany, a wiara przestała być potrzebna, nie tylko ta transcendentna, ale i ta „zwykła”. Za nimi w zanik wiary uwierzyły setki intelektualistów zwykłych zawierzać autorytetom. Choć nie da się jej zaprzeczyć, to bez trudu zauważamy, że niewielu ludzi nauki pytało o to, czym jest, niewielu odpowiadało i w tym miejscu spróbujemy zbliżyć tylko dwie próby rozpoznania jej istoty. Dla J.M. Bocheńskiego istotą wiary niereligijnej są założenia służące wyjaśnianiu i koordynowaniu doświadczeń. Taka wiara ma charakter hipotezy. Nie ma więc charakteru absolutnego $^{82}$. Ale istnieje i nie da się kwestionować w tej swojej wielopostaciowości. Wierzymy we wszystko to, w co możemy wierzyć - pisał natomiast W. James - a uwierzylibyśmy we wszystko, gdybyśmy tylko mogli.

Satysfakcjonujących nas prób wyjaśnienia istoty wiary immanentnej nie mamy wiele, a inna, jaką chcemy tu zaprezentować, jest niekonsekwentna próba E. Fromma, dla którego wiara jest przekonaniem o tym, co jeszcze niedowiedzione, to wiedza o rzeczywistych możliwościach, świadomość brzemienności przyszłości. Jest na swój sposób racjonalna, jeśli odwołuje się do wiedzy, ale daleko jej do takiej postaci racjonalności, jaką utożsamiamy z przewagą rozumu ${ }^{83}$. Nietrudno zauważyć to, iż praktyka potwierdza to, że przeciętny człowiek nie chce uzasadniać wiary rozumowo i często jest mu głęboko obojętne, czy ma jakieś mocne przesłanki dla niej, zbyt mocno chce wierzyć, potrzebuje wiary $^{84}$. Poza tym ilość wiedzy w wierze przypomina ta zawartość cukru w cukrze. Nie wiemy, w jakim momencie wiara w prawdopodobieństwo jakiegoś zdarzenia nie staje się pewnością. Rozpięci między wiara a wiedzą nie zastanawiamy się nad tym, co nami powoduje w jakiejś chwili, nie mamy na to czasu.

\footnotetext{
${ }^{82}$ J.M. Bocheński, Lewica, religia, sowietologa, Warszawa 1996, s. 259.

${ }^{83}$ E. Fromm, Rewolucja nadziei, Poznań 2000, s. 37.

${ }^{84}$ S. Langer, Nowy sens filozofii, Warszawa 1976, s. 55.
} 
Wspominaliśmy już wielokrotnie o tym, że człowiek jest najmniej $\mathrm{w}$ połowie istotą wiary i znowu podkreślamy, że nie mamy tu na myśli oczywistej wiary w transcendencję, a zwykła, codzienną wiarę zawsze obcująca $z$ tą pierwsza, bo potrzeby doświadczenia transcendencji przez każdego z nas także sa elementarne - zauważał filozof i nie sposób nie zgodzić się $\mathrm{z}$ nim${ }^{85}$. To nie tylko wiara we właściwa nadprzyrodzoność, ale także formy pośrednie z deizmem i teizmem na czele. Zapewne nigdy nie uda się obdarzyć wiary „pocałunkiem śmierci”, nie zdefiniujemy jej ostatecznie z korzyścia dla nas samych, ale musimy przynajmniej próbować ją zrozumieć i wyjaśnić dla dobra samych siebie w takich kształtach, na jakich stworzenie stać nas tu i teraz. Nie przeceniamy także tej wiary, bo „ilekroć wiara wynosi siebie do rangi normy absolutnej, tylekroć wiedza jest poważnie zagrożona" ${ }^{\text {". }}$. Stanem pożądanym zdaje się być to filozoficzne equilibrium - równowaga między wiara a wiedza, choć pewnie wielu, mających się za jednostki racjonalne, to oburzy. Jeśli zechcemy obserwować siebie nie zdając się na analizy innych, podówczas możemy zauważyć jak my, niezmiennie dualni, poruszamy się między swoistymi skrajnościami wiary i wiedzy czyniąc to wszystko po to, by pozostać takimi, jakimi jesteśmy w wierzeniach projektujacych.

Nader często rozziew między rzeczywistościa a wiarą w coś doczesnego jest tak wielki, że wyznawcy nie chca tego zauważać uciekając się do końca $\mathrm{w}$ wiarę ${ }^{87}$. Na co dzień spotykamy się z tym w reakcjach na bieżące wydarzenia polityczne i to jest, jakże często spotykane, naruszenie tej równowagi. Nawet wbrew świadectwu zmysłów, autorytetów i otoczenia niektórzy będą utrzymywać, że jednak jest inaczej i oni wierzą w to, że jest inaczej, a czasami sa gotowi poświęcić wiele w imię tej wiary. Bywa, iż oznacza to, że przedkładają wiarę nad poszukiwanie wiedzy, okopuja się na jej gruncie, w jakiejś mierze świadomi tego, że wiedza znaczy więcej, ale oni już dokonali wyboru. Podświadomie czują także, że musza kultywować jakieś postaci potwierdzania tej wiary i poszukują ich jako jednostki albo symetryczne wobec tej wiary zbiorowości. Psychologowie potwierdzają istnienie takich mechanizmów samoobronnych i wedle nich, kiedy raz przyjmiemy jakieś założenie, często staje się ono naszym żywotnym interesem, którego aktywnie bronimy, także wbrew doświadczeniu, zdrowemu rozsądkowi, opiniom większości. Różne zachowania percepcyjne i kognitywne nader często

${ }^{85}$ S. Hook, The Quest of Being, New York 1991, s. 98.

${ }^{86}$ Raport o stanie wiary. Z Księdzem Kardynatem J. Ratzingerem rozmawia V. Messori, Kraków 1986, s. 56.

${ }^{87}$ W. Greider, The Betrayal of American Democracy. Who will Tell the People?, New York 1998, s. 11. 
odrzucają fakty i logikę, prawdziwe jest to, co jest prawdziwe dla jednostki, a o prawdziwości wcale nie przesądza wiedza czy „argumenty racjonalne ${ }^{88}$. Nie wiemy czy jest sposobem ucieczki, jak widział to filozof $^{89}$, bo jeśli tak, to ucieczki od kogo, czego? Od siebie, świata, od wiedzy?

Ta „Zwykła” wiara to nie tylko azyl, miejsce ucieczki, to skrzydła, to moc czynienia rzeczy niemożliwych w każdej kulturze człowieka, a bodaj najwięcej tego potwierdzeń znajdziemy w mitologii indyjskiej i chińskiej i na zawsze pozostają w naszej pamięci uczniowie maga Li Tie-kuaja, którzy, uwierzywszy, przepływali rzekę na liściu bambusa, jak Czao-tu. My po prostu musimy w coś wierzyć, co tak chętnie kwestionuja ci, którzy wiarę są skłonni utożsamiać tylko z wiara w transcendencję. Jako społeczności jesteśmy wspólnotami wyobrażonymi, wspólnotami przetrwania poszukującymi mocnego spoiwa. Tylko wspólna wiara, w tym ta niezwykle istotna wiara w wartości, może nas scementować i utrzymywać pod kontrola - twierdzi „klasyk”90. Jej role społeczne zdają się być pojmowane empatycznie i temu choćby służą wykłady historii „świętej” - całego systemu wiary w szlachetna genealogię, posłannictwo jakiejś grupy społecznej czy narodu. $\mathrm{Na}$ jej przykładzie widzimy dominację właśnie wiary, nie wiedzy i niewiele zmienić tu mogą wysiłki historyków poszukujących „czystej” wiedzy o przeszłości.

Dążenie do całościowego postrzegania świata jest jakby naturalnym tropizmem każdego z nas i bezustannie pytamy o to, gdzie jesteśmy, bodaj częściej właśnie o to, niż o to, kim jesteśmy. Zaczynając od pytań o ogrom dalekiego i zawsze obcego świata wracamy z odpowiedziami do miejsc, które zdają się „nasze” i wracamy z wiara, że takie odpowiedzi sa dobre, że wystarczaja dla naszej stałej potrzeby osiagania tak potrzebnej nam ataraksji. Poszukujemy takich odpowiedzi w trójczasie sięgając tak głęboko, jak jest to możliwe, w wiele przeszłości i przyszłości z wiara w to, że jednak odnajdziemy nasze odpowiedzi na wielkie pytania. Nawet wtedy, kiedy przekonujemy siebie, że takie pytania nie maja sensu wierzymy w możliwość odpowiedzi. Taka wiara nie ma nic wspólnego $\mathrm{z}$ metafizyką rozumiana jako wiara $\mathrm{w}$ transcendencję, istnieje jakby obok niej, a czasami można odnieść wrażenie, że jest pierwotna. Poszukując choć namiastki odpowiedzi na pytanie o to, dlaczego obserwujemy spadek wiary $\mathrm{w}$ transcendencję na rzecz wiary w samorealizację w immanencji możemy zauważać także swoistą zależ-

${ }^{88}$ D. Winn, Manipulowanie umystem, Warszawa 2003, s. 131.

${ }^{89}$ J.E. Smith, The Spirit of American Philosophy, New York 1983, s. 12.

${ }^{90}$ D. Morris, Naga małpa, Warszawa 2005, s. 159. 
ność między jedną i drugą wynikająca z naszej dualności. Potrzebujemy jednej i drugiej, ale w naszym czasie wspieramy się o immanentna.

Wyjaśnialiśmy to $\mathrm{w}$ innych miejscach, ale dla porządku przypomnijmy, że konstruktami wiary sa struktury powszechnie nazywane mitami, choć mitami „właściwymi” raczej nie sa, ale ledwie mityzacjami - uproszczeniami pozwalajacymi nam na szybkie zakodowanie jakichś informacji czy zbiorów informacji. Mając owe informacje poszukujemy dla nich takiej struktury i nasza potrzeba pewności jest zaspokojona, utrzymujemy jednostkową homeostaze pozwalajacca trwać w codzienności w jakiejś formie zgody z samymi soba. I tak, jeśli słyszymy o zamachu bombowym, niemal automatycznie postrzegamy go jako terrorystyczny, jeśli słyszymy słowo „lewica”, także automatycznie wiążemy go z partiami mającymi się za lewicowe i za takie uważane sa przez ogół, choć tu tak często się mylimy, bo nie zwykliśmy poszukiwać kryteriów wyróżniających prawicę czy lewicę. Bezustannie zbieramy tworzywo dla tych struktur, które potwierdza lub podważa ustalone w nich zasady ${ }^{91}$. Najczęściej nastawiamy się na potwierdzanie w procesie socjalizacji i takie potwierdzanie czasami staje się nawykiem, wtedy zwłaszcza, kiedy nasze światy się kurcza, ograniczają do kilku kręgów: przyjacielskiego, rodzinnego, pracy. Jeśli nie potwierdzamy, sami stajemy się buntownikami, swego rodzaju herezjarchami uciekajacymi ze sfer wyobrażeń mitycznych zbiorowości. Konsekwencją takiego stanowiska być może wyłączenie jednostki ze społeczności i zdając sobie $\mathrm{z}$ tego sprawę, $\mathrm{w}$ imię trwania, godzimy się z tym, że kształtują nas inni, a sami stajemy się sumą innych. A taka suma, to suma mądrych i głupich, wierzacych i nie...

Dla wielu współcześnie żyjących - twierdzi G. Corey - problemem jest właśnie to, że tracą sens własnego Ja, gdyż poszukiwanie tożsamości skierowali poza siebie i możliwości stojące przed nimi otwierają im inni ${ }^{92}$. Oznacza to, że inni steruja kreowaniem ich hierarchii celów, to inni zapewniaja, że znają drogi ku spełnieniu materialnemu i duchowemu pod kilkoma warunkami, a pierwszym z nich jest zawierzenie właśnie im. Dla badacza jest to syndrom próżni wewnętrznej - skumulowanego rezultatu przekonań jednostki, że nie jest ona zdolna do kierowania własnym życiem, do zmieniania postawy ludzi wobec siebie, czy efektywnego oddziaływania na otaczajacy świat ${ }^{93}$. Praktyka codzienna potwierdza to, że wielu ludzi szuka gotowych odpowiedzi zamiast wskazówek, dzięki którym sami mogliby odpowiadać na te codzienne

${ }^{91}$ M. Sommer, Zbieranie. Próba filozoficznego ujęcia, Warszawa 2003, s. 332.

${ }^{92}$ G. Corey, M. Schneider, Sens życia i wartości, [w:] Mosty zamiast murów. O komunikowaniu się między ludźmi, red. J. Stewart, s. 163.

${ }^{93}$ R. May, Miłość i wola, Poznań 1998, s. 23. 
pytania, a gotowe odpowiedzi, najczęściej dostarczane z zewnątrz, sa zwykle przedmiotem wiary człowieka, którego zwać można wyznawca. Dla biologa jest to przejaw niebiologicznego i zarazem niebezpiecznego wygodnictwa. Niebiologicznego, bo zwalnia człowieka od krytycznego posługiwania się rozumem, a niebezpiecznego, ponieważ wiedza innych staje się władzą innych, dla tych, którzy tylko wierza.

Dostrzegana przez Reicha i innych zewnątrzsterowność nabiera innego wymiaru w społeczeństwie rzekomo informacyjnym, które wypadałoby jednak zwać inaczej po zadaniu kilku prostych pytań o to, co to oznacza, choć to zupełnie inny problem. Ideały spełnienia, z jakimi dziś ludzie stykają się na zewnątrz, głównie w mediach, poza materialnymi, chyba nie rodzą satysfakcjonującej ilości nowych celów, ku którym mogliby dążyć. A materialne sa to tylko ideały dla wybranych i jako takie nie desublimuja poczucia spełnienia, im możemy się tylko przyglądać z odrobina zazdrości. Ten naturalny voyeuryzm jest tylko namiastka uczestnictwa, spełnienia, a zdaniem teoretyka uczestnictwo w wydarzeniach medialnych, nie tylko nie wywołuje empatii, ale wręcz szkodzi, jak choćby tak popularne talk show ,pełne złych rad i braku rozwiązań problemów”94. Wielu zadeklarowanych „podglądaczy” imituje zachowania telewizyjnych i prasowych gwiazd mniemając, że takim sposobem osiagają jakaśs namiastkę pełni. Popularność programów z „gwiazdami” - ludźmi rzekomo spełnionymi, w jakiejś mierze zdaje się to potwierdzać. Takim sposobem przeżywamy to swoje życie nieprzeżyte.

Takie pół, a może ćwierć-uczestnictwo w życiu innych czasami tylko pogłębia uczucie pustki i świadomości niespełnienia, bo niezwykle trudno przekonać samego siebie, że taka imitacja jest ta pełnia, jaka oglądamy w serialach TV. Stąd pojawiają się tzw. symptomy falującego poczucia szczęścia, w tym polskiego, w jakiejś mierze wynikającego z niewiary w możliwość osiagnięcia swojego szczęścia, która jest jednak postacia wiary. Niejakie zgorszenie i niemal żadnych nie pytań budza polskie resentymenty, w których, poza niechęcią do większości elit politycznych i społecznych, pojawiają się te, rzekomo irracjonalne, tęsknoty Polaków za Gierkiem, czy Węgrów za Kadarem i twierdzenie, że najlepiej im było w latach 70. czy $80^{95}$. Tak i w takiej postaci przejawia się to, co nazywaliśmy za A. Demandtem schizochronia - tęsknotą za możliwościami, jakie otwierały się przed nami w przeszłości, a z jakich nie potrafiliśmy skorzystać wtedy, kiedy byliśmy młodsi i bardziej inicjatywni. Ale jest to także wyraz tęsknoty za stanem niby-pełni utożsamianej głównie z bezpieczeństwem socjalnym.

${ }_{94}$ J. Gamson, Freaks Talk Back, Chicago 1998, s. 7.

95 J. Czapiński, Makropsychologia czyli psychologia zmiany społecznej, [w:] Jednostka $i$ społeczeństwo, red. M. Lewicka, J. Grzelak, Gdańsk 2002, s. 149. 
Poszukiwanie siebie jest o tyle trudne, że jednak nie uświadamiamy sobie dualności i zwyczajności tego Ja, tak plastycznie opisanego przez K. Horney ${ }^{96}$. Każdy z nas musi poruszać się między skrajnościami wartości, emocji, a codziennie jesteśmy wystawiani na dziesiątki pokus, prób. Jesteśmy jak to rosochate, ale i rozdarte drzewo Kanta. Nader często nie rozumiemy siebie, choćby wtedy, kiedy pragnąc wolności nie możemy poradzić sobie z pragnieniem przynależności ${ }^{97}$, kiedy opowiadamy się za indywidualizmem, a chcemy żyć kolektywnie albo chcąc czynić dobro tworzymy zło obcując ze znanym każdemu „piekłem dobrych intencji”. Tu często nie radzimy sobie z samymi sobą próbując godzić naturalne, zbierackie pragnienie posiadania z pragnieniem bycia i to sa te dwa rodzaje pożądań, o którym mówił dawno temu prezydent Stanów J. Madison, zdający się dobrze rozmieć istotę poszukiwania pełni, ale i powtarzać I. Kanta uznającego w dziele o metafizyce moralności, że prawo żądz i skłonności jest prawem natury silniejszym niż prawa stanowione przez człowieka ${ }^{98}$. Ani w szkole, ani w domu nie odnajdujemy wyraźnych wskazówek jak powinniśmy stworzyć obraz siebie takiego, jakim być powinniśmy. Tworzymy go na nowo z każdym dniem, każdym znaczącym wydarzeniem i niekiedy taki obraz wydaje się karykatura, niekiedy posagiem. Takie, chaotyczne formy transgresji nie pomagaja nam w stworzeniu drzewa celów, sa to raczej gwiazdozbiory, a między gwiazdami-celami nader często można się zagubić.

To samo setki lat po nich powtórzył uczony: „Rzeczy się nie zmieniaja, pożądanie jest wielką siła generująca człowieka" 99 . Wspomniany prezydent USA myślał o tym, co inaczej nieco wyartykułował inny uczony: „Ciało jest naszym punktem widzenia świata, miejscem w którym umysł uwikłał się w pewną sytuację fizyczną i dziejową" ${ }^{100}$. W naszej kulturze uważamy to za antynomię, a nawet aporię, ale nam zdaje się to czymś naturalnym, bardzo ludzkim i godnym głębszej refleksji. Chcemy mieć i być zarazem, choć proporcje „bycia” i „posiadania” bywają różne. Łączy je jedno podobieństwo, bo chyba ani w byciu, ani w posiadaniu nie znajdujemy granicy zaspokojenia. Gdybyśmy utracili potrzebę spełniania się w rzeczach i nie tylko, groziłaby nam duchowa śmierć, bo to oznaczałoby utratę celów. A chcemy żyć i być i mieć, to naturalne, przy czym posiadanie zwykle bierze górę nad byciem, ale o byciu nie zapominamy chyba do końca rozpamiętując swoje przyszłe wybory, swoje „życie nieprzeżyte” Bezustannie stosujemy ten swój in-

\footnotetext{
${ }^{96}$ K. Horney, Wyktady ostatnie, Poznań 2000, s. 28.

97 J.J. Preece, Prawa mniejszości, Warszawa 2007, s. 19

${ }^{98}$ M. Nelson, The Presidency and the Political System, Washington 1995, s. 200.

${ }^{99}$ M. Foucault, Security, Territory, Population, New York 2007, s. 72.

${ }^{100}$ M. Merlau-Ponty, Proza świata, Warszawa 1976, s. 27.
} 
dywidualny rachunek szczęścia, by móc projektować się w jutrze ${ }^{101}$. Bezustannie dażymy do spełnienia fizycznego i duchowego i ,jest ono tym, co normalne” ${ }^{102}$. Ale taka „normalność" może mieć miejsce tylko w „normalnym” świecie, a taki świat jest konstrukcją idealną wsparta o wielką triadę ludzkości: wolność, równość, sprawiedliwość, kultywowaną na wiele sposobów w świątyniach wiary.

Potrzeba pierwotna, stale w nas obecna, jest to wspominane uzgodnienie się ze światem, przeszłością, teraźniejszościa, przyszłościa i zwykle jednostka jest zmuszana ulegać socjologicznemu, tzw. prawu powszechnej zgodności, czyli przyjmuje takie uzgodnienia, jakie dominują w wyobrażeniach zbiorowych, a jakie sa komponentem wiary zbiorowej. To prawo ulega czasami wzmocnieniom i dzięki niemu niektóre mity, idee, poglądy stają się dla jednostek i społeczności niewątpliwe, niemajace alternatyw i ich próby, nie tyle wyeliminowania, co zmiany, wymagaja niezwykłego trudu ${ }^{103}$. Takim mitem-archetypem jest idea wolności, pojawiająca się w kulturach człowieka od tysięcy lat, przybierając wiele alegorycznych postaci, od mobilizujących, po przejmujące grozą wizje pożeracza świata autorstwa M. Stirnera ${ }^{104}$. Mieliśmy i będziemy mieć z nią wiele kłopotów, a prawdziwe problemy zaczęły się od Hegla i jego zwolenników tworzących ideę wolności indywidualnej umożliwiającej jednostkom możliwość samorealizacji, stawiajacych pytanie bez odpowiedzi. Bo czym jest samorealizacja? Wedle powszechnych opinii jest to spełnienie się w wybranej przez siebie roli, realizowanie własnych celów w zgodzie ze zbiorowościa, oddawanie się ulubionym zajęciom. W każdym przypadku ma ona charakter indywidualny i w każdym przypadku, jak zauważaliśmy wcześniej, jest po prostu niemożliwa, jak niemożliwe jest całkowite spełnienie.

Możemy tylko pytać o to, czy owa samorealizacja jest poszukiwaniem nowych znaków tożsamości. Chyba tak, wiemy o tym, że poszukujemy ich stale. O ile ta tożsamość idem Ricouera pozostaje względnie niezmienna, o tyle tożsamość ipse, budowana przez coraz to nowe wybory jest procesem, który nie kończy się nigdy ${ }^{105}$. Szukamy tej tożsamości wszędzie, także w przeżyciach, które przekraczaja conditio humana. Niemal każdy z nas może potwierdzić te poszukiwania własną praktyką, ale wydaje się, że to tyczy także wspólnot wyobrażonych i jeśli przyjrzymy się tożsamości narodowej, to tam także odkryjemy stała potrzebę poszukiwania i potwierdzania.

\footnotetext{
${ }^{101}$ E. Aronson, Człowiek, istota społeczna, Warszawa 2002, s. 114.

102 R. Spaeman, Osoby. O różnicy między kimś a kimś, Warszawa 2001, s. 57.

${ }^{103}$ R. N. Bellah, Beyond Belief, California University 1991, s. 103.

${ }^{104}$ M. Stirner, Jedyny i jego wtasność, Warszawa 1995, s. 356.

${ }^{105}$ P. Ricoeur, Filozofia osoby, Kraków 1992, s. 33.
} 
Potrzebujemy spełnienia, wierzymy w nie, nie osiagając takiej pełni, jaka by nas satysfakcjonowała. Wciąż towarzyszy nam to kreatywne niezadowolenie ze swego stanu i osiagnięć. Dochodzi do tego, że im więcej człowiek wie, im więcej posiada, tym wyraźniej uświadamia sobie, że nie ma tego, czego by chciał, nie jest tym, kim chciałby być. Choć pewnie wiele razy wolałby nie uświadamiać sobie tego. To niweczy naszą wiarę w teleologię świata, ale wtedy poszukujemy innych jej źródeł, bo życie bez wiary jest niewyobrażalne. 


\section{2}

\section{ZbaWIENIE}

Zauważaliśmy już, że nie wiemy i zapewne nie będziemy wiedzieć, jak wyglądały wizje spełnienia/zbawienia człowieka pierwotnego, ale można mniemać, mając na uwadze sztukę pierwotna, iż nie były to tylko wizje wiązane bezpośrednio z przeżyciem następnego dnia i potrzebami fizjologicznymi. Jak wyglądały jego inne potrzeby? Być może istniały, były bardziej wysublimowane niż sądzimy, o ile zgodzimy się z naukowcem, który stworzył bardzo wysublimowaną koncepcję swojej przestrzeni mentalnej umiejscowionej poza materialną czasoprzestrzenia, choć budzi ona oczywiste wątpliwości ${ }^{1}$. Zapewne nigdy nie odpowiemy na takie pytania i wątpliwości, natomiast możemy stwierdzać, że człowiek walczący i o przetrwanie i o spełnienie, stworzył nie tylko sztukę pierwotna, ale i sztukę przewidywania, bez której nie mógłby przetrwać, bo ona oznacza myślenie o przeżyciu jutra i działaniach służących jutru. Być może i on uczył się dążyć ku niebu odkrywając, że osiaganie różnorako rozumianej pełni własnymi siłami jest niemożliwe przez istotę społeczna, czująca bariery w takich próbach, a w takich chwilach patrzył wyżej i wyżej próbując tłumaczyć po swojemu zachowania natury i kształty swojego ludzkiego otoczenia. Szukając sensu swego krótkiego życia z konieczności spoglądał i w niebo i na ziemię 2 . Chyba niewiele zmieniło się do naszego czasu, jesteśmy wciąż zawieszeni między niebem a ziemią.

Być może transmutacja „człowieka zwierzęcego” w „istotę ludzką" od barbarzyństwa do cywilizacji wyglądała tak, jak widział to A. Giddens: powoli przechodził od bezpośredniej satysfakcji do rozłożonej w czasie, od przyjemności do powściagania się od niej, od rado-

1 E. Meckelburg, Agenci PSI. Manipulowanie nasza świadomościa, Gdynia 1997, s. 322 .

${ }^{2}$ E.H. Erikson, Dopetniony cykl życia, Poznań 2002, s. 76. 
ści do mozołu, od receptywności do produktywności i od braku represji do bezpieczeństwa ${ }^{3}$. Redukował możliwości spełnienia w tworzonych przez siebie społeczeństwach w zamian za bezpieczeństwo powodowany instynktem samozachowawczym, ale o spełnieniu nie zapominał, bo to zdaje się to niemożliwe zważywszy naturalny, ludzki egotyzm. Czynił to powoli w ciagu tysięcy lat walcząc o przetrwanie, w jego imię zmieniając i formy społeczne i samego siebie. Ale także wtedy zasada naczelna było bycie-ku, dla filozofa podstawowa struktura przeżywania ${ }^{4}$. Zrozumienie jutra, tożsame z umiejętnościa przewidywania, jakie pozwoliło mu przetrwać, było rozumieniem celów w przyszłości, a te stawały się drogowskazami bycia. Wykazywał wyższość nad innymi gatunkami umiejąc przewidywać przyszłość, a za taką umiejętnościa szła także umiejętność jej kolonizacji w imię spełnienia indywidualnego i grupowego.

Dualny człowiek pozostawiony sam sobie, podporządkowany tropizmom i instynktom, zapewne byłby bliższy swoim złym stronom, bo niektórzy twierdzą i nie sa oryginalni, że czynienie dobra innym nie jest przewodnim motywem działania jednostek ${ }^{5}$, a on nie był odosobniony, żył we wspólnotach nakładajacych na niego kagańce kulturowe w imię przeżycia i jego, jako jednostki i części grupy. Ale także był ograniczany warunkami wspólnotowymi, choć nie przestawał poszukiwać indywidualnego zbawienia w doczesności, „bo jest ono oczywistym komponentem jego poszukiwań”, co tak mocno akcentował P. Clecak ${ }^{6}$. Wiara w spełnienie w dobrach, w to ziemskie zbawienie falowała, przez wieki człowiek żył w kulturach niespełnienia przekonywany przez rzadzących, przez władców symboli, że to naturalny porządek rzeczy, że nędza, głód to części naturalnego, niezmiennego ładu mającego boskie sankcje. Ale buntował się przeciw temu nader często i nie przestając poszukiwać własnych możliwości zbawienia, spełnienia, uczył się także szukania pełni we wspólnocie, ciagle buntując się, poszukując jego nowych form, od tych, jakie zwiemy prymitywnymi aż do form demokracji ponowczesnej.

Jeśli przyjmiemy sugestie wybitnego socjologa, to możemy zauważyć, iż mimo wahnięć, cywilizujemy się coraz bardziej, coraz dalsi od dawnych postaci zbawienia, ale znajdujacy nowe i wciąż nowe, a te nowe rychło staną się stare, w co nie wątpimy. Dawne, będące kiedyś przedmiotem skrytych pożądań dziś stały się częściami codzienności,

\footnotetext{
${ }^{3}$ A. Giddens, Stanowienie społeczeństwa, Poznań 2003, s. 289.

${ }^{4}$ R. Spaeman, Osoby, s. 53.

${ }^{5}$ S. Kelman, Why Public Ideas Matter, [w:] The Power of Public Ideas, ed. R.B. Reich, Harvard 1990, s. 37.

${ }^{6}$ P. Clecak, America's Quest for the Ideal State, New York 1983, s. 103.
} 
jakich nawet nie zauważamy, bo kto w bogatym, białym świecie pożąda wystarczającej ilości pożywienia? Jakie będą nowe formy? Zdaje się, że tu nie starcza inwencji nawet twórcom literatury Science-Fiction tworzącym w swoim czasie obrazy wyrafinowanych kultur spełnienia, materialnego zwłaszcza, choć niektóre antycypacje moga zdumiewać, a taką była głośna swego czasu powieść C.M. Kornblutha i F. Pohla The Space Merchants.

Nie wiemy także, kiedy człowiek pierwotny odkrył tę „prawdziwa” transcendencję, czy to odkrycie było tożsame z myślami o zbawieniu poza ziemia, nie wiemy, kiedy „odkrył” duszę i jej zadziwiająca go, inspirująca naturę. Możemy mniemać, że stawało się to na etapie konstruowania większych wspólnot, ale przesłanki, jakie czerpiemy choćby z dzisiejszych obserwacji społeczności prymitywnych są i zawodne i budzą osłupienie badaczy graniczące czasem z pełną bezradnościa, jak w przypadku Dajaków, tych słynnych łowców głów z Borneo, którymi kiedyś straszono dzieci, a w których wierzeniach człowiek ma dwie dusze (mana i semangat), z których jedna jest śmiertelna, umiera wraz z człowiekiem, druga zaś jest nieśmiertelna, a Dajakowie zdają się w to wierzyć od pokoleń, co może służyć za przesłankę do pochopnego wniosku, że byli bardziej wyrafinowani filozoficznie od starożytnych Greków. Wiemy tylko, choć są to także tylko pozory pewności, że człowiek, jako jedyne pośród stworzeń, zdaje sobie sprawę ze swej czasowości, przygodności, przemijalności, a równocześnie ma pojęcie nieskończoności trwania i to zderzenie inspiruje i sprawia ból pchający, zmuszajacy do zadawania wciąż nowych pytań i udzielania nowych na nie odpowiedzi. Wiedzac, że kres życia jest widoczny w narodzinach człowiek dąży do nieśmiertelności, a przejawem tego są ślady, jakie zostawia na ziemi, w tym także potomstwo, będące niejako przedłużeniem jego egzystencji. Takie próby zostawienia po sobie śladu w czasie inspiruja pogoń za sława, wyjątkowościa, ale także do jakiegoś stopnia determinuja też sposoby wychowania potomków, bo wielu ludzi chce, by ci potomkowie byli ukształtowani na obraz i podobieństwo jego, by osiągali to, czego nie udało się osiagnąć jemu. Oni są także nadzieją jego spełnienia w trójczasie.

Można jednak wattpić we wczesne odkrycie zbawienia poza ziemia przyglądając się religiom pierwszych cywilizacji ludzkich, ale chyba dość wcześnie zauważono, że religia jest mocnym spoiwem społeczności będąc źródłem systemów aksjonormatywnych, że legitymizuje formy władzy, jest depozytem wartości tak potrzebnych społecznościom nadając sens ich formom. Tworząc wielkie konstrukcje mityczne i pierwociny religii człowiek starał się przede wszystkim poradzić sobie z otaczającym go chaosem, a tworząc odkrywał, że te systemy symboli, jakie 
kreował, budują w nim samym nowe, wszechogarniajacce, trwałe nastroje i motywacje dzięki nowym strukturom ładu istnienia i trwania, a także i to, że owe nastroje i motywacje wydawały się rzeczywiste ${ }^{7}$. Te systemy zapewniały poczucie bezpieczeństwa, niepełnego, ale jednak, bo pierwociny religii to także wspomniane już zyskiwanie przychylności sił wyższych, które kierują biegiem przyrody i życiem człowieka jako integralnej części tej przyrody. Dopiero z czasem, czujący już smak swego panowania nad przyroda, człowiek zaczął poszukiwać nieśmiertelności i potąd nikt nie próbował prześledzić ścieżek tych poszukiwań po to, by odnaleźć ich konsekwencje w historii, a odkrycie nieśmiertelności miało swoje niepojęte konsekwencje, było przecież swego rodzaju rewolucja, bodaj donioślejsza od innych. Ono rodziło idee trwania, a w nich zawarły się, między innymi, nie tylko idee państwowości, „wiecznych imperiów”.

Mówiąc o zbawieniu w ogóle z pewnością wpierw myślimy o tym poza ziemią i życiem doczesnym, zwracając się ku religiom, jedynym depozytariuszom prawd o nim, którym to prawdom nie zagraża nic i nikt, choć tyle się mówiło i mówi o upadku niektórych z nich obserwując zmiany form religijności, defensywę kościołów, różne fundamentalizmy. Religiom nie zdaje się grozić upadek, choć czasami są tak statyczne, jakby nie nadążające za zmianami, co widać w kultywowaniu wielu form religijności nie przystających do czasu. Mają w depozycie istne skarby i ich prawdy objawione sa potrzebne przede wszystkim jako źródła wartości i tego chyba także nie da się kwestionować. Myślimy o tym i myśleć będziemy, bo człowiek - powiada filozof - tak naprawdę chce żyć w teraźniejszości, ale „życie przyszłe jest dla niego czymś więcej, bo wiecznościa, do której tęskni”". Przychodzi nam to z coraz większym trudem, bo od kilku wieków zaczynamy mocniej wierzyć w życie takie, jakim jest ono tu, na ziemi, a wyzwolenie od eschatologii, choć niepełne i chyba jednak niemożliwe, jest jakby naturalną konsekwencją porównań nieba i piekła niebieskiego z ziemskimi.

Prezentując powyżej jedno $\mathrm{z}$ wielu podobnych wyjaśnień istoty religii zwracamy tylko uwagę na elementarne trudności w zbliżeniu zjawisk jakościowych, jakie wymagają w rozważaniach teologów i filozofów tłumaczeń przez inne metafory. Brak tu komponentu pierwotnego, czyli samego człowieka adaptującego i reinterpretującego te systemy, a przecież chyba nie ma wątpliwości, że religie sa źródłem odpowiedzi na pytania najprostsze o sens istnienia, strukturę i istotę świata, przyczyny ludzkiej nietrwałości. Ale wiele takich odpowiedzi nie zawsze sa-

\footnotetext{
${ }^{7}$ C. Geertz, Interpretacja kultur, Kraków 2005, s. 112.

${ }^{8}$ R.N. Bellah, Beyond Belief, s. 23.
} 
tysfakcjonuje niepokornego człowieka, buntującego się nawet przeciw sobie. Wtedy zwłaszcza, kiedy nie są one mocno bijącym źródłem wzorów postaw i zachowań ${ }^{9}$. Takich wzorów, jakie są niczym innym, jak wzorami społecznego universum.

Próbujacc odpowiadać na pytanie o siły sprawcze religii zauważamy, że setki autorów zbliżających początki religii chrześcijańskiej z dawna i tak samo odpowiadaja na pytanie o to, jak stało się, że płomień chrześcijaństwa tak szybko rozświetlił mroki Rzymu i dlaczego tak, i szybko, i skutecznie nowa religia owładnęła wyobraźnią zbiorowa milionów biednych i bogatych, mądrych i głupich. Wiemy o tym, że do czasu pojawienia się chrześcijaństwa Rzymianie traktowali inne religie $\mathrm{z}$ iście rzymskim poczuciem symetrii i praktyczności. Rzym przyjmował dziesiątki obcych bogów nie prześladując zbyt często wyznawców tych bogów, a chrześcijanie, wedle tradycji, bardzo szybko zostali uznani za element niepożądany, niefunkcjonalny i to budzi zasadne pytania, $\mathrm{w}$ tym pytania o to, czy tak było na pewno, jeśli historia chrześcijaństwa była pisana wyłącznie przez chrześcijan. Nie sposób kwestionować starych i prostych wyjaśnien, że była to religia uniwersalna, mogąca łączyć wszystkich uciśnionych bez względu na wiek, płeć, kolor skóry, status społeczny i dlatego stanowiła tak wielkie niebezpieczeństwo dla imperium w rozkwicie. Można jednak kwestionować te argumenty, że była to religia uciśnionych, bo badacze wskazuja, że chrześcijaństwo korzeniło się najlepiej wśród warstw średnich i dlatego było takim niebezpieczeństwem dla rządzących Rzymem, nie odpowiadając na oczywiste pytanie o to, dlaczego było takim niebezpieczeństwem ${ }^{10}$. Można kwestionować także unikalny uniwersalizm chrześcijaństwa, czego często nie zauważają wyjaśniający. Nie wszystkie to wyjaśnienia z setek, ale wszystkie one pozostawiaja jednak spory niedosyt, bo nie wskazuja, jakie elementy przekonywały, łączyły najmocniej taką nowa postać wspólnoty wyobrażonej w tak krótkim czasie, dlaczego poddajaca się władzy świeckiej wiara, oddająca cesarzowi co cesarskie, była aż takim zagrożeniem, o ile była nim naprawdę, bo i tu mamy prawo mieć wątpliwości.

Porównując erupcję chrześcijaństwa z wybuchem islamu i sama istotę obu religii zaczynamy zauważać, że nie są to wyjaśnienia wystarczające i jeśli jeszcze zapytamy o elementy, jakie dawały chrześcijaństwu tak zdecydowaną przewagę nad religiami pierwotnymi i judaizmem, podówczas rysuje się inna, znacznie zmodyfikowana odpowiedź. Niepełna, bo nie sposób takiej udzielić nie badając grun-

\footnotetext{
${ }^{9}$ C. Staples Lewis, Listy o modlitwie i moralności, Warszawa 1980, s. 48.

${ }^{10}$ M. Simon, Cywilizacja wczesnego chrześcijaństwa, Warszawa 1979, s. 40.
} 
townie psychosfery tamtego czasu, co, zdaniem historyków, ociera się o granice niemożliwości. Tu musimy zauważyć, że zbyt często traktujemy ludzi z dalekiej przeszłości jako podobnych do nas, mierzymy ich swoimi miarami nie dopuszczając inności i nie próbując rekonstruować antroposfery. Oni przecież byli inni, bardzo inni, a inność determinuje inne postawy i zachowania. Widzimy to dziś, kiedy na przełomie nowoczesności sami zmieniamy się radykalnie w jednym pokoleniu, czasami stajemy się tak inni, że obcy dla siebie samych w ramach nawet rodziny. Chyba nie odczytamy tej inności tak, by zrozumieć wystarczająco dobrze człowieka tamtego czasu, ale odczytywać musimy, bo inaczej nie zrozumiemy siebie, ale takiej konieczności także zdajemy się nie rozumieć wystarczająco dobrze.

Kusząc się o udzielenie takiej odpowiedzi zauważamy, że obie, tak sobie bliskie, religie monoteistyczne, były przede wszystkim wielkimi religiami zbawienia, jakich potąd nie spotykano w kulturach biedy, obiecywały niebiańską rekompensatę za sumy niespełnień wszystkich ludzi, dobrych, złych i pół-dobrych w raju i to oznaczało stworzenie nadziei długiego trwania dla milionów zadających sobie to fundamentalne pytanie o to, czy śmierć jest końcem wszystkiego ${ }^{11}$. Obie stały się religiami spełnienia, tylko $\mathrm{w}$ transcendencji, ale jednak spełnienia majacego ziemską postać, bo raje wypełniały czysto ziemskie ogrody wszelkich rozkoszy gwarantujące spełnienie niedostępne na tym padole. A dodajmy tu jeszcze, że wizje raju utraconego, przede wszystkim $\mathrm{w}$ postaci złotego wieku, były archetypem spotykanym w większości kultur i kultów uprawianych w państwie cezarów. W wielu z nich pojawiały się nadzieje na jego odzyskanie, ale nie były tak pełne, przekonujące, jak w chrześcijaństwie czy islamie, bo te były pewnością. Trzeba także zauważyć i to, że chrześcijaństwo połączyło przede wszystkim ich poddanych, a komunikacja symboliczna w imperium ułatwiała jedność wiary.

Jak się wydaje, realnym zagrożeniem dla rządzących nie była władza Boga nad wiernymi, bo w każdej religii siła bogów nie dawała się porównywać z siłą zwykłych śmiertelników, ale te obietnice zbawienia poza ziemia, które sprawiały, iż chrześcijanie stawali się niefunkcjonalni wobec społeczności imperium odrzucając wiarę $\mathrm{w}$ zbawienie ziemskie, kwestionujac możliwość zbawienia na ziemi w państwie cezarów. Takie wizje zbawienia osłabiały wiarę w zbawienie $\mathrm{w}$ doczesności, a z tym wiarę we władzę, której obowiązkiem było zapewnienie spełnienia. Historycy wspominaja o ideach millenarystycznych rodzących

${ }_{11}$ A. Sepkowski, Millennialne marzenia, „Przegląd Humanistyczny”, nr 3, 2008, s. 1-14. 
wspólnoty nie chcące komponować się z rzymska, o wielkich ruchach monachicznych będących postaciami ucieczki od społeczeństwa tych, którzy wierzyli w szybka paruzję Chrystusa i nadchodzące Królestwo Boże. One były tylko jednym ze zjawisk zagrażających spoistości imperium i praktyczni władcy postanowili odsunać zagrożenie prześladowaniami, których wymiary kwestionuje się częściej i śmielej.

Ale islam? Tu w całej potędze objawiła się ta niepojęta siła spajająca setki dalekich od siebie kulturowo społeczności wyznających inne wierzenia, posługujących się innymi językami, odseparowanych od siebie przez wieki, często od wieków wrogich wobec siebie. Z tej nieobjętej, różnojęzycznej, wielokulturowej mozaiki w ciagu zaledwie wieku powstała wspólnota wiary połączona wizjami zbawienia po śmierci, dopiero poszukująca innych więzi poza religijnymi, w tym także w wojnie ze wszystkimi niewiernymi, bo wizja wspólnego wroga cementuje od prapoczątków. Tu także nie wystarczają ogólne wyjaśnienia, że islam był silna, świadomą siebie, zdobywcza wiara, bo jednak brak elementarnego pytania o to, dlaczego taką siłą stał się w tak niepojęcie krótkim czasie jednocząc setki tych, uprzednio wrogich sobie, plemion. Przypomnijmy sobie ile lat minęło od waśni Mahometa z Korejszytami do przekroczenia Gibraltaru przez Tarika. W skali historii te kilkadziesiąt lat to ledwie mgnienie

Wydaje się, że sam Mahomet doskonale rozumiał siłę soteriologii i przejmując jej treści z chrześcijaństwa stworzył formy, jakie najlepiej przemawiały do prymitywnych koczowników i jakie dziś także zdaja się wystarczająco przekonujące dla wyznawców, wśród których „ludzie wiedzy" są zdecydowaną mniejszościa. Bez tych wizji zbawienia stworzenie takiej jakości wiary spajającej taki kalejdoskop narodów, wydaje się nam niemożliwe. Stworzono je wzorując się na chrześcijańskich i dostosowujac do kształtów społeczności. Znajdziemy na to wiele potwierdzeń i tak, dla znawcy islamu, koncepcje eschatologiczne, a także opisy raju i tortur piekła „sa paralelne do odpowiednich partii pism chrześcijan syryjskich, ojców i mnichów"12. A dziś ta soteriologia, wespół z nędzą i nierównością rodzą bunt poszukujący zaskakujących nas form ekspresji ${ }^{13}$. Ten bunt jest jednak nakierowany na możliwość zbawienia siebie w doczesności. Nędzarze, tak często przepełnieni żądzą niszczenia, nie chca nawracać innych, pełni wstydu i upokorzenia poszukuja pełni życia na ziemi dla siebie zdając sobie sprawę z tego, że bogaci są Innymi ${ }^{14}$.

\footnotetext{
${ }^{12}$ H.A.R. Gibb, Mahometanizm. Przeglad historyczny, Warszawa 1965, s. 34.

${ }^{13}$ M. Walzer, Polityka i namiętności. O bardziej egalitarny liberalizm, Warszawa 2006, s. 192.

${ }^{14}$ R. Lister, Bieda, Warszawa 2007, s. 126.
} 
Jak wiemy, religie grecka czy rzymska, bo nie wspominamy o innych religiach starożytnych, właściwie nie miały wyrazistej eschatologii i soteriologii po części za sprawą, innego niż nasz, postrzegania czasu. Kołowe koncepcje czasu zakładały wieczne trwanie, to wiara $\mathrm{w}$ nieuchronne powtarzanie się cyklu dziejów co kilka tysięcy lat w tej samej formie, tej samej postaci. W tych kulturach nikt nie był ciekaw końca świata, bo ten świat właściwie się nie kończył ${ }^{15}$. Żyjący mieli pewność powrotu w następnym kole czasu i powtórzenia raz jeszcze cyklu życia bez żadnych zmian, co było oczywistą inspiracją dla jak najpełniejszego przeżycia tego czasu, jaki żyjącym dali bogowie w tym cyklu. Dla Greków soter oznaczał zbawcę niebiańskiego albo ziemskiego. Niebiańskim, zarówno w religii greckiej, jak i później w zimnej i prozaicznej religii Rzymian, bywał jeden z bogów, od którego oczekiwano pomocy w zwykłych, życiowych sprawach, chorobie, w interesach, miłości, tych małych, codziennych spełnieniach. Modlono się więc do Asklepiosa i Hermesa, Apollina i Ateny spodziewając się ich łask, ale obdarzano przydomkiem „zbawcy” także władców, którzy zdobywali miłość ludu szlachetnymi czynami, a władcy bardzo chętnie nazywali siebie sotera$m i$, bo niewielu zostało tak nazwanych przez ich poddanych.

Takich, którzy naprawdę zasługiwali się na takie miano nie było zbyt wielu i zwykle władcy nadawali sobie ten tytuł, nie zawsze w zgodzie ze swymi czynami. W Grecji i Rzymie religię traktowano nader praktycznie widząc w niej spoiwo społeczności i, także z praktycznych względów, bez cienia tego, co zwiemy fanatyzmem, czasami karano za bezbożność nawet śmiercia, choć to nie ludzie, a właśnie bogowie popełniali czyny gorsze niż słabi ludzie. Jeśli przyjrzymy się Zeusowi, to bez trudu zauważymy, iż popełniał wszystkie grzechy będąc hipostaza ludzkich słabości, ale i cnót. Ci śmiertelnicy, którzy szli w jego ślady ważąc się na podobne czyny, tylko potwierdzali swoją wielkość, jak ojcobójca Aleksander, o ile sugestie niektórych historyków starożytności sa bliskie prawdy historycznej.

Tylko wyjątkowi herosi, wybierani zwykle przez bogów, mieli szanse znalezienia się na Olimpie i ich szereg nie był najdłuższy, co wiemy z mitologii greckiej. Tylko wyjątkowi przestępcy przeciw bogom i ludziom trafiali do Tartaru, tego greckiego „piekła” znajdującego się pod Hadesem: Tantal, Syzyf, Iksjon. Ci, którzy najmocniej buntowali się przeciw tak bardzo ludzkim bogom, którzy byli personifikacjami nie tylko zalet, ale i wad człowieka. Wszyscy inni śmiertelnicy musieli znaleźć się w Hadesie, posępnej krainie podzielonej wieloma rzekami, jak przerażone cienie z Odysei zaprowadzone przez Hermesa na asfodelo-

${ }^{15}$ F. Cuomo, Wielkie proroctwa, Kraków 2004, s. 121. 
we łąki, „gdzie mary nieboszczyków zamieszkują blade”. Przywołany przez Odysa Achilles mówił, że wolałby być pastuchem świń niż królem podziemnych cieni, a w ostatniej księdze epopei wszyscy zabici przez Odysa zalotnicy tam właśnie wędruja. Nic nie wskazuje na to, że oddzielano dobrych od złych i praktyczne wskazówki dla żyjących były oczywiste - ziemskie postępki nie mają znaczenia dla losów po śmierci, o tych decyduja kapryśni i nieobliczalni bogowie. A skoro tak, to trzeba żyć jak najpełniej, najwygodniej, ciesząc się chwila. Dopiero orficy zaproponowali odmienną wizję świata i pośmiertnych losów człowieka. Grecy, przekonani, że w następnym cyklu raz jeszcze przeżyją to samo życie, poszukiwali spełnienia w doczesności i, można mniemać, że jednym z tych ich „wynalazków”, jaki przypisujemy przede wszystkim Ateńczykom, było zbawienie przez wiedzę. Problemem, jaki zniekształcał ów prosty z pozoru obraz był problem nieśmiertelnej duszy.

Te i inne problemy, z problemem zbawienia w doczesności na czele ${ }^{16}$, próbowali rozwiązywać gnostycy wszystkich czasów dążący do nadania życiu immanentnego sensu, wierzący, iż taki istnieje w głębokim ukryciu. Wiedza ezoteryczna, ich zdaniem pewna, miała być tu pomostem zbawienia i za wszelką cenę poprzez taką wiedzę dążyli do uzyskania pewności, co tak często zwodziło ich na mistyczne manowce poznania i potępienie zarówno przez ludzi wiary, jak i wiedzy. Tworząc swoje wyznanie gnostycy przypisywali sobie jedynie prawdziwą wiedzę $\mathrm{w}$ formie własnej doktryny skupiając się w sektach zamkniętych często dla nie rozumiejącego ich świata ${ }^{17}$. Już w pierwotnej teologii gnostycyzmu starożytnego Bóg jest pozaświatowy, obcy naturze świata, który nie jest jego dziełem. Świat jest dziełem sił niższych, które nie znają prawdziwego Boga, acz moga od niego pochodzić. Takie ślady gnostycyzmu spotkamy w niejednej herezji średniowiecznej, ale wydaje się, że w chrześcijaństwie gnostycyzm „właściwy” opierał się przede wszystkim na chrystologii ${ }^{18}$.

W soteriologii judaistycznej zbawienie ma dokonać się na tym świecie i Mesjasz umożliwi zbawienie narodu wybranego $\mathrm{w}$ historii dając mu spełnienie $\mathrm{w}$ potędze zbiorowości osiagającej za jego sprawa pełnię ziemskiego szczęścia, choć nie jest to spełnienie dla jednostek. Stary Testament wspomina, co prawda o wynoszeniu przez Boga wybranych jednostek, ale idea powstania z martwych i zbawienia poza ziemia jest w nim nieczytelna, a jeszcze bardziej powikłana w licznych egzegezach. Nietrudno zauważyć, że teologia judaistyczna była bardzo ostrożna w kreowaniu ram eschatologicznych wiązana chyba profetycz-

\footnotetext{
${ }^{16}$ M. Brumlik, Gnostycy. Marzenie o samozbawieniu człowieka, Gdynia 1999, s. 28.

${ }^{17}$ H. Jonas, Religia gnozy, Warszawa 1994, s. 48.

${ }^{18}$ M. Brumlik, Gnostycy, s. 199.
} 
nymi wizjami zbawienia całego narodu. Nadto, nie rozwiązano problemu rozdzielenia ciała i duszy, tak jak w soteriologii chrześcijańskiej. W niektórych wykładniach sprzed naszej ery dusze, zachowując świadomość tego, co dzieje się na ziemi, istnieja jako samoistne byty i już sam problem zmartwychwstania pozostawiał wiele wątpliwości. Może o wiele mniej w poczatkach naszej ery, kiedy inspiracje doktryny chrześcijańskiej okazały się niewątpliwe i rabini dostrzegli niezwykłe siły soteriologii, jakby dojrzewającej w wyobrażeniach zbiorowych. Rabin Jakub w II wieku stwierdzał, że ten świat jest tylko przedsionkiem świata przyszłego, ale nie były to wizje literalne, obrazowe. Kryły się pod postaciami hiperboli. Wedle Jakuba grzesznicy musieli odcierpieć swoje przewiny w gehinnom (dolinie Gehenny) będaccym połaczeniem piekła i czyśćca, a zbawieni odnajdywali się w Ogrodzie Edenu ${ }^{19}$. Wiara w Mesjasza, który miał wskazać drogę do ziemskiego raju. została przejęta przez chrześcijaństwo, a wraz z nią także wizje Królestwa Bożego na ziemi, czyli wizje spełnienia w doczesności.

Eschatologia i soteriologia chrześcijańska na swój sposób oswajały odwieczny strach przed śmiercia, nicościa, ten strach zakodowany przez ewolucję, a widomy choćby w tym, że zawsze najpierw widzimy jakieś zagrożenia ${ }^{20}$. Być może niemożność wyobrażenia sobie pełni zbawienia w doczesności pomagała w uczynieniu z wieczności miejsca spełnionych pragnień, ale nigdy nie wystarczających żyjącym, chcacym się spełniać w tym życiu, bo to się przeżywa, czuje i między „tu” a obietnica „tam” jest zbyt wiele przepaści. Historię i przyszłość, która staje się historia, uczyniono historia zbawienia i wpierw stała się poszukiwaniem pozaziemskiej doskonałości, aby po czasie przekształcić się w historię postępu ${ }^{21}$, choć miną wieki nim tak się stanie.

Wizje zbawienia i potępienia przybierały postaci nieba i piekła tworzone dla człowieka archaicznego, magicznego i mitycznego. Pozostały takimi także dla nas, choć świat zmienił się bardzo i dziśs nawet teolog przyznaje, że czuje wobec nich „zmieszanie” ${ }^{22}$. Nietrudno zauważyć, że wielka literatura wizyjna, która wykreowała „klasyczne” obrazy nieba i piekła, jest nam zupełnie nieznana i dziś już nie podziwiamy wizji piekła z Apokalipsy Piotra, wizji Sylwiusza z Tours, Bedy Czcigodnego, czy Drythelma. Możemy jedynie odnajdywać klimat tych wizji w ikonice okresu, a wspaniałym artystycznym wykwitem jest Sqd Ostateczny H. Memlinga. Wcześniej, w czasie wielkiej schizmy wschodniej, misję zbawienia ludzkości przejął młody Kościół kwestionując pierwot-

\footnotetext{
${ }^{19}$ A. Unterman, Żydzi. Wiara i życie, Łódź 1989, s. 45.

${ }^{20}$ R. Coniff, Korporacyjne zwierze, Warszawa 2006, s. 58.

${ }^{21}$ G. Vattimo, Koniec nowoczesności, Kraków 2006, s. 8.

${ }^{22}$ B. Sesboue, Wierzę, Warszawa 2000, s. 386.
} 
ne chrystologie i lex Christi (prawo Chrystusowe) zamieniajac na lex ecclesiae $\mathrm{w}$ interesie pantrokratorów bizantyjskich. I odtąd tylko ludzie Kościoła wskazywać mogli drogi zbawienia poza ziemią uzurpując sobie prawo na wyłączność. Kościół zapomniał jednak o konieczności tworzenia mutacji soteriologii ziemskiej przystającej do nowych czasów i efektem były tu ruchy heretyckie i „schizmatyckie”, które próbowały godzić obie formy zbawienia.

Przed wielkimi wizjonerami i twórcami wizji demono- i angelologicznych, do ówczesnych postaci zbawienia wiernych przekonywały wizje ewangelistów i filozofów chrześcijańskich, Jamblicha, Bazylidesa i samego Augustyna, poprzedzane ewangelicznymi wykładniami zła przeznaczonymi dla nędzarzy, tego zła, które, wedle nich, dotyka wszystkich. W społecznościach biedy owo ewangeliczne zło to troska ludzi o dobra tego świata, krótkotrwała i przejściowa, która sprawia, że człowiek odwraca się od Boga i skazuje się na potępienie w piekle. Obrazy nieba i piekła z aniołami i diabłami - miejsca, gdzie mieli znaleźć się zbawieni i potępieni miały budzić strach i nadzieję, ale w tych wizjach, zrytualizowanych jakby z obowiazku, brak było takiej konsekwencji, jaką znajdziemy w islamie i to zdaje się być inspiracją sposobu naśladowania soteriologii chrześcijańskiej przez twórców islamu. Oni chcieli uniknąć niedopowiedzeń i niejasności tworzac inne wizje skazania i wywyższenia, takie, jakie mogły zostać zaakceptowane przez innych adresatów.

A wszelkie pytania człowieka racjonalizujacego jakość przestrzeni między nim a Bogiem moga budzić ogrom wątpliwości poczynając od wątpliwości we wszechmoc Boga, tych dręczących pytań, które zrodziły bogomiłów, a potem inne herezje chrześcijańskie z satanizmem w końcu. Problemem, jakiego teologowie i filozofowie nie zdołali rozwiązać przez wieki był problem teodycei, pytania o źródła zła w świecie stworzonym przecież przez Boga będącego trójjednia prawdy, dobra i piękna, pytania o to, dlaczego ten świat nie jest ani dobry, ani piękny, ani prawdziwy, a człowiek jest w nim skazany na niespełnienie. By móc tłumaczyć takie niekonsekwencje, poza twierdzeniami, że Bóg stworzył zło dla próbowania człowieka, przywołano diabła (dość późno) i przywołano także kłopoty z nim po części za sprawą tertuliańskiego credo.

Kiedy przyglądamy się początkom „funkcjonowania” diabła w kulturze już budza się w nas spore wątpliwości, bo przecież diabły to upadłe anioły, wedle jednej wykładni potępione przez Boga za to, że pomagały, ale także deprawowały człowieka. Strącone z nieba po wielkiej bitwie nad Har Megiddo znalazły się w czeluściach tracąc swoje anielskie atrybuty, ale zyskując zarazem moc równą boskiej, co już zdaje się niezrozumiałe, bo przecież to podważało dogmat o wszechmocy Boga. 
Kościół po swojemu tłumaczył takie niekonsekwencje, ale postać diabła stawała się dla niego coraz bardziej atrakcyjna wtedy, kiedy wolał rzadzić wiernymi strachem, nie nadzieja ${ }^{23}$. W takim sensie diabeł stawał się większym sprzymierzeńcem Kościoła niż anioły, które i tak istniały poza obiecywanym rajem, a których istoty także nie zdołano „odkryć” pozostawiając je w granicach prawd objawionych. Kościół zapominał o sile nadziei zbiorowej, jaka go zrodziła, nie kultywując ani nie moderując wizji tamtego, lepszego świata i wierni nie wiedzieli nawet tego, czy ów raj ma być tym utraconym. Takie obrócenie się w kierunku strachu odbierało moc nadziei i wizje piekła przysłoniły wizje nieba, a, co za tym idzie, dróg wiodących ku prawdziwemu zbawieniu.

Wizje piekła i nieba korygowano wielokrotnie i modyfikowano wtedy, kiedy wiara eschatologiczna słabła, ale nietrudno zauważyć, że owe korekty były raczej umowne, powierzchowne i niekiedy niosły więcej strat niż pożytku, a były zwykle dziełem wyalienowanych elit kościelnych, tak to postrzegaja historycy średniowiecza z kręgu Annales. Nie wiemy dokładnie, jak wyglądały ekonomiczne i społeczne determinanty modyfikacji eschatologii o doktrynę czyśćca, ale wydaje się, że wtedy znacznie osłabła idea zbawienia poza ziemia, czego potwierdzeniem zdają się ruchy heretyckie i stworzono nowe ramy nadziei soteriologicznej dla zwykłych ludzi, ani dobrych, ani złych. Ale, wydaje się, że ciosem najsilniejszym, który radykalnie zmienił losy Europy i samego chrześcijaństwa, było utowarowienie zbawienia - kuriozalna instytucja odpustów, możliwość odkupienia także tych grzechów, jakich Bóg nie wybacza grzesznikom nawet na Sądzie Ostatecznym, co niektórzy herezjarchowie zasadnie zwali świętokradztwem. Ten cios, zadany przez Kościół samemu sobie, odczuto dopiero w czasie prawdziwego odrodzenia myśli, czasie wielkich schizm, ale nie wydaje się, by nawet wtedy Kościół wyciagną z tego pożyteczne nauki dla siebie. Zdaje się to potwierdzać głośny spór o uszczęśliwienie, między papieżem Janem XXII, a uczniem Ockhama Janem Buridanem.

Nie jest celem autora zbliżanie pełniejszych postaci zbawienia $\mathrm{w}$ transcendencji, takiego zbawienia, jakie wedle teologów jest pewnościa, ani wizji angelo- i demonologicznych. Ono jest dla nas istotne jako czynnik, który przez wieki dominował w wyobrażeniach zbiorowych, był źródłem nadziei dla biednych, fatalistycznych mas. Jakiekolwiek postaci wyzwolenia od nędzy dni powszednich przez wieki zdawały się tylko chimerami, liczyło się przeżycie każdego następnego dnia. Dla człowieka mitycznego, przywiązanego do miejsca urodzenia, ład świata zdawał się ustalony na zawsze przez demiurga, a on sam na łasce Jego

${ }^{23}$ G. Minois, Diabet, Warszawa 2001, s. 57. 
i depozytariuszy prawd o Nim. Tylko co jakiś czas krańcowa desperacja nędzarzy prowadziła do rewolt, powstań, rebelii i nie sposób nie zauważyć, iż były to wybuchy w imię spełnienia tu, na ziemi. I to spełnienia tylko w nieznanej, niewyobrażalnej sytości, którą zaczęto wyobrażać sobie dopiero w wieku utopii w najbogatszych krajach kontynentu.

Przyglądając się historii „dalekiej” z naszego czasu konsumeryzmu, my, wyzwoleni z chronicznego niedostatku wieków, zapominamy o tym, że przez tysiące lat przeważająca większość ludzi żyła w nędzy, jakiej nawet sobie nie wyobrażamy, zwyczajna zrytualizowanych przekonań, że jest to stan naturalny, niezmienny i niezgoda na taki stan jest występkiem przeciw Bogu czy naturze świata. Poza tą niewyobrażalna, niemal zupełnie pomijana przez badaczy przeszłości nędza, były to wielorakie formy zniewolenia oraz to, co ówcześni pojmowali jako niesprawiedliwość, choć w majestacie ludzkiego prawa, któremu przyznawano boskie legitymacje. Może budzić zdziwienie fakt, że w „cywilizowanej” Anglii XVII stulecia za samo tylko podejrzenie o kłusownictwo sędzia pokoju mógł skazać kogoś na śmierć ${ }^{24}$. Nie wspominamy już o postaciach niewolnictwa $\mathrm{w}$ wieku pary i żelaza, pracy dzieci w kopalniach i tym podobnych formach i nie sposób nie zauważyć, że Europejczycy nie są skłonni przyznawać się do tego, co w tej Europie było barbarzyństwem przed zaledwie stu kilkudziesięciu laty, choć barbarzyństwo to tylko eufemizm. Łatwo zapominamy także o tym, iż niełatwo jest sytym zrozumieć głodnych. Tę łatwość zapominania możemy weryfikować i dziś nie chcąc widzieć piekła Afryki i Azji.

Winniśmy pamiętać także o tym, że były to kultury spełnienia tylko waskich elit, ale takie konstatacje w nauce, zwłaszcza w historii, bywaja rzadkościa, choć nędza była, jest i na długi czas pozostanie wielkim, niedocenianym przez ludzi nauki motorem historii, ale uwag, podobnych do tej R. Jungka, nie zauważano ${ }^{25}$. Zastany świat zawsze gnębi przynajmniej część żyjących w nim ludzi, a oni mogą rozumieć owo gnębienie tylko przez odwołanie się do idealizacji ewangelicznych wolności, równości, sprawiedliwości ${ }^{26}$, a takie odwołania oznaczały właśnie powstawanie wielkich ruchów społecznych, ale i małych buntów często umykających uwadze historyków. Człowiek polityczny, gotów przejawiać aktywność i ofiarność w imię jakiejś idei, nawet trudno zrozumiałej, pojawia się właśnie wtedy, kiedy zaczyna aktywnie myśleć o spełnieniu, przede wszystkim materialnym i to, wydaje się, była reguła każdego czasu. Człowiek protopolityczny chyba myślał o spełnieniu tylko w desperacji, jaką rodzi głód, poczucie upodlenia.

${ }_{24}$ J. Burke, R. Ornstein, Ostrze geniuszu, Warszawa 1999, s. 163.

${ }^{25}$ R. Jungk, Człowiek tysiaclecia, Warszawa 1981, s. 22.

${ }^{26}$ M. Walzer, Polityka namiętności, s. 28. 
Ta niedostrzegana nędza pozostanie takim motorem dziejów aż po czas, kiedy wreszcie stanie się marginesem w skali świata, o ile sprawdzą się projekcje największych optymistów, choć takich jest niewielu i kilkunastu z nich przypomnimy w następnych rozdziałach. Dziś to, przede wszystkim za jej przyczyna mamy do czynienia z zalewem imigrantów z Azji i Afryki i nawet „raje utracone”, jak nazywa się Szwecję za sprawa zmian w polityce społecznej, są dla nędzarzy rajami odzyskanymi ${ }^{27}$. A państwa socjalne w dobie globalizacji zaczynają bankrutować, jak, z częsta u „prowokatora” przesada, twierdził L. Thurow i także w społeczeństwach bogatych pojawiają się ślady syndromu „raju utraconego", nie po raz pierwszy w dziejach człowieka, ale czasami twierdzi się, że tym razem jest to raj tracony naprawdę. Wiele wskazuje na to, że ten syndrom będzie się umacniał, rozbudowywał w dobie niekontrolowanej globalizacji grożąc bogatym, biednym i nędzarzom, a takie rozróżnienie zdaje się zasadne. Ogromna większość 6 miliardów ludzi - zauważał swego czasu E. Wilson - jest uboga, miliard wegetuje na skraju śmierci głodowej i wszyscy nędzarze tego świata za wszelka cenę starają się polepszyć warunki życia ${ }^{28}$. Bogaci, ale także „biedni”, nie chcą dostrzegać tego, że troska o polepszenie własnego losu stanowi cechę przyrodzona człowieka - co zauważał historyk, dodając, że może ona dotyczyć warunków bytu materialnego, jak osiagnięcie wyższego stopnia doskonałości duchowej ${ }^{29}$. Przede wszystkim dotyczy jednak tego, co pozwala przeżyć, bo trudno jest myśleć o spełnieniu duchowym przymierając głodem, jeżeli nie jest się derwiszem albo hinduskim sadhu.

Nie tylko nędza była codziennością człowieka w przeszłości, ale niekończący się przez wieki koszmar wojen, które, zdaniem władców symboli, także miały być naturalnym „regulatorem” społecznej homeostazy i czynić każdego z członków zbiorowości wojownikiem mającym umierać za ideały ${ }^{30}$. Powracając do głównego nurtu rozważań i zostawiając wojnę polemologom, zauważamy, że z eschatologii wyrastały jednak buntownicze ruchy zbawienia, które w historii zwie się heretyckimi, choć nie zawsze zasadnie, bo czy można zwać herezją inną od oficjalnej interpretację Pisma? Wiemy skądinąd, że tylko niektóre z takich reinterpretacji zostały potraktowane przez kościół jako herezje, niektóre zaś nie, choć herezjami jednak były. Nie to jest jednak istotne, ale to, że rodziły się z dopełniania postaci Boga Stwórcy Bogiem Zbawca, a to

${ }^{27}$ C.N. Schierup, P. Hansen, S. Castles, Migration, Citizenship and the European Welfare State, Oxford 2006, s. 195.

${ }^{28}$ E.O. Wilson, Przyszłość życia, Poznań 2003, s. 25.

${ }^{29}$ T. Manteuffel, Narodziny herezji, Warszawa 1964, s. 5.

${ }^{30}$ D. Tannen, Cywilizacja kłótni, Poznań 2004, s. 31. 
musiało rodzić bunt, niezgodę ${ }^{31}$. Zarówno te ruchy, jak i próby intelektualistów ucieczki przed wszechmoca kościoła wzięły się chyba stąd, że nader często praktyka instytucji kościelnych nie doskonaliła człowieka, zmieniała go w niewolnika rytuałów nie wskazując przekonujących wyznawców dróg zbawienia. Nie bez znaczenia było to, że ludzie Kościoła stawiali się często ponad prawem prowadząc życie niezgodne ze swoimi zaleceniami, jak delikatnie określił to historyk ${ }^{32}$. Joachim z Fiore, Franciszek z Asyżu, a przed nimi Waldo i setki innych poszukujących pełni wiary, pragnęli by Kościół pełnił swoją misję zbawczą wracając z powrotem ku wykładni chrystologicznej, a sam Franciszek, naiwny biedaczyna boży, chciał uczyć prałatów życia w zgodzie z Pismem. Te ich dezyderaty sa aktualne po dziś, wciąż rodzą nowe formy kontestacji postaci zbawienia sola fide.

Wtedy, kiedy wspólnota wiary przestaje być prawdziwa, namacalną wspólnotą zbawienia jednostki odchodzą od Kościoła tworząc swoją wspólnotę wyobrażoną i taka z pewnością „nie jest nieautentyczna” - stwierdzał historyk idei ${ }^{33}$. Takimi wspólnotami były monachiczne ruchy początków naszej ery, kiedy jeszcze nie istniały formalne struktury kościelne, a żywotna była wiara w ponowne nadejście Chrystusa i zbawienie przez niego nie w niebie, ale na ziemi. Później zaś ilość buntów indywidualnych przeciw fałszywej religijności, połączonych z próbami tworzenia „prawdziwych” wspólnot wiary, szła w setki aż po czas, kiedy wiekowe postaci religijności zaczęła kontestować filozofia Odrodzenia, a po niej Oświecenia pytające przede wszystkim o spełnienie zbiorowe $\mathrm{i}$ indywidualne, tu, na ziemi, ale i w niebie. Zdaje się, że wielu filozofów epoki nowożytnej podpisałoby się pod postulatem Herdera: „Celem, do jakiego zmierza nasze teraźniejsze istnienie jest kształtowanie człowieczeństwa, do wytworzenia którego mają służyć, a nawet prowadzić wszystkie nasze ziemskie potrzeby" ${ }^{34}$. One są ważniejsze niż się sądzi i pod takim sądem z pewnością podpisałby się klasyk nauki amerykańskiej Ch. Beard, powiadający iż pytaniem odwiecznym dla każdego $z$ nas jest pytanie o to, czego potrzebuję ${ }^{35}$. Na takie nie udzielono jeszcze odpowiedzi, ale nie to jest istotne, że nie uda się jej znaleźć, a to, że samo pytanie jest tylko częściowo obecne w naukach społecznych.

Pragnienie pełni życia w naszej erze, spełnienia się w materialności i duchowości zarazem, pojawiło się na krótko i tylko w waskich krę-

\footnotetext{
${ }^{31}$ M. Brumlik, Gnostycy, s. 315

${ }^{32}$ B. Kumor, Historia Kościoła. Czasy wspótczesne, Lublin 2001, s. 674.

${ }^{33}$ E. Lott, Love and Theft, Oxford 1995, s. 93.

${ }^{34}$ J.G. Herder, Myśli o filozofii dziejów, Warszawa 1962, t. I, s. 217.

${ }^{35}$ Ch. Beard, The American Spirit. A Study of the Idea of Civilization in the United States, New York 1942, s. 2.
} 
gach w okresie Odrodzenia. Elity umysłowe owego czasu poczęły kontestować obraz człowieka jako istoty kruchej, słabej i samotnej, odartej z godności, niby będącej dziełem Stwórcy na obraz i podobieństwo Jego, a jednak żyjącej w prochu, nie mogącej uczynić nawet jednego kroku samodzielnie. Czując smak spełnienia materialnego w okresie względnej ekonomicznej prosperity ten człowiek zapragnał odmiany, wolności i dlatego tak „namiętnie marzył o ziemskim raju” ${ }^{36}$. Nie znaczy to, że ludzie Odrodzenia „odkryli” prawo spełnienia się w materialności, co się czasami sugeruje. Oni po prostu przypomnieli współczesnym możliwości dobrze znane nie tylko Grekom i Rzymianom. Samo Odrodzenie było jakąś formą reakcji na to, co G.K. Chesterton nazwał przeżyciem się, dewiacją starych cnót chrześcijańskich, na swój sposób zdegenerowanych, zostawionych sobie ${ }^{37}$. Wydaje się, że religia i religijność budowane dla innego czasu powinny mutować, zmieniać się wraz $z$ drgnieniami czasu, ale one pozostawały niezmienne i stąd postaci buntu przeciw nim, a Kościół zapomniał o tym, że człowiek się zmienia, zmieniaja jego potrzeby, a marzenia o lepszym świecie, jakie wówczas powróciły, nie mieściły się w nauce Kościoła, one ugrzęzły w przeżytej eschatologii.

Formami „dewiacji” kontestowanych w tym czasie były zachowania elit kościelnych, które warowały dla siebie prawo do szczęścia, a reakcja na takie zachowania były „heretyckie” dezyderaty Zwinglego, Erazma, Melanchtona, którzy domagali się niezmiennie, by zasoby tego świata były pożytkowane dla dobra wspólnego, a także manifestowali, niekiedy wręcz hipostazowali, wiarę w wyższa, boską wolność i sprawiedliwość narażając się tym Kościołowi, zwykle bronieni przed jego gniewem opieką możnych protektorów ${ }^{38}$. Jak niemal zawsze przy kwestionowaniu roli Kościoła powracano do ideału chrystologicznego, co było czymś oczywistym dla Erazma, mówiącego: „Szukamy reguł życia - dlaczego na pierwszym miejscu stawiamy inny jakiś wzór, a nie właśnie ten pierwowzór, jakim jest Chrystus?" ${ }^{39}$. Dla takich jak on Chrystus został zesłany na ziemię po to, by stanowić wzór postępowania i ta obecność nie wymaga tłumaczenia tego przyjścia przez kościoły, jest przecież oczywista, tłumaczona przez Pismo. Wielki wzór był oczywisty także dla T. Campanelli, który powtarzał za Ojcami Kościoła, że wiara bez dobrych uczynków jest martwa, a któż jak nie Chrystus jest krynica dobra, wzorem dla tych, którzy chcą czynić dobrze? I nietrudno zauważyć, że za drogą chrystologiczną opowiadali się także sami ludzie

\footnotetext{
${ }^{36}$ J. Delumeau, Cywilizacja Odrodzenia, Warszawa 1987, s. 270.

${ }^{37}$ G.K. Chesterton, Ortodoksja, Warszawa 1998, s. 39.

${ }^{38}$ M. Horkheimer, Społeczne funkcje filozofii, Warszawa 1987, s. 161.

${ }^{39}$ Erazm z Rotterdamu, Trzy rozprawy, Warszawa 2000, s. 150.
} 
Kościoła. Na sto lat przed Campanella Tomas a' Kempis wydał swoje dzieło O naśladowaniu Chrystusa, a Mikołaj z Kuzy widział Chrystusa jako wzór dla całej ludzkości marząc o jednej religii dla całej wspólnoty ludzkiej jakby przeczuwając schizmy. Jakimś paradoksem jest to, że chrystologiczne wzory z pierwszych wieków zostały zaadaptowane przez inne religie, ale $\mathrm{z}$ podobnym skutkiem, bo co znaczy akceptacja tych, którzy czynią dobro w Koranie?

Wracając do Odrodzenia widzimy, że mieszkańcy bogatych miast przypominali sobie zwykłe przyjemności starożytnych, a kiełkujące poczucie wolności pozwalało na artykulacje takich dążeń jak to, które sformułował F. Rabelais w Gargantui i Pantagruelu jako regułę Opactwa Telemy: „Czyń coć się podoba”, co już wykraczało poza potrzeby czysto materialne, bo to było wezwanie do innych postaci spełnienia. Jak niemal zawsze przy rosnącej zamożności, idącej w parze $\mathrm{z}$ odwaga myśli, pojawia się pragnienie życia i użycia, pokusa zakwestionowania tego, co ogranicza naturalne potrzeby i pragnienia, a takie pragnienie na swój sposób wzmacniały praktyki książąt Kościoła sprzeniewierzających się na co dzień temu, co głosili z ambon wynosząc się wysoko ponad gmin. $\mathrm{Na}$ czas jakiś osłabły we wstrzasanej konwulsjami Europie, ale nie zapomniano o nich i powróciły dwa wieki później, w czasie oświeconych poszukiwaczy nowego spojrzenia na świat i jego mieszkańców. Pozostając przy Odrodzeniu nie sposób oprzeć się refleksji tyczącej postrzegania tego okresu przez nauki społeczne, bo budzą wiele zastrzeżeń.

Chyba patrzymy na ten okres właśnie tak, jak ludzie Odrodzenia nie chcieli, byśmy patrzyli. Odwzorowujemy na sposoby najprostsze osiagnięcia twórców tego okresu koncentrując się przede wszystkim na wielkich artystach pędzla i dłuta nie pytając o myśli, które były, wręcz musiały być, pierwotne wobec wyrafinowanych symbolizacji Leonarda, Rafaela, Michała Anioła, a koncentrując się na studiowaniu form ich dzieł, tych form, które często odrywa się od ich treści. Jakoś nie chcemy dostrzegać tego, że przecież to myśl/treść, a nie symbole ikoniczne, które sa tak wieloznaczne i trudne w interpretacji, przesądza o znaczeniu tego okresu i myśliciele, których nie brakło, a którzy, jak się powszechnie przyjmuje, ani dorównują wielkim Oświecenia. To wydaje się nieporozumieniem wynikającym z uwagi, jaką poświęcano obu formacjom intelektualnym. Ludzie Odrodzenia, choć doskwiera ten brak pośród nich myślicieli, jakich uznaje się za wielkich, dokonali przecież rewolucji w poznaniu, a więc i w nauce. Musimy zacząc pytać o to, czy dokonali tego najwięksi epoki? Santi, Michał Anioł, Leonardo? To pytania z rzędu tych, które bywają nazywane „prostymi”.

Raczej nie oni, to pozostajacy w cieniu ówcześni mocarze myśli zakwestionowali wiedzę kumulowana przez szereg wzajemnych po- 
twierdzeń, dzięki nim znowu pojawiło się rozróżnienie, poszukiwanie ładu. Zakwestionowali odwzorowanie jako zwornik wiedzy i w świecie wyobrażeń zbiorowych pojawiły się nowe symbole, które odczytuje się z trudem. Ono - jak zauważa Foucault - kierowało w znacznej mierze egzegezą i interpretacją tekstów, ono organizowało grę symboli, umożliwiało poznanie rzeczy widzialnych i niewidzialnych, rządziło sztuka przedstawiania $^{40}$. Dzięki tym, wciąż nieznanym szerzej, myślicielom kwestionującym prowidencjalizm, pojawiły się koncepcje naturalnej zmiany i właśnie wtedy powróciły wieczne idee postępu, nie później. Być może fascynacja tym, co powierzchowne, a więc wielkimi dziełami artystów, zepchnęła na plan drugi dorobek ludzi myśli, ale sądzić można, iż potrzeba ich przypomnienia pojawi się jeszcze $\mathrm{w}$ historii ludzi i dokonamy obrachunku z Odrodzeniem ku niezadowoleniu uczniów i wielu jego badaczy, ale może z korzyścią dla nas wszystkich.

Wydaje się, że dopiero w końcu wieku XVIII, wraz z ekspansją młodego, drapieżnego kapitalizmu, powszechniejszym staje się przekonanie, że nędza, niewolnictwo to nie jest to stan natury, a ład ustanowiony przez człowieka i z takiego przekonania narodziła się nie tylko teologia naturalna, a wedle niej człowiek może dowiedzieć się więcej o Bogu i świecie z nowych metod poznawania, naukowych obserwacji natury. Tak można odczytywać boskie plany, w tym plany zbawienia. Ze wskazówek oświeceniowych panteistów korzystali skwapliwie zwłaszcza romantyczni rewelatorzy, a ilość prób odczytania planów boskiego ekonoma szła wtedy nie w dziesiątki, a setki. Oni, zbuntowani przeciw Bogu i światu, byli już konsekwencja odkrycia, że zbawienie jest możliwe tu, na ziemi i nie jest to zbawienie w rzeczach, a w duchowości, co zdawało brać się stąd, że jednak kontestowały względnie syte elity. Młodzi romantycy, buntując się przeciw Bogu tolerującemu tak wiele jawnych niesprawiedliwości, znowu zaczęli kultywować millenarystyczne wzory zrywające duchowe i polityczne więzy krępujące ludzi. Ekonomiczne także, bo przecież tzw. socjaliści utopijni byli i utopijni i romantyczni, a romantyczności, utożsamianej ze słowem/czynem, nie można odmawiać także socjalistom „prawdziwym”, rzadko mierzącym siły na zamiary. A już w drugiej połowie wieku, mniej jakoś interesującej historyków idei, dzięki ekspansywnej nauce zaczęliśmy marzyć o wyjściu poza stare wierzenia, o kontroli naszych „zwierzęcych dusz”, „o zbudowaniu miejskich niebiosów na poddanej nam ziemi”"41.

Zbawienie eschatologiczne, do którego wracamy niejako z konieczności jak do awersu zbawienia na ziemi, domagało i domaga się także

${ }^{40}$ M. Foucault, Stowa i rzeczy. Archeologia nauk humanistycznych, Gdańsk 2006, s. 29.

${ }^{41}$ E. Davis, TechGnoza, Poznań 2002, s. 168. 
udoskonalenia człowieka w jego wszystkich wymiarach, co było oczywiste dla wielu Ojców i doktorów Kościoła ${ }^{42}$. Ci, którzy przyjmowali, że Chrystus pojawił się jako boski znak, jako wzór dla zagubionej ludzkości, pojmowali zbawienie przez niego, podobnie jak wielcy egzegeci początków chrześcijaństwa: biskup Apolinary, Diodor z Tarsu i sam Nestor, a przed nimi fryzyjscy prorocy z II wieku: Montanus, Prisca i Maximilla. Dla nich Zbawca był człowiekiem-znakiem od Boga, w którym Bóg zamieszkiwał jak w świątyni. Został zesłany po to, by marny, słaby człowiek ujrzał wzór i w imię swojego zbawienia poza ziemią dażył za nim starając się postępować tak, jak sam Chrystus, wiedząc że nie jest możliwe wierne naśladownictwo. Sam Chrystus był ludzkim znakiem od Boga innego niż ten ze Starego Testamentu. Chrystus, jak głosił herezjarcha Marcjon, objawił innego Boga, takiego, który umożliwia spełnienie się w człowieczeństwie, choć brak tu precyzji w określaniu „człowieczeństwa”. Takie postaci religii zagrażały pośrednikom między Bogiem a człowiekiem, czyli wczesnym Kościołom i zwalczano je zdecydowanie poszukując odpowiednich form tej bezwzględnej walki z tymi, którzy chcieli wierzyć inaczej, przede wszystkim sankcji transcendentnych. Kościół nie może tolerować takich pośredników między sobą a Bogiem w żadnym czasie, żaden Kościół, choć można było odnieść wrażenie, że bliski chrystologii był Jan Paweł II, mówiący w Redemptor hominis: „Człowiek, który chce zrozumieć siebie do końca - nie wedle jakichś tylko doraźnych, częściowych, czasami powierzchownych tylekroć nawet pozornych kryteriów tylekroć miar swojej własnej istoty - musi przybliżyć się do Chrystusa" ${ }^{43}$.

Mimo tylekroć objawiających się tendencji chrystologicznych, wstrząsających fundamentami wiary, Kościół nie czynił wiele, by doskonalić człowieka doskonaląc siebie, nie w strukturach, a w ludziach Kościoła i w wiernych. Ufny w swoja siłę, przez wieki nie czując zagrożenia ze strony władzy świeckiej, nie potrafił także reinterpretować swych ról wtedy, kiedy zmiany społeczne osłabiły idee prowidencjalne na tyle, że kontrola Kościoła nad wyobrażeniami zbiorowymi zaczęła słabnąć niezauważenie dla depozytariuszy zbawienia poza ziemia. Ludzie coraz wyraźniej dostrzegali, że zmiany ulepszające codzienne życie są dziełem słabego człowieka, że człowiek jednak może kontynuować boskie dzieło tworzenia w taki sposób, o jakim mówili kiedyś herezjarchowie i schizmatycy, a nauka może być narzędziem boskim. Pojawiły się naturalne pytania o to, kto winien stać na miejscu pierwszym, czy człowiek, czy daleki, niepojęty Stwórca, który zdaje się nie rozumieć

${ }^{42}$ O. J. Mazur, Od kerygmatu do ewangelii życia, Radom 2003, s. 27.

${ }^{43}$ Cyt. za: Wiara i kultura, wybór M. Radwan, S. Wylężałek, T. Grochula, Rzym-Lublin 1988, s. 234. 
swojego tworu, jego potrzeb. One, tak widoczne w Oświeceniu, nabrały mocy wraz z rozwojem świadomości pozytywistycznej, a w niej Bóg jest zbędny, nie jest już potrzebny do wyjaśniania tajemnic naszego świata, uznanych za pozytywne. I już w naszym czasie doszło do sytuacji, w której wielki człowiek Kościoła mówił z goryczą: „Bóg już nie liczy się w ludzkim etosie (...) Bóg nie zajmuje się nami, my nie zajmujemy się Bogiem" ${ }^{44}$.

Wedle wybitnego badacza mitów odchodzenie od Kościoła to etapy procesu desakralizacji istnienia ludzkiego, który prowadzi do hybrydycznych form niższej magii i spaczonej religii ${ }^{45}$. Eliade uważał, że polegające na sile tradycji chrześcijaństwo nie potrafiło zajać stanowiska wobec rozwoju technologicznego i społecznego świata zachodniego i naturalną konsekwencja takich zaniechań jest ilość katolików traktujacych wiarę jako rytuał zbawienia w sensie weberowskim. A taka wiara niezapewniajacca zbawienia, jeśli nie jest tak mocnym spoiwem społeczności, jakim bywała w przeszłości, przestaje być potrzebna także ze względów praktycznych. Tu znowu przypomnimy, że historycy Kościoła, ale nie tylko oni, powtarzali, że Kościół jest instytucją wieczna, że przetrwał wiele burz i wyszedł z nich nietknięty, a skoro tak było wczoraj, to tak też będzie jutro. To oczywista falsyfikacja, przekłamanie biorące się z niewiedzy albo odrzucania wiedzy. Jeśli spojrzymy tylko na kalendaria dziejów Kościoła przekonamy się, że jego dzieje to dzieje rozpadu pierwotnej ekumeny. Wpierw miała mjejsce schizma wschodnia, w kuriozalny sposób łączona z rokiem 1054 (cezaropapizm Euzebiusza z Cezarei, oznaczający pójście kościoła wschodniego własną drogą i przyjęcie tej koncepcji przez pantokratorów bizantyjskich, to przecież wiek IV naszej ery), potem zaś wielkie schizmy zachodnie oferujace wiernym inne rodzaje wspólnoty i inne postaci soteriologii, a wreszcie masowe odchodzenie od Kościoła w naszej ponowoczesności nie potwierdzają tego rodzaju sugestii. Powtarzanie, że Kościół przetrwał wiele burz dziejowych wydaje się tylko recentywna formą samouspokajania się przez hierarchów.

Filozof religii zauważał, że w naszym czasie religia chrześcijańska zachowała formę dogmatyki, ale w dużej mierze zaczęła tracić funkcję kodu dla procesów ogólnospołecznych ${ }^{46}$. Powiada się także, że wiara wyjałowiła się $\mathrm{w}$ zbiorowej świadomości, zubożała, zbanalizowała się, stała się rutyna, praktyką ze sfery obyczaju ${ }^{47}$, ale rzadko pyta się

\footnotetext{
${ }^{44}$ J.M. Ratzinger, Sól ziemi, Kraków 1997, s. 111.

${ }^{45}$ M. Eliade, Sacrum i profanum, Warszawa 1999, s. 171.

${ }^{46}$ N. Luhmann, Funkcje religii, Warszawa 1998, s. 139.

${ }^{47}$ G.F. Svidercoschi, W poszukiwaniu Ojca. Miejsce dla Boga w dzisiejszym świecie, Częstochowa 2007, s. 49.
} 
o przyczyny takiego wyjałowienia, a jeśli już, to pytania owocują odpowiedziami, jakie z pewnościa satysfakcjonować nie moga. Pozostaje opisywanie skutków i konstatacje, że mimo formalnej przynależności do Kościoła wierni coraz mniej identyfikuja się z nim, niewielu bierze aktywny udział w życiu wspólnoty i to udział, jaki nie polega na drobnych pracach dla parafii. To początek obojętności religijnej, mający początek w tym, że człowiek nie żyje już tylko dla zbawienia w niebie, że na planie pierwszym znalazło się zbawienie ziemskie, a to drugie jest tylko postacią swoistej asekuracji, nie przekłada się na czynienie dobra, jest tylko pustym rytuałem ${ }^{48}$. I tu można mieć wątpliwości, czy jest to stawianie świeczki Bogu.

Być może jest sporo racji w sądzie, że dzieje człowieka to historia usamodzielnienia się i powolnego odchodzenia od Boga ${ }^{49}$, ale racja to niepełna, bo wydaje się, że te dzieje człowieka to poszukiwania coraz to nowych postaci Boga, a tym samym nowych postaci wiary, eschatologii i soteriologii. Takie poszukiwania w początkach naszej ery przyniosły chrześcijaństwo, tysiąc pięćset lat później protestantyzm, a z pewnością nie zakończyły się jeszcze, choć zdawać się może, że jest inaczej, choć powiada się, że Bóg jest z pozoru coraz dalszy, pozaświatowy, to powrót ku niemu może okazać się konieczny. Próby stworzenia etyki opartej na innych podstawach niż religijne nie powiodły się, światy wartości zaczynają odpływać poza ludzkie horyzonty, a, jak wspominaliśmy, oddychamy wartościami i bez nich życie traci wiele. „Abolicja Boga - pisał P. Kreft - pociaga za sobą abolicję człowieka, abolicję wyraźnie ludzkiej władzy sumienia" 50 .

Religijność, czyli postawy i zachowania moderowane nakazami i zakazami przede wszystkim religii dominujących, staje się powierzchowna, sformalizowana, jakby proporcjonalna do nadziei zbawienia poza ziemia. Chyba można sugerować, że wiara w Boga znalazła się w kryzysie od czasu, w którym świadomość samozbawienia w doczesności stała się jakby oczywista, choć zdaje się to naturalnym przesileniem, falującym na sposoby, jakie wydają się nieprzewidywalne, tak jak nieprzewidywalna jest rzeczywistość. Miał swoje racje papież Benedykt mówiący jeszcze jako kardynał: „Gdy nie ma Boga, świat pustoszeje, wszystko staje się nudne, wszystkiego jest za mało"

Takie symptomy przesytu dobrami materialnymi i niedosytu duchowości sa w naszym czasie zauważalne tak, jak zauważalne jest to, że Kościół popełnił wiele grzechów, w tym o jeden więcej, o ile zanie-

\footnotetext{
${ }^{48}$ A.G. van Melsen, Nauka i technologia a kultura, Warszawa 1969, s. 365.

${ }^{49}$ T. Węcławski, Wspólny świat religii, Kraków 1995, s. 220.

${ }^{50}$ P. Kreft, Ekumeniczny dżihad, Warszawa 2005, s. 12.

${ }^{51}$ J. M. Ratzinger, Sól ziemi, s. 23.
} 
chanie jest prawdziwym grzechem, bo tu można mieć wątpliwości. Nie wydaje się, by od początków pontyfikatu papież Benedykt i Kościół czynili wiele dla przezwyciężania tego kryzysu, a wiadomo, że można iść z „duchem czasu”, co, jeszcze nieśmiało, potwierdza papież Franciszek. Nie wiemy, czym jest, czy być może nawrót ku duchowości, jeśli nie wiemy dobrze, czym jest sama duchowość, nie wiemy także jak można się w niej spełniać, bo tu daremnie szukamy jakiegoś wzoru. Praktyczne drogi ku innemu rozumieniu misji przetarli już duchowni francuscy powracajacy do idei Kościoła ubogiego. Po kryzysie lat 70., kiedy po raz któryś w historii zarzucano duchownym wystawność, pychę, dążenie do władzy, bez silnych inspiracji z zewnątrz większość francuskich księży stała się prawdziwymi „robotnikami bożymi” żyjącymi tak jak przeciętni Francuzi, a nawet skromniej. Zauważa się, że kiedyś tak antyklerykalna Francja zmieniła się bardzo w ostatnich latach, a posługa Kościoła stała się prawdziwym duszpasterstwem akcentującym potrzeby zaspokojenia ducha. Kościół słaby, walczący, potrafi znaleźć w sobie siłę, taki zaś jak polski, zadufany, triumfujący, upolityczniony, wykazuje coraz więcej oznak słabości, co owocuje cofaniem się w okopy Świętej Trójcy, a wiemy z historii, że te rowki konfederatów barskich nie były prawdziwymi umocnieniami i skuteczna obrona w nich jest iluzja.

Jednak pozory pełni życia i w dobrach w społecznościach konsumpcyjnych, nieograniczonego zakazami i nakazami religii sa tylko pozorami. Tu papież Benedykt zdawał się mieć pełne racje. Człowiek nie zmienił się aż tak bardzo od tysięcy lat, nadal czuje potrzebę istnienia transcendencji, „konsultowania” się z nia, zwłaszcza wtedy, kiedy widzi przed sobą kres ziemskiej wędrówki, ale taka potrzeba zmieniła się jakościowo. Poszukuje się jej nie tylko w religiach „właściwych”, ale $\mathrm{w}$ postaciach wiary przypominających $\mathrm{w}$ formach religijne. Tu, mając na uwadze ilość i jakość „, świeckich religii”, łatwiej zrozumieć H. Hesse, który powiadał: „Nigdy nie żyłem bez religii - nie wyżyłbym bez niej ani jednego dnia - ale jak żyję, mogłem się obyć bez kościoła" ${ }^{52}$. Żadna z tych świeckich religii (włączając amerykańska), często mających charakter indywidualny, nie dostarcza ani takiego systemu wartości, ani w miarę spójnej soteriologii immanentnej, a nadto, one nie tworza sfery sacrum, tak potrzebnej człowiekowi, a tego jakoś nie widzą ludzie Kościoła.

Inercja Kościoła staje się przeszkodą na drodze powstawania nowych mutacji soteriologii, zdaje się przekładać na mała pojemność oficjalnych eschatologii. Wydaje się, że jedną z przyczyn jest brak w nich tego, skutecznego przez wieki bodźca - przekonujaccych wizji zbawienia.

${ }^{52}$ H. Hesse, Moja wiara, Warszawa 1993, s. 45. 
Jeśli przyjmiemy, że soteriologia przesądzała o sile chrześcijaństwa w pierwszych wiekach, to możemy sugerować, że o odchodzeniu od religii w znaczącej mierze przesądza brak rzeczywistych, przekonujących wizji zbawienia poza ziemia. Z takimi stykamy się tylko na poziomie katechezy i to w formach przewidzianych chyba tylko dla dzieci. Soteriologia urzeczywistniona, czy eklezjalno-sakramentalna, znane tylko z prac teologów, nie spełniają tych ról, sa tylko zbiorami pustych metafor, a przywoływane w początkach katechezy wizje angelo i demonologiczne mogą tylko bawić dzieci ze szkół elementarnych. Nie można dziś nie zauważać atrofii wiary w zbawienie poza doczesnościa za sprawa niedoceniania soteriologii także przez kościoły. A powtarzamy, że naszym zdaniem dualny człowiek pragnie zbawienia i na ziemi i w niebie i tak będzie dopóty, dopóki nie będzie miał pewności co do istoty transcendencji, a tej nie zdobędzie nigdy. Obowiązkiem każdego kościoła winno być prezentowanie ostatecznych celów istnienia i uwzględnianie wszystkiego, co ludzkie, choćby grzeszne. Jeśli tego nie robia pasterze, wyrzekaja się eschatologii, to religia bez niej jest co najmniej niepełna, staje się tylko rytuałem.

Mając na uwadze odchodzenie od religii społeczności zbawiających się materialnie w doczesności, zdziwienie może budzić postawa samych ludzi kościołów, którzy nie rekonstruują pierwotnych warunków zbawienia, a co także dziwne, nie potrafia przekonywać do dróg zbawienia przez wiarę ani przez czyny ufając $\mathrm{w}$ prezentystyczne trwanie. $\mathrm{W}$ naszym czasie nawet człowiek mityczny, do pewnego stopnia racjonalizując swoje postawy, zaczyna wątpić, a wattpienie jest początkiem poszukiwania własnych dróg i do Boga i zbawienia, co jest poważną próbą dla tych kościołów. Zdaje się, że Polacy naszego czasu także zaczęli wątpić nie potrafiąc pogodzić swojej, rzekomo głębokiej wiary, z ich codziennościa, będąca jakimś zaprzeczeniem tej wiary. Katoliccy niemal w stu procentach powinni być przecież nacją szlachetniejsza, doskonalsza w czynach od innych, a sa tacy, jacy sa i nikt nie przekonuje z ambon, że powinni być inni. Wątpiąc tworzą pozory jeszcze głębszej wiary skłonni manifestować ją tak, jak kibice krakowskich zespołów piłkarskich po śmierci Jana Pawła II, ale takie manifestacje z pewnością nie wypływaja z wiary w cokolwiek, a z wiary dla wiary i przez wiarę, bo można odnieść wrażenie, iż wiara w transcendencję jest dla nich tylko mało znaczącym i sztucznym znakiem tożsamości, niczym nadto.

Wydaje się, że właśnie niedostatki soteriologii, brak wielkich, porywających wizji zbawienia rodziły nowe formy wspólnot, od heretyckich poczynając. Jeśli przyjrzymy się bogomiłom, katarom, anabaptystom, zauważymy, że wszystkie one były radykalne w kreowaniu nowych, porywających wizji zbawienia i nader często przenosiły owo zbawie- 
nie na ziemię korzystając zresztą z chrześcijańskich wzorów i uznając siebie za prawdziwych chrześcijan. Z dzisiejszych odłamów choćby świadkowie Jehowy stworzyli mutację soteriologii, w której na pełne zbawienie zasłuży ledwie 144 tysiące pomazańców bożych. Inni sprawiedliwi żyć będą wiecznie w raju na ziemi, na której władzę będzie sprawował „Rząd Królestwa Bożego” z Chrystusem na czele. Czerpiąc z doświadczeń millenarystów Świadkowie i nie tylko oni próbuja spoić w jedno obie postaci soteriologii akcentujac to, co czasami zwie się potrzebami duchowymi, choć, jak zauważaliśmy, te potrzeby to tylko pojemna metafora. Zwracaja na to uwagę badacze sekt zauważajacy, że ludzie odchodza od Kościoła, bo właśnie w sektach potwierdzaja poczucie przynależności do wspólnoty, akceptację, znajdują tam zbiorowe emocje, bliskośćc ${ }^{53}$. Nie sa im potrzebne puste, strzeliste rytuały, bo one nie zaspokajaja takich potrzeb w pełni.

Wykorzystują to nie tylko przywódcy sekt, ale także sataniści. Oni, lepiej od formalnych organizatorów wyobrażeń zbiorowych, wiedzą, że na ogół jednostki rzadko uświadamiają sobie ostateczne cele życia, choć poszukują ich stale i, zagubieni na ścieżkach życia potrzebuja duchowych przewodników. W kulturze odnajdziemy setki takich potwierdzeń poszukiwań i możemy tylko domniemywać, że przyczyny pustki kryją się w słabej znajomości naszej psyche, świadomym operowaniu wartościami i ocenami formułowanymi podświadomie. Cel, jakim jest zbawienie w transcendencji nie jest nim do końca, bo świadomość celu wiąże się z doborem środków do jego osiagania, a wiemy, że te, proponowane przez Kościół nie wystarczaja, sami zaś nie potrafimy ich szukać. Zauważają to współcześni herezjarchowie i przywódcy sekt umiejętnie łacząc poszukiwanie zbawiania na ziemi z transcendentna sankcja. Nie tylko oni, bo przecież i mormoni i inne grupy religijne, ale takie pragnienie zbawienia wykorzystywali także przywódcy robotniczy, dla których proletariusze, jak pierwsi chrześcijanie, żyja oczekiwaniem innego, lepszego świata, są czyści, zachowali miłość bliźniego, nikogo nie wyzyskiwali, a więc sprawiedliwość dziejowa winna im rekompensatę już tu, na ziemi ${ }^{54}$.

Wszelkie symptomy kryzysu duchowego objawił wielki bunt młodych w latach 60., nie majacy swego miejsca nie tylko w literaturze naukowej ani historii kultury, co budzi oczywiste pytania o przyczyny takich zaniechań. Wtedy to, na marginesach kultury, pojawił się New Age - ten szwedzki stół zastawiony duchowymi substytutami chrześcijaństwa uznający nieograniczoną zdolność człowieka do przekształcania samego siebie i świata tak, by zrodziła się nowa Era pokoju, światła

${ }^{53}$ Z. Danielewicz, Między Kościołem a sekta, Warszawa 1999, s. 7.

${ }^{54}$ R. Aron, Opium intelektualistów, Warszawa 2000, s. 101. 
i miłości ${ }^{55}$. Ruch tęsknoty za spełnieniem przez wiarę nie budzi szczególnego zainteresowania nauk społecznych, jako że ponoć nie prezentuje oryginalnych interpretacji świata ${ }^{56}$. Naszym zdaniem nie jest to ruch mniej oryginalny od wielu innych, jakie budza o wiele większe zainteresowanie.

Poza dziesiątkami różnych „wiar”, jakim nie chcemy się tu przyglądać, depozytariuszami idei duchowego zbawienia na ziemi stali się ludzie myśli, ci którzy dysponowali władzą słowa mówionego i pisanego, którzy zwykle kontestowali formy i treści wszelkiej władzy, stojący najbliżej czystych wartości ludzkich, poszukujący pełni Człowieka i najlepszych dla niego dróg. Myśląc o wypełnieniu pustych form człowieka współczesnego treścia, marząc o samozbawieniu duchowym, poczęli tworzyć wizje „dobrego życia” i stworzyli prawdziwe mgławice ideałów i marzeń o ziemskim spełnieniu, płaszczyzny czasu utraconego i odnalezionego ${ }^{57}$. Emanacje tych marzeń bywały niekiedy rzeczywiście prawdziwymi mgławicami, niekiedy zaś tylko próbami, jakie warto brać pod uwagę, jeśli myślimy o radykalnych zmianach psychosfery w imię przyszłości. Nie sposób nie zauważyć, że nowe sposoby wychowania w szkołach zachodnich już owocuja zachowaniami altruistycznymi, zwłaszcza u młodych ludzi, u których empatia i holizm odgrywają większe role niż u starszych, myślacych tylko o sobie i własnym dobru. Młodzi w jakimś stopniu dowodza, że egoizm nie jest trwałym kodem jednostek i zbiorowości, a spełnienie można odnaleźć także we wspólnocie.

Ale i te pozytywnie oceniane cechy kryja w sobie niebezpieczeństwo. Nie ma rozwiązań w pełni doskonałych. Nowe formy kształcenia owocują także jedną z form anomii, polegająca na niemożności osiągania idealizowanych celów przez zbyt wygórowane ambicje, pożądania, jakich nie można zaspokoić w naszym czasie chorego konsumpcjonizmu. Mimo wszystko szkoły nowego holizmu przyniosły wizje i projekty nowego ładu planetarnego i chyba maja jakiśs wpływ na zmiany zauważalne dzisiaj. Warunkiem nieodzownym inicjacji musi bowiem być zrozumienie wspólnych problemów, a zaczynać trzeba od ludzkich przekonań, bo bez tego nie zmieni się nic w naszym człowieczeństwie - jak mówił w Kongresie USA V. Havel ${ }^{58}$. Takie ślady zrozumienia widzimy pośród wielu alterglobalistów, propagatorów fair trade, ale ci, zwykle młodzi, pragnący fundamentalnych zmian ludzie zdają się jednak pozostawać na przegranych pozycjach i sami chyba nie wierza w możliwość korekty ładu w postkapitalizmie.

\footnotetext{
${ }_{55}$ M. Cole, What is New Age?, London 1990, s. 6.

${ }^{56}$ J. Haynes, Religion in Global Politics, London 1998, s. 13.

${ }^{57}$ P. Ricoeur, O sobie samym jako innym, Warszawa 2005, s. 296.

${ }^{58}$ S. Ramphal, Our Country, the Planet, Washington 1992, s. 199.
} 
Wspomniany egoizm $\mathrm{w}$ jego wielu postaciach jest jednak potężnym generatorem zachowań. Myśląc, mówiąc o zbawieniu w doczesności zwykle myślimy tylko o sobie i najbliższych, nie o zstępnych, nawet tych, którzy są nam bliscy, już dorastają i za jakiś czas będą musieli zmierzyć się z problemami przez nas stworzonymi. Odpowiedzialność za przyszłe pokolenia - pisał D. Birnbacher - stała się toposem mów niedzielnych, „zaś dictum: chrońmy świat naszych dzieci, stało się stałym składnikiem wzniosłej retoryki" ${ }^{9}$. Oczywiście retoryki uprawianej na bieżąco przez recentywnych polityków, którzy wymuszają taki recentywizm, stałe orientowanie się na chwilę bieżącą tylko obiecując działania dla przyszłości zstępnych. Widzimy to po wielu zachowaniach, w tym stosunku do ograniczenia emisji Co2. Nawet Amerykanie, którzy w swej „religii obywatelskiej” pomieścili imperatyw zostawiania lepszego świata swoim następcom i pozostawali mu wierni przez wieki ${ }^{60}$, teraz zanurzyli się $\mathrm{w}$ swoim mityzowanym spełnieniu wyznając dziś europejską zasadę: „po nas choćby potop”. W takiej sytuacji chyba wypada powtórzyć za S. Schneiderem truizm: „Nie gospodarzy dobrze ten, kto oddaje w zastaw nasza przyszłość, a ciężar znalezienia rozwiązań pozostawia przyszłym pokoleniom" "1. Powiadamy beztrosko, że musza sobie jakoś radzić. Podobno poradzą sobie z przyszłymi problemami równie dobrze jak my, ale kto powiedział, że my radzimy sobie z nimi?

W jakiejś mierze ten brak troski o zstępnych bierze się z zauważalnej przez psychologów zasady doraźnych przyjemności, która każe nam odsuwać nieprzyjemne sprawy, problemy w nieokreślone ,jutro” na rzecz dobra niedocenianego, jakim jest spokój, a zasada ta jest tak widoczna w „goracych” kulturach południa. A z dwóch przyczyn właśnie nasze generacje powinny wziąć większą odpowiedzialność za losy ziemi już teraz powinny zacząć myśleć o spełnieniu dla miliardów dziś i jutro. Po pierwsze, wiemy dziś więcej wiele więcej o zagrożeniach, a po drugie, dysponujemy już środkami, jakimi można nie tylko zapobiegać przyszłym kataklizmom ${ }^{62}$ i mamy tu na uwadze nie kataklizmy naturalne, a te, jakie rodzą bieda, analfabetyzm. Skoro jednak nie stać nas nawet na podjęcie choć próby rozwiązania części problemów, jakie staną się palące dla zstępnych, nie dziwmy się temu, że jesteśmy nieczuli nawet wobec samych siebie. Zapominamy o miliardach biednych i głodnych, którzy patrzą na bogatą Północ z zawiścią bliską nienawi-

\footnotetext{
${ }^{59}$ D. Birnbacher, Odpowiedzialność za przyszłe pokolenia, Warszawa 1999, s. 6.

${ }^{60}$ W. Straus, N. Howie, Generations. The History of America's Future 1584 to 2069, New York 1991, s. 368.

${ }^{61}$ S.H. Schneider, Laboratorium Ziemia, Warszawa 1998, s. 178.

${ }^{62}$ P.H. Sand, Lessons Learned in Global Environmental Governance, New York 1990. s. 1.
} 
ści, ale jak moga patrzeć, jeśli na ich oczach dzieci umierają z głodu, a tam, w dalekich, niepojętych rajach, marnotrawi się równie niepojęte bogactwo? Chyba nie ulega wattpliwości, że oni, wraz z ich „religią uciśnionych" będą rodzili największe problemy w najbliższych dziesięcioleciach $^{63}$. Dziś już powtarza się niemal chórem, że w naszym czasie ma miejsce powrót uciśnionych, a „proletariuszami” są wszyscy nędzarze III Świata i na takich powtórzeniach się poprzestaje ${ }^{64}$. Bogaci nie chca zauważać tego pragnienia wszystkich spełnień na ziemi, bo ci zwykle darzą biednych pogardą twierdząc często, że sami są sobie winni. Zbawieni zaś nie rozumieją tych, którzy chcą się zbawiać i te pragnienia już zagrażają samozadowoleniu tych zbawionych, którzy już czuja presję, napór nędzarzy, o czym przekonują nas nie tylko włoskie przykłady. A przypomnijmy, że pierwsze, poważne ostrzeżenia przed coraz większą desperacją biednych pojawiały się tuż po załamaniu się systemu kolonialnego i wtedy lekceważono je tak samo jak dziśs.

Zdumiewające jest to, że wage potencjalnych zagrożeń doceniano już w latach 60. i 70. kiedy mówiono bardzo głośno o możliwości konfliktów między bogatą Północa, a biednym Południem podkreślając konieczność prowadzenia polityki prewencji już teraz, kiedy możliwa jest taka prewencja. Niby pojawiały się takie anemiczne próby, bo przed kilkoma dekadami, próbując działać prewencyjnie, R. McNamarra stworzył koncepcje „imperializmu dobrobytu” tworząc następną mutację planu Marshalla dla Ameryki Południowej i Azji. Okazało się po kilku latach, że ów „plan” służył tylko „ideologii”, miał zwalczać wizje zbawienia oferowane przez komunizm, a tą pozorowana wojnę sekretarza stanu mieli stoczyć naukowcy pod skrzydłami ONZ ${ }^{65}$. Nieco później politykę zaawansowanej prewencji proponowali autorzy Raportów dla Klubu Rzymskiego z oczywistymi skutkami.

Egotyzmowi aktywnych pokoleń bogatego świata towarzyszy swoiste samozadowolenie $\mathrm{z}$ uzyskanych statusów - efekt dominującego $\mathrm{w}$ ponowoczesności recentywizmu, ale i zagubienia. Być może mamy do czynienia z sytuacja, jaką niedawno diagnozował A. Giddens, wedle którego nasz czas charakteryzuje egotyczny stosunek do przeszłości, wyrzeczenie się przyszłości, co jest zdeterminowane poczuciem utraty panowania nad rzeczywistością ${ }^{66}$. Próbując odzyskać panowanie nad nią i widząc daremność swoich wysiłków człowiek próbuje potwierdzać swoje prawa własności, zwłaszcza do materialnych symboli spełnienia. One są dla niego najistotniejsze i wszelkie oskarżenia człowieka współ-

\footnotetext{
${ }^{63}$ F. Major, Memory of the Future, Paris 1995, s. 108.

${ }^{64}$ N. Stevenson, Understanding Media Cultures, London 1995, s. 37.

${ }^{65}$ N.A. Mc Dougall, Promised Land, Boston 1997, s. 189.

${ }^{66}$ A. Giddens, Nowoczesność i tożsamość, Warszawa 2002, s. 237.
} 
czesnego o „materializm” są zasadne, nad czym ubolewał E. Fromm, mówiący: „Choć stworzyliśmy wspaniałe rzeczy, zawiódł nas projekt uczynienia samych siebie istotami, które warte byłyby tego ogromnego wysiłku"67. Nie osiagnęliśmy szczęścia wieszczonego przez profetów kapitalizmu, ani tego, o jakim mówił kiedyś F.D. Roosevelt, świadomy tego, że ten system ekonomiczny nie jest soterem: „Szczęście leży nie $\mathrm{w}$ pieniądzach, które mamy, ono leży w radości z naszych osiagnięć, w goraczce kreatywnych wysiłków"68.

Tu raz jeszcze pojawia się nam problem będący bodaj najważniejszym dla każdej jednostki, problem sumy wszystkich pragnień, jakim jest szczęście i nie sposób reinterpretować Dalaj Lamy powiadającego, że dążenie do szczęścia jest głównym motorem naszych działań, bo $\mathrm{z}$ tym godzi się chyba każdy ${ }^{69}$. Jedna $\mathrm{z}$ największych metafor w życiu jednostek i zbiorowości jest bezdyskursywna jako wielki archetyp kulturowy, ale zwykle jej konkretyzacja wiedzie ku wielu nieszczęściom egzystencjalnym, bywa tym nieszczęściem w szczęściu, czego przykładów, w literaturze zwłaszcza, znajdziemy setki. Stykamy się z takimi nieszczęściami wtedy, kiedy zaczynamy poszukiwać miar i granic swojego szczęścia w jego dwóch wymiarach, a poszukiwania i zawody staja się boleśniejsze w wieku dojrzałym, kiedy każdy z nas próbuje określać granice swojego spełnienia materialnego i duchowego dokonując naturalnego rachunku z samym sobą i swoimi spotkaniami z tym, często nieco wstydliwym, szczęściem w przeszłości. Rachunek jest naturalny tak, jak naturalne jest pytanie: jak żyłem? Może dokonujemy tylko rozrachunku z jego surogatami, bo wedle Jana Pawła II: „Świat nie jest zdolny uszczęśliwić człowieka (...) Ten cały świat ze swoim bogactwem i ze swoim ograniczeniem sam potrzebuje zbawienia i ocalenia"70.

Wieki wiary w zbawienie w transcendencji, w drogi zbawienia przez ubóstwo, wyrzeczenia i cierpienia, uczyniły ten tropizm wstydliwym, co widzimy choćby po stosunku nauki do różnych postaci hedonizmu, do epikureizmu zwłaszcza, który był przecież, przede wszystkim, wizja spełnienia duchowego, nie cielesnego. Ale właśnie jako taki stanowił tak wielkie niebezpieczeństwo dla soteriologii transcendentnej. Kierował cele człowieka na doczesność chcąc, by spełniał się przez wiedzę, szczęście w unikaniu cierpienia. Epikurejczycy utrzymywali, że pierwszym celem, jaki chce osiagnąć człowiecza natura jest przyjemność - hedone. Ale nie czynili tego na sposób Arystypa, dla którego celem dążenia

${ }^{67}$ E. Fromm, Psychoanaliza a religia, Poznań 2000, s. 33.

${ }_{68}$ American Perspectives. The United States in the Modern Age, Washington 1992, s. 101.

${ }^{69}$ H.C. Cutler, Sztuka szczęścia. Rozmowy z Dalajlama, Poznań 2005, s. 21.

${ }^{70}$ Jan Paweł II, Przekroczyć próg nadziei, Lublin 1994, s. 59. 
człowieka jest przyjemność za wszelką cenę. Cenili przede wszystkim umiarkowanie, bo taka cecha pozwalała na uniknięcie nieprzyjemności, na życie bez strachu, a to oznaczało nadzieję, odwagę mierzenia się z życiem, choć z pozoru imperatyw Epikura życia w ukryciu był zachęta do eskapizmu. Temu jednak przeczy jego słynny czwórmian.

Powinniśmy otwarcie przyznawać, że wszyscy gonimy za szczęściem i ta nieustanna pogoń jest głównym motorem naszych działań dla Dalajlamy ${ }^{71}$. Gonimy nie bardzo wiedząc, czym ono jest i im bardziej staramy się osiagnać szczęście, tym bardziej jest ono ulotne - potwierdzał stara prawdę D. Icke ${ }^{72}$. Zauważamy natomiast, że wszyscy unikamy nieprzyjemności i nieszczęść, a o tych wiemy lepiej, czym sa ${ }^{73}$, choć niekiedy nieprzyjemności jednego sa przyjemnościami dla kogoś innego. Człowiek, jak zauważaliśmy, jest istota dualna, jego przyjemności kojarzone ze szczęściem poczynają jednak dominować nad ich opozycją i nie wiedząc, czym jest „nieprzyjemność” przestajemy smakować, a nawet rozumieć przyjemność. Ona nie może istnieć bez swojego przeciwieństwa. Ale w naszym czasie obywatele rozwiniętego świata coraz rzadziej stykają się ze strachem, bólem, cierpieniem odsuwając je na plany dalsze, nie chcac ich przyjmować do wiadomości i po trosze stąd smak przyjemności jest czasami taki mdły, wymusza jej coraz bardziej wyrafinowane formy, niewyobrażalne jeszcze kilka dekad temu.

Dla K. Lorentza takie nasilenie naszego lęku przed przykrościami i podobne metody stosowane do ich unikania graniczą niemal z występ$\mathrm{kiem}^{74}$. W sytuacji unikających takich nieprzyjemności jakikolwiek, nawet niewielki wymuszony ból, czy strach, rodzą silne traumy, bo nie od dziśs wiadomo jak trudno nam zaakceptować to „gorsze”. One tworza nowe jakości społeczne i polityczne, jeśli takie postawy stają się masowe. Amerykańscy badacze zauważaja rosnąca obojętność zamożnych na cierpienie nędzarzy, niekiedy maskowana obojetność tych milionów zanurzonych w Ewangelii Dobrobytu, popularnej zwłaszcza w formie teleewangelizmu ${ }^{75}$. I to także zdaje się być konsekwencją ucieczki od nieszczęść innych, a przecież wiemy o tym, że mogą dotknąć i nas. To, rzecz jasna, jest zauważalne, ale chyba mniej niebezpieczne od aprobaty takich inicjatyw jak Patriot Act, których podłożem były strachy początku XXI wieku. Takie zatracenie dualności, eliminowanie tego, co nieprzyjemne dla człowieka, orientacja tylko na przyjemność, odbiera człowiekowi to, co przesądza o jego wyjątkowości. A zatracenie takiej

${ }^{71}$ H.C. Cutler, Sztuka szczęścia, s. 21.

${ }^{72}$ D. Icke, Wolność, s. 137.

${ }^{73}$ A.R. Damasio, Tajemnica świadomości, Poznań 2000, s. 43.

${ }^{74}$ K. Lorentz, Regres człowieczeństwa, Warszawa 1986, s. 161.

${ }^{75}$ A. Peck, Teleewangelizm, apokalipsa i praktyka, Tyczyn 2005, s. 87. 
wyjątkowości z kolei jest właśnie takim przestępstwem, o jakim myślał Lorentz. Konsekwencje unikania nieprzyjemności znieczulają na nieszczęścia innych i nie możemy nie dostrzec tego, że bogate społeczeństwa są tak nieczułe nie tylko na te nieszczęścia innych, ale także swoich. Obojętnie przyjmują wojny, klęski głodu, nędzę na ich podwórku, niezdolne do jakichkolwiek form protestu i zdobywające się jedynie na jakieś formy jałmużny, jakie pewnie starczają im do czystego sumienia. Po to, by je obudzić trzeba sporo wysiłku, by, jak to mówił Kant, wprowadzić je w pełnoletność. Same z pewnością się nie obudza.

Czy nieograniczone zaspokojenie wszystkich pragnień jest szczęściem? Nie dla E. Fromma w Mieć czy być?, nie dla wielu psychologów i socjologów i dla wielu z nas. Ci drudzy powiadaja, że wszelkie potrzeby i pragnienia sa dynamiczne, rodzą się nowe i te wymuszaja ich zaspokojenie, bo jednak jesteśmy jednak i niespokojni i nienasyceni tak, jak widział to św. Augustyn. Ci pierwsi natomiast utrzymuja, że iluzyjna pełnia rodzi pustkę i jej poczucie niknie w chwili jej osiągnięcia, a konieczność osiagania coraz to nowych pułapów pełni może rodzić cynizm, negatywizm, poczucie osaczenia z niepokojącymi konsekwencjami ${ }^{76} . \mathrm{Pu}$ łapki dobrobytu, dla wielu tożsamego ze szczęściem, rodzą wiele konfliktów nowego typu, w tym wiele postaci anomii dobrobytu. Ma tu swoje racje M. Gray, mówiąc: „Jeśli roztrwonimy naszą energię psychiczna w bezużytecznych walkach, w gonitwie za drugorzędnymi celami, które $\mathrm{w}$ gruncie rzeczy nie sa istotne, będziemy wyczerpani i nieszczęśliwi”"77.

Oczywiście autor myślał tu o spełnieniu materialnym, nie chcac zrozumieć tych, dla których taka gonitwa jest sprawa przeżycia, dla których prawdziwym szczęściem jest perspektywa pełnego brzucha. Oni na swój sposób interpretują słowa nieznanego im A. Huxleya, który w swojej dystopii zalecał: „Nigdy nie odkładaj do jutra przyjemności, która możesz mieć dzisiaj"78. My natomiast zatapiamy się w naiwnej, jak ją widzi J. Baudrillard, antropologii naturalnego dążenia do szczęścia, a dla niego: „Szczęście wypisane ognistymi zgłoskami stanowi absolutny punkt odniesienia dla społeczeństwa konsumpcji, jest ścisłym odpowiednikiem zbawienia"79. Nie sposób nie zauważyć tego, iż granice tego „szczęścia” wyznaczaja medialne autorytety, celebryci wiedzący wszystko lepiej od poszukujacych.

Spełnienie materialne, zbawienie w dobrach, jest ta podstawowa formą zbawienia w doczesności, zdecydowanie łatwiejszą w pozornym

\footnotetext{
${ }^{76}$ H. Levinson, Psychologia przywództwa, Gliwice 2007, s. 39.

${ }^{77}$ M. Gray, Sity życia, Warszawa 1988, s. 69.

${ }^{78}$ A. Huxley, Nowy wspaniały świat, Kraków 1988, s. 100.

${ }^{79}$ J. Baudrillard, Społeczeństwo konsumpcyjne. Jego mity $i$ struktury, Warszawa 2006, s. 45 .
} 
osiaganiu niż duchowe. Wtedy, kiedy osiagamy satysfakcjonujący nas poziom warunków życia (co raczej jest rzadkościa), zaczynamy poszukiwać gdzie indziej i pozostaje nam tylko spełnienie się w czymś innym. Jak zauważa psycholog, w analizie jakości amerykańskiego życia respondenci oceniali swoja sytuację finansowa jako jeden z najmniej istotnych czynników, mających wpływ na czerpanie satysfakcji z ży$\mathrm{cia}^{80}$. To mogłoby sugerować, że skoro czują się spełnieni materialnie, powinni poszukiwać innych form, a analizy amerykańskich socjologów takich poszukiwań nie potwierdzaja. Wydaje się, że respondenci oszukiwali samych siebie, a w części usprawiedliwia ich to, że byli pytani o enigmę.

Poszukując swoich zbawień, pewny swoich statusów materialnych człowiek obraca się choćby w kierunku swoistego hedonizmu J.S. Milla, dla którego do osiagnięcia szczęścia niezbędna jest możliwość doświadczania spokoju oraz możliwość przeżywania silnych wrażeń na tle realizacji dwóch wewnętrznych warunków: rozwoju moralnego i duchowego. To dla uczonego oznaczać powinno wyzbycie się egoizmu i podjęcie wysiłku altruizmu. Nie wszyscy orientują się na takie drogi, większość $\mathrm{z}$ nas pozostaje jednak $\mathrm{w}$ kręgach złudzeń zbawienia w rzeczach i przez rzeczy. Zdaje się, że Mill pozostał idealistycznym intelektualista, dla którego to, co pożądane, jest możliwe i jest to postawa właściwa wielu ludziom nauki. Bez wątpienia egoizm jest tworem dążeń do spełnienia materialnego, ale takie jednostkowe, wsobne zbawienie, nie jest możliwe poza zbiorowością. Egoista, czy tylko indywidualista, musi potwierdzać swoje statusy, swoją wyjątkowość w posiadaniu dóbr tylko wobec społeczności. Chcemy jednak spełniać się we wspólnocie, w niej doznania spełnienia zdają się dużo głębsze i egoista znajduje mocne potwierdzenie swojego pełnego szczęścia, swego spełnienia w oczach innych.

Nieco inne konteksty towarzyszą spełnieniu duchowemu, znacznie trudniejszemu w ocenach i osiaganiu, niejednorodnemu. Dla jednego takie spełnienie oznacza perfekcję w opanowaniu jakiejśs czynności, specjalizację czyniącą go wyjątkowym w jakiejś grupie. Dla innego taka postać spełnienia jest formą dewiacji i ten orientuje się na próby wszechstronnego rozwijania się, samodzielnego poszukiwania siebie w świecie, najczęściej zdany tylko na siebie. Takie poszukiwanie jest tożsame z poszukiwaniem prawd o sobie, innych, świecie, ale poszukiwanie prawd jest poprzedzane poszukiwaniem dróg. Filozofowie utrzymuja, że każda istota rozumna potrzebuje prawdy i samo jej poszukiwanie daje namiastki zbawienia, ale, nie mając pewności co do tego, czym jest ta prawda, zauważaja także, że temu dążeniu zawsze towarzyszy nie-

${ }^{80}$ M. Argyle, Psychologia szczęścia, Wrocław 2004, s. 93. 
dosyt, nienasycenie. Tuż po odkryciu nowej „prawdy” poszukiwacz na powrót czuje głód innych i nie ustaje w poszukiwaniach, nieszczęśliwy wtedy, kiedy nie wie, że owo mityczne spełnienie może znaleźć właśnie w poszukiwaniach. Inni, świadomi kruchości, relatywizmu wszelkich prawd, powiadaja, że winniśmy szukać w sobie samych źródeł równowagi, w stanach umysłu. Jeszcze inni, a tych jest jednak większość, nie czują takiej potrzeby, która zmusza do aktywnych poszukiwań. Oni czerpią takie „prawdy” choćby z mediów przekonując sami siebie, że wiedzą wszystko, co jest im potrzebne do życia i takie oszustwo zwykle starcza dla osiagnięcia tego „świętego spokoju”.

Nie wiedząc, czym jesteśmy, od czasów starożytnych filozofowie marzyli o osiagnięciu pełni duchowej przez jednostkę nie radząc sobie jednak z określeniem tej pełni, bo to nigdy nie zdawało się możliwe. Nie przywołując dziesiątków imperatywów pierwszych antropologów, z Sokratesem na czele, przypomnimy tylko Kanta, dla którego celem istnienia człowieka jest trwanie gatunku i pełna realizacja wrodzonych zadatków. Człowiek jest koniecznym celem stawania, gdyż jest jedyna istotą na ziemi, która może stworzyć pojęcie celów. Powinien odważyć się na stawanie mądrym, acz w kantowskiej koncepcji oświecenia nie znajdziemy początków dróg spełnienia w sobie i dla siebie. Z kantyzmu wyrosły koncepcje nowego immanentyzmu, czyli dyrektywy poszukiwania $\mathrm{w}$ sobie tych zadatków, jakie mogą być podstawą takiego spełnienia. Interpretowane przez prezesa Klubu Rzymskiego A. Peccei w jego Human Quality, znalazły jednak oddźwięk u teoretyków wychowania.

Myślaccy o spełnieniu duchowym Fromm zauważał naturalny eskapizm człowieka - nieuchwytną tęsknotę za radosnym, wartościowym istnieniem odpowiadającym tym specyficznym potrzebom człowieka, które rozwijał w ciągu tysięcy lat historii ${ }^{81}$. Erupcją takich tęsknot były dla niego lata 60. i wybuch żywiołowej młodości. Zdaje się, że jakaśs próba odpowiedzi organizatorów życia społecznego w warunkach welfare state na takie potrzeby było społeczeństwo zabawy, dające ludziom systemu fordowskiego świadomość odmienności tych konwencji od normalnego, rutynowego, nudnego życia. Niedostrzegana w nauce zabawa jest poszerzaniem świadomości wolności dla J. Huizingi ${ }^{82}$ i nie przypominamy tu innych jej funkcji. Ale takie sugestie zdaje się wzmacniać praca N. Postmana poświęcona Amerykanom, gotowym zabawić się na śmierć.

Soteriologia ziemska obejmuje sobą nie tylko jednostki, a całe zbiorowości aż po wspólnotę globalna, bo jednak niekiedy czujemy poczucie bliskości, symetrii uczuć z ludźmi o innych kulturach, religiach,

${ }^{81}$ E. Fromm, Rewolucja nadziei, s. 27.

82 J. Huizinga, Homo ludens. Zabawa jako źródto kultury, Warszawa 1998, s. 55. 
przekonaniach, kolorach skóry, choć tylko niekiedy. Najbliższe są nam jednak mniejsze wspólnoty wyobrażone, które tworzą własne postaci soteriologii, jak choćby zbawienie w narodzie i przez naród, o czym będziemy mówić niżej. Posiadacze władzy symbolicznej potrafią kreować takie formy zbawienia dla zbiorowości, nad którymi sprawuja władzę, choć niekiedy czynią to na sposoby wręcz prymitywne. Nie jest to zwykle ta bergsonowska konieczność doskonalenia „ja społecznego”"83, a tylko formy, jakie umożliwiają bezkonfliktowe rządzenie, zapewniają rządzącym czasowy spokój. Doskonałość form może być tylko zawadą w sprawowaniu złej lub jeszcze gorszej władzy. Lepiej powtarzać, zwłaszcza w demokracji, że społeczność jest mądra, dojrzała, rozumie intencje rządzących, a oni odpłaca jej za to wyższymi standardami życia i użycia.

Kończąc te rozważania o wymiarach zbawienia w transcendencji i poza nia, powtarzamy, że niemożność osiagnięcia choć jego namiastki $\mathrm{w}$ doczesności tworzy jakby naturalny klimat zwrotu ku soteriologii transcendentnej i zarazem przestrzeń dla organizatorów wyobrażeń zbiorowych obcujących na co dzień z transcendencją. Analizując swoje szanse zbawienia „tu” i „tam” dokonujemy swoistych bilansów, oswajamy się z tym, co tracimy „tu” i „teraz” i zastanawiamy nad tym, co możemy zyskać „tam”. Pytamy o to, czemu mamy coraz mniej, a poza tym o to, dlaczego stare struktury myślenia nie przystają do naszego czasu. Nie ma już starych granic, dziś „dryfujemy gdzieś w strefę niczyja, między życiem syntetycznym i organicznym, między prawdziwym a wirtualnym środowiskiem ${ }^{84}$. W takich czasach potrzeba wiary $\mathrm{w}$ zbawienie zarówno w doczesności, jak i poza nią zdaje się coraz silniejsza, ale po stronie podaży nie spotykamy przemyślanych prób wypełnienia pustki. Czasami zdaje się, że rację ma autor powiadający, że wszyscy znajdujemy się jakby w stanie lekkiego odrętwienia ${ }^{85}$. Z jednej strony wyalienowany Kościół, z drugiej miernej jakości politycy, którzy miast kreować wizje zbawienia, tak często i niefrasobliwie niszcza je wraz $\mathrm{z}$ nadziejami. Wydaje się, że w naszym czasie polityków stać na obiecywanie wszystkiego i niedawanie niczego z zadziwiajacca niefrasobliwością. Społeczności zostaja pozostawione samym sobie i zdaje się, że nadchodzi czas, by zaczęły same kreować wyobrażenia zbiorowe, tworzyć własne przestrzenie zbawienia.

${ }^{83}$ H. Bergson, Dwa źródta moralności i religii, Kraków 1993, s. 21.

${ }^{84}$ E. Davis, TechGnoza, s. 9.

${ }^{85}$ P. Virillo, Bomba informacyjna, Warszawa 2006, s. 37. 



\section{3}

\section{W STRONE NADZIEI}

Nadzieje jednostkowe i zbiorowe przez tysiące lat także znajdowały się poza refleksja, wpierw filozoficzna, a potem naukowa, aż po ostatnie dekady XX stulecia i narodziny „filozofii nadziei”. Przez wieki pozostawały wielka metafora literatury, przyjmująca postać wielu innych metafor, alegorii, spośród których tą niezmienna, wieczna, jest alegoria feniksa nie dotykającego ziemi i odradzającego się w powietrzu z własnych popiołów i taka trwała w przestrzeniach wyobrażeń zbiorowych niebaczna na to, że nie zwraca się na nią uwagi. Wielkie i małe nadzieje żyły własnym życiem, a właściwie tysiącami istnień w kulturach człowieka, bo taka jest natura feniksa, a właściwie miliardów feniksów. Ta wielka nadzieja towarzyszyła nam w mądrościach ludowych i przyznawaliśmy rację nawet tym, którzy mówili, że nadzieja jest matka głupców, a jeśli tak jest, to wszyscy jesteśmy głupcami i takimi pozostańmy nie wyrzekając się jej.

Niekiedy tylko wielkie metafory literatury stawały się integralnymi składowymi przestrzeni symbolicznych interpretowanymi na wiele sposobów, a tą bodaj najbardziej znaną jest metafora Dantego, dla którego świat bez nadziei był piekłem (porzućcie wszelką nadzieję ci, którzy tu wchodzicie). Jest ich wiele, ale jej niezwykła, współczesną i budzaca wiele emocji interpretacja, tak wiele znaczaca w naszym czasie dla młodych ludzi, okazała się trylogia J.R. Tolkiena Władca pierścieni. Wbrew pozorom, wbrew krytykom i historykom literatury, to wielki traktat o nadziei, wierze $\mathrm{w}$ pokonanie Zła, walce aż do kresu nadziei, jak w pieśni Eomera w bitwie na polach Pelennoru. Lekceważymy takie przesłania, ale ich nie można ani nie docenić, ani przecenić z wielu względów, a pierwszym jest choćby ten, że to jest własnością wspólna setek milionów ludzi i tu chyba nie przesadzamy mając na uwadze liczbę wydań w wielu językach i popularność filmowej trylogii P. Jacksona. 
Te metafory sa wspaniałymi lekcjami nadziei dla najmłodszych, ucza i marzeń i pokonywania przeciwności w drodze ku nim, a bohater tej wyjątkowej epopei, swego czasu wielbiony przez zbuntowaną młodzież amerykańska, Frodo, uczył, jak powinniśmy je rewitalizować, jak poszukiwać nowej nadziei mimo jej widocznego kresu i takie nauki pozostają w nas, choć czasami nie potrafimy ich nazwać, bo uważa się, że są to pytania z rzędu „głupich”. Co znamienne, trylogia Tolkiena ukazała się drukiem w połowie lat pięćdziesiątych i wtedy uznano ją za interesująca literaturę dziecięca, natomiast obiektem kultu stała się dopiero w końcu XX wieku. Mniej ciekawe jest już to, że nikt nie zapytał o przyczyny „odkrycia” autora właśnie w tym czasie, czyli w już rozkwitającej, eskapistycznej ponowoczesności, ale to już chyba konsekwencje braku stawiania „prostych pytań”.

W tym niezwykłym dziele, które dzięki P. Jacksonowi stało się własnością miliardów nadzieja przetrwała i zwyciężyła dzięki niziołkom - metaforze nas wszystkich - tchórzliwym, wygodnickim ludzikom niewiele sięgających nad ziemię, ale czasami potrafiącym zdobywać się na niezwykłą odwagę i poświęcenie, czasami nierozważnym czy lekkomyślnym, ale czasami także wiernym sobie i słowu. Widząc jej tyle w literaturze zauważamy, że nieco niepojęty jest niemal zupełny jej brak w nauce, jeśli zważymy, że ona, rozumiana jako postać horyzontu oczekiwania - jak widział to P. Ricoeur ${ }^{1}$, istniała zawsze i istnieć będzie póki istnieje człowiek - jedyne stworzenie, które potrafiło ją stworzyć i kultywować codzienna praktyką za sprawą zrozumienia (niepełnego, ale jednak) istoty przyszłości, bo nie wydaje się konieczne wyjaśnianie tego, że przeżywanie nadziei jest niemożliwe bez pojęcia przyszłości. To w niej i tylko w niej, przestrzeni otwartej ontologicznie i zamkniętej epistemologicznie, poszukujemy znaków, które mogłyby położyć kres napięciom i lękom zrodzonym $\mathrm{z}$ bezradności wobec niepojętego świata i życia, które cały czas przesuwa się w jutro ${ }^{2}$. Niepojęta, nieodgadniona przyszłość jest tym dalekim i bliskim zarazem, mglistym i wyrazistym horyzontem lęków i nadziei ${ }^{3}$. Tak widział to teolog, dla którego także nadziei nie można odłączyć od lęku, jej opozycji.

Została odsunięta poza pola nauki w jakiejś mierze za sprawa „koszmaru determinizmu", tej wiary nauki pozytywnej z jej naukowa religijnościa, która zaczęła triumfować niepodzielnie ponad dwa wieki temu po detronizacji innej postaci determinizmu - prowidencjalizmu (przypomnijmy, iż jest to przekonanie o stałej ingerencji Boga we wszystkie wydarzenia ziemskie, wiara w boskiego ekonoma projektującego histo-

\footnotetext{
${ }^{1}$ P. Ricoeur, Krytyka i przekonanie, Warszawa 2003, s. 179.

${ }^{2}$ M. Eliade, Sacrum i profanum, Warszawa 1999, s. 21.

${ }^{3}$ W. Pannenberg, Człowiek, wolność, Bóg, Kraków 1995, s. 58.
} 
rię i losy jednostek). Ten „solidny”, naukowy determinizm, tworzony z ludzkiej potrzeby ładu ${ }^{4}, \mathrm{z}$ czasem zaczą rościć sobie pretensje do absolutnej wiedzy i głosił niezmienny porządek świata, w jakiś sposób uzupełniał próżnię, jaka - zdaniem P. Halperna - pozostawiła po sobie religia ${ }^{5}$. Co do tej próżni mamy poważne wątpliwości nie wiedząc czym jest owa metafora, ale pozostawiając na boku uwagę uczonego zauważamy, że ludzie przez wieki szamotali się między potrzebą mądrości i potrzebą pewności hołdując zwykle tej ostatniej ${ }^{6}$, wierząc w „obiektywne” konieczności, „prawa dziejowe”, które bankrutowały wraz z kryzysami wiary $\mathrm{w}$ paradygmaty determinizmu korzenione $\mathrm{w}$ wyobrażeniach zbiorowych pierwszych społeczności ludzkich i rytualizowane przez wieki w wielu postaciach. Mierząc i ważąc drobiazgowo wszystko „racjonalistyczni determiniści" nader chętnie i nader pochopnie usuwali z pola widzenia nauki wszystkie determinanty, jakich nie dawało się kwantyfikować, a nadzieje sa przecież niemierzalne, choć nie do końca, bo przecież z powodzeniem można mierzyć tak zwane „oczekiwania społeczne”, co od lat czynią socjologowie. Celem deterministów była, tysiące razy ponawiana i bezskuteczna, próba ustalenia ścisłych i powszechnych praw $^{7}$. Nie sposób kwestionować jego istoty, bo sam determinizm jest oczywiście nie do zakwestionowania, inaczej musielibyśmy zaczać wierzyć w dzieworództwo, ale ma charakter zdecydowanie probabilistyczny. Nie zdołamy go opanować ufając tezom Carnapa-Poppera.

Wedle tych, próbujących oceniać postawy prospektywne, uczonych struktura wyjaśniania i prognozowania przyszłości jest identyczna. Wyjaśnianie dedukcyjno-nomologiczne zasadza się na tym, że zjawisko powinno być wyjaśniane wnioskiem logicznym ze zbioru ogólnych praw i tzw. warunków początkowych, czyli odpowiedniej ilości przesłanek. Przewidywanie cechuje się taka sama strukturą logiczna, z tym tylko, że zdarzenia przewidywane jeszcze nie nastapiły i przewidywać możemy tylko takie zjawiska i procesy, które sa wyjaśnialne, czyli takie, które podlegaja prawom i mają odpowiednią ilość warunków początkowych. Konsekwencja takiego rozumowania powinno być więc trafne przewidywanie. Zgadzając się z uczonymi co do poprawności formalnej modelu nie możemy nie zauważyć, że jesteśmy w stanie przewidzieć zaledwie niewielką część takich zjawisk, w innych przypadkach pozostaje nam tylko nadzieja, że ograniczona ilość warunków początkowych pozwoli nam trafnie przewidzieć przyszłość. Nie potrafimy sobie nawet wyobrazić zebrania wszystkich przesłanek do, nawet infantylnego

\footnotetext{
${ }^{4}$ K. Burke, Language and Symbolic Action, Berkeley 1966, s. 15.

${ }^{5}$ P. Halpern, Na tropach przeznaczenia, Warszawa 2004, s. 86.

${ }^{6}$ R. Rorty, Filozofia a zwierciadto natury, Warszawa 1994, s. 281.

${ }^{7}$ A.G. van Melsen, Filozofia przyrody, Warszawa 1968, s. 269.
} 
wniosku, jak choćby wniosku o tym, że będzie padał deszcz, bo gdybyśmy zechcieli uwzględnić przesłanki natury fizyko-chemicznej, musielibyśmy napisać saż̇nistą monografię, a przedtem znowu uczyć się chemii i fizyki. Oczywiście to może się nam udać, ale nie zbierzemy przesłanek do jakiegośs sądu o naturze człowieka albo społeczeństwa, nie mówiąc o tym, że nie znamy żadnych „praw” rządzących nimi. Teoria determinizmu po prostu jest teoria nie do weryfikacji, jeśli nie potrafimy ani zbierać wszystkich przesłanek-determinant, ani też przewidywać przyszłości ${ }^{8}$.

Praktyka potwierdza, że udaje się nam niezmiernie rzadko skonstruować sądy o społeczeństwie i jednostce oparte na mocnych, pewnych przesłankach i zrelatywizowany, „oswojony” determinizm dopiero czeka na swoje nowe miejsce w nauce. Miał swoje racje D. Hume, kiedy powiadał, że konieczność istnieje w umyśle, twierdząc dalej, że wiedza o przyczynowości jest intuicyjna i instynktowna, a przyczynowość jest jedynie konstrukcją nałożoną na przyszłe wydarzenia i wynika z siły naszego przyzwyczajenia. Filozof nie dodał jednak, że podobna, acz bardzo mglista konstrukcja, a właściwie jej zarysem, jest nadzieja zawłaszczana podówczas przez ludzi kościołów. Niekiedy obie kontaminuja się, nakładaja na siebie, bo wiele nadziei opieramy na intuicji konieczności, na wiedzy o praprzyczynach albo wierze w nie.

Wtedy, kiedy zawodzi nas próba pewnego odczytania konieczności znowu musimy zawierzyć nadziei i to ona tak często nadaje sens naszym krokom, bo każda nadzieja jest obietnica, jeśli nie zbawienia, to spełnienia, wielu spełnień w życiu. Ale nie jest tylko promienna panna młodą z tysiącem obietnic ze strof poetów, bo za nia, istniejąca tylko $\mathrm{w}$ jutrze, zawsze kryje się strach wiązany z wielością wyborów, z koniecznością marszu $\mathrm{w}$ to zbliżające się nieubłaganie jutro, co tak plastycznie ują $\mathrm{Ch}$. Handy: „W chwili, gdy wiemy dokąd mamy pójść, jest już za późno, by tam iść. Ale iść musimy nawet gdy cel nie istnieje, gdy wszystko jest gra, my musimy wierzyć, że ten cel jednak istnieje, a jeśli $\mathrm{w}$ to nie uwierzymy, nie będzie powodu, by cokolwiek robić, wierzyć w cokolwiek, by cokolwiek zmienić. Wtedy świat będzie zdany na łaskę tych, którzy nie wierzą w możliwość zmian”" Idziemy w przyszłość z nadzieją szukając celów, wiedząc, że gdzieś jednak dojdziemy i wtedy stykamy się z cieniami strachu, nieodłacznymi od niej.

Nadzieja towarzyszy nam na każdym kroku w przyszłość, ożywa i obumiera i jest w niej pragnienie spełnienia, sa inspiracje do działania, a dla polskiego papieża była i jest gotowością zajęcia stanowiska

$\overline{8}$ T. Honderich, Ile mamy wolności?, Poznań 2001, s. 83.

${ }^{9}$ Ch. Handy, Wiek paradoksu, Warszawa 1996, s. 53. 
i działania wedle przyjętego stanowiska ${ }^{10}$. K. Wojtyła, po swojemu pojmujacy nadzieję, zdawał się tu powtarzać zdanie G. Marcela, dla którego chrześcijańska nadzieja mieści się $\mathrm{w}$ ramach próby czynu ${ }^{11}$. Z pewnością może także oznaczać bierne czekanie na spełnienie, ale jej istota jest przede wszystkim inspirowanie czynów, poszukiwanie uzasadnień działania. Można by rzec, że jest wolnością niemal w czystym sensie - wolnością wyboru i zarazem kreowania tego wyboru. Jest wartościa w życiu każdego z nas, ale i brzemieniem, gdy wiemy, że za nią kryje się nieodłaczny strach. O jej sile i znaczeniu mogliśmy przekonywać się obserwując jej wielkie erupcje zmieniajace oblicze świata, bo naszym zdaniem wielkie rewolucje były wybuchami nadziei. Sądzimy, że uwzględnianie jej może pozwolić na inne, może pełniejsze wyjaśnienia istoty rewolucji francuskiej, czy rosyjskiej.

Ta jakościowa determinanta jest widoczna niemal w każdym wielkim wydarzeniu, jeśli o niej wiemy i niewidoczna w badaniach naukowych, a niekiedy próby zrozumienia i wyjaśnienia przyczyn rewolucji aż rażą uproszczeniami. Nie przypominamy tu nadziei, które tworzyły wspólnoty chrześcijańskie mając na uwadze tylko rewolucje nowoczesności z solidarnościową w ich liczbie. Naszym zdaniem, bez uwzględnienia sił nadziei, każde ich wyjaśnienie będzie co najmniej niepełne. Wiemy, jak wyglądaja dziesiątki wyjaśnień wybuchu Solidarności, a zwykle mówi się, że był to słuszny odruch buntu klasy robotniczej bioracy się z niewydolności systemu i wedle nas jest to tylko kiepska mityzacja, rażące uproszczenie. Poza wieloma istotnymi czynnikami o tej erupcji współdecydowały te czynniki niemierzalne, zwykle niedoceniane przez badaczy, od lat uważajaccych je za imponderabilia. Zawiedzione, nawarstwiające się nadzieje tych, którzy mieli być zbawcami socjalistycznego społeczeństwa, doprowadziły do tego wybuchu, a nadzieje większości Polaków przesądziły o tym, że w tak niepojęcie krótkim czasie Solidarność stała się ruchem milionów i dla nas rok 1980 był rokiem prawdziwej rewolucji nadziei.

Pytając o to, czym jest ta wielka metafora zauważamy, że stworzyło ją ludzkie rozumienie czasu, a charakterystyczną cechą zwierząt ludzkich jest ich świadomość temporalnego istnienia, nie tyle teoretyczna, co praktyczna ${ }^{12}$. Człowiek przetrwał także dzięki temu, iż stworzył zbiorowości, a ludzie nie żyją w społeczeństwie - zauważał M. Carrithers - ale tworza społeczeństwa po to, by żyć ${ }^{13}$. Żyć jak najlepiej i taka prawda nie budzi chyba najmniejszych zastrzeżeń, choć jest interpreto-

\footnotetext{
${ }^{10}$ K. Wojtyła, U podstaw odnowy, Kraków 1972, s. 179.

${ }^{11}$ G. Marcel, Homo viator, Warszawa 1959, s. 35.

${ }^{12}$ E. Tugenhand, Bycie. Prawda. Rozprawy filozoficzne, Warszawa 1999, s. 76.

${ }^{13}$ M. Carrithers, Dlaczego ludzie maja kultury, Warszawa 1994, s. 11.
} 
wana na wiele sposobów. Wszyscy poszukujemy lepszego świata i pragniemy, mamy nadzieję na to, co najczęściej zwie się samorealizacja, choć z konkretyzacją tego pojęcia możemy mieć problemy, co zauważaliśmy wcześniej. Jest z pewnościa postacia pragnienia spełnienia indywidualnego w obu, czy w trzech wymiarach, ale jakość tego spełnienia także budzi poważne wątpliwości każdego niemal człowieka. Może nim być osiagnięcie jakiegoś założonego celu, który z pozoru zdaje się nieosiagalny, choćby bycie posłem na sejm, wybitnym sportowcem czy kosmonautą. Może być małym szczęściem z ukochaną i odwzajemniająca uczucia osoba, ale też może być osiagnięciem ataraksji dzięki odkryciu w sobie cech i możliwości, których wykorzystanie daje nam poczucie pełni życia, jakiego nie zrozumieją inni, mający inne wizje tej samorealizacji. Nie wiemy i zapewne wiedzieć nie będziemy, co jest pełnia nadziei nie wiedząc do końca, czym jest ona sama. Mamy tylko w miarę mocną pewność, co do tego, że ludzkie potrzeby i pragnienia są nieograniczone, a one sa potężnym rezerwuarem nadziei ${ }^{14}$.

Nadzieja, co jednak podkreślać trzeba, pozwala nam otwierać się na budząca ja przyszłość, jest kluczem do niej także dla H. Arendt, a wedle niej człowiek myślacy żyje w przestrzeni między przeszłościa a przyszłościa, a to, co nazywa teraźniejszościa jest trwającą przez całe życie walką przeciw martwemu ciężarowi przeszłości, z tym, co już nie wróci. Walka, która $\mathrm{z}$ nadzieja kieruje go naprzód oraz przeciwko lękowi przed przyszłościa, który z kolei kieruje go wstecz ku „ciszy przeszłości”, napełnia go nostalgicznym wspomnieniem tej jedynej rzeczywistości, której człowiek może być pewnym ${ }^{15}$. Przeszłość, tożsama, a właściwie pełna przejawów wspomnianej schizochronii, wydaje się być choroba, a pełna nadziei przyszłość zdrowiem. Tylko tak się wydaje, bo ilość strachów w niej dorównuje ilości nadziei i ta równowaga też wydaje się być czymś naturalnym dla dualnego człowieka.

W ogromnej mierze dzięki historykom szkoły Annales, późno ale zaczęto zauważać - jak A. Giddens - że żadne badania właściwości strukturalnych systemów społecznych nie moga być owocne bez odwołania się do refleksyjności podmiotów działających ${ }^{16}$. Wielką zasługą Braudela, Bagby'ego, Delumeau i wielu innych „poszukiwaczy” reprezentujacych nowe spojrzenie, było obrócenie się na motywacje, niekwantyfikowalne inspiracje powodujące jednostkami i zbiorowościami, uczynienie $\mathrm{z}$ nich narzędzi nauki pomocnych w wyjaśnianiu na nowo tego, niby już wyjaśnionego. Oczywiście ci historycy odegrali role katalizatorów, a czynnikiem decydujacym o poszukiwaniach innych, jakościowych

\footnotetext{
${ }^{14}$ G. Lenski, J. Lenski, P. Nolan, Human Societies, New York 1991, s. 53.

${ }^{15}$ H. Arendt, The Life of Mind, New York 1978, s. 205.

${ }^{16}$ A. Giddens, Stanowienie społeczeństwa, Poznań 2003, s. 380.
} 
czynników zmian, okazywały się tak częste zawody nauk społecznych, daremnie poszukujących w miarę pewnych prawd o historii i teraźniejszości człowieka, a także w jakimś stopniu teologii okresu soborowego, która inspirowała poszukiwania „filozofów nadziei”. Po pierwszych próbach sięgania przez historyków do tych czynników zmian, w latach 60., w dużej mierze dzięki teologom i filozofom personalistycznym, wybuchła ta swoista „rewolucja nadziei” w filozofii katolickiej mająca sprowadzać religię $\mathrm{z}$ jej postaciami nadziei na ziemię, między ludzi, a ta „rewolucja” zdaje się być reakcją na postaci religijności społeczności zbawiających się pośród dóbr materialnych.

Przywołując maksymę Platona można by zauważyć, że tym więcej istnieje to, co jest więcej warte. A wartość nadziei dla „filozofów nadziei" miała stać się wprowadzeniem do innych postaci eschatologii chrześcijańskiej, bo dość zdecydowanie kontestowali takie jej postaci, jakie pozostają stałe od wieków i odrywaja nadzieje chrześcijańskie od realności. To oni dobrze zrozumieli przesłania historyków szkoły Annales i poczęli twierdzić, że chrześcijaństwo niedostatecznie uwzględniało perspektywę eschatologiczna, po macoszemu traktując zbawienie i taki brak zaowocował odwracaniem się od Kościoła nie tylko w społeczeństwach dobrobytu. Wedle nich Kościól, głoszący nadzieje w sposób nader abstrakcyjny, okazał się niezdolny do inspirowania życia we wszystkich jego wymiarach i przez to zatracił dynamizm działania. Mieli swoje racje, a taka inercja Kościoła jako instytucji musi budzić co najmniej zdziwienie, bo nie czyniono wiele, by w latach 60 . i 70 . przywracać na jego łono miliony Francuzów, Włochów, Hiszpanów, a dziś obserwujemy to w Polsce, nie bardzo wiedząc jak interpretować polska religijność. Nie przywiązujmy aż tak wielkiej wagi do wielu działań Kościoła, choć doceniać trzeba rolę soboru i niektórych działań papieży. Można było inaczej, dynamiczniej, a niejednokrotnie pojawiały się sugestie intelektualistów skupionych wokół Kościoła, by ten w nowym czasie zaczą proponować postawy nadziei i zaangażowania w prace mające zaowocować wizjami przyszłości ludzkości i nowego ładu ${ }^{17}$. Pozostały tylko sugestiami, nawet goraco dyskutowanymi w waskich kręgach kościelnych intelektualistów, ale nawet najmędrsze dysputy niewiele znacza, jeżeli nie mają przełożenia na praktykę. Praktyka Kościoła nie potwierdzała chęci korygowania soteriologii, chyba w jakiejśs mierze za sprawa jej niedoceniania, mimo zapomnianych nauk schizm. Te nauki poszły w las, a chyba jednak widząc to, w „polityce ekumenizmu" Kościół chce szukać nowych dróg.

${ }^{17}$ J.Y. Calvez, Upadek komunizmu, [w:] Chrześcijaństwo a integracja europejska, Kraków 1997, s. 203. 
Nadzieja chrześcijańska w mutacjach J. Metza, J. Alfaro prezentowała się jednak jako nowa postać egzegezy soteriologii, ale jednak niezwykle hermetycznej, obudowanej trudnymi w interpretacji metaforami, mającej służyć tylko uczonej dyspucie z innymi filozofami, co wróżyło płonnymi owocami. Niełatwo właściwie zinterpretować przesłanie Alfaro, dla którego nadzieja to oczekiwania w obietnicę Bożą zakodowaną w Chrystusie. Możemy to pojmować jak wstęp do chrystologii, możemy całkiem inaczej, ale jak zinterpretuja to ci, którzy interpretować nie potrafią i zdają się na tych, którzy uczynią to za nich? Jak ci, którzy czując niedosyt pustej wiary? Inaczej, bardziej praktycznie, widział to T. Moltmann, a według niego nadzieja chrześcijańska wymaga całkowitego, ufnego zaangażowania się w życie tego świata, społeczne, polityczne i wynikające z niego implikacje. Interpretując go możemy dojść do wniosku, że nadzieja jest nadzieją na lepszy świat, jaki zbudujemy wspólnie pomni tego, że jesteśmy kontynuatorami boskiego dzieła stworzenia, a takie chrystologiczne sugestie już nie bardzo zgadzały się z praktyką Kościoła. Próbując włączyć eschatologię w historię Moltmann i inni teoretycy zmierzali do zbliżenia transcendencji i zaznaczenia jej immanentnego wymiaru. Był na swój sposób bliski wielu herezjarchom, którzy opowiadali się za drogą zbawienia przez czyny, a na taką Kościół od wieków patrzy z dystansem opowiadając się konsekwentnie za zbawieniem przez wiarę. To, wedle hierarchów, pozwala na kontrolowanie wspólnoty, wymuszanie posłuszeństwa poprzez rytuały. Wydaje się, że takie cele sa osiagane, ale za sprawą takich stanowisk wspólnoty kurczą się orientując na czysto ziemskie postaci zbawienia.

Podobnie jak Moltmann widział ją najwybitniejszy filozof nadziei E. Bloch, twórca tak zwanej „religii obietnicy”. Dla niego Bóg jest absolutna przyszłością przez apostolską triadę wiara-nadzieja-miłość, objawi się człowiekowi w pełni wówczas, kiedy ten wypełni dzieło tworzenia, a teraz tylko otwiera nowe możliwości do lepszego życia, umożliwia swojemu tworowi zbawienie tu, na ziemi ${ }^{18}$. Filozof zakwestionował postać zbawienia przez wiarę oddając człowiekowi wolną wolę, zauważając, że w dysputach tamtego czasu przyznawano mu ja, ale tylko po to, by mógł wybierać między umownym dobrem a złem określanymi przez małych, omylnych ludzi. Po to, by stawać się sobą i zrozumieć swoje role w świecie musimy wybierać między czynami dla siebie w stawaniu się i czynami dla innych. Była to swoista interpretacja słów św. Pawła, który mówił, że w nadziei już jesteśmy zbawieni. Można to pojmować jako kreację wysiłków codziennych służących zbawieniu poza ziemia,

${ }^{18}$ R. Schaeffer, Filozofia religii, Częstochowa 1989, s. 81. 
ale zbawiając się także na tym padole. Prezentowaliśmy Blocha gdzie indziej i dlatego też przypomnimy, że nadzieja dla filozofa jest opozycja strachu tworzac wymiary, w których rodza się marzenia, niezwykłe, niezbywalne i niewykorzystywane możliwości człowieka. Cechy takich marzeń to: swoboda kształtowania obrazu przyszłości, zachowanie Ja marzącego; intencje poprawienia rzeczywistości nie tylko dla jednostki marzacej, ale dla całego gatunku ludzkiego ${ }^{19}$.

Przesilenia poznawcze, na wpół dokonane rewolucje paradygmatów drugiej połowy wieku XX, tworzyły nowe horyzonty poznawcze, mimo iż wychodzenie poza niektóre groziło poważnymi konsekwencjami ze strony środowiska tym naukowcom, którzy sięgali poza nie próbując inaczej rozumieć i wyjaśniać. Takie konsekwencje grożą zresztą i dziś, odwaga myśli nie jest już widziana w nauce zbyt mile, bardziej ceni się odtwarzanie, powielanie bez zadawania kłopotliwych pytań. Dopiero po przełamaniu paradygmatów pozytywizmu, powolnym uprawnieniu nowych sposobów spojrzenia przez autorytety na nadzieje i strachy, one powoli, bardzo powoli zaczęły powracać w krag zainteresowań nauk społecznych i przypomnimy tu tylko wybitnego uczonego A. Maslova, który powtarzał wiele razy, że uczucia, pragnienia i nadzieje sa tak samo ważne w teorii ludzkiego zachowania, jak wpływy i bodźce zewnętrzne ${ }^{20}$, ale podówczas takie sugestie trafiały tylko do psychologów pozostawiając obojętnymi przedstawicieli innych nauk społecznych, ze szkodą dla nich i efektów ich rozpoznań. Wydaje się nam oczywiste także i to, że zauroczenie nowymi kluczami do „natury” człowieka i społeczeństwa nie może zwodzić nas na manowce i tworzyć nowe sposoby wyjaśniania opierane przede wszystkim na jakościowych czynnikach zmian. One powinny komponować się w metodach ze znanymi, ilościowymi, opierać się na nowych przesłankach w sposób przemyślany i ostrożny z dużym udziałem tego, co nazywamy zdrowym rozsądkiem badacza.

W połowie XX wieku na nowo „odkryto” nadzieję w immanencji wraz z koniecznością kolonizowania przyszłości, jaka nie pojawiła się znikąd, ale została przypomniana u schyłku prowidencjalizmu, bo taka konieczność istniała od „zawsze”, a jej śladów w kulturze człowieka nie brakuje i tylko czasami nie chcemy jej zauważać. Skoro zaczęto przyjmować, że świat nie był już podporządkowany planom boskiego ekonoma, zaczęto uznawać, że człowiek sam winien poszukiwać dla siebie nowych celów, winien nauczyć się przewidywania, bo bez niego - twierdził R. Carnap - nauka i życie codzienne byłyby niemożliwe ${ }^{21}$.

${ }^{19}$ A. Sepkowski, Człowiek a przyszłość, Toruń 2005, s. 19.

${ }^{20}$ F. Capra, Punkt zwrotny, Warszawa 1987, s. 498.

${ }^{21}$ R. Carnap, Wprowadzenie do filozofii nauki, Warszawa 2000, s. 25. 
Praktyka społeczna dowodziła, że, mimo tylu nadziei na odgadnięcie kształtów przyszłości, trafne przewidywanie przyszłości nie jest możliwe i owe luki wypełniała właśnie nadzieja i to ona w głównej mierze umożliwia nam transgresję jednostkową i grupowa, organizację wysiłków indywidualnych i zbiorowych w imię przyszłości. Jednak ta niedoceniana nadzieja jest jakościowa determinantą zmian, choć jeszcze nie bardzo wiemy, jak ją badać i, póki co, oglądamy się na metody socjologów starających się badać preferencje i oczekiwania jednostek i zbiorowości, które do pewnego stopnia pozwalaja ja kwantyfikować, bo jednak w jakiejśs części jest także zjawiskiem ilościowym, tam zwłaszcza, gdzie chodzi o spełnienie materialne. Ale chyba powinniśmy zwracać na nia znacznie większą uwagę, jeśli słyszymy mocne zdanie K. Poppera z jego ostatniego dzieła: „Uważam za moralnie fałszywe to, że nie wierzy się w realność i nieskończoną doniosłość oraz realność i ważność ludzkiej nadziei”"22.

Niezwykle trudno jest kategoryzować metaforę wyjaśnianą przez inne metafory, symbolizowaną setkami symboli i wszelkie próby zbliżenia jej istoty są tworzeniem nowych metafor, a tak zdaje się w przypadku J. Guittona, dla którego nadzieja „polega na dążeniu do możliwie największego zbliżenia się do przedmiotu, ku jakiemu się zwraca i skrócenia odległości w czasie, jaka nas od niego dzieli” ${ }^{23}$. Widzimy tu taką trudność, albowiem uczony nie próbuje nawet oznaczać zakresu znaczeniowego pojęcia i taka „nadzieja” może być oczekiwaniem albo tęsknotą zawieszoną w przyszłości i w tym przypadku jest to nadzieja konkretyzowana celem, jakim jest ów „przedmiot”, a wiemy o tym, że nasze nadzieje, a zwłaszcza wyrastajace $\mathrm{z}$ nich marzenia, nie zawsze sa celowe, bo czyż marzenie przeciętnej nastolatki o byciu piękna, bogata i sławna jak Claudia Schiffer, jest celowe?

Równie metaforycznie określał ją filozof powiadając: „O nadziei mówię wtedy, gdy to, czego oczekuję, jest dla mnie dobre" ${ }^{24}$, a w tle tej refleksji widzimy strach, bo to, co nie jest dla nas dobre zwykle napawa strachem. Nie wystarcza nam również próba innego badacza, dla którego nadzieja oznacza najbardziej podstawową jakość Ja, bez której życie nie może się zacząc ani w sensowny sposób skończyćc ${ }^{25}$. Mimo takich sugestii, które poświadczają potrzebę choćby kategoryzacji, badacze traktuja te problemy z dystansem uważając, że nie znaja pola badań, nie mają odpowiednich narzędzi nauki i wydaje się, że żale takie, jak poniższy będą się powtarzać: „ Ciagle brak informacji na temat źródeł

\footnotetext{
${ }^{22}$ K. Popper, W poszukiwaniu lepszego świata, Warszawa 1997, s. 79.

${ }^{23}$ J. Guitton, Sens czasu ludzkiego, Warszawa 1999, s. 20.

${ }^{24}$ J. Pieper, Nadzieja i historia, Warszawa 1981, s. 11.

${ }^{25}$ E.H. Erikson, Dopetniony cykl życia, Poznań 2002, s. 76.
} 
naszych planów i wizji. W literaturze psychologicznej dominują niepotwierdzone koncepcje lub tylko krótkie wzmianki tłumaczące nam skąd biorą się „scenariusze” naszego życia” 26 .

Nie potrafiąc jej skategoryzować nie potrafimy także znaleźć w gasszczu symboli zapełniających pola znaczeniowe pojęć jej bliskich: spodziewania, oczekiwania, marzenia, tęsknoty i często pozostajemy tu bezradni używając tych werbalnych symboli. F. Jacob, chyba dość pochopnie, utożsamiał ja z marzeniami, kiedy pisał: „Nie należy zapominać o tym, że człowiek ma taka samą potrzebę marzeń, jak i rzeczywistości. Nadzieja jest tym, co nadaje sens życiu. W nadziei znajdziemy perspektywę, że pewnego dnia możliwe będzie przekształcenie świata obecnego w jakiś świat możliwy, który stanie się lepszy"27. Jakaśs jej postacia sa chyba złudzenia, które pozwalają nam wybierać takie alternatywy, jakie łączą się z większym ryzykiem ${ }^{28}$, Nie wiedząc dobrze, czym jest, starając się zbliżyć ją w miarę naszych skromnych możliwości, poprzestańmy na parafrazie św. Augustyna i powiedzmy, że wiemy, czym jest nadzieja wtedy, kiedy nikt nas o to nie pyta. Zdaje się, że możemy zarysować jej kontury i, jeśli jest oczekiwaniem przyszłości w wielu formach, to nietrudno zauważyć, że możemy ją badać metodami socjologicznymi, ale wpierw trzeba zgodzić się z tym, że jest znaczącym czynnikiem zmian, a mając $\mathrm{w}$ pamięci konfrontacje $\mathrm{z}$ polskimi uczonymi, można w to czasami watpić.

Codzienna praktyka potwierdza także i to, iż skupiamy uwagę na tym, czego się spodziewamy, układamy swoje życie w zależności od możliwości zrealizowania swoich oczekiwań, potrzeb, pragnień, marzeń wyrastających właśnie z nadziei. Dokonując codziennie wielu wyborów pomijamy różne możliwości, aby lepiej dostosować się do przyszłości, choć to nie zawsze nam się udaje - co zauważał filozof ${ }^{29}$. Nie ulega chyba wątpliwości, że chcąc realizować się w czasie i przestrzeni, poza przesłankami racjonalnymi, powodujemy się także pragnieniami, wiara w wykonalność jakiegoś zadania i tworzymy to, co T. Honderich trafnie nazwał „wierzeniem projektującym” ${ }^{30}$. I znowu codzienne doświadczenie podpowiada nam, że wielkie rzeczy, jakich udało się nam dokonać w mikro- i mikroskali nam samym, jak i zbiorowościom, osiągnęliśmy dzięki wierze i samej nadziei, znaczącym nie mniej niż

${ }^{26}$ C. Timoszyk-Tomczyk, Konstruowanie własnej przyszłości $w$ kontekście zmian we wspótczesnym świecie, [w:] Psychologia wspótczesna. Oczekiwania i rzeczywistość, red. M. Ledzińska, G. Rudkowska, Kraków 2005, s. 43.

${ }^{27}$ F. Jacob, Gra możliwości, Warszawa 1987, s. 99.

${ }^{28}$ M. Dymkowski, Wprowadzenie do psychologii historycznej, Gdańsk 2003, s. 138.

${ }^{29}$ J. Bańka, Ja, teraz, Katowice 1983, s. 410.

${ }^{30}$ T. Honderich, Ile mamy wolności?, s. 61. 
wiedza, a taka sugestia zdaje się potwierdzać, kiedy przyglądamy się późnym etapom wielu rewolucji. Wiara jest blisko nadziei, tak blisko, że niekiedy jedna zdaje się drugą i sami nie wiemy, czy wierzymy, czy mamy nadzieję. Wielka triada apostoła: wiara-nadzieja-miłość wciąż rodzi nowe egzegezy, nowe metafory.

Znajdziemy wiele innych potwierdzeń roli marzeń i pragnień u autorów nie kwestionujących scjentyzmu, ale uważających, że obowiązujące $\mathrm{w}$ naukach społecznych paradygmaty sa jednak czasami bardzo krępujące, czasami także nie owocujące praktyczną użytecznością nauki. W naukach społecznych, dzięki tym, wspominanym „odkryciom” szkoły Annales i filozofów nadziei, od kilkunastu lat coraz mocniej akcentuje się przekonanie, że nadzieje i strachy to czynniki kształtujące dzieje człowieka i zasługują na o wiele większą uwagę socjologów, historyków, politologów. Powiada się, że przy ich uwzględnianiu w próbach wyjaśniania nauki społeczne wspomogą działania kreatorów życia społecznego i politycznego. Być może pomogą nie tylko walczyć z psychozami, traumami społecznymi, ale także pomoga budzić nowe, aktywizujące nadzieje, jakich brakuje dziś nie tylko Polakom. Przy czym owo „mocniej” nie znaczy wcale, że mocno.

Sa potrzebne zwłaszcza w okresach atrofii wiary, nadziei, wartości, a takim dla J. Delumeau wydaje się nasz $\operatorname{czas}^{31}$.Widzimy symptomy tego braku w wielkich grupach społecznych, widzimy jak wielkie siły nadziei empatycznie pojmuja elity polityczne, zdobywające wyborców i wyznawców przez nowe symbolizacje strachów i nadziei, odczuwajacych brak nadziei w ideach, jakim zawierzyli. Taki właśnie brak - zdaniem I. Kristola - przesądził o metamorfozie amerykańskiego konserwatyzmu w neokonserwatyzm, a w nim przeważa nadzieja, nie pesymizm, strach o utrzymanie statusów i to przesądza o tym, że nowe idee sa nastawione na przyszłośćc ${ }^{32}$. Widzimy jak wiara w lepsze jutro zwykłego człowieka, będąca jego nadzieja, przekłada się na oczekiwania wobec polityków; jak pokazują to sondaże socjologiczne, ludzie oczekuja od polityków przede wszystkim realizacji wizji dobra wspólnego, a politycy odpowiadają na taki popyt podażą nowych nadziei i iluzji niekiedy beztrosko obiecując zbawienie w doczesności wszystkim ${ }^{33}$. Wyznawcy potrzebuja potwierdzenia zaspokojenia potrzeby wiary. Właśnie wiara rodząca nadzieję jest nam potrzebna, gdy nie potrafimy dowieść, że nasze istnienie ma w ogóle sens, taka wiara, która jest in-

\footnotetext{
${ }^{31}$ J. Delumeau, Rozmowy o końcu czasów, Wrocław 2000, s. 115.

${ }^{32}$ I. Kristol, Neokonserwatywne przekonania, [w:] Neokonserwatyzm, red. I. Stelzer, Warszawa 2007, s. 73.

${ }^{33}$ C. Trutkowski, Społeczna reprezentacja polityki, Warszawa 2000, s. 61.
} 
dywidualnym przekonaniem opartym na naszej wiedzy, przefiltrowanym przez wyobrażenia zbiorowe ${ }^{34}$.

Praktyka, zwłaszcza polityczna, zdaje się potwierdzać sądy, iż nie interesuja nas szczegółowe programy (w polityce są to tylko „programy"), plany z rozpisaniem celów dojścia i środkami, a właśnie niekonkretne wizje będace najlepszą pożywką dla nadziei i to także powinno dawać do myślenia kreatorom życia społecznego. Właściwie daje, bo politycy zdają się rozumieć to empatycznie, widzimy że chca zaspokajać potrzebę wiary, nie wiedzy i w każdym takim „programie” politycznym znajdziemy jakaśs wizję, acz najczęściej sa to wizje niekoherentne, tworzone intuicyjnie, z poczuciem, że człowiek potrzebuje organizacji nadziei w dwóch czasach, długim i krótkim czasie nadziei, ale za takim poczuciem nie idzie wiedza o istocie nadziei, co nader często owocuje skutkami odwrotnymi od zamierzonych, zamiast aktywizacji rodzi apatię, anomię wtedy, kiedy budzone nadzieje sa niespełnione i jest ich wiele, a tak zwykle bywa. Poza tym, na dobrą sprawę nie sa to programy polityczne i stąd ten nasz dystans do nich, program bowiem jest stworzeniem jakiegoś gwiazdozbioru celów i zaproponowaniem dróg dochodzenia do niego, a w programach choćby polskich partii politycznych zwykle brak konkretów. Owszem, moglibyśmy tak traktować znane i pamiętane zapowiedzi polityków PiS budowy 3 milionów mieszkań i iluś tam kilometrów autostrad, gdyby były to prawdziwe cele z prawdziwymi sposobami ich osiagania. Sa to tylko nieumiejętne, beztroskie i niekiedy zabójcze dla twórców tworzenia ram nadziei.

Ale tu okazało się, że politycy PiS nie potrafią kreować nadziei krótkiego trwania szafując obietnicami „stworzenia szczęścia dla Polski i Polaków" - jak ujął to lider partii w marcu 2005 roku. Jak wiadomo rząd Marcinkiewicza już nie wracał ku tym obietnicom i spora część odbiorców dostrzegła, że ich nadzieje są niszczone przez tych, którzy je krzewili, a reakcje na takie kroki musiały być oczywiste w przypadku tych, którzy dokonali „racjonalnego” wyboru opowiadając się za inna partią. Wyznawcom, którzy w oparciu o partię budowali swoja tożsamość, takie postaci oszustwa raczej nie przeszkadzały, ale oni, poszukujący pewności, mają zbyt mało nadziei. Jednak ją mają i wtedy, kiedy zaczną obumierać ich nadzieje krótkiego trwania rozbudzone przez rządy PO, obejrza się za innymi ich depozytariuszami i zapewne znajdą. Niefrasobliwość polityków PO może budzić zdumienie i trudno rekonstruować sposoby myślenia tychże obserwując niemoc nawet w prowizorycznym planowaniu, bo nie prawdziwej kolonizacji przyszłości anno 2014.

${ }^{34}$ D.C. Barker, Rushed to Judgement, New York 2002, s. 4. 
Takie, dalekie od „prawdy”, zapowiedzi biora się z intuicyjnego przekonania, że z jednej strony trzeba tworzyć dla człowieka zbiorowego te wspomniane nadzieje „długiego trwania”, jak w przypadku Amerykanów rytualizowana przez wieki wizję „miasta na wzgórzu”, a z drugiej nadzieje doraźne, które powinny mieć charakter w miarę konkretnych celów w „krótkich czasach nadziei”, czyli w następnych 2-3 latach, choć nie są to sztywne granice i wydają się zależeć od stopnia poczucia spełnienia i postaci strachu społeczności, bo chyba jednak społeczności nieczujące braku dóbr materialnych, trwaja przy swoich nadziejach dłużej, choć mogą zdawać sobie sprawę z tego, iż sa one nieziszczalne, bo przekonanie, że nic nie jest wieczne, jednak istnieje w wyobrażeniach zbiorowych. Przekonanie polityków o konieczności kreowania nadziei, o ile rzeczywiście jest racjonalne, celowe, pozostaje tylko projekcją bez brania pod uwagę konsekwencji takich zawiedzionych nadziei, co zakrawa na zwykła nieodpowiedzialność. Przekonywaliśmy się już nieraz, że wyznawcy często odrzucają tych, którzy zawiedli ich nadzieje, ale jeśli sa to nadzieje krótkiego trwania, to po jakimś czasie moga raz jeszcze zawierzyć, ale już z dużą dozą nieufności i to wtedy, kiedy nie ma innych depozytariuszy i szafarzy, co widzimy w reakcjach społecznych z początku A.D. 2012. Ci wyznawcy empatycznie czuja, że społeczność nadziei jest zwykle bardziej spójna, że pojawia się w niej poczucie siły ${ }^{35}$. Nadzieje, co powtarzamy raz jeszcze, aktywizują do działań w imię jutra, pomagają ujawnić rezerwuary kapitału społecznego, zwykle wykorzystywanego w niewielkiej tylko części, no i przygotowują działania dla przyszłości.

Zwykły recentywizm polityków, czyli wiara w wartość chwili bieżącej i niedocenianie przeszłości ani przyszłości, zdaje się w części wyjaśniać takie zachowania, które mogą wydać się samobójcze, bo politycy obiecujący wszystko wszystkim, budzący nadzieje zbiorowe, łudza się tym, że jakoś to będzie, że wyborcy szybko zapomna o ich obietnicach i pokładaja swoje nadzieje w charakterze pamięci zbiorowej, czyli w tym, że jest rzekomo krótka, co jest do pewnego stopnia prawdziwe. Nie chca przyjąć do wiadomości, że czasami trzeba słono płacić za takie zawiedzione obietnice, a pamięć zbiorowa cechuje się też innymi właściwościami, niekiedy powstają w niej mity, jakich nie można się było spodziewać stosujac „racjonalne” miary. Swoją cenę w polskich warunkach cenę płaca politycy SLD i nie wydaje się by, mimo zmiany elit partyjnych, mogli powrócić do władzy w najbliższych 8-10 latach, a to właśnie partie tzw. lewicy dysponują uniwersalnymi ideami, zawłaszczonymi w początkach ruchów socjalistycznych, jakie są mocno bijącym

${ }^{35}$ A. Baring, Czy Niemcom się uda? Pożegnanie złudzeń, Wrocław 2000, s. 70. 
źródłem nadziei. Dysponując nimi nie potrafią z nich robić użytku i jakoś nie chca się tego uczyć.

W ubogiej literaturze przedmiotu, znowu w ogromnej mierze dzięki uczonym z kręgu Annales, pojawiły się jakości nazywane nadziejami długiego i krótkiego trwania. Te pierwsze sa nadziejami kultywowanymi w wyobrażeniach zbiorowych przez pokolenia, rytualizowane przez posiadaczy władzy symbolicznej tak, że stają się mitami wspólnotowymi służącymi integralności zbiorowości. Taka nadzieją była ta zwiazana z nadejściem Mesjasza dla wyznawców judaizmu, z taka, choć to inna jakość, mieliśmy do czynienia przez wiek XIX mając nasze, polskie nadzieje na wojnę ludów i cud niepodległości. Każda zbiorowość ma swoje wielkie nadzieje, tak trwałe jak ona sama i poza nimi dziesiątki nadziei krótkiego trwania, zwykle wyrastających z tych pierwszych. Te drugie obumieraja i rodzą się na nowo jak feniksy i takimi są choćby nadzieje na czastkowe zbawienie, rozumiane jako zmiany na lepsze, które wiązane bywają ze zmianami ekip politycznych u steru władzy w państwach demokratycznych, co czasami, niezbyt udatnie wykorzystuja politycy. Regulacje idealistyczne sprawiaja, że jeśli owe nadzieje nie sa potwierdzane czynami rządzących, zwykle wątleją po dwóch albo trzech latach i tracacy je zaczynaja poszukiwania nowych depozytariuszy, nowych organizatorów nadziei, a taka potrzeba jest tym większa, im większy niedostatek materialny albo pustka ideowa uniemożliwiajacca tworzenie wspólnot zbawienia w ideach.

Politycy tworzacy tylko wizje mieszczone w dalekiej przyszłości zwykle nie zawodzą się; mając możliwości kreowania wyobrażeń zbiorowych - będących nie tylko płaszczyznami komunikacji - zaspokajaja elementarne potrzeby symbolizowania wielkich nadziei długiego trwania, a te maja charakter permanentny, jak wskazywał R. Bellah ${ }^{36}$. Po to, by móc pozostać soba, korygować te loty feniksa i zapobiegać jego przedwczesnemu spopieleniu człowiek, jako jednostka społeczna, musi także, w stałej komunikacji z innymi członkami społeczności, rekonstruować, stale odnawiać swoje światy wyobrażeń zbiorowych - przestrzeń mityczna, która zdaje się być jednością struktur ładu i trwania, a jest tak bliska kulturze symbolicznej będąc przecież jej integralna częścią. Bez stałej, umiejętnej rewitalizacji nadziei zbiorowych społeczności grozi stagnacja, marazm i takie zjawiska spotykamy najczęściej w tych społecznościach, które karmią się przede wszystkim iluzjami spełnienia materialnego. One są zorientowane tylko na teraźniejszość, a zanik umiejętności kolonizowania przyszłości musi mieć dla nich poważne konsekwencje i tu myślimy o stanie sytych, bezwładnych społeczeństw szeroko rozumianego Zachodu, które przestają myśleć o jutrze.

${ }^{36}$ R. Bellah, Beyond Belief, s. 25. 
Nadzieje trzeba umiejętnie kultywować, budzić i wygaszać, by zawiedzione nie zaowocowały traumą mająca także konsekwencje ekonomiczne, choć to tak trudno precyzować mając na uwadze dynamikę zmian ekonomicznych. To zdaje się oczywiste, ale tu chcemy przywołać tylko jeden epizod związany z „mała” nadzieja. Zupełnie nieodpowiedzialnie rozbudzono ją podczas Euro 2008, w ogromnej mierze dzięki dziennikarzom - tym zwłaszcza, którzy z takim zapałem współtworza „kulturę idiotów”37. Beztroscy, nie potrafiacy przewidywać konsekwencji swoich czynów, budzacy wielkie emocje zbiorowe, dziennikarze na papierze wygrali mecz z Niemcami na długo przed nim i nadzieje na triumf $\mathrm{w}$ finale były niemal pewnością nie tylko dla nich, choć prosta próba „racjonalizacji” mogłaby wskazywać na zwycięzcę. Po przegranej, równoznacznej z odpadnięciem z imprezy, zetknęliśmy się ze zbiorową frustracja, następnego dnia respondenci odpowiadali, że czują się po prostu podle i z trudem zmuszają się do pracy jeszcze przeżywając przegrana. Ergonomowie wyliczyli, że następnego dnia po meczu cała gospodarka była mniej wydajna i straciliśmy wszyscy około 50 milionów złotych, choć nie wiemy jak im się to udało ${ }^{38}$.

50 milionów to niby niewiele i wiemy o tym, że to nie da się policzyć, ale tu nie liczą się aż tak bardzo straty materialne, ale te, jakie w dłuższym czasie będą obniżały inicjatywność i aktywizm ludzi zawiedzionych na wielu polach działalności obietnicami bez pokrycia. Śmierć nawet małej nadziei bywa bolesna, osłabiająca, obezwładniajaca, co możemy potwierdzać własnymi doświadczeniami obcując z setkami takich śmierci i narodzinami nowych nadziei. Być może, ale tylko w części, ta swoista niefrasobliwość, brała się stąd, że nadzieję kojarzymy z optymizmem, widzimy ją radosna, wiosenna, a przecież tak nie jest. „Każda nadzieja niesie ze sobą lęk - pisała H. Arendt zauważając nierozłączność nadziei i strachu - a każdy lęk leczy sam siebie przechodząc $\mathrm{w}$ odpowiadająca mu nadzieję" ${ }^{39}$. O lęku, strachu jeszcze wspomnimy, bo nie da się tego pominąć mówiąc o nadziei.

Konsekwencje zawiedzionych nadziei, nie dajace się przeliczać na pieniądze, mogą być jeszcze bardziej brzemienne w długofalowe skutki, wtedy zwłaszcza, kiedy z tym spotykaja się dzieci, najczęściej za sprawą rodziców obiecujacych im wiele rzeczy za drobne lub większe ustępstwa, a najczęściej za chwilę tego upragnionego, świętego spokoju, jaki jest także znaczącym, jakościowym i niedocenianym czynnikiem zmian. One są niecierpliwe w kolonizacji życia, ich rezerwuary nadziei bywaja ogromne, a ich uczucia to także ogromne, nieobjęte światy, jakie traca

${ }^{37}$ S. Allen, Kultura newsów, Kraków 2006, s. 204.

38 „Dziennik PL”, 10.06. 2008, s. 8.

${ }^{39}$ H. Arendt, Wola, Warszawa 2002, s. 62. 
bezpowrotnie wychodząc z dzieciństwa dzięki tym, którzy wiedzą lepiej nie pamiętając siebie jako dzieci. Za chwilę takiego błogiego spokoju rodziców płaci się im obietnicami kina, wspólnego wyjazdu w plener i setkami innych, których rodzice nie zamierzają dotrzymać już nie pamiętając o nadziejach swojego dzieciństwa i konsekwencjach tamtych zawodów. Z pozoru to nic wielkiego, w każdej niemal rodzinie stosuje się takie praktyki nie bacząc na te długofalowe konsekwencje takich wtrętów w proces akulturacji. Dziecko, a potem dojrzała osoba, przekonana, że nadzieje są formą zwyczajnego oszustwa, stara się trzymać jak najbliżej ziemi, nie marzy, nie tworzy wierzeń projektujących, nie jest zdolna do transgresji, czyli odnajdywania nowych postaci siebie, nowych wcieleń. Staje się minimalista podatnym na zewnattrzsterowność, jednym z milionów. A nadzieje tworzone przez polityków traktuje często właśnie jak oszustwa, z jakimi stykała się jako dziecko i tak też będzie nimi gospodarować.

A wydaje się, że uniknąć tego można na sposób prosty. Zamiast obiecanych niebacznie przyjemności możemy zaproponować inne, skromniejsze, ale nie zabijające nadziei dziecka, które inaczej niż dorośli przeżywa ich śmierć, inaczej tworzy nowe. Nie możemy zachowywać się jak niektórzy Amerykanie wmawiający dzieciom, iż one są najważniejsze na świecie, że to one mają prawo być szczęśliwe, że świat jest po to, by realizować ich marzenia, a takie obrazy społeczeństwa amerykańskiego znajdziemy u obserwatorów z zewnątrz ${ }^{40}$. Takimi sposobami kreuje się wielkie nadzieje, zbyt wielkie i w efekcie zdecydowana większość z nich zawodzi się, przeżywa wielkie traumy i pokłosiem tego bywają różne formy anomii. A nadzieje muszą żyć własnym życiem, być kultywowane z ostrożnościa, muszą istnieć, bo jeśli pozbędziemy się nadziei - mówił J. Delumeau - staniemy się cyniczni, zblazowani, zamkniemy się w swojej małej skorupce i zaczniemy wegetować we własnej rozpaczy ${ }^{41}$.

Niektóre sa wieczne, ale te wielkie i małe rozkwitaja zwłaszcza w czasach zamętu, nieładu, ci zaś, którzy potrafia je organizować uchodzą także za organizatorów przyszłości, prawdziwych władców symboli, przywódców transmisyjnych. Czyniąc swoje tacy organizatorzy zwykle zwracają się ku wartościom archetypicznym, największemu źródłu wszelkich nadziei. Tak postępowali rewolucjoniści francuscy, tak twórcy faszyzmu tworząc „świętą trójcę nowego ładu - porządek, władza, sprawiedliwość" ${ }^{42}$. Przy pomocy takich, uniwersalnych metafor-kluczy, symbolizowanych na wiele sposobów, stworzono nowe przestrzenie

${ }^{40}$ J. Szczurowski, J. Surdykowski, Nasza Ameryka, Toruń 2002, s. 41.

${ }^{41}$ Rozmowy o końcu czasów, Wrocław 2000, s. 178.

${ }^{42}$ R. Eatwell, Faszyzm. Historia, Poznań 1999, s. 39. 
obietnicy dla wszystkich Włochów, Niemców, a potem dla Rosjan. Przy czym zauważyć tu trzeba miejsce nadziei, a właściwie jej brak po wypaleniu się tych nadziei krótkiego i długiego trwania, bo te społeczności uczyniły to, co uczyniły tracąc wszelką nadzieję ${ }^{43}$.

Nadzieje sa nam potrzebne dziś bardziej niż kiedykolwiek, tak może się wydać, kiedy spoglądamy na naszą skomplikowana, jeszcze nierozpoznana ponowoczesność i rosnącą bierność niby spełnionych społeczeństw. Kończy się coś i coś zaczyna, nowy ład wyzwala się z form poprzedniego i będzie generował swoje własne ograniczenia i problemy, które moga zostać rozwiązane na ich poziomie i wymagaja zbiorowego aktywizmu. Odwzorowywanie nowych problemów na starych wzorach rozwiązywania może prowadzić do tragicznych w skutkach pomyłek, a taka pomyłka jest choćby Irak, choć tu można mieć wiele wątpliwości co do intencji Amerykanów. Wiemy jedno. One nie moga nas obezwładniać, musimy starać się je zrozumieć, wyjaśnić, oswoić tworzac nowe wizje przyszłości pełne nowych nadziei. Wiele przesłanek potwierdza ich charakter w okresie wielkiego przełomu 1989 roku w naszym kraju i nie tylko. Ostatnie jego miesiace były ich prawdziwą erupcją, choć nie znając właściwości nadziei zbiorowych, nie bardzo wiedziano, jak skorzystać z takiego podglebia, jak zmieniać świat. Euforii dali się porwać także naukowcy i G. Sartori komentujacy Fukuyamę miał nadzieje na to, że to nie koniec historii, ale wreszcie koniec, po raz pierwszy w historii, kiepskiej polityki ${ }^{44}$. Zawiódł się tak, jak setki intelektualistów tego czasu przełomu, a stworzenie świata pokojowego, racjonalnego to także jedna z nadziei długiego trwania, kultywowana właśnie przez intelektualistów i pewnie pozostanie taką długi czas za sprawą coraz bardziej kiepskich polityków.

Nadzieją długiego trwania, jaką chcemy tu zbliżyć z uwagi na jej niezwykłe moce, jest millenaryzm, zawdzięczający swoją niepojęta siłę i trwałość w kulturach człowieka połączeniu zbawienia w transcendencji z ziemskim. Millenaryzm wyrastał z odwiecznych marzeń człowieka o raju utraconym, obecnych w każdej kulturze dualnego człowieka w postaciach mitów-archetypów, pełnił funkcje soteriologii w jej obu wymiarach. Ślady, artykulacje takich marzeń odnajdziemy pod każdym słońcem, chyba w każdej kulturze, ale właśnie w chrześcijańskiej odegrał i odgrywa role tak niezwykłe, że zasługuje na prezentację, tym bardziej, że można dostrzec jego niepospolity wpływ na poczynania globalnego hegemona - Stanów Zjednoczonych, choć polscy „amerykaniści” tego nie zauważaja. Natomiast wielu amerykańskich

${ }^{43}$ E. Fromm, Ucieczka od wolności, Warszawa 1978, s. 200.

${ }^{44}$ G. Sartori, Rethinking Democracy. Bad Polity and Bad Politics, [w:] Comparative

Politics, eds B.E. Brown, R. Macridis, Belmont 1996, s. 94. 
badaczy twierdzi z przekonaniem, że przesyca on amerykańskie idee od początków istnienia kolonii po nasz $\operatorname{czas}^{45}$. Inni zaś są zgodni co do tego, że „wiara w millenium jest jednym z najstarszych i najbardziej wpływowych wzorów zachodniej cywilizacji"46. Umyka naszej uwadze w wielości postaci dalekich od czystego modelu, ale pozostaje obecny w soteriologiach ziemskich kręgu chrześcijańskiego, z Rosją włącznie i, mimo że jest dostrzegany, to jednak nie próbuje się badać jego wpływu na praktykę.

Wedle naszej wiedzy millenaryzm, będący źródłem wielu herezji, buntów, wielkich ruchów społecznych, w swej pierwotnej postaci był oczekiwaniem na stworzenie przez Chrystusa tysiącletniego Królestwa Bożego na ziemi, królestwa dla żywych. Wcześni egzegeci Ewangelii św. Marka, Apokalipsy św. Jana czy listów apostoła Pawła interpretowali podsuwane przez nich przesłanki jako pewne zapowiedzi ponownej paruzji (nadejścia) Chrystusa, który powróci na ziemię w chwale i ustanowi prawdziwy zamysł Opatrzności wobec człowieka - Królestwo Boże na ziemi, w którym człowiek osiagnie pełnię doskonałości, spełni się materialnie i duchowo w idealnym społeczeństwie. Wybrani przez Chrystusa mieli być jednostkami doskonałymi, takimi które osiagnęły ideał bliski chrystologicznemu. W millenaryzmie pierwotnym (I i II wiek naszej ery) oczekujący na ponowne nadejście Chrystusa, a mający nadzieję na zbawienie, powinni iść soteriologiczną droga pracy, ascezy i cierpienia nakreśloną przez świętych Hieronima, Pachomiusza, Antoniego.

Ale kiedy wyczerpały się zbiorowe nadzieje, nadzieje krótkiego trwania na ponowne przyjście Zbawiciela, już w panujaccym w imperium chrześcijaństwie, poczęto na nowo odczytywać znaki w przekazach kilkudziesięciu ewangelistów i autorów Apokalips i w nowych interpretacjach ta nadzieja długiego trwania poczęła zmieniać kształty, stawać się własnością sekt takich jak mountaniści ${ }^{47}$. Paruzję poczęto odczytywać jako stałe przychodzenie Chrystusa w sakramentach, Królestwo Boże na ziemi miało być już efektem działań człowieka jako kontynuatora boskiego dzieła tworzenia. I z jednej strony takie egzegezy otwierały drogi do przezwyciężenia prowidencjalizmu, ale z drugiej ci, którzy poszukiwali prawd w Piśmie, nie zaprzestali odczytywania zapisów o ziemskim Królestwie Bożym i traktowali fragmenty o nim jak profecje i czasami jako dyspozycje czysto praktyczne. Tak interpreto-

${ }^{45}$ C.L. Albanese, Religion and Religions, Belmont 1991, s. 426, E.L. Blumhofer, Restoring the Faith, Chicago 1993, s. 13.

${ }^{46}$ R. Bloch, Visionary Republic. Millenial Themes in American Thought, Cambridge 1985, s. XI.

${ }^{47}$ M. Simon, Cywilizacja wczesnego chrześcijaństwa, Warszawa 1979, s. 117. 
wali je herezjarchowie średniowiecza tworzacy komuny ewangeliczne, a swoiste ich mutacje stworzyli rewolucjoniści wieków XIX i XX odzierajacc pierwotne przesłania $\mathrm{z}$ religijnej otoczki, ale potwierdzając niezwykłą rolę idei.

Istota millenaryzmu - zauważał w swej niezwykłej pracy E. Hobsbawm, uczony, który doceniał jego generujące role - to nadzieja na całkowitą i radykalną przemianę świata w nowy, zbawiony od zła, to oczekiwanie na millenium, które w dziesiątkach postaci pojawia się $\mathrm{w}$ ideach buntu, spotykanych zwłaszcza w średniowieczu ${ }^{48}$. Millenaryzm był dla niego prymitywna formą rewolucyjnego protestu społecznego, archaicznym rewolucjonizmem będącym emanacją radykalnego protestu społecznego społeczności przedprzemysłowych i zjawiskiem zdecydowanie prepolitycznym jako protoideologia. Taka próba syntezy jednak nie satysfakcjonuje do końca, budzi wiele watpliwości, choćby przez brak przywołania pierwotnych inspiracji, brak powiązania idei z eschatologia, co zdaje się niewatpliwe. Nie wiadomo także, co autor miał na myśli mówiąc o zjawiskach prepolitycznych, bowiem sugestia, że zachowania polityczne dziś sa stricte polityczne idzie zbyt daleko, co staramy się zbliżyć gdzie indziej, ale tu zauważmy, że współczesny człowiek mityczny, zewnątrzsterowny, nie umiejący racjonalizować swoich zachowań politycznych, wspierający się na strukturach przedrozumienia, zdaje się także być prepolityczny. Wielkiego historyka idei, jakim jest Hobsbawm, tłumaczy wiele, a przede wszystkim czas, w jakim tworzył dzieło pozostajace inspiracją po dziś. W swoim czasie był niezmiernie oryginalny próbując odkrywać jakościowe czynniki zmian, a przede wszystkim tęsknotę za wyzwoleniem od wojen, nędzy, poniżenia.

Spore kontrowersje budzą także stare próby J.L. Talmona, N. Cohna czy T. Olsona ${ }^{49}$, których nie będziemy tu zbliżać z braku miejsca. Ważna zdaje się zgoda co do tego, że projekcje millenarystyczne sa aktywne lub pasywne. Aktywne, bliskie chrystologii, zakładają niezbędność ludzkiego czynu wspomagającego także boskie zamysły, pasywne natomiast bywały bliskie postaciom felicytologii chrześcijańskiej i wymagały od jednostek tylko wewnętrznego oczyszczenia i biernego wyczekiwania na wypełnienie boskiej obietnicy odczytanej przez rewelatorów. Aktywny jest postmillenaryzm i w nim Królestwo Boże nadchodzi w procesie ewolucyjnym, realizuje się na ziemi z pomoca sił od dawna obecnych w historii. To emanacja nadziei rodzącej czyn w chwili

${ }^{48}$ E. Hobsbawm, Primitive Rebels, Manchester 1963, s. 32.

49 J.L. Talmon, Political Messianism. The Romantic Phase, New York 1960, N. Cohn, The Pursuit of Millenium, London 1957, tenże, Medieval Millenarism. It's Beginning on the Comparative Study of Millenarism Movements, [w:] Millenial Dreams in Action, Hague 1962, T. Olson, Millenarism, Utopianism and Progress, Toronto 1982. 
odczytania rewelacji boskiej. Premillenaryzm natomiast to ruch w czasie z góry w dół. Zapowiadane nadejście Mesjasza ma zwiastować ciag zapowiedzi, które należy tylko właściwie odczytywać i interpretować przygotowując się duchowo na jego przyjście, oczyszczając czynem, nie myśla, nie pustymi rytuałami. Królestwo Boże nadchodzi niespodziewanie zrywając łańcuch przyczynowości przyrodniczej i historycznej, a człowiek nie może wiele zdziałać bez nadprzyrodzonej ingerencji Opatrzności. Z wielkich idei millenarystycznych wyrastał mesjanizm, rozumiany jako poszukiwanie pośrednika zbawienia między Bogiem a ludzkością i nie zawsze miał nim być Chrystus. Po wyczerpaniu się nadziei zbiorowych na jego przyjście w pierwszych wiekach chrześcijaństwa, w okresie patrystycznym, jego role poczęto przypisywać narodom i jednostkom i to one miały pełnić funkcje mesjańskie. Takie interpretacje zrodziła potrzeba posiadania tych transcendentnych sankcji

Idea Królestwa Bożego na ziemi w jej postmillenarystycznej postaci zdominowała soteriologie ziemskie kręgu chrześcijańskiego będąc mocno bijącym źródłem nadziei długiego trwania, przyjmując wiele postaci, specyficznych dla narodów i społeczności, zmieniając się w czasie i nie zawsze poszukując tych transcendentnych sankcji dla wizji zbawienia w doczesności. Z niej wyrastały wielkie utopie myśli i czynu, o których niżej, ale jej ślady możemy spotkać po dziś, choć interpretowana setki razy idea jest już daleka od pierwowzoru. Niekiedy idea Królestwa pojawiała się jako koagulat zrozumiałych symboli i budziła oczekiwane reakcje, a tak było choćby w przypadku rewolucjonistów wieku XIX, chyba tak jest $\mathrm{w}$ przypadku nieżyjącego już wroga świata numer 1 , Osamy bin Ladena obiecujacego swoim wyznawcom sprowadzenie go na ziemię. Refleksy idei pojawiają się także w poszukiwaniach transcendentnych sankcji dla demokracji i kapitalizmu w koncepcjach tych teoretyków, którzy widzą w nich remedia na wszystkie bolączki świata, ale to może być poczytywane jak nadużycie interpretacyjne, o ile nim jest.

Swoiste rozumienie idei zrodziło specyficzny postmillenaryzm amerykański, którym chcemy się zająć, by uwidocznić wpływ idei na praktykę społeczna grup ludzkich, które w tak niepojęcie krótkim czasie, niemal z niczego stworzyły potęgę Stanów. Tu zauważamy zwykły brak pytań badawczych traktujących o tym fenomenie, bo przecież Stany dokonywały prawdziwych cudów przeobrażając się najpierw w rustykalne imperium, a potem, zaledwie w ciagu kilkudziesięciu lat, w imperium przemysłowe, globalnego dominatora (hegemona?). Śledzac początki giganta zauważamy, że pierwsi koloniści zagubieni, głodujacy, słabi, zawierzający Bogu, już w samych początkach pobytu na obcej ziemi poczęli określać siebie jako rewelatorów i realizatorów odczytywanych na nowo planów boskiego ekonoma. W istocie rzeczy prowi- 
dencjalni, poczęli tworzyć swoje „litanie nadziei” - jak wizje nazywał badacz doceniajaccy niezwykłe siły nadziei zbiorowej ${ }^{50}$. Tymi litaniami były wielkie wizje przyszłości opatrzone świętością misji, które pozostały światłami Ameryki do dziś - jak twierdził inny badacz i ma swoje racje, jeśli przyjrzymy się choćby deklaracjom Busha i Obamy ${ }^{51}$. Już w początkach ta wspólnota przetrwania, przypominająca komuny socjalistyczne autorowi wielkiej syntezy ${ }^{52}$, w poszukiwaniu nadziei, stworzyła wielką wizję „miasta na wzgórzu” i jej twórca J. Winthrop, po dziś pozostał jednym z największych organizatorów nadziei zbiorowej reinterpretując biblijna obietnicę wiecznego przymierza Boga z wybranymi. „Kiedy Bóg obdarza misja, uważnie obserwuje jak jest realizowana. Musimy być przekonani, że będziemy jak miasto na wzgórzu" - pisał i te słowa stały się testamentem dla pokoleń ${ }^{53}$. Nie był w tym zbyt oryginalny, bo wielu autorów przypomina, że takie koncepcje nie były rzadkością w samej Anglii, w ogarniętych wojną domowa Niemczech, czy przedtem, w okresie wielkich herezji średniowiecza. Wtedy wielu rewelatorów powtarzało, że ich zadaniem jest stworzenie prawdziwie ewangelicznej wspólnoty, która pozostanie niedościgłym wzorem dla innych i starali się je tworzyć natychmiast, tu i teraz z tą niecierpliwością rewelatorów prawd objawionych. Ale w przypadku Winthropa było to stworzenie niezwykle kreatywnego wierzenia projektującego, zarysowanie horyzontu nadziei długiego trwania dla kolonistów, spełnienia nie tylko materialnego, ale także w wartościach.

Jego profetyczni i bezkompromisowi następcy (Whitefield, Edwards), mimo siermiężnej rzeczywistości Ameryki tamtego czasu rewitalizowali wielka wizje głoszac z pasja, że Ameryka została odkryta po to, by pokazać światu drogę do przyszłości, do wspaniałych czasów i to w niej dokona się wielkie dzieło zbawienia całej ludzkości, bo tu stoja fundamenty pod tron Dawida - jak prorokowal inny profeta J. Cotton ${ }^{54}$. Dodać trzeba, że były to wizje tworzone dla osadników zagubionych na obcej ziemi, cierpiących niekiedy głód, żyjacych w strachu przed Indianami, chorobami, głodem. Im nadzieja długiego trwania była potrzebna jak powietrze i z takiej potrzeby rodziły się te wizje wielkością nieprzystające do tych prawdziwych kropli w morzu, jakimi były pierwsze kolonie. Głęboka religijność sprawiła, że nie zapomniano o tych wizjach w czasach względnego dobrobytu.

\footnotetext{
${ }^{50}$ S. Bercovich, The American Jeremiad, Wisconsin 1978, s. 11.

${ }^{51}$ P. Duignan, L.H. Gunn, The US and the New Europe, Cambridge 1994, s. 276.

52 A.J. Schmidt, Under the Influence, How Christianity Transformed Civilization, Grand Rapids 2001, s. 211.

53 J. Winthrop, A Model of Christian Charity, [w:] American Religious History, ed.

E. Potterfield, Oxford 2002, s. 172.

${ }^{54}$ O. Delbanco, The Puritan Ordeal, Harvard 1989, s. 91.
} 
Millennialni rewelatorzy nie baczyli na to, że pozwalają sobie na tak oczywiste uzurpacje, inne to były czasy i inne oczekiwania zbiorowe. Zrytualizowali wizje Królestwa z tego świata przekonani, że takie sa wyroki boskie. Niosąc posłannictwo wobec świata osadnicy musieli mieć genealogię szlachetniejszą od innych, a to wymagało i zerwania z historia angielskich Edwardów i Henryków i stworzenia nowej z wielkimi wizjami przyszłości nie mającymi właściwie żadnego umocowania, potwierdzenia takiej uzurpacji w realiach. Legitymizowali je prowidencjalną wiarą w to, że dzieje wygnańców są realizacją zamysłów Opatrzności, a jednostki i społeczności sa tylko aktorami grającymi napisane dla nich role. Być może świadomość tworzenia własnej historii także miała znaczenie, którego dziś nie doceniamy. Starali się odgadywać te role i czasami przelewali swoje wizje na papier, jak W. Penn. Wedle niego, z woli bożej, Ameryka znalazła się w boskim planie jako piąte Królestwo Chrystusa, które będzie miejscem przetrwania synów zachodniego świata ${ }^{55}$. Ta, skażona gnostycyzmem, wizja jest jedna z wielu i choć z pewnością znaczyła wiele, to równie wiele znaczyli ci, którzy dokonywali wytrwałej rytualizacji pośród osadników, czyli wędrowni kaznodzieje i przywódcy wspólnot interpretujący takie przesłania dla ludzi czystej wiary. A ludzie takiej wiary, chcący wierzyć w zbawienie po śmierci, marzyli także o zbawieniu w doczesności tożsamym z sytym i bezpiecznym życiem. Potrzebowali swoich nadziei długiego trwania odrzucając te angielskie, już obce, inne.

Tylko głęboka, bezkompromisowa wiara rodzaca nadzieje długiego trwania mogła przekonywać do promiennych wizji, a wiadomo, że ludzie tamtego czasu, zwłaszcza tak głęboko religijni jak osadnicy, byli bardziej podatni na prawdy wiary niż rozumu. Takie wspólnoty, zjednoczone strachem i nadzieja, wytwarzały specyficzne nadzieje komunitarne, które pozostały częścią amerykańskiej tradycji, co miało niebagatelne znaczenie dla dynamiki społecznej w następnych wiekach. Te wspólnoty cementowała niezwykle silna wiara $\mathrm{w}$ to, że buduja podwaliny idealnego społeczeństwa, pozostając w zgodzie z planami boskiego ekonoma, a powodzenie tych prób jest także świadectwem dobrego wyboru. Nietrudno zauważyć, że dzięki umiejętnemu kreowaniu nadziei długiego trwania amerykańscy kreatorzy ziemskiego królestwa wolności i równości nie przejawiali tak wyraźniej niecierpliwości europejskich rewelatorów i realizatorów, uczyli się czekania, co chyba owocowało imperatywem budowania lepszej przyszłości dla dzieci i wnuków.

W próbach realizacji utopii czynu widzimy, że europejscy poszukiwacze Królestwa Bożego na ziemi, czy to w wieku XVI, czy XIX, bywali

${ }_{55}$ J. Butler, Awash in a Sea of Faith. Christianizing the American People, Harvard 1990, s. 37. 
niezwykle niecierpliwi. Kiedy wydawało się im, że już odczytali boskie wyroki, chcieli osiagać stan doskonałości za ich życia, sprowadzać Królestwo na ziemię już teraz, jak choćby anabaptyści w Munster w roku 1533, a wieki później polscy i francuscy romantycy czy socjaliści utopijni. Anabaptyści, natychmiast po opanowaniu miasta, obwieścili światu powstanie Królestwa Niebiańskiego i wiele takich wieszczeń spotykaliśmy w Europie po koniec XIX wieku. Natomiast amerykańscy wygnańcy, dzięki konsekwentnemu przywództwu transformacyjnemu, potrafili sytuować soteriologię ziemską w przyszłości, obiecując ziszczenie obietnicy dopiero za kilka pokoleń i z takim postawami uczyli się pracy i cierpliwości, a z pewnościa niezwykle pomocna była tu purytańska etyka z protestancka teoria zbawienia.

Ameryka kolonialna, statyczna, rustykalna, dopiero wychodzaca z biedy, cierpliwie czekała na znaki zwiastujące zbliżanie się obietnicy i była nader ostrożna $\mathrm{w}$ ich interpretacji. Wedle organizatorów życia społecznego i wyobrażeń zbiorowych wszystko miało swoje wymiary i swoja, boska kolej rzeczy. Człowiek powinien cierpliwie pracować, uczyć się pokory i posłuszeństwa nie tylko wobec Boga, ale także pamiętać o tym, że nagrody rozdaje Bóg i każda próba wystapienia przeciw jego wyrokom jest niczym innym jak tylko świętokradztwem. Konsekwencja takiej wiary była swoista chrystologia, determinowana samymi treściami purytanizmu, choć bywała obecna także wśród herezjarchów i rewelatorów katolickich, którzy marzyli o zwartych, gotowych do boju szeregach żołnierzy Chrystusowych, pełnych wiary i wyzbytych strachu przed ciemnymi mocami. Ci żołnierze Chrystusa mieli nie tylko zbudować idealną wspólnotę, ale byli także depozytariuszami najwyższych wartości, które mogą ocalić Zachód ${ }^{56}$.

Wyznawcy nie mieli najmniejszych wattpliwości, co do swego pryncypializmu etycznego, choć przecież na co dzień eksterminowali Indian i nie zawsze bywali gościnni wobec nowych przybyszów, także Anglosaksonów. Ale ta świecka religijność, pokłosie naturalnej dualności człowieka, bywała traktowana jako „dobra rzecz” - zauważał G. Ritzer - była dobra dla narodowego samopoczucia i, wedle kolonistów, wcale nie musiała przekładać się na prawdziwie religijne postawy i zachowania $\mathrm{w}$ takim środowisku ${ }^{57}$. Najważniejsze było to, że pozostawała pełnym rezerwuarem nadziei długiego trwania i chyba ich kreatorzy mieli tego świadomość dzieląc dobro i zło. Te nadzieje były częścią tego dachu, a Amerykanie - zauważał historyk idei - najpierw zbudowali dach, który wymuszał kształty ścian ${ }^{58}$, dokonali prawdziwej rewolu-

\footnotetext{
${ }^{56}$ D. Weber, Rhetoric and History in Revolutionary New England, Oxford 1988, s. 105.

${ }^{57}$ G. Ritzer, K.C. Kammeyer, Experiencing a Changing Society, Boston 1982, s. 406.

${ }^{58}$ N.O. Hatch, The Democratization of American Christianity, New Haven 1988, s. 63.
} 
cji $\mathrm{w}$ architekturze wyobrażeń zbiorowości zaczynając od tego dachu. Nadzieje, jak idee, wymagaja ciagłego przepisywania i oczywistym, radykalnym reinterpretacjom poddawano wielkie wizje po zdobyciu suwerenności. Samozbawieni Amerykanie już podczas obrad pierwszego Kongresu artykułowali przekonanie (J. Mayhew), że ręka Boga sprawia, iż Ameryka daje początek nowej epoce w historii świata, a to wcale nie był margines. Jeszcze dalej szedł skrajnie misjonistyczny J. Farwell, twierdzący, że Amerykanie już mają ludzi i źródła do natychmiastowej ewangelizacji świata ${ }^{59}$.

Konieczność reinterpretacji niewystarczających już w nowym czasie nadziei długiego trwania sprawiła, że poczęto rytualizować wizję stworzenia przez Amerykę nowego, globalnego ładu, opartego na ich, najlepszych pod słońcem wzorach. Jej mutacją była projekcja oparta na wzorach postmillenarystycznych i jej wyznawcy twierdzili, że przed nimi wielkie dzieło budowania przykładu harmonii dla całej ludzkości. Takim misjonista był P. Frenan, który już w roku 1782 widział Amerykę jak imperium przyszłości oparte na wspaniałej agrokulturze, a to imperium dokona dzieła zbratania wszystkich narodów świata nie wyrzekajac się siły ${ }^{60}$. A takie zamysły usprawiedliwiano przykładami Jozuego i Kaleba zdobywających Ziemię Obiecana. Stary Testament dostarczał wielu legitymacji.

Nowym wymiarem nadziei długiego trwania dla Amerykanów okazała się idea „boskiego przeznaczenia” podbudowywana sądami niepozostawiającymi złudzeń. Amerykanie zdawali się osiagać kres horyzontu takiej nadziei w czasie prezydentury Monroe’a, który mówił: „Jest wiele przyczyn, by uwierzyć, że nasz system wkrótce osiagnie najwyższy stopień perfekcji, jaki możliwy jest $\mathrm{w}$ instytucjach stworzonych przez człowieka" ${ }^{\prime \prime}$. Widzimy tu postawę wizjonera nie przesądzającego, że Stany na pewno stana się ideałem. Monroe otwierał nowe perspektywy przed nadzieja zbiorowa, bardziej powściagliwy niż wielcy twórcy amerykańscy połowy wieku widzący potwierdzenia „świetlanej przyszłości”. Dla H. Melville’a choćby Ameryka już była politycznym Mojżeszem świata, „który doprowadzi ludzkość do krainy szczęścia i spokoju"62. Inni potwierdzali, że Królestwo Boże już zostało sprowadzone na ziemię wspólnym wysiłkiem pokoleń i niesienie go poza granice już traktowano jako święty obowiązek sugerując, że cel jest wszystkim.

Mit założycielski, jakim było tworzenie zaczynu idealnej wspólnoty z nadziejami z niego wyrastającymi, został rychło zastapiony hasłami

\footnotetext{
${ }^{59}$ R. Takaki, A Different Mirror. A History of Multicultural America, Boston 1988, s. 63.

${ }^{60}$ H.N. Smith, Virgin Land, Harvard 1995, s. 11.

${ }^{61}$ G. Dangerfield, Awakening of American Nationalism, Prospect Heights 1994, s. 142.

${ }^{62}$ S. Bercovitch, The American Jeremiad, s. 177.
} 
krzyżowców przekonanych o świętości swoich racji i chcących uszczęśliwiać innych na siłę dla ich oczywistego dobra. Pozostał takim do dziśs, a o jego zasadności świadczyć miały wszystkie wielkie wydarzenia polityczne od końca wieku XIX z udziałem Ameryki. Wielkie nadzieje długiego trwania nie spełniły się jednak do końca, bo wciąż pojawiają się nowe cele. Dziś celem misyjnej Ameryki jest stworzenie wielkiego imperium ducha, a oskarżanie Amerykanów o inaczej rozumiany imperializm zdaje się nieporozumieniem biorącym się z archaicznego myślenia o polityce. Ale to raczej sugestia majaca inspirować nowe pytania. Dzięki umiejętności ich kreowania, rewitalizowania, Stany w ciągu trzech stuleci $\mathrm{z}$ niczego zamieniły się $\mathrm{w}$ giganta i bodaj żadna wspólnota nie potrafiła tak korzystać z ogromnych rezerwuarów nadziei.

Przyglądając się polskim nadziejom długiego trwania zauważamy porażająca niemoc naszych władców symboli od okresu „wieku złotego" aż po uzyskanie niepodległości po rozbiorach. Polskie sny o potędze okresu piastowskiego i jagiellońskiego widoczne w literaturze, kultywowano w zupełnym oderwaniu od rzeczywistości, czasami jej na przekór w imię historii bez skazy. One nawet nie mogły aktywizować zbiorowości, bo rozziew między nimi a zastanym światem był przeogromny i wiara w nie nie rodziła aktywizujących nadziei ówczesnego mieszkańca ziem polskich, bo słabość, dojmująca słabość państwa, była widoczna na każdym kroku, choć dziś tuszuje się ją mitami „złotego wieku” i to raczej skutecznie. Swą rolę spełniły nadzieje kreowane dla pokoleń Polski porozbiorowej - nadzieje na niepodległość, ale po odzyskaniu jej nikt nie potrafił stworzyć wizji dla nowego czasu, a w dodatku, w demokratycznym chaosie, tak często i boleśnie umierały nadzieje krótkiego trwania rodząc niewiarę w następne. A kiedy umierają nadzieje pojawiają się nierozerwalnie z nimi wiązane strachy, niebezpieczne, bo dysjunktywne, rozbijające spoistość zbiorowości, bo każdy jej element, czyli pojedynczy człowiek, pragnie przede wszystkim własnego dobra nie wiążąc go zbyt często $\mathrm{z}$ dobrem wszystkich. Wtedy pojawia się apatia, różne postaci eskapizmu, zbiorowość staje się obca, wroga.

Jednak, o ile, mimo wszystko, nadzieje znalazły już jakieś prawo obywatelstwa $\mathrm{w}$ nauce i sa docenianym czynnikiem zmian jakościowych, o tyle strachy pozostały poza granicami refleksji naukowej, a z pewnością ich obecności w życiu jednostek i grup nie możemy zakwestionować, bo są integralną częścia naszej codzienności. One istnieja i odgrywają role tak znaczące jak nadzieje, ale wciąż bywają traktowane tylko jak zbyt pojemne metafory, których tak często boją się „racjonalni badacze”. Z pewnością doceniał ich role prezydent F.D. Roosevelt, który w apogeum Wielkiego Kryzysu, w swojej przemowie inauguracyjnej powiedział: „Jedyną rzecza, jakiej powinniście się obawiać jest 
sam strach"63. On zapewne zauważał, jak bardzo takie uczucia, emocje paraliżuja jak odbierają umiejętność projektowania się w przyszłości, zawężaja czas i przestrzeń, odbierają zdolność myślenia, jakie zwykle zwiemy racjonalnym. Zapewne doświadczany wieloma strachami o zdrowie i życie prezydent wiedział także o tym, jak wykorzystywać strach $\mathrm{w}$ bieżącej polityce, ale, w początku prezydentury, nie korzystał z tego uważając zapewne, że nadzieja jest bardziej twórcza. Nieco lepiej i w innych celach wykorzystywał strach sytych Amerykanów R. Reagan wymuszając zgodę milczącej większości na zbrojenia (gwiezdne wojny) często powtarzając, że nadchodzi czas Armageddo$n u^{64}$, a jeszcze lepiej szukajacy legitymacji dla swoich działań w polityce światowej prezydent G.W. Bush.

Strach jest jaką́s opozycją nadziei w naszej dualności, z pewnościa nie prosta $\mathrm{w}$ zrozumieniu, bo usytuowanie go obok czy przeciw niej może sprawić nie lada kłopot nie tylko piszacym ze współczynnikiem licentia poetica. Starając się o ledwie kilka impresji, z braku miejsca, zauważamy, że z pewnością nie jest kreatywny, jeśli nie utożsamiany go z poczuciem zagrożenia, bo to już inna jakość i z pewnościa potrafi także jednoczyć, aktywizować. Ludzie porażeni prawdziwym strachem dysjunktywnym zaczynają zawierzać instynktowi samozachowawczemu, zaczynają separować się od zbiorowości w imię przetrwania, zawężaja się ich granice zaufania nawet wobec najbliższych. Wiele racji jest w powiedzeniu, że strach zabija duszę. Dowodzili tego ci, którzy czuli, wiedzieli o dysjunktywnych mocach strachu i wiedzieli jak go stopniować, aby porazić nim miliony do tego stopnia, że nie myślały o oporze przeciw władzy, a takimi byli twórcy III Rzeszy i Rosji Radzieckiej, millenarystyczni bardziej niż nam się zdaje, do czego przekonywał nie tylko E. Voegelin ${ }^{65}$. A wspominamy o tym dlatego, że w początkach, zarówno w Rosji, jak i w Niemczech, dostarczano społecznościom wielkie nadzieje obiecując prawdziwe raje, a kiedy one nie zostały potwierdzone rzeczywistościa, pojawiła się konieczność rządzenia strachem, konieczność będąca chyba prostą konsekwencją krachu nadziei. Wiadomo, że nieumiejętnie siany strach może łączyć, zamiast dzielić i jeśli znajdą się organizatorzy zbiorowej nadziei, podówczas strach zainicjować może bunt, rewoltę, jaka zmiecie jego siewców. Takimi były polskie strachy lat 80. One integrowały, łączyły, choć raczej nie możemy twierdzić, że wtedy chciano rządzić strachem. Może i wtedy chciano, ale może nie potrafiono, co potwierdzają społeczne reakcje na stan wojenny.

${ }^{63}$ J. McGregor Burns, Roosevelt. The Lion and the Fox, San Diego 1984, s. 163.

${ }^{64}$ A. Peck, Teleewangelizm, apokalipsa i polityka, Tyczyn 2005, s. 29.

${ }^{65}$ E. Voegelin, Nowa nauka polityki, Warszawa 1992, s. 108. 
Z pewnością chcieli i potrafili to robić ludzie Hitlera i Stalina, a wzorów takiego rządzenia w przeszłości nie brakowało i tu historia okazywała się hojną rad mistrzynią. Obaj dyktatorzy stworzyli wielkie wizje zbawienia, nadzieje długiego trwania obliczanego na setki lat i kiedy przekonali do siebie wyznawców, świadomi, że ich wizje są tylko wizjami i nigdy się nie skonkretyzuja, poczęli gruntować swoją władzę przy pomocy eskalowanego umiejętnie, rzec by można, po aptekarsku dozowanego strachu i można pokusić się o twierdzenie, iż była to przemyślana eskalacja, a jakość teorii i praktyki stosowania tego strachu zmieniały się z czasem. Wpierw stworzono wizje zagrożenia z zewnątrz i od wewnątrz nie konkretyzując ich, bo to nie jest niezbędne, a nawet niepożądane. Strach określony, wiadomy, przestaje być pomocny takim siewcom, on musi być niewidoczny, wszechobecny, wszechprzenikajacy. On cały czas kontaminował się z nadziejami i jego przyczyny powinny być dla obywateli groźba przede wszystkim dla promiennych nadziei.

Ten strach, jaki siano, przedstawiano jako niezależny od rządzacych i ci deklarowali zwykle, że nie potrafią zaradzić złu. Tak czynili dwaj wielcy zbrodniarze i ich wierny uczeń Kim Ir Sen, który w państwie strachu przekonywał: „Nasz naród niezachwianie wierzy w świetlane perspektywy, które będą zrealizowane w najbliższych kilku latach"66, tak twierdził Kim Dzong Il i pewnie tak samo będzie twierdził jego syn. Jak wyglądały społeczności sparaliżowane strachem wiemy także z głębokiej historii, choć historykom trudno przywoływać psychozy strachu choćby średniowiecza, taka materia ich chyba przeraża, oni wola rekonstruować konsekwencje, czyli fakty, przyczyny zbyt często bywają nieważne albo spychane na trzeci plan, co widać $\mathrm{w}$ kwestionariuszach pytań badawczych tych badaczy przeszłości. A wiemy, choćby z profecji tamtego czasu, jak wiele strachów towarzyszyło naszym przodkom, poczynajac od strachu przed końcem świata. Z modlitw tamtego okresu dowiadujemy się, jak wyglądały litanie nadziei, a właściwie litanie strachu. Wiemy także, że spotykamy się z nim na co dzień, wiemy jak zniechęca do działania, jak obezwładnia w naszym społeczeństwie ryzyka.

Czymkolwiek miałyby być nasze czasy - powiadał O. Marquard - sa w każdym razie epoka przemiennego gospodarowania utopiami i apokalipsami, entuzjazmem do zbawienia na ziemi i pewnością katastrofy ${ }^{67}$. Sięgnięcie po niektóre z nauk „nauczycielki życia” zdaje się jednak potwierdzać, że wielkie nadzieje zawsze towarzyszyły wielkim strachom i bywały wobec nich swoiście proporcjonalne. To jest niejako

${ }_{66}$ Kim Ir Sen, Odpowiedzi na pytania dziennikarzy zagranicznych, Phenian 1975, s. 127.

${ }^{67}$ O. Marquard, Apologia..., s. 78. 
częścią natury dualnego człowieka. One, sąsiadując ze sobą w naszej dualności, toczą ze sobą ciągła walkę i to nadzieje są tymi siłami, które wypieraja strachy, „oswajaja” je, a z kolei strachy oswojone rodzą nowe nadzieje. Tak było ze strachem przed bronią nuklearna w latach 50 . i 60. który został tak skutecznie wyparty z pamięci zbiorowej. Widmo nuklearnej zagłady ludzkości, tak plastycznie rysowane w setkach literackich wizji sięgnęło kresu w drugiej połowie lat 50. Ale człowiek nie pozwolił im się sparaliżować wiedząc, czym to grozi. Począ wypierać ten koszmar z pamięci zbiorowej i jego miejsce zajmowała nadzieja na to, że jednak nie zrobimy tego ostatniego kroku w szaleństwo. O strachach wypieranych z pamięci zbiorowej myśląc U. Eco pisał, że ludzie rozpaczliwie próbuja nie przyjmować do wiadomości tego, co dzieje się od tysięcy lat ${ }^{68}$. Dodajmy, że z dobrym skutkiem oswajają się ze strachem wolac ufać nadziei.

Strach, w wielu postaciach, jest czymś zwyczajnym, codziennym dla każdego z nas, choć tak często nie chcemy go zauważać. Dla A. Kępińskiego każdy kontakt z otoczeniem jest swoista walka, a człowiek chce zwyciężać, narzucać otoczeniu struktury czynnościowe i taką walkę przesyca niepewność, co do jej rezultatów z różnym powodzeniem ${ }^{69}$. Był codziennością wieków, ale akurat w naszym czasie zagęszczenie Apokalipsy jest zbyt wielkie - utrzymywał, chyba z przesada, J. Baudrillard i jest to matka wszystkich strachów ${ }^{70}$. Nie sposób tego kwestionować nawet po pobieżnych obserwacjach. Media nieustannie wzmacniaja poczucie izolacji i zagrożenia, karmią w jednostce strach przed światem. Z empatycznego przekonania o deficycie, potrzebie strachu, media, zwłaszcza telewizja, dostarczaja setek, tysięcy informacji o kataklizmach, katastrofach wprowadzając nas w stan łagodnego odrętwienia, czegoś mieszczącego się między nadzieja a strachem ${ }^{71}$. Taki stan, choć czasami trudny do wyobrażenia, jest wielkim sprzymierzeńcem rządzacych. Niekiedy tylko odbiorca zauważy relatywizm takich przekazów pytając choćby o to, że jeśli z taką lubością mówi się o wypadkach drogowych, koniecznie z ofiara śmiertelna, to czemu nigdy nie informuje się o równie tragicznych samobójstwach?

Bronimy się przed nim oswajaniem, wypieraniem wielkich strachów do „zbiorowej podświadomości”, ale one tam istnieją i budzą się z każdym większym zagrożeniem. Od wieków wiedzą o tym ci, którzy chca posługiwać się nim dla celów politycznych, czyli różnej maści terroryści. Ale nie ten strach, jaki sieja, jest najbardziej porażający, bodaj

${ }^{68}$ U. Eco, Semiologia życia codziennego, Warszawa 1998, s. 115.

${ }^{69}$ A. Kępiński, Lęk, Warszawa 1977, s. 257.

${ }^{70}$ J. Baudrillard, Ameryka, Warszawa 1998, s. 59.

${ }^{71}$ P. Virillo, Bomba informacyjna, s. 37. 
bardziej destrukcyjne sa strachy długiego trwania, strachy innych. Wydaje się, że posługujący się tą metodą nie odkrywają niczego nowego, uczyli się posługiwania nim od państw i to nie tylko od komunistycznej Rosji czy hitlerowskich Niemiec. Każde państwo ma takie epizody w przeszłości nie wyłączając Stanów. Niczym innym jak wyrafinowanym użyciem takiego środka wymuszania pożądanych postaw i zachowań były palmeryzm i mccarthyzm, stworzone i pielęgnowane przez państwo. Spotykaliśmy takie próby także w Polsce okresu transformacji, a spełzły na niczym także dlatego, że nikt nie lubi się bać, choć to także tylko cząstkowa prawda dla wielbicieli horrorów. 


\section{4}

\section{IDEOLOGIE}

Historia ludzkości to historia idei - utrzymywał przekonaniem L. Misses nie próbując jednak pytać o to, czym sa, a nie wydaje się nam, że to było dla niego zupełnie oczywiste tak, jak nie jest dla nas. My także nie wiemy, czym sa, bo przecież nie uwierzymy w wyjaśnienie, że sa tylko symbolizacjami wartości. Dla niego, teoretyka, to właśnie idee i doktryny jako byty pierwotne wobec czynów, kieruja działaniami człowieka, determinują cele, do jakich dąży oraz wskazują środki, jakie trzeba zastosować dla osiagnięcia tych celów ${ }^{1}$. Sa tymi nierozpoznanymi praprzyczynami, ale czyny mają także oczywisty wpływ na kształty idei, bo przecież one nieustannie weryfikuja, może nie ich prawdziwość, ale skuteczność. Wciąż wypływają z głębokich źródeł, jakie sa nieuchwytne, nie sa statyczne, nie moga takimi być, by żyć własnym życiem, one musza być stale transferowane, rewitalizowane i właśnie o takich myśląc J. Dewey twierdził, że bez nich społeczności nie moga przetrwać ${ }^{2}$. Jeżeli nie moga przetrwać społeczności, to czy moga jednostki wraz z ich małymi, prywatnymi ideologiami? Po części będziemy odpowiadać na to pytanie w dalszej części wywodu.

Taki transfer musi oznaczać nie tylko uparta, może niebyt wyrafinowana rytualizację, z czym mamy do czynienia dziś, w czasie uprawiania tej „marnej polityki” Sartoriego. Politycy uwierzyli i uparcie wierzą $\mathrm{w}$ to, że ona wystarcza w zupełności dla ich praktyki i nie sa istotne jakieś przesłania, że ich moce sprawcze są naprawdę wielkie, a wydaje się, że sa zdecydowanie mniejsze od ich złudzeń potęgi władzy. Ten transfer to przede wszystkim wędrówka idei, ich obumieranie i rodzenie się od nowa w wyobrażeniach zbiorowych i przestrzeniach mitycznych przez wszystkie formy komunikacji międzyludzkiej, nad

\footnotetext{
${ }^{1}$ L.von Misses, Planowany chaos, Lublin 2005, s. 69.

2 J. Dewey, Democracy and Education, New York 1966, s. 3.
} 
jaka powinni panować prawdziwi politycy będący władcami symboli, a czego ci często zdają się nie wiedzieć sprawując swoją „władzę” nieświadomi tego. Idee wydają się zmieniać z dnia na dzień, a o ich kształtach przesądzaja nawet małe drgnienia rzeczywistości wymagające interpretacji. Każde takie drgnienie zmusza do redefiniowania idei, niekiedy spontanicznej reinterpretacji mogącej mieć znaczące skutki polityczne. Takim drgnieniem zdaje się być pamiętana jeszcze, powoli zapominana „afera Rywina”, wypierana przez „afery” Nowaka czy Hoffmana. W sumie nie bardzo wiadomo, czym była ta pierwsza ,afera”, ale nie to jest istotne, ale to, że ona podważyła wiarę w idee, których depozytariuszem była SLD i w konsekwencji takiej reinterpretacji partia straciła więcej niż władzę.

Taka wiara wyalienowanych elit w samą rytualizację szczytnych z pozoru, z pozoru wysublimowanych idei doprowadziła do spektakularnej klęski SLD i PiS, a nowe zdobycie wyznawców musi okazać się tożsame $\mathrm{z}$ procesem ukonstytuowania nowych konglomeratów idei $\mathrm{w}$ oparciu o wielkie archetypy mityczne i przegrani politycy powinni wiedzieć o tym, że to jednak ,idee nadaja formy życiu”, że nie są tak statyczne, jak im się wydaje ${ }^{3}$. Wyznawcy moga odnaleźć inne postaci wiary i czasami moga nie zaufać raz jeszcze, o czym przekonywało się wielu zadufanych polityków wpatrujących się z przejęciem w „słupki poparcia" i reagujących głównie na spadki owego poparcia. One muszą wyprzedzać to życie, potwierdzać swoją żywotność i w praktyce nie sposób nie zauważyć, że polscy (choć nie tylko polscy) politycy tego nie rozumieją traktując je jako sztafaże do prowizorycznych działań, zawierzając mitom PR, w których idee pojawiają się tylko jako ozdobniki. Zdaje się to wynikać także z tego, że traktuja oni swoje partie jak formacje trwania, jakimi na polskim gruncie sa PO i PiS, a wspominaliśmy już o tym, że ich wizje zbawienia prezentują się jak średniowieczne wizje nieba, a oni sami bywają traktowani jak mniejsze zło dla wielu wyborców, tych zwłaszcza, którzy potrzebuja prawdziwych idei.

Po trosze wynika to także z tego, że „ideologie”, do jakich się przyznaja politycy, sa niespójne, niekonsekwentne i odpowiadaja przede wszystkim potrzebom chwili, czyli dają się tak interpretować, by były odpowiednie na każdą okazję, a w dodatku towarzyszy im ta głęboka wiara w to, że sa nie tylko statyczne, ale mają także siłę niemal transcendentna jako hasła magiczne (liberalizm, konserwatyzm). Być może nie byłoby w tym aż tak wiele złego, gdyby nie to, że jednostki poszukujące znaków tożsamości politycznej chcą wspierać się o pewny system wiary, nie o lotne piaski, a tymczasem pytane o to, dlaczego wybieraja

${ }^{3}$ S. Bercovitch, The Puritans Origins of the America Self, New Haven 1975, s. 5. 
tych, a nie tych, są niepewne tego, co wybrali, choć nie kwestionujemy sądu, że ideologiczna identyfikacja jest opierana raczej na imponderabiliach niż generaliach ${ }^{4}$. Poza tym te „wielkie ideologie” z wyobrażeń zbiorowych sa korygowane przez nasze małe, indywidualne ideologie, które raczej nie interesują teoretyków, a powinny. Te poszukujące jednostki zdają sobie sprawę z tego, że taki system jest nieosiagalny, ale naturalnym dążeniem człowieka jest pragnienie posiadania pewności połączone z jakąś gwarancją spełnienia. Niekiedy, gdy pojawiają się wspomniane imponderabilia, owe jednostki odrzucaja ideologie tylko dlatego, że poczuły atawistyczną niechęć do ideologa albo tylko przywódcy partii reprezentującej określoną ideologię. Niekiedy taki wybór wymusza środowisko, a nawet osoby najbliższe, a wedle ich małych „ideologii” także te osoby powinny dbać o to, by inni byli na ich obraz i podobieństwo, by wybierali tak samo jak oni. Ale bodaj najmocniej o wyborze ideologii przesądzaja przestrzenie mityczne, w jakich się znajdujemy, charakter wiary ziemskiej.

Ideologie chyba nie są zwykłymi chimerami, jak chcą niektórzy, lecz zdeformowaną świadomością rzeczywistości, a tym samym realnym czynnikiem wtórnie deformującym zastaną rzeczywistośś ${ }^{5}$, jeśli założymy ich kreatywne moce wobec tej rzeczywistości. Tak widział to autor kontrowersyjnej pracy także nie odpowiadając na proste pytanie o to, czym są składające się na nie idee, a takie pytanie zdaje się konieczne w czasie, w którym nie miewamy raczej wątpliwości do tego, czym jest ideologia, choć nie zawsze potrafimy określić jej istotę i odpowiadamy zwykle, że jest to jakiś zbiór idei i mamy rację, ale nie do końca, bo dalej jednak musimy zapytać o sam przedmiot wiary, czyli idee. A czym jest sama idea? Wtedy, kiedy ideologie wspierano tysiącem „obiektywnych” racji dla ich uwiarygodnienia idee miały charakter „praw” społecznych, politycznych i ekonomicznych i za sprawą takiej „obiektywizacji”, które były niezbyt wyrafinowanymi mityzacjami, stawały się bezdyskursywne na zasadzie dura lex, zwłaszcza w ideologiach będących racja istnienia systemu politycznego. Kłopoty pojawiają się wówczas, kiedy zaczynamy pytać o idee będące własnością jednostek i są to kłopoty tak duże, że my bez kłopotu przyjmujemy sugestię van Dijka, że są to grona wierzeń w naszym umyśle.

Wedle teoretyków dziś idee to dzielone przez wielkie grupy społeczne przekonania, koncepcje zakorzenione w jakimś systemie wartości, rytualizowane przez media i akceptowane albo nie przez wielkie grupy społeczne. Nowe idee moga korzenić się wówczas, kiedy istnieje dla

${ }^{4}$ W.H. Flanigan, N.H. Zingale, Political Behaviour of the American Electorate, Boston 1979, s. 125.

${ }^{5}$ G. Debord, Społeczeństwo spektaklu, Warszawa 2006, s. 140. 
nich podatny grunt w przestrzeniach mitycznych zbiorowości albo pełna nieświadomość istoty jakiegoś nowego procesu, do którego chce się przekonać. Tak jest choćby z ideami „dobrej globalizacji”, bo nietrudno zauważyć, że wiedza na jej temat jest szczątkowa, choć mówi i pisze się o niej tak wiele zwykle ja „ideologizując”. Te także korzenią się na gruncie wielkich archetypów i, jeśli spojrzymy choćby na, ponoć istniejąca, „ideologię korporacyjną, to dostrzeżemy, że jest ona oparta na wartościach obecnych w kulturach „od zawsze”, obiecuje mityzowana wolność, równość, spełnienie ${ }^{6}$.

Kiedy opieramy się o autorytety politologiczne przyglądając się wielu typologiom nasza wiedza o ideologii zdaje się jeszcze bardziej wątleć, a zdaje się jednak potrzebna, bo nie wierzymy w niewyobrażalne, czyli $\mathrm{w}$ tyle razy wieszczona śmierć ideologii rozumianej jako zbiory idei organizujących fragmenty światów wyobrażeń zbiorowych, a tym samym przestrzeni mitycznych. Taka śmierć, naszym zdaniem, musiałaby być tożsama ze zniszczeniem nie tylko wielkiego świata mitów będących także rezerwuarem wartości, w jakim egzystujemy, ale także ze śmiercią wiary, tej immanentnej, co zdaje się już całkiem niewyobrażalne. Mity, będące ramami tej wiary, moga obumrzeć tylko wraz z ideami, a to także zdaje się niewyobrażalne. Nie można wyobrazić sobie zaniku archetypu wolności, równości czy sprawiedliwości w jakiejś zbiorowości, bo bez nich nie można wyobrazić sobie zbiorowych systemów wartości i nie tylko.

Potąd nie ma jeszcze uzgodnionej definicji ideologii - tak przynajmniej uważa A. Heywood 7 , a skoro jej nie ma (i dobrze), to poza możliwościami miałkich interpretacji tak złożonego zjawiska, pojawiają się niebezpieczeństwa nadinterpretacji, zwłaszcza przez teoretyków. Nie jesteśmy przekonani nie tyle do tego, czy jest to możliwe, ale czy potrzebne. Wydaje się, że potrzebne są tylko próby określenia tego pola badań, jego możliwych, mglistych granic. Stąd, niejako z obowiązku, pojawiają się poniższe przywołania autorów, którzy nie sa „klasykami” politologii ani historii, a które poprzedzimy swoiście ortodoksyjnym oglądem ideologii teoretyka, wedle którego jest to system symboliczny sytuacji historycznej klasy panującej ${ }^{8}$. Poprzestając na tym przypomnieniu, nie zadajac pytania o to, czy klasy inne od dominujacych nie mają ideologii, powracamy do politologów z przypadku, wierząc w ich intuicję, świeżość spojrzenia będąca konsekwencją swobody interpretacji i braku obaw przed reakcjami środowisk politologicznych, czy w ogó-

${ }^{6}$ Ch. Derber, Corporation Nation, New York 2000, s. 119.

${ }^{7}$ A. Heywood, Ideologie polityczne, Warszawa 2007, s. 19.

8 B. Hawkins, Ideology, Metaphor and Iconographic Reference, [w:] Language and Ideology, eds R. Dirren, R. Franf, Amsterdam 2001, s. 27. 
le naukowych. I tak, dla U. Eco ideologia jest całokształtem wiedzy adresata i grupy, do której należą jego systemy wierzeń, oczekiwań, jego postawy myślowe, doświadczenia, zasady moralne ${ }^{9}$.

Podobnie jak dla H. Gadamera, wedle którego każda idea jest zamykana w refleksji pierwotnej, przedrozumieniowej ${ }^{10}$, co sugeruje pierwotność „małych” ideologii. Jest swoistą organizacją rezerwuarów nieświadomych, choć takie stwierdzenie uchodzić może za próbę uniku, jeśli nasza wiedza o nieświadomości jest raczej szczątkowa. Wydaje się, że jednak każdą ideę, której istota jest tak ulotna, staramy się zrozumieć, konfrontować z rzeczywistościa pytając o to, czy jej praktyczna realizacja może polepszyć nasze życie, czy odpowiada naszemu systemowi wartości, czy wiara w nia zbliża poczucie spełnienia we wspólnocie politycznej. Potrzebujemy ich rozumiejacc, czy nie, bo właśnie potrzeba utopijnych wizji spełnienia jest „czymś, czego potrzebujemy”11.

Dla awangardowego R. Kirka ideologia zastępuje religię zawłaszczając chrześcijańską doktrynę zbawienia i ten właśnie teoretyk najmocniej podkreślił, że jakakolwiek ideologia bez wyrazistej, nakierowanej na jak najszersze zbiorowości soteriologii ziemskiej, nie ma szans na zdobycie wyznawców ${ }^{12}$, choć te sugestie o zastapieniu religii zdaja się być na wyrost, jeżeli uznamy, że religie także zaspokajaja potrzeby transcendencji.

Taka „analiza” zdaje się może trafna w odniesieniu do wielkich ideologii nowoczesności, które musiały obiecywać zbawienie materialne społecznościom dopiero dobijającym się o statusy ich satysfakcjonujace. Naszym zaś zdaniem ma mniejsze szanse na weryfikację, zwłaszcza dziś, w naszym czasie nazywanym ponowoczesnością, kiedy wśród sytych sybarytów zrodziło się przekonanie o bliskości zbawienia w doczesności i mamy na myśli szanse na stworzenie wspólnoty idei zdolnej przekształcać zastany świat. Stwierdzał to już dawno temu D. Bell w kontrowersyjnej w latach 60. pracy o końcu ideologii rozumianej przez niego jako antagonistyczne wobec siebie kapitalizm i socjalizm. Spełnienie w równości, wolności i sprawiedliwości, chociaż nie ma ostatecznego kształtu i mieć nie będzie, zdaje się ideologowi niby ziszczone i dawne ideologie opierane o wielkie archetypy już nie porywaja tych, którzy osiagnęli progi zaspokojenia materialnego, bo z pewnością nie duchowego czy emocjonalnego. $\mathrm{W}$ tamtym czasie nie pojawiły się natomiast ideologie $\mathrm{z}$ wizjami sięgającymi poza spełnienie materialne, a zdaje się, że w naszym czasie zapotrzebowanie na nie rośnie, zwłasz-

\footnotetext{
${ }^{9}$ U. Eco, Nieobecna struktura, Warszawa 1996, s. 109.

${ }^{10}$ H.G. Gadamer, Prawda i metoda, Warszawa 2004, s. 381.

${ }^{11}$ I. Wallerstein, Utopistic, New York 1999, s. 1.

${ }^{12}$ R. Kirk, The Politics of Prudence, New York 1994, s. 5.
} 
cza wśród ludzi młodych. Takie odnosimy wrażenie obserwując ruchy alterglobalistyczne, minimalistów i „oburzonych”, chcacych spełniać się w wartościach i przez nie. Dziwić może, że są one traktowane tylko jako sensacje medialne, coś doraźnego, przemijającego. Zdaje się, że znowu mamy do czynienia ze wspomnianym odwzorowaniem, co już nawet nie dziwi. Być może dopiero za jakiś czas jasnym się stanie, że był to początek czegoś nowego i pewnie takie „odkrycie” będzie spóźnione o lata albo i dekady, co także nie dziwi.

W takim czasie milionom samozbawionych materialnie starczy, że ideologia będzie jedynie obiecywała utrzymanie dotychczasowych statusów i tak jest z rozmyta ideologią liberalna, tak jest z konserwatyzmem, który, podobnie jak liberalizm, ma wielkie kłopoty z tożsamościa, także za sprawą braku koherentnej, wizyjnej soteriologii ziemskiej, która mogłaby odróżnić te nurty. Do tego stopnia, że niektórzy analitycy zasadnie uważaja, że różnice między liberalizmem a konserwatyzmem są umowne, że brak czytelnych kryteriów w ich odróżnianiu $^{13}$. Zarówno zwolennikom konserwatystów, jak i liberałów starczaja te rozmyte idee trwania, a mimo konfliktów, recesji, nie przyjmą do wiadomości tego, że to jeszcze jedna iluzja, bo wyznawcy muszą w coś wierzyć, a oni przecież są wyznawcami. Starczy, że zdarzy się coś nieprzewidzianego (choćby wielki kryzys) i one runą rodząc strach, desperację, nowe, o wiele skromniejsze nadzieje, a zarazem otworza drzwi do powrotu nowych koagulatów idei. Tym nieprzewidzianym, a możliwym do przewidzenia był i jest kryzys finansowy ostatnich lat, a reakcje „liberałów” i „konserwatystów” sa podobne, mimo z pozoru innych argumentów. Nie pierwszą ani ostatnią próbą poruszenia sybarytów amerykańskich, zmuszenia do myślenia o nieprzewidywalnej przyszłości i kolonizowania jej, był serial „Jerycho”, w którym wszystko kończy się w jednym dniu kataklizmem nuklearnym i miast trwać trzeba zaczaćc żyć, walczyć o przetrwanie w małych grupach z tymi, którzy jeszcze wczoraj byli sasiadami, przyjaciółmi. Często sami jesteśmy zadziwiani popularnością ruchów eurosceptycznych będących efektem zagrożeń kryzysowych. Inną „ideologią” zdaje się być ta, którą zaproponujemy poniżej, mówiąc o konsumpcjonizmie, nowa jakościowo, ale na swój sposób konsekwentna, intensywnie rytualizowana w mediach.

Takie nijakie „ideologie” jak konsumpcjonizm chyba nie wyczerpia się do czasu, w którym ideologowie nie zrozumieja, że w nowych warunkach trzeba tworzyć nowe idee, nowe iluzje, jeśli chce się aktywizować społeczeństwo, osiagać nowe cele i nie poprzestawać na recentywnym trwaniu, jakie możemy dostrzec w Europie i Polsce. Trzeba

${ }^{13}$ W.H. Flanigan, N.H. Zingale, Political Behaviour of the American Electorate, s. 117. 
szukać i prezentować nowe wymiary idei, jakie wyprą miałkie treści, dziś dominujące. Tego zdają się nie rozumieć kreatorzy jednoczącej się Europy nie mający na nia pomysłu. Tego z pewnością nie rozumieja ideologowie (o ile tacy istnieja) SLD, przy czym partia ta służy nam za swoisty model. Grupy, które nie tak dawno tworzyły grona wyznawców już nie istnieja, ich potrzeby zaspokajają inne idee, a poszukiwanie ich dla pozyskania radykalnych grupek feministek czy mniejszości seksualnych nie przyniesie pożądanych rezultatów, jako że ich „ideologie” sa tworzone przez nie same, a nie tych, którzy próbuja je wykorzystać wierząc w swoją polityczną podmiotowość. Mówiąc o „ideologach” SLD myślimy jednak o ideologach wszystkich partii politycznych, którzy po prostu nie zauważają konieczności tworzenia nowych koagulatów idei skazując się na przegrana, a przez prawdziwa przegraną rozumiemy niezdolność mobilizacji skrystalizowanych grup społecznych, czy całych społeczeństw. Być może to brak wyrazistych idei w praktyce partii politycznych przesądza w jakiejś mierze o tym, że doraźne „ideologie” przeżywaja się i coraz głośniej mówi się o ich zmierzchu i nawet nie próbuje przewidywać tego, co będzie po nich i tylko czasami mówi się o nadchodzeniu nowego cezaryzmu, jakiej bezideowej jakości, której kształtów nikt nie waży się rysować, nawet ci, którzy wieszczą nadchodzenie postpolityki, o której także nie wiemy nic. To przeżywanie jest chyba zarazem traceniem przez nie ról depozytariuszy idei i początkiem zaniku, co widać w odmasowieniu partii, choć nie wiemy, co może partie zastapić.

Takie próby określenia istoty zjawiska, jak te Eco i Gadamera, także nie mogą satysfakcjonować z wielu względów, ale nie próbując ich analizy, zauważmy że znaczyć to może także i to, że każdy z nas posiada własną ideologię, a skoro jest opierana o stabilne fundamenty mityczne i racjonalne, to powinna przekładać się na nasze przewidywalne postawy i zachowania polityczne. Tymczasem te zachowania i wybory zwykle bywaja nieprzewidywalne, być może nie za sprawą samych postaw myślowych czy doświadczeń, ale oczekiwań, jakie traktujemy jak wielkie kompleksy nadziei zbiorowych rodzone z idei. Oczekiwanie spełnienia determinuje choćby tzw. chwiejność zachowań wyborczych, która w Polsce, w latach 1997-2001 wynosiła niemal 50\%, podczas gdy w Europie Zachodniej około $8,5 \%^{14}$. To znaczyć może, że Polacy nie maja wyrazistych nadziei długiego trwania, nie potrafia identyfikować się ideologicznie i nie myślimy tylko o obywatelach, ale zwłaszcza bezradnych politykach reagujących tylko na drgnienia teraźniejszości i przyjmuje się to za coś naturalnego. Nie potrafiący stworzyć wyrazi-

${ }^{14}$ M. Kolczyński, M. Mazur, Wojna na wrażenia, Warszawa 2007, s. 13. 
stej ideologii z celami umieszczonymi w jutrze politycy PiS „podczepiaja się" pod posiadajace wyrazistszą ideologię Radio Maryja, politycy PO prezentuja synkretyzm, który nie może wyglądać jak spójna całość, a o mniejszych partiach nawet nie wspominamy, bo one zwykle mówią tylko o stworzeniu jakiejśs namiastki ideologii tonąc w hasłach zapożyczonych z zewnattrz, znaczacych niby wiele, ale pustych dla potencjalnych wyznawców, a tak jest z partia Janusza Palikota, beneficjentką ideowej bylejakości. Ta chwiejność wyborcza świadczyć może także o chaosie w przestrzeniach mitycznych obywateli zmuszanych do spontanicznych rewitalizacji wielkich mitów organizujących i założycielskich. Żywiołowa transformacja naruszyła je mocno, a nowi ludzie władzy nie potrafili poradzić sobie ze swoją władzą symboliczna, której mocy i znaczenia nie doceniali i nie wydaje, by zaczęli doceniać, bo wulgarny PR tego raczej nie zastapi.

Chyba te polskie, ale nie tylko, ideologie nie moga wyglądać inaczej, jeśli systemy wiary zbiorowej nie sa oparte o w miarę niewzruszone prawdy ${ }^{15}$. Wydaje się, że każda musi być mocno oparta o fundamenty mityczne, zakorzeniona w przestrzeni mitycznej społeczności, grupy czy warstwy społecznej. A jeśli mity są tą skrajną nieautentycznościa, to i sama ideologia jest tym, co Mannheim nazywał fałszywa świadomością ${ }^{16}$. Nie wiemy jak może wyglądać „prawdziwa” świadomość, ale wracając do fałszywych zauważmy, że każdy jednostkowy system wierzeń jest niezwykle dynamiczny, a ten dynamizm tworzący fałsz skutecznie uniemożliwia przewidywanie postaw i zachowań, a jest jeszcze większy wtedy, kiedy organizatorzy wyobrażeń zbiorowych nie potrafia stworzyć takiego systemu wiary, w którym rozpłyną się jednostkowe wierzenia. On czeka na skanalizowanie i uczynienie tych małych „ideologii” wiarą z nieodłączną od niej sferą ziemskiego, politycznego sacrum. Nie wydaje się, by można było dziś wymusić tak mocną wiarę przy pomocy metod stosowanych przez Hitlera czy Stalina i oczywiście myślimy o społecznościach rozwiniętego świata, choć pewni tego nie jesteśmy mając na uwadze zewnątrzsterowność człowieka naszego czasu. Przyszłość ideologii jest i jeszcze długo pozostanie nieprzewidywalna.

Wspomniany Eco zaakcentował oczywistą raczej właściwość ideologii jako systemu wiary, bo chyba jest w niej niewiele miejsca na racjonalność, ale inni ideologowie, czyli ci, którzy w miarę dobrze rozumieja istotę władzy symbolicznej i ludzkie oczekiwania na spełnienie, czynia wiele, by racjonalności (w tym wypadku nauki jako tego „racjonalnego” sztafażu), było jak najwięcej, a to konfirmuje inne komponenty usyste-

${ }_{15}$ R.S. Robins, J. Post, Paranoja polityczna. Psychopatologia nienawiści, Warszawa 1999, s. 227.

${ }^{16}$ K. Mannheim, Ideologia i utopia, Lublin 1992, s. 49. 
matyzowane z pewnego punktu widzenia i czasami łączone w sposób dość ekwilibrystyczny. A wiemy skądinąd jak ciężko jest połączyć naukę z metafizyką tak, by nie budziło to podejrzeń czy oporów, zwłaszcza wśród tych, którzy starają się racjonalizować jak najwięcej i najczęściej z podziwu godnym uporem. W tym przypadku możemy dostrzec zgodność rozpoznania filozofa z tymi, jakich autorami są historycy nie przywiązujący większej wagi do „historii nieświadomej”, a twierdzący po prostu, że ideologia to zbiór wierzeń, przekonań, wartości, uprzedzeń, które tworzą systemy politycznych wierzeń grup, jednostek.

Przy czym, przyjmując zasadność takiej próby sądzimy, że wierzenia jednostek powinniśmy stawiać zdecydowanie wyżej, jeśli przyjmiemy, że „ideologie" maja wymiar indywidualny ${ }^{17}$. Ale raczej w rozumieniu T. Paine'a. Pierwszy „obywatel” Stanów uważał, że idee sa produkowane w jednostce przez aktualną sytuację i warunki życiowe i wtedy jednostka może zawierzyć tylko tym, którzy obejmą swoimi „gronami wierzeń" taką sytuację i takie warunki. Wtedy poszukujemy siebie w grupach wyznających podobne wartości i próbujemy się w nie wtapiać. Niemal o tym samym pisał filozof utrzymujący, że obraz świata, jaki posiada każdy z nas jest jego prywatna własnością ${ }^{18}$. Obaj zdawali się mieć na myśli indywidualne przestrzenie mityczne nieustannie uzgadniane ze zbiorowymi, pierwotnymi wobec nich, niezwykle dynamicznymi, co wymaga nieustannych korekt.

Tu raz jeszcze podkreślamy, że ten obraz świata w ogromnej mierze zależy od wartości strukturyzowanych i rytualizowanych w procesie akulturacji. Idee nie majace mocnej podbudowy aksjonormatywnej miewają zwykle żywot jętek. Być może dlatego nie znalazły się na polach badawczych nauki. Niektórzy badacze, zwłaszcza historycy, choć nie tylko oni, uważaja, że rekonstrukcja takich systemów wiary raczej ich nie interesuje ze szkodą dla zrozumienia istoty procesów, zjawisk historycznych, ich interesują przede wszystkim czyste fakty, choć powinni zauważać, że fakty sa czasami prosta konsekwencja takich wierzeń. Zajmują się więc skutkami pomijając przyczyny i takim sposobem wyjaśnianie jest spychane na plan drugi przez opisy skutków. Jeśli przyjmiemy, że ideologia jest mediacją między ideami a warunkami społecznymi ${ }^{19}$, a jako taka kreuje te warunki, ona powinna znajdować się w centrum uwagi badaczy przeszłości i chyba wtedy historia może stawać się lepszą „nauczycielką życia”. Wspominamy o nich, gdyż to

${ }^{17}$ I. Schiffer, Charisma. A Psychoanalytic Look at Mass Society, New York 1973, s. 89.

18 W. Tatarkiewicz, Droga do filozofii i inne rozprawy filozoficzne, Warszawa 1971, t. I, s. 21.

19 J. Ernst, „Ideology” and the Economic Interpretation of the Revolution, [w:] The American Revolution, ed. A.F. Young, Illinois University 1979, s. 161. 
w jakiejś mierze dzięki nim i nauce historii w szkołach idee jako takie są nie tyle marginalne, co nieważne, liczą się tylko hierarchizowane fakty-skutki.

Powracając do generujących ról ideologii chcemy zauważyć, że inne potwierdzenia ideologii-wiary generujacej zachowania zbiorowe znajdziemy w wielu społecznościach, w tym amerykańskiej, widzianej tak często jako najbardziej religijna w naszym czasie ${ }^{20}$, choć zasadność takich sądów bywa często wątpliwa, jeżeli deklaracje porównamy z naga praktyka. Prawdziwe problemy pojawiają się wtedy, kiedy zaczynamy pytać o istotę wiary poprzedzajaccej taką religijność. I tu powtarzamy, że naszym zdaniem, jest to przede wszystkim wiara w wielorako rozumiane zbawienie ziemskie, zbliżanie się ku ideałom wolności, równości, sprawiedliwości, wiara która jest żyzna glebą rodzącą idee dynamiczne, plastyczne w interpretacjach. Taka wiara oznaczać może nic innego jak ufność w świetlana, bezproblemowa, sytą przyszłość dla wszystkich, niezależnie od umiejętności, wkładu pracy. Ideologia, jaka by nie była, musi być prospektywna, rysować w przyszłości cele, do których zbliżanie się potwierdza nasza codzienna praktyka. J. Szacki twierdził zasadnie, że ideologia nie jest nią tak długo, jak długo nie poucza nas, jak być powinno i jak można osiaggnaćc pożądany stan świata ze swoim w nim miejscem ${ }^{21}$. I jako taka wręcz musi być zdominowana przez wielkie wizje przyszłości i one powinny zajmować w niej poczesne miejsce, a chyba nie sposób wyobrazić sobie takiej generujaccej ideologii nakierowanej na przeszłość. Nawet „konserwatywne utopie przeszłości” romantyków były marzeniami o powrocie dawnego stanu szczęśliwości, emanacjami tęsknot za rajem utraconym, jego mitami. Dziś niektóre odłamy konserwatyzmu, zwane bardzo różnie, artykułuja, co prawda, idee gloryfikacji przyszłości, ale przecież chcą je implantować w jutro.

Dziś powiada się (J. Horkheimer) ${ }^{22}$, że idee ulegają instrumentalizacji tak dalece, że tracą autonomiczny sens jako myśli. Zaczynaja uchodzić za rzeczy, maszyny i w wielu przypadkach idea choćby wolności, tak bliska każdej jednostce, staje się tylko werbalnym ozdobnikiem, bez wyraźnych desygnatów i można ją bez konsekwencji interpretować na dziesiątki sposobów. Wolność naszego czasu staje się plastyczną metafora dającą się dopasować do każdych warunków, każdego przypadku, zawiera wszystko i nic ${ }^{23}$, a jako pusta skorupa nie przydaje się na

\footnotetext{
${ }^{20}$ S. Fath, Religia $w$ Biatym Domu, Warszawa 2007, s. 21.

${ }^{21}$ J. Szacki, Dylematy historiografii idei oraz inne szkice i studia, Warszawa 1991, s. 225.

22 J. Horkheimer, Krytyka instrumentalnego rozumu, Warszawa 2007, s. 51.

${ }^{23}$ S. Ewen, All Consuming Images, New York 1989, s. 20.
} 
wiele w praktyce społecznej. Tak zinstrumentalizowane mogą stać się niebezpieczne jak każda idea, jeśli „,jej się nadużywa” - zauważał badacz ${ }^{24}$. Ale jeśli przyjrzymy się bliżej historii idei, postaciom ich transferu i kultywacji, możemy konstatować, że one były instrumentalizowane od „zawsze”, choć nie w takich formach jak dziś. Tylko postaci wiary w nie i sposoby rytualizacji zmieniły się radykalnie. Dziś, zwłaszcza w świecie bogatych, nie ma już idei, dla których można i trzeba było się poświęcać w imię przyszłości, ale nie znaczy to, że za jakiś czas nie pojawią się jeszcze wraz z jakimiś radykalnymi zmianami. Poczucie spełnienia nigdy nie jest pełne, a staje się swoim odwróceniem wtedy, kiedy zakwestionuje je zjawisko takie, jak kryzys ekonomiczny, podobny do tego z 2008 roku, który trwa i rodzi nowe interpretacje idei, moderowane innymi strachami i nadziejami.

Choć ma swoje racje Horkheimer, racje potwierdzane obserwacjami, to jednak wydaje się, że każda relatywizacja idei spotyka się z reakcjami tych, którzy zauważaja, że bez określenia ich istoty w nowych warunkach nie jest możliwe określenie się wobec świata, a wiemy o tym, iż jest to swoisty tropizm każdej jednostki. Ona musi posiadać swoje „grona wierzeń”, poszukuje ich bezustannie i bardzo często zdobywa je, uzupełnia nawet dzięki modom na jakieś interpretacje. A tzw. efektu Diora, czyli efektu naśladownictwa nawet się nie zauważa w naukach społecznych. Tak było i jest z ideologizacją lewicowości przez młodych ludzi, lewicowości pochopnie przez nich utożsamianej z czystymi wartościami i to zdaje się być symptomem niejednej z „chorób dziecięcych”. Jednostka, odnajdując się w dorosłym życiu, musi posiąść spoisty system wiary, jakiego często konsekwentnie broni i nie sposób wyobrazić sobie takiej wiary bez elementów spełnienia. Taka wiara usprawiedliwia relatywizacje, wynika z dualności człowieka i tego pragnienia pewności, jakie towarzyszy nam stale. A jednostki ze swą wiara sprawiaja, że pojęcie ideologii samo zostało poddane ideologizacji ${ }^{25}$.

Muszą te „grona” wierzeń posiadać politycy, także poszukujący racji istnienia swego „zbawienia” przez idee. Oni intuicyjnie czuja to, o czym mówił M. Foucault, reinterpretując wiele refleksji spotykanych już u starożytnych i wędrujących przez wieki. A wedle niego głupi despota może przymuszać niewolników żelaznymi łańcuchami, ale prawdziwy polityk wiąże ich o wiele mocniej łańcuchami własnych idei ${ }^{26}$. Idee mogą oszukać i uwięzić, ale nie zapominajmy i o tym, że mogą także otwierać i otwierają nowe przestrzenie dla myśli i idących za nimi czy-

\footnotetext{
${ }^{24}$ P. Kreft, Ekumeniczny dżihad. Ekumenizm i wojna kultur, Warszawa 2005, s. 52.

${ }^{25}$ U. Hannerz, Powiazania międzynarodowe. Kultury, ludzie, miejsca, Kraków 2006, s. 225 .

${ }^{26}$ M. Foucault, Nadzorować i karać. Narodziny więzienia, Warszawa 1998, s. 100.
} 
nów ${ }^{27}$. Stają się wielkimi motorami historii wtedy, kiedy przyjmują postaci proste, łatwe w rytualizacji, zgodne z podstawowymi wartościami, mieszczące się w przestrzeniach mitycznych wielkich zbiorowości i potrafiące aktywizować tę zbiorowość. Podówczas ideologie moga stawać się „religia”, jak dla Mussoliniego, a dla niego faszyzm był nową religia i mówił, że wiara w nią może przenosić góry ${ }^{28}$. Nie sposób nie godzić się z nim widząc role większych i mniejszych ideologii w przeszłości, przy czym znowu wypada spróbować odpowiedzieć na ciagle aktualne pytanie o istotę ideologii, choć wiemy o tym, jak jest to trudne, choćby po analizie tej istoty przez K. Mannheima i innych, dla których każda ideologia jest postacia oszustwa, fałszowania wartości. Do pewnego stopnia jest, jeżeli rozpatrujemy ja w kontekstach teorii prawdy, ale z drugiej strony winniśmy pamiętać także o tym, że także te nieprawdziwe idee nadają formy życiu, a ono nie jest już takim oszustwem.

Mimo to, prawie wszystko w świecie społecznym, dzieje się pod płaszczykiem ideologii - tak sugeruje D. Morris - z pozoru bywaja to kwestie ideałów, zasad moralnych, ale w rzeczywistości są to owe „łańcuchy”, jakimi krępują nas przede wszystkim politycy i jednostki i grupy mające wpływ na politykę, a mający na celu własne korzyści i posiadający władzę symboliczną ${ }^{29}$. Politycy także zdaja sobie sprawę $\mathrm{z}$ tego, że idei nie odrzuca się $\mathrm{w}$ wyniku negatywnych rezultatów eksperymentów naukowych - zauważała A. Motycka ${ }^{30}$. One bywaja przecież niemierzalne, niekiedy nadczasowe, obudowane setkami bezdyskursywnych mitów i doraźnych mityzacji. Ale czasami są także statyczne za sprawą nadmiernego obudowania ideologii mitami (ideologia komunistyczna), czasami zbyt statyczne, by kreować czyny i tak było z implodująca szybko ideologią socjalizmu. Sam dyskurs ideologiczny - zauważał Althusser - jest systemem zamkniętym. Jako taki może stawiać przed sobą tylko takie problemy, które potrafi rozwiązać. Chcąc pozostać bezpiecznym w wyznaczonych granicach musi unikać pytań grożących wyjściem poza te granice ${ }^{31}$, ale wtedy staje się rytuałem coraz bardziej obcym wyznawcom.

Ideologie są swego rodzaju „świeckimi religiami” opartymi o fundamenty mityczne i obowiązuja tu prawie te same reguły, co w religiach bez przymiotników. Nie chcąc burzyć gmachu ideologii budowanego

${ }^{27}$ S. Bercovitch, Problem ideologii w czasach niezgody, [w:] Kultura, tekst, ideologia. Dyskursy wspótczesnej amerykanistyki, Kraków 2004, s. 137.

${ }^{28}$ A.M. Schlesinger jr., The Politics of Upheaval, Boston 1988, s. 147.

${ }^{29}$ D. Morris, Ludzkie zoo, s. 111.

${ }^{30}$ A. Motycka, Rozum i intuicja w nauce, Warszawa 2005, s. 41.

${ }^{31}$ J. Storey, Studia kulturowe $i$ badania kultury popularnej. Teorie i metody, Kraków 2003, s. 36. 
przez dziesiątki lat, nie zadajemy pytań mogących kwestionować jakiś jej filar, jakiś wielki mit-archetyp. Próba naruszenia jakiegoś dogmatu może oznaczać naruszenie fundamentów całej budowli i zagrozić jej runięciem, a przynajmniej pochyleniem. Dlatego też o wiele bezpieczniej dla władców symboli jest zastapić ideowy dyskurs rytuałami, a zwykle jest to możliwe w przypadku ideologii dominującej, która potwierdza się jako trwały system wiary. Tworzymy wtedy system swoistej „religijności” ideologicznej i nietrudno zauważyć, że jej formy sa przejęte $\mathrm{z}$ religijnych, a te tworzono na wzorach tak starych jak społeczności ludzkie. Rytuały sa z pewnością źródłami siły nie tylko dla liderów, ale także wyznawców ${ }^{32}$. Widząc, słysząc depozytariuszy swoich prawd wierzacy umacniaja się $\mathrm{w}$ wierze, potwierdzaja swoją tożsamość, umacniają poczucie wspólnoty, aktywizują się do czynów w imię idei pod warunkiem, że sa już wyznawcami, nie akolitami wiary. Bycie wyznawca jest już znakiem tożsamości.

Ideologie byłyby martwe bez wywodzacych się z magii i wciąż magicznych rytuałów będących jakby fizycznym potwierdzaniem istoty mitów. Dla teoretyka rytuał to symbolicznie uporządkowany składnik każdego działania zbiorowego ${ }^{33}$, ale dla nas, przyjmujących, że działania sa poprzedzane ideami, rytuał to także konfirmacja idei. Tylko dzięki temu staje się ona częścią sfery sacrum. Dzięki nim wyznawcy umacniaja poczucie tożsamości, czują więź z innymi wyznawcami, nawet jeśli jest to uczestnictwo mediowane przez prasę, czy telewizję, a te media fałszuja idee jeszcze bardziej, dysponując mocami ich „obiektywizacji”. Wydaje się, że znacznie przyczyniają się do tworzenia złudzeń spełnienia.

Sama rytualizacja ideologii, choć niezwykle ważna w zdobywaniu i przywiązywaniu wyznawców, nie wystarcza, tak jak nie wystarcza wymuszane uczestnictwo w życiu politycznym (wiecowe, telewizyjne) i mamy na to sporo potwierdzeń. Kolektywne idee i wierzenia w ideały albo przynajmniej w doskonały system polityczny muszą być podparte wiara, że jest on rzeczywiście możliwością stworzenia lepszego świata, bo bez takich wizji przeradzających się w konkretne projekty i programy aktywizacja wielkich grup społecznych zdaje się niemożliwa i tu potwierdzanie takich supozycji nawet nie zdaje się konieczne. Ale łatwiej je zrozumieć, jeśli widzimy jak w Europie naszego czasu zanikaja przejawy wiary w idee demokracji, która miała być remedium na wszystkie nasze bolaczki, miała być tłem prawdziwego zbawienia, a stała się tylko rytuałem. Tylko część społeczności została do niej prze-

\footnotetext{
${ }^{32}$ J.K. Galbraight, The Anatomy of Power, Boston 1983, s. 44.

${ }^{33}$ E.W. Rothenbuhler, Komunikacja rytualna, Kraków 2003, s. 20.
} 
konana, uwierzyła w to, że rzeczywiście przynosi ona widome korzyści, część zaś, konfrontując nowe idee z rzeczywistościa, odkryła, że jest daleka od spełnienia się w równości czy sprawiedliwości i spontanicznie manifestuje swoją niewiarę, zarówno w krajach „starych”, jak i „nowych" demokracji. Tu o braku tożsamości między ideą a wyznawcami w znacznej mierze przesądzają odnoszone przez nich korzyści i pojawia się ten pragmatyzm ludzi, którzy swoją identyfikację ideową opieraja raczej na imponderabiliach niż generaliach, a owe imponderabilia to pieniądze, dobra materialne, spokój, gwarancje bezpieczeństwa. Dla zagwarantowania tych nabytych wartości i dóbr potrzebują takich form, które zapewnią stałość ich posiadania i będa zawierzać tym, którzy pokuszą się o danie takich gwarancji. Mityczna demokracja takich form nie zapewnia, choć tak często twierdzi się, że tak i wiara w to, że jest właśnie tak podtrzymuje ją jak kroplówka.

Gdzie świat - powiada filozof $-\mathrm{z}$ powodu przyspieszenia zmian, staje się coraz bardziej złożony, tam ten świat wymusza uproszczenia, a każde uproszczenie oznacza życiowe kłamstwo ${ }^{34}$. Szukamy takich kłamstw poszukując siebie w świecie ludzi i, opierając się na swych gronach wierzeń, odnajdujemy je w zbiorowych ideologiach wiążąc się nimi na dłużej lub krócej nie zawsze wiedząc dlaczego z lewicowca stajemy się prawica. Czasami samo przyjęcie ideologii oznacza zaangażowanie się w jej realizację wespół z innymi współwyznawcami, choć praktyka społeczna wskazuje, że czasami, miast działania, jest to tylko bierna akceptacja, a ta, tylko akceptacja świadczyć może o słabości ideologii, o braku horyzontu obietnicy. Tu znowu zwracamy uwagę na regulacje typu idealistycznego, jak nazywają to psychologowie społeczni, czyli na zaakcentowanie rozbieżności między ideałami a praktyką społeczna. Jeśli takie rozbieżności są wyraźne, wówczas jednostka jest skłonna do odejścia od ideologii i szukania innej i tu spore znaczenie miewają także motywacje egotyczne, a wedle L. Discha, teoretyka systemów politycznych, „racjonalny” wyborca zwykle decyduje o wybraniu takiej orientacji ideowej, która da mu jak najwięcej korzyści materialnych, czyli pomoże w zbawieniu doczesnym ${ }^{35}$.

Co do tego nie miał także złudzeń $R$. Conquest, powiadający, że ideologie obiecujace ludziom zarówno obronę ich tradycji, jak i bezbolesny, niosacy powszechny dobrobyt rozwój ekonomiczny w warunkach równości i sprawiedliwości zawsze znajdą chętnych słuchaczy ${ }^{36}$. Nie zawsze jednak maja one znaczenie kluczowe, zwłaszcza w społecznościach zrytualizowanej latami wiary w wielkość idei, która nie przynosi

${ }^{34}$ O. Marquard, Apologia..., s. 87.

${ }^{35}$ L. Disch, The Tyranny of Two Party System, Cambridge 2002, Cambridge 87.

${ }^{36}$ R. Conquest, Przeszłość pewnego złudzenia, Poznań 2002, s. 101. 
widomych oznak spełnienia. Tak było z wiarą w jakość idei kultywowanych przez ideologie socjalizmu w ich wielu odmianach. One, statyczne, starzejące się, przestały pełnić swoje role na długo przed upadkiem „komunizmu", kiedy wiara w nie zetlała zupełnie. Nawet ludzie tzw. aparatu byli zasadnie podejrzewani o bezbożnictwo pragmatyzmu, a wielu z nich przyznawało się do tego publicznie i nie myślimy tu o „pragmatyku” A. Kwaśniewskim.

Każde nowe wyzwolenie niesie za sobą niebezpieczeństwo nowej niewoli - powiadał R. Aron i miał swoje racje, jeżeli myślał akurat o ideach ${ }^{37}$. Właśnie w naszym czasie mówi się o tym, że wyzwoliliśmy się z okowów wielkich ideologii, że nastapił ich zmierzch, a w ich miejsce motorem polityki stało się znowu sacrum - tak widział to C. Jean w swojej rozprawie o geopolityce, mający ma myśli powrót wielkich religii i ich nowe role polityczne. Naszym zdaniem nie zmieniło się aż tak wiele, z tym, że w społecznościach jednak protopolitycznych, pojawiły się nowe systemy wiary z mocną legitymacja religijna, ale religie w nich wykorzystywane sa na sposób czysto instrumentalny. Choćby tak zwane „fundamentalizmy” prezentują się jak wielkie herezje, których związki z religiami macierzystymi zdają się mocno wattpliwe, choć niewattpliwie sa to nowe reinterpretacje soteriologii „właściwej”. Jeśli porównamy je z obumierającymi wielkimi ideologiami, zauważymy, że i fundamentalizmy sa opierane na tych samych archetypach mitycznych i religijne sztafaże nie powinny nas mylić. Te fundamentalizmy, jeśli mamy na uwadze islamskie, są ideologiami biednych, wykluczonych, marzących o swojej pełni równości i sprawiedliwości, a powinniśmy pamiętać o tym, że bieda i przemoc zawsze idą ze sobą w parze, co zauważał M. Duffield ${ }^{38}$ i mogą owocować uciekaniem się do takich metod jak terroryzm. Co zaś do upadku wielkich ideologii, czyli kapitalizmu i socjalizmu, to zauważamy raz jeszcze, że one rzeczywiście zatraciły swoje moce, tracąc możliwości tworzenia horyzontów zbawienia dla tych, którzy sądza, że już są zbawieni. Sa, wedle siebie, zbawieni, ale chca wierzyć, poszukują wiary uzgadniającej ich ze światem, innymi i samymi soba. Namiastką takiej wiary, takiej ideologii jest konsumpcjonizm, o którym niżej.

R. Bacon pisał dawno temu, że religia jest najmocniejszym spoiwem społeczności ludzkiej jakby zapominając o konfliktach religijnych, które dzieliły, miast łączyć, ale mając swoje racje, wydaje się nam, że pisząc o religii w swoim czasie myślał jednak o wierze immanentnej. Ta spaja wszystkich bez względu na kolor skóry, narodowość i... religię. A spo-

${ }^{37}$ R. Aron, Opium intelektualistów, Warszawa 2000, s. 38.

${ }^{38}$ M. Duffield, Global Governance and the New Wars, London 2007, s. 121. 
iwem najmocniejszym są idee kreujące spójne światopoglądy, niekiedy zmuszające wręcz do działań jednostkowych i zbiorowych. Potocznie sa to poglądy jednostki na świat, a więc przekonania normatywne, wartościujące odnoszone do natury świata, Boga, społeczeństwa, służące umocowaniu się w świecie, zbiorowości. Jednostkowe światopoglądy sa organizowane przez idee i zdaje się, że idee spełniały takie role już w czasach, które są dla nas nie historia, ale antropogenezą. Pierwotna idea, symbolizowana na tysiące sposobów, zdaje się idea przetrwania, żywotna od zarania ludzkości. Nie wiemy o tym wiele, ale literackie wizje H. Rosny'ego i filmowe J.J. Annaud z Walki o ogień są przekonująca próba potwierdzenia pierwotności takiej idei, która niewiele straciła z atrakcyjności. Wciąż walczymy o „ogień”, tyle że nie o ten sam.

Dziś wiara w idee pozostała taka sama, a może nawet jej potrzeba stała się jeszcze większa po upadku wielkich ideologii tam zwłaszcza, gdzie tak wielkie sa pragnienia spełnienia. Ich brak zdaje się owocować regresem, powrotem ku protoideologiom, zauważalnym nie tylko wśród tych, którzy uzurpuja sobie prawa obrony biednych i uciśnionych. $\mathrm{Ci}$, w wielości społeczności, będąc większością, zawsze znajdą gorliwych obrońców, zdających sobie sprawę z siły masy, a tworzących dla nich aktywizujące wizje zbawienia. Ten nawrót to nie tylko owe egzotyczne „fundamentalizmy”, ale także nowe postaci wiary w społeczeństwach bogatych. W jakimś stopniu zanikły racjonalizowane, legitymizowane nauką ideologie spajające zbiorowości polityczne i społeczne i ich miejsca zaczęła zajmować wiara bezrefleksyjna, wynikająca z tego, co teoretyk bardzo uczenie nazwał niemożnością zasymilowania pewnego poziomu rzeczywistości wobec naszej świadomości, a my możemy nazwać to niezdolnościa do zrozumienia najprostszych zjawisk.

„Ideolodzy” dostarczajacy gotowych i najprostszych wyjaśnień złożoności świata mogą zdobyć grupy pragnące za wszelką cenę zrozumieć jak najmniejszym wysiłkiem siebie, swoje role społeczne, a to jest im tak potrzebne jak chleb. Czasami to, jak się określaja, nie ma większego znaczenia dla nich samych. Liberał może okazać się konserwatysta albo, co jest ciekawą hybryda, liberalnym konserwatysta, czy na odwrót. Nie przypadkiem w tych wyjaśnieniach istoty świata miejsce centralne zajmują wizje zbawienia. Jedna z takich propozycji są idee uniwersalistów postulujące kreowanie świadomości globalnej. Ci jednak, stawiajac na miejscu pierwszym zbawienie zbiorowe, nie chca zrozumieć tego, że indywidualne zawsze będzie planem pierwszym. Oni wydają się być przekonani, że szlachetność intencji jest najlepszą legitymacja, że zbiorowe spełnienie możemy postawić nad swoim, ale nie zawsze tak bywa. 
Potrzeby reintegracji na prostych poziomach Ja zaspokajać zaczęły protoideologie, które istniały „od zawsze”, ale w ich nowej postaci zaczęły interesować ludzi nauki od czasu, kiedy w nauce zaczęto przywiązywać większą wagę do ruchów populistycznych i do pewnego stopnia odmityzowano „święte” ideologie, znowu z opóźnieniem kilku dekad. $\mathrm{W}$ samych początkach tego zainteresowania niezbyt fortunnie potraktowano protoideologie jako postaci „fałszywej” wiary, co nie wydaje się zbyt szczęśliwe, jak już zauważaliśmy, gdyż podówczas ideologie mogłyby uchodzić za wiarę „prawdziwa”, a to już zdaje się sporą przesadą. Zdaje się, że nie przypomniano sobie na czas refleksji Condillaca: „Ludzie prości i filozof z tych samych wrażeń dobywaja zupełnie inna wiedzę" 39 . Ci zaś, którzy w ogóle nie potrafia „dobyć” takiej wiedzy, oglądaja się na zachowania innych ludzi, uruchamiają swoje rezerwuary wiary i jeśli poczuja, że sa w tej samej przestrzeni mitycznej, co organizator, podówczas są w stanie zawierzyć mu, niekiedy nawet oddać się na dobre i złe w imię tego zbawienia. A wiemy skądinąd jak łatwo przy pomocy nawet niespójnych haseł jest nakłaniać wielkie wspólnoty ludzkie do działań wręcz samobójczych, a takimi były i są częste wybory polityczne legitymizujace wojny, ludobójstwo. I tu nie możemy nie przywołać maksymy przewrotnego M. Ridleya; „Milion ludzi nie może się mylić, chyba, że by się mylił" 40 .

Pozbawieni swoistej „głębi ideologii”, czyli możliwości częściowej racjonalizacji systemu wiary, pozostawieni samym sobie, ludzie - wyznawcy protoideologii - są w stanie poruszać się tylko na poziomie najprostszych metafor, poziomie „przedrozumienia” często bywają skłonni interpretować je literalnie, bez analizy, refleksji, relatywizacji, na które ich zwyczajnie nie stać. Dla nich wolność, równość czy sprawiedliwość muszą przybierać formy idealne, muszą odnajdywać mocne potwierdzenia w praktyce życiowej, podczas gdy wyznawcy znajdujący się na poziomach ideologii sa w stanie zrozumieć wszystkie ograniczenia i w swoisty sposób akceptować brak pełnej tożsamości między mityzowanymi symbolami a rzeczywistościa. Te poziomy protoideologii interesują nas szczególnie, gdyż ostatnimi czasy tak często „poważne” partie bywaja, nie tyle podejrzewane, co coraz częściej oskarżane o populizm bez większych konsekwencji, a bierze się to z przekonania, że populizm jest zły, dlatego, że jest zły. Dodajmy, że wcale nie bezzasadnie, choć być może sami politycy nie wiedzą o tym, że stają się populistami. Inaczej nie można trafić do jednostek prelogicznych, a są to przecież miliony wyborców, których trzeba zdobywać wszelkimi sposobami. Sa to

${ }^{39}$ E.B. de Condillac, Traktat o wartościach, Warszawa 1958, s. 247.

${ }^{40}$ M. Ridley, O pochodzeniu cnoty, Poznań 2000, s. 207. 
wielkie rezerwuary głosów dla niezmiennie kontrowersyjnego K. Wilbera, który uważa, iż jest to około $40 \%$ populacji ${ }^{41}$, a można suponować, że jednak więcej i będzie jeszcze więcej. A w takim miejscu już trzeba pytać o konsekwencje polityczne.

Dla Levy-Bruhla taka prelogiczna umysłowość dokonuje syntez bez wstępnych analiz, których po prostu nie jest w stanie dokonywać. Związki między nowymi wyobrażeniami są tu na ogół dane wraz z zakodowanymi już wyobrażeniami, zwykle prymitywnymi. Umysłowość logiczna zaś najpierw trawi tworzywo myślenia, poddaje dysocjacji, klasyfikacji. W jej przypadku sądy opierają się na w miarę ściśle zdefiniowanych pojęciach, które są dziełem uprzedniej pracy logicznej. Ale ilość umysłowości logicznych stale się kurczy, są one spychane na marginesy życia, a w centrum zainteresowań polityków demokratycznych znalazły się prelogiczne i te nie sa zbyt zainteresowane zdobywaniem tej mniejszości i widać, to choćby w ich praktyce politycznej. Trudno odnaleźć ślady wysiłków dla zdobycia poparcia „wykształciuchów” w deklaracjach polskich polityków wszystkich odcieni. Czyżby nie dlatego, że tak mało w nich wiary?

Chcac pozyskać elektoraty z protoideologicznego poziomu rozumienia liderzy polityczni muszą używać najprostszych i skutecznych środków do ich przekonania, przywołuja „czyste”, idealne postaci równości czy sprawiedliwości, co wcale nie znaczy, że maja zamiar walczyć $\mathrm{w}$ praktyce o pełny egalitaryzm czy poszerzać zakresy wolności, o jakich mówią. Owo poszerzenie ma zwykle charakter pozorny - politycy odwołują się do emocji z nadzieja, że na czas jakiś poruszą serca i przekonaja rozumy ${ }^{42}$. Robią to w imię doraźnych korzyści nie oglądając się na przyszłość, co zbyt często kończy się spektakularnymi klęskami polityków czy partii zdobywających władzę, a często takie zdobycie bywa początkiem upadku. Ta praktyka bywa całkiem inna w przypad$\mathrm{ku}$ „klasycznych” partii populistycznych. Z naszych obserwacji wynika, że specjaliści od marketingu nie zdaja sobie jednak sprawy z tego, iż skuteczność ich działań powinna wynikać z przynajmniej dobrej znajomości przestrzeni mitycznych odbiorców, a tak raczej nie jest. Zbyt często, próbując przekonać do swoich propozycji, mieszają środki, ich zdaniem skuteczne wobec środowisk podatnych na proste przesłania i tym sposobem utwardzaja tylko elektorat przekonanych, czyli tych, których przekonywać nie trzeba, gdy ich wiara stała się podstawa dla potwierdzania tożsamości. Ta mocna wiara jest wiara w to, że tylko depozytariusze ich prawd poprowadzą ku samozbawieniu. Ale także ona eroduje

${ }^{41}$ K. Wilber, Integralna teoria wszystkiego, Poznań 2006, s. 30.

${ }^{42}$ A. Pratkanis, E. Aronson, Wiek propagandy, Warszawa 2003, s. 181. 
za sprawa niejako automatycznych regulacji idealistycznych, czyli tych stałych mechanizmów konfrontacji idei z rzeczywistościa.

Sytuując wyznawców protoideologii w przestrzeniach mitów-archetypów i ograniczonych kręgów symboli badacze zauważaja, że czasami bez sprzeciwu przyjmuja oni gotowe konglomeraty alegoryczne, symboliczne (w tym aksjonormatywne) przez prymitywne formy socjalizacji politycznej, a takie zbitki zwane sa bardzo różnie. W naszym czasie funkcjonujący na poziomach protoideologii członkowie społeczności zwykle przyzwyczajaja się do statusów obserwatorów, nie aktywnych uczestników życia politycznego, oczekuja, że ich wybrańcy pomogą im spełnić się w trudnej rzeczywistości, a im jest trudniejsza, tym mocniej chca zawierzyć poszukujac zbawcy, sotera, swojego Mojżesza. Czasami zdają sobie sprawę ze swojej zewnątrzsterowności, czasami, w imię lepszego dla siebie świata, aktywizują się przyjmując role „żołnierzy z kartkami wyborczymi" wierząc w swoją podmiotowość, choć często bywa to wiara kilkudniowa. Zwykle kieruja się opiniami innych, imituja zachowania, zwłaszcza wtedy, kiedy ich położenie jest niepewne i gorliwie poszukuja zbawców. Wiara wyznawców na tych poziomach jest zwykle głębsza, ale, na co wskazuja badacze, czasami ludzie tak głębokiej wiary łatwiej tolerują odstępstwa od deklarowanych zasad uważajac, że sama wiara wystarczy by być innym, lepszym i zdaje się, że dla potwierdzenia takiej supozycji nie trzeba sięgać do Savonaroli czy Torquemady, starczy przyjrzeć się reakcjom rodziny toruńskiego radia albo „obrońcom krzyża”. Nie nazywamy takiej wiary fanatyzmem nie wiedząc jak sprecyzować istotę tej niezwykle pojemnej metafory.

To raczej tylko wiara, głęboka, bezrefleksyjna w wyrazistych soterów, która rodzi całkowite, pełne zawierzenie połączone tak często z gotowością deprawującego poddaństwa. To rodzaj trwałej w społeczeństwach fascynacji totalitarnościa - powiada Schnedelbach - a ona ma coś wspólnego z obietnica uwolnienia nas jednym pociągnięciem od mozołu i trudu pracy ${ }^{43}$. Zgadzając się z taka, choć bardzo metaforyczna, próbą określenia zjawiska zauważamy, że ma jednak wiele wspólnego z takim pragnieniem, jeśli przyjrzymy się totalitaryzmom z komunizmem na czele. Pamiętając o wielkich rezerwuarach nadziei zbiorowych, o częstym chichocie historii, chcemy zacytować zdanie sarkastycznej i prowokacyjnej S. Drakulić: „Jeszcze nie przeżyliśmy komunizmu i nie ma się z czego śmiać"44. Ideologie obiecujące pełnię zbawienia, zwłaszcza materialnego, będą się pojawiać dopóty, dopóki będą istniały horyzonty zbawienia, a wydaje się, że te są tak żywotne, nieodganione

${ }^{43}$ H. Schnedelbach, Próba rehabilitacji animal rationale, Warszawa 2001, s. 160.

${ }^{44}$ S. Drakulić, How we Survived Communism and even Laughed, New York 1992, s. XI. 
jak sam człowiek. Nie ma wielkiego znaczenia to, jak będa nazwane, jesteśmy przekonani, że pozostaną częścią życia i będą generowały zachowania zbiorowe. Dziś łatwo dostrzec, że takie wizje zawłaszczaja ci, którzy sa kojarzeni z „lewicami”, a inni ideologowie chyba jakby oddali $\mathrm{w}$ dzierżawę tzw. lewicom horyzonty zbawienia, przy czym ta umowna lewica zbyt często nie wie, czym one sa, jakie pełnią role.

Wspomnieliśmy, że na poziomach protoideologii powstaja „,ruchy populistyczne" i niektórzy obserwatorzy zdumiewają się tym, że takie ruchy mogły korzenić się w krajach tzw. „starych demokracji”, bo nie były i nie sa od nich wolne Stany Zjednoczone, W. Brytania, Francja. Takie spontaniczne reakcje, będące wybuchami wiary, mogły i będą się korzenić dopóty, dopóki nie zabraknie człowieka archaicznego, mitycznego, magicznego, który będzie poszukiwał możliwości spełnienia się w doczesności przy pomocy pośredników, przewodników. Ich pojawienie się zaś można traktować jako brak wiary człowieka archaicznego w możliwość spełnienia w zastanych warunkach. Starczają mu wyjaśnienia, że przyczyny zła, jego niedoli tkwią właśnie tam, a nie gdzie indziej, że on jest sola społeczności, a aktualnie rządzący sa jego wrogami zamierzającymi odebrać mu jego wolności i dobra. I czasami nie jest zbyt ważne, gdzie mieści owo „tam”, dla niego zawsze znajdzie się jakieś miejsce. O sile albo słabości umownego populizmu przesądza wiele czynników, ale zawsze znaczącymi są ci, którzy organizuja przestrzenie mityczne potencjalnych wyznawców i tu przywołamy J. Haidera w Austrii, choć nazywanie go populistą także jest tylko próbą etykietowania.

Badacze ruchów populistycznych zauważaja, że do gron zwolenników populizmu zwykle należą grupy wykluczonych, ale już rzadziej wspominają o tym, że o wykluczeniu najczęściej przesądzają wykształcenie i kwalifikacje, jakie sytuują ich w określonych przestrzeniach mitycznych, określaja aspiracje spełnienia materialnego i intelektualnego. Przyjmuje się, że słabo wykształceni zwolennicy prostych idei integruja się na swoistej bazie protoideologii i tam pragną artykułować, bronić jak potrafią swoich nieokreślonych interesów, ale nie tylko, gdyż obrona tożsamości także jest dla nich ogromnie ważna, tym ważniejsza, im mniej mają dóbr. Wtedy, kiedy zagrożone sa podstawy egzystencji, gdy lęk budzi niezrozumiały, zbyt szybko zmieniający się świat, wzmaga się potrzeba potwierdzania tożsamości celów wśród jednostek o podobnych statusach, oznaczająca także poszukiwanie siły dzięki przynależności do grupy, postrzegania siebie jako części społeczności, która znajduje się w podobnym stanie i chce dla siebie lepszego życia. Jeśli pojawi się organizator rozumiejacy istotę ich przestrzeni mitycznej, to tworząc nowy koagulat idei będzie mógł porwać za sobą te grupy, które znajdują się $\mathrm{w}$ takiej przestrzeni. 
Takimi zdolnościami organizatorskimi wykazywali się choćby ci „władcy symboli”, którzy tworzyli nowe grona wierzeń w okresie wielkich załamań ekonomicznych i degradacji społecznej milionów. Jeśli przyjrzymy się bliżej tym władcom, możemy znaleźć sporo przesłanek do wniosku, że wielkie rewolucje, od francuskiej po październikowa, zostały dokonane przez wyznawców protoideologii, którym starczały najprostsze hasła obiecujace wyzwolenie i realizację wielkich wizji spełnienia. Idąc dalej możemy zauważać, że protoideologia - wielkim systemem wiary w rychłe zbawienie były i komunizm i faszyzm. Przyglądając się tym postaciom wiary możemy przypomnieć zdanie B. Barbera i uznać, że wiara może być najbardziej szlachetna, a zarazem najbardziej toksyczną siłą wśród tych, którzy sa prawdziwymi wyznawcami.

Hipostazami tak silnej wiary bywali i bywaja przywódcy zwani charyzmatycznymi, pośród których przez wieki poszukiwano soterów i poszukiwania których sa emanacją tęsknot za nieoczekiwanymi zbawcami. Charyzma to raczej nie to, o czym pisał M. Weber uważajacy, że charyzma to niepowszednie cechy jakiejś osobowości, z racji której jest uważana za obdarzona zdolnościami nadprzyrodzonymi ${ }^{45}$. Nie wiemy zreszta jak mają objawiać się te zdolności, czy mamy ich szukać w transcendencji, czy immanencji, szukać aureoli czy tylko aury? Mając wiedzę o próbach kategoryzacji charyzmy chcemy zauważyć, że charyzma oznacza pełne, bezkrytyczne zawierzenie jakiemuś przywódcy transformacyjnemu przez jakąś zbiorowość, która dla potwierdzania swojej wiary w niego obdarza go niepowszednimi cechami, ale nie nadprzyrodzonymi, bo takich nawet nie chcemy sobie wyobrażać. Taka osobowość staje się dla wyznawców hipostazą nadziei, przewodnikiem w lepsze jutro. Dla innych grup społecznych taki „charyzmatyk” może być nawet przedmiotem niewybrednych żartów. Nie zawsze pozostaje charyzmatykiem do końca życia czy działalności politycznej, zawierzenie można utracić przez zwykłe niekonsekwencje, niezgodność słów z czynami. Politykiem zawierzenia był A. Lepper, którego z niechęcia zwiemy charyzmatykiem, a jeśli teraz spróbujemy zliczyć szeregi jego wyznawców?

Kiedy próbujemy poszukiwać tła wielkich i „mniejszych” ideologii, podówczas bez trudu dostrzeżemy liczne zapożyczenia z treści i form religii, dzisiaj zwłaszcza, kiedy z pozoru religijne fundamentalizmy wykazują cechy czysto polityczne ${ }^{46}$. Pojawiaja się tam archetypiczne treści odwiecznej walki dobra ze złem i owo zło zwykle hipostazuje się

${ }_{45}$ M. Weber, Gospodarka $i$ społeczeństwo. Zarys socjologii rozumiejacej, Warszawa 2002 , s. 181.

${ }^{46}$ R. Corm, Religia i polityka wXXI wieku, Warszawa 2007, s. 37. 
wyobrażeniami przeciwników czyniąc z nich dzieci Szatana, sługi Zła czy jeszcze bardziej wyrafinowanie. Każda ideologia, w tym te mutacje fundamentalistyczne (o których jednak też nie bardzo wiadomo czym sa) obiecuje przede wszystkim spełnienie w doczesności i tu inwencja ich twórców często bywa skażona eschatologia religii dominującej. Nie każda potrafi to czynić tak, by zjednać wielkie grupy społeczne. I sądzimy, że takie, jak się wydaje, skazane są na zanik.

Zamiast wielkich, obumierających, czy, jak chca inni, już umarłych ideologii chcemy zaprezentować jakość nazywana czasami (wspomniany J. Baudrillard) ideologia zbawienia, jaka rzekomo wypełnia pustkę ideowa ostatnich dekad i jest potwierdzana coraz to nowymi poziomami. Zasługuje na uwage jako „ideologia” epoki globalizacji, jeśli rację ma G. Soros uważający ją za ideologię wytworzona przez siły globalizacji $^{47}$. Konsumpcjonizm, jaki chcemy w tym miejscu zbliżyć miast choćby komunizmu, konserwatyzmu czy liberalizmu, jest jakimś surogatem nieustannego zbawiania, potwierdzania tego zbawiania, obudowanego zasadami przyjemności, co czyni go uniwersalnym w społecznościach względnego dobrobytu. Dla Baudrillarda jest to ideologia totalnej organizacji codzienności, totalne ujednorodnienie, gdzie wszystko zostaje wyparte przez łatwość, prostotę i przejrzystość abstrakcyjnego szczęścia, określonego wyłącznie przez zniesienie napięć ${ }^{48}$.

Służąc potrzebom producentów i polityków - ta „ideologia” zdaje się być nowa postacią hedonizmu obróconego tylko na rzeczy materialne, choć wiele mówi się i pisze o konsumpcji dóbr duchowych, ale nietrudno zauważyć, że zwykle takich, jakie sa towarem, jaki można sprzedawać za godziwa cenę. Tenże konsumpcjonizm rozumiany jako masowe spożycie nie tylko dóbr materialnych, stał się znamieniem epoki przełomu nowoczesności, czy, jak kto woli, ponowoczesności Ta swoista „ideologia"49 (a może tylko protoideologia) ostatnich dekad wieku XX i już naszego stulecia pełniła i pełni znaczące role społeczne, których nie można nie docenić, ale przeceniać także nie, jeśli zważymy, że taka jej postać stoi jednak w sprzeczności z ideami produkcyjności, pracy, dyscypliny dominującymi w odchodzącej nowoczesności ${ }^{50}$.

Z pewnością konsumpcja na uśrednionych poziomach jest czynnikiem integrującym, stabilizującym, z pewnością znakomicie organizuje porządek ekonomiczny i społeczny, z pewnościa pacyfikuje nastroje sytych, ale i określa aspiracje głodnych, którzy w społecznościach kon-

${ }^{47}$ G. Soros, Nowy okropny świat, Warszawa 2006, s. 117.

48 J. Baudrillard, Społeczeństwo konsumpcyjne, s. 14.

${ }^{49}$ M. Bogunia-Borowska, M. Śleboda, Globalizacja i konsumpcja. Dwa dylematy wspótczesności, Kraków 2003, s. 157.

${ }^{50}$ E. Fromm, Mieć czy być?, Poznań 2003, s. 40. 
sumpcyjnych są mniejszością a także tych, którzy znajdują się poza ich marginesami. Partycypujacy w masowej konsumpcji sa zwykle gotowi oddać wiele za zapewnienie stałego lub względnie stałego poziomu dobrobytu - tej namiastki zbawienia, by konsumować przyjemności i to nie w kształtach stworzonych przez Greków, Rzymian, choć charakter codziennych przyjemności zmienił się niewiele. Z pewnościa konsumpcja jest także punktem odniesienia dla relacji międzyludzkich, współtworzy układy stratyfikacji, neutralizuje lęki społeczne i indywidualne (choć może rodzić też nowe, z lękiem o utratę dotychczasowych statusów na czele, o czym najlepiej wiedzą dłużnicy), wspomaga mechanizmy sprawowania władzy i kontrolę systemową. Społeczeństwo prawdziwie konsumpcyjne zaś to już system przymuszania do konsumpcji, społeczeństwo tresowane i konsekwentnie wdrażane w konsumpcję - uważał ze spora przesadą promujący je J. Baudrillard ${ }^{51}$. Alu tu już musimy zauważyć jedno. Konsumpcję poprzedza konieczność zarobienia na nia, pierwotna i ważniejsza i dziwne jest to, że teoretycy zwykle o tym zapominaja fascynując się przede wszystkim sposobami konsumowania. Tu także pojawia się przesłanie z opowieści o Midasie chyba inspirujące D. Kortena. Przefrymarczenie życia za pieniądze - pisał ten autor - to fatalny interes, ponieważ to życie i tylko ono, nadaje wartość pieniądzom ${ }^{52}$.

Prawie zbawieni obywatele sytego świata chętnie zawierza tym, którzy będą obiecywali jego pełnię jak najmniejszym kosztem. Miał swoje racje B. Pascal, kiedy pisał, że człowiek ceni tylko tych, którzy zaspokoja wszystkie jego potrzeby ${ }^{53}$ i nie był pierwszym z tak mówiacych. Prawie zbawieni, gdyż nieograniczona konsumpcja jest jeszcze marzeniem bogatych, sprowadzanym na ziemię przez rzeczywistość. Oto badania Eurobarometru z 1993 roku przyniosły informacje, że 2 na 3 mieszkańców Europy jest przerażonych biedą w sasiedztwie ${ }^{54}$. To już zdaje się burzyć niby nieograniczoność konsumpcji. Ale nawet ci „nowi biedacy” partycypuja w masowej konsumpcji wielu towarów, wymuszanej przez producentów starajacych się sterować efektywnym popytem przy pomocy dostępnych środków. Rynek telefonii komórkowej zdaje się dobrym tego potwierdzeniem, a to tylko mały segment wielkiej przestrzeni. Zapewne korporacje marza tylko o takim poziomie konsumpcji, jaki pojawił się w głośnej dystopii F. Pohla i C.M. Korblutha The Space Merchants, a w niej istniał jej przymus i każdy obywatel szczęśliwego państwa musiał wykonać swoją konsumencką normę,

${ }_{51}$ J. Baudrillard, Społeczeństwo konsumpcyjne, s. 94.

${ }^{52}$ D. Korten, Świat po kapitalizmie, Łódź 2002, s. 75.

${ }^{53}$ B. Pascal, Myśli, Warszawa 1983, s. 36.

${ }^{54}$ R. Hudson, A.M. Wiliams, Re-shaping Europe, [w:] Rethinking European Welfare State, eds J. Fink, G. Lewis, London 2001, s. 48. 
a jeśli nie, narażał się na poważne konsekwencje. Na razie są to tylko marzenia i producentów i wielu konsumentów, ale zdaje się, że te marzenia będą kultywowane, żywe. Siła codziennego życia - pisał J. Fiske - ta mizeria codzienności, mimo pozorów dobrobytu, sprawia, że będa się w nas rodziły nowe pragnienia spełnienia ${ }^{55}$.

Społeczeństwo konsumpcyjne to już nowa jakość charakteryzujaca się inspirowaniem dążenia do wykorzystywania konsumpcji jako środka do podkreślania własnej odrębności i niepowtarzalności. Ponoć pojawiło się i to już w nowoczesnej postaci w latach 20 . XX wieku w Stanach, ale temu zdaje się przeczyć margines nędzy obejmujący wówczas około $20 \%$ społeczeństwa amerykańskiego ${ }^{56}$. Przyjmuje się jednak, że pojawiło się i takie właśnie społeczeństwo narzuca konieczność ogromnej ilości decyzji o charakterze konsumpcyjnym, a także konieczność nabywania wiedzy o nowych przedmiotach konsumpcji. Konsument dysponujący wiedzą o funkcjonowaniu nowych produktów i technologii ich wytwarzania staje się w oczach innych konsumentów kimś wyjątkowym. Jest człowiekiem wyjątkowym, uzgodnionym z wymogami narzuconymi przez kreatorów stylu życia, opinii, idei ${ }^{57}$. Nie zauważa, że oczywistą konsekwencją konsumpcjonizmu staje się prawdziwe jego urzeczowienie, a nawet upodmiotowienie produktu $\mathrm{w}$ tej relacji człowiek-produkt i to już nie jest zagrożenie, a prawie nobilitacja.

Dla wielu, bo z pewnością nie wszystkich konsumentów naszego czasu, obietnice i nadzieje sprawiaja - jak zauważał Bauman - że zaspokojenie potrzeby pojawia się wcześniej niż sama potrzeba i takie obietnice już będą większe niż te potrzeby ${ }^{58}$. Ale o samym upodmiotowieniu produktu, jak i istocie potrzeb $\mathrm{w}$ naszym czasie $\mathrm{w}$ znaczacym stopniu przesądza wszechobecna reklama poszukująca coraz to nowych form ekspresji w celu zdobycia nowych klientów. Wedle specjalistów ta reklama stwarza nowy typ fikcji roszczącej sobie prawo do bycia prawda, składnikiem świata rzeczywistego. Fikcja reklamowa jest praktyka podróbki, metaetycznym pastiszem fikcyjności i fizykalności - pisze teoretyk nie zaspokajając jednak naszej potrzeby sensu ${ }^{59}$, bo pisząc o reklamie trzeba przede wszystkim mieć na uwadze odbiorcę, nie jej twórcę, czego w rozważaniach o reklamie zwyczajnie brakuje. Ona nie jest już znaczącym źródłem informacji, twierdzi się także, że bez skru-

\footnotetext{
${ }_{55}$ J. Fiske, Understanding Popular Culture, Washington 2007, s. 33.

${ }^{56}$ D. Horowits, The Morality of Spending. Attitudes toward the Consumer Society, Chicago 1992, s. 134.

${ }^{57}$ A. I H. Toffler, Rewolucyjne bogactwo, Przeźmierowo 2007, s. 15.

${ }^{58}$ Z. Bauman, Praca, konsumpcjonizm i nowi ubodzy, Kraków 2006, s. 57.

${ }^{59}$ E. Szczęsna, Poetyka reklamy, Warszawa 2001, s. 129.
} 
pułów wykorzystuje wyrafinowane techniki manipulacji ${ }^{60}$. A jeśli przyjrzymy się jej bliżej, to odkryjemy, że jej siła jest obietnica spełnienia.

Zaspokojenie - dodawał G. Ritzer - jest zaspokojeniem nadziei, nie potrzeb, a to wręcz musi owocować tym, że lepiej nam z falsyfikatem niż oryginałem ${ }^{61}$, choć zapewne wielu uważa, że spełniając się $\mathrm{z}$ falsyfikatem nigdy nie poczuja pełni spełnienia i pozostaje w nich niedosyt wymuszający poszukiwanie nowych przedmiotów konsumpcji. Konsekwencje kulturowe takiej zmiany relacji to nowy hedonizm z akcentowaniem swoistej „kultury przyjemności”, nowymi formami spędzania wolnego czasu i nowymi sposobami podkreślania statusu ,jednostek konsumenckich" przez nabywanie produktów przeznaczanych dla nowych elit. To także wykształca nawyki spojrzenia na światy idei i zwolennik „kultury przyjemności” z pewnością wybierze takie, które nie zakłóca jego spokoju. Obojętnie będzie patrzył na olimpiadę w Pekinie chcąc przeżywać tylko „wrażenia sportowe”, będzie domagał się od polityków, by zakończyli konflikt Rosji z Gruzja, ale tylko tak, by reperkusje tego konfliktu nie dotknęły właśnie jego. Podpisze się pod deklaracjami majacymi eliminować konflikty, a to nie kosztuje go wiele.

Kultury przyjemności, choć nie zawsze jest to przyjemność oznaczajacca spełnienie na poziomach określanych płacami realnymi, stały się dotykalna rzeczywistościa, to one określają rezerwuary dóbr możliwych do osiagnięcia. Te zaś, choć nie musi to być jeszcze jedna z intelektualnych prowokacji, zdają się kończyć, jeśli wg. pesymistycznego L. Thurowa od 1973 do 1994 roku PKB Stanów zwiększył się o 33\%, a płace realne spadły o $14 \%{ }^{62}$. Wedle wybitnego ekonomisty tak rodza się wielkie grupy „nowych biedaków” nie zdających sobie sprawy z poziomu upadku. Z pozoru mają dobra konsumpcyjne, ale nie tworzą nic własnego, na nic nie mają wpływu, nawet na względną samodzielność w określeniu tych przyjemności ${ }^{63}$. Nie wydaje się, by ci kiedykolwiek poznali uczucie przesytu, rzekomo powszechne w społecznościach bogatego Zachodu, choć jeszcze wierzą w pozorny egalitaryzm konsumpcji. A jednak są zadowoleni, manifestują swoje szczęście z posiadania, tym głośniej, im większe jest poczucie niedosytu. Stali się wyznawcami tej nowej ideologii, „bogatymi biedakami” i to im wystarcza w aurze strachu dostrzegalnej za tymi zasłonami przyjemności. Straszeni wieloma zagrożeniami oddają wiele, by utrzymać jakiś status quo. Przesyt znaja chyba tylko waskie elity konsumpcji izolujące się od zwykłego świata

\footnotetext{
${ }^{60}$ M.G. Donhof, Ucywilizowany kapitalizm. Granice wolności, Warszwa 2000, s. 55.

${ }^{61}$ G. Ritzer, Magiczny świat konsumpcji, Warszawa 2004, s. 295.

${ }^{62}$ L. Thurow, Przyszłość kapitalizmu. Jak dzisiejsze sity ekonomiczne ksztattuja świat jutra, Wrocław 1999, s. 41.

${ }^{63}$ R. Jungk, Człowiek tysiaclecia, s. 170.
} 
i za konsumowanie dobra, takiego jak izolacja gotowe sa płacić wiele, tak wiele, że reszty nie stać na to dobro statusowe ${ }^{64}$.

Konsekwencje polityczne konsumpcjonizmu są widoczne na każdym kroku w ponowoczesnym spektaklu polityki, kiedy stajemy się uczestnikami i konsumentami przekonywanymi usilnie przez media do naszej podmiotowości, już chyba bezpowrotnie utraconej ${ }^{65}$. Także kultura stała się „spółdzielnią spożywców”, co zauważał Z. Bauman ${ }^{66}$, a w spółdzielczym sklepie spotykamy coraz to nowe wzory postaw i zachowań politycznych, zgodnych z aktualnie obowiąujacymi kanonami politycznej poprawności, tym politycznym Wersalem, jaki nie budzi oporów tzw. „opinii publicznej”. Jako konsumenci zauważamy, że w dużym stopniu sprawdza się tu socjologiczna zasada dowodu społecznego i o tym, co jest poprawne lub nie decydujemy się przez odwołanie do tego, co na ten temat myślą inni ${ }^{67}$. Inni zaś w większości myślą jednak tak, jak chca tego organizatorzy wyobrażeń zbiorowych konsumując setki surogatów dóbr i idei.

Dziś lepiej możemy weryfikować konceptualizacje kontrowersyjnego J. Baudrillarda sugerującego nam, że na konsumpcyjnym etapie ponowoczesności nastapiła stała zamiana miejsc między przedmiotem a podmiotem. Wedle niego przedmioty uzyskały podmiotowość manipulując ludźmi za ich przyzwoleniem, a ci stali się zakładnikami nie zauważając tego, że pojęcie naturalnych ludzkich potrzeb stało się fałszywe do tego stopnia, że stan zaspokojenia, pełni, jest wręcz niewyobrażalny, co ma niezwykłe konsekwencje dla nie tylko rządzących. Taki stan jest niewyobrażalny w jego simulacrum - świecie odrealnionym albo hiperrealnym, zdominowanym przez wielorakie symulacje. Jest to świat niepojęty, w którym zamiast rzeczywistości podstawiono jej umowne znaki, sobowtóry, homeostatyczne maszyny znakotwórcze. Taka zamiana objęła wszystkie aspekty rzeczywistości z polityka włącznie, coraz bardziej niepojęta, daleka od zwykłego człowieka, zdominowana przez wąskie elity „zawodowych polityków”. Społeczeństwa zatracają wiekowy charakter i zachowania, burzy się stare światy wyobrażeń zbiorowych podstawiając $\mathrm{w}$ to miejsce namiastki wraz $\mathrm{z}$ namiastką zbawienia w doczesności. Poza nimi ustala się reguły spektaklu, w którym towarom podporządkowuje się całość życia społecznego ${ }^{68}$.

Pośrednio animatorzy konsumpcji zdają się nieustannie mówić, że prawdziwa pełnia spełnienia może mieć miejsce tylko tu i teraz i obja-

${ }^{64}$ Z. Bauman, Globalizacja, Warszawa 2000, s. 29.

${ }^{65}$ M. Edelman, Constructing the Political Spectacle, Chicago 1988, s. 122.

${ }^{66}$ Z. Bauman, Ponowoczesność jako źródto cierpień, Wrocław 2000, s. 29.

${ }^{67}$ R.B. Cialdini, Wywieranie wpływu na ludzi. Teoria i praktyka, Gdańsk 2003, s. 111.

${ }^{68}$ G. Debord, Spoteczeństwo spektaklu, Warszawa 2006, s. 48. 
wiać się w zdobywaniu nowych dóbr i tylko ona jest prawdziwa, cała reszta zaś jest wtórna, nieważna. To część strategii, stymulacja pragnień, które mają czynić nas wiecznie niespełnionymi, choć już sugerowaliśmy, że niespełnienie to stan niejako naturalny ${ }^{69}$. To już część swoistej „ideologii” globalizacji współtworzonej przez korporacje. Ci animatorzy tej jakości umiejętnie rytualizuja mit spełnienia przez konsumpcję nadając jej niemal religijny charakter - zauważał Ritzer dodając także, że od kiedy świątynie konsumpcji nabrały charakteru religijnego, doszło do swoistego sprzężenia zwrotnego i kościoły zaczęły je naśladować, choć nie do końca godzimy się z tym mając na uwadze wielkie religie ${ }^{70}$. Ale tak prezentują się amerykańskie, nastawiające się na teleewangelizację i konsumpcje „dóbr duchowych" w imię zbawienia poza ziemia ${ }^{71}$. Takie spotkanie $\mathrm{z}$ systemami wiary $\mathrm{w}$ nieograniczona konsumpcję może być inspirujące, zwłaszcza dla polityki. Inni teoretycy mówia, że czy w tych świątyniach, czy poza nimi nasze potrzeby i tak będą rosły, sugerując w domyśle, że zostaną w nas implantowane, wmówione, a my poddamy się presji natrętnej, kłamliwej reklamy. Zakładaja, że spełnienie to zanurzenie w dobrach czysto materialnych. Zdaja się jednak zapominać o tym, że ilość dóbr zaspokajających potrzeby człowieka znajduje się wewnątrz niego, choć pamiętają o tym, że każdy jest szczęśliwy na swój sposób ${ }^{72}$ i stąd taka pozorna różnorodność ofert. Na razie zdają się zaspokajać wiarę człowieka w to, że żyje w najlepszym ze światów. Starsi mieszkańcy bogatych krajów raczej chętnie $\mathrm{w}$ to wierza, ale młode generacje zdają się poszukiwać czegoś więcej.

Spełnienie, jak próbowali dowodzić choćby stoicy czy cynicy, jest naszą wewnętrzną sprawą i możemy skutecznie opierać się przymusom konsumpcji w jej wielu formach poszukując tego spełnienia nawet $\mathrm{w}$ odmowie konsumpcji, a tak w ostatnich latach prezentuja się amerykańscy i europejscy „śmieciarze” - młodzi ludzie chcaccy dowodzić, że potrafią przeżyć z tego, co znajdą w śmietnikach albo modni od pewnego czasu, wyśmiewani w mediach, podobnie jak „,śmieciarze”, „minimaliści”. Tu ekstrawagancja jest sposobem na poszukiwanie, może nie szczęścia, ale satysfakcji z odrzucenia ideologii „tłumu”, z bycia innym choć przez jakiś czas. $Z$ pozoru nie czynią tego w imię idei, ale takie postępowanie zdaje się świadczyć, że młodzi ludzie mają swoja „ideologię” przypominającą te, jakich twórcami byli altruiści choćby wieków średnich, Ariald, Landulf, Bernard z Thiron. Sa bliscy uniwersalizmowi,

\footnotetext{
${ }^{69}$ A. Aldridge, Konsumpcja, s. 96.

${ }^{70}$ G. Ritzer, Magiczny świat konsumpcji, Warszawa 2004, s. 24.

${ }^{71}$ H. Johnson, Sleepwalking Through History. America in the Reagan Years, New York 2003, s. 201.

${ }^{72}$ M. Frank, Świadomość siebie i poznanie siebie, Warszawa 2002, s. 13.
} 
holistyczni, symetryczni wobec innych, egalitarni. Oni sami, poszukujacy własnych dróg, nie chca przyznawać się do żadnej ideologii uważając, że to, co czynią jest po prostu ludzkie, ale także w tym są bardzo ideologiczni i idealistyczni zarazem.

Zaspokojenie nie płynie już z wartości użytkowej obficie produkowanych towarów, obecnie poszukuje się go w wartości towarów jako towarów ${ }^{73} \mathrm{i}$ konsumpcja znaków towarowych znowu służy prestiżowi, jak w latach 60., kiedy zwykła, wcale nie rozpasana, konsumpcja była znakiem „klasy próżniaczej” T. Veblena. Pseudopotrzebom narzucanym przez współczesną konsumpcję nie można przeciwstawić jakichś potrzeb autentycznych albo naturalnych pragnien, które nie zostałyby ukształtowane przez społeczeństwo i jego historię. Pseudoideologia konsumpcjonizmu sprawia, że takie pseudopotrzeby sa zaspokajane substytutami towarów. Swego czasu w Stanach 57\% respondentów było głęboko zmartwionych jakościa produktów. Wedle niektórych narastało to do rozmiarów plagi i pojawiały się jeremiady w rodzaju: „Ameryka jest dotknięta plagami rzeczy, które nie są przydatne, które nie działaja”. Dziś zaś oderwanie marki od produkcji, sytuowanie tejże w krajach z najtańszą siłą roboczą także owocuje coraz gorszymi parametrami jakościowymi nawet najlepszych firm, którym i tak to nie przeszkadza, gdy jesteśmy gotowi płacić za logo, za fetysz.

Powiada się, co prawda, że świat pozbawiony wszelkich fetyszy, podporządkowany myśleniu w kategoriach użyteczności, nie jest prawdziwy $^{74}$. Ale trudno zrozumieć takie opinie, bo przecież „od zawsze” żyliśmy wśród fetyszy, a właśnie dziś ich ilość może porażać. A jednym z takich, przypisanych naszej rzeczywistości, sa choćby znaki McDonalda i formy idolatrii, jakie zauważaliśmy wtedy, kiedy w Polsce powstawały pierwsze bary tej sieci. To jest i irytujące i niepojęte, ale ulegamy makdonaldyzacji w każdej dziedzinie życia, z polityką włącznie, jej macdecyzjami, macideologiami.

Jako konsumenci podejmujemy wybory, zmuszani do tego rozmaitością ofert, ale paradoksalnie - zauważał Aldridge - sam akt wyboru przyczynia się do zniewolenia ${ }^{75}$, owocuje ogromną ilością symptomów schizochronii, bo ilość wyborów rośnie z dnia na dzień, pogłębia pragnienie oparcia się na czymś trwałym, a dookoła siebie mamy ogrom iluzji spełnienia i wciąż pojawiają się nowe. Ciagła konsumpcja „życia nieprzeżytego", o wiele bardziej intensywna niż w nowoczesności, tworzy nowy rodzaj identyfikacji. Kulturowe technologie ponowoczesności, czyli telewizja i gazety skłaniają nas do identyfikacji ze sztucznymi

${ }^{73}$ G. Debord, Społeczeństwo spektaklu, s. 60.

${ }^{74}$ A. Finkielkraut, Zagubione człowieczeństwo, Warszawa 1993, s. 109.

${ }^{75}$ A. Aldridge, Konsumpcja, s. 107. 
wizerunkami nowych herosów, czasami z pełnym powodzeniem ${ }^{76}$. Ich wpływ został doceniony. One stworzyły nowe katalogi sztucznych potrzeb, wzory spełnienia i są to najczęściej wzory pożądane przez korporacje. Ale mimo konsumenckiego zauroczenia milionów jest nadzieja na jakościową zmianę, jeśli zważymy, że socjologowie potwierdzaja wzrost akceptacji „starych” wartości, aspiracji, nadziei i traktuja je jak przesłanki do takich wniosków ${ }^{77}$.

Mitu pełni życia sytym konsumentom dostarcza kultura masowa, która do codziennej przeciętności dodaje czegoś w rodzaju eliksiru wartości, kompensacji sensu życia przez identyfikację z cierpiącymi, kochającymi naprawdę bohaterami filmów, seriali ${ }^{78}$. Pogłębiająca się alienacja sprawia, że coraz więcej mieszkańców Zachodu przejawia głód fantazji i te oferuje im film i TV ${ }^{79}$ jako dostawcy tanich wzruszeń. W erze konsumpcjonizmu konsumuje się przecież także dobra kultury masowej i wymusza się taką konsumpcję przy pomocy nie reklamy, ale zwykłych oszustw nazywanych eufemistycznie ,chwytami reklamowymi”. Każda książka, każdy film, co widać na okładkach, sa wyjątkowe, oryginalne, jedyne i nie tyle poznanie, co obcowanie z nimi jest obowiązkiem. Na promocję przeznacza się wręcz astronomiczne sumy i tak, na reklamę jednej z książek o Harrym Potterze przeznaczono podobno 20 milionów dolarów z pewnościa, że te nakłady się zwróca. $\mathrm{W}$ zrelatywizowanych klimatach postmodernizmu takie oszustwa wcale nie uchodzą za naganne, ale nie sposób nie zauważyć spontanicznych odruchów protestu przeciw życiu w takich warunkach, chęć ucieczki $\mathrm{w}$ fantasy, wirtualne światy, a niektórym, zwłaszcza młodym, takie zdają się bardziej rzeczywiste niż ten, w którym żyjemy.

Eskapizm jest zauważalny zwłaszcza wśród wstępujących generacji, ale nie tylko, gdyż w naszym czasie jednostki nie wiedza, z jakim światem mają się uzgadniać niewiele wiedząc o jego aktualnych kształtach. Nie pomagają im media proponujące masową konsumpcję informacji i takie nie sa dla W. Lippmana lustrem świata, one tylko dostarczają przesłanek do wniosków - epizodów, incydentów, wybuchów ${ }^{80}$. Wydaje się, że i one uległy siłom konsumpcji i ich kreatywne moce zastapił chaos rodzacy chaos, bo przesłanek mamy setki, ale nie wiemy, jak moga posłużyć przy budowie wniosków. Do czasu, w którym pojawiła się telewizja, były posłuszne swoim panom, zmieniały style życia,

\footnotetext{
${ }^{76}$ L. Manovich, Język nowych mediów, Warszawa 2006, s. 135.

${ }^{77}$ M.C. Elsmar, The Impact of International Television. A Paradigm Shift, London 2003, s. 35.

${ }^{78}$ J. Bańka, Przeciw szokowi przyszłości, Katowice 1977, s. 99.

${ }^{79}$ M.F. Rogers, Barbie jako ikona kultury, Warszawa 2003, s. 40.

${ }^{80}$ D.A. Graber, Mass Media and American Politics, Washington 2006, s. 287.
} 
profilowały systemy polityczne, funkcjonalne wobec nich. Dziś władcy informacji przestali nad nimi panować podporządkowani wskaźnikom czytelnictwa, oglądalności (a te oznaczają konkretne pieniądze) i pojawiły się pytania o to, jak uporządkować ten chaos po stronie popytu. Tego chyba nie powinni robić politycy, jak radzi amerykański polito$\log ^{81}$ i ma swoje racje, jeśli zważymy jakość „klas politycznych”.

Nie tylko polskie realia dostarczają nam przesłanek, że byłoby to potęgowanie chaosu. Nie tylko nie powinni, ale chyba nie mogliby jednak z wielu względów. Korporacje medialne są od niech niezależne, nadto powiązane mocnymi łańcuchami korporacyjnymi. Według jednego ze specjalistów aż 80\% mediów w roku 1997 było zależnych od kapitału finansowo-przemysłowego ${ }^{82}$. Ich moce sprawcze w tworzeniu nowych przekonań, twierdzeń, jakie stają się częściami systemów wiary, staja się coraz większe i niezależne od świata polityki. To one uczyniły konsumpcjonizm ideologią milionów i zdaje się, że od czasu pojawienia się telewizji skutecznie rywalizuja z dawnymi, oddolnymi i jednak spontanicznymi formami tworzenia ideologii przez dążących do realizacji wartości. Taka spontaniczność zdaje się wątpliwa, jeśli zważymy, że tworzyli je intelektualiści, ale oni cały czas konfrontowali swoje pomysły z odbiorcami, dziś zaś odbiorcy odbijają się od szklanego ekranu.

${ }^{81}$ D.A. Graber, Media Power in Politics, Washington 2007, s. 229.

${ }^{82}$ J.B. Atkins, Journalism as a Mission, [w:] The Mission. Journalism, Ethics and the World, ed. J.B. Atkins, Iowa State University 2002, s. 10. 


\section{5}

\section{DemokraCja}

Co miał na myśli prezydent F.D. Roosevelt powiadajac: „Dajcie mi demokracji, jeszcze demokracji i jeszcze więcej demokracji”" ${ }^{1}$ Niby odpowiedź na takie pytanie powinna być prosta, ale chyba nie do końca. Naszym zdaniem prezydent nie myślał o jej formach, uznawanych już wtedy przez Amerykanów za najdoskonalsze na świecie, ale o treściach, zbawczych treściach demokracji, w Ameryce wszechobecnych, bo bodaj w żadnej demokracji nie mówi się tyle o wolności, równości, sprawiedliwości i dążeniu do sprowadzania ich na ziemię z wielką wiarą w taką możliwość. Prezydent mówił to przecież w czasie, w którym Wielki Kryzys był także kryzysem nie samych form, bo te nie zmieniły się radykalnie, ale także treści. One jakby pozostaja poza granicami refleksji, zwłaszcza politologów, a przecież wiemy, zgadzamy się z Arystotelesem, że hyle nie może istnieć bez morfe i ta współzależność powinna nas inspirować przy poszukiwaniu i optymalnych form i moderujących je, inspirujących treści demokracji, które determinują jej kształty, wymuszaja zmiany.

Jeśli zastanowimy się nad jej sprawczymi mocami, wiarą w niąjako skuteczne remedium na wiele bolączek, to powinniśmy dostrzec, że to nie formy nas do niej przekonuja, a właśnie treści, bo formy (poczynając od wolnego wyboru), zwłaszcza w naszym czasie, raczej zniechęcaja do niej i będą zniechęcały jeszcze bardziej i w takich warunkach o jej żywotności przesądzają dynamiczne treści implantowane w życie. Wiele o tym świadczy, bo jeśli znani politycy, jak choćby senator Moynihan, powiadają o amerykańskim systemie politycznym, że w Stanach mamy do czynienia z normalnieniem dewiacji, to już znaczy wiele $e^{2}$. Te pierwsze bywają czasami kalekie, niekiedy karykaturalne, a jednak

\footnotetext{
${ }^{1}$ H.W. Mc Coil, The History of Liberty, New York 1965, s. 48.

${ }^{2}$ G. Himmelfarb, Jeden naród, dwie kultury, Warszawa 2007, s. 43.
} 
nie odwracamy się od niej niekiedy wcale nie dlatego, że niczego lepszego jeszcze nie wymyślono, jak powiadał Churchill, chyba nie będący najlepszego zdania o ludzkim myśleniu. Przekonują nas do niej treści. Nie chcąc mówić o nich obudowano formy setkami mityzacji mającymi charakter prawdziwych świątyń i codziennie uświęcaja je media ${ }^{3}$.

A wymyślono „system polityczny posiadajacy konstytucyjne gwarancje możliwości regularnej zmiany osób u władzy oraz mechanizm społeczny zapewniający możliwie największej części ludności wpływ na podstawowe decyzje za pomocą wyboru spośród osób ubiegających się o stanowiska polityczne" 4 . Teoretyk, jak łatwo zauważyć, mówił tylko o formach, podobnie jak inny, wyliczający warunki demokracji, a są nimi: rzeczywiste uczestnictwo, równe prawo głosu, oświecone rozumienie, nadzór nad podejmowanymi zadaniami ${ }^{5}$. Jedynie owo enigmatyczne „oświecone rozumienie” zdaje się nieco, ale tylko nieco korespondować z treściami, choć nie wiemy, co naprawdę może znaczyć, zwłaszcza dla „mniej oświeconych”. Nadto, teoretyk nie zauważał tego, że każdy nadzór obywateli nad zadaniami był i jest czystą iluzja. Bez kompetentnych, sprawnych pośredników między rządzącymi a rządzonymi taki nadzór grupy społecznej jest praktycznie niemożliwy, a nie uznajemy za formę nadzoru różnego rodzaju nacisków, choćby strajkowych, te sa tylko próbami wymuszania korekt politycznych i, tym samym, korzystnych dla jakiejś grupy decyzji politycznych. Inny zaś przyznawał, że zdefiniowanie demokracji jest niemożliwe, gdyż jest ona zbyt dynamiczna, nabiera różnych znaczeń w czasie ${ }^{6}$. Takie postawienie sprawy nawet zdaje się wygodne dla tych, którzy chcą unikać dysput o jej treściach i formach, a tym samym nie chca moderować jej kształtów. Nie sposób godzić się z takimi stanowiskami, jeśli przyjmiemy za R. Kaganem, że demokracja jest jednym z najrzadszych, najbardziej delikatnych kwiatów w dżungli ludzkiego doświadczenia ${ }^{7}$. Trzeba uczyć się pielęgnować ja, ale jak, skoro nie wiemy jak wygląda ów kwiat?

Po takiej konstatacji i lekturze wywodów teoretyka form demokracji można zrozumieć, dlaczego ów wyżej wspomniany teoretyk uznał ją za niedefiniowalna. Powód był raczej prosty. Wyznawczy autor zamierzył stworzyć panegiryk na cześć jej form nie dostrzegając w ogóle treści, a nie wspominamy o tym, że przyjmując niemożność jej zdefiniowania

\footnotetext{
${ }^{3}$ W.L. Bennet, The Politics of Illusion, Washington 1996, s. 193.

${ }^{4}$ S.M. Lipset, Homo politicus. Społeczne podstawy polityki, Warszawa 1998, s. 48.

${ }^{5}$ R. Dahl, O demokracji, Kraków 2000, s. 39.

${ }^{6}$ G. Sorensen, Democracy and Democratization, Oxford 1993, s. 23.

${ }^{7}$ Cyt. Za: D.R. Hiley, Doubt and Demands of Democratic Citizenship, Cambridge 2006, s. 5 .
} 
nie powinien zajmować się nią w ogóle, choć wiemy, że takie „zdefiniowanie" nie jest możliwe. Ono pojawia się najczęściej wtedy, kiedy chcemy konfirmować potrzebę pewności. Ale gdyby je nawet zauważył, podówczas musiałby chyba przyznać, że jej dynamika to tylko sztafaż, tylko pozory mające przekonywać innych wyznawców do powtarzania demokratycznego credo. Demokracja rzekomo jest najlepszym w dziejach rozjemca między jednostką a społeczeństwem, z którym pozostaje w odwiecznym konflikcie, ale takie sugestie zdają się prostymi nadużyciami, bo wydaje się, że inne formy władzy skuteczniej zapobiegaja takim konfliktom, a demokracja, umożliwiająca artykułowanie tysięcy interesów jednostkowych i grupowych, jest jednak z natury bardziej konfliktogenna, choć konflikty mają z pewnościa łagodniejszy charakter, w jakiejś mierze dzięki temu, że społeczeństwa demokratyczne sa spełnione materialnie i swoje umiarkowane niezadowolenie wyrażaja w formach łagodnych, jak choćby Niemcy po reformach kanclerza G. Schroedera i A. Merkel. Ale brak zaufania do demokratycznego państwa nie dbającego o reformy socjalne, a tym samym o realizację wartości takich jak równość i sprawiedliwość może przynieść więcej epizodów podobnych do pamiętnych starć młodzieży niemieckiej z policja w Helligendamm. Jeżeli przyglądamy się rozwojowi form demokracji, to chciałoby się kusić o wniosek, iż formy takie, z jakimi spotykamy się dziś są możliwe w realizacji w społeczeństwach bogatych.

Podobne takiej, jak Lipseta, definicje klasyków politologii prezentuja się czasami jak prawdziwe „pocałunki śmierci”, ale sa zwykle tak suche, że nie mówią nam właściwie nic o istocie demokracji, o ideach, które sa pierwotne wobec form i rodzą te formy. Definicje wyznawcze brzmia jak święte przykazania nakazujące bezkrytyczną wiarę w dogmaty, które nimi nie sa, bo trudno tak traktować formy będące tylko mglistą emanacją dogmatów i takie pojmowanie form wygląda jak idolatria, a rytualizatorzy stosuja praktyki podobne do tych, jakimi książęta Kościoła traktowali herezjarchów. Mamy z nimi do czynienia niemal na co dzień i czasami można myśleć jak P. Philips, powiadajacy, że czasami propaganda działa o wiele skuteczniej na jej twórców niż odbiorców ${ }^{8}$. Ale nietrudno zauważyć, że elastyczne i praktyczne zarazem formy okazywały się niezwykle funkcjonalne w nowoczesności i to przesądzało o trwałości i popularności demokracji jako symbolu ustroju bliskiego pełni.

Nie sposób także nie dostrzegać tego, co noblista, zauważający że mimo wszystko demokracja zapewnia tę elastyczność polityki ekonomicznej i adekwatność działań publicznych w sytuacji kryzysów spo-

${ }^{8}$ P. Philips, Media Democracy in Action, Censored 2004, New York 2003, s. 297. 
łecznych ${ }^{9}$. Wedle niego państwa demokratyczne nie znaja głodu, krańcowego ubóstwa i zawdzięczaja to właśnie tej zbawczej sile, ale zdaje się, że poszedł zbyt daleko w uogólnieniach. Nie bardzo godzi się to z praktyka młodych, statusowych przecież, europejskich demokracji XIX wieku, pełnych wstydliwej nędzy, ale też nie da się ukryć, że treści demokracji niejako wymuszały stała poprawę bytu obywateli i to w dwojaki sposób. Z jednej strony były to działania misyjnych polityków, a z drugiej wymuszenia kultywujacych te treści obywateli, rewolucjonizujacych się, buntujących, strajkujących, powodowanych wiara w wolność, równość, sprawiedliwość. Formy demokracji generowane przez ukryte treści moga wymuszać to, do czego nie byli zdolni kapitaliści, którzy zapewniali sobie dzięki nim spokój. Ona sama zaś, jej instytucje, są zawieszane między siłą służąca efektywnemu działaniu, a słabością biorącą się z konieczności przestrzegania politycznych i ekonomicznych wolności - twierdził zasadnie teoretyk dostrzegający generująca siłę treści ${ }^{10}$.

Podobny mit rytualizuje inny badacz, powiadajacy że szerzenie się demokracji i kapitalizmu redukuje problemy globalne ${ }^{11}$. Taki sąd jest częściowo potwierdzony praktyka „,starych demokracji”, ale sugestie, że formy moga stawać się siłami sprawczymi zmian na lepsze w krajach zacofanych, rolniczych, sa już zwykła przesada, a z taką możemy zetknąć się u natchnionych krzewicieli takich form w Afganistanie, Iraku. "Demokracja tu? - dziwił się analityk - ci ludzie tego nie rozumieja" ${ }^{2}$. Politycy amerykańscy także zdają się tego nie rozumieć, mimo, że teoretycy wielokrotnie zauważali, że żaden typ rządu nie jest odpowiedni do wszystkich warunków ${ }^{13}$. Powinni zrozumieć to ci misjonarze, którzy przecież od lat zauważają bliski mariaż demokracji z kapitalizmem, a choćby „demokratyzowany” Irak kapitalizmu nie doświadczał. Z pewnościa Irakijczycy mają swoje poczucie wartości archetypicznych, ale od wieków ich wolność, równość i sprawiedliwość odnajdywały się w innych formach i narzucenie im nowej formy wiary w te wartości wraz z demokratycznymi obyczajami, zwyczajami, rzeczywiście jest krucjata i to skazaną z góry na niepowodzenie i nie wykluczamy przypuszczenia, iż animatorzy krucjaty wiedzieli o tym dobrze i być może zakładali, że to „krzewienie” demokracji potrwa o wiele dłużej niż deklarowano, a wiara w deklaracje amerykańskich polityków jest tylko wiarą.

\footnotetext{
${ }^{9}$ A. Sen, Rozwój i wolność, Poznań 2002, s. 58.

${ }^{10}$ M. Mandelbaum, The Case of Goliath, New York 2005, s. 79.

11 J. Norberg, Spór o globalizację. Kto zyskuje, a kto traci, ile i dlaczego, Warszawa 2006, s. 64.

12 J. Ashcroft, Making a Killing, London 2006, s. 88.

${ }^{13}$ C.G. Ryn, Democracy and the Ethical Life, London 1979, s. 16.
} 
Z pewnością demokracja pełna treści zapewnia homeostazę, ułatwia kompromisy między porządkiem, jaki jest niezbędny do funkcjonowania społeczeństwa ludzkiego, a zachowaniem takiej swobody działania jednostki, która stanowi jedno z jej ludzkich praw, warowanych kodeksami w „państwie prawa”, ale takie państwo to jeszcze jeden z mitów, tak brutalnie potraktowany przez Sartoriego. Z pewnością solą demokracji formalnej jest kompromis, będący w dużej mierze jakby esencją treści, bo istota kompromisu wynika z wartości takich, jak równość i sprawiedliwość ${ }^{14}$. Ale nader często te kompromisy antagonistycznych zasad - zauważał teoretyk - prowadzą do tego, że zasady znoszą się, przestają być zasadami ${ }^{15}$. Choćby w przypadku Polski kompromis rzadzących z jedna grupą społeczną oznacza pogorszenie statusów innych i tu przykłady możemy mnożyć. Można pokusić się o sugestię, że takie kompromisy, majace często charakter „zgniłych”, oznaczają nie tylko erozję wartości, ale także wiary w zbawienie przez demokrację w niektórych grupach społecznych, zwłaszcza wśród wykluczonych.

Budowana na wartościach oświeceniowych demokracja zakładała także pryncypializm etyczny podbudowywany zaufaniem i tolerancja. Taki pryncypializm miał oznaczać tożsamość słowa i czynu, wiarę w słowa demokratycznych polityków, deklarujacych zreszta takie postawy na co dzień i na co dzień je łamiących. Powiada się, że wiara w słowa jest jak puls demokracji, a szczególnie na to uczuleni sa Amerykanie powtarzający z emfaza, że wszystko, co razi amerykańska wiarygodność, razi Amerykę ${ }^{16}$. Sarkastyczne komentarze do takich manifestacji wiary zdaja się zbyteczne. Demokratyczni politycy, zwłaszcza w naszym czasie, zdają się pogrążać w klasycznym sytuacjonizmie etycznym i trzeba naprawdę głębokiej wiary, by poważnie traktować ich deklaracje, ale wiemy także, że są one traktowane poważnie przez miliony wyznawców. Czy tego chcemy, czy nie, taki sytuacjonizm oznacza także kryzys form demokracji, a ponieważ jest to stały, wznoszacy się trend, możemy go ekstrapolować sugerując, że będzie się pogłębiał i jej zbawcze role poczną zanikać albo zaniknie wiara w nie i wtedy, nie bacząc na powiedzenie Churchilla, trzeba będzie wymyślać coś nowego. $\mathrm{W}$ takiej sytuacji winniśmy chyba przestawać poddawać w wątpliwość konieczności stworzenia normatywnego modelu ustrojowego w celu stworzenia tzw. lepszej demokracji, co sugeruje inny teoretyk ${ }^{17}$.

\footnotetext{
${ }^{14}$ J. Habermas, Democratic Theory, [w:] Democracy and Difference, ed. S. Benhabib, Princeton 1996, s. 26.

${ }^{15}$ R.A. Dahl, A Preface to Democratic Theory, Chicago 1956, s. 4.

${ }^{16}$ K. Hall. K.K. Jamieson, P. Campbell, The Interplay of Influence, Belmont 2001, s. 153.

${ }^{17}$ M. Maese, System demokratyczny i mediatyzacja polityki, [w:] Media masowe w systemach demokratycznych, red. B. Dobek-Ostrowska, Wrocław 2003, s. 47.
} 
Jeśli przyjrzymy się pracom wielu znanych teoretyków poszukujących korzeni demokracji w dziejach człowieka, bez trudu zauważymy niezwykła, generująca moc wielkich archetypów mitycznych z mitami wolności, równości i sprawiedliwości na czele, bo to one stanowia podstawy demokratycznego porządku ${ }^{18}$. One właśnie sa tymi treściami obudowywanymi dziesiątkami mityzacji i dynamicznych form, choć wciąż nie mogą znaleźć odpowiedniego miejsca w refleksji politologicznej. Poszukiwanie ich ziemskich hipostaz $\mathrm{w}$ nadziei na znalezienie ideału spełnienia od wieków było motorem rozwoju docenianym tylko przez niewielu, którzy dostrzegali generujące role czynników „historii nieświadomej”, od K. Poppera poczynając. Te poszukiwania w ideach i praktyce codziennej są dla filozofa zarazem poszukiwaniami „życia świętego", wypełnionego moca, innego od codziennej szarości, życia pełnego spełniajacych się wartości ${ }^{19}$.

Te mity przyciagaja, obezwładniają człowieka chcącego spełnić się w zbiorowości, w wartościach, a wydaje się, że jest to potrzeba każdej jednostki, zawoalowana, czasami maskowana, ale rzeczywista, nawet dla człowieka podwójnie zewnątrzsterownego, nie powodującego się własnymi doświadczeniami, a tylko kierowanego takimi bodźcami, jakie otrzymuje z zewnattrz. Człowiek spełnia się w formach, jakie sa konsekwencją wyborów zbiorowości i jedną z takich historycznych form jest demokracja.

Dla J. Pennocka, potwierdzającego rozumienie treści demokracji, swoistym eksperymentem w skali wieków jest wykorzystanie koagulatu wiecznych mitów tworzacych podstawy demokratycznego credo ${ }^{20}$. Autor ma swoje racje. Demokracja jest konstrukcja mityczna, ale nie nowa, jak się sugeruje z uporem godnym lepszej sprawy. Naszym zdaniem, a częściowo potwierdzają to teoretycy poszukujący dla niej szlachetnych genealogii, nie jest to eksperyment ostatnich wieków, ale proces transferu generujących idei, który zaczą się chyba wraz z wielkimi rewelacjami mitów fundamentalnych w kulturach pierwotnych, a one, wraz z idealizacjami wolności, równości i sprawiedliwości, pojawiały się przecież w mitologiach starożytnych, od krainy wiecznego szczęścia Dilmun w mitologii sumeryjskiej poczynając, a kończąc na wynaturzeniach XX wieku, bo przecież idee wolności i sprawiedliwości doskonałej były fundamentalne dla socjalistów, komunistów, faszystów ${ }^{21}$,

\footnotetext{
18 J.M. Morone, Democratic Wish. Popular Participation and the Limits of American Government, New York 19990, s. 23.

${ }^{19}$ G. van der Leuw, Fenomenologia religii, Warszawa 1997, s. 177.

20 J.R. Pennock, Democratic Political Theory, Princeton University 1979, s. 16.

${ }^{21}$ A.J. Schmidt, Under the Influence. How Christianity transformed Civilization, Grand Rapids 2001, s. 258.
} 
a ci wykorzystali skwapliwie brak związku treści z formami. Jakimś tego poświadczeniem jest poszukiwanie przez historyków demokracji bohaterów walczących o wolność i równość w starożytności, że wspomnimy tu Kleomenesa, Agisa, Spartakusa, będących także herosami dla wszystkich uciśnionych, ale czy demokratami?

Naszym zdaniem człowiek zbiorowy przez tysiąclecia poszukiwał form dla tych treści tak mocno utwierdzonych w społecznej immanencji, że nie udało się wykorzenić ich ani w niewolnictwie, ani w okresie feudalizmu. Być może, twierdzac, że idea demokracji poszukiwała dla siebie nowych miejsc i form, zbliżamy się do „wulgarnej” postaci kumulatywnego postępu, ale takie refleksje, takie wnioski nasuwaja się nieodparcie. Demokracja i jej treści wyrastały z pnia mitycznego, ulegając wielu mutacjom w czasie, jakby dojrzewając, poszukując coraz bardziej pełnych postaci. Sprowadzanie jej tylko do form i procedur nie jest zasadne i nie może przynieść efektów w praktyce - uważał nie tylko V. Possenti ${ }^{22}$. Za tym muszą iść konkretne, namacalne potwierdzenia wiary w treści, a nie czysta kosmetyka, jaka jest niewielkie poszerzanie wolności i równości zbiorowości, zwykle nieproporcjonalne do rosnących oczekiwań. Modyfikacje form, takie jak modna swego czasu idea demokracji deliberatywnej tylko na jakiś czas dodają jej atrakcyjności, budzą ożywione dysputy intelektualistów i naukowców, chyba niewarte zachodu, skoro nie ma to żadnego przełożenia na praktykę i raczej mieć nie będzie. Demokracja deliberatywna - zauważał enigmatycznie M. Walzer - ma swoje miejsce w demokracji, ale nie jest to miejsce niezależne ${ }^{23}$.

Weryfikacja tej nowej formy w praktyce społecznej już zdaje się dowodzić, że ten eksperyment zakończył się niepowodzeniem, ale to sprawa drugoplanowa, twórcom tego modelu udało się potwierdzić, że demokracja ewoluuje, cały czas poszukuje swojej pełni, ale pełni przede wszystkim formalnej, a takie poszukiwania zmierzają czasami do czynienia z niej zdumiewającego spektaklu, jakiego nie rozumieją miliony zwykłych ludzi, zmuszane do wiary $\mathrm{w}$ doskonałość form demokracji. Podobnym potwierdzeniem jest mityzowany, niezbyt oryginalny, libertarianizm, przywracający do życia prawa człowieka do indywidualnego wyboru drogi życia czy obowiązek poszanowania praw innych ${ }^{24}$. Naszym zdaniem ma tylko urok nowości, jest przeznaczony dla konsumentów McFaktów i ma potwierdzać żywotność demokracji, nic więcej.

${ }^{22}$ V. Possenti, Religia $i$ życie publiczne. Chrześcijaństwo $w$ dobie ponowożytnej, Warszawa 2005, s. 137.

${ }^{23}$ M. Walzer, Polityka i namiętności. O bardziej egalitarny liberalizm, Warszawa 2006, s. 157.

${ }^{24}$ D. Boaz, Libertarianizm, Poznań 2005, s. 12. 
Po to, by wzmocnić sugestie wiążące demokrację z wiecznymi archetypami, odwołamy się do autorytetów, co zwykle owocuje interesującymi sugestiami. Demokracja w jej treściach zdawała się być konstruktem mitycznym dla J. Deweya, który dość enigmatycznie powiadał, że demokracja to coś więcej niż forma rządu, dużo więcej niż system emanacji władzy przez wybory. Demokracja to dla niego jedność, zbiorowa droga życia oparta na demokratycznym duchu, to wiara: „która musi zostać wyartykułowana i jest wielkim wyzwaniem dla filozofii ${ }^{25}$. Dewey nie był pierwszym, bo przed nim W. James powiadał, że demokracja jest rodzajem religii, świeckiej wiary i w imię wolności i równości jesteśmy zobowiązani do zapobiegania jej upadkowi ${ }^{26} \cdot R$. Conquest zaś utrzymuje, że to, co nazywamy „demokracja” jest w znacznie mniejszym stopniu kwestią instytucji, a w znacznie większym kwestią nawyków psychicznych ${ }^{27}$.

Co maja oznaczać te nawyki nie bardzo wiemy i w tym przypadku uwaga wybitnego filozofa jest także tłumaczeniem nieznanego przez nieznane. Nie wiemy także, o czym myślał inny uczony twierdząc: „Jeśli obywatele nie doświadczaja demokracji jako realności, to ona nia nie jest" ${ }^{28}$. Pojawiaja się spore kłopoty, jeśli spytamy o to, co jest ta realnościa, a prędzej jej praktyką? Raczej nie sa to obowiązki obywatelskie, jakie często przyjmuje się jak balast, a realizacja jej zbawczych treści tylko częściowo potwierdzanych demokratycznym prawem, które przecież nie oznacza sprawiedliwości. Zaufanie w jej formy rośnie, jeśli zwykli obywatele przekonują się, że równość, wolność i sprawiedliwość sa zasadami niewzruszonymi, obowiąujacymi bezwzględnie, a chyba nie znajdziemy takich demokracji, które zapewniaja takie, realizowane wartości blisko ich pełni. Setki potwierdzeń odchodzenia od zasad opierających się o treści odnajdziemy przede wszystkim w kulturze masowej, setkach filmów, w których bycie politykiem demokratycznym oznacza bycie amoralnym, bezwzględnym draniem mającym na uwadze tylko swoje dobro i takiej demokracji doświadczamy prawie codziennie. A poza tym one nie sa do zrealizowania i nie będą dopóty, dopóki nie stworzymy ich idealnych modeli zaakceptowanych przez społeczności, a raczej nie stworzymy. Te pojęcia są naznaczone „nieusuwalną niejednoznacznością" - twierdził teoretyk myślący o tych wielkich metaforach ${ }^{29}$.

${ }^{25}$ Cyt. za: M. Kilanowski, Individual and Community, [w:] Deconstruction and Reconstruction, eds J. Ryder, M. Wilkanowski, Amsterdam 2004, s. 29.

${ }^{26}$ J. Herring, The Politics of Democracy. American Parties in Action, New York 1968, s. 25.

${ }^{27}$ R. Conquest, Uwagi o spustoszonym stuleciu, s. 37.

${ }^{28}$ J.C. Goldfarb, The Cynical Society. The Culture of Politics and the Politics of Culture in American Life, Chicago 1991, s. 197.

29 H. Brighthouse, Sprawiedliwośc, Warszawa 2007, s. 12. 
Naukowe i moralne autorytety (pełne wiary) przez dziesiątki lat uprawniały instrumentalne traktowanie mitów założycielskich, wskazywały drogi rytualizacji form i w jakiejś mierze dzięki takiemu traktowaniu nie próbuje się kwestionować wiary w demokrację, jej wartości. Możemy tu nawet zauważyć przejawy prawdziwej idolatrii, bo dziś podejrzenie o antydemokratyzm - zauważał ze spora przesada jeden $\mathrm{z}$ autorów - ma taką samą moc jak kiedyś podejrzenie o antychrześcijaństwo ${ }^{30}$. Chyba nie jest aż tak źle, bo dziś jak dogmat traktuje się twierdzenie, że „żadna demokracja nie może przeżyć, jeśli ludzie nie dzielą fundamentalnych wierzeń" ${ }^{31}$. I traktuja go tak zwykli ludzie manifestujący swoja wiarę. Inną sprawa jest to, że wielu trzeźwych teoretyków naszego czasu zaczęło kwestionować formy demokracji i nie dość, że nie są traktowani jak herezjarchowie, to jeszcze spotykają się z uznaniem środowisk choćby naukowych, choć ich herezje nie docierają do większości wyznawców. Herezjarchami jednak powoduje zwykle uporczywa chęć poszukiwania form idealnych bez zwracania uwagi na treści.

Jeśli potraktujemy demokrację jako postać wiary, a demokratyczne postawy i zachowania jako postaci swoistej religijności, to przypominamy, że powinniśmy także przyjmować, iż dogmaty tej wiary nie moga zostać naruszone, bo każda próba podważenia jednego byłaby zarazem podważeniem całego gmachu wiary. Nadto, winniśmy jeszcze przyjać, że muszą istnieć jakieś sposoby przejawiania się tej religijności, czyli manifestowanie postaw i zachowań i, podobnie jak w teologii, gdzie zażarcie dyskutuje się imponderabilia, w demokracji także powinniśmy stale reprodukować i rewitalizować nie imponderabilia, ale idee przez niekończący się dialog, bo same idee zmieniają się wraz ze światem społecznym i choćby nasze poczucie sprawiedliwości z dnia na dzień staje się inne. Idee demokracji są żywe, otwarte, ale dziś pojawiają się tylko jako mutacje płytkich refleksji nad fundamentami mitycznymi, których nie można kwestionować. A demokratyczni politycy powinni pamiętać o tym, że kapitał polityczny, jaki zdobywają dzięki mechanicznej rytualizacji form i swoiście rozumianych treści demokracji, wymaga stałego odtwarzania, bo on nie da się deponować i jest to swoista dyrektywa postrzegania mitów demokracji jako żywych, które trzeba stale pielęgnować nie ograniczając się do ich podziwiania, co zdaje się być codzienna praktyką tzw. „młodych demokracji”.

Politycy i depozytariusze idei demokracji muszą nie tylko deklarować, że chca poszerzenia zakresów wolności, równości i sprawiedliwości, ale i potwierdzać takie chęci, przekonując wyznawców praktyką.

${ }_{30}$ J. Zadencki, Wobec despotyzmu wolności, Kraków 1995, s. 173.

${ }^{31}$ B. Ginsberg, T.J. Lowi, M. Weir, We the People, New York 1997, s. 192. 
Na naszym, polskim gruncie przez jakiś czas dobrze rozumieli to liderzy PiS orientujący się na swoiście pojmowaną sprawiedliwość w obronie interesów słabych, wykorzystywanych i dzięki temu zdobywający władzę. Zapewne wiedzieli o tym, że nie zdołaja zwiększyć przestrzeni wolności czy równości tych, którym to obiecywali i obrócili się w stronę mitycznej sprawiedliwości, bodaj najtrudniejszej dla zwykłego człowieka w konfrontacjach typu idealistycznego. Inna już było sprawą to, że nie potrafili przekonać swoją praktyką do zwiększania tych przestrzeni i ta kulawa praktyka obróciła się w końcu przeciwko nim wieńczona spektakularnymi akcjami służb specjalnych. Wszyscy politycy musza także pamiętać o tym, że tworzenie i rytualizacja nowych mitów tyczacych form w demokracji może czynić z niej karykaturę. Tak jest w tych młodych demokracjach, gdzie wygrane wybory z poparciem nawet $10 \%$ społeczeństwa pozwalają na tworzenie iluzji mitycznej, że to naród oddał władzę wybrańcom. Tu pojawia się stare ostrzeżenie teoretyków powiadajacych, że w demokracji nie ma takiej większości, która byłaby przepustką do wszechwładzy, a już na pewno większości mniejszościowej. Jakość bliską wszechwładzy można zdobyć tylko wtedy, kiedy za obietnicami zbawienia $\mathrm{w}$ doczesności pójdą $\mathrm{w}$ demokracjach zdecydowane czyny tej władzy.

Siła mitu demokracji zdaje się być tak wielka jak niekonsekwencja człowieka mitycznego wobec własnego tworu, zdająca się pochodzić z inercji psychicznej, co dla teoretyka oznacza tendencję do sięgania po stare wzory w interpretacji tych mitów, bo te sa zwykle łatwiejsze $\mathrm{w}$ rozumieniu ${ }^{32}$. Intuicyjnie apologizując treści demokracji obywatele akceptują formy nie zagrażające $\mathrm{w}$ miarę pełnej realizacji tych treści, akceptując zarazem fundamentalne wierzenia, jakie owe treści obudowuja. Ale dla tych, którzy osiagnęli zadowalające ich poziomy wolności, równości mit demokracji jest wartościa, choć ta wolność również jest dziedzictwem nieco kłopotliwym, bo zmusza nas do zadawania wielu nowych pytań ${ }^{33}$. Status materialny determinuje w ogromnym stopniu stosunek do niej i najzagorzalszymi wyznawcami demokratycznych mitów stają się ci, którzy już się zbawili albo ci, którzy mają nadzieje na rychłe zbawienie w niej, przez nią ${ }^{34}$.

Demokracja z definicji oznacza władzę należącą do ludzi, ale wtórna mityzacja czyni ją systemem, w którym ludzie maja prawo do głosowania, a to z pewnością nie jest to samo, choć tak często utożsamia się władzę z tym „prawem” w wulgarnych wyjaśnieniach dla człowieka mitycznego. Demokracja ograniczona do tego prawa jest tylko systemem

32 J. Conrad, Człowiek, rasa, kultura, Warszawa 1971, s. 124.

${ }^{33}$ Z. Bauman, Wolność, Kraków 1995, s. 76.

${ }^{34}$ R.A. Dahl, Dillemas of Pluralist Democracy, London 1982, s. 153. 
głosowania zamkniętym $\mathrm{w}$ procedurach ${ }^{35}$, a relacje między treściami a formami, które mogą czynić z niej jakość jedności form i treści powinny wyglądać zdecydowanie inaczej, o ile nie jest możliwe sprowadzenie na ziemię zrealizowanych treści. Formy przynajmniej powinny zapewnić jednostkom wolność i równość w warunkach życiowego startu, a także równość obowiązków ${ }^{36}$. Takie odczucia miewają nawet politycy markujący wysiłki zmierzające do stworzenia takich warunków, ale w kulturze pozorów one mają moc działań magicznych i takie zwykle przekonuja człowieka magicznego.

Droga od tego „prawa” do realnej i jednak niewyobrażalnej „władzy ludu" jest zbyt długa dla przeciętnego, samozbawionego obywatela państwa demokratycznego, który chętnie zadowala się rolą obserwatora, nie uczestnika ${ }^{37}$, co nie znaczy, że przestał marzyć o byciu prawdziwym uczestnikiem, kreatorem, bo część tożsamości jest polityczna. Wiemy, jakie miejsca zajmują rozmowy o polityce w rozmowach towarzyskich. Zwłaszcza dziś, kiedy stylem dla większości wyznawców stała się medialna substytucja uczestnictwa w polityce polegająca przede wszystkim nie na interpretacjach, a powielaniu medialnych przesłań i oni jednak zdają sobie sprawę z iluzyjności takiego uczestnictwa powtarzając opinie dziennikarzy i różnej maści „ekspertów”. Nie przypadkiem demokracja jest tworem kapitalizmu i to społeczeństwo kapitalistyczne stworzyło system, w którym bogactwo ekonomiczne przekładało się na władzę polityczna, ale także symboliczna, zwykle znajdująca się na drugim planie zainteresowania polityki ${ }^{38}$. Nie przypadkiem jej twórcy czynili ją systemem statusów społecznych w czasie, w którym umacniali polityczne i pozapolityczne struktury władzy pieniądza. Nie przypadkiem przez długie lata była luksusem dla bogatych. Powszechna w niej partycypacja stała się faktem dopiero wtedy, kiedy przekonano się, że za pomoca wielu narzędzi można sterować preferencjami wyborczymi, przekonując zarazem, że jej formy sa zgodne z wolą mitycznego „ludu”, a o realizację treści zadbają ci, którzy kontrolują formy.

Jak blisko jej z kapitalizmem przekonywaliśmy się śledząc jej rozwój w warunkach amerykańskich, w okresie „wieku pozłacanego”. Prawdziwi władcy uczynili słabe, demokratyczne państwo swoim narzędziem, nominalnie tylko zarządzanym przez nijakich prezydentów takich, jak A. Johnson, U. Grant, R.B. Hayes, Ch. A. Artur. Takie pań-

${ }^{35}$ C.G. Ryn, Democracy and the Ethical Life. A Philosophy of Politics and Community, London 1979, s. 3.

${ }^{36}$ G. Sorensen, Democracy and Democratization. Dilemmas in World Politics, Boulder 1993, s. 10.

${ }^{37}$ N. Chomsky, Media Control, s. 17.

${ }^{38}$ L. Thurow, Przyszłość kapitalizmu, s. 328. 
stwo było zbyt słabe nawet w roli „nocnego stróża”, a wiemy jak zwykle wyglądają tacy stróże. Baronowie-rabusie byli jego prawdziwymi władcami, ale wtedy, kiedy pojawiła się konieczność powołania arbitra, rozjemcy, a także gwaranta udanych interesów na zewnątrz, zdecydowali się na wzmocnienie jego siły, ale, niejako wbrew nim, słowo „demokracja" stawało się głośniejsze we wznoszącym się crescendo $^{39}$, gdy w formach nie było wystarczającej wyznawcom treści. Potrzebna była powszechna wiara w idealne treści demokracji. W wypełnienie pustych form równością i sprawiedliwościa, by spacyfikować tłum Le Bona, a masy sa nieprzewidywalne, ich emocje mają niepojęte moce destrukcyjne, emocje zaś rodza się z pragnień. Treści demokracji dostarczyły źródeł emocji konstruktywnych i ich role w pacyfikacji nastrojów sa bardzo dobrze widoczne. Starczy czasami obiecać więcej wolności czy równości. Chyba im można zawdzięczać to, że tzw. „stare demokracje” uniknęły parkosyzmów rewolucyjnych po I wojnie światowej.

$\mathrm{W}$ takiej konkretnej sytuacji istnieje wiele przesłanek dla prostego wniosku, że demokracja jest tworem młodego kapitalizmu, jego symbiontem za wymuszona zgodą kapitalistów. Tworzono jej formy po to, by samoograniczała wilcze formy kapitalizmu przez choćby łagodzenie form nieograniczonej konkurencji, tej, tzw. wolnej gry sił. Twór kapitalizmu sam tworzył pozory ograniczenia twórcy i czynił to skutecznie. Wydaje się, że od samego początku jej treści widomie kłóciły się z kapitalizmem. Jak może wolność i równość pomieścić się w porządku kapitalistycznym? Chyba tylko wówczas, kiedy demokracja zacznie dażyć do opanowania, etatyzacji gospodarki, na co się nie zanosi, choć socjaliści różnych maści zdaja się marzyć o tym. Ale jeśli zacznie to czynić, podówczas pojawi się równość w biedzie, bo jednak kapitalizm szybciej mnoży bogactwa, choć rozdziela je nierówno. Demokracja oparta na etatyzmie byłaby tworem gorszym od jakiegokolwiek socjalizmu podobna socjalizmowi $\mathrm{w}$ tym, że pewnie stworzyłaby jakieś namiastki wolności czy równości, jak pamiętna idea „demokracji socjalistycznej” i krzewiła wiarę w nie. Dobrze, że gospodarka kapitalistyczna nie poddaje się władzy polityki, bo demokratyczni politycy dowodzili wiele razy, że sa prawdziwymi wrogami gospodarki nie tylko za sprawa niekompetencji i takimi pozostaną dzięki woli tych, którzy dysponuja prawdziwą władza.

Poprzez samo głosowanie, przez wyrażenie swoich preferencji, jednostka nie jest w stanie wpływać na kształt polityki, nie czuje swojej części władzy ani tego, że sama pomaga sobie w spełnieniu, choć jest do tego goraco i regularnie przekonywana. Zdaje sobie sprawę z tego, że

${ }^{39}$ H.W. Mc Coil, The History of Liberty, New York 1965, s. 47. 
wiara $\mathrm{w}$ ziszczenie idealnych treści powinna wymuszać działania dla doskonalenia demokracji, ale nawet nie jest w stanie wyartykułować konieczności odwołania reprezentantów, którzy sprzeniewierzyli się woli wyborcy i wręcz uwłaczają tej politycznej świętości. Taki wyznawca czasami wierzy w siebie jako czastkę opinii publicznej, w zdolność do wymuszania decyzji na rządzących, ale ci, którzy racjonalizują swoje odczucia sa skłonni przychylać się do zdania J. Baudrillarda, powiadającego, że ta „opinia” to mityczna, opatrznościowa i suwerenna rzeczywistośćc ${ }^{40}$.

Taka „opinię" kształtują media sugerujac odbiorcom, że to emanacje ich emocji, przekonań, poglądów, wiary. One zaś sa integralna częścią demokracji tworzaca pozory chęci bycia korektorem systemu, ale są także integralną czéścią współczesnego systemu korporacyjnego $^{41}$, co powinno podważać zaufanie do nich i kształtów tych „opinii”, jakie tworza, ale, jak wiadomo, nie podważa, bo człowiek wiary musi w coś wierzyć. Ze szczególną troską media dbają o to, by „opinia” była przychylna i demokracji i kapitalizmowi w jego współczesnej postaci. Nietrudno choćby zauważyć, że media nie poświęcają wiele miejsca globalizacji $\mathrm{w}$ jej wielu odsłonach unikając $\mathrm{w}$ ten sposób wielu pułapek wiązanych z wyjaśnianie wielu faktów i procesów mających ogromny wpływ na życie jednostek.

Zauroczeni rytualizowanymi wytrwale przez media mitami demokracji nie jesteśmy w stanie zauważyć, że sama forma nie wystarcza, że mamy tu do czynienia z tym, co Ch. Handy nazwał symbolem pustego płaszcza ${ }^{42}$. Jego zdaniem, aby wypełnić ten płaszcz ludzka treścia, trzeba dać więcej władzy temu, co lokalne, małe, bo tam równość, wolność, sprawiedliwość są bliżej ziemi, zależą od zwykłych obywateli czujących, że posiadająjednak cząstki władzy. Mając na uwadze proces konstytuowania się form demokracji amerykańskiej Handy chciał wracać do korzeni zapominając jednak o tym, że żyjemy w postkapitalizmie i taka władza zależy od pieniędzy. Ale jego zdaniem właśnie tam można o wiele skuteczniej pomagać małym wspólnotom $\mathrm{w}$ realizacji ich małych celów. Naszym zaś zdaniem, pusty płaszcz można wypełnić tylko żywym ciałem wyborców, którzy, pamiętając o treściach, sami z siebie muszą ulepszać formy, na przykład wymuszać rezygnację prezydentów, gabinetów, których poparcie społeczne opada poniżej przyjętych granic, wychodzić z oddolnymi inicjatywami, organizować to, co zwiemy społeczeństwem obywatelskim, choć nie zawsze wiemy dlaczego coś

\footnotetext{
${ }^{40}$ J. Baudrillard, Społeczeństwo konsumpcyjne, s. 101.

${ }^{41}$ E.S. Harman, R.W. Chesnay, The Global Media. The New Mission of Corporate Capitalism, London 1999, s. 10.

${ }^{42}$ Ch. Handy, Wiek paradoksu, s. 97.
} 
tak nazywamy. A poparcie dla demokracji spada nie dlatego, że wykoślawia się jej formy, ale dlatego, że wybrańcy zbyt mocno godzą w jej treści z „demokratycznymi” frazesami na ustach. To właśnie ci wybrańcy często sa powietrzem wypełniającym pusty płaszcz Handy'ego.

Od chwili jej narodzin problemem był wybór jednostek najlepszych, kompetentnych i altruistycznych, problemem sztucznym, bo mechanizmy selekcji w demokracji od jej nowoczesnych początków były i sa nastawione na elastycznych, posłusznych, interesownych polityków, którzy jakoś nie przystaja do ideału B. Cricka, powiadajacego, chyba z przekonaniem, że polityka jest rodzajem działalności moralnej, sprawnej, kompetentnej i ci najlepsi, czyli wybrańcy ludu, czerpia $\mathrm{z}$ tego satysfakcję ${ }^{43}$. Tego rodzaju sąd może nawet bawić po pobieżnym oglądzie polskich polityków. Wybór najlepszych pozostawał tylko swoistym imperatywem od czasów krytyki ochlokracji ateńskiej, imperatywem zmieniającym się w pobożne życzenia, które literalnie pojmowało niewielu polityków, jak choćby $\mathrm{T}$. Roosevelt inspirujacy zjawisko zwane muckrakingiem (demaskatorstwem) i posługujący się nim w celu stworzenia sprawnej, kompetentnej i wiernej normom administracji. Próba stworzenia przy pomocy „demaskatorów” prawdziwie nowoczesnej elity władzy skończyła się, mimo wszystko, niepowodzeniem, jak i większość podobnych wtedy, kiedy o kształtach elit przesądzali władcy pieniędzy.

Powiada się, że one pozostały takimi, jakie są społeczeństwa, o ile jest nieco prawdy w sądzie, że wybrańcy są emanacją wyborców, w co raczej wattpimy. Natomiast wybitny polityk, prezydent Stanów, zdawał się mieć za sobą lekturę Monteskiusza, który w „O duchu praw” pisał, że istnienie demokracji jest zagrożone, gdy zapomina się o tym, że choć każdy ma kwalifikacje po temu, by wybierać, to nie każdy po temu, by być wybranym. A jeśli tak, to demokracja pozostaje cały czas zagrożona. W wielu formach demokracji wybrańcy zdają się dobrze o tym wiedzieć, przynajmniej w Polsce. Zadbali o to, by ograniczyć ja do roli rytuału legitymizującego i reprodukującego klasę polityczna ${ }^{44}$, a dbając o swoje interesy zdają się pewni tego, że nie wystapią przeciw nim żadni herezjarchowie, bo ci zostaną natychmiast potępieni, oczywiście jako wrogowie demokracji i z takim potępieniem zgodzi się człowiek mityczny.

Takie zjawiska nie są właściwością polska, są powszechne, wspólne także „starym” demokracjom, choć tam są umiejętnie maskowane. Sama demokracja w tej postaci, w jakiej ja znamy, jest zjawiskiem zrodzonym na przełomie I i II fali, tworzono jej formy dla nowych, eks-

${ }^{43}$ B. Crick, W obronie polityki, Warszawa 2004, s. 76.

${ }^{44}$ J. Staniszkis, Wtadza globalizacji, Warszawa 2003, s. 99. 
pansywnych grup społecznych przez kapitalistów i one po jakimś czasie stały się zbyt ciasne dla tych, którzy osiagnęli władzę polityczna po feudałach. Jak zauważaliśmy, zdobyli swoje wykorzystując treści demokracji, kreujacc odpowiednie, jak najwygodniejsze dla nich formy. Ale po czasie, czując ciasnotę tego gorsetu, ograniczając formy z pozorami poszukiwania nowych, twórcy polityki w warunkach postkapitalizmu, sa zainteresowani jej dalszą limitacja. Gdzie indziej przywołamy argumenty przeciwników, tu zaś pozwolimy sobie przywołać autorytet sugerujący swego czasu (a czas jest ważny), że kapitalizm to spełnienie w polityce, bo tylko „kapitalizm tworzy warunki niezbędne dla politycznej wolności" ${ }^{45}$, ale autorytet nie pytał o to, jaki kapitalizm, jakiej wolności i ile jej dla różnych grup społecznych. Czyli tworzy warunki dla demokracji, w której ulotna wolność jest filarem pierwszym i ta metafora służy jako wyjaśnienie. Przyglądając się podobnym sądom jesteśmy jednak przekonani, że w naszym czasie koniecznie trzeba będzie dopełnić powiedzenie Churchilla o tym, że demokracja nie jest czymś najlepszym, ale lepszego nie wymyślono. W naszym czasie czynienia z niej niezbyt wymyślnej karykatury chyba czas zacząć jednak wymyślać.

Takie punkty widzenia powinny zasługiwać na większą uwagę, ale nie wydaje się, by pojawili się organizatorzy wyobrażeń zbiorowych, którzy w naszym czasie wypełnią coraz bardziej pusty płaszcz. Przeszkodą pierwszą są strażnicy, depozytariusze klasycznego mitu demokracji, przy pomocy wypróbowanych rytuałów, przekonujacy do wygodnych dla nich form, a mający wiele narzędzi perswazji i wiernego sojusznika w postaci człowieka wiary. Przypomnijmy, że poza władza polityczną (przymusu) i gospodarcza istnieje jeszcze ta niedoceniana władza symboliczna, której depozytariuszami sa produkujacy kapitał symboliczny i sa to pisarze, dziennikarze, uczeni, ale użytek z tworzywa przez nich dostarczanego czynią właśnie politycy ${ }^{46}$.

Dla jednego z badaczy władza symboliczna wywodzi się z działalności zmierzającej do produkowania, przekazywania i odbierania form symbolicznych będących nośnikami znaczenia ${ }^{47}$. Poznanie jej istoty jest tożsame z koniecznością pogłębionych, systematycznych badań nad kultura symboliczną i powinniśmy zdawać sobie sprawę z tego, że ta niedoceniana także przez badaczy kultura jest dla zbiorowości formą utrzymania spoistości, tożsamości - uważał D. Bell i zdaje się, że podobne przekonania ludzi nauki przełożyły się w jakiejś mierze na praktykę amerykańską ${ }^{48}$, a tam docenia się jej moce, co widzimy w ry-

\footnotetext{
${ }^{45}$ M. Friedman, Capitalism and Freedom, Chicago 1982, s. 10.

${ }_{46}$ T.A. van Dijk, Elite Discourse and Racism, Newbury Park 1993, s. 47.

${ }^{47}$ J.B. Thompson, Media i nowoczesność. Społeczna teoria mediów, Wrocław 2001, s. 24.

${ }^{48}$ D. Bell, The Cultural Contradiction of Capitalism, London 1979, s. 36.
} 
tuałach politycznych. Jej lepsze poznanie może okazać się przydatne w kreowaniu wizji zbawienia, jakich potrzebuja społeczeństwa, a wybitny teoretyk miał na myśli stała kultywację wyobrażeń zbiorowych ze szczególnym uwzględnieniem wartości utwierdzonych w wyobrażeniach zbiorowych przez wytrwałą i długotrwałą rytualizację.

Nietrudno zauważyć w enuncjacjach amerykańskich polityków tak częstych odwołań do treści demokracji, stałych rytualizacji symboli i alegorii wolności, równości, sprawiedliwości. Oni zdają sobie sprawę z tego, że te fragmenty świata wyobrażeń zbiorowych trzeba kultywować stale, pieczołowicie pamiętając o tym, aby, w miarę możności, praktyka choć trochę potwierdzała takie deklaracje. Tak było choćby z programem Reagana walki z nędzą w imię sprawiedliwości. Oczywiście było to czcze deklaracje i po kilku latach pełnych działań pozorowanych, prezydent przyznał, że jednak ubóstwo zwyciężyło, co nie zaszkodziło jego popularności właśnie dzięki dziesiątkom działań pozorowanych, magii politycznej - prawdziwej soli demokracji ${ }^{49}$. Na marginesie zauważmy, że nie wydaje się, by polscy politycy należycie rozumieli taką akurat konieczność wykorzystywania narzędzi władzy symbolicznej, choć można dostrzec, że czasami jednak pojmują ją empatycznie, wtedy zwłaszcza, kiedy przyparci do muru, rewitalizują stare symbole wielkiej triady, choć samą rytualizacją zwodzą zbiorowość tylko w krótkim czasie nadziei, nie mając zamiaru wspierać obietnic działaniami. Tworząc wizje nie wiedzą o tym, że takie rewitalizacje sa to odpowiedzi na wyzwania i możliwości jutra, że zweryfikuje je przyszłośćc ${ }^{50}$.

Dysponujący władzą symboliczną mają niezwykłe możliwości kreowania nowych i rytualizacji starych mitów. Mają moc (choć nie radykalnego) zmieniania całej przestrzeni mitycznej i czasami nie korzystają z niej z niewiedzy albo próbują korzystać tak, że działają na własna niekorzyść, nie zdając sobie sprawy z istoty tej władzy, podobnie jak wielu przedstawicieli tzw. „czwartej władzy”. Tymczasem, dysponując mediami, czy majac na nie duży wpływ, moga korzenić i rytualizować nowe symbole pomni tego, że w ponowoczesności ludzie oswoili się z iluzyjnościa poznania, przeżywania, zaakceptowali to, że teraz mapy rodzą nowe terytoria, choć to stwierdzenie J. Baudrillarda znakomicie przystaje do granic przestrzeni mitycznych tworzonych przez człowieka niejako „od zawsze”1. Dysponujący cząstkami władzy symbolicznej także „od zawsze” współtworzyli systemy wiary w wartości uniwersal-

\footnotetext{
${ }^{49}$ J.T. Patterson, America's Struggle against Poverty, Harvard 1994, s. 224.

${ }^{50}$ G. Hamel, C.K. Prahald, Competing for the Future, Cambridge 1994, s. 74.

${ }^{51}$ J. Baudrillard, Procesja symulakrów, [w:] Nowe media w komunikacji społecznej $w X X$ wieku, Warszawa 2002, s. 629.
} 
ne, obudowując je aksjonormatywnymi z ich zakazami i nakazami. Ale powtarzamy, że kreacje nowych „map” muszą iść w parze choćby z markowanymi intencjami poprawy bytu zbiorowości. Jeśli nie, podówczas wiara w nie zwątleje i społeczność poszukująca zbawienia zrezygnuje z pustych form demokracji i zawierzy innym. Tak było z demokratycznie wybranym kanclerzem Niemiec w 1933 roku. Przypomina się to często i chyba zasadnie.

Egzemplifikacją bastionu świata mitycznego jest jeden z filarów demokracji, czyli równość. Wiemy o tym, że odwieczny mit równości ma niebywała moc sprawczą i od wieków wykorzystuja go politycy wszystkich opcji, a nawet wszyscy organizatorzy świata społecznego. W miarę chłodna, w miarę racjonalna analiza jego istoty powinna doprowadzić nas do konstatacji podobnej do tej, jaką kiedyś zaprezentował V. Pareto, dla którego samo twierdzenie o równości ludzi jest tak absurdalne, że nawet nie zasługuje na to, by je obalać, „natomiast subiektywna idea równości wywiera potężny wpływ na zmiany, jakim ulega społeczeństwo" "52. A jeśli tak jest, że równości jako zasady domagają się ci, którzy się jej boja - jak widział to M. Scheler - to możemy uznać, że ten mit jest tak wieczny jak strach ${ }^{53}$. Podobnie można interpretować wolność i sprawiedliwość, nie dające się bronić przy pomocy „racjonalnych” argumentów, a każdy z nas filtruje te obrazy w ramach rzeczywistości widzianej przez pryzmat swojej kultury i swojego świata mitycznego, przywołując do tego, korygujące ogląd, swoje doświadczenia.

Wyobraźmy sobie, że aspirujacy do władzy, demokratyczny polityk podejmuje próbę podważenia mitu równości twierdząc choćby, że nierówności społeczne są stanem naturalnym (a znamy takich polityków z polskiego podwórka). Zderzyłby się wówczas z wielkim archetypem mitycznym zrytualizowanym przez wieki i można założyć, że byłby z góry skazany nie tylko na klęskę, ale i na potępienie społeczne. Równość, o której każdy wie, że jest nieosiagalna, jest tylko marzeniem i to marzeniem o konotacjach materialnych, ale miliony jej interpretacji, biorących się z ludzkich tęsknot za światem idealnym, przesądzają o zachowaniach zbiorowych pełnych wiary w równość ziszczona, idealna.

Przeciętny człowiek, pełen naturalnej zawiści, może tolerować to, że, wszyscy spełnią się w świecie materialnym tak samo jak i on i taka równość byłaby dlań satysfakcjonująca, a wiemy skądinąd, że argument o podobnych żołądkach jest uniwersalny. Natomiast nie chce równości w spełnieniu duchowym, tu nawet $\mathrm{z}$ łatwością godzi się na to, że są ludzie od niego mądrzejsi i bardziej utalentowani, ale tej pierwszej

${ }_{52}$ V. Pareto, Uczucia i działania. Fragmenty socjologiczne, Warszawa 1994, s. 83.

${ }^{53}$ M. Scheler, Resentyment a moralność, Warszawa 1977, s. 173. 
będzie bronił zaciekle, traktując swoje prawo do równości niezwykle poważnie, co widzieliśmy w wielu ruchach społecznych. Równość jest częścią jego esencji, jego przestrzeni wiary, a praktyka potwierdza sugestie, że tradycyjne mityczne wzory nie daja się eliminować bez trudu - zauważał amerykański badacz - i by je choć trochę nadkruszyć potrzebny jest ogromny, rozłożony na lata, a nawet generacje, wysiłek ${ }^{54}$. Jest to jednak możliwe, czego dowodzi amerykańska praktyka, w której wszyscy są równi, ale w szansach, odpowiedzialności i jeśli nie wykorzystują szans, sa już mniej równi. Godzą się z tym obywatele i Amerykanie raczej nie sa w stanie zrozumieć wielu uroszczeń europejskich egalitarystów, swoiście zresztą niekonsekwentnych. Być może także dlatego udało się im uniknaćc wielu paroksyzmów społecznych, jakie bywały codziennością starej Europy. Ale mit takiej właśnie równości rytualizowano od początków istnienia kolonii przenosząc go do prawa i odstępstwo albo próba zakwestionowania jego istoty jest traktowana w Ameryce niemal jak świętokradztwo i trudno nam to zrozumieć, gdyż polski mit równości po eksperymencie socjalistycznym jest bezwzględny, interpretowany w utopijnym duchu równości doskonałej. Za oceanem zaś spełniono warunek dobrego wkomponowania go w przestrzeń mityczna - przyznawał badacz zauważający, że to rzutuje na charakter amerykańskiej formy demokracji ${ }^{55}$.

Fundamenty mityczne demokracji składające się na wielką triadę zdają się mocne, tak mocne, że niekiedy rytualizacja, symbolizacja wielu mitów ma charakter przypadkowy, nie całkiem świadomy, co możemy zauważyć choćby w interpretacjach teorii tzw. sprawiedliwości społecznej, prawa stanowionego, czy też w sugestiach o służebności władzy wobec obywateli. Ale istotne jest to, czy mity-archetypy sa rytualizowane stale, konsekwentnie, a jeśli są akceptowane przez społeczność, wówczas pozostają trwałymi wzorami ładu, których nie da się wykorzenić ani łatwo, ani szybko i podówczas pojawiaja się wymuszenia wobec demokratycznej władzy ze strony obywateli. Takimi były w społeczności, z której wyrosło społeczeństwo uważajace się za jedynego i prawdziwego depozytariusza treści i form demokracji, czyli amerykańskie.

Amerykanie, którym chcemy się przyjrzeć, stosując z musu uproszczenia, byli w początkach tymi, którzy stanęli przed koniecznością poszukiwania nowego, lepszego świata i szukając znaleźli go na nowej ziemi, swoim Kanaan ${ }^{56}$. Głęboko wierząc w możliwość zbawienia po śmierci chcieli także wierzyć w zbawienie za życia. Soteriologia trans-

${ }^{54}$ R.N. Bellah, Beyond Belief, s. 103.

${ }_{55}$ O. Patterson, The American Democracy, New York 1993, s. 2.

${ }^{56}$ M. Pollack Sadker, D.M. Sadker, Teachers, Schools and Society, New York 1991, s. 181. 
cendentna grała $\mathrm{w}$ ich życiu większą rolę niż jesteśmy to zrozumieć w naszym czasie, gdy przywiąując większą wagę do tego, co na ziemi, niefrasobliwie stawiamy Bogu świeczkę a diabłu ogarek. Była korygowana przez protestantyzm w jego wielu mutacjach, a odrzucając drogi zbawienia przez wiarę, narzucała protestantom konieczność podjęcia wysiłków zmierzajacych do kontynuacji boskiego dzieła tworzenia. Powodzenie w życiu doczesnym było jakby znakiem od Boga, że idzie się właściwą droga, co było i jest argumentem na rzecz możliwości spełnienia na ziemi i w niebie. Dla nich prawdziwa wiara musiała przejawiać się w czynach, inaczej była martwa i pierwsi Amerykanie po swojemu rozumieli przesłanie św. Izydora mówiącego o „pustych młynach” ${ }^{57}$. Z takiego stosunku do soteriologii „właściwej” wyrastała swoista etyka pracy, ale nie tylko, bo także inne, bardziej praktyczne, rozumienie wolności, równości i sprawiedliwości. Nieświadomi tego, że kultywuja prastare treści demokracji protestanci obudowali je mitami pobocznymi i dzięki takiemu usytuowaniu w przestrzeni mitycznej poszukiwanie form dla tych treści stało się bardzo dynamiczne, a odnajdywane formy stawały się właściwe tylko dla Ameryki i realizowały się powoli aż stworzyły specyficzną formę demokracji.

Od początku istnienia wspólnot na nowej ziemi kultywowano przeniesione ze starego kraju cnoty, które miały być szczególnie bliskie Bogu i etykę oparto o cechy tak szczegółowo i trafnie zbliżone przez M. Webera: pracowitość, uczciwość, powagę, symetrię w kontaktach, prawdomówność, oszczędność pieniędzy i czasu. Takie cechy profilowały rozumienie wolności czy sprawiedliwości Anglików na nowym lądzie. Kultura protestancka, konsekwentna w wymuszaniu stosowania ich $\mathrm{w}$ praktyce, zdecydowanie sprzyjała rozwojowi czyniąc świat przede wszystkim polem do działania i tu wyznawcy byli bliscy temu, co przez wieki było obecne i niewykorzystane w katolicyzmie, czyli praktycznej chrystologii, z której wynikają dyrektywy do działania. Wedle nich człowiek otrzymał od Boga świat, by dopełnić boskie dzieło tworzenia a jego wartość, szanse zbawienia zależą przede wszystkim od tego, ile da od siebie światu i innym, nie zaś od demonstracji wiary i ilości odmawianych modlitw. Drogę ku prawdziwemu odczytywaniu życia Bóg wskazał przez Chrystusa. Idąc jego drogą mamy szanse na odnalezienie właściwej ścieżki zbawienia. A jeśli po drodze odnajdzie szczęście, to jest to widomy znak od Boga i tak sądząc protestanci przygotowywali dobry grunt pod teorie utylitarne, które istniały w swych zarodach o wiele wcześniej, bo, jak wspominaliśmy, marzenia o szczęściu w życiu są nieodłączne od istoty człowieka i niemal każdy z nas dąży do maksy-

${ }^{57}$ J.E. Smith, The Spirit of American Philosophy, New York 1983, s. 13. 
malizacji rachunku szczęścia ${ }^{58}$. Wysiłki katolików zbawiania na ziemi wydaja się niekonsekwentne, czasami jakby wstydliwe, bo nieco wstyd było być bogatym i szczęśliwym. Monachiczne ideały millenarystów położyły się prawdziwym cieniem na ziemskiej soteriologii katolików, którzy przecież także pragną spełnienia w doczesności, ale nawet mówienie o tym zdaje się wstydliwe, kryje się za cieniami grzechu.

Maksymalizacja tego szczęścia $\mathrm{w}$ ciężkich warunkach początków osadnictwa była możliwa dzięki zawierzeniu w zbiorową mądrość i jej emanacje - wybranych za powszechna zgodą przywódców i ta forma swoistego „ludowładztwa”, jaka pojawiła się z potrzeby przetrwania, stała się integralna częścią życia zbiorowego nadając później formom demokracji szczególny charakter. Stawiając na miejscach pierwszych altruizm i kompetencje wybranych, koloniści domagali się od nich w zamian i polepszenia warunków życia, i poświęcenia tych, którzy zostali obdarzeni zaufaniem, a zwykle wybierali dobrze. Po drodze godzili kolektywizm z indywidualizmem przy pomocy praktycznych zasad: bądź niezależny, a jeśli to osiagniesz, zostań częścią wspólnoty, co dla rozwoju form demokracji miało niebagatelne znaczenie ${ }^{59}$. Upewniali się, że ich praktyka owocuje dobrymi skutkami i już w wieku XVII kreowali swój misjonizm, którego prawdziwą erupcję możemy obserwować w naszym czasie i jest to misjonizm demokratyczny w deklaracjach. Dziś chca uszczęśliwiać innych siłą z niezłomnym przekonaniem, że ci inni zbawią się jak oni, jeśli tylko przyjmą doskonały, sprawdzony model $\mathrm{z}$ ich rozumieniem wielkiej, mitycznej triady.

Jeszcze w społeczności homagialnej odnaleziono formy, jakie nazwać można demokratycznymi i takie pozostawały zgodne z kultywowanymi treściami. One przesądzały o tym, że Ameryka statyczna, rustykalna, stworzyła dla siebie wielkie wizje przyszłości, miała być dla innych „miastem na wzgórzu”, „latarnia dla świata” i te wielkie wizje Winthropa, Wiliamsa, Edwardsa także wymuszały dążenie do doskonałości postaw i zachowań, choć raczej nie czyniono niczego na siłę. Wedle organizatorów życia zbiorowego i dyrektyw wynikajacych z wyobrażeń zbiorowych wszystko miało swoje wymiary i boską kolej rzeczy, której nie można zmieniać. Człowiek powinien cierpliwie uczyć się pokory i pracować, winien pamiętać o tym, że nagrody rozdaje Bóg i każda próba buntu przeciw jego wyrokom jest świętokradztwem, a także może oznaczać wykluczenie ze wspólnoty. Takie postawy zaowocowały jeszcze jednym komponentem „ja powinnościowego” Amerykanów i „od wieków każda generacja miała święty obowiązek zostawienia swoim

${ }_{58}$ R.A. Posner, The Economic of Justice, Harvard University 1983, s. 44.

${ }^{59}$ W.O. Boeman, The Melting Pot, [w:] Symbolizing America, s. 58. 
następcom bezpieczniejszego i bardziej sytego świata"60. Koloniści rozumieli takie powinności literalnie i w odróżnieniu od Europejczyków, hołdujących zasadzie „po nas choćby potop”, Amerykanie czynili i czynią wiele w tym kierunku poszerzając powoli zakresy wolności, równości i sprawiedliwości aż po granice, które ukazały się po zamachach 11 września. A jeżeli stare zasady przełożyły się na stabilność i dobrobyt, to oczywista powinnością dla zstępnych powinno być ich poszanowanie i takie dostrzegamy, nie tylko w stosunku Amerykanów do ich „historii świętej”.

Zjawiskiem specyficznym, właściwym tylko Ameryce, były ich Wielkie Przebudzenia. Wiek po pojawieniu się pierwszej fali osadników zdawała się kończyć akumulacja kapitału społecznego, wspólne wartości i normy słabły zagrażając ideowej spójności wspólnot. Zauważano zanikanie symetrii $\mathrm{w}$ stosunkach wzajemnych, zdolności do zawierania kompromisu, przedsiębiorczości, a powstawanie nawyków wyrastajacych z rosnącego powoli dobrobytu. Sybarytyzm to także zamykanie się przed innymi w gronach elit, zaniedbywanie obowiązków społecznych. Zauważalna atrofia takich cech pobudziła do działań przywódców duchowych rozumiejących konieczność rewitalizacji wyobrażeń zbiorowych. Fundamentalne mity budowane na gruncie wolności, równości miały zostać radykalnie skorygowane przez czas, zmiany. $\mathrm{Na}$ kilkadziesiąt lat przed swoją wielka rewolucją Amerykanie przeżywali swa „mała rewolucję” - Wielkie Przebudzenie lat 1740-176061. Było to pierwsze z Przebudzeń (następne we latach 1800-1820, 1890-1910, 1960-1980, choć umowność tych ram jest oczywista), które było niczym innym jak rewitalizacja przestrzeni mitycznych, odnowieniem ich w nowej/starej postaci. Tu także nie sposób nie zauważyć fundamentalnych różnic między Amerykanami a Europejczykami. Europejczycy tego czasu zawierzyli rewolucjom, chcieli zaczynać wszystko od początku burząc stare czasami do fundamentów, Amerykanie zaś uwierzyli w mądrość czasu i zbiorową.

Jak mocno utwierdziły się formy nazywane protodemokratycznymi można dostrzec tuż po odzyskaniu suwerenności, w tzw. „okresie krytycznym”, na który i tak z taką zazdrością patrzyli Europejczycy. Dla wielu intelektualistów tego czasu Ameryka była refleksem aspiracji, jakie spotykamy na starym kontynencie ${ }^{62}$. Widząc w Stanach realizo-

${ }^{60}$ W. Strauss, N. Howie, Generations, The History of American Future, New York 1991, s. 368.

${ }^{61}$ G. Wills, Inventing America. Jeffersonian's Declaration of Independence, New York 1979, s. 53.

${ }^{62}$ B. Levine, The Migration of Ideology and the Contested Meaning of Freedom, Washington 1992, s. 22. 
wane marzenia o wartościach w praktyce Europejczycy czasami popadali w swoista idolatrię patrząc zza Atlantyku na dowodzoną możliwość realizacji ideału i czasami nie kryli zazdrości. Tam, za oceanem, każdy mógł stawać się tym, kim chciał, mógł się realizować, każdy bez trudu zarabiał na chleb. Często spotykamy ślady utożsamiania Ameryki z demokracja, racjonalnościa, i nauką - ziemi obiecanej naukowej, racjonalnej przyszłości.

Patrzacy z dystansu Europejczycy zwykle nie zauważali kontekstów, w jakich utwierdzały się nowe zasady i wynikające $\mathrm{z}$ nich procedury mierzac innych swoimi miarami. Historycy przypominaja choćby epizod mający miejsce $\mathrm{w}$ dziesięć lat po przyjęciu pierwszej poprawki do Konstytucji, kiedy trwał jeszcze okres swoistej euforii rewolucyjnej. Wtedy federalistyczny Kongres uznał za przestępstwo federalne „, pisanie, drukowanie i publikowanie fałszywych, skandalicznych i chorych pism przeciw rządowi Stanów”63, a takich w owym czasie nie brakło, bo braknąc nie mogło. Kongres zakwestionował jedno z podstawowych praw Amerykanów, uznał za przestępstwo wolność słowa traktowana jak forma czystej wolności i oburzenie zwykłych obywateli sięgnęło progów rewolty, a w głosach obrońców wolności słowa pojawiły się argumenty, że jeżeli nie będzie zgody na dzielenie się opiniami i wrażeniami, świat zostanie zdominowany przez barbaryzm, podejrzenia, niesprawiedliwość, tyranię i najgłupszą ignorancję.

Wiara w mityzowane prawdy była tak wielka, że wystapienia przeciwko nim bywały traktowane jak zbrodnie. Ten epizod był niezwykły przez to, że poszukujący postaci idealnej wolności odnaleźli ją właśnie w wolności słowa i taka jej postać zmityzowano w swoistej tęsknocie za hipostazą wolności. Przy czym od samych początków można było mówić o Amerykanach, że są ludźmi przedkładającymi zasady nad prawdę i potrafia tych zasad bronić nawet przeciw prawdzie ${ }^{64}$. Tak mówiono o nich już wtedy, a wieki później powtarzano stare sądy o Amerykanach, że sa właśnie jak pierwsi purytanie, czasami maja niezwykłą łatwość zawierania kompromisów, a czasami są moralnymi ekstremistami wymagającymi od innych poświęceń, na jakie nie stać ich samych ${ }^{65}$. Potwierdzenia takich sądów znajdziemy także dziś w stosunku do tych, którzy nie chca akceptować form ich demokracji widzianej jako remedium na wiele problemów świata.

Ta głęboka wiara w wielkie mity wymuszała poszukiwanie nowych form demokracji, a determinanty ekonomiczne i społeczne znaczyły

${ }^{63}$ R. Buel, Freedom and Press in Revolutionary America, [w:] The Press and the American Revolution, eds B. Boilyn, J.B. Hench, Boston 1981, s. 61.

${ }^{64}$ P.K. Tonkin, Puritans and Pragmatists, New York 1976, s. 12.

${ }^{65}$ M. Equal, Divergent Paths. How Culture and Institutions have Shaped North American Growth, New York 1996, s. 128. 
tu bodaj najwięcej. Amerykanie uznali, że odnaleźli optymalne formy dla treści po „przewrocie” Jacksona, a ich korzenieniu się z pewnością sprzyjał naturalny optymizm i niezmienna wiara w szczęśliwa przyszłość mieszanki narodów ${ }^{66}$. Swoistym memento dla obietnic zbawienia w doczesności przez demokrację dla samego Jacksona był dzień inauguracji prezydentury, kiedy do Białego Domu wtargnęły setki zwolenników nowego prezydenta, by zająć się degustacją potraw i trunków przygotowanych dla gości oficjalnych, bo skoro wszyscy są równi? A takie podglebia stosunku do treści tworzyli już przywódcy partii politycznych przedstawiający się jako jedyni zbawcy, depozytariusze remediów na wszystkie bolączki zwykłego człowieka.

Mimo takich zachowań ludzi wiary, jak to w dniu inauguracji, demokracja w jej pierwotnej formie potwierdzała się w praktyce będąc ramami dla samoorganizowania się w postaciach społeczeństwa obywatelskiego i w Stanach XIX wieku raczej nie była hamulcem rozwoju - jak widział to R. Dahrendorf, choć on myślał raczej o pierwocinach takiego w Europie Wschodniej początków transformacji ${ }^{67}$. Nie jesteśmy tego tak pewni, jak wybitny politolog, u progu przemian zwanych transformacją systemowa. Zdaje się, że nieprzystawalność form i treści demokracji w krajach postkomunistycznych staje się coraz bardziej zauważalną bariera rozwojową. Brak wiary w realizację treści niszczy koherencję społeczna, wiarę w przyszłość i samą demokrację rozumianą jako jednię form i treści, a co za tym idzie, aktywizm zbiorowości nakierowany na wspólne cele. Bodaj najbardziej jest to dziś widoczne w Niemczech wschodnich, gdzie ludzie stracili poczucie bezpieczeństwa i znowu zawierzaja lewicowym zbawcom, takim jak O. Lafontaine. Polacy swego czasu poszukiwali i odnaleźli swoich zbawców, uwierzyli w formy demokracji ufając jej treściom, ale poziom zawierzenia spada, co potwierdzają badania socjologów, podobnie jak poziom wiary w to, że jest to system optymalny.

Wielkie laboratoria amerykańskiej demokracji zaowocowały rozwiązaniami, jakie rychło stały się swoistymi paradygmatami ustrojowymi na następne dziesięciolecia nie tylko dla niej, ale które też ulegały setkom mityzacji wartościowanych zdecydowanie dodatnio, niekiedy tak dalece, że w niektórych interpretacjach wyznawców demokracja zdawała się być wynikiem ingerencji transcendencji, nie zaś dziełem ułomnego człowieka pragnącego realizować swoje marzenie o spełnionym ideale. W warunkach amerykańskich, jak ze spora przesadą uważało wielu teoretyków, sprawdzało się przekonanie, że dążeniem demokracji jest „stworzenie warunków wolnego rozwoju ludzkich zdolności

${ }_{66}^{6}$ P.G. Lewis, Democracy and it's Future in Eastern Europe, [w:] Prospects for Democracy, ed. D. Held, London 1994, s. 297.

${ }^{67}$ R. Dahrendorf, Reflections on the Revolution in Europe, London 1990, s. 83. 
i równości wszystkich członków społeczności ${ }^{68}$. Taka demokracja była więc dla wyznawców formą organizacji amerykańskiego snu, śnionego od czasów Winthropa, ale miała wymiar praktyczny, bo ten sen miał przyjść do tych, którzy mają inicjatywę i ciężko pracuja.

Takie przekonanie towarzyszyło mitom równości, wolności i sprawiedliwości przez cały wiek XIX, a wyznawcy, jak zauważaliśmy, zwykle nie konfrontuja ideału z rzeczywistościa, czasami wierzą nawet wtedy, kiedy jest to więcej niż absurdalne. Sądy mitoburców bywaja przez takich wyznawców pomijane, niekiedy zbywane wzruszeniem ramion, jak choćby sądy autora, dla którego „kapitalistyczna demokracja jest tylko mydleniem oczu, demokratyczne instytucje sa tylko kotarami ukrywajacymi kapitalistyczna autokrację i czynia ja bardziej strawna dla mas", a dodajmy, że ów autor mówił to przed trzydziestu laty ${ }^{69}$. Mityzatorzy tworzą specyficzny, demokratyczny klimat polityczny z cynicznym przekonaniem, że sprawy nie muszą być prezentowane takimi, jakimi są naprawdę, starczy, że zaspokoja powszechne oczekiwania - konstatował badacz ${ }^{70}$. Rzecz jasna, takie powszechne oczekiwania sa już wykreowane przez posiadaczy narzędzi władzy politycznej i wyznawcy oczekują na rzekomo pożądane przez siebie treści, odpowiednio spreparowane przez naukowych i medialnych mediatorów. Oczekuja tego, czego zawsze, czyli zapewnień, że mimo poważnych problemów ich sprawy idą w pożądanym kierunku, a takie zapewnienia wygłaszają zawsze pewni swoich racji politycy.

Twórcy nowych form demokracji parlamentarnej w znaczącej mierze przyczynili się do stałego wzrostu partycypacji wyznawców w życiu politycznym, rozszerzania tych form na obywateli płci obojga, choć warto pamiętać o tym, że demokracja w treściach miała charakter mityczny zanim zniesiono statusy majątkowe dla posiadaczy czynnego i biernego prawa wyborczego. Demokracja w jej treściach i formach spełniała podwójną rolę, była unifikujacca wizją spełnienia wartości idealnych i, z drugiej strony, tworzyła nowe formy samoorganizacji społeczeństwa, umożliwiała zbawienie w doczesności. Rozwiązaniem, jakie uznano za optymalne miał być system przedstawicielski, kreujący wolę zbiorowości, będący emanacją tej woli, czyli partie polityczne. One, reprezentujące społeczność, orientując się na kompromis, muszą artykułować jej interesy i stale walczyć o to, by demokracja nie stała się tyrania większości, o co obawiał się nie tylko J.S. Mill i obawiał się raczej zasadnie, bo i dziś zbyt często słyszymy argumentację typu: „wolą większości jest...”. A ta większość jest jedną z iluzji nowoczesności, a chyba

${ }^{68}$ C.B. McPherson, The Real World of Democracy, Oxford 1996, s. 58.

${ }^{69} \mathrm{~J}$. Schell, The Time of Illusion, New York 1976, s. 7.

${ }^{70}$ W. Greider, The Betrayal..., s. 123. 
zbliża się czas, w którym będzie można mówić, że w demokracji „wolą mniejszości jest...”.

Wyborcy swoje iluzje uczestnictwa podtrzymuja przejmując opinie, naśladując zachowania innych, zwłaszcza wtedy, gdy ich położenie jest niepewne i muszą wykazywać większy aktywizm. Są tak często współuczestnikami „demokracji imitacyjnej” - tworu wiary opieranego na fundamentach mitycznych. Takim tworem zdaje się właśnie polska demokracja przełomu wieków, gdy tzw. zdyscyplinowani wyborcy rekrutuja się właśnie spośród tych, dla których mityczne ideologie i ich emanacje sa tworami „racjonalnymi”. Oni wierza przede wszystkim $\mathrm{w}$ mit racjonalnego wyborcy, a taki mit jest przyjmowany tak łatwo, bo ułatwia identyfikacje polityczna, konstytuuje tożsamość politycz$n a^{71}$. Wyborcy racjonalizujacy zaś, dostrzegając mityczny charakter „programów” politycznych, deklarują brak wiary przez nieuczestniczenie w wyborach. Oni nie wierza już w mit altruizmu polityków, a taka wiara, sprzężona z emocjami, jest podstawą aktywizmu politycznego, z czym można się godzić albo nie ${ }^{72}$. I to raczej nie te grupy przesądzaja o erozji demokracji, o co były tak często oskarżane w III RP. Nie ich winą jest to, że nie chca legitymizować formy bez treści, a takich treści nie zauważaja tam, gdzie być powinny, czyli choćby w kodeksach prawa. Dziś w Polsce mamy do czynienia z syndromem „pustego płaszcza”, $\mathrm{z}$ tym, że jeden $\mathrm{z}$ autorów zasadnie nazwał nasz system partiokracja uznając ja za nowotworową chorobę demokracji ${ }^{73}$. Tak ostre tony nie sa rzadkością w naukach społecznych, ale pozostaje wciąż niedosyt, bo poza tak zdecydowanymi diagnozami nie spotykamy prób proponowania skutecznych terapii.

Polscy wyborcy i wyznawcy zarazem są na swój sposób specyficzni, ale i bliscy właściwie uniwersalnym regułom. Potwierdzaja racje teoretyka, że partycypacja w demokracji jest niezwykle trudna, jeżeli społeczność jest pogrążona $\mathrm{w}$ anomii i niedostatku ${ }^{74}$. Biedni i niewykształceni obywatele, czujący wykluczenie, nie chcą wybierać, jakby na przekór zdrowemu rozsądkowi nie wierząc już w ziszczenie ideałów. Przecież dobry wybór mógłby być początkiem zbawienia, a tymczasem oni wykazują nie tyle rezerwę, co niechęć w uczestnictwie w wyborach, apatię, zdaniem przedstawicieli demokratycznego establishmentu, trudną do zrozumienia i wyjaśnienia. Tak ogromny dystans między

${ }^{71}$ K.S. Johnson-Cartee, S.A. Copeland, Manipulation of the American Voter, Westport 1997, s. 76.

${ }^{72}$ S. Kelman, Why Public Ideas Matter, [w:] The Power of Public Ideas, ed. R.B. Reich, Harvard 1990, s. 47.

${ }^{73}$ J. Muszyński, Polskie Państwo Partyjne, Warszawa 2002, s. 11.

${ }^{74}$ D. Held, Models of Democracy, Cambridge 1987, s. 271. 
nimi a formą władzy zdaje się pochodzić znowu z regulacji idealistycznej, z pokładów wiary stale konfrontowanej z ułamkami wiedzy. Ci wyborcy po prostu nie wierza w zbawienie przez nią i odnajdują setki przesłanek, zwłaszcza w zachowaniach polityków, potwierdzających takie ich tezy. Jakimś tego potwierdzeniem jest poszukiwanie w demokracjach jednostkowego sotera i wiara w magię zmiany. Często daja się uwieść działaniom pozornym, co zdaje się pochodną wiary. Badania socjologów potwierdzają nowa formę wiary chyba większości Polaków $\mathrm{w}$ mityzowaną demokrację, ale manifestując taką wiarę respondenci uważali zarazem, że krajowi jest potrzebny silny przywódca, który zaprowadzi w kraju porządek. To nie zwykła sprzeczność, ale postać wiary w siłę zbawcza, jaka zdaje się gwarantować lepsze warunki życia. Paradoksem było jedynie to, że owa silna jednostka nie mogła mieć prawa do ograniczania przywilejów demokracji.

Próbując antycypować jej rozwój jesteśmy raczej bezradni, pewni tylko tego, że jej treści wymuszają nowe formy i z pewnością te, jakie pojawiają się w naszym czasie nie są ostatnimi nowościami nadającymi tym formom nieco karykaturalne oblicza. Taka forma mająca potwierdzać żywotność demokracji i podkreślać jej swoiście rozumiana postępowość jest polityczna poprawność, ten rodzaj „odwróconego maccartyzmu"75 - zauważał z przekasem P. Ricoeur. Ale to nie tylko ta, czasami wręcz karykaturalna, „poprawność”, przypominająca wysublimowane konwenanse dworskie XVII i XVII wieku, a także poszukiwania wszelkich możliwości poszerzania ram wolności, sprawiedliwości w krajach, gdzie demokracja jest fetyszem, bywa forma dla formy jakby potwierdzając obecność magii. Ona musi się potwierdzać, ale niekiedy te jej nowe formy czynia ją samą czymś sobie przeciwnym i osiaga to już nie granice antynomii, a aporii.

Demokracja form z pozoru pozwala się spełniać materialnie jakiejś części społeczeństwa, bo musi ulegać dynamice treści, bo tęsknoty za wolnościa, równością i sprawiedliwością przybierają coraz to nowe formy w nowych warunkach i muszą być zaspokajane nie przy pomocy placebo. A tak dzieje się w demokracjach z pozoru doskonałych form i w zgiełku postnowoczesności szuka się nowych poziomów równości dla dzieci, a nawet małp naczelnych (Hiszpania), jakby powinności państwa i społeczeństwa wobec dzieci i małp nie wystarczały. Pojawiły się także głosy, by radykalnie obniżać prawo głosowania przyznając je właśnie dzieciom - przyszłym wyborcom. Argumenty zdają się nawet racjonalne, bo przecież wybierając polityków dzieci wybieraja swoja przyszłość. Ale, mając na uwadze stosunek tych polityków do przyszłości, a także sposoby spe-

${ }^{75}$ P. Ricoeur, Krytyka i przekonanie, s. 84. 
cjalistów od marketingu politycznego moglibyśmy obawiać się o to, że byłyby to wybory najgorsze. Elektorat dziecięcy byłby o wiele łatwiejszy w manipulacjach. Dzieci mają więcej wiary niż dorośli, a ich spełnienie zdaje się prostsze i... tańsze. Zamiast kiełbasy wyborczej starczyłyby cukierki. Efekty eksperymentu mogłyby być podobne do tych, jakie spotykamy u J. Korczaka w jego powieści o królu Maciusiu I.

W naszym czasie demokracja przestaje być forma zbawienia właśnie za sprawa tych, którzy tworzą jej formy - polityków. Z pozoru oni tworza wiele wizji zbawiania, konstytuuja niespełnione nadzieje, a nie spełniając ich odzieraja społeczności z tego, co zwie się złudzeniami albo iluzjami posybilnymi. Prawie zawsze - zauważał teoretyk propagandy - stopniujący technikę schlebiania obiecuja przyszłość, której nie sa w stanie zapewnić. Dla przekonania i zdobycia poparcia społecznego rysowane są obrazy przyszłych sukcesów, zwycięstw, osiagnięć gospodarczych, powszechnego bogactwa. Pragmatyczni i oszukańczy obiecuja, że wszystko to znajdzie się w zasięgu ręki, jeśli społeczeństwo podporządkuje się ich woli i takie obietnice wykorzystuje się nie bacząc na nic ${ }^{76}$. Dziś polityka stała się domeną jednostek kratycznych (władczych) myślących przede wszystkim o samozbawieniu i owe obietnice są zwykle tylko środkiem do indywidualnego celu. Zdaje się także, że to politycy naszego czasu, choć z pewnością nie wszyscy, najprędzej przesiąkli postmodernistycznymi „,innowacjami” i to za ich sprawa polityka stała się farsa. Po części dlatego, że w takim czasie poznali granice własnej niekompetencji i zrezygnowali z prób prawdziwego rządzenia ufając w sprawność aparatów biurokratycznych, a wtedy, kiedy one zdaja się zawodzić, po prostu je rozbudowuja powtarzając zwykle, że walcza z biurokracją. Stając przy tej granicy niekompetencji powtarzają także, że polityka jest oddzielona od gospodarki i tu nie zdaja sobie sprawy z tego, iż przyznaja tym samym, że sa potrzebni tylko sobie.

Nieprzystawalność demokracji do naszego czasu to jeden z megatrendów J. Naisbitta ${ }^{77}$. Obserwując ten nasz czas można stwierdzić, że chyba jednak odwracanie się od demokracji jest trendem, jaki można ekstrapolować w przyszłość, choć bardzo ostrożnie mając na uwadze ogrom pułapek wiązanych z prostym przedłużaniem trendów. Coraz częściej pojawiają się pytania o przyczyny procesu i tu spotykamy wiele prób, poczynajac od tych S. Huntingtona, poszukującego źródeł regresu w braku identyfikacji elit z masami, załamaniach gospodarczych, czyli braku bogactwa ${ }^{78}$. Wiele z takich przesłanek spotykaliśmy już w poprzednich rozdziałach i poza tymi, zauważanymi przez teoretyka

${ }^{76}$ O. Thompson, Historia propagandy, Warszawa 2001, s. 449.

${ }_{77}$ J. Naisbitt, Megatrendy, Poznań 1997, s. 18.

${ }^{78}$ S.P. Huntington, Trzecia fala demokratyzacji, Warszawa 1995, s. 289. 
możemy przywołać społeczną inercję sparaliżowanych sytą gnuśnością społeczeństw, przekonaniami o trwałości, wręcz nadczasowości systemu. Naszym zdaniem takich przyczyn powinniśmy doszukiwać się także $\mathrm{w}$ rosnącym braku treści $\mathrm{w}$ formach, ale także $\mathrm{w}$ osłabieniu wiary immanentnej w ogóle za sprawą wspomnianego recentywizmu, jaki staje się znamieniem kultury ponowoczesnej. Być może to ta słabość sprawia, że rządy demokratyczne muszą bezustannie potwierdzać swa wierność wolności, równości i poszerzać ich granice, a nie bardzo wiedza, jak to robić. Muszą sprawiać, że wielkie masy ludzkie wiedza, co robią i dlaczego to robią, ale nie wtedy, kiedy wydaje się im, że wiedza, co robia - twierdził Chomsky ${ }^{79}$, ale nam zdaje się, że w takim sądzie jest wiele przesady. One musza sprawiać, by te wielkie masy robiły to, co rządzący chca, by zrobiły. Samoświadomość mas nie jest i nie będzie ich celem z zupełnie oczywistych względów.

Ale o słabości form przesądzają ci, którzy je tworza, czyli my wszyscy, majaccy teoretyczne moce sprawcze, teoretyczna moc wymuszania na twórcach demokracji znaczących korekt. Tyle teoria, bo praktyka zdaje się potwierdzać, iż prawdziwymi twórcami jej dawnych i dzisiejszych form sa, jak przed laty, oligarchowie, którzy także, według E. Todda, właściwie sa zmuszeni do radykalnych przekształceń systemowych ${ }^{80}$. Z jednej strony demokratyczne rządy nie satysfakcjonuja tych, którzy mają pieniądze, a z drugiej zrelatywizowane klimaty ponowoczesności sprawiaja, że społeczeństwa nie tyle nie wchodza w dorosłość ${ }^{81}$, co gubią się w gąszczu ideologicznych niedomówień, półprawd i półkłamstw i przez to nie sa już tak zewnątrzsterowne. Jeszcze wierza, ale ta bezkrytyczna wiara w demokrację przyzwala na tolerowanie złych wyborów, ale także kruszy tą wiarę.

W naszej epoce uzbrojonej globalizacji marzenia o demokracji sa już definitywnie przegrane - to zdanie twórców równie głośnego, co kontrowersyjnego „Imperium” ${ }^{2}$. Nie tylko oni sa takiego zdania. Podziela je wielu sceptycznie, ale i prospektywnie nastawionych autorów. „Dla nas - pisał D. Korten - którzy dorastali wierząc, że kapitalizm jest fundamentem demokracji i wolnego rynku, koszmarnym przebudzeniem było uświadomienie sobie, że pod rządami kapitalizmu demokracja jest na sprzedaż, a rynek opanowany przez megakorporacje, potężniejsze niż większość państw"83.

\footnotetext{
${ }^{79}$ N. Chomsky, Language and Politics, London 2004, s. 109.

${ }^{80}$ E. Todd, Schyłek imperium. Rozważania o rozkładzie systemu amerykańskiego, Warszawa 2003, s. 23.

${ }^{81}$ P. Virillo, Bomba informacyjna, s. 90.

${ }^{82}$ M. Hardt., A. Negri, Multitude. War and Bureaucracy in the Age of Empire, New York 2004, s. XI.

${ }^{83}$ D.C. Korten, Świat po kapitalizmie, Łódź 2002, s. 11.
} 


\section{6}

\section{DUCH I PRAKTYKA UTOPII}

Od kiedy człowiek uwierzył w to, że regnum hominis może zastapić regnum Dei poszukiwania nowej, postmillenarystycznej postaci zbawienia nabrały innego charakteru zmieniajac radykalnie socjo- i antroposferę. Nieziemskiego sotera zastapił on sam poszukując zbawienia dla siebie i przez siebie, tu, na ziemi i te poszukiwania powoli wiodły ku utopiom czynu, a bodaj pierwsza z takich, jeśli pominiemy anabaptystów z Munster i kilka innych prób tworzenia prawdziwie bożego królestwa na ziemi, były redukcje paragwajskie - eksperymenty jezuitów próbujących stworzyć namiastkę prawdziwie doskonałej, chrystologicznej wspólnoty mającej millenarystyczne korzenie ${ }^{1}$. Te eksperymenty miały już znamiona utopii czynu i takiej sugestii można bronić, mimo iż nie wiemy dobrze, jakie idee je generowały. Nowe drogi ku takiemu zbawieniu wskazał T. More swa skromna książeczką o przygodach Rafaela Hytlodeusa. Nie był aż tak oryginalny, jak się niekiedy powiada, choć z pewnościa przyczynił się do tak wielkiej metamorfozy świata ludzi i pozostaje jednym z największych „poszukiwaczy” odpowiedzi na pytania dla człowieka najważniejsze.

Po wiekach dominacji prowidencjalizmu More, człowiek Kościoła, stworzył jednak swoistą wizję raju utraconego, przywrócił prawie zapomniane tęsknoty za stanem, jaki był gwarancja prostego, pełnego szczęścia ${ }^{2}$ i uczynił to w czasie, w którym pragnienie tego szczęścia osiagnęło punkt szczytowy, czyli w spragnionym życia Odrodzeniu. Takie stany w naszej erze tworzyli wspominani millenaryści czekający na Królestwo Boże na ziemi, choć dodajmy, że wielka odwaga More’a przejawiła się w tym, że odrzucił ingerencję transcendencji przyznając czło-

${ }^{1}$ O. Jan Mazur, Od kerygmatu do ewangelii życia, Radom 2003, s. 88.

${ }^{2}$ W. Welsch, Sztuczne raje, [w:] Nowe media w komunikacji społecznej XX wieku, Warszawa 2002, s. 461. 
wiekowi niebywałe moce stwórcze, widząc jego esencjonalne dobro, co także miało ogromne znaczenie. A poza tym, że człowiek w wizji utopisty postanowił kontynuować boskie dzieło tworzenia, rychło pojawiły się tęsknoty za rajem odnalezionym i poczęto szukać go na wszystkich kontynentach aż do pełnej demityzacji pięknego mitu o krainie wiecznego szczęścia, który przetrwał po dziś w wielu mutacjach. Mogliśmy spotykać go choćby w zachwytach pierwszych antropologów badających społeczności nazywane pierwotnymi i konstatujaccych, że każdy ma swoją ideę utopii zawierającą w sobie równość, sprawiedliwość, wolność od mozołu ${ }^{3}$.

Powiada się, że dopiero wtedy narodziło się myślenie utopijne, co zdaje się tylko nieporozumieniem będącym wynikiem symplifikacji, prostego utożsamienia More'a z pierwszą utopią myśli. Nie wydaje się, by tak było. Człowiek zmuszony do nieustannego antycypowania, przekraczania siebie, wchodzenia w przyszłość, wręcz musi być utopijny, nie można bowiem wiązać nadziei ze stanami będącymi gorszymi od poprzednich, a w marzeniach zwykł przekraczać wszelkie granice wierząc w czyste, spełnione wartości do zrealizowania tu, na ziemi. Poza tym nędza jest wielkim pomocnikiem każdego utopisty, materia, w której pracuje, substancja, jaką żywi swe myśli ${ }^{4}$, a przecież żyliśmy w nędzy przez tysiące lat i utopiści pojawiali się w każdej epoce. Dla wspomnianego wyżej Blocha i wielu innych teoretyków myślenie utopijne wypływa z chęci wyzwolenia się człowieka spod władzy czasu, jest swoista postacia ucieczki przed bieda, samotnościa, starościa, śmiercią i jest zarazem nieustannym poszukiwaniem jedności, zbawienia, poszukiwaniem przepełnionym wiarą w możliwość stworzenia ideału społecznego i w esencjonalne dobro człowieka. Takie myślenie zdaje się tak stare jak społeczności ludzkie marzące o swej pełni. Nietrudno zauważyć, że mimo bankructwa różnych systemów myślowych - pisał T. Delpech - i teorii uniwersalnych, dążenie do ustanowienia królestwa sprawiedliwości nadal pociaga umysły ludzkie ${ }^{5}$. Można nawet wnioskować, iż wzory myślenia utopijnego kreowały demokrację w jej formach i treściach, bo przecież wszelka utopia jest niewyobrażalna bez równości, wolności, sprawiedliwości.

Przyglądając się jej dojrzewaniu do form wieku XVI możemy sugerować, iż utopia rodziła się i rodzi z pragnienia przekroczenia barier czasu dzielących człowieka od innych, lepszych stanów, a my wszyscy, nie od dziś, konstruujemy obraz świata zgodnie z tym, czym chcieliby-

\footnotetext{
${ }^{3}$ N.N. Taleb, The Black Swan. The Impact of the Highly Improbable, New York 2007, s. 192.

${ }^{4}$ E. Cioran, Historia i utopia, Warszawa 1997, s. 66.

${ }_{5}^{5}$ T. Delpech, Powrót barbarzyństwa, Warszawa 2008, s. 57.
} 
śmy, by ten świat był ${ }^{6}$. Tworzymy idealne światy istniejące tylko w wyobraźni kreatorów i z nimi porównujemy siermiężną rzeczywistość, dokonujemy bezlitosnych sądów nad nią z perspektywy zawieszonego poza czasem ideału manifestując często wiarę $\mathrm{w}$ to, że sprowadzenie owego ideału na ziemię jest jednak możliwe. Ten nawyk utopistów, czy to wielkich twórców, czy milionów szarych marzycieli, właściwy im od czasów Oświecenia przyniósł w konsekwencji utopie czynu.

Te zastane światy, w których żyliśmy i żyjemy, nigdy nie sa doskonałe, choćby były pełne dóbr i wymyślnych sposobów zaspokajania potrzeb ciała i umysłu. Myślenie utopijne zaś jest myśleniem specyficznie wartościującym, oceną rzeczywistości właśnie z perspektywy ponadczasowego ideału, zrealizowanej sprawiedliwości, równości, wolności. Taki typ myślenia, chyba właściwy człowiekowi od początków istnienia, zapładnia ludzkie umysły pierwiastkami idealnymi i dzięki niemu pojawia się niezwykła dynamika dziejów. Człowiek zaczął określać stany idealne normami absolutnymi, a to, co rzeczywiście było osiagalne, w statystycznych ${ }^{7}$. A przekraczając to, co osiagalne, znów oglądał się na to, co idealne, a aby się do tego przekonywać wcale nie musimy znać dobrze historii. Nie wspominamy o tym, że pojęcia utopii, utopijności nie zostały dobrze skategoryzowane, nie maja nawet nieostrych pól znaczeniowych, ale chyba żaden z czynników jakościowych, konstytuujących pojęcie, nie da się zdefiniować. To oczywiście owocuje nadużywaniem tych określeń, przy czym często mają one wydźwięk pejoratywny i wygląda na to, jakbyśmy sami wstydzili się swoich marzeń o lepszych światach wtedy, kiedy mówimy: „utopia”, „utopista”, „utopijny”. A mówimy tak zbyt często bardziej utopijni niż nam się zdaje.

Dla każdego z nas obcowanie z tym, co idealne jest integralną częścią poszukiwania siebie spełnionego, a samo myślenie utopijne - przekonywał z moca A. Świętochowski - tkwi w „naturze człowieka i za jego sprawa człowiek nie jest gadem pełzajacym po ziemi ${ }^{8}$. Przed pojawieniem się właściwych utopii czynu socjalista miał swoje racje tak widząc zbawienie ludzkości. Dopiero kilka dziesiątków lat później, kiedy pojawiły się pierwsze utopie czynu i okazało się, czym być moga, mogliśmy dopiero konstatować jak wybitny socjolog: „Utopia jednego może być koszmarem innego"9.

Niektórzy powiadaja, że dziś znikło wszelkie myślenie utopijne, ale takie sądy zdają się pobieżne, niczym nieuprawnione ${ }^{10}$. Upadek my-

\footnotetext{
${ }^{6}$ U. Eco, Dzieło otwarte. Forma i nieokreśloność w poetykach wspótczesnych, Warszawa 1994, s. 160.

${ }^{7}$ G. Hofstede, Kultury i organizacje, s. 45.

${ }^{8}$ A. Świętochowski, Utopie $w$ rozwoju historycznym, Warszawa 1910, s. 344.

9 J. Riffkin, The Age of Access, New York 2000, s. 97.

${ }^{10}$ M. Brumlik, Gnostycy, s. 317.
} 
ślenia utopijnego oznaczać musiałby koniec marzeń o lepszym świecie, a takich człowiek nie wyrzeknie się chyba nigdy dążąc do sumy spełnienia wszystkich spełnień. Być może marzenia o równości i wolności doskonałej są dobrami symbolicznymi, starymi jak nasz świat, ale wyraźniej możemy je zauważyć dopiero na początku naszej ery wraz z chrześcijaństwem, choć dysputy o egalitaryzmie i granicach wolności toczyli starożytni Grecy i Rzymianie, a głosy Platona i Lukiana z Samosaty z jego Historii prawdziwej po dziś bywaja przywoływane jako poważne argumenty $\mathrm{w}$ dyskusjach o demokracji, choć równie często i bezzasadnie obaj bywają nazywani utopistami. Owszem, w ich konceptualizacjach pojawiają się elementy utopijne, nieodłączne od dziejów człowieka przesiąkniętego duchem utopii, który szukał i wciąż szuka nowych form ekspresji ${ }^{11}$. Obaj stworzyli wizje społeczności, wedle ich mniemania doskonałych, ale przecież możliwych w ziemskiej kreacji i te, nie jedyne przecież w starożytności, autorskie wizje, te artykulacje nadziei zbiorowych, które zauważali u współczesnych sobie, zdawały się być inspiracjami przez wieki dla tych, którzy poszukiwali „sprawiedliwych" światów człowieka. Obaj wreszcie konsekrowali istnienie dwóch sfer - bytu i znaczenia, a symbole będące nośnikami znaczenia nie maja bytu rzeczywistego - jak zauważał E. Cassirer - za to właśnie maja znaczenie ${ }^{12}$.

Poszukiwanie niejednako rozumianej sprawiedliwości, tożsamej z doskonała równościa, to wręcz filary ludzkiej immanencji, a wartości te, to cele dążeń jednostek i grup, które generowały wielkie procesy społeczne i kulturowe i one wszystkie były na swój sposób utopijne. Absolutyzowane, uświęcane niekiedy wręcz zmieniały świat będąc warunkami zmiany na lepsze, inercji, a czasami nawet zbiorowego szaleństwa $^{13}$. Zbyt często walka o absolutne dobro zamieniała świat w piekło i taka walka o wartości nie zawiera idei pokoju, o czym dziś przekonuja nas wszelkiej maści fanatycy, rzekomo walczący o najlepsze ze światów. Ona skończyć się może wraz z zejściem ideału na ziemię i to ideału prawdziwego, nie do zakwestionowania, choć nie wiemy, czy taki ideał da się w ogóle wyartykułować, jeśli wizje wielu rajów nie przekonuja wszystkich. Nie potrafiliśmy nigdy stworzyć skończenie idealnej wizji, może dlatego, że nieczęsto korygujemy swoje spojrzenie na zachowania zbiorowe przez to, co J. Bentham nazywał indywidualnym „rachunkiem szczęścia”, wspomagającym nas w ustalaniu tego, co jest dobre,

${ }_{11}$ J. Hormon, A.T. Baumeister, Literature and the Political Imagination, [w:] Literature and the Political Imagination, ed. J. Horton, London 1996, s. 23.

${ }^{12}$ E. Cassirer, Esej o człowieku, Warszawa 1977, s. 133.

${ }^{13}$ B. Baczko, Wyobrażenia społeczne. Szkice o nadziei i pamięci zbiorowej, Warszawa 1994, s. 42. 
a co złe, a będącym rachunkiem wartości zrealizowanych. Nieczęsto dlatego, że racjonalizując nie uważamy, iż szczęście jest czymś, co jest wartością. Ono jest jakasś nadwartością istniejąca tylko w odważnych i wstydliwych marzeniach o doskonałości, a poza tym nie jest trwałe.

Tu przeszkodą zasadnicza, poza programową niechęcią nauk społecznych do badania zjawisk jakościowych, w poszukiwaniu istoty jeszcze nierozpoznanych sił sprawczych, takich jak myślenie utopijne, sa ogromne trudności w rekonstrukcji światów wyobrażeń jednostkowych i zbiorowych ludzi przeszłości, niepojętych światów kultury symbolicznej, w których rodzą się wielorakie postacie wizji przyszłości i przeszłości, czyli pamięci zbiorowej. Te światy sa coraz śmielej eksplorowane, zwłaszcza przez psychologów badających zdolność człowieka do tworzenia wyobrażeń czy problemy kodowania, rozumiane jako tworzenie reprezentacji świata, samego siebie i własnych procesów psychicznych, ale ich ustalenia nie wspomagają wysiłków nieufnych wobec nich historyków czy politologów, choć zauważamy, że dziś wydatnie korygują ustalenia przekonanych do tego socjologów. Wydaje się co najmniej zasadne posiłkowanie się ustaleniami badaczy reprezentujących inne dziedziny nauki, jeżeli godzimy się z tym, że postawy i zachowania zbiorowe sa reakcjami afektywnymi na określone symbole. Taka kooperacja, chyba jednak do pomyślenia, mogłaby zbliżyć rozumienie samej utopii i jej „ducha”, a znaczy chyba więcej niż sądzimy, do czego przekonywać będziemy zbliżając to, co nazywamy utopiami czynu.

Przez pięciuset laty altruistyczny, zbuntowany człowiek Renesansu stworzył nowe wizje świata i nowa antroposfery, a jakby konfirmacją tego przełomu była właśnie ta niepozorna książeczka T. More’a, oddająca pragnienie czasu i chyba to przesądza o jej wielkości. To More stworzył paradygmat w ogromnej mierze przesądzający o kształtach wyobraźni społecznej wieków następnych, nie tylko XVI. Dzięki niemu prowidencjalizm i wizje soteriologiczne średniowiecza zaczęły blaknać i na czas jakiś w cieniu znalazły się projekcje millenarystyczne. To More, człowiek Kościoła kontestujący jego role, odkrywał kreatywne moce człowieka równe mocy samego Boga dokonując swoistej egzegezy Ewangelii, powiadając że człowiek sam może stworzyć społeczność doskonałą opierając się o pokłady dobra istniejące w każdym z nas, może zbawić sam siebie w tym okrutnym świecie. Wespół z Erazmem z Rotterdamu mocno akcentowali wiarę w możność radykalnego przekształcenia jednostki, czynienia z niej „człowieka w sobie”14, doskonałego w boskim zamyśle, a prostą konsekwencją takiego założenia była doskonałość społeczna, możliwa jedynie w warunkach wolności i rów-

${ }^{14}$ Erazm z Rotterdamu, Trzy rozprawy, Warszawa 1960, s. 53. 
ności. Apologizując renesansową chrystologię przez suponowanie, że to sam Chrystus stworzył filozofię nazywaną przez nich Odrodzeniem, zachęcali do prób przenoszenia ideału w doczesność, tworzenia zarodów społeczności doskonałej, do prób utopii czynu, które pojawiły się w Niemczech czasu wojen religijnych.

W dużej mierze to dzięki ich odwadze i odwadze interpretatorów formą organizowania nadziei zbiorowych stały się wizje społeczności pełnej, idealnej, złożonej z jednostek doskonałych moralnie, a głęboka wiara $\mathrm{w}$ esencjonalne dobro człowieka towarzyszyła wszystkim twórcom setek wizji utopii myśli powstających po czasy I wojny światowej. Takie wizje obiecywały spełnienie materialne i intelektualne, w nich człowiek stawał się prawdziwym kreatorem. Powstawały wtedy, kiedy człowiekowi brakowało wiary, nadziei i hartu ducha - sugerował swego czasu E. Fromm ${ }^{15}$, także zafascynowany kreatywną moca nadziei jednostkowej i grupowej, które dopełniają się nawzajem, inspirują rodząc utopie. Jednak trudno zgodzić z takim sądem, bo przyglądając się historii utopii na tle dziejów powszechnych zauważymy, iż utopie są właśnie artykulacjami głębokiej wiary i bywały, choć nie wszystkie, nowymi sposobami organizacji czy rytualizacji nadziei zbiorowej, ale niemal zawsze opieranymi o archetyp rajski obecny przecież w soteriologii immanentnej. Być może pojawiają się częściej wtedy, kiedy nasila się to - zauważane przez M. Eliade'a - przekonanie tkwiące w każdym $\mathrm{z}$ nas, że świat powinien odrodzić się od nowa, taki, o jakim marzy$m^{16}$. Nie tylko w okresach kryzysów, jak myślał Hegel i przekonywał Fromm, bo także w okresach prosperity, wtedy bowiem sama rzeczywistość dostarcza wielu przesłanek do takich kreacji. W takich okresach pragniemy nie tylko stabilizacji, ale i polepszenia tego dobrego.

Nie jest naszym celem prezentowanie nawet zarysu sporów o istotę utopii, choć wypada przypomnieć znaczące, traktowane jak odkrywcze, konstatacje K. Mannheima, utrzymującego, że utopia jest postacia świadomości fałszywej, podobnie jak ideologia ${ }^{17}$, czy też rozważania R. Nozicka, Ch. Welsha i J. Talmona, dla których utopia, będąc forma poszukiwań dobra absolutnego $\mathrm{w}$ immanencji, stała się koszmarem, moderowała formy totalizmu przynosząc komunizm, faszyzm, terroryzm wreszcie. Można się godzić z tym, że utopia cały czas sasiaduje $\mathrm{z}$ apokalipsa (rozumiana nie jako objawienie, ale zniszczenie), niekiedy bywa śmieszna, naiwna, ale bywa straszna wtedy, kiedy zbliża się ku rzeczywistości - zauważał E. Cioran ${ }^{18}$. Oskarżanie jej o inspirowanie

\footnotetext{
${ }^{15}$ E. Fromm, Rewolucja nadziei, Poznań 1996, s. 44.

${ }^{16}$ M. Eliade, Traktat o historii religii, Warszawa 2000, s. 433.

${ }^{17}$ K. Mannheim, Ideologia i utopia, s. 49.

${ }^{18}$ E. Cioran, Historia i utopia, s. 69.
} 
zła wydaje się jednak wynikiem prostych komparacji założeń twórców państw totalitarnych z praktyka, a jest w sumie oskarżeniem marzeń człowieka o lepszym świecie, które to marzenia mają rodzić tylko zło. Utopia jest tylko jedna z postaci takich marzeń, mutacją millenaryzmu i wielu innych postaci nadziei na świat wartości zrealizowanych i wcale nie musi być źródłem zła, takie źródła biją wszędzie tam, gdzie chce się złem walczyć o dobro, a jeszcze mocniej tam, gdzie się chce walczyć o dobro absolutne. Stawała się nim tylko wtedy, kiedy człowiek zbyt szybko, zbyt niecierpliwie starał się osiagnać to dobro doskonałe, co wcale nie znaczy, że musi być koszmarem. Poszukując form transferu idei moglibyśmy zauważyć, że z utopijnej gleby wzrosła demokracja i wiele tendencji uważanych za „postępowe”, a także i to, że oskarżając ją oskarżamy sami siebie, swoją dualność, swoje pragnienia odnalezienia się w tym ideale.

Wobec tak wielu nieporozumień tyczących tej postaci zbiorowej nadziei warto tylko mocniej zaznaczyć pole znaczeniowe samego pojęcia. Utopia to wytwór wyekstrahowany z rzeczywistości i jako nierealizowalny, bywa sytuowany albo „obok” czasu historii, albo w nieokreślonej przyszłości. Utopia zakłada zwykle skończoną doskonałość rozwiązań społecznych, a także moralną doskonałość członków społeczności, która często osiagga się przez nagła iluminację. Autorzy projektów utopijnych przedstawiali się często jako rewelatorzy prawd absolutnych zwykle nie prezentując dróg dojścia do stanu idealnego, uznając przy tym aksjomaty o nadrzędności instancji ontologiczno-aksjologicznej i odnajdując transcendentne sankcje dla swoich projektów, utrzymując przy tym, iż stan idealny jest zdeterminowany przez Boga, Naturę, Rozum, czy Siły Wytwórcze.

Nie wydaje się, by zasadne były sugestie, że utopie są tylko emanacjami potocznie rozumianego, jednostkowego idealizmu, gdy nie sposób nie zauważyć funkcjonalności tych wizji, społecznych reakcji na nie. $\mathrm{Z}$ pozoru dogmatyczni epistemologicznie rewelatorzy ${ }^{19}$ dokonywali wysiłku organizacji czasu zbiorowego na poziomie symbolicznym. Taka funkcja jest „wyraźnie widoczna w przypadku utopii, które egzorcyzmuja przyszłość gromadząc i nadając strukturę nadziejom i marzeniom o przyszłym społeczeństwie" ${ }^{20}$. Takie marzenia i nadzieje były pożywką buntów i rewolucji, przygotowywały największe wydarzenia w historii świata. Zwykle bywały naiwne, niekiedy wręcz infantylne, co nie pomniejsza ich niezwykłej siły, czego nie zauważaja niektórzy badacze.

${ }_{19}$ T. Olson, Millenarism, Utopianism and Progress, Toronto 1982, s. 154.

${ }^{20}$ B. Baczko, Wyobrażenia społeczne, s. 15. 
Zauważaliśmy już, że nie można kwantyfikować czynników konstytuujących utopie, ale także nie można wątpić w ich istnienie konstatując kreatywne role triady: Wolność, Równość, Braterstwo w Rewolucji Francuskiej albo stale obecnej wiary w „sprawiedliwość społeczna”,, wiary która wymusza na rządzących decyzje polityczne. Nie sposób jednak prześledzić dróg, sposobów reinterpretacji ideałów stale obecnych w utopiach, zrytualizowanych bodaj w każdej społeczności, ale to dzięki nim w społecznościach każdego czasu odnajdywano nowe cele w przyszłości, w tym także nowe formy demokracji. Jak wspominaliśmy, More zapoczątkował dwuwiekowe poszukiwania nowego świata, a bodźcami przez cały czas poszukiwań najsilniejszymi, były nadzieje na pełną wolność i czystą sprawiedliwośćci i pewnie takimi pozostaną na zawsze w dziejach człowieka. Poszukiwania lądu podobnego do władztwa króla Utopusa zakończyły się fiaskiem. Poznawano świat taki, jakim on był, a ani Indianie, ani Maorysi nie przypominali poddanych Utopusa i przez jakiś czas tylko tworzono mit „szlachetnego dzikusa”, później zaś ten mit stał się tylko przeszkodą w "niesieniu cywilizacji” i wycierano go z pamięci zbiorowej zastępując „brzemieniem białego człowieka” niosącego prawdziwą cywilizację. Próbowano tworzyć podwaliny idealnego świata podczas Rewolucji Francuskiej i dziesiątków rewolucji XIX wieku i wszystko bezskutecznie, bo zwykle kończyło się na próbach.

Nadzieje na ziszczenie ziemskiego ideału w początku utopii myśli pobudzały nie tylko wielkie ruchy społeczne destruujące porządek feudalny i inspirujące powstawanie podwalin systemów demokratycznych. Poprzedzały je niezwykłe eksperymenty psychospołeczne, które zdaja się nosić wszelkie znamiona „utopii czynu”, a które także znajdują się na marginesach nauk społecznych i co jakiś czas pojawiaja się tylko jako argument w legitymizacji jakiejś nowej/starej idei. Zasadność posługiwania się pojęciem „utopii czynu” tłumaczy się istnieniem utopii realizowanych w praktyce społecznej wedle jakiejś recepty albo ad hoc, niekiedy bez podbudowy teoretycznej, a także dziesiątkami prób tworzenia zaczynów społeczności idealnej, zwłaszcza w wieku XIX, w którym nasiliło się pragnienia usytuowania nadziei nie poza historia, ale „tu” i „teraz”22, a takie nasilenie wydawało się konsekwencja wszelkich niedostatków kapitalizmu i niezrealizowanych obietnic młodych demokracji, niezwykle szczodrych w szafowaniu nimi, obiecujących pełnię życia $\mathrm{w}$ dobrobycie i spokoju. Być może było to także konsekwencja niezwykłych postępów nauki w drugiej połowie XIX wieku, bo wtedy to, w euforii inspirowanej postępem naukowo-technicznym, zdaniem

${ }_{21}$ J. Cullen, The American Dream, Oxford 2003, s. 17.

${ }^{22}$ I. Pańków, Filozofia utopii, Warszawa 1990, s. 74. 
rewelatorów, pojawiła się szansa zbawienia w doczesności, szansa potęgowana tym żywiołowym rozwojem nauki i techniki, które traktowano przecież jak narzędzia zbawienia. Potraktowano je jak przesłanki do wniosków o możliwości stworzenia doskonałego społeczeństwa już w takim czasie. Nie zapominamy przy tym, iż do jakiegoś stopnia „utopistami czynu" byli przywódcy powstań niewolników czy heretycy średniowiecza.

Wiek XIX właśnie jawi się jak wielki poligon prób wieku następnego i to nie tylko poligon totalitaryzmów, jesteśmy bowiem przekonani, że utopiści myśli i czynu inspirowali, antycypowali nie tylko społeczeństwo dobrobytu, ale i unifikacje regionalne i globalne, a także sama globalizację. Wielu utopistów, zwłaszcza romantycznych, chciało weryfikować fragmentaryczne, niespójne wizje z praktyką i wielu to czyniło, a wtedy utopie stawały się dziełem zbiorowym, innym jakościowo od utopii myśli i stawały się utopiami czynu. Czasami dopiero, na gruncie praktyki, weryfikowano pierwotne założenia albo je modyfikując, albo zarzucając eksperyment, jak czynili to polscy twórcy utopii czynu (Koło Towiańskiego, Bracia Zjednoczeni, Gromady Ludu Polskiego). Wspominamy o tym pomijajac eksperymenty Owena, Fouriera, Noyesa. Nikt nie pokusił się o nazwanie ich utopijnymi, ale akty fundujące te wspólnoty noszą wszelkie znamiona utopii czynu.

Ale to zwłaszcza francuscy prorocy nowych światów głęboko wierzyli w to, że inicjuja zmiany będące albo wymogami Rozumu, albo założone w boskich planach świata, choć ci rewelatorzy nie przekroczyli granic zła tak dalece, jak ich następcy w wieku XX. Niepowodzenia swoich eksperymentów interpretowali inaczej niż ci, którzy uznali, że dobro można czynić przez zło. Wedle nich, godzacych się z fiaskiem eksperymentów, człowiek nie dojrzał jeszcze do realizacji idei doskonałości, ale taki czas niewatpliwie nadejdzie i to przekonanie artykułowano jak pewnik. Twórcy wielu utopii czynu nie zauważali komentarzy P. Proudhona, twierdzącego z sarkazmem po upadku Ikarii Cabeta, że „komunizm to filozofia nędzy”, komentującego autokratyczne zapędy utopijnych rewelatorów, którzy „z urzędu dzierżą w swym ręku cały zasób rozumu, wolności, godności człowieka" ${ }^{23}$. Komentując w taki sposób niepowodzenia Ikarian w Nauvoo Proudhon antycypował kształty późniejszych utopii czynu uważając, że przyczyną zła jest bezkrytyczna wiara w esencjonalne dobro człowieka i chęć jak najszybszego zrealizowania wartości doskonałych. A krytykując sam pozostał utopijny, choć nie był utopista poszukując innych form zbawienia dla uciśnionych, tworząc dla nich swoją „religie”.

${ }^{23}$ P. Proudhon, Wybór pism, Warszawa 1974, t. I, s. 30. 
Amerykański eksperyment E. Cabeta, tak goraco dyskutowany w Europie, potwierdził raz jeszcze, że bez użycia przemocy nie da się wyzwolić całego dobra w człowieku ani osiagnąć pełni wartości i z pewnością w dużej mierze przesądził o tym, iż od początków lat 50. XIX wieku aż po jego kres nie podjęto już prób na taką skalę, choć nie znaczy, że je porzucono. Doświadczenia Ikarian i innych eksperymentatorów były długo analizowane i komentowane, zwłaszcza przez Amerykanów i być może w jakiejś części za ich sprawą socjalizm i komunizm w Stanach nie zakorzeniły się tak, jak w Europie, choć pewnie główna przyczyna była „amerykańska wiara”, która zbliżamy gdzie indziej ${ }^{24}$. Mimo niepowodzeń eksperymentatorów rozległy się liczne głosy sugerujące możliwość osiąnięcia stanu idealnego pod warunkiem innego, lepszego wykorzystania „materiału ludzkiego”. Zdawano sobie sprawę z tego, że pełne potępienie prób Cabeta, Owena, Fouriera oznaczać może atrofię nadziei na nowy, lepszy świat, zakwestionowanie ideałów.

Utopie myśli ożyły w nowym „czasie nadziei”, a pamięć o niepowodzeniach wielu utopistów czynu falsyfikowano, zacierano, utrzymując przy tym, że nauczeni doświadczeniami następcy unikną takich błędów, jak tamci. Ożyły za sprawą socjalistów chcących na nowo zorganizować zbiorowe nadzieje milionów ludzi pracy najemnej zyskujących statusy „grup dla siebie” w ostatnich latach XIX wieku. Taka reorganizacja byłaby niemożliwa przez formy relatywnie wysublimowane, jakie zauważyć możemy choćby u Sorela, krytykującego demokrację jako dzieło oszustów i manipulatorów ${ }^{25}$, poszukującego idealnych rozwiązań niezbyt zrozumiałych dla ludzi pracy najemnej. Pojawiła się potrzeba wykreowania wielkich wizji, rytualizacji starych mitów wolności, równości, sprawiedliwości, wskazania ludzkości nowych celów i socjaliści różnych maści zrozumieli ją bodaj najlepiej. Prawdziwą eksplozję „klasycznego" utopizmu przyniosły lata 90., choć mało kto zauważał utopie amerykańskie i ich inność. Utopiści zza oceanu (J. Clopper, J.F. Cooper, G. Tucker) zakładali ewolucyjność zmian i możliwość takowych. Ale to nie oni przydali nowych impulsów utopizmowi, a amerykański sympatyk socjalizmu E. Bellamy.

Jego wielkie wizje, jego konceptualizacje, zdają się być wyjątkowe, godne porównania z tymi More'a ze wzglądu na niezwykłą kreatywność. Budziły zachwyty intelektualistów przełomu wieków, inspirowały kreatorów nadziei dostarczając im tworzywa propagandowego $\mathrm{w}$ tworzeniu nowego obrazu świata-ideału już w innych warunkach. Było to o tyle łatwe, że wielu z nich zniechęciło się do praktyki demo-

\footnotetext{
${ }^{24}$ A. Sepkowski, Poczatki misji. Narodziny amerykańskiej „religii obywatelskiej”, Toruń 2008.

${ }^{25}$ J. Sorel, Złudzenia postęu, Kraków 1912, s. 12.
} 
kracji, jak choćby późniejszy chwalca systemu radzieckiego J. Reed ${ }^{26}$, autor głośnej książki o dziesięciu dniach, które wstrząsnęły światem. Podobieństwa niektórych propozycji Bellamy'ego do praktyki radzieckiej lat 20. sa wprost uderzające, a choćby jego pomysł na „komunizm wojenny" zdaje się wyglądać prawie jak scenariusz dla poczynań Lenina. Obie projekcje Bellamy'ego to wyidealizowane obrazy świata około roku 2000, w którym, na skutek ewolucji porządku społeczno-politycznego, panuje ład, dobrobyt. Człowiek sam, dzięki sobie, powrócił do raju utraconego, a siła sprawczą tych zmian okazały się powszechna zgoda, ckliwa wręcz miłość, no i etatyzm, wprowadzany przez nieludzko wprost kompetentnych i altruistycznych polityków, dla których dobro wspólne jest wartościa najwyższa. Przejęcie całej industrii przez społeczeństwo okazało się sprawą dla autora dziecinnie łatwą. Po prostu, zarówno pracodawcy, jak i pracobiorcy dojrzeli do uznania takiej formy za optymalna dla wszystkich. W ten sposób naród stał się pracodawca i pracobiorca zarazem, wymagającym, ale i sprawiedliwym, bo każdy obywatel dysponował kredytem publicznym odpowiadającym jego udziałowi w produkcji ${ }^{27}$. Owa dojrzałość była dla amerykańskiego sympatyka socjalizmu niczym innym jak osiagnięciem prymatu „bycia”, ograniczeniem ludzkich przywar, w tym zachłanności.

Równość w ideale Bellamy'ego jest mocno relatywizowana będąc tylko równością praw i obowiązków. Powszechny altruizm pozwalał na bezkonfliktowe zarządzanie gospodarką i dystrybucją dóbr, a także ładził wzajemne układy między poszczególnymi (także socjalistycznymi) podmiotami polityki światowej: Europa, Ameryką i Australią należacymi do, stworzonej bez większych problemów, federacji światowej ${ }^{28}$. Po nim ideał zrytualizowali niezwykle popularni swego czasu autorzy z Th. Hertzka (Freeland. A Social Anticipation), Th. Von Harbou (Metropolis) i I. Donnely (Caesar's Column) na czele, tworzac zbiorowe przekonanie, że ów ideał jest osiaggalny i nie zdawało się, że może być to również ideał niszczycielski, bo to zauważono poniewczasie ${ }^{29}$, już po zainicjowaniu eksperymentów wielkich utopii czynu wieku XX. Ci autorzy upowszechniali wiarę w to, że sama inicjacja utopii czynu stworzy człowieka doskonałego i tak szczęśliwego, że pozostanie mu tylko kontentowanie się swoim szczęściem. W ich przypadku wiara w esencjonalne dobro osiagała granice pełnej apologii rozmaicie interpretowanego ideału Człowieka. Twórcy przepojeni taką wiara zupełnie nie brali pod uwagę realiów, a one były słabymi przesłankami ich wizji.

\footnotetext{
${ }^{26}$ S. Hook, Marxism and Beyond, New Jersey 1983, s. 133.

${ }^{27}$ E. Bellamy, W roku 2000, Warszawa 1890, s. 58.

${ }^{28}$ E. Bellamy, Equality, London 1910, s. 34.

${ }^{29}$ R. Pipes, Wtasność a wolność, Warszawa 2000, s. 314.
} 
To paradoksalne na swój sposób, ale kresem socjalistycznej utopii na zachodzie stał się czas sprowadzenia ideału na ziemię przez bolszewików - powstanie Rosji Radzieckiej i początek wielkich eksperymentów Lenina i Stalina, którzy być może w początkach wierzyli trochę w możliwość stworzenia doskonałej społeczności, ale ta wiara, o ile istniała, załamała się natychmiast po pełnym zwycięstwie. Przestając wierzyć w taką możliwość „ojcowie rewolucji” stworzyli to, co J.M. Bocheński nazwał eschatologia komunistyczną ${ }^{30}$, choć to stwierdzenie pozostało dla autora tylko ozdobnikiem. Po przejęciu władzy nie wiedzieli, od czego zacząć budowę socjalizmu ${ }^{31}$ - co zauważał nie tylko Kołakowski i porzucili naukowe spekulacje, egzegezy Marksa, oglądając się na zwykłego, zabobonnego, wynędzniałego Rosjanina, który marzył o kawałku chleba i dniach spokoju, nawet za cenę tak wygórowaną jak odebranie wolności, niby nie żądając tak wiele dla siebie. Dali Rosjanom marzenia, o jakich ci zwykli, mocno wierzacy, ludzie nie śmieli nawet myśleć, a to, że wiara Rosjan w transcendencję była tak głęboka, miało znaczenie. Zawłaszczyli dziedzictwo odwiecznych ideałów - zauważał R. Conquest ${ }^{32}$, dodając $\mathrm{w}$ innym dziele, że wyznawcy do natury rzeczy zaliczyli to, że dla dobra całej ludzkości trzeba posłużyć się dyktatura i przemoca ${ }^{33}$.

Raz jeszcze, z pewnością nie ostatni, dualny człowiek dał się przekonać, że o dobro niekiedy trzeba walczyć złem. I przynajmniej w początkach nie kwestionował zawłaszczania przez wizjonerów ideałów uniwersalnych ani tego, że owi wizjonerzy zamienili je w prawdy transcendentne zmuszając przeciwników do dowodzenia, iż nie sa to prawdy święte. W samych początkach twórcy nowej Rosji, beztrosko, chyba nie do końca przemyślanie, deklarowali stworzenie idealnego ustroju, nowego, radzieckiego człowieka, a to było, wedle nich, zdeterminowane rozwojem sił wytwórczych, czymś pewnym, choć czas spełnienia nie został określony. Wypełniali więc wszystkie znamiona utopii myśli tworząc ramy dla praktyki społecznej. Realizacja tej utopii myśli w czynie stała się jej oczywistą negacją.

W Rosji kilku tysiącom zdecydowanych na wszystko wyznawców idei udało się najpierw nadać nowy kształt nadziejom milionów wynędzniałych i głęboko wierzących Rosjan, wykorzystać ich najgłębsze rezerwuary wiary dzięki prostym, zrozumiałym hasłom, jakie od stuleci przemawiały do nędzarzy pod każdym słońcem. Ideologowie radzieccy nigdy nie deklarowali tego, co Kim Ir Sen, który wprost przyznał,

\footnotetext{
${ }^{30}$ J.M. Bocheński, Lewica, religia, sowietologa, s. 250.

${ }^{31}$ L. Kołakowski, Gtówne nurty marksizmu, Poznań 2002, t. III, s. 31.

${ }^{32}$ R. Conquest, Przekleństwo wieku, Warszawa 2000, s. 41.

${ }^{33}$ R. Conquest, Uwagi o..., s. 25.
} 
że najpotężniejszymi motorami rewolucji były nędza i ciemnota ${ }^{34}$, ale możemy przypuszczać, iż o tym dobrze wiedzieli. Dla tych milionów chcących wierzyć nędzarzy ustrój zorientowano na cel eschatologiczny $\mathrm{w}$ diamacie i histmacie ${ }^{35}$, ale zapomniano o czymś szczególnie ważnym, zapomniano o tym, że integralną częścią eschatologii jest soteriologia i że będzie to rodziło oddolne potrzeby dopełnienia tej eschatologii, że pojawią się te regulacje typu idealistycznego wymuszające konfrontację teorii i praktyki. Ale w początkach z tych pierwotnych założeń zrodziła się ta wizyjność, atrakcyjność marksizmu-leninizmu-stalinizmu, która tak zachwycała filozofa katolickiego, choć nie przyznawał wprost, że ziemska soteriologia Rosjan skutecznie rywalizowała z transcendent$n a^{36}$. Ona konkurowała z nią ledwie przez kilka lat. A kiedy okazało się, że te naturalne regulacje typu idealistycznego nie potwierdzaja zbawienia na ziemi, porażeni strachem, który zajął miejsce nadziei, Rosjanie zapadli w apatię pozorując uprawianie świeckiej religijności, a po krachu idei zbawienia przez siły wytwórcze w latach 80., powrócili do zbawienia w transcendencji.

Wystarczająco dobrze konieczność prostoty zbawienia rozumiał Lenin mówiący, że rosyjskie masy muszą dostać coś prostego, coś, co moga pojaćc, czyli rady i komunizm ${ }^{37}$. Obiecywano wszystkim (także kucharkom) władzę, dobrobyt, równość, wolność, sprawiedliwość i te obietnice-odwołania do kodowanych w nieświadomości zbiorowej, prelogicznych z natury mitów, zdają się być pierwszą siła rewolucji, nie zaś z pozoru wyrafinowane konceptualizacje Lenina, Stalina i innych teoretyków rewolucji, którzy tylko dostosowywali teorie do praktyki swojej rewolucji tworząc hermetyczne dzieła, niezrozumiałe nawet dla późniejszych interpretatorów i nie wiemy też, czy rozumieli je sami. Wyznawcom zaś pozostawała tylko wiara w przywódców i ich idee i patrząc na tę rewolucję przez pryzmat dokonań psychologów społecznych można zaryzykować tezę, że ta rewolucja powiodła się i mogła powieść w społeczeństwie czystej wiary, a Rosjanin archaiczny i magiczny był wtedy jednym z najgłębiej wierzących Europejczyków, co potwierdzają liczne świadectwa kulturowe $\mathrm{z}$ wielką literaturą rosyjską w początku. Jego wiara, z natury prelogiczna, była tak zakorzeniona w postaci swoistego, rosyjskiego cezaropapizmu, że zamiana Boga na człowieka mogła się powieść przy użyciu narzędzi tak skutecznych jak nadzieja i idący za nią strach. Być może dlatego ideologia przybrała postać

\footnotetext{
${ }^{34}$ W.J. Dziak, Kim Ir Sen, Warszawa 2001, s. 92.

${ }^{35}$ R. Imos, Wiara człowieka radzieckiego, Kraków 2006, s. 53.

${ }^{36}$ J. Alfaro, Teologia postepu ludzkiego, Warszawa 1971, s. 25.

${ }^{37}$ B. Wiliams, Lenin, Wrocław 2002, s. 73.
} 
„świeckiej religii” - jak widział to polski poeta tratując ową „religię” jak metaforę ${ }^{38}$.

Nie był oryginalny, gdyż przed nim dostrzegał to ostrożny Schumpeter. Wedle niego marksizm-leninizm był religia w „pewnym sensie”, ale system celów ostatecznych nosił znamiona eschatologii i soteriologii określającej sens życia, wymuszającej absolutne normy nieosiagalne dla zwykłego człowieka. Zawierał także plan zbawienia dla zbiorowości wskazując zło, od którego komuniści mają zbawić ludzkość po zwycięstwie „jedynie słusznej idei” ${ }^{39}$. Dalej autor dodawał, że można nazywać marksizm fałszywą religia albo karykaturą wiary, nie można jednak żadna miara nie podziwiać wielkości samego dokonania. A tym dokonaniem była soteriologia ziemska - wszystkie obietnice zbawienia tu i teraz, których siły nie doceniali analitycy mówiący enigmatycznie o stanach świadomości społecznej. Nie podzielamy jednak tego swoistego zachwytu Schumpetera synkretyzmem, jaki uznano za konceptualizacje niezwykle oryginalne. Jeśli przyjrzymy się planom zbawienia rysowanym przed Rosjanami dostrzeżemy tam kopie konceptualizacji millenarystów, utopistów XIX wielu (od których tak się odżegnywano), a przede wszystkim pomysłów Bellamy'ego. I to już zakrawa na paradoks, bo amerykański intelektualista, „tylko” sympatyk socjalizmu, może uchodzić za jednego z „ojców” rosyjskiej utopii czynu.

Opisujacy dzieje Związku Radzieckiego jako „historię pewnego złudzenia” F. Furet dokonał niezwykle ciekawej analizy początków Rosji Sowieckiej suponując, że to niepojęte powodzenie, obcy, nieznani zwykłemu Rosjaninowi bolszewicy, zawdzięczali zupełnemu wyczerpaniu się nadziei zbiorowych i jednostkowych w okresie wojny, spotęgowaniu się tęsknot za zwykłym życiem sprzed wojny, które wydawało się rajskim. Tęsknoty za tym „rajem utraconym” zrodziły tak potężne ruchy, które miały przetrwać tak długo, jak nadzieja na zbawienie przez owe rajskie idee. Ich śladami poszli inni utopiści czynu - faszyści włoscy i niemieccy, różnice między którymi zdają się francuskiemu uczonemu kosmetyczne ${ }^{40}$, choć można zauważyć inna ,gospodarkę" dobrami symbolicznymi w Rosji i Niemczech, która przełożyła się na jakość poparcia Stalina i Hitlera przez ich społeczeństwa. Podobieństw między totalitaryzmami jest oczywiście wiele, a oczywista jest równość wobec władzy - równość w strachu, wielkim i szalonym w Rosji i reglamentowanym w Niemczech. Różnic także sporo. W Niemczech idee zbawienia były kultywowane przez lumpeninteligencję, tak często roszczącą sobie

${ }^{38}$ Cz. Miłosz, Zniewolony umyst, Kraków 1989, s. 17.

${ }^{39}$ J.A. Schumpeter, Kapitalizm. Socjalizm. Demokracja, Warszawa 1995, s. 5.

${ }^{40}$ F. Furet, Przeszłość pewnego złudzenia. Esej o idei komunistycznej w XX wieku, Warszawa 1996, s. 265. 
prawa do wskazywania dróg społeczności, w Rosji natomiast takie role pełniła serwilistyczna nowa inteligencja, akolici nowej wiary. Rosjanie mocno wspierali się o tradycje religijne, Niemcy zaś o filozofie marginesu, w tym ariozofię, co miało dodawać ideologii „obiektywizmu” ${ }^{41}$.

Złudzeniami bliskości ideału karmili się nie tylko Rosjanie. Twierdzi się powszechnie, że intelektualiści europejscy, poza nielicznymi wyjątkami (Orwell, Koestler), byli zauroczeni jakością rosyjskiego eksperymentu socjalistycznego, ale nagły zanik utopii socjalistycznych na zachodzie Europy zdaje się podważać ten utarty sąd, utopie myśli bowiem powstawały właśnie w kręgach intelektualnych, choć nie kwestionujemy tego, że zbyt wielu wielkich z tych kręgów uległo zauroczeniu, po części stąd, że socjalizm miał wielką siłę mitotwórczą, a kapitalizm nie ma jej prawie wcale - pisał ze spora przesada P. Berger ${ }^{42}$. Naszym zdaniem zauroczenie intelektualistów miało także inna przyczynę. Oto przez stulecia byli depozytariuszami idei utopijnych nie mając nadziei na ziszczenie ideałów i niespodzianie, po klęsce całego gatunku, ujrzeli możliwość i uwierzyli. Taką wiarę można było zauważyć u amerykańskiego muckrakera L. Steffensa, który po obejrzeniu kilku wsi potiomkinowskich w 1920 roku, pisał: „To nie fantastyczny sen. Takie doskonałe społeczeństwo jest w każdej chwili budowane w Związku Radzieckim" 43 .

Widząc powstającą utopię czynu, będąca jakby zwieńczeniem wysiłków twórców setek utopii myśli, jakby zwątpili w umysł, a w tej właśnie grupie zauważyć można - to zauważał R. Rorty - zwycięstwo pragnienia pewności nad potrzebą mądrości ${ }^{44}$. Pragnący pewności zdawali się nawet obawiać krytycznych analiz pism Lenina (ta obawa jest zauważalna także dziś) wybierając wyznawczą egzegezę, a wtedy krytyka zdawała się konieczna dla zrozumienia teoretycznych źródeł totalitaryzmu. Sięgnięcie po kilka dzieł „klasyka” dało autorowi więcej niż się spodziewał. Zwłaszcza wizje demokracji socjalistycznej Lenina moga szokować. Prostym wnioskiem wyciaganym z lektury jednego z dzieł jest ten o tożsamości dyktatury proletariatu z demokracja ${ }^{45}$. Dyktatura proletariatu zaś, jak wynika z supozycji w innych miejscach, jest równoznaczna z dyktatem partii komunistycznej. Demokracja więc to dyktatura i tak prezentowała się jedna z prawd komunistycznej wiary. Zdumiewać może też przywiąanie do swoistej mutacji demokracji - demokracji socjalistycznej, jako wyższego stopnia jej rozwoju. Tam

\footnotetext{
${ }^{41}$ N. Goodrick-Clarke, Okultystyczne źródła nazizmu, Warszawa 2001, s. 141.

${ }^{42}$ P.L. Berger, Rewolucja kapitalistyczna, Warszawa 1995, s. 326.

${ }^{43}$ L. Steffens, Letters, New York 1939, s. 182.

${ }^{44}$ R. Rorty, Filozofia a zwierciadto natury, s. 281.

${ }^{45}$ W.I. Lenin, Rewolucja proletariacka a renegat Kautsky, Dzieła, t. 28, s. 257.
} 
postępowano tak, jak radził Tertulian, każący wierzyć w coś właśnie dlatego, że jest to absurdalne. Wierzono w to, co mówili i pisali „klasycy", ale do czasu największą wiarę pokładano w promiennym jutrze komunizmu i pełni zbawienia w doczesności.

Do czasu, bowiem służalczym, prymitywnym ideologom nie udało się usytuować soteriologii komunistycznej w długim czasie nadziei, a krótkie jej czasy wyczerpały się w latach 20., kiedy większość z tych, którzy po swojemu racjonalizowali obrazy swego świata, poczęła zauważać, że świetlane wizje przyszłości zmieniają się w ponurą szarość i nic nie zapowiada odmiany ${ }^{46}$. Widząc atrofię nadziei, która rodziła przecież entuzjazm dla nowego ustroju, politycy-ideologowie obrócili się w stronę strachu i Rosja Stalina stała się krajem strachu, którego kształtów i ról jeszcze nie rozpoznano. Później, o upadku Rosji Radzieckiej przesadził upadek ideologii, która łączyła wyznawców, tak widział to D. Bell doceniający, a niekiedy przeceniajaccy czynniki ekonomicz$n \mathrm{e}^{47}$. Właściwie początkiem końca wspólnoty wiary w ideały, była utrata nadziei na ich ziszczenie, a jej wyraźne symptomy były zauważalne w początkach lat 60 . Wyraźne tylko dla tych, którzy potrafią odnajdywać przesłanki jakościowe do wniosków prospektywnych, a takimi okazali się ci, którzy posługiwali się współczynnikiem licentia poetica.

Zarówno socjalizm radziecki, jak i niemiecki po rok 1939, zdawały się wykazywać wszelkie znamiona utopii czynu. Obie ideologie proponowały idealne społeczeństwo złożone ze swoiście doskonałych jednostek, obie odnajdywały transcendentne sankcje dla takich kreacji, obie sytuowały osiagnięcie celu poza czasem historii, choć to ostatnie można zakwestionować. Z pewnością obie orientowały się na dążenie do umownego, metaforycznego dobra przez zło dokonując jakby konsekracji metod terroru państwowego. W obu państwach przekroczono granice tego zła, o które tylko ocierali się wcześniejsi, francuscy i amerykańscy utopiści czynu. I tu i tam swoiście interpretowano równość, wolność i sprawiedliwość projektując inne ich formy w przyszłości. I tu i tam sięgnięto po strach, kiedy wyczerpały się nadzieje zbiorowe. W obu także przypadkach przekonywano, że liczy się cel, nie środki, a ideały bywają celami nadrzędnymi.

Nowa organizacja nadziei zbiorowej szybko zaowocowała stworzeniem nowych jakości państwowych i społecznych. Nie jest łatwo zrekonstruować ten proces w Niemczech hitlerowskich, ale raczej nie ulega wątpliwości, że w bardzo krótkim czasie społeczeństwo zintegrowało się na nowych podstawach nie bez pomocy aparatu przymusu. Tu

${ }^{46}$ E. Morin, O naturze Zwiazku Radzieckiego, Warszawa 1990, s. 28.

${ }^{47}$ D. Bell, As we go into the Nineties, [w:] The United States un the World Political Economy, ed. T. Reuter, New York 1994, s. 381. 
pojawia się pytanie, na które nie ma odpowiedzi, pytanie o to, dlaczego stało się to tak szybko, choć wiele działań przekonuje, że nie był to proces przemyślany. Większe kłopoty z kreowaniem i rytualizacją nadziei mieli Rosjanie, nie radząc sobie z tym nie tyle po czasy M. Gorbaczowa, co Putina, który przekonywał się w styczniu 2005 roku, czym może grozić atrofia nadziei. W czasach Lenina i Stalina zapowiedziom stworzenia społeczności doskonałej nie towarzyszyły materialne potwierdzenia, a na odwrót, nadzieje jednostkowe nie pokrywały się z tymi, które prezentowano jako zbiorowe i ten dysonans w znaczący sposób zagrażał koherencji społecznej. Zmniejszano go, a raczej tuszowano przy pomocy środków przymusu, ale takimi środkami tylko pogłębiano regres, bo dysjunktywnej, regresywnej funkcji strachu nie sposób nie zauważyć.

Wydaje się, że w początkach Rosjanie popełniali kardynalne błędy, których później uniknęli Niemcy. W początkach tworzenia swego Kraju Rad, w rewolucyjnej euforii, ideologowie konkretyzowali metafory obiecując osiagnięcie ideału jeszcze za życia świadków przemian. Widać to w poezji Majakowskiego, dokonaniach teoretycznych A. Łunaczarskiego, ale najlepiej w wydawanej w wielotysięcznych nakładach literaturze pięknej, kreującej wspomniana nieświadomość zbiorowa, której istotę starał się wyjaśniać L. Pervin. Wedle psychologa nieświadomość poznawcza (niekontrolowane przetwarzanie informacji) odnosi się do tych zjawisk, z których nie zdajemy sobie sprawy, które nie staja się przedmiotem świadomego myślenia dopóty, dopóki nie zajda jakieś szczególne okoliczności ${ }^{48}$. Społeczność co jakiś czas znajdowała się w takich „szczególnych” okolicznościach, wtedy zwłaszcza, kiedy pojawiały się nowe wizje promiennej przyszłości i kiedy konfrontowano je świadomie z uprzednimi, a podobnymi obietnicami, no i z szara, biedną rzeczywistością. Nie tylko literatura upewniała „lud pracujący”, że względny dobrobyt tożsamy z zapewnieniem podstawowych potrzeb miał być kwestią najbliższej przyszłości, ale jej wpływ na kulturę symboliczna i normatywną zdaje się tak duży, że poświęcimy jej nieco miejsca.

Sztandarową wizję komunizmu współtworzyli autorzy tacy, jak: J. Łarri, J. Guriewicz, A. Bielajew, W. Obruczew, poszukujący zastępczych form nadziei spełnienia dla zniewolonego, spauperyzowanego narodu, przekonywanego do stale nasilającej się walki klas i konieczności zaciskania pasa dla wspólnego dobra. Formuła „jesteśmy biedni jako Rosjanie, ale potężni jako Związek Radziecki”, wymyślona w latach trzydziestych i funkcjonująca po nasz czas mimo tylu radykalnych zmian, nie mogła wystarczać tym, którzy, mimo wszystko, zauważali przepaści między oficjalnymi wizjami a nadziejami zbiorowymi i indy-

${ }^{48}$ L.A. Pervin, Psychologia osobowości, s. 218. 
widualnymi rodzonymi przez byt, a przecież on jednak określa świadomość. Nie wystarczała także obezwładniająca formuła J. Safronowa, zawarta $\mathrm{w}$ tytule sztandarowej powieści kreatora nowego czasu nadziei. Komunizm - suponował autor - zobaczą dopiero wnukowie naszych wnuków, ale to nie zwalnia nas od odpowiedzialności za daleka, ale przecież wyobrażalna, promienna przyszłość ${ }^{49}$. Hasło pracy dla dobra przyszłych pokoleń znamy także z naszego gruntu, a przecież oznaczało ono praktyczną niemożność kolonizowania naszej indywidualnej przyszłości w imię lepszego życia nas samych. Wierzacym pozostawała tylko pracowita egzystencja w szarości

Społeczeństwu tej utopii czynu odebrano nadzieje na ziemski raj dając ludziom w zamian równość biedy w imię świetlanej przyszłości wnuków naszych wnuków i pozostawał bunt albo marazm. Każda próba, a nawet podejrzenie buntu, była niszczona w zarodkach, ale jego symptomy można było zauważyć w zachowaniach tych, którzy swego czasu pozostawali „sumieniem narodu” i w dokonaniach pisarzy radzieckich były to symptomy wielce znamienne. Trzeba zauważyć, że w roku 1956 ukazała się powieść I. Jefremowaa Mgławica Androme$d y$ i była to ostatnia literacka apologia komunizmu przez liczacego się twórcę. Odtąd piszący i wydający w ZSRR autorzy omal nie zauważaja przyszłości komunizmu, co widać tak dobrze zwłaszcza w dorobku A. i B. Strugackich, D. Bilenkina, czy K. Bułyczowa. Bez trudu można dostrzec, że twórcy zmierzaja ku eskapistycznemu, „małemu realizmowi” i dystopii przemycając w swoich powieściach całkiem nieprawomyślne treści jakoś niezauważane przez cenzurę, co nawet powinno dziwić.

W jednej z powieści braci Strugackich czytelnik rosyjski i nie tylko, mógł znaleźć niezwykła, czytelną metaforę komunizmu - dziwnego promieniowania, które „oddziaływało na układ nerwowy każdej istoty ludzkiej (...) jego istota sprowadzała się do tego, że mózg poddany napromieniowaniu tracił zdolność krytycznej analizy rzeczywistości. Człowiekowi, który znajdował się w polu promieniowania można było, za pomoca najprymitywniejszych środków wmówić każdą rzecz i poddany takiej sugestii uważał wtłaczane mu do głowy brednie za święte i jedyne prawdy, za które warto było żyć i umierać" ${ }^{50}$. Takie przesłanie było aż nadto czytelne. Nie tylko w Związku Radzieckim państwo nazywano „strefą" wykorzystujac inną metafore Strugackich z Pikniku na skraju drogi. W tej powieści bohater Stalker to prawdziwy myśliwy, który w imię przeżycia musi poruszać się w „strefie”, niby pozostałości po wizycie kosmitów, którzy nawet nie chcą skontaktować się z ziemia-

${ }_{49}$ J. Safronow, Wnuki naszych wnukow, Moskwa 1949, s. 35.

${ }^{50}$ A. i B. Strugaccy, Przenicowany świat, Warszawa 1971, s. 264. 
nami, najwidoczniej gardząc nimi, a w niej, tych kosmicznych śmieciach, jak ma się trochę szczęścia, można znaleźć wiele pożytecznych rzeczy. A „strefa” jest miejscem, w którym wszystko jest niebezpieczne, nawet to, co wczoraj nie groziło niczym i, by przeżyć, trzeba uczyć się niezwykłej sztuki przetrwania, by dożyć do następnego dnia. Nietrudno odgadnać, iż owi „kosmici” to dla Strugackich komuniści, ziemianie zaś to zwykli Rosjanie.

Powieści, które ukazywały się w latach 60 . ubiegłego wieku były nie tylko przejmujacymi dystopiami, ale przede wszystkim potwierdzeniem atrofii nadziei zbiorowych elit intelektualnych. Autorzy radzieccy, a rychło za nimi polscy, mocno i czytelnie przejawiali nieufność wobec wizji promiennej przyszłości oferowanej przez partyjnych technokratów, a tym samym tej swoistej „ideologii utopijnej”. Pole Strugackich od razu zostało zinterpretowane jako ta ideologia systemu i to bez hermeneutycznych wskazówek. Nie brakowało literackich manifestacji niewiary w deklarowane przez rządzących dobro, na co dzień widziano siermiężność, biedę, różnice społeczne. Takie zło stanowi tło niezwykłych opowiadań K. Bułyczowa i dziesiątków powieści twórców ostatnich dekad Związku Radzieckiego. Daremnie propagandyści późnych lat 70. utrzymywali, że „socjalizm jest nieuniknionym przeznaczeniem ludzkości" ${ }^{\prime}$, bo takie sugestie były przyjmowane z obojętnością bliska apatii nie tylko przez intelektualistów, ale i zwykłych ludzi. Nadzieje na realizację ideału wyczerpały się zupełnie i Związek Radziecki implodował, żegnany raczej bez żalu przez większość obywateli, którzy dziś równie obojętnie przyjmuja zapewnienie o zbawczych rolach demokracji. Pokłady rosyjskiej wiary w spełnienie zdaja się coraz mniejsze, choć zdumiewać może bezkrytyczna wiara zwykłych obywateli Rosji w sotera, jakim jest dla nich W. Putin.

Socjalizm w jego sowieckiej postaci został zniszczony przez tych, których nadzieje zawiódł. Potwierdziła się praktyka utopistów czynu z wieku XIX, tak żarliwie pragnących sprowadzić ideał pełni szczęścia na ziemię. Spotykały ich takie same klęski, jak tych, którzy projektowali szczęśliwość komunizmu. Zostali unicestwieni przez tych, których dobra rzekomo poszukiwali. Siłę nadziei zbiorowych i wiary w ziemskie zbawienie potwierdzali także ci, którzy analizowali historię Solidarności, twierdząc choćby, że robotnicy walczyli z socjalizmem dlatego, że nie dotrzymał obietnic ${ }^{52}$. Istotne jest właśnie to, że to robotnicy, mocniej niż racjonalizująca inteligencja, zakwestionowali komunistyczna soteriologię, oni nie maskowali rozziewu między obietnicą a rzeczywi-

${ }^{51}$ G. Szachnazarow, Socjalisticzieskaja sudba cziełowieka, Moskwa 1978, s. 9.

${ }^{52}$ N. Easterbrook, State Heterotopia, [w:] Political Scence-Fiction, eds D.M. Hassler,

C. Wicox, Columbia University 1977, s. 44. 
stością metaforami czując swoją siłę, którą zresztą przez dekady wmawiali im ideologowie nie czujący zagrożenia ze strony tych ludzi wiary. W ich przypadku uwewnętrznione oczekiwania lepiej służyły jako zasada „kontroli rzeczywistości” ${ }^{33}$.

Utopia jest zwykle uniwersalna, w swoich ramach zamyka cała ludzkość i w ogromnej mierze dzięki niej nie przestajemy marzyć o tym pokojowym, globalnym superplemieniu, jakie zapewni powszechne szczęście. Takie marzenie może stać się rumowiskiem już po położeniu pierwszych cegieł, jeśli będzie realizowane z żarliwością utopisty, a tak było z projektem prezydenta Wilsona. Dziś trzeba na czas jakiś zapomnieć o nim mając na uwadze kształty naszego świata. D. Morrisowi wydawało się, że jedynie zagrożenie z zewnątrz, z kosmosu, mogłoby być spoiwem dla ludzkości, choć i dla niego to nie jest takie pewne ${ }^{54}$. $\mathrm{O}$ tych marzeniach wspomnimy jeszcze niżej

$\mathrm{Z}$ ducha utopii przesycającego światy symboliczne wyrastała idea społeczeństwa globalnego, zwykle traktowana jako utopia, choć nie nosi wszystkich znamion utopii, a czy jest utopijna? Tylko wtedy, jeśli uznamy, że utopijność można stopniować, a tak często widzi się ją w nauce usprawiedliwiając taki zabieg na sposoby niekiedy ekwilibrystyczne. Takie społeczeństwo tylko w połowie ma transcendentne sankcje racjonalności (o której nie wiemy czym jest), w połowie ma być doskonałe, $\mathrm{w}$ połowie poza historia. Jednak i w tych kształtach utopia funkcjonuje $\mathrm{w}$ światach symbolicznych przez wieki, żywotna, niezniszczalna, mocno zakorzeniona $\mathrm{w}$ archetypach. Wieczna kraina szczęścia - mutacja archetypu rajskiego przez wieki była marzeniem człowieka bojącego się każdego następnego dnia i takim marzeniem pozostaje. Widzimy to $\mathrm{w}$ wielu nie stykających się ze sobą kulturach. Istniała jakby w dwóch wymiarach: praktycznym i idealnym, przeplatając się, uzupełniając, zwalczając, zniechęcając i znów kusząc idealistów. Ta „gorzka tęsknota” za państwem globalnym, jak nazwał ją G. Tinder ${ }^{55}$, stała się idea powrotów, tak trwała, że nie sposób jej nie dostrzegać.

Ten praktyczny wymiar to wielkie próby podboju całego świata barbarzyńców powodujace praktycznymi Grekami i wojowniczymi Rzymianami przez wieki walczącymi o pokój. Grecy pragnęli poznać i cywilizować cała oikumene, stać się hegemonem dla wszystkich i choć odnosili wiele sukcesów na takiej drodze, to przegrywali u siebie sami ze sobą prowadząc swoje liczne myomachie. Rzymianie natomiast stworzyli generująca ideę pax Romana marząc o podboju całego znanego świata i przekonujac się, że granice świata człowieka są niezmierzone.

${ }^{53}$ P.L. Berger, Rewolucja..., s. 331.

${ }^{54}$ D. Morris, Ludzkie Zoo, s. 46.

${ }^{55}$ G. Tinder, Myślenie polityczne, Warszawa 2003, s. 53. 
Rzym, niezmiennie ekspansywny, załamał się pod ciężarem takich wysiłków, ale ta idea została przejęta przez triumfujace chrześcijaństwo i mutacja rzymskiej była karolińska idea pax Christiana przywołująca legitymację apostołów i inspirujące podboje pod znakiem krzyża. Kultywowano ja z nadzieja, że zdominowanie całego świata i oparcie go na fundamentach wiary będzie uwieńczeniem marzeń o świecie spełnienia, prawdziwym Królestwie Bożym, ale nie w wersji millenarystów a Kościoła i marzycieli takich, jak papież Hildebrand-Grzegorz VII. Ku takiemu Królestwu Bożemu dążono w wyprawach krzyżowych z nadzieja, że z boską pomocą uda się podporządkować i uporządkować cały znany świat.

Spoiwem dla wszystkich zwolenników globalizmu była i jest ciagle wizja lepszego, pokojowego ładu dla wszystkich, bez względu na narodowość i kolor skóry. Zdaje się wyrastać z utopii i bywa traktowany jak „utopizm”, choć nie był takim dla tych, którzy w państwie globalnym widzieli cel rozwoju ludzkości. Ta idea niezmiennie towarzyszyła Amerykanom chcącym ziścić ich założycielski mit „miasta na wzgórzu” - idea ukryta, będąca zbiorowym marzeniem i generujacca działania polityczne czy to w postaci Manifest Destiny, czy w innych. Objawiła się światu z chwilą wchodzenia Ameryki w wojnę światową i wtedy to W.Lippman uprzedził deklaracje prezydenta Wilsona piszac na łamach „New Republic”: „Wielka nadzieja świata to nic więcej jak Federacja Światowa" 56 . Sam misyjny prezydent czuł wielka misję prowadzenia ludzkości do nadnarodowego społeczeństwa opartego na prawie. Jeszcze przed przystapieniem Stanów do wojny innym misyjnym idealistom wydawało się, że rząd światowy powstanie, a Wilson stanie się zbawca ludzkości ${ }^{57}$. Wiele wskazuje na to, że prezydent chciał tego, takie idee propagowała otwarcie wspierana przez niego organizacja zwana Liga do Wymuszania Pokoju (Liga Tafta).

Praktyczni Amerykanie, wspomagani zreszta w tym przez Europejczyków, ograniczyli jednak wizjonerskiego Wilsona i nie wierząc w stworzenie ex nihilo państwa globalnego, proponowali i akceptowali pokojowy ład świata oparty o silna, demokratyczną organizację międzynarodową rozwiazująca problemy globalne środkami pokojowymi. Po z pozoru przychylnym przyjęciu projektu Wilsona i ożywionych dyskusjach, w lipcu 1918 roku świat ujrzał Pakt Ligi Narodów. Zdawać się mogło, że potencjalny zawiązek rządu globalnego stawał się faktem politycznym i wzorem dla wszystkich zwolenników globalizmu, w tym późniejszych twórców ONZ.

${ }^{56}$ W. LaFeber, The American Age, New York 1989, s. 49.

${ }^{57}$ N.G. Levin Jr., Woodrow Wilson and World Politics, London 1970, s. 180. 
Sama idea została jakby konfirmowana stworzeniem Ligi Narodów mimo częściowego niepowodzenia i jej depozytariuszami stały się europejskie autorytety z H.G. Wellsem na czele, którego zdania nie można było nie słyszeć, zwłaszcza po tym, jak ukazała się jego książka The Shape of Things to Come, w której antycypował nie tylko II wojnę zaczynajaca się od konfrontacji Polski z Niemcami, a kończąca stworzeniem Związku Państwa Nowoczesnego - uniwersalnej państwowości dbałej o interesy wszystkich jej obywateli. Wedle siebie Wells nie był utopistą żądając niemożliwego, a jego projekty z innej pracy wcale nie wydaja się mrzonkami. Postulował powszechna ochronę naturalnych bogactw planety, stworzenie jednego prawa dla wszystkich państw i wymuszanie jego przestrzegania oraz ustalenie federalnej kontroli transportu i komunikacji międzynarodowej58, a podobne postulaty i dziś nie wydają się „utopijne”. Wells przejawiał pewność rewelatora ostatecznych prawd powiadając, że rząd światowy, pokój i uniwersalna religia sa przeznaczeniem świata ${ }^{59}$. Droga ku takiemu państwu wolności powszechnego szczęścia stoi otworem - powtarzał po wielokroć - jesteśmy przed granicami Ziemi Obiecanej, ale wysiłek człowieka, by przekroczyć tę granicę, jest wciąż znikomy, ludzkość wciąż wierzy w wojnę, jest nią fascynowana jak królik przez węża - dodawał B. Russel ${ }^{60}$, także „utopijny” jak dziesiątki mocarzy słowa. Te imperatywy wielkich intelektualistów sprzed tylu lat nie zdezaktualizowały się po latach, bo niemal taka samą argumentację spotykamy w Raportach dla Klubu Rzymskiego czy w opracowaniach autorów tworzących w ramach World Order Models Project.

Kultywujący ideał intelektualiści uważali i uważają taką utopię czynu za formę uniwersalnego zbawienia. Tak myślał Einstein pisząc swój głośny list z apelem o stworzenie rządu globalnego gwarantującego zapobieżenie wojnom. Podobnie Toynbee uważający, że mamy niewielki wybór między samozagładą a połączeniem się w jedną wielką rodzinę, czy F. Znaniecki propagujący ogólnoludzka „cywilizację humanistyczna" ${ }^{\prime 1}$. Depozytariuszami idei stali się twórcy i współpracownicy Klubu Rzymskiego, bezustannie powtarzajacy, że świat jest systemem potrzebującym homeostazy, a hasłem Klubu, powtarzanym niezmiennie od lat, jest: „przetrwać, ale w lepszym stylu”. Nieodmiennie prospektywni i altruistyczni twórcy wielkich Raportów konsekwentnie powtarzaja: „Musimy szerzyć na całym świecie ideę rozumnego, wspólnego rodza-

${ }^{58}$ G.H. Wells, Jutro ludzkości, Łódź 1946, s. 21.

${ }^{59}$ R. Sobel, The Age of Giant Corporations, London 1993, s. X.

${ }^{60}$ B. Russel, Per Aspera ad Astra, [w:] Science and Future of Mankind, New York 1964, s. 339.

${ }^{61}$ F. Znaniecki, Ludzie teraźniejsi a cywilizacja przyszłości, Warszawa 1974, s. 25. 
ju ludzkiego i ludzkich społeczeństw"62. Potwierdzają konstatację, że utopia ciagle szuka nowych form ekspresji wbrew sceptykom odmawiającym jej prawa obywatelstwa nie tylko w nauce, ale życiu ${ }^{63}$. Będzie je odnajdywała, bo powtarzamy, że marzenia o lepszych światach nie umra nawet wtedy, kiedy spełnienie zbliży się do pełni, co dziś zdaje się niemożliwe. Po czasie, po fiasku wielkich utopii czynu, nie była już projekcja świata idealnego zamieszkałego przez idealnego człowieka, a tylko świata o wiele lepszego.

Podobnie prezentowały się głośne, już bliższe nam w czasie rozwiązania J. Friedrichsa, wedle których rząd światowy, którego konieczność powstania jest dla niego poza dyskusja, powinien okazać się zdolnym do podejmowania decyzji i działań umożliwiających szybkie i optymalne rozwiązywanie zadań narzucanych przez postępy rewolucji naukowo-technicznej przy znalezieniu demokratycznych hamulców ograniczajacych jego władzę i zapobiegających alienacji aparatu biurokratycznego, a gwarantujacych obywatelom osobowość polityczna. Dalej niemiecki wizjoner suponował konieczność korekt systemów wartości w koherencji z tworzeniem drzew celów globalnych, problemami i ograniczeniami w ich osiaganiu, a także tworzenia alternatyw dla tych celów. Takie alternatywy mieliby proponować ludzie nauki i intelektualiści przy pełnej akceptacji mądrych, altruistycznych polityków. Oni także mieliby prowadzić społeczny dyskurs nad różnymi wariantami, oceną ich powiązań, możliwością realizacji w zastanych warunkach. Niejaką odpowiedzią na takie sugestie były rozliczne modele nowej, globalnej społeczności tworzone przez wybitnych naukowców: „globalne społeczeństwo humanitarne” J. Saint-Marca, „ponadnarodowe społeczeństwo globalnej modernizacji” J. Jacobsena, „społeczeństwo uniwersalne” J. Hirszfelda, „społeczeństwo globalnego pokoju” R. von Weizsackera czy „ogólnoświatowe społeczeństwo integralne” P. Sorokina. Nie można zapominać o propozycjach J. Burtona z głośnej kiedyś pracy World Society. Dla wszystkich autorów, co podkreślano, i inspiracją i mocną przesłanką był cud jednoczenia się Europy.

Ilość i jakość tych propozycji sygnowanych przez niewątpliwe autorytety, poświadcza niezwykłą żywotność idei, niemal nieobecnej w literaturze naukowej, co może dziwić. Nierzadko spotykamy się z nieporozumieniami wynikającymi stąd, że myli się globalizm (pierwotny i starszy o dekady) z globalizacja, a globalizacja nadała mu tylko inny wymiar, w tym postaci global government i global governance. Pozosta-

${ }_{62}$ A. King, B. Schneider, Pierwsza rewolucja globalna. Jak przetrwać?, Warszawa 1992, s. 298.

${ }^{63}$ J. Horton, A.T. Baumeister, Literature and Political Imagination, [w:] Literature and Political Imagination, ed. J. Horton, London 1996, s. 23. 
jąc przy globalizmie zauważamy, że dziś podział na globalistów i piewców idei narodowej staje się coraz wyraźniejszy, a polemiki między nimi coraz głośniejsze po kryzysach lat 70., kiedy to godzono się z sugestiami, że świat, jaki znamy, może nie przetrwać następnego kryzysu i potrzebne sa mu mocne zabezpieczenia. Dysputa toczyła się bez udziału znaczących polityków, ci czasami sugerowali jedynie, że nadmiernym optymizmem grzesza takie organizacje jak Światowi Federaliści, czy autorzy Raportów dla Klubu Rzymskiego, którzy śmiało atakowali problemy suwerenności w świecie zamykającym się w ciasnych nacjonalizmach, uważający pomysł stworzenia rządu światowego za prosty wymóg zwykłej racjonalności. Politycy mogą uważać (całkiem zasadnie), że jest to dla nich poważne zagrożenie.

Wedle autorów Raportów samo osiagnięcie porozumienia co do globalnych potrzeb i celów ludzkości może spowodować szerokie ożywienie intelektualne, poważne dyskusje międzynarodowe, zarówno na płaszczyznach rządowych, jak i pozarządowych, co mogłoby wreszcie doprowadzić do wypracowania podstawowego zestawu celów całej ludzkości. Uzyskanie tego rodzaju konsensusu mogłoby stanowić warunek podstawowy do osiagnięcia już szczegółowych celów globalnych w sferze politycznej, gospodarczej, a przede wszystkim: trwałego zabezpieczenia pokoju, wyżywienia ludzkości, wyrównania poziomów rozwoju gospodarczego, a tym samym życia. Uważa się, że autorzy Raportów grzeszą idealizmem, ale tak uważają ci, dla których idealizm jest fanaberią.

Owe cele, z którymi godzono się powszechnie (przynajmniej oficjalnie), bo nie wypada się nie godzić z takimi, wymagaja - dodawano - adaptacji lub radykalnych przekształceń instytucji międzynarodowych, już istniejących, po to, by mogły podołać ogromowi zadań. Według Światowych Federalistów taką instytucją jest ONZ, która tworzono dla realizacji podobnych celów, a która jest dziś tylko listkiem figowym światowych dominatorów. Wedle nich konieczna jest demokratyzacja i odbiurokratyzowanie organizacji, choćby przez zniesienie dysfunkcjonalnej, niedemokratycznej Rady Bezpieczeństwa, a podniesienia rangi organów takich, jak WHO, FAO, organów do spraw rozbrojenia i bezpieczeństwa międzynarodowego oraz nowych, które miałyby zajmować się organizacją eksploracji zasobów mórz i oceanów czy przestrzeni kosmicznej, co wymagałoby dużej ofiarności państw członkowskich. Manifest programowy Federalistów proponował także rozwiązanie problemów finansowych rozbudowanej ONZ. Poza składkami członkowskimi znaczącymi sumami w budżecie miałyby być opłaty tranzytowe od morskich i powietrznych przewoźników korzystających z międzynarodowej przestrzeni powietrznej i akwenów będących w gestii $\mathrm{ONZ}^{64}$.

${ }^{64}$ World Federalists, What we Seek, [w:] Future Politics, Berkeley 1971, s. 283-284. 
Wedle niektórych teoretyków kreowanie nowych i modyfikacja tych instytucji, które sprawdziły się, a kierują działaniami w skali horyzontalnej, winny być oparte o placówki zwane przez autorów wywodzących się z WOMP Wydziałami Doradczymi do Spraw Celów i Badań, działajace jako organy konsultacyjne przy rządach krajowych, a podporządkowane odpowiednim organom wspólnoty europejskiej i ONZ.

Prace WOMP z ostatnich dekad wciąż prezentuja się ciekawie niemal nie tracąc na aktualności, choćby ze względu na to, że sa podbudowane teoria i metodologia prognostyki politycznej, a także dlatego, że Unia Europejska jest, mimo kryzysów funkcjonalnych, spełniającym się marzeniem globalistów. Bez wątpienia jedną ze sztandarowych propozycji WOMP była ta, autorstwa R. Kothari. Autor wielkiego opracowania uważał, że nim zaczniemy poważnie myśleć o próbach unifikacji na większą skalę, winniśmy wpierw odpowiedzieć na szereg podstawowych pytań, a między wieloma na następujące:

- jaki model instytucjonalny federacji światowej mógłby spotkać się z akceptacją nie tylko polityków, ale i całych społeczeństw?

- jak mogłaby wyglądać forma organizacji terytorialnej?

- jak i na jakiej podstawie prawnej można zainicjować powszechnie akceptowalny proces reorganizacji?

- jak mają wyglądać składowe federacji światowej?65

Wedle autora projektu odpowiedzi na pierwsze i czwarte pytania nie powinny nastręczać większych kłopotów, jako że istnieją już sprawdzone praktyką zawiązki unifikacji regionalnych, które powinny, czy nawet muszą kooperować ze sobą gospodarczo i politycznie dla obopólnych korzyści, jak robią to dwa potężne subsystemy, Europa i USA. Dla potrzeb korzystnej współpracy i bezpieczeństwa wręcz konieczny jest zewnętrzny arbiter i tu autor wyraźnie wskazuje organizację taka, jaka dziś jest ONZ, pośrednio pytając o to, czy da się odpowiednio zmodyfikować i zoptymalizować w działaniach nie tylko wobec ukształtowanych subsystemów, gdyż celem podstawowym musiałyby być także wysiłki idące w kierunku tworzenia i umacniania systemów składających się z krajów słabo rozwiniętych.

Umiarkowany, ale jednak sceptycyzm wobec ONZ jako potencjalnego zaczynu rządu światowego był podzielany przez innych autorów WOMP. R.A. Falk zdawał się nie zauważać prototypu takiego rządu sugerując wyraźnie konieczność powołania zupełnie nowych organizmów, która miałyby zadbać przede wszystkim o cel nadrzędny, który - wedle niego - nie da się zakwestionować, a tym jest światowy pokój. Zaproponował stworzenie Komitetu do spraw Bezpieczeństwa Światowego ze

${ }^{65}$ R. Kothari, Footsteps into the Future, Stockholm 1978, s. 149. 
Światowymi Siłami Bezpieczeństwa (zaczątek armii światowej), Światową Służbę Rozbrojeniową i Trybunału Światowego, który miałby rozsądzać sprawy łamania praw narodów i państw. Przyszłą skuteczność działań takich instytucji może wykluczać czy tylko paraliżować demokratyzm ciał nimi zarządzających i niezbędne sa tu porozumienia najważniejszych podmiotów polityki światowej, nowe kodyfikacje prawa międzynarodowego i kroki niezbędne, jak np. zahamowanie transferu broni do krajów rozwijających się, skuteczna egzekucja wyroków Trybunału na łamiacych prawa, bez względu na ich podmiotowośćc6. Tenże Falk, niezmiennie globalistyczny, wzywa dziś do stworzenia parlamentu globalnego mającego krzewić ideały demokracji ${ }^{67}$. To już nie jest „utopizm”, ale propozycje radykalnych zmian w stosunkach międzynarodowych, które, choć wyobrażalne, są krępowane przez dominujący „realizm polityczny”.

Zapewnienie globalnego bezpieczeństwa byłoby wstępem do kroków zmierzających do egalitaryzacji, poszukiwania dróg do względnego dobrobytu wszystkich ludzi na ziemi. Dalej autor poszedł śladami prac Klubu Rzymskiego sugerując pojawienie się imperatywów globalnych wobec krajów biednych, przypominając groźby konfrontacji Północy z Południem, która dziś przybrała postać zagrożeń asymetrycznych eskalujących się z roku na rok i zapowiadających nowe zagrożenia, jakie daja się przewidywać. Uzasadniając synoptyczny charakter swojej propozycji podkreślał, że jakiekolwiek konkretne propozycje moga pojawić się dopiero po wstępnej zgodzie najbogatszych, o której wiemy, że nie pojawiła się dotąd i pewnie nieprędko pojawi.

W podobny sposób przyszłość światowego ładu wyobrażał sobie, konsekwentnie stojący „twarzą ku utopii”, symetryczny wobec propozycji Klubu Rzymskiego, G. Picht, utożsamiający przetrwanie ludzkości ze spełnieniem elementarnych warunków. Wedle niego (a mówił to ponad 30 lat temu, jeszcze nie rozumiejąc mechanizmów globalizacji ekonomicznej) konieczne sa inwestycje w preindustrialnych regionach globu dla zabezpieczenia egzystencji i minimum poziomów życia gwałtownie rosnącej liczby ludności. Są to jednak wielkości takiego rzędu, że można je realizować tylko przez nowy podział bogactw światowych, a większość ludzi żyjących na ziemi jest przekonana, że to może dokonać się tylko przez wielką rewolucję. Można jednak stworzyć takie formy porządku politycznego, które uchodzą za utopijne ${ }^{68}$. Myślał oczywiście o rządzie światowym zauważając wiele razy z gorycza, że bogaci nie chca zbawienia biednych ich kosztem.

${ }^{66}$ R.A. Falk, A Study of Future Worlds, Amsterdam 1975, s. 242.

${ }^{67}$ A.M. Slaughter, A New World Order, Princeton 2005, s. 238.

${ }^{68}$ G. Picht, Odwaga utopii, Warszawa 1981, s. 69. 
Dalekie echa koncepcji globalistycznych w ich amerykańskiej mutacji pojawiły się po ,jesieni ludów”, kiedy dynamiczna rzeczywistość odebrała odwagę nawet „realistom”. Przyznawano, jak P. Wofowitz, że „początek lat 90. dramatycznie ukazał trudności w przewidywaniu stanów środowiska międzynarodowego" 69 i były to usprawiedliwienia w tym czasie bierności dominatora. Rolę bodźców mogły spełnić wielkie wizje, które zawsze towarzyszyły Amerykanom i takie wizje trzeba było przekładać na śmiałe, globalne projekty, czego nie czyniono, zarzucajac potem pierwszemu Bushowi i Clintonowi utratę szans na stworzenie nowego porządku światowego ${ }^{70}$, a wedle politologa Stany nigdy nie miały takich szans na realizację swej misji wobec świata, jak wtedy. Stworzenie takich wizji w czasie przełomu mogło wyzwolić i aktywizm i dać pełną legitymację do działania śmiałym wizjonerom. Ameryka i świat potrzebowały wizji zdolnych tworzyć nowe drzewa celów, ale w owym okresie wielkich nadziei brakło takich rewelatorów i ludzi władzy zarazem, takich jak Wilson czy F.D. Roosevelt. One nie powstawały, choć tak często powtarzano: „Żyjemy w czasie, który bardziej niż inne potrzebuje uniwersalistycznego projektu"71. Nie zdobywali się na nie ani politycy, ani intelektualiści, tak mocno manifestujący odwage przed przełomem, jakby sparaliżowani świadomością że właśnie w takim czasie moga stać się prawdziwymi kreatorami. A nietrudno zauważyć, że podówczas dominator miał wystarczająca siłę i wolność wyboru, by narzucić swoją wolę także krajom II Świata. ${ }^{72}$.

Ani teoretycy, ani politycy amerykańscy nie byli w stanie zdobyć się na tak często i chętnie deklarowany polityczny idealizm i altruizm, stworzyć wizje nowego globalnego ładu w czasie, w którym takie działania były palące i pilace zarazem. Nie trafiało do nich przekonanie, że geopolityka to także geointelektualizm, śmiałe wykraczanie w przyszłość zamiast trwania. Za sprawa wielu zaniechań Amerykanie stali się zawiedzioną nadzieją świata, oskarżana, nie zawsze zasadnie, o całe zło dni dzisiejszych, choćby przez Hardta i Negriego w Imperium albo R. Corma, według którego Amerykanie pełnymi garściami dostarczaja mocnych argumentów siłom antydemokratycznym ${ }^{73}$. Niczym złym jest dbanie o interesy swoich obywateli, którzy animują globalizację, ale można mieć do nich żal o to, że (myśląc i pilnując tych interesów) nie wykorzystali szans na stworzenie tego ładu wtedy, kiedy mogli wła-

\footnotetext{
${ }^{69}$ P. Wolfowitz, The New Defence Startegy, [w:] Rethinking America's Security, s. 181.

${ }^{70}$ F. Cameron, US Foreign Policy after the Cold War, New York 2002, s. 24.

${ }^{71}$ E.M. Wood, What is „Postmodern” Agenda, [w:] In Defence of History. Marxism and Postmodern Agenda, eds E.M. Wood, J.B. Foster, New York 1997, s. 13.

${ }^{72}$ W.P. Shively, Power and Choice, New York 1991, s. 73.

${ }^{73}$ R. Corm, Religia i polityka w XXI wieku, s. 186.
} 
ściwie robić wszystko. Próbują tworzyć imperium, co im się nawet zasadnie zarzuca, ale chyba nie jest to imperium podobne do dawnych. Amerykanie, dzięki monopolowi kulturowemu, pragną stworzyć swoje imperium ducha, ale choć to tylko próba zdominowania wyobrażeń zbiorowych, to i tak taka próba nie jest pozbawiona gwałtu, wykluczenia, dominacji - uważa, nie bez racji, radykalny D. Korten ${ }^{74}$. Nietrudno się z nim zgodzić, jeśli rejestrujemy treści i formy amerykańskiej kultury, w naszym czasie dominującej.

W zfragmentowanym, relatywistycznym świecie jest nam potrzebny uniwersalizm zapobiegający dalszej fragmentyzacji ${ }^{75}$. Taki uniwersalizm ożywa w dobie globalizacji, okresie zauważalnego osłabienia państw narodowych (ale nie samych idei narodu), czasie konieczności stworzenia nowego ładu w miejsce tego zdestruowanego przez korporacje. Wielu analityków mówi nawet o spirali chaosu, co dla innych jest przesłanką do wniosków podobnych temu: „Globalizacja pociagnie za sobą koniec narodów, zwiastuje nieuchronnie powstanie państwa globalnego"76, choć takie wnioski bywają chyba pochopne. W takich manifestacjach pewności pojawia się to głębokie przekonanie co do możliwości samoregulacji systemu światowego, jakby cienie wiary w „ducha świata”, tego deus ex machina, który nie opuszczał człowieka w najbardziej krytycznych momentach. Ale czym jest taka pewność, jeżeli nie jest opierana o konkretne przesłanki?

Wielu uczonych przejawia przecież niezwykłą pewność co do możliwości stworzenia państwa globalnego. Wedle jednego z nich budulec na stworzenie postnarodowego, uniwersalnego imaginarium znajduje się w zasięgu ręki ${ }^{77}$, choć także ten autor nie wskazuje ani na cegły, ani na spoiwo. Niektórzy wręcz chcą czynić zakłady (bezpieczne) uważając, że prawdopodobieństwo powstania rządu globalnego w okolicach roku 2100 wynosi $100 \%{ }^{78}$. Nam nie starcza imaginacji, nie możemy wyobrazić sobie wielkich, zbawczych struktur tworzonych przez polityczne elity takie, jakie mamy, a już zupełnie przez intelektualistów. Znane nam próby odszyfrowania istoty global government czy global governance są nieśmiałe, ale panuje przekonanie co do tego, że procesy globalizacji i regionalizacji kreuja nowe sieci interakcji i siły, że jest to proces nie-

${ }^{74}$ D. Korten, The Great Turning, From Empire to Earth Community, San Francisco 2006, s. 33.

${ }^{75}$ R. Braidotti, Transpositions, Cambridge 2007, s. 15.

${ }^{76}$ A. Baring, Czy Niemcom się uda?, s. 118.

77 A. Appadurai, Nowoczesność bez granic. Kulturowe wymiary globalizacji, Kraków 2005 , s. 37.

${ }^{78}$ S. Mendlowitz, A Perspective on the Cutting Edge of World Order Inquiry. The Past, Present and Future of WOMP, International Interactions 1981, nr 1, s. 159. 
uchronny ${ }^{79}$. Przy czym kształt tych sieci i interakcji jest tak mglisty, że prawie niezauważalny.

Sięgając po metafizykę intelektualiści poszukuja wyjaśnień odwołując się do „twardego determinizmu”, na powrót odnajdują wzorce prowidencjalne, co nie dziwi w przypadku T. de Chardin. Wedle niego ludzkość coraz bardziej konstytuuje się jak organizm wyposażony w pewną fizjologię i nie są to więzy powierzchowne. Wielkie, transcendentne siły już zdecydowały o telosach Człowieka i one wypełnią się wtedy, kiedy nadejdzie czas. Zdaje się w nie wierzyć także kontestujący, zwykle radykalny D. Korten, mówiący z przesada, że globalna wspólnota to wybór i odpowiedzialność wszystkich, a budowa takiej wspólnoty zaczęła się w 1999 roku w Seattle ${ }^{80}$.

${ }^{79}$ D. Held, Global Government, Cambridge 2007, s. 89.

${ }^{80}$ D.C. Korten, The Great Turning. From Empire to Earth Community, San Francisco 2006 , s. 52. 



\section{7}

\section{ZBAWIENIE W POSTĘPIE}

Wypada zaczać od konstatacji, że mgliste, niedopowiedziane idee postępu towarzyszyły człowiekowi od zawsze, a intuicyjnie za postępowe uważał to, co ułatwia, usprawnia jego życie i cały czas artykułował nadzieje na nowe ulepszenia potwierdzając je codzienną praktyka, choć nie określił istoty samej idei albo nie zauważając wtedy takiej potrzeby, albo ograniczany koncepcjami czasu, jak filozofowie greccy, zdeterminowani, uwięzieni w kołach czasu. Później także pojawiały się problemy $\mathrm{z}$ ich rozumieniem, a tłumaczenie ich żywotności choćby teza, iż zaspokajają ludzka potrzebę znaczenia zdecydowanie nie wystarcza ${ }^{1}$. Takie, „prymitywne” rozumienie idei postępu oznaczało dla ludzi z przeszłości wzrost ilości dóbr materialnych, zdolność samoorganizacji zbiorowości, spełnienie emocjonalne i wydaje się, że bez niej, bez tej nieokreślonej idei nie kolonizowałby przyszłości tak szybko i skutecznie, nie byłby tak ekspansywny. Nawet łatwo godził je z ideami regresu zgodny ze swoją Janusową dualnością. Idee postępu bywały zwykle emanacjami nadziei zbiorowych, a ich rewersy strachu odnajdujemy w niemal każdej kulturze jako niesprzeczne ze soba wiary w koniec przemijających światów z jednej strony, a z drugiej w możliwość odzyskania raju utraconego. Wiarę w postęp, już w naszej erze, odnajdziemy choćby w ruchach millenarystycznych i herezjach kontestujacych prowidencjalizm wraz z towarzyszącą mu apologia ubóstwa. A taka wiara nie była tożsama z kwestionowaniem chrześcijańskiej postaci eschatonu, ona tyczyła tylko tego, co ziemskie.

Poszukując ich $\mathrm{w}$ dalekiej przeszłości raczej bez trudu zauważymy w wielu kulturach archetyp rajski i idee upadku od wieku złotego do stanu ognia i kamienia, ale jakże często towarzyszy mu wiara

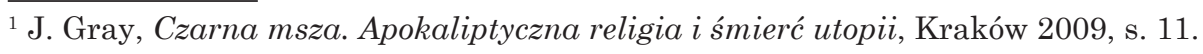


w jego odzyskanie albo na mocy transcendentnych wyroków, albo za pośrednictwem zbawcy, albo bez niego. Właściwie wszystkie mitologie starożytne taką wiarę artykułowały nie tworząc spójnych eschatologii. Nam samym nietrudno zauważyć, że będąc zwolennikami klasycznego degeneratywizmu jesteśmy skłonni zawierzać także w progresywizm zawierający wiarę w lepsza przyszłość, a czasami godzimy je orientując się na retrogresywizm, czyli cyklizm rozwojowy obejmujący i postęp i regres, a ten przekłada się choćby na akceptację kryzysów, jak tego, który gnębi nas od 2008 roku. Nawet bez godzenia ich retrogresją obie postaci wiary nie rywalizują ze soba, one zdają się uzupełniać tworząc z pozoru antynomiczną całość.

Czasy nowożytne, czyli wieki od X, oznaczają walkę z ideami postępu i możemy mieć spore kłopoty pytając o przyczyny takiej orientacji. Odpowiedź, że spełnienie materialne w doczesności mogłoby posłużyć jako argument przy kwestionowaniu zbawienia poza ziemią zdaje się co najmniej niepełna, dziś nie może satysfakcjonować, bo soteriologia transcendentna skomponowana z ziemską tworzą całkiem spójną całość, choć kłopoty z ich uzgodnieniem chyba nigdy dla nas nie znikna. Ale w początkach chrześcijaństwa pojęcia regresu człowieczeństwa prowadzącego do wielkiej katastrofy mającej charakter autodestrukcji przeniesiono w praktyce w Ewangelie i Apokalipsy mówiące o tym, że to człowiek sam przesądzi o swoim końcu wypełniając po brzegi czarę swoich nieprawości, nieustannie karany za grzechy chorobami, nędza, klęskami żywiołowymi, ale przecież może liczyć na zbawienie poza ziemią. Kwestionowanie takich koncepcji dziejów człowieka było podówczas co najmniej herezją i nawet heretycy unikali tego, ale czynami potwierdzali zdecydowany sprzeciw wobec takiej teleologii. Nader często ludzie Kościoła i herezjarchowie wykorzystywali argumenty o retrogresji utrzymujacc, że jeśli ludzie nie poprawią się radykalnie, to czara nieprawości wypełni się i szybko nastapi koniec. Sami jednak poszukiwali spełnienia na sposoby zakazane przez Kościół, na swój sposób „postępowi”, bezustannie poszukujący nowego świata w przyszłości i przeszłości.

Przeniesione z transcendencji idee stały się integralną częścią wyobrażeń zbiorowych człowieka epoki, w jakiej zanegowano klasyczny prowidencjalizm - stałą obecność Opatrzności w historii zaplanowanej przez boskiego ekonoma - i człowiek Odrodzenia odsunął na plan drugi takie projekty świata i człowieka, które były tylko częścią boskiego planu tworzenia universum, a ich ślady pozostały w wielu ideologiach wieków XIX i XX². Z pozoru będąc opozycją idei prowidencjalnych, sa

${ }^{2}$ C.M. Young, Portrait of an Age, London 2002, s. 5. 
prowidencjalne, choć miejsce Boga zajęły inne postaci transcendencji (Rozum, Natura, siły wytwórcze w marksizmie). Prowidencjalizm z towarzyszącym mu millenaryzmem, pozostał wzorem żywym do dziś i mówiący także o wyrokach Opatrzności prezydenci Stanów zdają się to potwierdzać tymi nadużywanymi metaforami, choć chyba nie sa tak prowidencjalne, jeśli czasami oni sami mają się nie tyle za narzędzia Opatrzności, co za nią samą. Te swoiste reinterpretacje prowidencjalizmu zrodziły także dystans wobec wizji zbawienia w transcendencji, co widać w atrofii średniowiecznej angelo i demonologii w wiekach XVII i XVIII. Projekty raju i piekła pozostały takimi, jakimi tworzono je dla człowieka średniowiecza, oswojono się z nimi w czasie, w którym nowe wynalazki nie bywały już traktowane jak piekielne wymysły. W naszym czasie pozostały jedynie mało wymyślnymi opowieściami, jakie nie działają na wyobraźnię człowieka współczesnego, nie inspirują czynów i powoli zanikaja.

W czasie początków wielkich odkryć naukowych i rozkwitu nowożytnej idei postępu tworzono nowe raje na ziemi (mody na arkadyjskie ogrody) albo wieszczono takie zmiany jak rewolucjoniści francuscy, z których wielu dopatrywało się w rewolucji zamiaru Boga, który chce odmienić oblicze świata ${ }^{3}$. Wielkie szkoły filozoficzne przełomu XVIII i XIX wieku powodowały się przekonaniem, że społeczeństwa rozwijaja się w przewidywalnym, rządzonym przez określone prawa kierunku zastępując Boga Rozumem czy Naturą ${ }^{4}$, bo pełna ucieczka w immanencję okazała się ułuda, tu wszystko było nieprzewidywalnościa, chaosem. Postęp dokonywany dzięki tym siłom ludzie myśli utożsamiali z radykalna poprawa doli milionów nędzarzy, z ruchem w czasie ku lepszym stanom i nietrudno zauważyć, że taka idea niosła w sobie ogromne niebezpieczeństwo dla rządzących w każdym czasie, zbyt była „rewolucyjna". Nietrudno było zauważyć, jak czynił to pozytywista F. Harrison, że wiara w postęp na ziemi ma zastapić oczekiwanie tego, co w niebie ${ }^{5}$. W oczywisty sposób takie idee były wrogie Bogu i kościołowi, bo oto człowiek zbawiał się na ziemi wyręczając Tego, który zapomniał o swoim tworze skazując go na cierpienia i nędzę, a owa nędza, o której tak chcemy zapomnieć, dotykała większości społeczeństw, co przypominamy raz jeszcze, zauważając jej nieobecność zwłaszcza w historiografii.

Poczucie radykalności przemian $\mathrm{w}$ wieku XVIII, wiązane $\mathrm{z}$ rewolucja przemysłowo-techniczną w jej fazie przemysłowej, zrodziło swoista „religię postępu” z soteriologia postępu, tak mocna, że , jakakolwiek

\footnotetext{
${ }^{3}$ A. de Tocqueville, Dawny ustrój i rewolucje, Warszawa 2005, s. 37.

${ }^{4}$ I. Berlin, Zmyst rzeczywistości, Poznań 2002, s. 33.

5 J. Jedlicki, Świat zwyrodniały. Lęki i wyroki krytyków nowoczesności, Warszawa 2000, s. 147.
} 
próba podawania jej w watpliwość była uważana za niedorzeczność czy herezję" - pisał z niejaka emfazą Ch. Dawson, bo prób takich było wiele. Były to próby indywidualne i te znalazły się w cieniu, bo idee postępu zaanektowały i zaakceptowały wielkie ideologie z socjalistyczna na czele ${ }^{6}$. Dla prowokującego D. Boorstina natomiast idea postępu była pierwszą nowoczesną ideologia, pierwszym, „naukowym” dogmatem dziejów ludzkich ${ }^{7}$. Ta swoista „religia”, dla prostoty przypisywana Condorcetowi i Turgotowi, jako jej twórcom, w naszym czasie została uzupełniona „ewangelia przyspieszenia” i chyba nie sposób kwestionować sugestii, że w naszym świecie myślenie o zmianie zostało zdominowane przez zmityzowane idee postępu w setkach postaci i można się zgubić w tym bezliku\&. Postępu utożsamianego przede wszystkim z technicznym, bo jeśli chodzi o zauważany przez jednego $\mathrm{z}$ autorów wzrost empatii, stępienie agresywności, to wypada zachować dużą rezerwę, empatia i agresja nie uległy „postępowym” przemianom, przybrały tylko inne postaci ${ }^{9}$. Podobnie wypada podchodzić do sugestii o stałym postępie moralnym ludzkości czasami używanych przez obrońców idei Człowieka. Owszem, pewnie nie potraktowalibyśmy publicznej egzekucji jako formy zabawy, nie dobijalibyśmy rannych na polach bitewnych tłumacząc się litością, ale przyglądamy się wojnom i kataklizmom inspirowanym przez człowieka $\mathrm{z}$ obojętnościa dorównującą obojętności naszych przodków albo i większa, bo oni nie byli świadkami takiego ludobójstwa jak my. Postęp techniczny zaś - zauważał J. Bobryk - dokonuje się bez rozwoju i doskonalenia człowieka $^{10}$ i mamy wattpliwości, czy naprawdę jest forma prawdziwego postępu, o ile taki istnieje.

Zawierzyliśmy Condorcetowi powiadającemu, że natura nie wyznaczyła żadnego kresu ludzkim możliwościom tworzenia Nowego ${ }^{11}$ i ludzka praktyka potwierdzała to. Idee postępu reinterpretowane przez innych „kapłanów postępu” następnych wieków obiecywały wszystkim spełnienie w doczesności, a ich nośnikami miały być wszystkie innowacje, wynalazki, które zadziwiały, odurzały zwykłego, żyjącego w ubóstwie, człowieka, odkrywającego, że otwierają się granice jego małego świata i pojawia szansa na spełnienie materialne, a przypomnijmy raz

${ }^{6}$ Ch. Dawson, Postep i religia, Warszawa 1958, s. XXI.

7 D.J. Boorstin, Poszukiwacze. Dzieje ludzkich poszukiwań sensu świata, Warszawa 1998, s. 224.

${ }^{8}$ P. J. Taylor, The Way the Modern World Works, New York 1996, s. 83.

${ }^{9} \mathrm{~K}$. Wilber, Integralna teoria..., s. 41.

${ }^{10}$ J. Bobryk, Spadkobiercy TRUTA. Ludzie i media, Warszawa 2001, s. 28.

11 J.A. de Condorcet, Szkic obrazu postepu ducha ludzkiego poprzez dzieje, Warszawa 1957, s. 213. 
jeszcze, że przeważające części społeczeństw progu nowożytności żyły w biedzie bliskiej nędzy. Było to odkrycie nie tylko człowieka mitycznego, ale i ówczesnych mocarzy myśli, którzy musieli zauważać inność czasu, zmian, przyspieszenia. Potwierdzały je rosnące ilości dóbr, coraz większe bezpieczeństwo materialne i to, co Chaunu nazywał „awansem ciała"12, czyli odwaga otwartego zaspokajania zakazanych, sublimowanych dotąd potrzeb, potrzeb stanowiących fundament piramidy Maslova. Siła idei postępu była tak ogromna, że nie kwestionowali jej nawet romantycy, zwykle przeciwni technice, temu wykwitowi postępu, na swój sposób konserwatywni, jakże często marzący o „starych, dobrych czasach" i powrocie do nich. Nie kwestionowali go także katoliccy reformatorzy wieku XIX poszukujaccy źródeł nędzy w kapitalizmie, jak ksiądz F. de Lamennais, dla którego zmiana i postęp były siłami zbawczymi, pochodzacymi od Boga ${ }^{13}$. Tak twierdzac musiał kontestować nauki Kościoła, zbyt konserwatywnego, zbyt zajętego sobą i dlatego bywał traktowany jak herezjarcha.

Degeneratywne wizje zmiany były powoli wypierane $\mathrm{z}$ pamięci zbiorowej, ale nie wydaje się, by wielkie archetypy raju utraconego i stopniowego upadku ludzkości straciły swe sprawcze moce, bowiem przez owa wiarę w postęp cały czas przebijały i przebijaja „heretyckie” konceptualizacje tych, którzy nie zawierzyli w postęp, przede wszystkim technologiczny. Oni nie zaufali dogmatom „religii postępu”, które były tylko metaforami, stale konfrontowali wizje kumulatywnego postępu z rzeczywistością konstatując, że praktyka młodego kapitalizmu wyraźnie kłóci się z założeniami proponowanymi przez „kapłanów” postępu i mieli swoje racje. Swego czasu zwolennicy Condorceta utrzymywali, że postęp jest nieodmiennie kumulatywny i poprawia byt mas, że regres jest wręcz niemożliwy, co korygowali myśliciele XIX wieku obserwujący rozwój „postępowego”, wilczego kapitalizmu niosacego niebywały pauperyzm, niszczącego z bezwzględnością stare struktury społeczne, formułujaccego swoje wilcze „prawa”. Te wizje postępu implantowano w teorie nowoczesności tworząc wiarę w to, że rozwój produkcji przemysłowej, techniki, organizacji, stanowią gwarancję wzrostu dobrobytu materialnego wszystkich i tego nie można było kwestionować bez obaw o potępienie przez zbiorowość. Wyraźne artykulacje takiej modernizacyjnej wiary spotykamy już w pierwszej połowie wieku XIX, kiedy E.A. Poe mówił, że technika została podniesiona do rangi najwyższej, a kiedy zasiadła na swoim tronie, spętała łańcuchami umysły, które ją stworzyły ${ }^{14}$.

\footnotetext{
${ }^{12}$ P. Chaunu, Cywilizacja wieku Oświecenia, Warszawa 1989, s. 283.

${ }^{13}$ P.N. Stearns, Ksiadz Lamennais, Warszawa 1970, s. 100

${ }^{14}$ P. Virillo, Bomba informacyjna, s. 34.
} 
Przez rytualizację umacniano zwycięski mit postępu umieszczając go w transcendencji jako siłę jasna, dobra, co prawda jeszcze nieznana, bo nowo objawiona, potężna, i było to jakimś efektem odwrotu od religii z jej soteriologia na rzecz nowej wiary immanentnej. Ludzie tamtego czasu byli przekonani, że postęp opiera się na odkryciach, wynalazkach, kreatywności i projektowaniu, na czysto ludzkich dokonaniach, ale takich, za którymi kryją się te jasne, ale nieokreślone siły sprawcze. Uwierzywszy $\mathrm{w}$ te siły zakładano, że ten postęp dokonuje się tak czy inaczej, sądzono, że i tak dokona się on przez przypadek albo dzięki kilku jednostkom majacym motywację, by iść naprzód miast poprzestawać na tym, co jest. Nowe wizje miały budzić euforię zbawienia i wyglądały tak jak słynne hasło z magazynu Independent: „Powrót do natury? Nigdy! Naprzód do Maszyny!"'15. Technikę poczęto traktować jako czynnik dynamiczny i autonomiczny i teoretycy tacy jak J. Ellul odnajdywali te narzędzia zbawienia $\mathrm{w}$ transcendencji łacząc technikę $\mathrm{z}$ postępem ${ }^{16}$. Nie oglądali się nawet na prawa ekonomiczne zauroczeni trendami postępu i każdy nowy wynalazek, każda innowacja stawały się znamieniem tego postępu ${ }^{17}$. Dzięki nowym wyznawcom duchem, symbolem stulecia XIX stał się silnik. Nie tylko duchem, ale też metaforą mocno umocowana w wyobrażeniach zbiorowych w dużej mierze dzięki sztu$\mathrm{ce}^{18}$. Jego wydajna doskonałość stawała się inspiracją dla wszystkich poszukiwaczy doskonałości, w tym doskonałości społecznych, co widać w wielu formach inżynierii społecznej, nazwanej tak całkiem zasadnie.

A początkiem takiej inżynierii były pomysły Saint-Simona, który zaprezentował pomysł, by rządzić ludźmi tak, jak rzeczami, oczywiście dla ich dobra. Po nim Veblen tworzył zasady technologicznego fundamentalizmu, a ich następcy, już w połowie wieku XX, zafascynowani możliwościami ówczesnych komputerów, tworzyli „guzikowe utopie”, proponowali zarządzanie społecznościami przy pomocy „obiektywnych”, beznamiętnych i skończenie skutecznych komputerów, które moga rozwiązywać także problemy społeczne i swego czasu czyniono to z głęboką wiarą. Podówczas nie zauważano tego, co później choćby N. Postman, a wedle niego ludzie tracą zdolności twórcze poddając się technologii i miał na myśli oczywiście nie tych, którzy tworzą technikę, a nas wszystkich, ci zaś, którzy tworzą nowe technologie sa przecież zaledwie ułamkiem procenta ludzkości ${ }^{19}$. Niestety, postęp techniczny

${ }^{15}$ C. Purcell, The Machine in America. A Social History of Technology, Baltimore 1995, s. 229.

${ }^{16}$ J. Ellul, The Technological Society, New York 1964, s. 128.

${ }^{17}$ N. Postman, Zabawić się na śmierć, Warszawa 2002, s. 222.

${ }_{18}^{18}$ P.N. Carroll, D.W. Noble, The Free and Unfree, New York 1989, s. 259.

${ }^{19}$ N. Postman, Technopol, Triumf kultury nad technika, Warszawa 1995, s. 144. 
może dokonywać się bez udziału człowieka z niego tylko korzystającego, bez jego rozwoju i doskonalenia, bo umiejętność obsługi wielu gadgetów doskonaleniem nie jest. Samorealizacja w części zostaje zastąpiona przez różnorakie maszyny przyjemności.

Taki postęp oznaczał dla człowieka epoki atomowej formę zbawienia w dobrach, ale, co zauważa wielu badaczy antroposfery, także zagubienie duchowe, poczucie pustki wśród coraz większej ilości rzeczy, choć nie wszyscy ludzie uważają reifikację za zło, niektórzy jej nawet nie dostrzegaja. Poza tym został zmuszony do życia w kilku światach na raz, tak szybkie stały się przemiany cywilizacji technicznej, tworzonej przez człowieka jakby obok niego, choć niby dla jego dobra przez tych, którzy lepiej wiedza, czym owo dobro jest. Taka akceleracja potęguje odczucie wyobcowania, zrywa stare więzi społeczne, uzależnia od sił sprawczych, których natury do końca nie rozumiemy. A zauważaliśmy już potrzebę homeostazy i to, że dążenie do równowagi psychicznej, korelowane przez pragnienie poczucia bezpieczeństwa, jest tym tropizmem każdego z nas, od którego chyba się nie uwolnimy. Nie możemy tego osiagać za sprawą absolutyzowanej techniki - powiadaja niektórzy. Wedle krytyków cywilizacji technicznej, przypominających nieco XIX-wiecznych luddystów, technika ze środka przekształciła się w cel sam w sobie, w autonomiczną siłę, której jednostka musi się podporządkować, by móc funkcjonować w zbiorowości. Wielu takich krytyków zauważało, że jako w pełni autonomiczna technika zniewala człowieka, pozbawia go możliwości wyboru, narzuca środki, jakie musza być stosowane przy wyborze celów. Utrzymywali, że technika stawała się bytem transcendentnym i zdumiewać może przyznawanie jej takiego statusu w naszym czasie, bo przecież nie istnieje bez człowieka. Wygląda to tak, jakby permanentnie technicyzowany człowiek poszukiwał nowego podmiotu wiary i czynił nim własne dzieło godzac się także na technicyzację stosunków międzyludzkich z zasadą „korzystasz i płacisz" na czele ${ }^{20}$.

Ten swoisty wulgaryzm technologiczny, wynikający znowu z konieczności zdobycia pewności, może zdumiewać, ale przede wszystkim był i jest zjawiskiem potwierdzającym naukową idolatrię ostatnich dekad wieku. Wpierw zachwycano się niepojętymi możliwościami samej nauki i techniki, a po czasie zachwytu okazało się, że nie obudziliśmy się na czas z utopijnego snu i wpadliśmy w koszmar ${ }^{21}$. Udanym komentarzem do takiej sytuacji są słowa Fromma: „Człowiek współczesny ma

${ }^{20}$ O. Spengler, Zmierzch Zachodu. Zarys morfologii historii uniwersalnej, Warszawa 2001, s. 284.

${ }^{21}$ M. Equal, Divergent Paths, s. 432. 
wspaniała inteligencję, a jego rozum dysponuje potęgą technologiczną - stanowi zatem poważne zagrożenie dla samego siebie"22.

Dla dziesiątków autorytetów zauroczonych takim postępem, technosfera stała się ważniejsza od antroposfery. Niewielu tylko dopatrywało się źródeł takiego zła w systemach politycznych, przede wszystkim w takich, które sa moderowane ideami affluent society i społeczeństwa masowego, a takie zauważał dawno temu Tocqueville. Podobne zagrożenia widzieli Ortega y Gasset i Ch. Reich, którzy sugerowali, że zło tkwi nie w samej, obojętnej technice, ale w tworzonych i sankcjonowanych przez człowieka strukturach władzy, postaciach nowej wiary służaccej nie tylko przetrwaniu, ale i zbawieniu „pospolitego człowieka masowego" ${ }^{23}$. On potrzebował wiary w bardziej dostatnie życie, a gwarantem takiego życia stawała się mityzowana technika. Ona tłumaczyła nie tylko jego coraz to wyższe statusy materialne, ale także maskowała wszystkie niepowodzenia polityków, usprawiedliwiała poczynania monopoli. Można ją było apologizować, ale i oskarżać bez obaw o to, że oskarżymy siebie.

Wielki, rytualizowany przez dziesięciolecia, nie dający się dyskutować mit postępu ubezwłasnowolnił nas w dwojakim sensie - powiadali jego dawni i współcześni przeciwnicy, ale oni, jak i zwolennicy, utożsamiali ten postęp $\mathrm{z}$,ideologią" wzrostu gospodarczego odsuwając na plan dalszy tę pierwotną interpretację, wedle której powinien oznaczać dobro wszystkich, a wiemy dobrze, że postęp gospodarczy wcale nie musi oznaczać lepszego życia wszystkich, choć stale się nam powtarza, że jest warunkiem numer jeden tego dobrego życia i wierzymy w to wbrew praktyce życiowej, której czasami nie potrafimy analizować, choć tego pragniemy. To ubezwłasnowolnienie polega na tym, że po pierwsze, obfitość powszechnie dostępnych dóbr, jakie niosły postępowe zmiany, tworzy miękkie, neurotyczne, zewnątrzsterowne, zasiedziałe społeczeństwa, a po drugie, postęp techniczny niesie ze sobą nowe zagrożenia, w tym hipertrofię organizacji i specjalizacji, co przekłada się na przeciążenie systemu z jednej strony, a $\mathrm{z}$ drugiej prowadzi do redukowania jednostki do roli liczby. Liczby zaś nie moga nawet marzyć o samozbawieniu. One poddają się rachmistrzom, liczącym, organizujacym szeregi cyfr w dobie tej supernowoczesnej przynależności ${ }^{24}$.

Mit postępu, rytualizowany przez pokolenia, nie bywał zbyt często naruszany przez mitoburców, a przecież „wszelkie myślenie o zmianie zostało zdominowane przez ideę postępu”"25. Przyglądając się rytualiza-

\footnotetext{
${ }^{22}$ E. Fromm, Zdrowe społeczeństwo, Warszawa 1996, s. 268.

${ }^{23}$ J. Ortega y Gasset, Bunt mas, Warszawa 2004, s. 20.

${ }^{24}$ Ch. Handy, Głód ducha. Poza kapitalizmem, Wrocław 1998, s. 80.

${ }^{25}$ P.J. Taylor, The Way the Modern World Works, New York 1996, s. 83.
} 
cji tego wielkiego mitu zgadzamy się z politologiem, który utrzymywał, że „historia idei wymaga ciagłego przepisywania”"26. Wymaga tego dynamiczna rzeczywistość, ale jeśli przyjrzymy się przepisywaniu idei postępu, to chyba zauważymy, że od dziesiątków lat przepisujemy to samo jak sumienni kaligrafowie zmieniając tylko kształty liter. Zwłaszcza wtedy, kiedy przyglądamy się ideom umownej lewicy, która miast kumulatywnego postępu apologizuje jeszcze bardziej „postępowy” Nowy Początek - rewolucje, o których wiadomo, że były eksperymentami wielce kosztownymi. Rytualizujacc taką postać postępu faktycznie kwestionuja, odrzucaja go, choć mają się za niezwykle postępowych.

Rytualizując „postęp” w jego wielu odmianach nie zauważano znamion regresu będących jego konsekwencjami i awersami. Postęp industrialnego zachodu oznaczał przecież regres krajów podległych, kolonialnych i neokolonialnych. Dla S. Ramphala 2/3 ludzkości to ofiary rozwoju świata, tego naszego postępu ${ }^{27}$. Tam, wśród biednych, nie majacych przyszłości miliardów, nie odnajdziemy takiego bałwochwalstwa technologii. Korzyści z takiego postępu nie są rozdzielane równo nawet w społeczeństwach zamożnych - zauważał D. Landes i takie uwagi możemy konfrontować także z polską rzeczywistością ${ }^{28}$. Nędza i wykluczenie miliardów to oczywista konsekwencja takiej realizacji postępu, całkiem inne jakościowo symptomy spotykamy tam, gdzie postępowi zawdzięcza się najwięcej. On także ma swoje drugie oblicze, maskowane, skrywane przez wyznawców, o czym wspominaliśmy wyżej. Po trosze te problemy sa skutecznie maskowane przez tych, którzy sa zainteresowani utrzymywaniem wiary w doskonałość tych „postępowych rozwiązań" w imię przyziemnych korzyści i mamy tu na myśli „kapłanów” globalizacji.

W wirtualnej technotopii - przekonuja nas amerykańscy badacze - powstaje nowa klasa. Autokratyczna, arogancka, intensywnie przekonująca do swoich statusów i racji, monopolizująca tworzenie nowych technologii ${ }^{29}$. Jej przedstawiciele przekonuja, że dziś postępowe jest oswobodzenie jednostek z form społeczeństwa przemysłowego; klasy, warstwy, rodziny ${ }^{30}$. Twierdząc tak, niby racjonalni, przydaja swojemu postępowi status bytu transcendentnego pragnac uniemożliwić korekty tej metafory w wyobrażeniach zbiorowych, z dobrym zresztą skutkiem, bo jednak większość z nas ma się za „postępowych”.

Sam postęp potocznie kojarzy się z dynamiką rozwojowa, ale nie zawsze z kierunkowością samych zmian, bowiem coraz częściej za-

\footnotetext{
${ }^{26}$ T. Bender, Intellectual and Cultural History, New York 1997, s. 6.

${ }^{27}$ S. Ramphal, Our Country, the Planet, Washington 1992, s. 4

${ }^{28}$ D.S. Landes, Bogactwo i nędza narodów, Warszawa 2007, s. 17.

${ }^{29}$ A.i M. Crocket, Code Warriors, [w:] The Cyberculture Reader, ed. D. Bell, New York 2000, s. 59 .

${ }^{30}$ U. Beck, Społeczeństwo ryzyka, Warszawa 2004, s. 111.
} 
uważamy z drobiną goryczy, że to właśnie swoiście rozumiany postęp doprowadził nas do stanu godnego pożałowania. Choćby „postępowa” industrializacja Polski w latach 70. doprowadziła do degradacji środowiska naturalnego, stworzenia inertnego, wręcz irracjonalnego molocha przemysłowego, a prostym następstwem takiej „postępowości” sa dzisiejsze problemy z poszukiwaniem dróg do społeczeństwa informacyjnego, jakie także budzi wiele wątpliwości, a jest traktowane jako postępowe.

Mając na uwadze nasze, polskie, podwórko zauważamy, że z pewnością umiejętność poruszania się w przestrzeni wirtualnej może być dobra dla wielu Polaków, ale wielu potrafiących się w niej poruszać traktuje ja tylko jak egzotyke i nie wynika $\mathrm{z}$ tego nic produktywnego. I nie wydaje się to przesada, jeśli zauważymy, iż kiedy traktujemy tamte procesy w taki właśnie sposób, mylimy wtedy postęp z regresem. Postępem sa tylko takie zjawiska i procesy, które zbliżają nas do stanów lepszych od poprzednich i to bez relatywizacji. Wydaje się także, że postęp to spełnienie materialne i duchowe albo tworzenie optymalnych warunków do takiego spełnienia. Przy czym nie mamy tu na uwadze tylko dobra ludzi żyjących w naszym czasie, ale także dobro przyszłych pokoleń. Jeżeli uznajemy, że jakiś proces, zmiana stanu rzeczy przesadza, nawet o subiektywnej ocenie tego stanu jako gorszego, uprawnia nas to do konstatacji, że nie jest on postępowy dla nas samych, ale jeśli zbiorowe odczucie jest sprzeczne z naszym, wówczas postęp „obiektywizuje” się. W sferze mitycznej staje się postępem, choć na dobrą sprawę jest regresem, a my sami stajemy się „reliktami przeszłości” i wrogami postępu, co jest równoznaczne z potępieniem.

Symplifikacje, a potem mityzacje wielopostaciowej idei postępu często prowadzą do przypisywania na stałe jakimś procesom dodatniego wartościowania, a nawet absolutyzacji, a to często uniemożliwia nam zmianę wartości kierunkowej procesu, który może jakościowo przekształcić się w swoje przeciwieństwo i stać się regresem. Zbyt często zachwycamy się rzekomo postępowym procesem nie chcąc zauważać, że ten staje się swoim negatywem, zbyt często zmiana reorientacji, dostrzeżenie konieczności przewartościowania, zabiera nam zbyt wiele czasu, co wynika z nawyków, presji środowiska i wielu innych czynników, których uchwycenie zdaje się wręcz niemożliwe. W jakiejś mierze bywa to efektem zagubienia pierwszych celów rozwoju, choćby fetyszyzacji samej techniki widzianej jako Wielka Matka, która zaspokaja wszystkie pragnienia ${ }^{31}$, jak to, uciekając się do wielkich metafor, zauważał E. Fromm. Technika - Wielka Matka Technologia stała się

${ }^{31}$ E. Fromm, Kryzys psychoanalizy, Poznań 2000, s. 114. 
eschatologią z takim skutkiem, że technomania współczesnego świata pozostaje przesiąknięta wiarą religijna - zauważał z dużą przesada twórca niezwykle popularnego dziełka ${ }^{32}$. Religijna taka wiara chyba nie jest, takie spojrzenie autora ciekawej pracy bierze się zapewne $\mathrm{z}$ automatycznego kojarzenia wielu postaci wiary z religia, ale z pewnościa taka wiara jest mocna, głęboka, do czego przekonują nawet pobieżne obserwacje.

W jakiejś mierze jest to efekt zarówno fetyszyzacji techniki, jak i samej intencjonalności. Przyzwyczajenia do magicznej rytualizacji mitów prowadzą nas choćby do tworzenia fałszywej teleologii intencjonalnej wobec nowych, supernowoczesnych urządzeń i maszyn, które, miast stać się wyzwoleniem, moga stać się koszmarem, a często staja się takim za sprawą nieprzewidywalnych skutków zastosowania jakiejś innowacji, z czym stykamy się nagminnie i czasami pozostajemy bezradni. Niekiedy mówi się przecież o tym, że nasza cywilizacja jest efektem skutków niezamierzonych, a ubocznych zmian technicznych. Być może przeceniamy siły takich mityzacji, ale zgadzamy się choćby z D. Algerem powiadającym, że „mitologia rządzi nami wszędzie i w polityce i ekonomii i stosunkach międzynarodowych"33, choć nie wiemy, czym jest dla niego owa mitologia.

Postaciami mityzacji, jakie miały dodać społecznościom aktywizmu, były zachodnie, optymistyczne projekcje kreowane przez przedstawicieli establishmentu, czasami wręcz absolutyzujące dobrodziejstwa rewolucji naukowo-technicznej. Technokratyczno-konwergencyjne, oficjalnie promowane wizje społeczeństw, przybierały różne postaci, acz wszystkie zdaja się oparte na zasadzie harmonii przy założeniu jedności, ku której zmierza świat: ekonomicznej, politycznej, kulturowej. Teoretycy schyłku II fali, nie zauważający III, ale sięgający w przyszłość, mienili je wielorako: społeczeństwem obfitości, nowym społeczeństwem przemysłowym (J.K. Galbraight), społeczeństwem aktywnym lub postmodernistycznym (A. Etzioni), poprzemysłowym społeczeństwem programowanym (A. Touraine), społeczeństwem masowej konsumpcji (W. Rostow), zabaw (E. Hoffer), czy społeczeństwem unaukowionym (H. Schelsky). Choć czasami traktowano je niemal jak samosprawdzające się prognozy, głośno dyskutowane w mediach, to ilościowo prezentowały się jak margines, a niby optymistycznie nastawieni autorzy zbyt często tworzyli projekcje opozycyjne, jakby nie do końca przekonani do takich legitymizacji systemowych.

Dziś oswajamy się z mitami wirtualnego świata, przekonywani przez „autorytety”, że on jest przyszłościa, nową postacią postępu

${ }^{32}$ E. Davis, Tech Gnoza, s. 327.

${ }^{33}$ D.E. Alger, The Media and the Politics, Belmont 1996, s. 21. 
umożliwiająca spełnienie. Zwłaszcza młodzi ludzie sa karmieni iluzjami pełni, a takie iluzje ostatecznego spełnienia w wirtualnym świecie tworzy wielu zwolenników tego „wulgarnego” postępu. Pośród nich T. Leary, „guru” tego świata powiadający: „wszystko, co możesz pomyśleć, wyśnić może być zrealizowane w cyberprzestrzeni” ${ }^{34}$. Rzadko spotykamy próby innego spojrzenia na świetlane wizje obcowania z cyberprzestrzenia. Dla W. Sztumskiego jest to tylko droga do społeczeństwa niewiedzy i dezinformacji, do szerzenia się w coraz szybszym tempie „masowej głupoty” ${ }^{35}$ Nie pozostając przy tym dłużej do pewnego stopnia zgadzamy się ze zwolennikami optymistycznego postrzegania Internetu. Z pewnością zaspokaja on potrzeby społeczne, pozwala na tak potrzebne kontakty bezpośrednie (prawie) z innymi, ale gróźb jest także wiele i to poważnych, jeśli przed dziesięciu laty Amerykańskie Towarzystwo Psychologiczne uznało korzystanie z Internetu za uzależnienie traktowane na równi z narkomania i alkoholizmem. Jest niebezpieczny, ale nie tylko dla uzależnionych od gier, niebezpieczny także jako pole bitew. Cyberataki Rosjan dokonane na Estonię i Gruzję w czasie konfliktu o Osetię przez Russian Bussines Network, pozostajaccy na usługach FSB, sparaliżowały ruchy Gruzinów i w jakiejś mierze przesądziły o tak wstydliwej jednak klęsce chlubiących się swoją odwaga i walecznością Gruzinów, a niedawno cyberwojna Korei Południowej groził nowy przywódca Północnej. Ostatnio zaś pisze się o chińskich jednostkach wojskowych majacych zajmować się właśnie cyberatakami.

Powinniśmy pamiętać o tym, że postępowość techniczna bywa ograniczana w czasie, a nowe wynalazki bywają wartościowane dodatnio tylko przez pewien czas, a jak zauważają to niektórzy, potem wiele z nich zdaje się obracać przeciw samemu człowiekowi, egotycznemu, myślącemu tylko o doraźnych korzyściach, zapominającemu o regułach homeostazy, dobru gatunku, o tym także, że konsekwencje błędów zwykle okazują się większe niż przypuszczano w początkach, co zdaje się być owocem braku wyobraźni prospektywnej. Nadzieja na zbawienie niepostrzeżenie zamienia się w źródło wielu strachów, jakie paraliżuja „człowieka masowego”. Wiedząc o tym wiemy także, że nikt nie zdejmie z nas brzemienia odpowiedzialności za los ludzkości i aby uniknąć katastrofy sami musimy wyznaczyć granice naszych pasji tworzenia i niszczenia - pisał A. Camus w Człowieku zbuntowanym. Wiara w postęp nader często sprawia, że nie chcemy nawet myśleć o szukaniu takich granic, gdyż ta wiara implikuje schlebiające nam przekonanie

\footnotetext{
${ }^{34}$ K. Robins, Cyberspace and the World we Live In, [w:] Cyber Space, Cyber Bodies, Cyber Punk, ed. M. Featherstone, R. Burrows, London 1995, s. 138.

${ }_{35} \mathrm{~W}$. Sztumski, Ku społeczeństwu niewiedzy $i$ dezinformacji, „Transformacje” 1-4, 2007-2008, s. 140.
} 
o wszechmocy człowieka. Brak tej refleksji jest, być może, wynikiem zaburzenia istoty podstawowej struktury przeżywania - bycia-ku ${ }^{36}$, być może naruszeniem tego, co U. Eco nazywał dążeniem do stworzenia świata zgodnego z naszymi marzeniami ${ }^{37}$. Być może, gdyż w nieustannym dyskursie ze światem nie potrafimy nawet stawiać pytań na czas.

Przestaliśmy na dobre wierzyć w kumulatywny postęp - zauważał uczony ryzykując taką karkołomną tezą ${ }^{38}$ i można by traktować ja ze zrozumieniem intencji, gdyby badacz miał na myśli techniczny. Nie przestaliśmy wierzyć $\mathrm{w}$ postęp jako taki, a kumulatywny nie oznacza wiele dla zwykłego wyznawcy. Nasze, powszechne przekonanie do idei postępu to mocna wiara w to, że dziś jest lepsze od wczoraj, a jutro będzie lepsze od dziśs ${ }^{39}$. Takiej wiary, która jest konsekwencja wielu niespełnień, nie wyzbędziemy się chyba nigdy, nawet wtedy, gdy będziemy w głębokiej depresji. A wierząc, nawet głęboko, nie wyzbędziemy się także wiary w regres, bo ta nie może istnieć bez tej pierwszej, jest jej alter ego, a bywa także niepojętą inspiracją do zmian świata na lepsze. Kryzysy jakby tylko poświadczaja, akcentuja siłę idei i bez nich postęp nie byłaby tak zauważalny, może nawet niemożliwy, jak zło nie byłoby możliwe bez idei dobra. Zajmując się myślą prospektywna, jej formami i treściami, zauważamy, że zdecydowana większość prospekcji obejmujacych trójczas jest katastroficzna i mamy tu na myśli i wizje przyszłości z przeszłości i wielość profecji, jakie od lat odpowiadaja na wyzwania czasu. Bezkompromisowo „postępowe” utopie są tylko marginesem takiej wizyjności. Paradoksalnie zdecydowana większość projekcji jutra to klasyczne wizje strachu. Ale sama idea postępu, odrywana od techniki, rozumiana raczej jako wiara w lepsze jutro jest matka postaw i zachowań, jakie zwiemy optymizmem indywidualnym i zbiorowym. Ten nie pojawia się zbyt często w nauce jako rzekomo niemożliwy do zbadania, ale nam musi towarzyszyć jako wykwit nadziei, a jej, jako jakościowego czynnika zmian, nie można nie zauważać. Nie da się także zakwestionować, wyrzucić go z języka czy praktyki życiowej

Rewers postępu - katastrofizmy, rozumiane jako postaci wiary w naturalne, „obiektywne” kataklizmy, zdają się być pochodną mitów tworzaccych degeneratywizm i w naszym mniemaniu są czymśs więcej niż odbiciem partykularnych, czasowo ograniczanych kryzysów będąc

\footnotetext{
${ }^{36}$ R. Spaeman, Osoby. O różnicy między kimś a kimś, s. 53.

${ }^{37}$ U. Eco, Dzieło otwarte. Forma i nieokreśloność w poetykach wspótczesnych, Warszawa 1994 , s. 160.

38 J.B. Foster, In Defense of History, [w:] In Defense of History. Marxism and Postmodern Agenda, eds E.M. Wood, J.B. Foster, New York 1997, s. 192.

${ }^{39}$ L. Goodwyn, The Populist Moment. A Short History of the Agrarian Revolt in America, Oxford 1978, s. IX.
} 
ich potwierdzeniami. Zmieniały się jakościowo w czasie generowane przez nowe zagrożenia i w naszej ponowoczesności maja już zdecydowanie inne postaci, choć ciagle żyjemy w cieniu wielkich katastrof, widoków których nie szczędzą nam media. Przez wieki wielkie kataklizmy były zwykle zapowiadane przez profetów, od niedawna zaś przez naukę. Swego czasu siały grozę wśród prostaczków, dziś ogarniaja, porażają wszystkich dzięki mediom. Kiedyś miewały ograniczony charakter, a w dobie globalizacji i mediów otwartych maja już charakter uniwersalny. Dawne wierzenia pozostawiały nadzieję na przeżycie wybranym, dzisiaj nikomu, choć najczęściej nie na przeżycie, a uniknięcie konsekwencji kryzysu.

Bywają okresy, w których ich natężenie rośnie i wydaje się znowu, że dziś mamy do czynienia $\mathrm{z}$ ich nawrotem $\mathrm{w}$ postaci bardziej skondensowanej, co niektórzy łączyli ze spodziewanym przesileniem czasu łączonym z końcem tysiąclecia, a co nie wydaje się wyjaśnieniem satysfakcjonujacym, jeśli zważymy, że nasilenie nastrojów strachu zauważamy w okresie pełnego Odrodzenia i tam dostrzeżemy katastrofistów takich jak Leonardo i Bruno ${ }^{40}$. Nie tylko tam, gdyż każde pokolenie ma swoje strachy, swoje wizje katastrof. Być może ich nasilenie jest przymiotem „okresów przebudzenia do tożsamości”, choć jest to jeszcze jedna metafora mówiąca o nieświadomych reakcjach zbiorowości na zmianę, której istoty nie rozumieją ${ }^{41}$. Można ją jednak konkretyzować dodając, że były to przejawy strachu wiązane z czasowa prosperity, pragnienia, by ten stan zatrzymać, zakonserwować, bo przecież każde wieszczenie załamania aktywizuje, inspiruje nowe cele, które moga stanowić zagrożenie dla zdobytych już statusów. Bez wątpienia strachy zbiorowe w postaci katastrofizmów są realnością, a ta niepewność $\mathrm{w}$ próbach ich usytuowania bierze się w jakiejś mierze z ich nieobecności w refleksji naukowej.

Zauważając stałą obecność archetypu wielkiej katastrofy w kulturach człowieka zauważmy i to, że każde przesilenie budzi podskórne niepokoje, których nauka nie potrafi (nie może) jeszcze rozpoznawać, jakieś przeświadczenia, że coś się kończy na zawsze i czeka coś innego, nieznanego, a nieznane budzi lęk rywalizujący z nadzieją ${ }^{42}$. Bardziej konkretni zdają się ci autorzy, którzy łączą obecność katastrofizmów w naszym czasie z tym, co A. Toffler przed prawie trzydziestu laty nazywał „zderzeniem się fal”. Toffler nie był tak oryginalny, mówiąc o tym, że „agonia przeszłości przyćmiewa nadzieję, jaką daje przyszło-

\footnotetext{
${ }^{40}$ F. Cuomo, Wielkie proroctwa, s. 228.

${ }^{41}$ W. Straus, N. Howie, Generations, s. 348.

${ }^{42}$ Ch. Lasch, The Culture of Narcissism, New York 1991, s. 3.
} 
ść" ${ }^{43}$, zdawał się powtarzać sugestie J. Huizingi analizującego zjawiska jakościowe towarzyszące ,jesieni średniowiecza” na sposoby nieobecne dotąd w nauce. Obaj zauważali powstawanie nowej, otwartej sytuacji historycznej, początki wielkiej zmiany, jaka ludzie odbierają intuicyjnie nie czekając na diagnozy nauki, a poświadczeniami tej zmiany są dla nich budzące niepokoje, spontaniczne próby przekształcenia światów symbolicznych, których źródła także są nierozpoznane ${ }^{44}$. Członkowie społeczności naszego czasu zauważają nagle, że nowe warunki wyzwalają ich z form społeczeństwa przemysłowego: klasy, warstwy, rodziny, że ryzyko stopniowo narasta, a jest to pokłosie refleksji tyczących stosunku człowieka do świata, uzgodnienia się z nim w tych nowych warunkach. Wyznając wiarę w postęp dualne jednostki i zbiorowości hołdują i jego opozycji, a nieumiejętność wyboru albo odnalezienia się między skrajnościami, przesądza o tym, że nie są w stanie nie tyle wykorzystać, jak widział to $\mathrm{K}$. Wittfogel, ale nawet rozpoznać tkwiących $\mathrm{w}$ tej zmieniającej się teraźniejszości nowych możliwości ${ }^{45}$. Można odnieść wrażenie, że brak umiejętności rozpoznawania przyszłości przesądza o tym, że jesteśmy zwykle spóźnieni.

Miotając się między postępem-nadzieja, a regresem-strachem, ludzie czasami zapominają o poszerzaniu horyzontów zbawiania w doczesności i poprzestaja na zachowywaniu tego, co maja tu i teraz zapewniając się, że to jest ta pełnia, ku której dążyli, choć pewnie spora ich część nie wierzy w to do końca. Akceptują stagnację nie przyjmując do wiadomości tego, że to właśnie rytm zmian na lepsze i gorsze jest miara czasu człowieka ${ }^{46}$. Do tego naturalną miara czasu ludzkiego jest wynikająca ze struktur adaptacyjnych umiejętność przystosowywania się, przejawiająca się w tym, że jesteśmy krótkotrwałymi pesymistami i długotrwałymi optymistami. Cykliczne badania placówek związanych z Klubem Rzymskim potwierdzaja takie tendencje, a tym samym i to, że nadzieje długiego trwania sa jakościowo inne od tych krótkiego.

Według Tofflera i nie tylko jego, jesteśmy świadkami zderzenia się fali industrialnej z informacyjna i ten zwrot jest już trwały, ma charakter megatrendu i dla wielu teoretyków już żyjemy w epoce informacyjnej, choć analitycy miewaja poważne kłopoty z określeniem jej charakteru, co widać $\mathrm{w}$ przebogatej literaturze pełnej kontrowersyjnych hipotez i sądów. Druga, industrialna fala rozwojowa, przez wieki opierana na „postępowym” rozwoju przemysłowym, przeżyła się w ostatnich dekadach, a wraz z nią tradycyjne instytucje społeczeństwa prze-

\footnotetext{
${ }^{43}$ A. i H. Toffler, Budowa nowej cywilizacji, s. 11.

${ }^{44}$ J. Fitoussi, P. Rosanvalon, Czas nowych nierówności, Kraków 2000, s. 5.

${ }^{45}$ K. Wittfogel, Wtadza totalna, Toruń 2002, s. 513.

${ }^{46} \mathrm{~K}$. Lynch, What Time is this Place?, s. 65.
} 
mysłowego, a między nimi systemy edukacyjne oraz ustroje rządów „pseudoprzedstawicielskich”, czyli demokracja w jej klasycznej formie. Dzisiejsze kryzysy funkcjonalne dla wielu analityków są wynikiem agonii cywilizacji drugiej fali opartej na sile rak. Trzecia fala zawierzyła sile umysłów kwestionując podstawowe wzory drugiej: standaryzację, centralizację, maksymalizację, koncentrację i biurokratyzację. Wymaga nowych umiejętności, w tym elementarnej umiejętności adaptacji do nowych warunków, ale jej postępowość i „zbawczość” może być kwestionowana przez miliony obrońców drugiej fali, którzy nie są w stanie odnaleźć się w trzeciej i dla nich skomplikowane społeczeństwo zwane informacyjnym, jest tylko przekleństwem, nie forma postępu, swoista „suma wszystkich strachów”. Te miliony nie są w stanie sprowadzać złożoności świata do poziomu rozumienia i stąd taka podatność na sugestie z zewnątrz ${ }^{47}$, stąd ich wiara w to, że żyjemy w czasie, w którym kończy się stary świat i trzeba zatrzymać go w sobie jak najwięcej używając wszelkich dostępnych środków. One marzą o takich postaciach postępu, jakie uczynią ich życie lepszym.

Nierozpoznana przez człowieka ponowoczesność (niejako z rozpędu widziana jako postępowa), swoisty wynik działania nie poprzedzonego detekcja efektów, doprowadziła do pojawienia się setek skutków ubocznych, które postrzegane sa jako zagrożenia, poświadczenia nowych kryzysów zwykle sytuowanych na tle starych katastrofizmów. Szybki, niekontrolowany wzrost zjawisk doby nazywanej także „późnym kapitalizmem" zrodził specyficzne dla niego kryzysy limitujące systemy - naruszenie równowagi ekologicznej i radykalne napięcia w stosunkach międzynarodowych - zauważał dość dawno J. Habermas ${ }^{48}$ notując tylko niektóre efekty kryzysu rozpoznawanych dopiero początków ponowoczesności. Wiele $\mathrm{z}$ nich implantuje się $\mathrm{w}$ stare struktury, a nie jest to trudne, gdyż choćby katastrofizm osobowościowy znany jest od setek lat.

Znaczace ich natężenie można zauważyć u progu lat 70. po wojnie bliskowschodniej i szokujacym świat kryzysie paliwowym, choć zdawały się istnieć jakby obok idei postępu, jakby nie były jego opozycja. Wtedy to, jak ze spora przesadą utrzymywał profetyczny A.Toffler, na dobre załamała się scjentystyczna i technicystyczna arogancja świata rozwiniętego. „Ogłupiano się nawzajem - pisał - najtęższe umysły próbowały utrzymać stan jakiegoś niejasnego status quo, co musiało rozpaść się w drzazgi pod naporem przyspieszenia" ${ }^{49}$. Wtedy to odczuto,

\footnotetext{
${ }^{47}$ B. Reeves, Media i ludzie, Warszawa 2000, s. 295.

${ }^{48}$ J. Habermas, Legitimated Crisis, [w:] Comparative Politics, eds B.E. Brown, R.C. Macridis, Belmont 1996, s. 68

${ }^{49}$ A. Toffler, Szok przyszłości, Warszawa 1974, s. 276.
} 
że zbieramy owoce nieczynienia niczego dla przyszłości, wtedy zdawać się mogło, że wieszczenia katastrof mogą stać się bodźcem do zdecydowanych działań prewencyjnych, działań w imię przyszłości. Ale tak się tylko zdawało. Po przezwyciężeniu kryzysu wszystko znów wróciło $\mathrm{w}$ stare tory, tak przynajmniej sądzili politycy. Katastrofizmy jednak pozostały w wyobrażeniach zbiorowych czekając jakby na swój czas.

Chcemy im się przyjrzeć nie tylko dlatego, że są rewersami postępu, ale dlatego, że one są inspiracjami do poszukiwań uniwersalnych, „prawdziwych” postaci postępu. Odpowiednie reakcje na nie, polityka prewencji w wymiarze krajowym i międzynarodowym, mogłyby stać się prawdziwie postępowe, czyli dobre dla całej ludzkości. Podówczas postęp nie byłby może tak relatywizowany i to, co dobre dla jednych nie musiałoby być koszmarem innych i inaczej spoglądano by na mityczne „koszty postępu”.

Katastrofizmy, utożsamiane czasami z bardzo nieostrym pojęciem pesymizmu zbiorowego, uwypuklaja destrukcyjne efekty działania człowieka, on to przecież tworzy nowe źródła zagrożenie w imię spełnienia, on przesądza o tym, że ich ilość rośnie w postępie geometrycznym. Niektóre z nich są mutacjami mitycznego przeświadczenia, że to sam człowiek przesądzi o swoim końcu i takim jest katastrofizm nuklearny - wykwit wielkiego mitu wojny jako remedium na problemy świata. Gdzie indziej poświęcaliśmy mu więcej miejsca, tu zauważmy tylko, że paraliżujące $\mathrm{w}$ latach 50 . strachy nuklearne szeroko rozumianego Zachodu stosunkowo szybko zostały wyparte, oswojone w imię spokoju, radości z życia pełnego dóbr materialnych. Żyjąc w strachu ludzie „korzystali z chwili”, bo pragnienie życia w beztrosce okazywało się silniejsze od owego paraliżujacego strachu, optymizm dualnego człowieka przeważył nad paraliżującym pesymizmem. I teraz nie boimy się nowych wojen, a ich kształty rysują się wyraźniej, choć sa jeszcze mgliste, poza mityzowaną wojną z terroryzmem. Toczące się gdzieś na peryferiach wojny o wodę czy wojny głodowe sa poza imaginacja bogatych i spełnionych, co zdaje się potwierdzać stosunek do konfliktu w Rwandzie.

Podobnie oswojono katastrofizm populacyjny, przeżywający apogea za sprawą T. Malthusa i zauważyć można, że tak oswojone strachy nie sa postrzegane jako źródła kryzysów przez społeczności, choć są nimi dla decydentów. Doceniono ich wagę, kiedy powróciły w Raportach dla Klubu Rzymskiego i kiedy pojawiły się szacunki ich autorów. Wedle niektórych z nich ludzkość osiagnęła miliard około roku 1850, w roku 1950 było nas 2,5 miliarda a w roku 1997 5,9 miliarda. Oznaczało to, że w ciaggu zaledwie 47 lat ludność globu zwiększyła się o $132 \%$. W roku 2050 (wg szacunków World Population Prospect) ma wynieść około 
10 miliardów. Swego czasu głośne były ekstrapolacje brytyjskiego fizyka J. Fremlina, które zaprezentował w roku 1964, gdy ludzkość przyrastała w tempie $1,9 \%$ rocznie. Według niego, przy takim tempie wzrostu ludność globu będzie liczyła 260 miliardów za 400 lat, a za następnych 370 lat wzrośnie do 3 bilionów ${ }^{50}$. One także miały służyć tylko prowokowaniu, a mimo wszystko nie spełniły swoich ról, a miały racjonalizować przerost populacji.

Jeszcze w latach 70. problemy i potencjalne zagrożenia z tym wiązane budziły obawy zbiorowości, dziś zaś trudno zauważyć ślady tego katastrofizmu w dysputach naukowych czy publicystyce, choć chyba trzeba znowu zaczaćc go rytualizować właśnie w imię postępu. Problemy wojen głodowych będących konsekwencją procesów demograficznych zaszokowały opinię światową u końca lat 90., okazały się zagrożeniami mogaccymi owocować konfliktami o charakterze asymetrycznym, jakich nie będzie w stanie rozwiązać nikt, bo wiara we wspólnotę międzynarodowa jest zawodna. Prostą i głośną dziś konsekwencją nierównowagi demograficznej jest niepowstrzymany napływ imigrantów, który już zmusił Stany Zjednoczone do przyznania sobie statusu oblężonej twierdzy, a Europę może zmusić w najbliższym czasie. Oni, głodni i wierzący, będą atakować nawet twierdze w poszukiwaniu swoich wyobrażeń o raju, choć najczęściej spotykają ich upokorzenia, gwałty rodzące czasem nienawiść do kraju przyjmującego. Postępowe polityki multikulturalizmu, opierane o bardzo watłe przesłanki, bardzo wysublimowane, uzgadnianie $\mathrm{z}$ formami demokracji i normami poprawności politycznej, zawodzą i zawodzić będa, bo przybysze nie chcą się asymilować, jak ostatnio w Stanach i Europie Zachodniej. Oni chca się samozbawiać traktując ziemię obietnicy jak swoją, a ludzi zamieszkujących ją od wieków za obcych.

Mieszane odczucia budza społeczne reakcje na katastrofizm ekologiczny, bo z jednej strony widzimy niby szczere manifestacje społeczności w obronie środowiska, a z drugiej oburzenie wtedy, kiedy nie chce się radykalnie ingerować $\mathrm{w}$ to środowisko dla doraźnych korzyści mieszkańców albo w imię korzyści wspólnych i tu mamy na uwadze protesty mieszkańców terenów podobno bogatych w gaz łupkowy. Wygoda czy namiastki bezpieczeństwa sa zdecydowanie ważniejsze od tych dóbr, jakich nie da się odtworzyć, o czym dobrze wiadomo. Nasz stosunek do przyrody także jest poświadczeniem braku myślenia prospektywnego, dbania o dobro nasze, nie zstępnych i to cechuje nie tylko zwykłych obywateli, ale elity, które nie myślą o tym, by stworzyć spójną doktrynę ochrony zasobów naturalnych ${ }^{51}$. To zwykle znajduje się na trzecim

${ }^{50}$ A. Berry, Nastepne 500 lat, Warszawa 1997, s. 214.

${ }^{51}$ K. Lynch, What Time is this Place?, s. 29 
planie zainteresowań, bo niby zawsze są ważniejsze sprawy, a ekologia wraca wtedy, kiedy zdarzy się jakaś katastrofa.

Ten katastrofizm, będący częścią archetypu raju utraconego, jest przyjmowany z zadziwiająca obojętnością i zagrożenia są zbywane z łatwościa, zwłaszcza wtedy, kiedy nie dotykają nas bezpośrednio, nie zagrażaja naszemu wygodnictwu. Ludzkie doświadczenie przeszłości rodzi fatalistyczne przekonanie, że tak było „od zawsze” i od zawsze człowiek radził sobie z tymi problemami, jakie niesie czas, a jeśli sobie jakoś radził, to poradzi sobie i tym razem. One sa jakby częścia doświadczeń gatunkowych i zakodowany w nas, postprowidencjalny fatalizm połączony $\mathrm{z}$ wiarą $\mathrm{w}$ transcendentna mądrość natury rodzi przeświadczenia, które sprawiaja, że człowiek naszego czasu jest tak nieczuły na argumenty „zielonych” lub environmentalistów ${ }^{52}$. Nie bez znaczenia pozostaja tu przesłania religijne o ziemi poddanej człowiekowi, mającej mu służyć, choć one służą tylko czasami jako drugorzędny argument.

Prawdziwe wyzwanie stało się ciałem dla całej ludzkości po ogłoszeniu raportu U'Thanta, z którego wyrosła Światowa Karta Przyrody, swego rodzaju ekologiczny katechizm, który przez lata pozostawał martwą litera, a w założeniach miała być deklaracją postępu rozumianego jako dobro całej ludzkości. Już wtedy nie sposób było kwestionować zasadności jego powstania ani sugestii, by użytkować zasoby biologiczne tak, by nie przekraczało to ich zdolności reprodukcyjnych albo użytkowanie gleb przy dbaniu o ich długoterminową użytkowość. Szlachetne apele pozostawały tylko zapisami aż po czas, w którym zaczęto odkrywać, że zanieczyszczenie środowiska stało się prawdziwą bariera wzrostu i przekłada się na poziomy życia także w krajach bogatych, ale to także wlicza się w „koszty postępu”. Uprzednio takie nawoływania nie poruszały nawet wtedy, kiedy dowodzono jak szkodliwe dla zdrowia są niektóre zagrożenia. Wtedy też sprawdzało się powiedzenie mówiące, że w szczęściu i nieszczęściu jesteśmy samotni, a nadto, że zawsze mamy nadzieje na to, że takie nieszczęście dotknie kogoś innego. Zaliczano je w szereg wypadków losowych, ale teraz, kiedy okazało się, że niszczenie natury odbije się na wszystkich bez wyjątku, poczęto ponownie zastanawiać się nad wzajemnymi więziami człowieka i środowiska. Niezwykłe role odegrali naukowcy dowodzacy, że człowiek jest istota biofilna, ustawicznie wiązaną wieloma nićmi z przyrodą żywą i dzięki E. Wilsonowi, E. Morinowi, J. Monod, V. Pottersowi bioetyka zaczęła stawać się własnością milionów. Pojawiła się zbawcza idea dla całej zielonej planety i pozostaje tylko szlachetną idea, choć jest postępowa.

${ }^{52}$ A. Rand, Powrót człowieka pierwotnego, Poznań 2003, s. 9. 
Z kolei ten katastrofizm od czasu głośnego raportu U'Thanta i Ekospazmu A. Tofflera zmieniał się jakościowo determinowany ilościa zagrożeń będących efektem tego „postępowego” rozwoju. Od pierwszych ostrzeżeń przed nowymi groźbami, jakie przyniosły wymierne efekty, znowu doszliśmy do bariery oswojenia strachu, czego symptomem sa choćby dyskutowane często problemy wiązane $\mathrm{z}$ implementacja porozumień z Kioto zakładajacych daleko idąca, ale wciąż niewystarczająca redukcję emisji gazów wywołujących efekt cieplarniany. W imię idei „zbawienia” całej planety warto przypomnieć, że rok 1997 został ogłoszony jako najcieplejszy w dziejach Ziemi i wtedy pojawiły się przerażające ekstrapolacje trendów, które mogły działać na wyobraźnię nawet polityków. Suponowano, że jeśli nie uda się zahamować poziomu emisji, to rok 2030 będzie tym, w którym runie bariera bezpieczeństwa i w latach następnych ogromne połacie lądów znikną pod wodami mórz i oceanów na skutek topnienia lodów Arktyki i Antarktyki. Na razie takie zagrożenia są realnością dla setek wysp na Oceanie Indyjskim. Ale takie przestrogi nie działaja tak skutecznie jak efekty anomalii pogodowych na ekranach telewizorów. One są w stanie wywoływać traumy i na krótki czas budzić „sumienie ekologiczne” dużych grup społecznych, choć ich ozdrowieńczych ról przeceniać nie można.

Nietrudno zauważyć, że w obronie swoich ekosystemów część obciążeń świat nazywany rozwiniętym spycha na barki krajów najbiedniejszych, choć wiadomo od dawna, że ekosystem globalny nie jest w stanie przeciwstawić się inwazji odpadów i nowych produktów, zwłaszcza chemicznych ${ }^{53}$. Takim sposobem przekonujemy się do swego karygodnego recentywizmu, uwalniamy się na jakiś czas od problemów, ale jest to ledwie odsuwanie ich w czasie, gdyż konsekwencja tworzenia nowego środowiska są także nowe choroby i mutacje starych ${ }^{54}$, a nie wiemy czy choćby ptasia grypa i inne choroby odzwierzęce takimi konsekwencjami nie sa. Politycy i ekonomiści zapewniają nas, że tego rodzaju przykłady destrukcji sa jedynie przejściowymi niedogodnościami w drodze do nieograniczonego dobrobytu, ale nie dodaja, że konsekwencje niektórych procesów sa już nie do odwrócenia i zagrażają owemu imaginowanemu dobrostanowi, bo te problemy będzie trzeba kiedyś rozwiązać.

Reakcje państw na zagrożenia ekologiczne cechują sprzeczności będące chyba w jakiejś mierze pokłosiem procesów globalizacyjnych. „Racjonalność” partykularna konfrontuje się z „racjonalnościa” globalną ze szkodą dla biosfery i nas wszystkich. Ogromnie trudno osiagnąć konsensus w sprawach niewątpliwego i zagrożonego dobra wspólnego.

${ }_{53}$ A. Peccei, Przyszłość jest w naszych rękach, Warszawa 1987, s. 26.

${ }^{54}$ E.P. Eckholm, Człowiek $i$ środowisko, Warszawa 1987, s. 39. 
Szczyty Ziemi, konwencje klimatyczne, owocują ustaleniami, których nie można wyegzekwować, o czym przekonują zachowania Amerykanów, którzy nie mieli i nie mają zamiaru przestrzegać postanowień z Kioto. I wydaje się, że politycy postępowali tak rozumiejąc istotę wiary przeciętnego człowieka nastawionego na zbawienie $\mathrm{w}$ doczesności. Amerykanie zdali się zapomnieć o wspomnianym obowiązku zostawiania następcom bezpieczniejszego świata, czym szczycili się przez lata. Swoje role w kreowaniu takich postaw grają różnego rodzaju wyjaśnienia, które można reinterpretować na wiele sposobów, jak choćby przy pomocy modnej swego czasu koncepcji społeczeństwa ryzyka. Teoretyk powiada, że „ryzyko generuje nowy typ społeczeństwa, w którym solidarność jest oparta na poczuciu niepewności" ${ }^{55}$, ale takim wyjaśnieniom przeczą obserwacje wielu zachowań społecznych, gdyż biorąc je pod uwagę nietrudno zauważyć, że ryzyko jest jednak dysjunktywne, atomizuje daną społeczność rozumiejącą walkę o byt w mityzowanym, darwinowskim sensie i rodzi konflikty $\mathrm{z}$ innymi.

Niewiele mówi się o poważnych barierach w usuwaniu zagrożeń ekologicznych. Swego czasu autorzy Raportów dla Klubu Rzymskiego ostrzegali, że sumy mogace stworzyć formy detekcji i usuwania takich zagrożeń mogą sięgać 0,2\% dochodów narodowych krajów rozwiniętych, a dziś mówi się, że mogą sięgać 1,5\% dla niektórych krajów i ilość środków potrzebnych do zneutralizowania najpoważniejszych zagrożeń będzie rosła aż do poziomów niemożności uporania się z nimi - przestrzegali swego czasu aktywiści Greenpeace. Zreszta, wielu krajów nie stać już nawet na próby zapobiegania, z jednej strony za sprawą braku środków, a z drugiej ze względu na presję korporacji międzynarodowych, oskarżanych o to, że zupełnie nie dbają o ochronę środowiska. Nie tylko korporacje moga być o to oskarżane, ale wiele państw chcących osiagać takie poziomy samozbawienia i tu przywołamy Chiny i Indie.

Z pewnością dziś stać nas na ekstensywne formy zapobiegania zagrożeniom w imię spełnienia $\mathrm{w}$ doczesności gdyby właściwie oceniano zagrożenia i myślano o prewencji. Konsekwencje zanieczyszczeń są dla środowiska ludzkiego oczywiste, spada długość życia, wzrasta śmiertelność niemowląt, zachorowalność na choroby krążenia i nowotworowe, a tego się nie da kwestionować. Takimi formami, które choć nieco mogą pomóc nam żyć i umierać zdrowiej są te mieszczące się w edukacji ekologicznej. Co prawda, nasze myślenie staje się coraz bardziej holistyczne, naturalistyczne, ale te zmiany sa zbyt powolne wobec szybkości procesów degradacji środowiska. Wciąż zbyt wiele w nas pozostałości

${ }_{55}$ B.S. Turner, Mc Citizens, [w:] Resisting McDonaldization, ed. B. Smart, London 1999, s. 86. 
oświeceniowych idei postępu tożsamego z „ujarzmianiem” dzikiej przyrody dla dobra ludzkości, zbyt wiele ciasnego egoizmu tożsamego z płaceniem przez innych kosztów naszego postępu.

Zamiast nad zagrożeniami dla wszystkich syty, zmęczony sobą biały świat woli deliberować nad swoim katastrofizmem osobowościowym i wypływającymi z niego kryzysami jednostek i zbiorowości. W dyskursie o statusie współczesnego człowieka mówi się o tym, że poszukiwanie tożsamości skierował poza siebie, że zabija siebie i zbiorowość przez akceptacje kultury narcyzmu, hołdowanie prymatowi rozumu instrumentalnego, makdonaldyzacji w kontaktach interpersonalnych. Uczeni amerykańscy zwłaszcza bezustannie mówią o kryzysie moralności protestanckiej, zagubieniu jednostki w społeczeństwie ryzyka i zdaja się powtarzać to samo od lat 50. To, o czym jeszcze będziemy wspominać dalej, zdaje się być eksponowaniem problemów drugiego i trzeciego planu, a do tego czasami problemów sztucznie tworzonych, bo ilość odnajdywanych, spontanicznych sposobów przywracania homeostazy przez jednostki jest ogromna, choć nie da się ukryć, że rozsądnie pomyślana ekologia człowieka byłaby przydatna właśnie w naszym czasie, w tle innego myślenia o środowisku zewnętrznym i mogłaby być prawdziwym znamieniem postępu. Nietrudno zauważyć, że środowiska nas socjalizujące nie uczą jak żyć, jak się spełniać poza dobrami czysto materialnymi. One wszystkie uczą nas tylko tego, jak się najlepiej przystosować, by odnosić jak największe korzyści, właśnie materialne. Przechodzimy całkiem dobre szkoły mimikry i myślimy przede wszystkim o formach człowieka, nie treściach.

Przywołanie powyższych katastrofizmów nie może napawać optymizmem, rodzi coś przeciwnego. I tu pojawia się proste pytanie o to, dlaczego optymizm i pesymizm jako jakościowe czynniki zmian i emanacje wiary w postęp i katastrofę pojawiają się w literaturze naukowej nie jak określone metafory, ale nic nie znaczące ozdobniki i niekiedy czytamy, że taki czy ów polityk był nadmiernym optymistą i miało to opłakane konsekwencje albo, że pesymizm innego przełożył się na to czy na to. Optymizm i pesymizm, jednostkowy czy zbiorowy są koagulatami emocji, ulotnymi, zmiennymi w naszej dualności i niekiedy starczy nawet mało znaczace wydarzenie, by zastapić jedno drugim w dualnym człowieku, tak jak wiara w postęp przeradza się w wiarę w regres. O ile łatwo wiązać je ze strachem, nadzieja, o tyle zdecydowanie trudniej zdefiniować choćby dla własnych potrzeb. Nawet nie próbujacc kategoryzacji chcemy w tym miejscu tylko przekonywać do optymizmu zaczynając od A. Tofflera, który mówił, że żaden pesymista nie odkrył sekretu gwiazd ani nie odkrył nieznanego świata, czy nie otworzył nieba 
dla ludzkiego ducha ${ }^{56}$. Choć będzie to wielkie uproszczenie, to możemy uznać optymizm za znamię ,postępowca”, pesymizm zaś katastrofisty.

Jeszcze w latach 60. D. Gabor pytał o to, czy stać na pesymizm i odpowiadał, że nie, że koszty jednostkowe i społeczne braku odwagi wobec jutra sa zbyt wysokie ${ }^{57}$. Pesymizm jednostkowy, oznaczający przecież brak wiary w spełnienie, charakteryzuje się nieufnością do przyszłości skojarzona zwykle z nieufnością do ludzi. Pesymista zwykle oczekuje najgorszego nawet ze strony bliskich i bywa, że właśnie im przypisuje najgorsze cechy, egotyczne motywacje, chęć wykorzystywania innych i prawdziwa tragedia jest sasiedztwo dwóch takich osobowości. Dla pesymisty społeczeństwo to zbiorowość wroga, i, wedle jego przekonania, chcąca wykorzystywać go na wszelkie sposoby. Negując jej istotę maluje ją zwykle w czarnych kolorach wszędzie poszukując wrogów, hołdując prymitywnym teoriom spisku i spiskowym. Wobec możliwości tkwiących w jutrze pesymista jest zwykle nieufny szukając najpierw przeszkód, trudności, minimalizujac cel, niewart, jego zdaniem zachodu. Pesymista indywidualny cechuje się tendencją do zarażania pesymizmem, negatywizmem i pasywizmem innych i często jedna osoba potrafi nim zainfekować setki. Oczywiście nigdy nie osiaga granicy swojego pesymizmu, bo to byłoby równoznaczne z autodestrukcja. Pesymista w swej dualności zna smak optymizmu, z tym, że on raczej rzadko przeważa.

Wydaje się, że pesymizm zbiorowy kumuluje się wraz z nowymi strachami naszego czasu, staje się źródłem stagnacji, lenistwa, biernej kontestacji utrwalanej czasami mocno przez pesymistyczna zbiorowość. Taki pesymizm przekłada się na zbiorową inercję, podatność na indoktrynację zawężaną do argumentów zbieżnych z postawami i jeśli chcemy zorganizować, zaktywizować grupę pesymistów, musimy zacząć powtarzać, że wszyscy wokół są wrogami, złodziejami i tylko my zaspokoimy tych leniwych pesymistów zaspokajając wszystkie ich potrzeby i dbając o ich przyszłość. Ale taka organizacja kryje w sobie niebezpieczeństwa metamorfozy, bo pesymista wierzacy w to, że może odmienić swoje życie na lepsze stać się może optymista, rodzą się $\mathrm{w}$ nim wierzenia projektujacce i pojawiaja roszczenia wobec organizatora, który wykorzystał ,zalety” pesymizmu, a takim organizatorem byli choćby komuniści. Zdaje się, że dobrym potwierdzeniem takiej metamorfozy było byłe zaplecze partii A. Leppera, zmieniające się w zbiorowość nowych nadziei, w optymistów żyjących dla przyszłości. Tak, ale już innymi sposobami, można zmienić inne grupy społeczne, uczynić

\footnotetext{
${ }^{56}$ A. i H. Toffler, Revolutionary Health. How it will be Created and how it will Change our Lives, New York 2006, s. 380.

${ }^{57}$ D. Gabor, Inventing the Future, New York 1964, s. 204.
} 
je otwartymi tak, jak społeczności zachodnie. Fizjonomia pesymisty to skrzywiona w grymasie twarz człowieka wiecznie niezadowolonego, gotowego w każdej chwili na konflikt z innymi w obronie swoich rzekomo niezbywalnych praw i racji. Starczy spojrzeć na stu Polaków, by przekonać się, że optymistami jednak nie jesteśmy, choć powtórzymy tu raz jeszcze, że jesteśmy dualni, że nawet skończony pesymista ma w sobie sporo optymizmu. Czasami tylko nieszczęściem dla niego jest wewnętrzna rytualizacja tego czekającego na uwolnienie pesymizmu, która nie pozwala na możliwą metamorfozę.

Optymistę natomiast cechuje zwykle otwartość na ludzi i przyszłość, gotowość do podejmowania ryzyka. Jeśli osiagnięcie jakiegoś niebotycznego celu wydaje mu się im niemożliwe, wówczas odnajduje ujście dla właściwej mu aktywności poszukując nowych, mniej ambitnych celów. Optymista zwykle ufa ludziom, choć zaufanie także ma swoje granice. Stara się odnajdywać w innych najlepsze cechy i próbuje organizować ich na bazie tych właśnie cech. Optymiści sa marzycielami, wizjonerami, przywódcami transformacyjnymi, ciagle poszukującymi nowych form kreowania przyszłości wspieranej na śmiałych wizjach. Zawsze ocierają się o granice ryzyka i ono stanowi dla nich nie barierę, a wyzwanie do stawania się, spełniania w nowych postaciach transgre$\mathrm{sji}^{58}$. Sa pełni marzeń i złudzeń i dzięki złudzeniom optymistów świat zmienia się tak radykalnie i nawet nie próbujemy kontrfaktoryzować wyobrażając sobie świat zdominowany przez pesymistów.

Optymista wierzy, że sam decyduje o swojej przyszłości, szuka, eksperymentuje, zawsze posiada cały arsenał rozwiązań alternatywnych $^{59}$. Jest niepokorny, czasami zbyt pewny siebie, co jest integralna częścią poszukiwania siebie lepszego, pełniejszego, gotowego do stałego podejmowania wyzwań. Właśnie tacy optymiści sa nam potrzebni jako organizatorzy życia zbiorowego, nie zaś politycy markujący programowy optymizm, manifestujący go wyłącznie słowami. Tu mamy na myśli polityków PO, partii rzekomo „optymistycznie patrzącej w przyszłość”. Ich inercja sięgająca granic lenistwa, ciagle wymawiają się właśnie przeszkodami, „trudnościami obiektywnymi” i nie zauważają tego ci, którzy są im podobnymi „optymistami”. Nie wiemy czy można nazywać to „kulturą pesymizmu", ale jesteśmy przekonani, że społeczności optymistyczne są bardziej ekspansywne, twórcze, a taką wydaje się nam społeczność amerykańska, której „religia obywatelska” jest zdecydowanie prospektywna i staraliśmy się do tego przekonywać w innym miejscu ${ }^{60}$.

\footnotetext{
${ }^{58}$ A.L. Mc Ginnis, Potęa optymizmu, Warszawa 1993, s. 29.

${ }_{59}$ Tamże, s. 43.

${ }^{60}$ A. Sepkowski, Narodziny misji. Poczatki amerykańskiej „religii obywatelskiej”, Toruń 2008.
} 
Kreatywnego, zbawczego i prawdziwego optymizmu można się uczyć, jego drobin możemy nabierać wraz z przekonaniami, że musimy zacząć częściej sięgać po „jutro”, by móc lepiej zrozumieć „dziś” i odnajdywać w nim inspiracje do działań, bo takich wystarczających wyjaśnień nie znajdziemy we „wczoraj”, choć przeszłości lekceważyć nie można. Pytając jak najczęściej o to, co będzie, co być może, oswajamy się z koniecznościami coraz częstszego stawiania przed sobą nowych alternatyw i dokonywania wyborów. Jak powiadał ongiś G. Picht, życie dokonuje się jako ciagłe wybieganie w przyszłość i jesteśmy zmuszeni do orientowania się w niej zwodzeni fałszywymi wyobrażeniami o niej, a ile razy myślimy o niej błędnie, tyle razy musimy za to pokutować ${ }^{61}$. A ta nasza pokuta to symptomy wspomnianej schizochronii.

Przez wieki, aż po oświeceniowy przełom, byliśmy pesymistami, do czego przekonywać moga profecje, niezauważalne w nauce, ale nie możemy zakwestionować ich wpływu na kształty myślenia prospektywnego milionów ludzi w przeszłości, a także dziś, jeśli zważymy choćby ilość apokryfów proroctw sybilińskich, Daniela, reakcje na kwatrieny Nostradamusa. One wszystkie bywały ponurymi wizjami straszliwego i już przesądzonego końca, takiego, jaki zniechęca do wszelkich działań $\mathrm{w}$ imię polepszenia losu swojego i bliskich. Wiara w nie, o wiele mocniejsza dawniej, jest tożsama właśnie z pesymistycznym stosunkiem do znikomych ludzkich możliwości w przekształcaniu świata na lepszy. Taka wiara okazywała się funkcjonalna społecznie, wygodna dla rządzących. Bo jeśli jutro będzie gorsze, to powinniśmy uszanować to, co jest dziś i ufać gwarantom status quo aż po granicę, którą M. Friedman nazywał „tyrania status quo”"62.

$\mathrm{Z}$ pozoru teorie kumulatywnego postępu zakorzeniły się na dobre i powiada się, że zdominowały już wiek XIX, że królują w kulturze symbolicznej, ale taka dominacja winna oznaczać zbiorowy, nie tylko epistemologiczny optymizm elit naukowych. Tymczasem w niezwykłym wieku XX nie spotkaliśmy zbyt wiele optymizmu i to nie dziwi aż tak bardzo, choć może powinno, bo przecież przesycone niewiarą w jutro pokolenia dokonały tak wiele mimo dwóch kataklizmów wojennych, które to kataklizmy były w jakimś stopniu owocem degeneratywizmu, bo tylko w takim kontekście można było sugerować i wierzyć w to, że wojna jest „naturalnym” regulatorem rozwoju. Dziwiąc się możemy przecież zadać oczywiste pytanie o to, czego dokonałyby te generacje, gdyby hołdowały progresywnym modelom rozwoju, gdyby udało się uniknąć wojen. Zdaje się, że osiagnęlibyśmy statusy dzisiejszego speł-

${ }^{61}$ G. Picht, Odwaga utopii, s. 45.

${ }^{62}$ M. Friedmann, Tyrania status quo, Sosnowiec 1997, s. 1. 
nienia wcześniej, choć zwolennicy takich regulatorów zaczną mnożyć argumenty na obronę swoich tez zaczynając od tego, że wojna stała się wielkim „motorem postępu”, oczywiście technicznego. Możemy także konstatować, że ludzie wieku XX wierzyli w postęp, ale po bliższym przyjrzeniu się tej wierze odkryjemy, iż była ty tylko wiara w to, że tzw. postęp technologiczny wyzwoli nas, uszczęśliwi. 


\section{8}

\section{ZBAWIENIE W NARODZIE I EUROPIE}

Naród wciąż pozostaje wielkim rezerwuarem emocji zbiorowych, a jego idee są źródłem jakościowych czynników zmian - są mitami bezdyskursywnymi, wciąż rytualizowanymi na dziesiątki sposobów, niezmiennie żywotnymi mimo tylu wieszczeń upadku idei narodowych, z jakimi stykaliśmy się w jednoczącej się Europie przełomu wieków. Ożywające nacjonalizmy w Europie na styku tysiącleci uczyniły go znowu przedmiotem żywego zainteresowania nauki, kiedy okazało się, że niedawne „paradygmaty” zostały mocno naruszone, że pojawiły się nowe spojrzenia na to, co jest spoiwem tych zbiorowości, które w dobie rzekomego przeżywania się idei narodowych w Europie Zachodniej, przypominają wiek XIX, tocząc krwawe wojny właśnie w imię tych idei i mamy tu na myśli byłą Jugosławię. Zaczynamy więc znowu pytać o przyczyny tych niepojętych wydarzeń i odpowiadać na nowo mając w pamięci konsekwencje niespodziewanej erupcji nacjonalizmów bałkańskich, czując obawy przed ożywaniem podobnych nawet $\mathrm{w}$ „starych" demokracjach, co wcale nie jest nieprawdopodobne, jeśli zważymy jak często twierdziliśmy, że historia się nie powtórzy, a ona powtarza się uparcie przekonując, że jednak bywa nauczycielka życia. Pozornie bezpieczny świat sprawia, że państwa narodowe zdają się mniej potrzebne, ale poważny wstrzas, nawet ekonomiczny, może sprawić, że ożyją wtedy, kiedy pojawi się potrzeba obrony interesów zbiorowości i kryzys finansowy przełomu pierwszej i drugiej dekady naszego wieku potwierdza to.

Przyglądając się praktyce życia narodowego zauważamy bez trudu umocowane $\mathrm{w}$ wyobrażeniach zbiorowych przekonanie, że członkowie własnego społeczeństwa są w jakimś sensie bardziej ludzcy, a przez to bliżsi niż członkowie obcych społeczności, a takie mniemanie było i jest - twierdzi antropolog - jednym z najpowszechniejszych ludzkich 
złudzeń ${ }^{1}$. Zdaje się wyrastać $\mathrm{z}$ herderowskiego przekonania, iż każdy naród jest powiązany więzami kryjącymi się we „wspólnym duchu”. To chyba nie tylko złudzenie, ale i potrzeba ukształtowana historycznie, kulturowo, wyrastająca z kolei z potrzeby tworzenia tożsamości zbiorowej. Na początku były wspólnoty przetrwania i walka w ich obronie (rodziny, plemienia) przywiazywała przez kształtowanie ja powinnościowego jednostek. Później, kiedy pojawiały się inne formy organizacji społeczeństw, te, zakorzenione w tradycji, zrytualizowane wzory zostały tam przeniesione i funkcjonowały na zasadzie bezdyskursywnych mitów założycielskich w społecznościach feudalnych jeszcze nie będacych nowoczesnymi narodami. Takie „złudzenia” znakomicie służyły i służą potrzebie potwierdzania tożsamości zbiorowej czy to $\mathrm{w}$ feudalizmie, kapitalizmie, czy postkapitalizmie, który już okrzyknięto epoka postnarodowa. Uczyniono to przedwcześnie, w euforii towarzyszącej zmianom uważajac, że prawdy I Świata są uniwersalne - to stare złudzenie bogatych i silnych.

Naród nie został dany ludziom przez nature - to stwierdzenie A. Giddensa nie wymaga komentarza ${ }^{2}$. Jest to jedynie rodzaj idei wspólnoty niejednako rozumiany i kultywowany w przeszłości, a kontrowersji wiązanych z pojęciem narodu, narodowości, nacjonalizmu nie wspominamy, bo jest ich bezlik i z pewnościa nie zrozumie ich przeciętny członek narodowej zbiorowości. Spośród wielu prób określenia narodu wybraliśmy tą, która mówi, że jest on wspólnotą wyobrażona (dla M. Webera sentymentalna), mająca w zamysłach jednoczyć, co nie zawsze sprawdza się w praktyce oraz należy do sfery wartości ${ }^{3}$. Nie chcemy akcentować cech tej wspólnoty od wspólnej historii „świętej” i języka poczynając, a kończąc na wspólnej gospodarce. One wszystkie albo daja się kwestionować, albo nie mają takiego wpływu na konstytuowanie się narodu, jaki im się przypisuje. Ale nie można zapominać o tym, że mitem założycielskim przypisywanym filozofom narodowym końca wieku XVIII jest także ten, który mówi, że naród może spełnić się tylko w państwie. Tylko w nim i przez niego może znaleźć swoją pełnię, zbawienie w doczesności. Takie przekonania, rytualizowane w wyobrażeniach zbiorowych, stworzyły nie systemy wiary, ale prawdziwe religie ${ }^{4}$.

Dla teoretyka narodu ta idea zbawienia w narodzie tworzacym państwo służy jedynie interesom partykularnym, bywa wykorzystywana w celach innych od deklarowanych, a by była skuteczna, powinna

${ }^{1}$ J. Conrad, Człowiek, rasa, kultura, Warszawa 1971, s. 20.

2 A. Giddens, Trzecia droga. Odnowa socjaldemokracji, Poznań 2000, s. 115.

${ }^{3}$ B. Andersen, Wspólnoty wyobrażone, Kraków 1997, s. 18.

${ }^{4}$ A.D. Smith, Nacjonalizm, Warszawa 2007, s. 40. 
zakładać dobro wszystkich członków tej wyobrażonej wspólnoty ${ }^{5}$, czyli winna być także wspólnotą celów mającą zapewnić korzyści wszystkim. Zakładała ja w teorii, praktyka zaś prowadziła do eskalacji obietnic zbawienia w takiej zbiorowości i takie, nacjonalistyczne „klapki” tworzące złudzenia potęgi - jak pisał H.G.Wells - przyniosły pierwszą wojnę światowa. A, co ciekawe, w takim czasie z Wellsem zgadzał się W. Sikorski, uważajacy, iż kult narodowości prowadzi nieuchronnie do imperializmu narodowego, a ów „imperializm” to chyba eufemizm zastosowany przez generała obawiającego się o reakcje czytelników swojego czasu $^{6}$. Miał swoje racje obserwując imperialne tendencje, polskie sny o potędze wynikające ze słabości, tak boleśnie zweryfikowane II wojna. Być może także zastanawiał się nad siła tej zbawczej idei, która, miast zbawiać, unieszczęśliwiała.

Idee narodowe owładnęły wyobraźnią zbiorową w początkach kapitalizmu i ich związki z nim zdają się niewątpliwe, choć filiacje między nimi a ideami kapitalizmu nie sa chyba tak oczywiste, jak sądził m.in. M. Foucault ${ }^{7}$, jeśli zważymy, że narodowe owładnęły także społecznościami rustykalnymi, jak choćby polska, stworzone w warunkach utraty państwowości przez marginalne $\mathrm{w}$ początkach, romantyczne elity narodotwórcze. Wiedząc o tym, jak wielki to problem chcemy tylko zauważyć polskie opory przed ideami kapitalizmu oraz wielki mit Polski-Chrystusa rodzący dziś jeszcze jakieś zbawcze pretensje elit.

Ta marginalność polskich elit narodotwórczych może nieco kłócić się z wizjami „historii świętej” narodu, ale wiele świadectw, dokumentów, potwierdza fakt, iż upadek nadziei zbiorowych łączony z przegrana Napoleona zaowocował „antynarodowym” zjawiskiem nazywanym „roztropną uległością. Elity Królestwa, wraz z dawnymi jakobinami i żołnierzami Napoleona, zmęczone wojnami, kultywujące homagialne wzory, chętnie poddawały się Aleksandrowi, a potwierdzeniem takich wiernopoddańczych postaw był i kościół pod wezwaniem św. Aleksandra i Hymn na rocznice ogtoszenia Królestwa Polskiego zaczynajacy się od słów: „Boże, coś Polskę...”, skomponowany przez A. Felińskiego. Późniejszy kreator postaci człowieka-narodu, K. Brodziński, nazywał cara „ojcem” w utworze kierowanym do obojętności ziomków, a później, już na emigracji napisał, że „Aleksander nie miał nad nich przywiązańszego ludu"8 i były to epizody, jakie chętnie przemilcza się w historiografii. Feudalni patrioci, tacy jak K. Koźmian, nie pojęli nowej istoty narodu i nie chcieli jej pojmować, zanurzeni w homagialnej przeszłości

\footnotetext{
${ }^{5}$ S. Fenton, Etniczność, Warszawa 2007, s. 196.

${ }^{6}$ W. Sikorski, Przyszłe wojny, Warszawa 1984, s. 41.

${ }^{7}$ M. Foucault, Filozofia, historia, polityka, Warszawa 2000, s. 104.

${ }^{8}$ Nieznane poezje K. Brodzińskiego, wyd. K. Łucki, Kraków 1910, s. 69.
} 
uważali ją za fanaberię i można ich usprawiedliwiać. W okolicach Listopada ta nowa, polska idea narodowa była własnością ledwie kilku tysięcy młodych, romantycznych zapaleńców chcących poruszyć z posad bryłę świata i wierzących w to. Powoli, bardzo powoli, korzeniła się w Polaku mitycznym. Badacze wspominaja, że jeszcze w niepodległej Polsce policja meldowała z niektórych ziem byłego zaboru rosyjskiego, że tamtejsi, mówiący po polsku, chłopi z wielkim sentymentem wspominaja państwo carów ${ }^{9}$.

Natomiast mit Polski-Chrystusa, ten zbawczy mit żyjacy dziś w jednej postaci jest założycielskim dzięki falsyfikacji, nadinterpretacji i późniejszej, trwałej rytualizacji. On nie był tylko darem, jak widzieli to liczni interpretatorzy, ale także brzemieniem. Oni, wbrew Mickiewiczowi już twierdzili, że Polska, a więc wszyscy Polacy są Chrystusem, on zaś, widząc mizerię emigracji, te potępieńcze swary, domagał się tego, by się nim stali zmieniając się wewnętrznie. Widział jak wygląda doskonałość emigracyjnych pieniaczy, słyszał szyderstwa Francuzów (o których zupełnie się zapomina opisując dzieje emigracji) i jako pryncypialista etyczny po prostu nie mógł zwać Polski spełnionym Chrystusem narodów, narodem-ideałem. Miał nadzieję, że tak się stanie, jeśli emigranci podejmą się wielkiego, moralnego czynu. „Możemy przemienić się wewnętrznie - utrzymywał poeta - trzeba rozpoczaćc nowe życie, robić sobie nową świadomość”. A potem dodawał: „Każdy musi stać się w rzeczywistości, w czynie, duszą i ciałem podobny do Chrystusa" ${ }^{10}$.Niewielu chciało zrozumieć konieczność takiego wysiłku i częścią polskiej „historii świętej” uczyniono nadużycie, nie ostatnie. Ale ta uświęcona historia jest niczym innym jak ciagiem mityzacji dla każdego narodu.

Powracając do pytań o relacje między narodami a kapitalizmem zauważmy, że przyjmuje się, iż II fala zgłosiła zapotrzebowanie na wszechstronny, wykształcony potencjał ludzki potrafiący sprostać wymogom wczesnego kapitalizmu ${ }^{11}$, ale dalej twierdzi się, że odpowiedzią na takie zapotrzebowania były działania państwa nie dodając, że państwa narodowego ${ }^{12}$. Trudno zrozumieć takie sugestie po analizie fenomenu amerykańskiego, bo tam pojawiały się tylko tęsknoty za byciem narodem, a poza tym kapitalizm amerykański potrzebował państwa tylko jako tego „nocnego stróża”. Zdaje się, że i ten problem wymaga „dobrego wyjaśnienia”, bo przyjęcie symetrii tworzenia się narodu z ka-

\footnotetext{
${ }^{9}$ J. Rytel, Tezy o świadomości narodowej Polaków, [w:] Patriotyzm. Nacjonalizm. Stereotypy narodowe $w$ edukacji historycznej, red. K. Zaufal, H. Wesołowska, Kraków 1995, s. 17.

${ }^{10}$ A. Mickiewicz, Dzieła, Warszawa 1955, t. II, s. 445-447.

${ }^{11}$ A.D. Smith, Nacjonalizm, Warszawa 2007, s. 87.

${ }^{12}$ I. Wallerstein, Analiza systemów-światów, Warszawa 2007, s. 82.
} 
pitalizmem posłużyło za asumpt do prostego wniosku, że skoro przeżywa się kapitalizm, to wraz z nimi idee narodowe, a to ledwie watła przesłanka. Natomiast chyba nie wymaga komentarza prosta konstatacja, że identyfikacja narodowa obok instytucji demokratycznych ukształtowała kulturę nowoczesnej Europy ${ }^{13}$. Nietrudno także zauważyć jak wyglądają wspólnoty narodowe, które nie przeżyły kapitalizmu.

Idee narodu rozkwitły $\mathrm{w}$ wieku XIX $\mathrm{i}$ to $\mathrm{w}$ jakiejś mierze dzięki jednemu z założycielskich „mitów państwa narodowego”, a wedle niego tylko ono gwarantuje pełny rozwój kultury, gospodarki i powszechna szczęśliwość wszystkich członków narodu. Ta wiara w samozbawienie, nieczęsto potwierdzana przez rzeczywistość, pozostawała silna przez dwa ostatnie wieki, a trwała rytualizacja przesądza dziś o jej ogromnej sile. Właściwie taka jej postać jest główna składowa „religii narodu" owocującej nacjonalizmem i patriotyzmem. Choć oba te pojęcia sa wciąż mgliste, niedookreślone, to nam trafia do przekonania próba filozofa, także świadomego jej ułomności: „Patriotyzm i nacjonalizm nie mają wyraźnych granic. Ale jeśli wartości narodowe przyczyniają się do uszlachetnienia człowieka, to można mówić o patriotyzmie, jeśli zaś kogoś deformuja i upadlaja, mamy do czynienia z nacjonalizmem" ${ }^{4}$. Przyjęcie właśnie takiego rozgraniczenia może uczynić analizę patriotycznych postaw Polaków raczej bolesna. Być może powinniśmy iść śladami tych, którzy powiadaja, że nacjonalizm jest ograniczany, skupia się na sobie, nie stać go na uniwersalizm, a skrajny nacjonalizm, jak przekonywały tragedie bałkańskie, może być także ratio moriendi. A ten bałkański, jak wiele innych, zdaje się być reakcją na słabość, peryferyzację.

Nie próbując komentować i takich sugestii zauważamy jedynie, że obie postaci uwielbienia dla własnego narodu sa kształtowane i rytualizowane przez organizatorów wyobrażeń zbiorowych poczynając od tak zwanych „budzicieli narodowych” tego wieku narodów i od nich w wielkiej mierze zależy to, czy członkowie narodu zorientują się na taki patriotyzm, czy taki nacjonalizm, czyli wybór zależy od ich interesów. Zwłaszcza w czasie przełomu ,jesieni ludów” takim organizatorom łatwo było kształtować takie postawy i zachowania, kiedy nie wiadomo było co robić z wolnością, a przejmujaccy władzę, co z państwem, jak przekonać swoich pobratymców do bycia we wspólnocie, gdy pojawiały się wcale silne tendencje odśrodkowe. Strach, gniew okresu transformacji pozwalał na instrumentalne wykorzystanie mitu zbawienia w narodzie i głoszono, że tylko w takiej wspólnocie odnajdziemy się na

${ }_{13}^{13}$ I. Wallerstein, Koniec świata, jaki znamy, Warszawa 2004, s. 34.

${ }^{14}$ M.A. Krapiec, Dzieła, t. 10, Lublin 1993, s. 153. 
powrót, staniemy jednościa, w której każdy znajdzie swoje miejsce byle byśmy pozostali wierni narodowej idei. Miał swoje racje V. Tismaneanu, kiedy pisał, że „żadna polityczna wizja nie okazała się w naszym stuleciu bardziej prężna, wielokształtna i trwała niż nacjonalizm. Ta wielka, potencjalnie agresywna, konstelacja symboli, emocji i idei dostarcza także długo podporządkowanym lub poniżanym grupom zbawczego języka wyzwolenia"15. Ukazując takie racje chcielibyśmy tylko zauważyć, że role niezwykle ważne, a niezauważane, niedoceniane, odgrywał język zbawienia obecny bodaj w każdej idei narodu.

Wtedy też, dokonując, a właściwie rewitalizując wielkie mityzacje czasu kreowania narodów, przekonywano przy pomocy nowej wizji historii, że narody i państwa istniały „od zawsze”, że sa nieśmiertelne ${ }^{16}$, że powoduje nimi nieśmiertelny „duch narodu”. Idee narodu uświęcono tak skutecznie, że uprawniały przemoc wobec mniejszości i członków samego narodu, którzy kontestowali te idee. Swego czasu epitet „wróg narodu” był oskarżeniem o najcięższą zbrodnię, a i dziś też ma swoją oskarżycielską moc. Same idee rytualizowano uparcie dodając do innych argument bezpieczeństwa mimo zwykłej nieumiejętności albo niemożności zapewnienia tego bezpieczeństwa przez państwa narodowe. Wiemy z naszej praktyki jak często jest nadużywany i wiemy także, że czasami jest to zwykłe kłamstwo. Wiemy także, że nie ma „czystych” państw narodowych, choć wiele chce takimi być. Wiadomo także, że nawet w około $90 \%$ krajów granice państw nie pokrywają się z terytorium etnicznym.

Dla jednego jest to wspólnota żywa, spojona wieloma nierozerwalnymi więzami, dla innego zaś naród to kategoria subiektywna, której obiektywizm gwarantuje jedynie państwo, żywotnie zainteresowane rytualizacją mitu o sobie, jako gwarancie wspólnego dobra ${ }^{17}$. Nie sposób dyskutować z sugestia, że nie istnieje ani „naturalność”, ani stabilność narodu, lecz proces jego stałego rekonstytuowania ${ }^{18}$. Oznacza to stała, intensywna witalizację idei narodowych i dodawanie nowych treści do mitów założycielskich. Miał swoje racje autor powiadający, że naród, który przestaje tworzyć wyobrażenia siebie przestaje być narodem $^{19}$. W wielkich ideach narodowych dobro poszczególnych jednostek

${ }^{15}$ V. Tismaneanu, Wizje zbawienia, Warszawa 2000, s. 134.

${ }^{16}$ D. de Rougemont, List otwarty do Europejczykow, Warszawa 1995, s. 135.

${ }^{17}$ W. Żelazny, Etniczność. Ead - konflikt-sprawiedliwość, Poznań 2006, s. 69.

${ }^{18}$ E. Balibar, Trwoga mas. Polityka i filozofia przed Marksem i po Marksie, Warszawa 2007,s. 309.

${ }^{19}$ R. Kroes, The Commodification of America Icons of Freedom, [w:] „Here, There and Everywhere”. The Foreign Politics of American Popular Culture, eds R. Wagneleleitner, E.T. May, London 2000. 
znajduje się na drugim i trzecim planie, jakby one nie były częściami narodu, a każde zło społeczne tłumaczy się znowu tzw. „obiektywnymi racjami”. Rzekomo ten „interes narodowy” ma być interesem każdego członka społeczności, ale takiej interpretacji zbawienia przez państwo narodowe przeczą idee poświęcania się w imię tego interesu, górujące zwykle nad tymi pierwszymi. Zdaje się, że najlepiej rozumieli to Włosi, zawsze pytajacy o to, w imię czego mają umierać i odpowiadający, że jeśli naprawdę nie wiedza, to poświęcenie w imię jakiegoś fantomu nie ma sensu. I chyba lekceważą sobie opinie innych o sobie jako żołnierzach.

Dziś można zauważać, że jeśli idee poświęcenia pojawiają się w wyobrażeniach zbiorowych państwo i jego słudzy staje się coraz bardziej obcy, a bywa że członkowie wspólnoty wyobrażonej czuja pogłębiająca się izolację samoreprodukujących się elit, pytając o cele takiego poświęcenia, co zdaje się mieć dziś miejsce w krajach postkomunistycznych. Jednak stała, wytrwała rytualizacja motywów zbawienia sprawiła, że naród stał się najważniejszym sposobem wyobrażenia wspólnoty, a każde wyobrażenie wspólnoty jako narodu zostaje nadkodowane i stąd nasza koncepcja wspólnoty jest dotkliwie zubożona - zauważali twórcy kontrowersyjnego dziełka ${ }^{20}$. Można rozumieć to jako konfrontację wielkiej mityzacji z tym, co wcześniej nazwaliśmy „zasadą kontroli rzeczywistości”. Z jednej strony naród jest obiektem stałej adoracji, którego nie można żadnym sposobem kwestionować, jest bytem niemal konsekrowanym, a z drugiej sami o sobie mówimy rzeczy złe i jak najgorsze, chcemy topić się w smole, a przysłowiowe „polskie piekiełko” jest tego widomym potwierdzeniem, choć takie „piekiełka” maja także inni. Nietrudno było to zauważyć i E. Cioran pisał, że narody wzniecaja w nas, o wiele bardziej niż jednostki, uczucia sprzeczne; kochamy je i nienawidzimy jednocześnie ${ }^{21}$. Kochamy wtedy, kiedy pomagają nam w samorealizacji, a powody do nienawiści pojawiają się wówczas, kiedy czujemy, że stają się źródłem ograniczeń.

Jedni twierdza, że nacjonalizm z wielością mitów założycielskich powoli staje się ideą obca zbawieniu zbiorowemu, a skoro naród nie gwarantuje nam spełnienia materialnego ani duchowego, zaczynamy poszukiwać innych depozytariuszy prawd zawierzając Europie, wizjom państwa globalnego, choć te poszukiwania nie zagrażaja jeszcze ideom państw narodowych. Sugeruje się także, że powolnej erozji ulegaja mocne dotąd filary nacjonalizmu. Wraz z weryfikacją treści z formami demokracji kruszy się wiara $\mathrm{w}$ to, że naród jest wyłącznym źródłem władzy politycznej, że lojalność wobec niego jest nadrzędna jeśli wi-

${ }^{20}$ M. Hardt, A. Negri, Imperium, Warszawa 2005, s. 123.

${ }^{21}$ E. Cioran, Historia $i$ utopia, s. 13. 
dzimy, że tym źródłem jest polityczna emanacja części narodu nie zawsze utożsamiająca się z nim. Zauważając atrofię idei depozytariusze „prawd narodowych” zamieniają tę ideę w zbiór prymitywnych resentymentów, mocowanych w wyobrażeniach zbiorowych przez mało wyrafinowane symbole i kwiecista retorykę ${ }^{22}$.

Inni natomiast powiadaja, że idea narodu wciąż gwarantuje cała dynamikę społeczną i oferuje ramy myślenia o przeszłości, przyszłości ${ }^{23}$. Tacy także zdają się mieć swoje racje i potwierdzaja je rozkwitające nacjonalizmy, których erupcji w naszym czasie nie potrafi się przekonująco wyjaśnić. Taką nieprzewidzianą erupcja w dobie rzekomej atrofii uczuć narodowych były i sa wstrzasy w pozornie spokojnej, stabilnej, bogatej Belgii. Można by taką atrofię nazwać „rzekomą” z przekonaniem, gdyby nie to, że podłoże ma zbawczy charakter. Bogatsi Flamandowie nie chcą łożyć na biedniejszych Walonów powodując się naturalnym egoizmem grupowym traktujacc się jak wspólnota przetrwania. Racje zbawienia zdają się przesądzać o tym, że problem państwa narodowego nie jest już problemem, Belgowie jako umowny naród są bliżsi swoiście interpretowanej idei glokalności, a Flamandowie i Walonowie traktuja siebie praktycznie, nie jak narody, a prędzej jak wspólnoty przeżycia.

Zgadzamy się z sugestia, że narody jako wielkie zbiorowości są raczej inertne, trudno sterowne i jeśli czasami mówimy o inicjatywności, witalności, żywotności narodu, to winniśmy przyjrzeć się państwu, a nie narodowi i tam zaczać szukać prawdziwych źródeł aktywności. Nie wydaje się, by można było poważnie traktować publicystyczne argumenty o mądrości zbiorowej, bo ta zwykle jest tak wielka, jak zbiorowa głupota. I tylko wielkie wizje zbawienia albo wizje strachu są w stanie pobudzić, zaktywizować na tyle, by doszło do czynu prawdziwie narodowego. Zwykle jednak widzimy inercję i jakimś potwierdzeniem tejże jest jakże częsta obojętność społeczeństw wobec wyborów ważkich dla całego narodu. A nietrudno zauważyć, że to właśnie małe kolektywy często generują atmosferę entuzjazmu, w której nic innego nie wydaje się równie istotne, co wyznaczony cel ${ }^{24}$.

Wedle kardynała J. Ratzingera, jeszcze nie jako papieża, nacjonalizm zepchną Europę na skraj destrukcji i zrodził zagrożenia dla tych wartości, które przez stulecia kształtowało uniwersalistyczne chrześcijaństwo, ten nacjonalizm, który to, co lokalne wynosi do rangi uniwersalizmu ${ }^{25}$. Z takim stawianiem spraw także trudno się godzić, nie tylko

${ }^{22}$ A.D. Smith, Nacjonalizm, Warszawa 2007, s. 36.

${ }^{23}$ U. Hannerz, Powiazania międzynarodowe, s. 134.

${ }^{24}$ A. Philips, Przestrzeń publiczna, ̇̇ycie prywatne, [w:] Aktorzy życia publicznego, red.

R. Siemieńska, Warszawa 2003, s. 48.

${ }^{25}$ J. Życiński, Europejska wspólnota ducha, Warszawa 1998, s. 47. 
ze względu na Amerykanów, którzy właśnie wynoszą i siłą implantują swoje wzory na zewnątrz, ale nie są nacjonalistami nie będąc narodem i ciagle zadaja pytanie: „kim jesteśmy”? A poza tym prawie wszystkie wzory lokalne roszczą sobie pretensje do uniwersalizmu i wcale nie muszą być rozsadnikami zła, a tak było z polskimi uroszczeniami i w wieku XIX i w końcu XX, kiedy chcieliśmy uszczęśliwiać Europę naszymi wersjami wartości narodowych czyniąc to może w dobrej wierze.

Państwa narodowe nie zbawiały narodów i taka prawda powoli trafiała wtedy do wyznawców nacjonalizmów o różnym natężeniu, a wiemy skądinąd, że takie tendencje bywały silne w krajach „starych demokracji”. Dziś tam właśnie powiada się, że państwa narodowe sa tworami stosunkowo młodymi, hołubionymi głównie przez ludzi władzy wykorzystujacych trwałość mitów narodowych w przestrzeniach mitycznych ${ }^{26}$. Okazują się coraz bardziej obce wtedy, kiedy państwo nie jest w stanie odnaleźć wspólnych celów, a właśnie wspólnota celów wydaje się mocnym i niechcianym przez polityków spoiwem ${ }^{27}$ wtedy, kiedy ci nie są w stanie stworzyć tych celów. Jeśli zrozumiałe, obiecujace spełnienie cele nie pojawiają się w wyobrażeniach zbiorowych niknie zaufanie do państwa, tej niby emanacji narodu i erozja tego zaufania postępuje, może nie tak szybko, ale jest procesem, jakiego chyba nie da się zatrzymać. Wspólne cele stają się celami większych wspólnot i widzimy to w Polsce. Nadzieje i cele z nich wypływające coraz częściej wiązane są z jeszcze mglistą Europa przez tych, którzy staraja się racjonalizować. Dostrzegamy to, że funkcjonariusze państwa narodowego nie podejmuja decyzji innych niż peryferyjne i zaczynamy watpić w moce państwa narodowego i samego narodu. A takie wątpliwości potęguja się jeszcze wtedy, kiedy spotykamy się z sugestiami, że państwa narodowe przekształcają się w lokalne agendy globalnego systemu i zostana za jakiś czas zredukowane do poziomu władz komunalnych. Spotykając się weryfikujemy je z praktyką przekonując się, że jest w nich sporo racji.

Tożsamość narodowa jest raczej polityczna niż narodowa - to także konstatacja niezbyt kontrowersyjna. Jeśli przyjrzymy się choćby polskim kreatorom i rytualizatorom idei narodu po odzyskaniu niepodległości, to zauważymy bez trudu, że bez wielkiego wysiłku polityków poszukujących dla siebie zaplecza, narodowość nie obudziłaby się tak szybko i nie stworzyła takiej jakości, jaka jest naród polski. Po owładnięciu władzą symboliczną zaczęto intensywnie, przemyślanie kultywować tą religię narodu z pożądanymi skutkami. Patriotyzm (nacjo-

\footnotetext{
${ }^{26}$ A. Peccei, Wstęp do: B. Hawrylyshyn, Drogi do przyszłości, Warszawa 1990, s. 11.

${ }^{27}$ J.C. Plano, M. Greenberg, The American Political Dictionary, New York 1993, s. 19.
} 
nalizm) Polaków w przededniu II wojny był poświadczeniem wielkiej wiary, bo moc takiej wiary mierzy się postawami i zachowaniami, a te mogły zadziwiać, kiedy przyglądamy się ofiarności społeczeństwa.

Taka tożsamość była szczególnie potrzebna w systemach totalitarnych tworzacych swoja „rzeczywistość fikcyjna” w oparciu o idee na$\mathrm{rodu}^{28}$. Kontrola wspólnoty musiała być legitymizowana najpierw koniecznością jej tworzenia i pozostawania w niej. Tworzono ja w oparciu o pradawne wzory określania się wobec Obcego, zwykle krańcowo emocjonalne i konstytuowane na przesłankach „fałszywych” - jak określał to jeden $\mathrm{z}$ autorów ${ }^{29}$, a dla nas były to mityzacje majace postaci stereotypów, rytualizowane długo i wystarczająco umiejętnie, by przekonywać choćby Niemców czasu hitleryzmu, że sa niemal doskonali i zasługuja na miano rasy nadludzi panującej nad innymi. Wykorzystano stare marzenia jednostek i zbiorowości o doskonałości, a widząc siebie w takich lustrach Niemcy uwierzyli i ta wiara uczyniła ich na tyle silnymi i zdeterminowanymi, że stworzyli prawdziwą wspólnotę szaleństwa. A jej stworzenie było przecież reakcją na lata głodu, niepewności, na mniemane poczucie krzywdy, jakie nader łatwo zakrzewić w każdej schizochronicznej wspólnocie, a taką może stać się każda. Wspominaliśmy o tym, że spełnienie nigdy nie jest pełne, że poprzestawanie na osiagnięciu jakiegoś poziomu odbiera człowiekowi jego naturalne atrybuty, a w tym przypadku jego pragnienie było ogromne.

Państwa narodowe sa ciagle obiektami adoracji, mityzacji przez realizujących swoje cele polityków, ale już nie gwarantują zbawienia i zdaje się, że obywatele krajów takich jak Polska odczuwaja to coraz silniej i przywiązanie do takiego państwa słabnie. Czego jakimś poświadczeniem jest stosunek społeczeństw do „demokratycznych przywódców”. Obywatele dostrzegają ich słabość, widzą że nie mają wielkich szans w globalnej metagrze, do czego przekonuja choćby polskie boje z Rosja o mięso, ale także U. Beck ${ }^{30}$ i B. Barber, który zauważał, że państwa narodowe sa potrzebne w turbokapitalizmie tak samo jak demokracja, czyli sa przeżytkami i sa skazane na obumarcie. Wedle tych autorów stwarzają zbyt wiele barier, ograniczają mityczna „wolność ekonomiczną", a ci którzy przeszkadzają w robieniu pieniędzy, sa wrogiem śmiertelnym dla tych, którzy mają władzę rzeczywista ${ }^{31}$. Ta-

${ }^{28}$ H. Arendt, Korzenie totalitaryzmu, Warszawa 1993, t. I, s. 399.

${ }^{29}$ E.C. Król, Propaganda i indoktrynacja narodowego socjalizmu w Niemczech 19191945, Warszawa 1999, s. 511.

${ }^{30}$ U. Beck, Władza i przeciwwładza w epoce globalnej. Nowa ekonomia polityki światowej, Warszawa 2005, s. 30. Metagra oznacza dla Becka symultaniczne splatanie się reguł starego systemu z regułami nowego, które je nieustannie przekształcaja tworząc nowe jakości.

${ }^{31}$ B. Barber, Dżihad kontra McŚwiat, Warszawa 2001, s. 21. 
kie argumenty stają się z roku na rok coraz głośniejsze. Nie mają co do tego wątpliwości autorzy głośnego Imperium pisząc, że: „Nie ulega wątpliwości, że wraz z procesami globalizacji maleje - choć jeszcze nie zanikła - suwerenna władza państwa narodowego"32. Zdecydowanie brak tu pytań o to jak będzie wyglądała przyszłość zaniku takich form, ale do braku prospekcji w wielu analizach i syntezach zdążyliśmy się przyzwyczaić.

Nie przypadkiem ilość państw upadłych (failed states) albo upadajacych (failing states) rośnie tak szybko w dobie globalizacji ekonomicznej, choć nie przypadkiem także tak szybko „upadaja” te, które narodowe nie sa. Taki upadek odrywa państwa od narodów znajdujących się pod jego władzą i pojawiają się konwulsje w poszukiwaniu identyfikacji, znaków tożsamości właściwych wspólnotom wyobrażonym. Politycy i niektórzy organizatorzy przestrzeni mitycznych w tych krajach próbują ratować to, co stanowi dla nich wartości nie zauważajacc, jak sugeruje N. Stevenson, że kulturowa hegemonia państw narodowych skończyła się bezpowrotnie ${ }^{33}$, a to oznacza niemożność uprawiania pożądanej postaci rytualizacji mitów narodowych. Te państwa, które jeszcze nie „upadły” tak nisko jak klasycznie „upadłe”, wyglądają czasami anachronicznie nie potrafiąc sprostać wyzwaniom czasu, przede wszystkim za sprawa niekompetentnych elit. Ma swoje racje uczony, który powiada, że konwencjonalna polityka jest niedostosowana do nowej, znacznie rozszerzonej w czasie i przestrzeni odpowiedzialności człowieka, a to już sugestie tyczące polityków ${ }^{34}$. Daleko nam do statusu państwa upadłego, ale należymy do sporego grona państw kurczacych się populacyjnie, co ową upadłość może przyspieszyć. Ostrzeżenia P. Buchanana ze Śmierci Zachodu sa ciąle aktualne i dla nas. Tu chcemy tylko zauważyć za Buchananem, że stare społeczeństwa tracą naturalny dynamizm, wymuszaja zachowawczość, ostrożność. Przy czym nie jesteśmy pewni, co autor miał na myśli, czy średnie wieku czy zmęczenie społeczeństw spełnionych materialnie.

Nietrudno zauważyć, że my, Polacy, oceniamy przyszłość z perspektywy przeszłości mityzując siłę i narodu i państwa, tworząc nasze rezerwuary nadziei długiego trwania $\mathrm{w}$ warunkach transformacji. A nasza narodowa siła zaprezentowała się inaczej w skojarzeniu z potęga Unii i widzieliśmy to choćby na majowym szczycie w Samarze (2007 r.), gdzie J.M. Barroso i A. Merkel jednoznacznie dawali do zrozumienia, że Unia jest jednościa, a pretensje Polaków o marginalizowanie we wspólnocie sa niezrozumiałe i nie były to jedyne komentarze do jakości

${ }^{32}$ M. Hardt, A. Negri, Imperium, s. 7.

${ }^{33}$ N. Stevenson, Cultural Citizenship, Berkshire 2003, s. 39.

${ }^{34}$ J. Łukasiewicz, Eksplozja ignorancji, Warszawa 2000, s. 273. 
tej siły. Politycy zachodni na bieżąco zrytualizowali symbol jedności akcentując, że z niego powinny wypływać postawy i zachowania obywateli państw członkowskich. Ale mimo takich zachowań polityków unijnych nie wydaje się, by politycy sprawujący władzę w krajach nowej 12 -stki (bez Chorwacji) zrezygnowali z posługiwania się retoryką narodową będącą dla nich tarczą i możliwością zachowania władzy wraz z jej przywilejami. Po części powoduje nimi partykularny egoizm, bo zdają sobie sprawę z tego, że w ogóle nie są przygotowani do rywalizacji na unijnej arenie, walki o polskie interesy na forach europejskich, światowych $\mathrm{i}$, z małymi wyjątkami, nie maja nic do powiedzenia, zaoferowania i starczy tu przywołać zapomnianych już eurodeputowanych M. Giertycha i B. Pęka z ich ofertami dla Europy. Nie maja zwykle wiele do powiedzenia w sprawach kontynentu i argumenty rodzaju: zawsze byliśmy w Europie, Europa nas potrzebuje, moga zdawać się tylko nadużyciami, choć członkowie narodu zwykle mile przyjmują takie „argumenty". Nie ida za nimi proste i oczywiste pytania o to, czy Europa nie dałaby sobie rady bez nas, co jej dajemy, nie przywołujemy także licznych głosów, w których daje się odczuć zniecierpliwienie polskimi „wiecznymi pretensjami”.

Inną forma spełnienia zbiorowego, podobną do tej, jaka proponuje zbawienie w narodzie, jest szukanie go we wspólnocie religijnej tam, gdzie narody nie powstały. Taki świat to dziesiątki milionów analfabetów żyjących na skraju nędzy, rządzonych zwykle autorytarnie, uprzedmiotowionych do tego stopnia, że nie posiadaja swojej zbiorowej wizji zbawienia w doczesności, nie wiedzą jak ona może wyglądać naprawdę. Ten świat minęła eskalacja oczekiwań i zaspokojeń kapitalizmu, który stopniował takie zaspokojenia. Wizje biednych, inspirowane kontaktami z bogatym, niepojętym światem przez media, zostały przeniesione $\mathrm{z}$ feudalizmu od razu w niebiosa, gdzie stykają się z niewiarygodnymi obrazami życia zbawionych sybarytów. Nie wiemy, czym naprawdę jest islamska wspólnota zbawienia, kojarzymy świat arabski z ropa, bajecznie bogatymi szejkami, ale sa to symplifikacje opierane na opozycji ja-obcy, niemajace wiele wspólnego z rzeczywistościa, bo w tym świecie codziennościa jest nędza. Starczy sięgnąć do danych statystycznych, by przekonać się, że utożsamianie islamu z męską supremacją święta wojna i aktami terroru jest co najmniej nadużyciem ${ }^{35}$. Trzeba zaczaćc dostrzegać to, że ten świat jest światem biedy, chaosu, to świat feudalny, który odkrywa siebie na tle zbawionego świata bogatych dzięki globalizacji przeżywając traumę, jakiej nie potrafimy sobie wyobrazić, a prawie na pewno zrozumieć. Skoro zaś tak trudno nam zrozumieć, jeszcze trudniej wyjaśnić.

${ }^{35}$ I.G. Shahen, Reel Bad Arabs, New York 2001, s. 9. 
Pozostawiając na boku ten, tylko sygnalizowany problem chcemy zauważyć, że istnieją silne przesłanki, by twierdzić, że pożądane jest tworzenie nowych modeli świata z inaczej rozumianymi wspólnotami narodowymi i poddawania ich pod dyskusję ${ }^{36}$. Coraz częściej i głośniej mówi się wręcz o konieczności stworzenia tego, co przez wieki było tylko marzeniem wizjonerskich kapłanów i intelektualistów - państwa globalnego, które wreszcie okiełzna transnarodowe siły i przesądzi o racjonalnym zarządzaniu w skali globalnej ${ }^{37}$. O państwie globalnym wspominaliśmy wcześniej nie zauważając tego, iż to marzenie intelektualistów ma składać się ze wspólnot narodowych, a świadomość globalna ma być dziełem pokoleń i wieków koegzystując z narodową. Ale wpierw musimy odnaleźć się w Europie, darze ostatnich lat, na który podobno nie musieliśmy się zasługiwać będąc jej częścią od setek lat, a nie jest to proste, do czego przekonujemy się niemal codziennie. $\mathrm{Na}$ razie nie chcemy zauważać trzeźwych głosów mówiących o tym, że przez długie lata będziemy tylko dodatkiem do Unii ${ }^{38}$. Lat zapóźnień nie da się nadrobić nawet w ciagu kilku dekad.

Jak donosiła prasa, w roku 2007, wpływy z kasy unijnej znacznie przekroczyły wpłaty i wyniosły 5,1 miliarda euro, a korzyści mogłyby być jeszcze większe, gdybyśmy - co zauważała komisarz Grybauskaite, - wykorzystywali większą część funduszy dla nas zarezerwowanych. Wiemy o tym, że zmieniło się wiele, ale przypomnijmy, że Polska od 2000 do 2006 roku wykorzystała tylko 63\% tychże plasując się na miejscu trzecim od końca wśród państw unijnych, a i tak Polacy sa zadowoleni z naszego członkostwa we wspólnocie, choć droga do zbawienia przez Europę i w Europie zdaje się bardzo daleka, po części z naszej także winy, przy czym mamy tu na myśli tzw. elity polityczne. One zdają się nie widzieć tego, że nie one, ale Polska, którą nie potrafią rządzić, potrzebuje Europy zdolnej do działania, subsydiarnej i solidarnej. Nie ze względu na subsydia, znaczące tak wiele, ale ze względu na stworzenie możliwości rozwojowych wręcz niszczonych przez te elity w imię interesów nazywanych politycznymi, choć prawdziwy interes polityczny to przecież interes społeczny, czyli narodowy. Widzimy jak to otwarcie na Unię wygląda w społecznościach lokalnych korzystających z inspiracji europejskich, nie tylko finansowych. Dla nich Europa jest synonimem nowej siły, znakiem nadziei i tego lokalnego „zbawienia”. W nich Europa wyzwoliła siły i chęć do działania.

Nie dla wszystkich, bowiem to lokalne elity rozumieja sens wejścia do wspólnoty, choć teoretycznie nie powinny. Wieki przebywania na

\footnotetext{
${ }^{36}$ B. Hawrylyshyn, Drogi do przyszłości, Warszawa 1990, s. 235.

${ }^{37}$ A. Giddens, Trzecia droga, s. 126.

${ }^{38}$ M. Castells, Społeczeństwo sieci, Warszawa 2007, s. 118.
} 
peryferiach uczyniły nas takimi, jakimi jesteśmy, choć chyba nie jest tak, jak twierdziła M. Marody, że cywilizacja zachodnia jest dla nas tak obca jak cywilizacja islamu i tylko waskie elity intelektualne i interesu sa zachodnie, a reszta lokalna, a inni dodaja, że jednak zaściankowa, siermiężna. Jest $\mathrm{w}$ tym sporo racji, bo trudności w porozumiewaniu się nie tylko za sprawa języka, brak obeznania wszyscy założeniach, motywacjach, praktyce innych społeczności to bariery Huntingtona ${ }^{39}$, które będziemy musieli przezwyciężać w zbyt krótkim czasie, a terror chwili może przynieść traumę kulturowa, pogłębianą stosunkiem do nas, przypominającym ten, jaki reprezentuje holenderski populista G. Wilders. Ale to nie wszystkie racje, bo nietrudno zauważyć, że Polacy chcą i jednak potrafią odnajdywać się w Europie z prostych względów. Zauważaja, że wspólnota gwarantuje to, czego nie może dać słabe państwo narodowe. Nie artykułują tego wprost, nie sa „opinią, ale miliony poszukiwaczy szczęścia na zachodzie są przesłanką raczej mocną do takiego sądu i ci z pewnością nie są zachwyceni wyjściem Anglii z Unii ani perspektywą rozpadu strefy euro.

My wszyscy mówimy „Europa” w różnych tonacjach, próbujemy się z nią utożsamiać nie wiedząc, a nawet czasem nie chcąc wiedzieć, czym jest, czym być powinna i czym będzie kontentując się jej trwaniem w takiej postaci. Brak tu rzetelnych dysput, choć wiemy, że można stawiać mądre pytania poszukując mądrych odpowiedzi. Możemy wreszcie odważniej pytać o to, czy ta Europa to tylko kształt na mapie, czy rodzaj wspólnoty kulturowej, czy tylko fantazmat. Świadomi własnych kompleksów zadajemy sobie pytanie o to, czy także jesteśmy integralna jej częścią, czy tylko peryferiami ze wszelkimi statusami i licznymi kompleksami peryferii. Czy, jako Europejczycy, jesteśmy tylko „narodem filozoficznym” i w jej konstrukcji filozofia powinna odgrywać większa rolę ${ }^{40}$. Jeżeli tak, to raczej filozofia praktyczna, polityczna, a w takim sądzie jest wiele treści. Przecież narody „twardego rdzenia” Europy same idee wspólnoty budowały w oparciu o filozofię, w separacji od religii ${ }^{41}$. Próbujacc ją tworzyć chyba powinniśmy być bardzo uważni, bo znajdziemy wiele racji w sądzie autora, który utrzymywał, że tworzony mit Europy kulturowej jest przykładem działania, którego skutki bywaja odwrotne do zamierzonych ${ }^{42}$. Taka wspólnota oznacza przecież tożsamość kultur normatywnych i symbolicznych, a na pierwszy rzut oka widzimy, że nasze wartości, nasze wyobrażenia zbiorowe są inne

\footnotetext{
${ }^{39}$ S.P. Huntington, Zderzenie cywilizacji, Warszawa 1997, s. 181.

${ }^{40}$ R. Braidotti, Transpositions, Cambridge 2007, s. 21.

${ }^{41}$ T.G. Ash, Free World, New York 2005, s. 47.

${ }^{42}$ E. Lewandowski, Pejzaż etnicznej Europy, Warszawa 2005, s. 103.
} 
niż Niemców, Włochów czy Litwinów i nieprędko spotkamy się z nimi na jednej płaszczyźnie, jeśli zawierzymy w automatyzm zmian.

Być może, poszukując siebie, Europejczycy, z nami w tym rzędzie, powinni spojrzeć innym okiem na „naród narodów”, na wspólnotę amerykańska. Amerykanom udało się stworzyć jakość nazywana przez nich samych „religia obywatelską" i ona pozostała spoiwem tak mocnym, że wspólnocie nie zdołały zaszkodzić nawet konwulsje wojny secesyjnej. Bywały okresy, kiedy Ameryka marzyła o byciu narodem jak europejskie, o ostatecznym zdefiniowaniu się wobec świata ${ }^{43}$, o odnalezieniu swojego zbawienia, o czym mówił. R. Kipling ${ }^{44}$. Znalazła tylko swoje „boskie przeznaczenie” (Manifest Destiny) dzięki konsekwencji w rytualizacji tych wartości, jakie uznano czysto amerykańskimi, choć Amerykanie jednak nie sa narodem wedle „klasycznego” wzoru narodu, sami maja co do tego wiele watpliwości, ale narodem w europejskim znaczeniu być nie muszą. Sa natomiast narodem dla tych, którzy uważaja, że naród istnieje przede wszystkim właśnie jako wspólnota wyobrażona ${ }^{45}$. Sa także wspólnotą celów jednoczącą się wokół takich polityków i partii, które sa symbolizowanymi ikonami Ameryki. Budując wielką świątynię ,narodowej” wiary zaczęli od dachu zawieszając go na niewidzialnych filarach symboli, a potem dopiero przystępując do budowy ścian. Jeśli nie wierzymy autorowi twierdzącemu, że wspólnota europejska istniała od zawsze jako te ściany oczekujace na zwieńczenie dachem, to pomyślmy o dachu dla wspólnego domu ${ }^{46}$. Takim dachem moga być wielkie, rytualizowane wizje zawieszone w dalekiej przyszłości, konstruowane tak, jak amerykańskie wizje "miasta na wzgórzu" czy „latarni dla świata”. Animatorzy poszerzania i pogłębiania integracji powinni robić wiele, by Europejczycy, poza wizjami, ujrzeli przed sobą wspólne cele i to takie, jakie będą obietnica pełni.

Chyba naturalnym jest pytanie o to, czy, jeśli chcemy budować Europę z Europejczykami, nie powinniśmy korzystać z tamtych wzorów, czy możemy wykorzystać tamte doświadczenia, czy architekci naszych wyobrażeń zbiorowych i sprawujący władzę symboliczną nie powinni zwrócić na nie uwagi biorąc pod namysł wszystkie podobieństwa i różnice, których przecież nie brakuje. Europa państw narodowych, które jeszcze nie przeżyły etapu narodowego, które są zanurzone w głębi historii i z niej czerpią znaki tożsamości zbiorowej, jest jakościowo inna,

\footnotetext{
${ }^{43}$ J.D. Hunter, Culture Wars. The Struggle to Define America, New York 1990, s. 50.

${ }^{44}$ P. Duignan, L.H. Sann, The United States and the New Europe, s. 6.

${ }^{45}$ R. Kroes, The Comodification of Americans Icons of Freedom, [w:] „Here, There and Everywhere". The Foreign Politics of American Popular Culture, eds E. Wagneleitner, E.T. May, London 2000, s. 273.

${ }^{46}$ C.J. Friedrich, Europe! An Emergent Nation?, New York 1969, s. 1.
} 
naznaczona śladami wielu kataklizmów, ciągle wracająca w przeszłość nie po nauki, ale środki obrony lub ataku. Amerykanie zaś konstytuowali swoją zbiorowość w czasie, w którym plebejscy imigranci nie przenosili z sobą wartości czysto narodowych, jako że Europa tego czasu (zwłaszcza wschodnia i środkowa) dopiero wchodziły na etap narodowy. Imigranci jeszcze byli przyzwyczajeni do homagialnych wzorów i wtedy te nawyki pomagały w spontanicznej legitymizacji władzy opartej na symbolach. Lata współżycia sprawiły, że Amerykanie zaakceptowali swoje formy lojalności wobec centrum, Europa zaś nie miała takiego i w walkach wszystkich ze wszystkimi wiekami uczyła się wrogości ${ }^{47}$. Nominalnie takim centrum po czas schizm był Rzym, ale wiemy, do jakiego stopnia nominalnie.

Inna postać pamięci zbiorowej zdaje się niezbędna, żyjemy przecież w czasie, w którym bardziej niż w innych potrzebujemy wielkich, uniwersalistycznych projektów - twierdził z przekonaniem E. Wood ${ }^{48}$. Nie wystarczą bowiem zaklinania rzeczywistości, tak częste w naszym czasie w ustach zadeklarowanych zwolenników pełnej integracji, utrzymujacych choćby, że Europa musi być mocarstwem i traktujaccym to jak swoisty imperatyw ${ }^{49}$. Podobne deklaracje nie wystarcza, bo Europa jest już mocarstwem nie potrafiacym upodmiotowić tej mocarstwowości - tak przynajmniej twierdzi T. Reid w The United States of Europe. Przywołując statystyki, które moga przywracać wiarę w „stara, zmęczoną Europę”, widzimy, że wśród czołowych firm światowych dominują europejskie, podobnie jak w bankowości. Europejczycy sa bardziej energooszczędni niż Amerykanie, bardziej inicjatywni, czego poświadczeniem jest dynamika powstawania małych firm. Potrzebuja tylko nowych bodźców i autorowi tej pracy marzy się wykreowanie jakości, jaka można by nazwać „European dream”. Przeszkód na drodze realizacji takiego „marzenia” jest wiele, ale jest ono marzeniem osiagalnym, czego dowodzą postępy unifikacji mimo wielu niedostatków, w tym zarzutów o nadmierny biurokratyzm ${ }^{50}$.

To zdaje się także swoistym epimeteizmem, nierzadko spotykanym w historii Europy i w takim przypadku przypominaja się górne deklaracje tuż po zawarciu traktatu w Maastricht, kiedy $\mathrm{z}$ emfaza pisano o trzynastym państwie, trzynastym narodzie, jakim mieli być Europej-

\footnotetext{
${ }^{47}$ M.J. Vile, Politics in USA, New York 2007, s. 18

${ }^{48}$ E. Wood, What is Postmodern Agenda, [w:] In Defence of History. Marxism and Postmodern Agenda, eds E.M. Wood, J.B. Foster, New York 1997, s. 13.

${ }^{49}$ J. Karczmarek, Unia Europejska. Trudne dojrzewanie, Wrocław 2003, s. 35.

${ }^{50}$ Y.H. Ferguson, R.W. Mausbaum, History's Revenge and Future Shock, [w:] Approaches to Global Governance Theory, eds M. Hewson, T.J. Sinclair, New York 1999, s. 203.
} 
czycy $^{51}$. To trzynaste państwo fundowano na unikalnej architekturze instytucjonalnej - zauważał badacz ${ }^{52}$. Nieustannie eksperymentowano, z tym, że niektóre z tych eksperymentów kończyły się na fazach projektowania, a tak było i jest choćby z eurokorpusem, tak z trwałym pytaniem o to, czy pogłębiać, czy poszerzać, tak z tworzeniem strefy euro. To jednak choroby demokracji sprawiły, że Europa nie ma ani zasad, ani strategii, co powtarzają coraz głośniej analitycy, a za nimi publicyści obserwujący zachowania polityków europejskich i głowę państwa w prezydujacej Unii Francji w czasie olimpiady w Pekinie. Byliśmy bliżsi Europie w czasie polskiej prezydencji, ale była to bliskość tylko nominalna. Ta prezydencja nie pozostawiła śladów w pamięci zbiorowej, nie tylko polskiej, a afera korupcyjna z nią wiązana jest jakby suplementem do niej.

Po pierwszym, psychologicznym etapie poszerzania i pogłębiania Europa zdaje się popadać w marazm z braku wizji rodzących prawdziwe cele, czego poświadczeniem jest ilość i jakość działań magicznych polityków europejskich potęg. Okres wiary w poszerzanie i pogłębianie skończył się chyba wraz z dyskusjami nad planem Foucheta. Fiasko pomysłu nierozerwalnej unii sześciu państw prowadzacych wspólna politykę zagraniczną zakończyło ten okres, który dziś zdaje się czasem niewykorzystanych szans. Ferwor jednoczenia, swoisty terror chwili etapu integracji ekonomicznej odsuwał na plan drugi i trzeci organizowanie nadziei zbiorowych obywateli państw Wspólnoty, osiagających progi spełnienia $\mathrm{w}$ dobrach materialnych i czujaccych się $\mathrm{w}$ miarę bezpiecznie pod parasolem NATO. W wyobrażeniach zbiorowych pojawiły propagowane przez polityków i media się przekonania, że jest to Wspólnota oparta o wymianę dóbr i ograniczony transfer ludzi i taka powinna pozostać, bo niesie wystarczające korzyści wszystkim jej członkom. Z Królestwa Możliwości nie wybrano tej, jaka proponowali konstytucjonaliści. Przyjęcie konstytucji jeszcze w latach 50. mogło być ramami dla zorganizowania wspólnoty spełnienia o zupełnie innych kształtach, a takie kształty narzucałyby już strategie poszerzania o nowych członków.

Swego czasu zdawać się mogło, że taka, generującą wizją może być Strategia Lizbońska, której celem głównym miało być stworzenie w Europie do roku 2010 najbardziej konkurencyjnej gospodarki świata. Strategia miał opierać się na kilku czynnikach z innowacyjnością na czele. Pozostała tylko wizja, w dużej mierze za sprawą niemożności wyjścia poza taktykę wobec państw członkowskich, stworzenia prawdziwej

${ }^{51}$ C. Kastoryano, Transnational Nationalism, [w:] Identities, Affiliations and Allegiances, eds S. Benhabib, I. Shapiro, Cambridge 2007, s. 159.

${ }^{52}$ B. Eberlein, E. Grande, Reconstituting Political Authority in Europe, [w:] Complex Sovereignity, eds E. Grande, L.W. Pauzy, Toronto 2005, s. 146. 
strategii w oparciu o taką wizję i konsekwentną realizację pochodzących od niej celów. Za sprawą imponderabiliów wyszukiwanych przez niektóre państwa narodowe obraz sytej, bezpiecznej dla wszystkich Europy rozmył się w podejrzeniach o dyktat, o obronę partykularnych interesów najsilniejszych i nie spełnił swojej aktywizujaccej roli, a w tle ukazały się źródła niemocy. Skrywając się za tarczami narodowości politycy krajów takich, jak Polska falsyfikuja swoje role społeczne, jako „kapłani ojczyzny”, bronią imponderabiliów, bo zbyt często nie stać ich na ochronę generaliów ekonomicznych, społecznych czy politycznych, o których maja raczej małe pojęcie, choć umiejętnie tworzą pozory pełnej kompetencji. Wchodzenie na poziomy nadnarodowe wymaga zdecydowanie innych kompetencji, jakich ci politycy raczej nie posiąda i tu starczy przyjrzeć się naszym eurodeputowanym i ich praktykom. Wina leży nie tylko po stronie polityków małych krajów, bo wśród tych, którzy reprezentuja ,twardy rdzeń” także nie spotkamy wizjonerów, a najczęściej zarządców myślących tylko o sobie i teraźniejszości.

Dla stworzenia wielkiej wspólnoty będacej oazą dobrobytu i bezpieczeństwa, nie wystarcza mgliste projekty integracji kulturowej, przywoływanie sokratyczno-chrześcijańskich korzeni Europy, które dla zwykłego człowieka sa tak głęboko ukryte, że nie bardzo wiadomo z czym ma je kojarzyć. Rozliczne ich interpretacje przez teoretyków raczej nie mówią mu wiele i nie powiedza, jeśli nie przełożymy ich na czytelny język symboli mogący posłużyć większym konstrukcjom godząc się z tymi, którzy powiadaja, że integracja potrzebuje przede wszystkim tworzywa duchowego ${ }^{53}$, ale nie dodaja jakiego. Na razie służą tylko napuszonym, górnym sądom wyglądającym na klasyczne uzurpacje, służącym tylko samouspokajaniu, jak choćby poniższy: „Europa nowożytna uwierzyła w przyszłość. Człowiek stał się naprawdę kreatorem”54.

$\mathrm{Z}$ pewnością Europejczykom udało się dokonać wiele w ciagu tak krótkiego czasu, ale te wszystkie prace zdaja się zaledwie początkiem wielkiego dzieła, bo nowe wyzwania wymagaja reorientacji, zdecydowania podobnego do tego z okresu psychologicznego. Przyglądając się tym wszystkim zabiegom mającym służyć nowym projektom stajemy się po prostu sceptykami widząc inercję, brak synergii, a niekiedy zwykły egoizm państw narodowych, na pewno w wielu przypadkach zrozumiały, ale chyba nie do przyjęcia na dłuższą metę, bo ten egoizm szkodzi nie całej Europie, a przede wszystkim słabszym ogniwom Unii, z czego te słabsze ogniwa winny zdawać sobie sprawę i zdaja, jeżeli zauważymy deklaracje (2013) Litwy i Łotwy wyrażające chęć wejścia do

${ }^{53}$ J. Życiński, Europejska wspólnota ducha, Warszawa 1998, s. 139.
${ }^{54}$ N. Luhmann, Observations on Modernity, Stanford University 1998, s. 65. 
strefy euro. Nie wydaje się, by rację miał D. Moisi mówiący, że Europa znalazła się w samym środku poważnego kryzysu tożsamości, że sparaliżowana nie może sprecyzować swoich wartości ani kryteriów geograficznych po zniknięciu dawnego wroga, czyli Związku Radzieckiego. Wedle niego dla tak innej wspólnoty nie zbuduje się tożsamości zbiorowej na opozycji ja-obcy, która sprawdzała się w tworzeniu państw narodowych. Chcemy zauważyć, że taka opozycja jest tylko piaskiem, cementem zaś stać się powinno zupełnie co innego i takim spoiwem może być tylko to, co może łączyć, a najlepiej łączą wspólne cele. Niełatwo je określić, a trudnościa zasadniczą jest jakość polityków w postpolityce (choć nie wiemy zbyt dobrze czym ona jest). Dziś mamy do czynienia z politykami transakcyjnymi, reagującymi tylko na bieżące problemy, a wspólne dla wszystkich cele moga być dziełem wizjonerów, kreatorów obdarzonych odwaga i wyobraźnią. Takich dziś nie ma, co widać w czasie kryzysu finansowego, bo tu kreuje się nastroje wyczekiwania na deus ex machina.

Może mają swoje racje Amerykanie twierdząc od dziesiątków lat, że Europa jest stara i zmęczona, jeśli tak chętnie i to od ponad stu lat potwierdzają to sami Europejczycy, ale przecież to, co czynia, świadczy o ich żywotności. Różnie tłumaczy się takie sądy, ale do zrozumienia i wyjaśnienia takiego pesymizmu jeszcze daleko. Dla nas problemem jest to - zauważał J. Baudrillard - że nasze stare cele - rewolucje, postęp, wolność - rozmyły się zanim zostały osiagnięte, poza wszelka możliwością realizacji ${ }^{55}$. Poczucie bezsiły, mimo pozornych sukcesów, podważa podstawy społeczeństw, wiarę w przyszłość - to zauważał już Gadamer w Dziedzictwie Europy także nie poszukując źródeł owej bezsiły, a te można chyba znaleźć w gnuśnym sybarytyzmie po zaspokojeniu potrzeb materialnych, spełnieniu się w nich z braku pragnień innego spełnienia. Ci teoretycy także uważaja, że potrzebne sa nam nowe cele, a poprzedzać je powinny generujące wizje przypominające amerykańskie „miasto na wzgórzu”, konsekwentnie rytualizowane i interpretowane przez posiadających władzę symboliczna i zdających sobie sprawę z istoty tej władzy, potrafiących wykorzystywać jej narzędzia. Nie tworzy się ich dla czasowej aktywizacji, ale dla podtrzymania nadziei długiego trwania i takie wizje musza rodzić coraz to nowe drzewa celów. Bo inaczej obumierają wraz z nadziejami zbiorowymi na to, na co człowiek ma zawsze nadzieję. Cele powinny wynikać z wizji, a wydaje się, że rację ma L. Pervin powiadając, że najbardziej mobilizuja nas serie bliskich w czasie, spójnych celów pośrednich, które prowadza do głównego ${ }^{56}$. Na razie nie ma takich, sa tylko potwierdzenia, że bar-

55 J. Baudrillard, Ameryka, Warszawa 1998, s. 106.

${ }^{56}$ L.A. Pervin, Psychologia osobowości, Gdańsk 2002, s. 291. 
dzo wielu politykom i ekonomistom odpowiada taki wygodny i efektywny w sumie układ wymiany dóbr materialnych i ograniczony jeszcze transfer ludzki.

W telosach Europy naszego czasu widać jednak paraliżujący recentywizm, to stałe oglądanie się na chwilę bieżącą i reagowanie tylko na to, co ona przynosi. W praktycznej postaci przekłada się na ślamazarne rozwiązywanie problemów bieżących bez podporządkowania ich wizjom, projekcjom, strategiom. Wydaje się, że zupełnie nie widać działań prewencyjnych, co jest jakimś potwierdzeniem tego recentywizmu. Niekiedy nawet tworzy się sztuczne, małe problemy, by, rozwiązując je, przekonywać do sprawności aparatu, a z pewnością wielu z nich można unikać stosujac proste metody prewencji, jakie sa nieodłączną częścia każdej projekcji, bo w takich konkretyzacjach wizji zwykle przewiduje się alternatywy dla rozwiązań, jakie się nie sprawdzają albo mogą się nie sprawdzić. One zdaja się niezbędne choćby po to, by często pytać o zagrożenia dla europejskiej wspólnoty narodów, a takich, oczywistych pytań, po prostu brakuje, jakby wszyscy byli pewni, że Europa została już zapisana w planie świata i nikt tego planu nie skoryguje, nie zakwestionuje. Powinniśmy pytać jak najczęściej poszukując tych zagrożeń, nie czekając na nie. Wiemy już, że strachy mogą być także ożywiające, inspirujace, o ile ich kreatorzy nie przekraczaja pewnych granic. Nie musimy ich tworzyć, starczy zaczać pytać o niebezpieczeństwa, jakie już istnieja, sa maskowane przez establishment, a jakie pojawić się moga tu i teraz. Tymczasem dominuje syte, bierne zadowolenie, a pojawiające się kryzysy, jakich ukryć się nie da, rodzą prawdziwe traumy i służą całkiem nieźle politykom, akcentującym w takich sytuacjach swą niezbędność.

Taka teleologia musi także cechować się konsekwencja, a zniechęca do siebie, jeżeli przypomnimy sobie cele Strategii Lizbońskiej, potwierdzające stare nawyki myślenia i działania magicznego. Takie „wizje” jak Strategia nie organizuja tzw. długiego czasu nadziei społeczności, nie sa w stanie aktywizować wielkich grup, tym bardziej, że tylko waskie elity wiedza, czym jest ta strategia. Zwykły Europejczyk musi ujrzeć przed sobą nowe, kuszące przestrzenie obietnicy, nowe jakości spełnienia w jego wszystkich wymiarach. Wspominaliśmy już o tym, że wizje amerykańskie generowały soteriologię ziemską w wulgarnej, ale przekonujaccej postaci i nie brakło w nich obietnic spełnienia materialnego i duchowego w doczesności, a co najmniej utrzymania przez bogatych ich dotychczasowych statusów, a przez biednych osiaganie poziomów tych bogatych, co sprawdzało się w polskich wizjach zbawienia początków transformacji. Wiemy, jaką moc miały wizje znalezienia się w rodzinie „wolnych” krajów, jak przekładały się na aktywizm zbioro- 
wy, inicjatywność polityczną i postaci „zgody narodowej” przez pewien czas. W naszym zaś czasie pojawiaja się takie przestrzenie obietnicy i będą się poszerzały, choć twierdzi się, że europejski model społeczeństwa zbudowany na fali późnej nowoczesności stał się luksusem ${ }^{57}$. Społeczeństwa dobrobytu powoli staja się rajami utraconymi za sprawa innej polityki socjalnej, będącej pokłosiem kryzysu, ale pozostają społecznościami sytości i stabilizacji, jakiej nie doświadczały generacje mieszkańców początku wieku i nie doświadczają dziś obywatele biedniejszych państw. Wiele wskazuje na to, że czas jakiś jeszcze pozostana azylami spokoju i dostatku, o ile nie zdarzy się coś nadzwyczajnego.

Wydaje się dziś, że w ożywającej i zanikającej debacie konstytucyjnej mogłyby znaleźć się wizje Europy upodmiotowionej, silnej, zapewniajacej wszystkim Europejczykom takie same warunki życia, bo kompleksy biednych wobec bogatych są oczywiste i wpływają na wzajemne stosunki, w których nie brakuje uprzedzeń, a nawet zwykłej pogardy. Miast oglądać się w przeszłość, przywołując choćby niewiele mówiące tradycje karolińskie, winniśmy spojrzeć w przyszłość odrywając się od historii, która nie będzie łączyć, ale dzielić, co nie znaczy, że mamy tę historię zapomnieć, bo zapomnieć się nie da. Przesłanek do takich właśnie wniosków dostarczają ożywione i niezmiennie bezowocne dysputy o możliwościach stworzenia jednej historii europejskiej, niemożliwej do napisania nawet $\mathrm{w}$ formie przypominajacej najbardziej prymitywne, narodowe „historie święte”. Jak dowodzą te próby wspólna historia tylko dzieli zamiast łączyć i lepiej już z nią nie eksperymentować dla wspólnego dobra. O wiele lepiej łączyć moga cele, jakimi sa, przede wszystkim, bezpieczeństwo zbiorowe i stabilność gospodarcza wspólnoty rodząca przekonanie, że nic nie zagrozi naszym statusom. Bezpieczeństwo pod parasolem NATO nie stało się większe dla Polski niż ze strony ZSRR w okresie zimnej wojny, o ile nie przyjmiemy, że Rosjanie bezustannie myśleli o ataku na bogatą Europę, jak sugerowali to autorzy powieści sensacyjnych tworzący samodestruujące się prognozy (F. Forsyth, T. Clancy, D. Jones).

Z pewnościa Europa i dla lepszych stosunków ze Stanami i dla własnego bezpieczeństwa powinna zadbać o własną obronę - uważa S. Strange jakby nie zauważając, że te próby są skutecznie torpedowane przez Amerykanów i tu można przypomnieć M. Albright i jej „trzy D”58. Europejczycy w sumie wydają na obronność o połowę mniej niż Stany, ale mimo to sa prawie bezbronni w przypadku, gdyby zawiodły siły NATO, a to nie wydaje się niemożliwe. W budżetach krajowych prze-

${ }^{57}$ P.A. Chilton, Ch. Schaffner, Politics as Text and Talk, Amsterdam 2002, s. 69.

${ }^{58}$ S. Strange, The Future of American Empire, [w:] The United States in the World Political Economy, ed. T. Reuter, New York 1994. 
znacza się ogromne sumy na niesprawne, marnotrawne armie, które czasami służą tylko dobremu samopoczuciu polityków przyjmujących defilady, ale nie sa w stanie skutecznie bronić obywateli ani przed zagrożeniami symetrycznymi, ani asymetrycznymi. Za połowę sum przeznaczanych głównie na bieżące utrzymanie i remonty, można stworzyć euroarmię tak silną i mobilna jak amerykańska, a może nawet silniejsza. Tak się wydaje, jeśli przyjrzymy się amerykańskiemu molochowi zbiurokratyzowanemu do granic absurdu.

Raz jeszcze wracając do wątku narodowego zauważmy, że twórcy pomysłów na inaczej rozumianą Europę zdają się uwięzieni w starych paradygmatach myśląc o stworzeniu narodu europejskiego na miarę definicji, uważając za niemożliwe stworzenie go bez wspólnej historii. Przywoływaliśmy Amerykanów także po to, by sugerować, że stworzenie wspólnoty celów, która wcale nie musi być narodem nie musi być tożsame z tworzeniem wspólnej wizji przeszłości. Pierwsi Amerykanie, czyli Anglicy, oderwali się od przeszłości, od historii Edwardów i Henryków i na nowo zaczęli ja pisać od „Mayflower”. A jeśli już zdecydujemy się na tworzenie europejskich wizji historii, to powinniśmy tworzyć historię idei, a nie czynów.

Powinno być w niej jak najmniej akcentów narodowych, choć nie wydaje się, by historycy i politycy mogli znaleźć formułę kompromisową w najbliższym czasie, a tego czasu po prostu nie ma, co zauważono $\mathrm{w}$ apogeum kryzysu finansowego wieszcząc nawet koniec Unii, co miało chyba otrzeźwić niektórych polityków. Jeżeli będziemy marnotrawić czas tak jak dotąd, następny kryzys, którego istota jest nieznana, może rzeczywiście okazać się końcem marzeń o Europie. Powtarzamy: jeśli już zdecydujemy się na tworzenie europejskiej wizji historii, to powinniśmy tworzyć historię idei, a nie czynów. Tak to zrobili Amerykanie czyniąc swoja historię historią wolności nie zwracając zbyt wielkiej uwagi na fakty, które jej przeczyły, na niewolnictwo, eksterminację Indian, zaborcze wojny. Oni zdawali się najlepiej rozumieć to, że historia jest dialogiem o przeszłości toczonym w teraźniejszości w imię przyszłości i posługujemy się nią instrumentalnie w swojej polityce pamięci. Dla Europejczyka zaś historia bywa tylko potwierdzeniem triumfów i klęsk zagrożonych tożsamości zbiorowych i nie interesuje go jako proces, a tylko epizody, które potwierdzają idealne wizerunki narodu albo legitymizują aktualna władzę. Zacznijmy pisać historię z perspektywy przyszłości. Wizje przyszłości - jak górnie pisał G. Therborn - to nowy horyzont naszych dążeń, pełnego miejsc, jakich nie widziało ludzkie oko ${ }^{59}$.

Potrzeba tworzenia nowych wizji przeszłości i przyszłości zdaje się bardzo piląca w naszym czasie swoistego zawieszenia między ja-

${ }^{59}$ G. Therborn, Drogi do nowoczesnej Europy, Warszawa 1998, s. 508. 
kościami narodowymi i nadnarodowymi. Państwa narodowe zaczęły się jednak przeżywać, słabości narodowych legislatyw i egzekutyw zauważano już po II wojnie, a przed powstaniem wspólnoty europejskiej i sądzono wówczas, że są to słabości czasowe ${ }^{60}$. W dodatku demokracja w nich nie jest sprzymierzeńcem kompetencji i altruizmu władz i wybrańcy nie sa w stanie zapanować nad materia gospodarczą i społeczna bez wspomożenia przez siły intelektualne, do których czują nieufność ze szkodą dla obywateli. Niedostatki kompetencji przejawiają się w kalekiej legislacji i zaniechaniach egzekutyw nie majacych ani jasnych celów, ani determinacji w ich realizacji, co w jakiejśs mierze wynika z kadencyjności władz. Sprawujący władzę polityczną zdają sobie sprawę z własnych niedostatków i legitymizują tę władzę przy pomocy symboli i mitów utożsamianych z wartościami narodowymi, a wiemy o tym, że mity sa z natury bezdyskursywne, ale także i to, że słabną w wyobrażeniach zbiorowych i wyborcy jednak racjonalizują swój stosunek do wybrańców oczekując rządów kompetentnych i skutecznych.

Przy pomocy takich mitów falsyfikuja rzeczywistość przekonując społeczności co do konieczności kultywowania państw narodowych w starym kształcie ${ }^{61}$, zwłaszcza w Europie postkomunistycznej, choć z różnym natężeniem. Być może rację mają ci, którzy twierdza, że wschód Europy nie jest odpowiednio przygotowany na ponowoczesną samoidentyfikację wspólnot narodowych ${ }^{62}$, nie jest jeszcze kompatybilny z zachodem, ale takie sugestie winny być inspiracjami dla organizatorów wyobrażeń zbiorowych, chyba wiedzacych o tym, że można je zmieniać, profilować. Taka próba, choć niekonsekwentna, była próba stworzenia wizji „małych ojczyzn”, wedle niektórych teoretyków tożsama z koniecznością budowy społeczeństw obywatelskich, ale tu czasem ciężko zrozumieć, co mają na myśli twórcy takich form społecznych, bo ilość form społeczeństwa obywatelskiego może zadziwiać i często nie wiemy, do jakich odwołują się ci niektórzy.

Być może państwa narodowe za czas jakiś umra śmiercia naturalna, być może budulec na postnarodowe imaginarium znajduje się w zasięgu umysłu - jak odważnie zauważał badacz ${ }^{63}$, ale, póki co, żyjemy w państwach narodowych zwiazani narodowymi wyobrażeniami i nie możemy przesądzać, kiedy do głosu dojdą te proteiczne generacje R. Liptona, czyli takie, które nie są zakorzenione w konkretnych kul-

${ }^{60}$ R. Cameron, Historia gospodarcza świata, Warszawa 2001, s. 422.

${ }^{61}$ A. Peccei, Wstep do: B. Hawrylyshyn, Drogi do przyszłości, s. 11.

${ }^{62}$ W. Burszta, Dwie Europy, [w:] Dylematy tożsamości europejskich pod koniec drugiego tysiaclecia, red. J. Mucha, W. Olszewski, Toruń 1997, s. 47.

${ }^{63}$ A. Appadurai, Nowoczesność bez granic. Kulturowe wymiary globalizacji, Kraków 2005, s. 37. 
turach, generacje e-obywateli będące rzekomo niedaleką przyszłością ${ }^{64}$. Nie wydaje się, by w naszym czasie można było dochodzić do poszerzania tego imaginarium metodami stosowanymi w demokracjach i ingerować mocniej w politykę wewnętrzną państw narodowych, by wymuszać odchodzenie od propagowania idei narodowych, tych zwłaszcza, w których historia jest narzędziem władzy, rezerwuarem symboli pilnie strzeżonym przez czasami przewrotnych, czasami obłudnych strażników.

Kto szuka europejskiej jedności - pisali przed ponad dekada R. Boyes i B. Cywiński - ten skazany jest na przeżycie wielu rozczarowań. Nie ma jednolitej Europy ${ }^{65}$. Nie byli zbyt odkrywczy. Ona może stać się ciałem tylko wtedy, kiedy zachowa się pełną synchronię między procesami poszerzania i pogłębiania, jeżeli co jakiś czas nie będa pojawiały się projekty Europy dwóch albo trzech prędkości oznaczajacce de facto dezintegrację i zepchnięcie państw, takich jak Polska do ról zdecydowanie podrzędnych, a wiele takich obaw towarzyszyło nam w czasie kryzysu finansowego i pełnej dominacji duetu Merkel-Sarkozy. Te dość stare koncepcje, bo pamiętające jeszcze czasy L. Tindemansa i W. Brandta, znowu pojawiły się w czasie kryzysu politycznego Unii w latach 2008-2012 i ta częstotliwość pojawiania się projektu zaczyna niepokoić, bo może on spełnić rolę samosprawdzającej się prognozy jak wiele innych, kreowanych i rozpowszechnianych z zadziwiająca beztroską nie tylko przez eurosceptyków. Wydaje się, że Unia może stać się ciałem wtedy, kiedy wszystkie jej państwa znajdą się na przybliżonych poziomach rozwoju ekonomicznego, bo wtedy pojawi się równość korzyści nie wynikających z form dystrybucji budżetu unijnego.

To sa sugestie funkcjonalistów, zwykle nie biorących pod uwagę możliwości osiągania tych poziomów w krótkim czasie, ufających w „naturalność" procesów gospodarczych i politycznych. Takie procesy, pozostawione samym sobie, moga zająć nawet dziesiątki lat, a czas może okazać się wrogiem największym, bo pojawić się moga zjawiska, które moga wręcz zagrozić kruchej jedności Europy, a takim zjawiskiem jest już choćby masowa migracja na stary kontynent mieszkańców Afryki i Azji, wobec których Europejczycy zachowują się tak, jakby nie chcieli widzieć w tym problemu mimo oczywistego fiaska polityki multilulturalizmu. Ich obecność i konieczność akulturacji zdaje się oczywista, a nie robi się praktycznie nic, by nawet zmuszać tych gości do korzenienia się w nowych warunkach tworząc enigmy politycznych poprawności, o których wiemy, czym sa. Przez taki brak zdecydowania,

${ }^{64} \mathrm{~J}$. Mikułowski-Pomorski, Jak narody porozumiewaja się ze sobq $w$ komunikacji międzykulturowej i komunikowaniu medialnym, Kraków 2007, s. 369.

${ }^{65}$ R. Boyes, B. Cywiński, Sezon na Europę, Warszawa 2003, s. 16. 
miast europejskiego patriotyzmu, tworzymy postać europejskiego natywizmu, a poza tym można obawiać się poważnie o to, że powiększajace się enklawy imigrantów będą starały się o zdobywanie niezależności, podmiotowości w krajach osiedlenia, bo takie obawy potwierdza praktyka włoska, angielska, francuska, hiszpańska, a wiemy z przeszłości, że ziemie nie były niczyją własnością od „zawsze”.

Wydaje się, że trzeba intensywnie poszukiwać czynników generujących poczucie wspólnoty starych mieszkańców i takie czynniki znajduja się $\mathrm{w}$ niedocenianych rezerwuarach kulturowych. Wyobrażenia zbiorowe Europejczyków, jakie dopiero się krystalizuja, chyba muszą nabrać pełnego kształtu, zawrzeć w sobie wszystko, co może łączyć, a nie dzielić, a to wymaga zupełnie innego spojrzenia na władzę symboliczna, na formy jej sprawowania. Wydaje się, że kreację takiego świata można oprzeć o to, na czym wspierali się Amerykanie, o bezdyskursywne mity wywodzone z wielkich archetypów wolności, równości, sprawiedliwości i tu nauki amerykańskie mogą okazać się bardzo przydatne. Nie tylko amerykańskie, bo warto przypomnieć sobie „metodę Moneta” - czyli rodzaj łagodnego despotyzmu przy stosowaniu polityki faktów dokonanych, swego czasu dopuszczalnego w demokracjach zachodnich ${ }^{66}$. Takie światy moga stworzyć niedoceniani intelektualiści, ludzie nauki przekonani do tego - jak D. de Rougemont - że dopóty nie będzie Europy, dopóki nie będzie Europejczyków ${ }^{67}$.

Wielkie wizje wielokulturowej Europy muszą znaleźć swoich depozytariuszy, tak konsekwentnych i zdecydowanych jak WASP-s w Stanach, a ci skwapliwie unikali przywoływania symboli narodów składających się na amerykańską mozaikę, nie toczyli bezładnych sporów o symbole majacce reprezentować „wartości”, bo te były niekwestionowane, z wolnościa, równością i sprawiedliwością na czele. Inaczej, nawet z pozoru tak oczywiste dla wielu chrześcijańskie korzenie, staja się przedmiotem sporów, jakie mogą dziwić albo wydawać się bezsensowne, niepotrzebne przy wzięciu pod uwagę niezgody między katolicyzmem a protestantyzmem, które jednak dzieli tak niewiele, a te wspólne korzenie to oczywistość. Nie wydaje się także, by zasadne było poszukiwanie syntezy wielu spojrzeń na światy wyobrażeń społeczności europejskich. Starczy spojrzeć na polskie i francuskie rozumienie wolności, by dojść do wniosku, że polski i francuski świat wolności moga spotkać się tylko w przestrzeni mitycznej, tworzonej wspólnymi siłami jako formy idealne, bo praktyczne ich interpretacje moga tylko dzielić, co potwierdzają dotychczasowe próby konstrukcji wspólnej historii Eu-

${ }_{66}^{66}$ F. Fries, Spór o Europę, Warszawa 1998, s. 20.

${ }^{67}$ D. De Rougemont, List otwarty do Europejczyków, s. 68. 
ropy. Jakimś argumentem przemawiającym za możliwością stworzenia jednolitej przestrzeni mitycznej dla wielu narodów kontynentu są tęsknoty narodów Europy Środkowej za prawdziwą wspólnotą idei.

Przypomnijmy, że poparcie dla wstapienia Polski do Unii w początku wieku wahało się w granicach $70-80 \%$ i pozostało na takim poziomie po wstapieniu, a nie wydaje się, by stopień tego poparcia zależał tylko od przewidywanych i rzeczywistych korzyści materialnych, bo przecież tylko część Polaków odczuła to na własnej skórze. Wiele znaczy nadzieja, chęć znalezienia się w wielkiej wspólnocie narodów, dalekich i bliskich, wspólnocie zapewniającej nie tylko pokój, ale i dostatek. Nie została dobrze wyartykułowana, ale to poparcie jest jakaśs przesłanką do wniosku, że Polacy, zmęczeni wewnętrznymi sporami, niekompetencja polityków, nadużywaniem górnej symboliki, powoli przestają wierzyć w zbawienie w narodzie i szukaja go w Europie.

Powinniśmy - utrzymuje wielu autorów i polityków - poszukiwać idei europeizmu, bo bez niego nie będzie struktury prawdziwie zintegrowanej ${ }^{68}$. Czym zaś ma być ten europeizm? Przy próbie odpowiedzi na to pytanie pojawiaja się spore kłopoty, bo jest fenomenem jak ten rzekomy europejski duch dostrzegany przez naukowych euroentuzjastów $^{69}$. Poszukując fantomów-symboli chyba trzeba wciąż reinterpretować, dopełniać kompetencje poszczególnych organów unijnych wobec narodowych, bo tu dowolność jest zbyt wielka, czego swoistym poświadczeniem jest, trudna do zrozumienia, podwójna lojalność niektórych składowych Unii, wobec potęg zewnętrznych, w tym lojalność Polski, jaka nie świadczy o nas zbyt dobrze. Nie wydaje się także, by zasadne było poddawanie takich problemów pod dyskusje społeczne, którymi dowolnie steruja pośrednicy medialni, zależni od rządzących w państwach narodowych. To oni decyduja o efektach takich, rzekomo demokratycznych, dysput. Politycy „twardego rdzenia” Europy zdaja się to rozumieć stosując coraz częściej formuły „dobroczynnego dyktatu" wobec słabszych partnerów, którzy mieliby kłopoty z radzeniem sobie poza strukturami Unii pozbawieni dodatkowych środków na rozwój i tu przypomina się Grecja. Taka niecierpliwość bierze się stąd, że zwolennicy Europy w pełni zintegrowanej zauważają niewykorzystanie ogromnego potencjału państw Unii i, patrząc w przyszłość, zauważaja także jak trudno byłoby radzić sobie z potencjalnymi zagrożeniami bez parasola ochronnego Stanów, być może dziurawego, ale jednak. Mając i to na uwadze niektórzy jednak sugeruja, że Europa jako organizacja

68 J. Liszka, Ojczyzna, naród, państwo, region w procesie integracji Europejskiej, [w:] Społeczeństwo wobec problemów transformacji i integracji, red. J. Liszka, Ustroń 2001, s. 187.

${ }^{69}$ C.N. Schierup, P. Hansen, S. Castles, Migration, Citizenship, s. 256. 
międzynarodowa staje się samodzielnym uczestnikiem życia międzynarodowego - takie sądy są uprawnione, ale tylko w części. Choćby w stosunku wielu państw do wojny w Iraku widzimy, że samodzielność podmiotowej Europy pozostaje tylko marzeniem.

Nie sądzimy, że przesadzamy mówiąc, iż w naszym czasie Europie najbardziej brakuje wiary, nadziei w spełnienie w tej nowej jakości i właściwie symbolizowanych wartości, które tworza przestrzeń działania. Wydaje się, że ta Europa poprzestała na kontentowaniu się trwaniem pozostając w stanie „wyuczonej bezradności”, choć w ostatnim czasie, po inicjatywach kanclerz Merkel i premiera Verhofstadta, widzimy jakby nowe siły i determinację w poszukiwaniu nowych form dla europejskich treści, o na swój sposób koryguja je tacy politycy jak Cameron i Holland. Czynią to właśnie politycy wizyjni, transformacyjni, bo oczekiwanie na presję społeczności i oddolne inicjatywy musi okazać się płonne, jeśli syte społeczności są bierne, zobojętniałe na wszystko, co nie zagraża ich statusom. Nie sposób nie godzić się z przekonaniem tych kreatywnych polityków, że Europa musi zacząć walczyć o swoja podmiotowość, by móc samodzielnie radzić sobie z wyzwaniami i zagrożeniami, że pogłębianie musi zmierzać w kierunku jakości, jaką niektórzy autorzy ze spora przesadą zwa już „narodem europejskim”, fascynują się starymi pomysłami na obywatelstwo europejskie. Zauważono, że spillover efect funkcjonalistów do pewnego stopnia sprawdza się, ale $\mathrm{w}$ okresie tak niepojętego przyspieszenia i kompensacji zagrożeń wymaga wzmocnień nie tylko przez większe zdecydowanie, ale także przez przejęcie ośrodków władzy symbolicznej i kreację wielkich wizji Europy z akcentowaniem korzyści materialnych, bo te przekonuja najmocniej. Pamiętając o konieczności politycznego i gospodarczego upodmiotowienia winniśmy mieć na uwadze sugestie takie, jak poniższa: „Dziedzictwo Europy polega, w istocie rzeczy na wezwaniu, byśmy nie ustawali w próbach poszukiwania obrazu człowieka Europy, kreatora, który potrafi pytać i odpowiadać"70. Ale wpierw musimy zapytać o to, czego tak naprawdę potrzebują Europejczycy, niezależnie od narodowości i na tym oprzeć wysiłki poszukiwaczy.

Po to, by rewitalizować społeczny aktywizm politycy muszą zacząć przekonywać, że zbawienie leży właśnie w pełnej integracji i inspirować tworzenie wspólnoty celów, nie przetrwania, a właśnie o takiej wspólnocie mówiło się w latach 2011-2012, choć dość nieśmiało. Deus ex machina z pewnością nie pojawi się, a warto przypomnieć, że swego czasu T. Pangle miał nadzieję na to, że to właśnie ze Wschodu przyjść może antidotum na osłabiający relatywizm, który wsącza swą truciznę

${ }^{70}$ N. Lobkowitz, Czas kryzysu, czas przełomu, Kraków 1996, s.19. 
w zbiorową świadomość zachodnich demokracji ${ }^{71}$. Przypominał niezbyt wysublimowane teorie słowianofilów wieszczących zbawienie świata przez młody, świeży, tajemniczy Wschód. Ich echa pojawiły się w czasie, kiedy polskie nadzieje zbawienia w Europie sięgnęły szczytów poparcia, bo w latach 1994-1996 wahały się między 70 a $80 \%{ }^{72}$. Wtedy też pojawiały się głosy, że możemy dać Europie nowe impulsy, ale wnet okazało się, że nie jesteśmy ani młodzi, ani świeży, może tylko trochę tajemniczy, a aura tajemniczości, egzotyki zanikła przy bliższym poznaniu.

Wtedy to polscy eurosceptycy, niekonsekwentni po swojemu, przypomnieli dawne idee sugerując, że to właśnie Polacy mogą stać się depozytariuszami wartości europejskich, które odmłodzą Europę, dadzą jej nowe impulsy rozwojowe. Przy czym nikt nie wspominał o tym, że kultywujemy wartości sprzed wieków, anachroniczne dla ludzi zachodu, że Europa naszego czasu jest ufundowana na wartościach Oświecenia i nie zamierza od nich odstapić i myślimy tu o Europie „pierwszej prędkości”. Przejawiając swego czasu eurosceptycyzm, a dziś zachowując się co najmniej niekonsekwentnie wobec wspólnoty powinniśmy zdawać sobie sprawę z tego, że: „Polska to kraj biedny i fatalnie rządzony, zapyziała prowincja Europy w sensie materialnym i kulturowym. Mamy olbrzymie długi i zero zapału do pracy. Jeżeli znalazł się frajer, który chce nam dać choć jedno euro, chce zainwestować w naszą ziemię, który chce nauczyć nas ogłady i zmusić do pracy, nie mamy nad czym myśleć. Alternatywą jest tkwienie w kołchozie pod wezwaniem Łukaszenki z winem Arizona w spracowanej dłoni. Będziemy wówczas tworzyć harmonijną całość z liderami naszego życia publicznego"73. Ten przydługi cytat publicysty jest bodaj najlepszym komentarzem do uroszczeń sprzed kilku lat, znacznie lepszym niż wyważone, niezwykle ostrożne uwagi naukowców i zarazem sugestia, jakimi argumentami możemy skutecznie profilować przestrzenie mityczne wielkich grup Polaków, którzy widzą Unię jak zagrożenie nie chcąc zdawać sobie sprawy, że ona jest forma obrony przed zagrożeniami o wiele większymi. Po pierwsze, przed siłami globalizacji, a po drugie, przed nami samymi.

Teoretyk zauważający połowiczność zbawienia bogatej Europy zdawał się marzyć o spełnieniu w wartościach zatraconych w sybarytyzmie. Wschód Europy, choć i tam powtarzano, że jest depozytariuszem autentycznych wartości, nie odnowi Europy. Tam, narodowe fobie wiazane z poczuciem braku spełnienia rodzą tylko nowe postaci euroscep-

\footnotetext{
${ }^{71}$ T. Pangle, Uszlachetnianie demokracji, Kraków 1994, s. 119.

${ }^{72}$ U. Świętosławska, Stosunek Polaków do integracji z Unia Europejska, [w:] Cywilizacja $w$ czasie $i$ przestrzeni, red. U. Świętosławska, Torun 2002, s. 57.

${ }^{73}$ K. Czabański, Przyjdzie Unia i wyrówna, „Gazeta Wyborcza”, 4.03.2002, s. 18.
} 
tycyzmu, poczynając od gróźb utraty tożsamości narodowej do wizji Europy tępych eurokratów rzekomo czyhajaccych na dobra tego Wschodu. Oskarżający zarzucają im niepohamowaną żądzę regulacji, totalizm i większość grzechów głównych. Pisze się o tym, że urzędnicy unijni chca decydować o wszystkim poświęcając dyrektywy nawet lusterkom wstecznym w ciagnikach rolniczych ${ }^{74}$. Mają swoje racje, bo istota biurokracji generuje ogrom działań magicznych, ale swoje racje mają także urzędnicy. Muszą przecież zorganizować chaos znajdując się na początku tworzenia i robia to na swoje sposoby. Chyba jednak nie najgorsze, bo ci, którzy konfrontowali się z biurokratami polskimi i europejskimi utrzymuja, że eurokraci właśnie mogą być stawiani polskim jako wzór.

${ }^{74}$ V. Angress, C.P. Hutter, L. Ribbe, Banany dla Brukseli. Ciemne strony Unii Europejskiej, Wrocław 2002, s. 127. 



\section{9}

\section{Polskie Wizje ZBAWIENIA}

Pejzaż po komunizmie to żyzna gleba dla zbiorowych namiętności, złudzeń i rozczarowań - powiadał V. Tismaneanu ${ }^{1}$, przekonany nie tylko do tego, że czynniki jakościowe odgrywały i odgrywają ogromne role w procesach politycznych, ale i do tego, że są badalne. Takie przekonanie, nie o możliwości, ale konieczności badania tej gleby staje się silniejsze zwłaszcza wtedy, kiedy przyglądamy się analizom polskiego Sierpnia i bezradności wielu autorów nie potrafiacych odpowiednio uwzględniać czynników jakościowych, a zwłaszcza nadziei zbiorowych po okresie marazmu lat 80. Nadzieje kultywowane w niedawnej przeszłości obumarły wraz z Okragłym Stołem i pierwszymi wyborami, a zrodziły się nowe w erupcji, jaka odmieniła nie tylko Polaków.

Te nowe wspierały się o wielkie nadzieje długiego trwania i były doraźnymi nadziejami na szybką i radykalną zmianę życia wszystkich, niezależnie od miejsca w hierarchii społecznej, roli społecznej, umiejętności, kwalifikacji. Nadzieje były otwarte, niewinne przez pierwsze miesiące, aż zderzyły się z brutalną dla milionów, nieodgadniona, tajemniczą rzeczywistościa transformacji i porażającym strachem tych milionów o utratę wszystkiego. Wyrastały w tej glebie z poczucia odzyskanej wolności, tej wolności, jaka nigdy nie przybiera ziemskich postaci, ale która przez czas jakiś rodzi radość spełnienia się w takiej wartości i był to krótki czas nadziei. Nie dostrzegali tego rządzacy decydujacy się na „chirurgiczne cięcia”, nie ważący milionów ludzkich dramatów i powtarzajacy, że działają w imię wspólnego dobra, co brzmiało jak drwina w uszach milionów czujących wykluczenie. Zdaje się, że politycy już w pierwszym roku transformacji skutecznie znieczulili się na nieszczęścia innych powracając do argumentów o dobru przyszłych po-

${ }^{1}$ V. Tismaneanu, Wizje zbawienia, s. 18. 
koleń, dobrze pamiętanych z czasów socjalizmu. Pojęcie transformacji, a właściwie metafora, może tłumaczyć wszystko, co dobre i złe i posługujemy się nim nie bardzo wiedząc jak wygląda jego istota.

Nie cieszono się długo tą zyskaną wolnością i rychłe zderzenie z nowa, chaotyczna rzeczywistością zrodziło niepokoje, nerwice zbiorowe, zachowania graniczace $\mathrm{z}$ desperacją ludzi, którzy zupełnie stracili dopiero co zdobytą wiarę w przyszłość. A chyba można sugerować, że brak tej wiary przesądzał o wykluczeniu. Ma swoje racje J. Stiglitz pisząc, iż rzadko kiedy rozziew między oczekiwaniami a rzeczywistościa był większy niż w przypadku przejścia od komunizmu do kapitalizmu². Konsekwencje tego rozziewu czujemy także dziś, choć one mało kogo interesuja, nawet programowych „obrońców biedaków”. Tym „biedakom” nagle zabrakło tych, którzy ich prowadzili, planowali i pośród milionów pojawiło się oczekiwanie na sotera, na nową eschatologię, nowe wizje zbawienia i, nie wierząc nowym zbawcom, sięgano w przeszłość, tam gorączkowo poszukując odpowiedzi na pytania współczesności, mityzując intencje i dokonania komunistycznych władców, zwłaszcza Gierka. Przy czym żądania odkłamywania przeszłości najczęściej kierowano pod adresem tych, którzy tę przeszłość umiejętnie zakłamywali licząc na co? Na ekspiację?

Nowe wizje historii także nie satysfakcjonowały wszystkich, ale pozwalały na odnajdywanie azylu w narodzie, kreatorze tej historii. Ten, już istniejący $\mathrm{w}$ dobie deklarowanego internacjonalizmu, azyl istniał jako forma kontestacji ustroju, ale po przełomie stawał się schronieniem pewnym, swojskim. Był nim w komunizmie w innej postaci, żył wtedy w setkach mitów zrytualizowanych spontanicznie mimo oficjalnych prób demityzacji. Ani Katynia, ani Piłsudskiego nie udało się wyprzeć z pamięci zbiorowej, mimo wielu wysiłków. Wspólnota narodowa zdawała się wypełniać pustkę, dawać choć namiastkę spełnienia, jakiego nie dawał ten nagle obcy i wrogi świat. Nie była wspólnotą zbawienia jak w II Rzeczpospolitej. Polacy odkrywali w sobie zbyt wiele obcości walczac o swoje miejsca w tej nowej rzeczywistości, a nikt nie zaoferował im wizji prawdziwej wspólnoty celów, wizji zbawienia. Poszukując znanego azylu w narodzie, w tych nowych warunkach odnaleźli wspólnotę wykluczonych i na scenie politycznej pojawiły się partie „populistyczne”.

Ten świat transformacji okazywał dla wielu się coraz bardziej obcy, zachłanny, zrelatywizowany tym bardziej, że okazał się takim po tak szalonych nadziejach. Po niezwykle krótkim okresie euforii zauważono, że koniec starego systemu nie był wyzwoleniem, a przyniósł poczucie

$\overline{2}$ J. Stiglitz, Globalizacja, Warszawa 2005, s. 141. 
przegranej i wnet powróciły resentymenty, pragnienia powrotu do starej klatki zapewniającej stabilność na niskich poziomach i bezpieczeństwo socjalne i ci, którzy stracili najwięcej nie chcieli zauważać, że była to równość w biedzie. W tej swoistej kulturze rozczarowania i nostalgii za przeszłością przegrani nie potrafili otrząsnać się z traumy i po utracie pierwszych, wielkich nadziei nie uwierzyli w deklarowaną równość szans wszystkich nie mając ku temu żadnych mocnych przesłanek, a ich zreszta nie było wiele w całej dekadzie lat 90 . Rozczarowania zaczęły być pożywką rozpaczy, odruchów buntu. Tych, którzy przeżywali je najsilniej czując pełne wykluczenie, zaczęli organizować ludzie tacy, jak A. Lepper, mający odpowiedników w każdym kraju postkomunistycznym. Oni poszukiwali prostych wyjaśnień swoich niepowodzeń i odnaleźli je w prostych słowach takiego przywódcy, który znakomicie wczuł się w rolę organizatora wyobrażeń zbiorowych „ludzi zbędnych” i spełniał się jako taki, a okazał się tak wielkim nieporozumieniem jako „polityk”. Znajacc, może nie naturę, ale moc teorii spisku i spiskowych, począł odnajdywać wrogów na zewnątrz i wewnątrz zdobywając zaplecze bez trudu, stał się depozytariuszem nadziei milionów wykluczonych dając im tylko krótki czas nadziei. Dawał je tym, którzy przeżyli kres nadziei przełomu i czuli strach przed Nowym. Najczęściej młodzi, nie pamiętający tego przełomu, socjalizowani w III RP, już zmienili postać swej wiary w spełnienie odnajdując ją nie w narodzie, a Europie, świecie. Dla nich naród zaczął stawać się tylko wspólnotą sentymentalna, a wedle ostrożnych szacunków około 2 milionów młodych postanowiło szukać spełnienia poza narodem.

Po tym raptownym zderzeniu z Nowym okazało się, że dzięki nowym władcom symboli wciąż jesteśmy zakładnikami mesjańskich koncepcji tworzonych w specyficznych warunkach dla innej zbiorowości, a przestrzenie naszych wyobrażeń zbiorowych wciąż wypełniają mity tworzone z innych potrzeb i dla innego człowieka. W tym czasie odzywały się tęsknoty za „prawdziwym”, nieskażonym komunizmem, wartościami, jakie zdawały się utracone wraz z tym, już idealizowanym komunizmem i jego misja dziejowa. One odpowiadały potrzebom ludzi wiary i, wbrew pozorom, mają mesjańską aurę.

Kiedy pojawiły się pierwsze konieczności radykalnych reorientacji postaw i zachowań, wyrzeczeń i poświęceń zarazem, wróciliśmy do mesjańskiego cierpiętnictwa spontanicznie implantując $\mathrm{w}$ wyobrażenia zbiorowe stary mit ofiary, za którym szły te „wieczne, polskie pretensje" do świata, że polski cud nie spełnił się tak, jak widzieli to profeci XIX wieku, od romantyków po księdza Cieplaka i przepowiednie z Tęgoborzy, że pozostaliśmy takimi, jakimi byliśmy, zjadaczami chleba czekającymi na anielskie skrzydła. One, także konsekwencja naszej 
schizochronii, przebijają niemal na co dzień i zaczynamy je traktować jako stały komponent naszego zbiorowego charakteru nie poszukując u siebie takich cnót, które pozwoliłyby na oswajanie Nowego, w tym tego syndromu, który nazywany jest cnotami obywatelskimi. Można zauważyć, że niekiedy wbrew sobie wciąż reinterpretujemy nasze wizje narodu wybranego dla nas samych, bo nieco krępujemy się występować z takimi uroszczeniami wobec innych zdając sobie najlepiej sprawę z naszych ułomności i słabości, a takich chyba nie brakuje. Przejawiaja się $\mathrm{w}$ wielu postaciach, a moglibyśmy je zauważyć w czasie negocjowania nowego budżetu Unii. Wielu polityków i obywateli miało pretensje do premiera Tuska, że wynegocjował tak mało.

Poszukujac nadziei w tym trudnym okresie Polacy zaczęli rekonstruować nowe nadzieje długiego trwania sięgajac także po mesjanizm, bo w takim czasie te „krótkiego” nie zaspokajały, nie były w stanie wystarczająco aktywizować, tworzone jakby od przypadku do przypadku poczynając od nadziei na drugą Japonię. Nie mogły aktywizować, rachityczne, nieumiejętnie kreowane, a społeczność nie potrafiła stworzyć własnych, spontanicznych, była zbyt bezwładna, bezwolna, a nowe elity zawodziły zainteresowane tylko sobą zapominając o sile, która ich legitymizowała. W komunizmie wszystko było proste, ludzie oddawali życie prywatne Bogu, publiczne partii ${ }^{3}$, teraz pozostał tylko Bóg, bliższy dzięki polskiemu papieżowi, ale i on stawał się coraz dalszy za sprawą hierarchów, także zagubionych w labiryntach transformacji, choć gubiących się jeszcze bardziej w labiryntach wyobrażeń zbiorowych nowego czasu. Niewiele było trzeba, by u progu transformacji polski Kościół, przynajmniej na jakiś czas, stał się prawdziwym duchowym przewodnikiem narodu, może starczyłoby kilkadziesiąt hospicjów, szkół, akcji charytatywnych, prób nacisku na rządzących w imieniu odrzuconych i oszukanych. Tego wszystkiego zabrakło i owocuje to dziś sporami z państwem, egoizmem hierarchów z jednej strony, a z drugiej bierna, tępą religijnością Polaków, nie przynoszącą integracji postaw i zachowań godnych prawdziwego narodu.

Jesteśmy dumni z manifestacji naszej wiary (bo nie samej wiary) i obnosimy się z tym wierząc, że to czyni nas wyjątkowymi, co jest jednak postacia zbiorowego spełnienia emocjonalnego i intelektualnego. $\mathrm{Z}$ niejakim zdziwieniem patrzą na to obserwatorzy z zewnątrz pytajacc, dlaczego jesteśmy tacy, jacy jesteśmy mimo tej religijności deklarowanej w niemal stu procentach, a maja na myśli te wszystkie przejawy życia zbiorowego, które świadczą o nas jak najgorzej. Wierzący i prak-

\footnotetext{
${ }^{3}$ A. Michnik, J. Tischner, J. Żakowski, Między Panem a Plebanem, Kraków 1995, s. 296.
} 
tykujący katolicy, tacy jak Polacy, sa argumentem dla innych, odchodzących od Kościoła, którzy powiadaja, że jeśli rzekomo głęboko wierzący Polacy są właśnie tacy, to oni nie chcą być jak Polacy

Niektórzy organizatorzy wyobrażeń zbiorowych, próbując przezwyciężać marazm, zaczęli przywoływać to, co rzekomo w Polakach najlepsze, trwałe, ale nie wydaje się, że możemy sobie przypisywać koherentny, stabilny „charakter narodowy”. Można tylko zgodzić się z tym, że za sprawa rytualizacji wielopokoleniowych wzorów socjalizacji zbiorowość polska cechuje się jednak tym, co widział badacz: łatwemu myśleniu życzeniowemu (co jest nie tylko polska przywara), rozbujała wyobraźnia, powierzchownym tradycjonalizmem, wybujałym indywidualizmem, zbytnim przywiązaniem do symboliki tradycji narodowej. ${ }^{4}$. Zabrakło tu heroizmu i paru innych cech, ale nie wydaje się jednak, by te, bardzo enigmatyczne, nieokreślone cechy „charakteru” Polaków, były oryginalne, właściwe tylko nam, wyjątkowe. Takie można przypisywać właściwie każdemu narodowi i narody przypisuja je sobie, a nieświadomość tego wynika z naszej nieznajomości historii innych narodów, choć czasami miewamy pretensje o to, że to inni nie znają naszej. A my, swoiście narcystyczni, nie chcemy zauważać tego, że nasza wyjątkowość nie jest tak prawdziwa, jak chcielibyśmy. Ot, choćby tak często przywoływane bohaterstwo narodowe. Trudno wyobrazić sobie taki naród, który nie przypisałby sobie tej cechy, ale nasze ponoć jest wyjątkowe i odnajdujemy dziesiątki argumentów na jego rzecz pomijając wszystko, co może kwestionować ten heroizm, a wiemy, że bez trudu moglibyśmy znaleźć równie wiele takich wydarzeń, które go demityzuja, bo obok Grunwaldów w naszej historii były Chojnice, Piławce, Batoh. Były to wizje nie klęsk, a hańby narodowej. Nie znajdziemy ich w wersjach „historii świętej”, ale sa częścią integralną tej „właściwej”.

$\mathrm{Z}$ bezradności przyjmowano przekonanie artykułowane przez niektórych polityków, że już mamy zapewnione poczesne miejsce w historii i teraźniejszości Europy dzięki choćby bitwie warszawskiej i nie chcemy zauważać, że niewiele robiliśmy i robimy, by takie miejsce utrzymać poza przypominaniem niektórych wydarzeń z przeszłości mającymi czasami charakter zwykłych uzurpacji ${ }^{5}$. Ośmieszamy się i irytujemy innych sobie i tylko sobie przypisując choćby „ocalenie” Europy w 1683 roku. Nie chcemy wiedzieć, że wojska Sobieskiego nie stanowiły nawet połowy tych, które zwyciężyły pod Wiedniem i ich rola wyglądała całkiem inaczej niż twierdzą twórcy polskiej historii heroicznej, bez skazy. Wysiłki tak zwanych elit symbolicznych skupiają się na konfirmacji

${ }^{4}$ J. Szmyd, Religijność i transcendencja, Kraków 2000, s. 282.

${ }^{5}$ A. Suchoński, Opinie o Polsce i Polakach w podręcznikach do nauczania, [w:] Kultura polityczna w Polsce. Swoi i obcy, Poznań 2005, t. IV, s. 6. 
takich wizji historii, jakie mają przekonywać przekonanych do tego, że jesteśmy wyjątkowi, predestynowani do wielkich ról, jakie rzekomo już odgrywaliśmy w przeszłości wiele razy ratując Europę, a to przed zalewem islamu, a to bolszewizmem. Sięgając bliżej, przywołując choćby Solidarność, powiada się, że w chwilach próby stać nas wyczyny godne herosów, acz wiemy także i o tym, że nie podźwigniemy większych ciężarów i nie potrafimy wyobrażać się w skórze tych herosów. Przekonywaliśmy się wielokroć co do tego, że nasze pospolite ruszenie częściej kończy się Piławcami niż Grunwaldem i mieliśmy przed sobą próbę, która była weryfikacją naszego heroizmu, a taką próba, na jaką patrzyła cała Europa, było udane organizacyjnie, ale nie sportowo Euro 2012. Samo przyznanie organizacji tak wielkiej imprezy odebrano jak sukces, ale i brzemię. W czasie pamiętnej awantury o kuratora w PZPN można było odnieść wrażenie, że rządząca $\mathrm{PO}$ chce zrzucić to brzemię i w imię „czystości” polskiej piłki nożnej zrezygnować z organizacji w aurze prawie męczeństwa. Byłoby to bardzo polskie.

Ilość i jakość potocznych rozpoznań istoty polskiej transformacji, sprzężonych z mniej lub bardziej udanymi próbami analizy przymiotów Polaków, idzie w dziesiątki, tak samo jak ilość naukowych analiz, diagnoz i terapii. Przyglądając się tym dziesiątkom opracowań można zauważyć bez trudu, że uwaga analityków jest skierowana na wielkie struktury, o których wspominaliśmy i w nich upatruje się przyczyn zmian, je się analizuje, pozostawiając na samym końcu samego kreatora - prawdziwy podmiot dziejów. Wydaje się, że w jakiejś mierze stąd biora się liczne zaskoczenia ludzi nauki zachowaniami zbiorowymi, „nieracjonalnymi” przejściami elektoratu z prawa na lewo albo odwrotnie i późniejsze tłumaczenia takich reorientacji metaforami o „zmianach preferencji wyborczych”, a o tych nie bardzo wiadomo, czym sa. Zdumiewać może, że nawet nie próbuje tłumaczyć się fenomenu powstania i trwania tej znaczącej wspólnoty, jakim jest Rodzina Radia Maryja i to chyba nie tylko z obawy przed ojcem Rydzykiem. Naszym zaś zdaniem ojciec Tadeusz, chyba nieświadomie, wykorzystał stałe pragnienia zbawienia $\mathrm{w}$ transcendencji tych, którzy zupełnie stracili nadzieje na zbawienie $\mathrm{w}$ doczesności - ludzi starszych i zupełnie wykluczonych. Wykorzystał i czyni to z premedytacja odbierając konkurentom możliwości pretendowania do pełnego „rządu dusz” wśród ludzi magicznych i mitycznych przekonując, że potrafi bardzo umiejętnie korzystać z narzędzi władzy symbolicznej, a przede wszystkim umiejętnie wykorzystywać siły nadziei zbiorowej.

Czasami w próbach wyjaśnienia, zrozumienia zjawisk i procesów bywamy całkiem bezradni zadowalając się ogólnikami, twierdzeniami, nierzadkimi u autorytetów, że polska demokracja i kapitalizm to 
konieczności dziejowe, choć czasami zauważamy z jakim dystansem przyjmuja je Polacy mityczni, zwykle bezkrytycznie wierzacy w „obiektywne" racje, słuchajacy apologetów rodzimego kapitalizmu tłumaczacych to tymi właśnie koniecznościami.W większości sa zobojętniali, apatyczni, poszukujący mocniej bijących źródeł wiary bliższej ich potrzebom zbawienia na ziemi, czyli najczęściej potrzebom przeżycia na niskich poziomach konsumpcji. Ale mimo wszystko te mityzacje powoli staja się bezdyskursywne, stają się trwałymi mitami po biernej, zbiorowej akceptacji, w jakiejś mierze wymuszanej stała rytualizacja medialna. Pojawiły się po brutalnej konfrontacji byłych elit opozycyjnych z rzeczywistościa przełomu i sa także wyrazem tego, co nazwać trzeba impotencja władzy. Znowu idealizacje zderzaja się z ponura rzeczywistością i wyrazy nieufności, powątpiewania w ich zbawcze role, wattleja także wśród inteligencji, która, ufając wierze, sądziła że pokłada zaufanie w wiedzy o mocach kapitalizmu i demokracji.

Chyba nie możemy wątpić w jakość nadziei i intencji tych, którzy przejmowali władzę z rąk komunistów, ale tylko w pierwszych miesiącach transformacji. Przejmujący władzę, inteligenccy przywódcy Solidarności, jeszcze w opozycji, widzieli Polskę jak pole wielkiego eksperymentu i budowania nowego, nieznanego dotąd w dziejach społeczeństwa zorganizowanego w „związku zawodowym” i systemie różnych samorządów, co w efekcie miało połączyć demokrację polityczna z ekonomicznym egalitaryzmem ${ }^{6}$. Nawet nie próbowali dokonywać takich eksperymentów i chyba jednak szczęściem dla nas wszystkich były wymuszenia z zewnątrz, które otrzeźwiły kwietystycznych wizjonerów nie mających doświadczeń w praktyce politycznej, nie znających reguł gospodarowania i nie czujących potrzeby odwoływania się do ekspertów. Zostali zmuszeni do obrócenia się na normalność wierząc zachodnim teoretykom, że Polska kapitalistyczna i w pełni demokratyczna ma największe szanse na skok cywilizacyjny, dużo większe niż inne, byłe kraje socjalistyczne ${ }^{7}$. Ale nie wiedzieli jak te szanse wykorzystać, bo do tego, poza wieloma innymi warunkami, trzeba kompetencji, jakich brakło, bo braknać musiało. Zabrakło także, tego tak mocno deklarowanego altruizmu i nowe elity, widząc jak zmienia się rzeczywistość, zaczęły myśleć o sobie.

Po kilku już latach okazało się, że byliśmy tylko potencjałem i zachodni analitycy mieli na uwadze nasz kapitał społeczny, ten którego nie potrafiono zagospodarować, a nie wysilano się zbytnio walcząc o władzę. Okazało się także, że byli dysydenci po przejęciu władzy stali

\footnotetext{
${ }^{6}$ L. Mażewski, Wobjęciach utopii, Torun 2001, s. 57.

${ }^{7}$ M. Zonis, D. Semler, The European Opportunity, New York 1992, s. 8.
} 
się politycznie jałowi - zauważał obserwator z zewnątrz ${ }^{8}$. Poza próbami mityzacji demokracji i kapitalizmu, które i tak nie tłumaczyły istoty przełomu ani kosztów, nie zaproponowali niczego nowego przyzwalając, by Polacy poczęli poszukiwać wzorów w przeszłości. Odkrywając taka jałowość, swoją niemoc w kreowaniu rzeczywistości, obejrzeli się na indywidualne postaci samozbawienia biorac przykład z uwłaszczających się elit postkomunistycznych w krajach byłego Związku Radzieckiego i zaczęli upodabniać się do nich. Rychło zjawiska patologiczne poczęto traktować jak normalność i tak też postrzegało je i postrzega kontestujące, ale bezradne, zagubione społeczeństwo.

Zauważajac zawłaszczanie państwa przez stare i nowe elity obywatele zaczęli oglądać się na tych, którzy dostarczą im nowych mitemów, jakie ustrukturyzuja na nowo wyobrażenia zbiorowe, przestrzenie mityczne, dostarczą im nowych, tak potrzebnych znaków tożsamości. Pojawiło się wiele propozycji ideowych, ale zdaje się, że kresem eksperymentów na pierwszym etapie transformacji okazała się Polska Partia Przyjaciół Piwa, której powodzenie jakby dookreśliło krajobraz po przełomie. Dla bacznego obserwatora, jakim jest V. Tismaneanu awanturnicy, szarlatani i rekietierzy zajęli miejsce tępych, ponurych członków nomenklatury wykorzystując społeczne zagubienie ${ }^{9}$. Ich nie interesowało to, że umierajace zbiorowe nadzieje krótkiego trwania oznaczają także brak aktywizmu społecznego, gotowości społeczeństwa do naprawdę wielkich prac w imię zbiorowego zbawienia. Zawierzyli wpierw swoim instynktom, a potem transcendencji, czyli tym „,naturalnym" siłom, jakie miały powodować zmianami, co widać było w powtarzaniu przez takich polityków, że tak właśnie musi być. Część wyborców, która poczuła się oszukana, zaczęła poszukiwać formy kontestacji i znalazła na krótki czas. Partia J. Rewińskiego nie była partia ani „oszołomów”, ani szarlatanów politycznych. Wydaje się, że aktor i satyryk chciał tylko dowieść, że każdy może dobijać się o władzę, że to swoisty postaw sukna do podziału, a z drugiej strony dowodził Polakom, jak bardzo sa zagubieni w poszukiwaniach zbawców i zdaje się, że oba cele osiagnął bez większego trudu, a osiagnąwszy powrócił do swojej profesji. Podobnie zreszta jak J. Palikot, który raczej nie musiał zdobywać kontestatorów, bo nie widać było większego wysiłku z jego strony w kampanii wyborczej 2011 roku. Byliśmy i jesteśmy zagubieni w takich poszukiwaniach po eksperymentach z wieloma „zbawcami” i teraz, zdezorientowani, zmęczeni szukamy już tylko mniejszego zła, ale zło zawsze pozostaje tylko złem.

\footnotetext{
${ }^{8}$ C. Offe, Zmieniajaca się Europa. Drogi transformacji, Kraków 1999, s. 53.

${ }^{9} \mathrm{~V}$. Tismaneanu, Wizje zbawienia, s. 36.
} 
Pytanie o istote zmiany, samej transformacji ustrojowej, sa codziennością dla polskich nauk społecznych, odpowiedzi także, ale te odpowiedzi zbyt często satysfakcjonuja tylko przedstawicieli nauki. Nie zawsze sa praktyczne, a poza tym ich głosy nie dochodzą do tych, którzy funkcjonują w kręgach własnych wyobrażeń poruszając się w przestrzeniach, których naukowcy nie są w stanie ogarnąć, a bardzo często nie starają się zrozumieć, uważając, że politycy powinni pełnymi garściami czerpać z ich analiz. Z drugiej strony, z pozoru demokratyczni, „zawodowi” politycy, nie potrafią pojać choćby tego, że choćby kapitał polityczny wymaga stałego odtwarzania, bo ten na pewno nie da się deponować. Nie czują takiej potrzeby wierząc w to, że ani miałkość argumentacji, ani zmienianie profilu politycznego nie maja przełożenia na szanse wyborcze. Wystarczy, że sa osobami publicznymi obecnymi w mediach i to już promuje ich w oczach Polaka mitycznego. Maja swoje racje potwierdzane tym, że wciąż znajdują się na scenie, może czasami mniej doceniani niż celebryci, ale wciąż tam sa.

„Normalni” politycy, których nie mamy zbyt wielu, nie chca natomiast zauważać także tego, że wybory wygrane nawet w $30 \%$ nie pozwalają na tworzenie iluzji, że naród oddał władzę wybrańcom, ani tego, że teoretycy demokracji ostrzegają przypominając, iż w demokracji nie ma takiej większości, jaka byłaby przepustką do wszechwładzy, a czasami idą dalej, zauważając, czym grożą nadużycia w sferze prawa, powszechne w naszej praktyce legislacyjnej. Polscy politycy, zauroczeni możliwością kreowania przestrzeni normatywnych, tworzący setki ustaw dla samej radości tworzenia, winni pamiętać o uwadze G. Sartoriego: „Kiedy rządy prawa sprowadzają się do rządów prawodawcy, to $\mathrm{w}$ zasadzie otwarta jest droga do najbardziej wyrafinowanego ucisku, do ucisku w imieniu prawa"10. Znaleźli się w swoim kręgu mitycznym ze swoimi wizjami zbawienia, zwodzeni przeświadczeniami, że produkcja norm prawnych świadczy o ich aktywizmie, a w miarę zdrowy rozum podpowiada, że to właśnie najmniejsza ilość naprawdę dobrych aktów prawnych świadczy jak najlepiej o legislatywie, poświadcza jej sprawność i poziom kompetencji, zapobiega chaosowi działań i przekłada się na sprawność aparatu państwowego. To także jeden ze specyficznie polskich mitów kultywowanych i przez media i ludzi nauki. Można poddawać go demityzacji kwantyfikując choćby ilość ustawowych dziwolagów, które miast poprawiać, psuja prawo, życie nas wszystkich. Ale tego się nie robi informując obywateli, że w szufladach, ,zamrażarkach" czekają setki nowych ustaw. To, że o inicjatywności tak rzutkich polityków przesądza ilość projektów ustaw ma poprawiać nasze samopoczucie i wydaje się, że niektórym konsumentom polityki poprawia.

${ }^{10}$ G. Sartori, Teoria demokracji, Warszawa 1994, s. 402. 
Licytując się na ilość ustaw i ich projektów nasi politycy nader często poświadczaja, iż są i niesprawni i niekompetentni, a piekło tych legislacyjnych, dobrych intencji jest tylko piekłem albo, jak wolimy, polskim piekiełkiem. Co gorsza, oni instytucjonalizują nieodpowiedzialność - zauważaja teoretycy, a ona owocuje tym, że przysłaniając swoją niekompetencję pozorami działań, personalnych choćby, promują na wysokie stanowiska ludzi podobnych sobie i mamy do czynienia ze spiralą nieodpowiedzialności, całkiem nieźle opłacanej. Czynią to z pomoca partii politycznych nie mających określonego charakteru, pełnych ludzi skłonnych do wspierania każdej partii mającej szansę na partycypację we władzy w imię korzyści własnych i swojego zaplecza, do czego od kilkunastu lat przekonuje PSL. Łamiąc zasady czują bezkarność wynikająca po części z tego, że społeczność jest zwyczajna nepotyzmu, korupcji i akceptuje je jako integralne części demokracji nie pytając o to, jakiej demokracji. Obywatele poprzestają na pesymistycznych sądach potwierdzanych przez niektórych publicystów prasowych i telewizyjnych, ale na swój sposób sugerowany przez dziennikarzy. Ci zwykle piętnuja głównie patologie indywidualne nie oskarżajacc systemu. Tak zwane „afery korupcyjne" związane z nazwiskami ministra S. Nowaka czy rzecznika PiS A. Hoffmana pełnią rolę listka mającego przysłaniać ponura rzeczywistość „państwa prawa” i to wcale nie figowego, a prędzej wierzbowego. Raczej nie interesuja nas formy dystrybucji państwowych, czyli, rzekomo naszych, pieniędzy, bo nawet cieszymy się z tego, że będziemy mieć Pendolino i autostrady, choć tam nikną miliardy.

W poniższych uwagach chcemy skupić się na zbliżeniu takich przestrzeni mitycznych, w jakich sytuujemy się wszyscy, na próbie odnalezienia relacji między Polakiem mitycznym a racjonalnym, choć nie będzie to wywód pełny, choćby z tego względu, że próby rozpoznania przestrzeni mitycznych podejmowaliśmy gdzie indziej. Ale nie tylko na nich, bo wyobrażenia zbiorowe, światy mityczne Polaków to ugory, na których nikt nie chce siać ani zbierać, choć te ugory są tak żyzne. Gorzej, bo często sama próba wejścia na taki ugór kończy się niechęcią do jej ponowienia, a mamy tu na myśli przede wszystkim ludzi nauki, nie przekonanych do tego, że to ma sens, nieskorych do zadawania pytań, niekiedy oczywistych, ale wymagających ogromnego wysiłku w próbach odpowiedzi. Tu chcemy tylko zasugerować potrzebę uwzględniania istnienia czynników, które pomogą nam w wyjaśnianiu i kreowaniu świata wyobrażeń zbiorowych Polaków naszego czasu.

Nie zadowalają nas bowiem nawet takie próby wyjaśnienia, z którymi się w części zgadzamy, ale które w pełni satysfakcjonować nie moga. Takie choćby, jak tłumaczenie przegranej L. Wałęsy w wyborach pre- 
zydenckich zawiedzeniem społecznych nadziei ${ }^{11}$. Zgadzamy się z tym, że były to zawiedzione nadzieje, ale autorka takiej sugestii nie starała się zbliżyć istoty nadziei zbiorowej i dla niej nadzieja jest tylko pojemną metafora, a stać się może, a nawet powinna, narzędziem wyjaśniania dzięki analizie proponowanej przez filozofię nadziei, a także dzięki badaniom socjologów mogących mierzyć poziomy oczekiwań, aspiracji i zaspokojenia materialnego i czyniących to z dobrym skutkiem. Wyjaśnianie ignotum per ignotum pozostawia tylko poczucie niedosytu. Podobnie jest z oczekiwaniami społecznymi, o których oczywiście najwięcej wiedzą dziennikarze, w dużej mierze kreujący te oczekiwania, a one sa zarodami nadziei i nie można ich oddawać dziennikarzom, choć wielu z nich z pewnością zasługuje na taka dzierżawę.

Starajac się zbliżyć tak ciężko uchwytne determinanty postaw i zachowań jednostek i zbiorowości przyjęliśmy o wiele większe znaczenie władzy symbolicznej, która jest postacią władzy nad wyobrażeniami zbiorowymi społeczności, tożsamą z mocą ich kreowania, a raczej korygowania, bo takie wyobrażenia nie dają się łatwo wykorzenić ani korzenić, choć jest to możliwe w dłuższych okresach czasu. Dla jednego z badaczy władza symboliczna wywodzi się z działalności zmierzającej do produkowania, przekazywania i odbierania form symbolicznych będacych nośnikami znaczenia ${ }^{12}$. Poznanie jej istoty jest tożsame $\mathrm{z}$ koniecznościa pogłębionych systematycznych badań nad kulturą symboliczna i powinniśmy zdawać sobie sprawę z tego, że ta kultura jest dla społeczności formą utrzymywania tożsamości - uważał D. Bell i to zdaje się wystarczać do naszych rozważań ${ }^{13}$. I zdaje się, że podobne przekonania ludzi nauki przełożyły się na praktykę amerykańską, natomiast nie jesteśmy przekonani, by polscy politycy rozumieli taką konieczność, bo mimo wszystko zbyt często kultura kojarzy się im z wysoką albo z ludową i raczej nie pojmują tego, że jej najważniejszymi komponentami sa, szeroko rozumiane, kultura symboliczna i normatywna.

Tacy politycy raczej nie pojmują tego, że dysponujący władzą symboliczną mają możliwość kreowania i rytualizacji nowych mitów i czasami nie korzystaja z niej w ogóle albo próbują korzystać tak, że działają na własną niekorzyść, nie zdając sobie do końca sprawy z istoty, mocy tej władzy. Bodaj nie zdają sobie także sprawy z tego przedstawiciele „czwartej władzy”, pełniący jakby role regentów w królestwie symboli, czasami tylko zadziwiani swoją wszechmoca, jak choćby dzi-

${ }^{11}$ J. Janicka, Obraz transformacji polskiej i relacji polsko-niemieckich $w$ prasie niemieckiej w latach 1980-1998, Torun 2002, s. 83.

12 J. B. Thompson, Media i nowoczesność. Społeczna teoria mediów, Wrocław 2001, s. 24.

${ }^{13}$ D. Bell, The Cultural Contradiction of Capitalism, London 1979, s. 36. 
siaj, fascynujący się postaciami public relations, które nie są tożsame z kreacją wyobrażeń zbiorowych, a nader często pełnia role wirusów niszczacych je beztrosko, skutecznie, zwłaszcza w przypadku systemów wartości. Powinni zdawać sobie sprawę z tego, że symbole są tylko tworzywem w kreacji konstruktów mitycznych będących istotą kultury symbolicznej, a pożądanych przez społeczności i jednostki. Winni także wiedzieć o tym, że posiadaną władzę symboliczną trzeba sprawować z pietyzmem nie mniejszym niż ta właściwa, a takie jej sprawowanie oznacza konieczność stałego przekształcania światów mitycznych, ciagłych rewitalizacji, które i tak dokonuja się spontanicznie, ale spontaniczna rewitalizacja może oznaczać zagrożenie dla władzy politycznej, dla spoistości społecznej.

Tam, w przestrzeniach mitycznych, mieszczą się ogromne pokłady nadziei i strachów zbiorowych. Przyglądając się historii polskiej po roku 1989 zauważymy bez trudu, jak ogromne sa jej rezerwuary po stronie podaży i popytu mimo falowania po obu stronach. To, zwykle na marginesach, zauważali niemal wszyscy analitycy konstatując automatycznie, że „nadzieje nie tylko na wolność, ale i na dobre życie były powszechne w pierwszych latach transformacji" ${ }^{14}$. Zwłaszcza po stronie popytu, bo Polacy nie mieli i nie maja elementarnej wiedzy o mechanizmach polityki ani nie maja świadomości wyzwań, jakim muszą sprostać $\mathrm{w}$ tych nowych warunkach, nie racjonalizują swoich oczekiwań, żyją w kręgach mitów, niekiedy z musu rewitalizowanych w małych zbiorowościach. A mitem generującym postawy i zachowania jest rytualizowany w komunizmie i po nim mit o omnipotencji władzy. Stąd nadzieje kreowane przez posiadających ja sa przyjmowane bez racjonalizacji, przynajmniej w początkach, co obserwowaliśmy przy intronizacji ekip Marcinkiewicza, Kaczyńskiego, Tuska i zapewne będziemy to obserwować jeszcze wiele razy uważając, że jest to część demokratycznego spektaklu. Obezwładnieni mitem omnipotencji nie pytamy o kompetencje tej władzy, o prawdziwe programy, a odpowiedzi mogłyby być tak proste.

$\mathrm{Z}$ przekonaniem, że pozostając $\mathrm{w}$ kręgach wspólnych wierzeń nowe ekipy rządzące, mniej lub bardziej umiejętnie, stale rewitalizuja te same nadzieje na zbawienie przez kapitalizm i demokrację i choć umierały one już wiele razy, to wyborcy wciąż zawierzają takim samym obietnicom i sugestia, że jest to racjonalne, zdaje się zwykłym nadużyciem. To prezentuje się jak czysta emanacja wiary, nie wiedzy, ale wiary, która ma swoje granice. Nie znaczy to, że nie powinniśmy domagać

${ }^{14}$ M. Jarosz, Dysfunkcje procesu prywatyzacji, [w:] Kondycja moralna społeczeństwa polskiego, red. J. Marjański, Kraków 2002, s. 260. 
się od polityków konkretyzacji wizji wobec wyborców, wyznawcy religii także przecież domagają się potwierdzeń wiary od Boga. Ale, choć nie jest to obrona polityków, dla nich takie zachowania byłyby wręcz samobójcze wobec człowieka nie do końca racjonalnego. Wyobraźmy sobie, że polityk prezentuje w mediach prawdziwy program, czyli konkretne cele i środki przy pomocy wielu danych stara się dowieść, iż osiagnięcie takiego przyrostu PKB jest możliwe. Być może do końca takiej prezentacji wytrzymałoby iluś tam ekonomistów, natomiast zwykły odbiorca uznałby tak „racjonalnego” polityka za zwykłego nudziarza i zapewne wybrałby tego, który zaprezentuje mu jakaśs mglista, niekonkretną wizję dobrobytu i bezpieczeństwa, będzie po wielokroć deklarował, że zrobi wszystko, by zrealizować jego marzenia o wolności, równości, sprawiedliwości, nie wspominajac ni słowem o tym, jak to zrobi i czy jest to możliwe.

Tak racjonalnym politykiem okazywał się swego czasu wicepremier L. Balcerowicz, zdajacy się zupełnie nie rozumieć człowieka wiary, jego nadziei, a Polacy początku zmian systemowych mieli przeogromne nadzieje nie tylko na wolność, ale i dobrobyt tu i teraz. Te nadzieje, które kumulowały się w okresie tego „postu” między 1981 a 1989 rokiem, a które wybuchły w polskim „karnawale”, były niezwykle silne, ale Balcerowicz tego nie rozumiał, chyba był zbyt „racjonalny”. Stał się dla wielu synonimem zła dokonując takich właśnie konkretyzacji reklamujacc swoje reformy w mediach. Dotrzymał obietnicy zapełnienia pustych półek sklepowych, ale nie tej, wedle której za rok Polacy mieli odczuć radykalna poprawę warunków życia. Optymizm płynący jeszcze z euforii stworzył nadzieję krótkiego trwania, która, jak feniks, spłonęła w locie w ciagu kilku miesięcy, a sam Balcerowicz stał się hipostazą zła dla milionów i taką jeszcze czas jakiś pozostanie.

Zdaniem zachodnich teoretyków ten właśnie krótkotrwały optymizm, będący emanacja nadziei, te oczekiwania na bezproblemowa zmianę polityczną rzekomo przesądziły o polskim zaufaniu w demokra$\mathrm{cję}^{15}$. Tu widzimy klasyczny sąd opierany o mityzacje form demokracji, o jakich wspominaliśmy wyżej i zarazem wiarę $\mathrm{w}$ to, że taki koagulat mitów można na trwałe wszczepić w tak krótkim czasie. Naszym zdaniem polskie zaufanie $\mathrm{w}$ demokrację $\mathrm{u}$ progu transformacji miało zupełnie inne korzenie i jeśli przyglądamy się nie formom, a treściom demokracji, to, nie wspominając o mitach II Rzeczypospolitej, możemy zauważyć te stałe rytualizacje treści, jakie miały miejsce w polskim „komunizmie”. Przez dziesiątki lat byliśmy atakowani ideami prawie

${ }_{15}$ P.G. Lewis, Democracy and its Future in Eastern Europe, [w:] Prospects for Democracy, London 1994, s. 297. 
doskonałej formy demokracji, czyli demokracji socjalistycznej, pełnej haseł wolności, równości i sprawiedliwości. Jej rytualizacja rodziła tęsknoty za prawdziwa realizacją tych wartości, a taką zdawała się ta forma, jaka kojarzyła się z bogatym i demokratycznym inaczej Zachodem.

Nieustannie powtarzano, że tylko socjalizm gwarantuje wolność, równość (ekonomiczna) i sprawiedliwość ludowa obudowując to teoriami demokracji socjalistycznej, rzekomo o wiele doskonalszej od kapitalistycznej, bo zapewniającej realną równość ekonomiczną o której wiemy, że była to równość w biedzie. Ale taka rytualizacja odegrała swoje niebagatelne role, zarówno w adaptacji nowych form demokracji, jak i egalitaryzmie transformacyjnym, chociaż mówiono, że demokracja socjalistyczna tak przypomina krzesło, jak krzesło elektryczne. W niemal pełnej dekadzie lat 80. nadzieje na zbawienie przez demokrację rosły proporcjonalnie do niedostatków życia codziennego, a taka mieszanina stawała się wybuchowa-zauważał T. G. Ash ${ }^{16}$. Nie wiemy jak postrzegali ją ci, którzy postanowili zrzec się władzy w przełomowym 1989 roku i czy determinanta główną takiej abdykacji było uświadomienie sobie, że te wszystkie problemy ich przerastaja. Ich rezerwuary nadziei na trwanie wyczerpały się, mieli ją za to ci, którzy dochodzili do władzy.

W roku 1989 czekał nas ogromny przeskok w inne światy, w tym $\mathrm{w}$ inne światy mityczne wciąż pozostające poza refleksją badaczy. Jego nagłość wzmacniały wszystkie niedostatki „straconej dekady”, kiedy stykaliśmy się z prawdziwą biedą i wiązanym z nią poniżeniem na skalę dotąd nieznaną. Nie wydaje się, byśmy określili się jako część Zachodu po pierwszej wizycie papieża, jak widział to amerykański autor ${ }^{17}$. To były tylko tęsknoty, „wierzenia projektujące”, jakie kumulowały się aż do roku 1989 w różnych formach, bo nasz stosunek do Zachodu cechowała niezwykła ambiwalencja. W samych poczatkach Nowego pojawiły się polskie wizje zbawienia i $\mathrm{w}$ tym przypadku karnawał poprzedził najbardziej postny z polskich postów - postkomunizm ${ }^{18}$. Wizje nagłego zbawienia przez demokrację i kapitalizm tożsame z Zachodem, jakie przywoływali politycy pierwszego i drugiego roku transformacji zostały zastapione tymi, które wyjaśniały niedostatki okresu transformacji falsyfikujące niekompetencje, brak altruizmu nowych elit, ale uznano to za szkodliwe miazmaty Zachodu. Wielkie grupy społeczne poczęły uznawać, iż elity zaprzedały się Zachodowi porozumiewając się z wielkim kapitałem, umożliwiając złodziejską prywatyzację, wyprzedaż majątku narodowego obcym. Nie były to tak puste argumenty jak przekonują niektórzy beneficjenci systemu. Widzimy dziś jak te elity maskuja

${ }_{16}$ T.G. Ash, The Polish Revolution. Solidarity, New York 1999, s. 194.

${ }^{17}$ D. Dayan, G. Katz, Media Events. The Live Broadcasting of History, Cambridge 1994.

${ }^{18}$ Z. Bauman, Etyka ponowoczesna, Warszawa 1996, s. 334. 
intencje, tworzą sztafaże argumentami choćby o modernizacji przy pomocy inwestycji zagranicznych przekonując wielu spośród tych, którzy raczej nigdy nie zetkną się ze słowami N. Klein: „Ściagając kapitał rządy biednych krajów mają nadzieję na miejsca pracy, nowe technologie (...) Kraje te wystawiają na aukcję własnych obywateli prześcigając się $\mathrm{w}$ minimalizacji zarobków, rezygnując z podatków. Walka z nędzą rodzi jeszcze większą nędzę"19. Nie jesteśmy krajem aż tak biednym jak wiele innych, ale w mitach polskich takie zabiegi sił zewnętrznych znalazły swoje miejsce.

Upadek wiary w rzeczywiste zbawienie w doczesności zaowocował zbiorowymi neurozami i nawrotem do wiary w wartości, wiary w transcendencję, nawrotem jak najbardziej naturalnym ${ }^{20}$. Takie nawroty bywaja niekiedy pochopnie oceniane jako nowy obskurantyzm, ale nie przez tych, którzy są ludźmi czystej wiary i poruszaja się w takich samych przestrzeniach mitycznych. Odnajdują się w nich ci, którzy już stracili wiarę $\mathrm{w}$ zbawienie $\mathrm{w}$ doczesności i nie potrafią jej odzyskiwać, czyli przeważnie wykluczeni ludzie starsi, słabo wykształceni. Oni tworzą tą polską egzotykę, o której na zachodzie krąży wiele powierzchownych i nawet zabawnych opinii, a taką spotkaliśmy w poważnej próbie syntezy: „jeśli chcesz (w Polsce) by twój syn jeździł mercedesem, nie posyłaj go na medycynę, ale do seminarium duchownego"21.

Wielkie nadzieje na rychłe zbawienie materialne zostały zniszczone beztrosko, z niefrasobliwością kapryśnego dziecka. Można było choć próbować czynić je nadziejami długiego trwania, bo ich rezerwuary były ogromne. Raz jeszcze powtarzamy, że wraz z nimi zniszczono niepojęty aktywizm społeczny, wiarę w siebie, jaka mogła przełożyć się na zbiorowe działania, na poświęcenia, na jakie stać wiele społeczeństw w odpowiednich warunkach. Jesteśmy przekonani, że to było możliwe w takim czasie. Posłużymy się tu analogia, która zdać się może nietrafna, ale według nas jest potwierdzeniem, że zbiorowe nadzieje można kierunkować i moderować do czasu ich wyczerpania. Biorac przykład z towarzyszy radzieckich, którzy mieli to za soba, polscy wykorzystali je w społeczności wiary równie wielkiej, jak nędza w końcu lat 40. i początku 50. Obiecując szybkie zbawienie w doczesności, tworząc wizje szczęśliwości komunistycznej wykorzystali do maksimum zapał, zwłaszcza młodych, i na tym, ekstensywnym etapie rozwoju „nowej gospodarki”, chwytliwymi hasłami zachęcili setki tysięcy Polaków do niemal niewolniczej pracy w imię promiennego jutra. Ten eksperyment

\footnotetext{
${ }^{19}$ N. Klein, No logo, Warszawa 2004, s. 224.

${ }^{20}$ R. Kirk, The Politics of Prudence, New York 1994, s. 209.

${ }^{21}$ N.J. Demerath, Crossing the God. World Religions and Worldly Politics, London 2001, s. 41.
} 
zakończył się powodzeniem, jakie po czasie okazało się klęską i niezwykłą analizą tej zwycięskiej klęski okazał się film Wajdy „Człowiek z marmuru”. Majacc na uwadze tamte próby można było podjać nowe wystrzegając się tamtych błędów i orientując się raczej na tych, którzy obiecywali „krew, pot i łzy”.

Wydaje się, że elity nie zdawały sobie sprawy z tego, że nadzieje powinny zostać przetransformowane na postawy i zachowania wszystkich, łącznie z nimi. A w transformacji niezbędne okazują się takie cnoty i dyspozycje moralne, jak: łatwość adaptacji, cierpliwość, rozwaga, dociekliwość, umiejętność wybory między preferencjami, tolerancja wobec nierówności ${ }^{22}$. Zdawać się mogło, że w początku zatriumfowała moralność opierana o mityczna „,społeczną naukę Kościoła”, o której nie wiadomo czym jest, ale wnet okazało się, że takie sztafaże są bliskie świętokradztwu, bo elity zaczęły przekonywać społeczeństwo, że nie dysponuja ani jedna z takich cnót transformacyjnych, choć na dobra sprawę to winny być kultywowane na co dzień cnoty polityków.

Takie rekonstrukcje wyobrażeń zbiorowych były w takim czasie niezbędne, by nie doprowadziły do zbyt szybkiej atrofii wiary człowieka zbiorowego w zbawienie przez demokrację i kapitalizm, a wiara początku lat 90. sięgała prawdziwych Himalajów. Poza rytualizacją argumentów o konieczności wejścia w to, co jest normą dla rozwiniętych społeczeństw, pojawił się kuriozalny mit przypadkowego społeczeństwa z wyraźnym wskazaniem winnych, a poza nim spontaniczne, oddolne mityzacje tylko częściowo obwiniające elity, ale mityzacje dysfunkcjonalne, które ścierały się z kultywowanymi i rytualizowanymi przez rzadzących. Nie zrodziły się z niczego, bo wielu analityków konstatowało, że humanitarne i etosowe elity przełomu szybko zaczęły ewoluować od elity moralności do elity interesu, a o wiele wcześniej zauważali to obywatele poszukujący winnych zmian na gorsze i odnajdujących bez trudu $^{23}$. Można to interpretować bardziej zdecydowanie sugerując, iż tak szybka i radykalna reorientacja pozwala zakwestionować zarówno uprzedni humanitaryzm, jak i owa „moralność”. Mimetyzm i bierność sprawiły, że polskie partie, stworzone głównie przez te elity, stały się formalistyczne, pochłania je samoobsługa, instytucjonalizacja i utrwalanie swojego statusu. Fetyszyzują swoje zasady, hasła i pojęcia, kostnieja ${ }^{24}$. Nie można ich podejrzewać o chęć zbawiania społeczności, a przecież nietrudno zauważyć, że te elity zbawiaja siebie zawłaszczając wspólne dobro i tu wykazują się całkiem sporymi umiejętnościami.

${ }^{22}$ C. Offe, Zmieniajaca się Europa, Warszawa 1999, s. 57.

${ }^{23}$ I. Wasilewski, Moralność elit politycznych, [w:] Kondycja moralna społeczeństwa polskiego, red. J. Mariański, Kraków 2002, s. 190.

${ }^{24}$ M. Karwat, Miernoty i figuranci, Toruń 1999, s. 7. 
Moga to czynić nie obawiając się reakcji społeczeństwa wiary, a nietrudno zauważyć, iż wiarę w niedoskonałą demokrację i kulawy kapitalizm potwierdzają nawet intelektualiści.

Otwarcie pisze się i mówi o tym, że elity skwapliwie korzystaja z tzw. „renty transformacyjnej” - korupcji i klientyzmu, a korzystając i zbawiajac siebie, samozbawione, bez przekonania rytualizuja obietnice zbawienia innych nie mając zamiaru ich spełniać. Zdają się być pewne, że rezerwuary nadziei zbiorowych w czasie długiego trwania tworza obszar przyzwolenia na arbitralność i niestabilność reguł prawno-instytucjonalnych. Wszelkie patologie traktowane sa jak naturalne koszty transformacji i tego nawet nie próbuja kwestionować wspomniane elity intelektualne, te zwłaszcza, które także są beneficjentami transformacji, a same patologie pozostaja nimi stając się zwyczajami tolerowanymi z musu. W jakiejś mierze bierność społeczeństwa to właśnie dzieło tych elit, które Z. Brzeziński już dawno temu widział je jako pozbawione wizji nowoczesnego społeczeństwa ${ }^{25}$. Po czasie możemy powiedzieć, że te elity nie mają żadnych wizji, sa nastawione na trwanie z ponowoczesnym złudzeniem zbawienia. Intelektualiści maja sobie do zarzucenia równie wiele, jak politycy, a przede wszystkim serwilizm, bo sprzedajności nie da się ukryć.

Wedle M. Karwata jest jeszcze gorzej, bo elity zanurzają się w magię, głębią się w na nowo „zaczarowanym” świecie biorąc życzenia i dążenia za rzeczywistość ${ }^{26}$. Inni badacze, nie dokonując rozróżnień między elitami politycznymi, gospodarczymi i społecznymi, oskarżaja je o niszczenie systemu wartości, o to, że za ich sprawą załamało się poczucie wspólnotowości uniemożliwiając solidarną obronę interesów wielkich grup społecznych, a nie tylko partykularnych ${ }^{27}$. Próbując komentować takie stanowiska bywamy zwykle bezradni. Takie oceny są zasadne, bo elity trwania sa tak inertne, takie bez wyrazu, że nolens volens niszcza nadzieje na zbawienie przez nie Polski, oczywiście w immanencji. Słabość, nijakość tych elit sprawia, że to, co psychologowie nazywają orientacja kooperatywną ustępuje miejsca orientacji wycofania do małych wspólnot albo poszukiwania miejsca poza granicami kraju, czym nikt się nie przejmuje, mimo iż są to wielkie problemy, które trzeba rozwiązywać teraz, kiedy ponad dwa miliony młodych ludzi uciekły z kraju i nie ma zamiaru wracać. Wydaje się, że poszukujacy spełnienia obywatele, nie tylko młodzi, będą częściej i chętniej patrzyli w stronę Europy,

${ }^{25}$ Z. Brzeziński, Polska scena obrotowa, [w:] Wizje Polski, red. A. Targowski, Warszawa 1995, s. 27.

${ }^{26}$ M. Karwat, Miernoty i..., s. 51.

${ }^{27}$ A. Szahaj, Niesprawiedliwość a demoralizacja, [w:] Demokracja spektaklu, red. P. Żuk, Warszawa 2004, s. 39. 
choć teraz kwestionuja wstapienie do strefy euro. A powtórzyć trzeba, że nie buduja już tożsamości na klasycznej opozycji ja-obcy. Oznaczać to będzie słabnięcie mitów narodowych i ono już następuje, co widząc, politycy próbuja je rewitalizować kuriozalną „polityką historyczna”, która budzi prawdziwą grozę nie tylko profesjonalnych historyków.

Politycy naszego czasu wyrządzają wiele szkód, chyba więcej niż im się zarzuca. Niekompetencja sprawia, że nie są w stanie kontrolować i zmieniać gospodarki i rozwiązywać newralgicznych problemów społecznych, że akceptowana i moderowana przez nie atrofia norm sprawia, że instytucjom i grupom społecznym brak regulatorów i drogowskazów, a od lat upowszechnia się przekonanie, że wielu sytuacji nie regulują żadne normy, nie obowiązują żadne reguły ${ }^{28}$. A jeśli wszyscy z założenia gotowi sa grać nie fair, to demoralizacja osiaga swoje apogea i wygrywa ten, kto jest gotów najszybciej i najradykalniej łamać reguły gry ${ }^{29}$. Łamiąc je, politycy i nie tylko oni, zwykle ubierając się w szaty obrońców najświętszych dla wyznawców wartości, odwołuja się do emocji tak zwanych „moralnych większości”, które są spotykane w każdej społeczności, ale - dodawał sarkastycznie badacz mający na uwadze amerykańskie praktyki - jeśli ta „moralna większość” zdobywa przewagę lepiej zacznij się modlićc ${ }^{30}$.

Broniac siebie politycy przegranych ugrupowań spontanicznie dostarczali mitemów i zrytualizowali łatwo krzewiące się mity o złodziejskiej prywatyzacji, wyprzedaży majątku narodowego obcym, o wszelkiego rodzaju „układach” spowalniających rozwój, oczywiście układach, w które nie byli uwikłani. Owe układy pojawiały się i były akceptowane w przestrzeniach mitycznych nie tylko tych grup, które poczuły się krzywdzone nowym systemem i rytualizacja sprawiła, że „układy” stały się mitem. Każdy z takich mitów dawał się wyjaśniać przy pomocy „racjonalnych przesłanek”. Nietrudno było uwierzyć w mityzacje „złodziejskie", bo niemal każdy Polak zalazł jakieś jego potwierdzenie albo podejrzenie, choć gorzej było ze sprowadzeniem na ziemie mitu „układu" mimo tak upartej rytualizacji w czasach rządów PiS. Być może dlatego, że brakło mu symboli, ale także dlatego, że jakaśs przeszkodą było i to, że niemal każdy z nas jest wkomponowany w jakiś „układ” nie majacc czasem pewności co do tego, czy jest on zgodny z prawem, normami życia społecznego. Kreatorzy mitów winni rozumieć taką konieczność,

\footnotetext{
${ }^{28}$ A. Kaider, Spojrzenie na przemiany ustrojowe $w$ Polsce $w$ latach 1989-1997, [w:] Imponderabilia wielkiej zmiany, red. P. Sztompka, Kraków 1999, s. 130.

${ }^{29}$ A. Szahaj, Niesprawiedliwość a demoralizacja, s. 39.

${ }^{30}$ J.K. Hadden, Ch.E. Swann, Prime Time Preachers. The Rising Power of Teleevangelicism, Reading Massachusetes 1981, s. 145.
} 
o jakiej mówił D. Miller - każda rewelacja musi być mediowana przez symbole i formy, w jakich jednostka może je zaakceptować ${ }^{31}$.

Warunkiem nieodzownym skutecznej mediacji zdaje się odwołanie do mitów fundamentalnych, zwanych niekiedy założycielskimi dla społeczności. Takie mediowanie musi być celowe, przemyślane, ale zwykle bywa spontaniczne, czasami trafione, czasami nie, jak choćby bywało z odwoływaniem się do polskiej solidarności. Trafione przez to, że mediujący poruszają się w takiej samej przestrzeni mitycznej; odwołując się do wartości wywołujących takie same reakcje afektywne. Deklarujacy walkę $\mathrm{z}$ korupcja polityk prawie zawsze znajdzie zbieżność z odbiorcami. Nie można zapominać także o tym, że mity sa cały czas konfrontowane, weryfikowane z naszą racjonalnością i jeśli ogląd mityczny jest rażąco sprzeczny z „racjonalnym”, jeśli posiadana przez nas wiedza kłóci się z przesłaniem mitycznym, wtedy pewnie zostanie odrzucony.

Wielkie mity zbawcze kapitalizmu i demokracji rytualizowano spontanicznie na długo przed wybuchem Solidarności. Obrazy Zachodu były mityzowane, a symbole bogactwa stawały się prawie fetyszami, jak choćby Coca-Cola, czy nawet puszki z zachodnim piwem, co przypominamy sobie z rozbawieniem, a w co nie wierza młodzi. Potwierdzała je siła magicznej waluty-dolara, którą można było i nie można było mieć. Rytualizacja trwała tak długo, że wyższość demokracji i kapitalizmu przyjmowano jako racje „obiektywne”. Tu przywołajmy obserwację psychologa o tym, że zwykli ludzie łatwo dają się zbić z tropu „obiektywizmem” różnych racji i nawet jeśli taki „obiektywizm” kłóci się z naszymi odczuciami, to sa one tłumione i zbywane jako nieważne, choć sa ważniejsze niż sądzimy ${ }^{32}$. Te „obiektywne” wartości przyjęli z ochotą ci, którzy skorzystali, stali się beneficjentami zmian, natomiast przegrani, choć nie artykułują tego głośno, odrzucili i kapitalizm i polska formę demokracji, co widać w uczestnictwie w wyborach i opiniach o niej. Mimetyzm zauważalny $\mathrm{w}$ pierwszych latach transformacji przestał wystarczać.

Nawet ludziom nauki niełatwo definiować wielki koagulat mitów demokracji obejmujących nie tylko treści, ale i formy, co staraliśmy się zbliżyć wyżej. Zwracali na to uwagę niektórzy teoretycy traktujący z dystansem mocno utwierdzany i rytualizowany mit racjonalnego wyborcy. „Duża część obywateli posiada niewielką wiedzę o kwestiach poddawanych pod głosowanie - zauważała z ogromną ostrożnością badaczka - i w rezultacie zastępuje je wiara" ${ }^{33}$. A jak demonstruje się ta wiara?

${ }^{31}$ D. Miller, American Iconology, New Haven 1993, s. 47.

${ }^{32}$ J. Kozielecki, Transgresyjne koncepcje człowieka, Warszawa 1987, s. 10.

${ }^{33}$ M. Marczewska-Rytko, Demokracja bezpośrednia, Lublin 2001, s. 107. 
To pytanie wręcz niezbędne w kwestionariuszach pytań badawczych ludzi nauki, a jednak nieobecne. Podobnie, bo z wiarą prezentują się wybory przedstawicieli do organów demokratycznych, w których wybieramy tylko sztuczny wizerunek kreowany przez media, przekonując się po jakimś czasie, że dokonaliśmy złego wyboru, że znowu powodowaliśmy się wiara, że zawierzyliśmy mitom i będziemy jednak przekonywać się długo, bo rezerwuary wiary są niewyczerpane. Wydaje się, że w Polsce naszego czasu zanikła wiara w to, że demokracja jest skutecznym remedium na nasze codzienne bolączki. Tylko część społeczności została przekonana do tego, że rzeczywiście przynosi wiele dobrodziejstw, że jest ramami zbawienia. A wiemy o tym, że o braku tożsamości między ideologią a jednostką mogą przesądzić bieżące, nawet niewielkie korzyści odnoszone przez wyznawcę - ten swoisty pragmatyzm ludzi, którzy swoją identyfikację ideową opierają na imponderabiliach, nie mitycznych generaliach, a owe imponderabilia to pieniądze, dobra, gwarancje bezpieczeństwa ${ }^{34}$. W dobie kryzysu zaś możemy utożsamiać demokrację z biurokratyzacja, partiokracja, fiskalizmem i powinniśmy zaczać zastanawiać się nad tym, czy tak powinna wyglądać „władza ludu”.

Być może, próbując rozpoznawać istotę takich wyborów, winniśmy dokonywać zabiegów porządkujących, podobnych do tych, jakich używał prowokacyjny ideolog kojarzony z New Age, dla którego na poziomie prenaukowym znajduje się człowiek archaiczny i magiczny ${ }^{35}$. Wedle niego taki człowiek nawet nie próbuje analizować rzeczywistości przejmując od innych gotowe konstrukcje mityczne i tylko do pewnego stopnia je interpretuje, zawierzając, zwykle bezkrytycznie, różnym autorytetom. Jest zewnątrzsterowny i zarazem konsekwentny w obronie swojego świata mitycznego, jaki jest fundamentem jego rozmytej tożsamości. Nie pozwoli go sobie odebrać, bo byłoby to odebraniem części siebie. Można go przekonywać do określonych zachowań nie przy pomocy argumentów racjonalnych, ale nowych albo rewitalizowanych mitów czy tylko mitemów (składowych mitów), czego czasami nie chce zrozumieć wielu polityków, ale czasami inni politycy wydają się rozumieć to $\mathrm{w}$ miare dobrze i obserwowaliśmy takie rozumienie $\mathrm{w}$ czasie wyborów prezydenckich w Rosji AD 2012. Politycy zwykle i bez skrupułów, nie zawsze patrząc na konsekwencje, wykorzystuja mity zakorzenione w wyobrażeniach zbiorowych i nietrudno to zauważyć w ich deklaracjach. Doceniając role symboli, używają języka nie konkretów, a metafor ${ }^{36}$. I „Każdy polityk owładnięty instynktem przywódczym i egoistycz-

\footnotetext{
${ }^{34}$ W.H. Flanigan, N.H. Zingale, Political Behaviour of the American Electorate, s. 125.

${ }^{35}$ K. Wilber, Krótka historia..., s. 79.

${ }^{36}$ P.A. Chilton, C. Schaffner, Politics as Texst, Amsterdam 2002, s. 51.
} 
nymi skłonnościami, przedstawiać będzie swoją działalność polityczną jako przejaw miłości ojczyzny, dążenie do wspólnego dobra grupy, którą rzekomo reprezentuje" ${ }^{37}$.

Odbiorcy zaś, nie zawsze zdając sobie sprawę ze sztuczności, nieprawdziwości takich deklaracji albo traktując oczywiste łgarstwa jak część spektaklu, bywają skłonni udzielać poparcia znajdując się w takiej samej przestrzeni mitycznej, choć ich interpretacja niektórych mitów często różni się radykalnie od polityków. Spora część elektoratu zdaje się wierzyć w to, że politycy sa z natury altruistyczni pełniąc służbę społeczna, ale dla samych polityków jest to tylko dobrym, czasami koniecznym sztafażem. Czasami zdarza się, że dochodzi do otwartej konfrontacji mitu z rzeczywistością i owocuje to swoista trauma, jak w przypadku „afery Rywina”, czy „Begergate”, które rodzą nowe mity o bylejakości i egoizmie elit. Politycy, jak mogliśmy zauważyć, nie dostrzegali w tych sprawach nic dziwnego, dla nich była to „polityczna rzeczywistość”, nie potrafili pojąć, że takim sposobem burzą część świata mitycznego wyborców, którzy wciąż wierzą w ich prospołeczne misje. Czym innym były tylko insynuacje, a czym innym okazała się ta naga prawda.

Mimo spadającego udziału w wyborach politycy nie czynia nic, by odsunacc, zniweczyć ten głęboki syndrom braku zaufania do władzy, bo wciąż dla wielu władza jest konieczna, wręcz nadczasowa ${ }^{38}$. Wydawać się może, że ta milcząca większość, która nie głosuje, może być zagrożeniem dla tego, co eksperci nazywaja „polaryzująca się scena polityczna”. Poza „wykluczonymi”, niejako za sprawą statusu apolitycznymi i tymi, którzy są elektoratem wiary, stanowią ją przede wszystkim ludzie młodzi i ci, którzy w miarę możliwości racjonalizują swoje wybory do takiego stopnia, że ich nie można zdobywać prymitywnymi chwytami PR, które zresztą są wręcz fetyszyzowane przez specjalistów od marketingu. Ci młodzi, kontestujący jakość rządzących, dali o sobie znać wybierając partię J. Palikota, manifestując swoją podmiotowość w sprawie ACTA. Zdarza się często, że w takie magiczne zabiegi public rtelations najbardziej wierzą sami ich twórcy. A skoro tacy młodzi nie sa do zdobycia albo swoim wyborem moga dokonać radykalnego przewartościowania sceny politycznej, partie zawierzaja swoim wiernym wyznawcom i ci rzeczywiście pełnią role „żołnierzy” z kartami wyborczymi, są trwałym elektoratem wiary.

${ }^{37}$ J. Szczepański, Społeczny kontekst polityki, [w:] Homo politicus, red. S. Filipowicz, Warszawa 1993, s. 70.

${ }^{38}$ P. Sztompka, Zaufanie - warunek podmiotowości, [w:] Oblicza społeczeństwa, red.

K. Gorlach, Z. Saręga, Kraków 1996, s. 119 
Polskie wyobrażenia zbiorowe od roku 1989 wypełniły się nowymi mitami, nowymi protoideologiami, tymi ,gronami wierzeń w naszym umyśle" - jak kwieciście ują to T. van Dijk ${ }^{39}$. Te, wspominane protoideologie, także pozostające poza refleksją naukowa, wypełniaja rozmaite teorie spiskowe, teorie tak ostro potępiane przez badaczy zawierzajacych racjonalnym paradygmatom i to jest bardzo wygodne, bo zwalnia od myślenia. Dla autora ciekawej pracy, teorie spiskowe, wraz z ksenofobią i antysemityzmem stanowią fałszywą formę świadomości i sprzeciwiaja się ,jednoczacym nurtom w Europie i na świecie" ${ }^{40}$. Przyjmując takie ich wyjaśnienie skazał się na swoisty dogmatyzm i raczej nie byłby skłonny podzielić zdania, że twórcami takich teorii byli prezydenci Bush i Kaczyński. Z pewnością nie, bo w innym miejscu nazwał je „głupimi teoriami”. Takich teorii, w których siły sprawcze zmian, procesów, zjawisk są anonimowe, nieokreślone, nie brakuje w nauce, choć do tego trudno się przyznać ich twórcom. Zbyt często wykorzystuja je dla „wyjaśniania" problemów, których po prostu nie rozumieja.

Odbiorcy funkcjonujaccy na poziomie protoideologii, starajacy się umacniać i potwierdzać swoją wiarę przy pomocy dostarczanych z zewnątrz argumentów, przyzwyczajają się do statusów obserwatora, a nie aktywnego uczestnika życia politycznego, choć nader często chętnie przyjmują role „żołnierzy z kartkami wyborczymi” wierząc $\mathrm{w}$ swoja podmiotowośćc ${ }^{41}$. Bez zastrzeżeń akceptują miałkie treści i z niejaka satysfakcją także agresywną taktykę zabiegających o ich głosy polityków, bo i takie „zalety” moga się podobać. Być może te nowe twarze agresji to już wpływ ponowoczesności, ale nie sposób nie zauważyć, że agresywna, ani trochę merytoryczna, dyskusja jest wysoko oceniana, po części przez sam fakt jej stosowania ${ }^{42}$. Możemy przekonywać się o tym codziennie oglądając programy z gośćmi, którymi są politycy. Ponowocześni może do końca nie sa, ale stosuja metody wypracowane przez jej emanację kulturowa, czyli postmodernizm i odbiorcy nie reagują na brutalne przerywanie wypowiedzi, ewidentne kłamstwa, w ogóle na łamanie wszelkich reguł erystyki, jakich chyba jednak nie znaja, jeśli nie potrafią słuchać, czasami siebie też.. Zdaje się, że dla odbiorcy nieważne jest to, co mówia politycy, ale to, że właśnie się kłócą nawet nie próbując rozważać racji innych. Dlaczego to się lubi? Na to pytanie nie odpowiada przywołana niżej autorka Cywilizacji kłótni, ale być może jest to forma desublimacji agresji widza?

${ }^{39}$ T.A. van Dijk, Ideology. A Multidisciplinary Approach, s. 26

${ }^{40} \mathrm{~L}$. Zdybel, Idea spisku $i$ teorie spiskowe $w$ świetle analiz krytycznych $i$ badań historycznych, Lublin 2002, s. 21.

${ }^{41}$ N. Chomsky, Media Control, New York 2002, s. 17.

${ }^{42}$ D. Tannen, Cywilizacja kłótni, s. 39. 
Wracając na polski grunt zauważamy, że przez lata nie znaliśmy pokus i pułapek prawdziwego konsupcjonizmu i ta forma zbawienia w doczesności była tylko obiektem tęsknot, nawet nie horyzontem nadziei, zwłaszcza w latach 80. Zanurzaliśmy się w wymuszonym tradycjonalizmie i pasożytniczej innowacyjności, porażani przy tym zjawiskami syndromu wymuszonej bezradności ${ }^{43}$. Według M. Marody forma pierwsza była poszukiwaniem sposobów na zapewnienie minimów konsumpcji (zwłaszcza w tych szarych latach 80.) przez poszukiwanie substytutów dóbr albo produkowanie ich we własnym zakresie. Natomiast innowacyjność pasożytnicza oznaczała wypracowywanie układów umożliwiających dostęp do dóbr właśnie przy pomocy układów, znajomości i takie postawy homo sovieticus znakomicie komentował S. Bareja, a aktualność jego komedii to niejako poświadczenie trwałości tej formy, zwłaszcza jeśli myślimy o „układach”. Zewnętrzny obserwator twierdził, że Polacy pragną dóbr konsumpcyjnych i wolnego rynku i w połowie miał rację, tylko $\mathrm{w}$ połowie ${ }^{44}$. Z pewnością pragnęliśmy dóbr, ale wolny rynek był tajemnicą i jeśli go pragnęliśmy, to w wierze, iż on zapewni nam obfitość tych dóbr.

Reifikację, alienację i fetyszyzm towarowy zaczęliśmy poznawać dopiero po szoku progu lat 90. Zmuszani do tworzenia własnych wyjaśnień sytuacji tworzyliśmy dziesiątki symplifikacji będących i apologiami i atakami na „prawdziwy” kapitalizm, którego istota zdawała się nie odgadnięcia dla przeciętnego obywatela i na demokrację, która nie okazała się wystarczajaccym remedium na polskie bolaczki w tym cyklu złudzeń. W początkach transformacji, jakby na przekór doświadczeniom, wieszczono, że społeczeństwo potrafi się samoorganizować, że stworzy autentyczne, spontaniczne formy emanacji i kontroli władzy (do tego istniały watłe, ale jednak przesłanki z lat 1980-1981). Rychło okazało się, że to tylko złudzenia opierane o nadzieje krótkiego trwania idealistycznych polityków. Analitycy stwierdzali po niewielu latach, że wskaźniki stanu społeczeństwa obywatelskiego i wielkości kapitału społecznego w Polsce nie daja powodów do optymizmu ${ }^{45}$. Rzekoma umiejętność samoorganizacji poświadczająca wysoki stopień „świadomości społecznej” Polaków okazała się tylko mitem, a spod tła wydarzeń zaczął się wyłaniać upiór z niedalekiej przeszłości. Homo sovieticus, uzależniony od komunizmu z jego wizjami zbawienia, wziął udział $\mathrm{w}$ wielkim buncie, był siłą sprawczą zmian nie rozumiejąc ich istoty, nie potrafiąc przewidzieć ich konsekwencji ${ }^{46}$. Pozostał przy starych wizjach

\footnotetext{
${ }^{43}$ S. Chełpa, T. Witkowski, Psychologia konfliktów, Warszawa 1999, s. 244.

${ }^{44}$ D. Pichaske, Poland in Transition 1989-1991, Southwest State University 1994, s. 9.

${ }^{45}$ M. Grafowska, T. Szawiel, Budowanie demokracji, Warszawa 2003, s. 155.

${ }^{46}$ J. Tischner, Etyka solidarności i homo sovieticus, Kraków 1992, s. 125.
} 
zbawienia mityzując je coraz bardziej w chaosie transformacji i pozostanie przy nich przez lata. Tak można mniemać, jeśli ślady czysto komunistycznych uroszczeń są tak powszednie wśród młodych ludzi.

Piętno komunizmu wciąż daje o sobie znać, także, a może nawet szczególnie pośród tych, którzy najmocniej się od niego odżegnuja. Rytualizowane przez lata sposoby sprawowania władzy przez komunistów pozostawiły po sobie głębokie ślady. Swego czasu rzecznik praw obywatelskich T. Zieliński, komentując dążenie AWS do obsadzania wszystkich stanowisk państwowych skojarzył je z leninowskim modelem służby państwowej - nomenklatura ${ }^{47}$. Dodać należy, że nawet analitykom amerykańskim wydaje się niewątpliwe to, że to Polska jako pierwsza pośród krajów postkomunistycznych zaczęła kreować kapitalizm nomenklaturowy ${ }^{48}$. Nie inaczej wyglądaja praktyki SLD, PiS, PO, przy czym można odnieść wrażenie, że ślady homo sovieticus sa najwyraźniejsze w praktyce PiS za sprawa „pisowskiej” wizji zbawienia - prostej receptury na zbiorowe szczęście „sprawiedliwych”, czyli niespełnionych w III RP. Państwo w wizji IV RP miało wreszcie wrócić do tradycyjnej moralności, miało zbawiać emerytów, najbiedniejszych.

${ }^{47}$ Z.I. Hirsz, Historia polityczna Polski, Białystok 1998, t. V, s. 323.

${ }^{48}$ P. Duignan, L.H. Sann, The United States and the New Europe, Oxford 1994, s. 6. 


\section{0}

\section{ZBAWIENIE DLA WSZYSTKICH - GLOBALIZACJA}

Od czasu, w którym ją nazwano, stała się ciałem i zaczęła funkcjonować w wyobrażeniach zbiorowych wielu społeczeństw, pozostając stałym fragmentem dyskursu naukowego, choć istniała na długo, nim ja jeszcze nazwano. Dyskursu jeszcze nie społecznego, bo taki z pewnością zacznie się wtedy, kiedy szerokie grona społeczności mocniej odczuja jej skutki (zwłaszcza ekonomicznej) na swoich statusach życia i odkryja, że ich pragnienia spełnienia oddalają się coraz bardziej, choć nie tak dawno wszystko wskazywało na to, że złe czasy mamy już za soba, że przed nami wizje świata homogenicznego, dostatniego, bez konfliktów, świata bliskiego marzeniom utopistów ${ }^{1}$. Te skutki już sa odczuwalne w oszczędnościowych standardach życia, ale sa zagrożeniami jeszcze niedocenianymi, z pozoru nie zagrażajacymi tak mocno, by przyjać postawy obronne. Ale pojawiają się nowe i nowe, niby dalekie, jak choćby ten kryzys finansowy który zaczął się na dobre w roku 2008, co do którego nie mamy wątpliwości, że jest owocem globalizacji i to owocem hodowanym przez długie lata, dojrzałym tak, że zaczyna się psuć. Ten owoc to chyba jednak skutek utraty kontroli państw nad kapitałem finansowym.

Przestrogi przed jej skutkami, przed utratą tego „raju odzyskanego” konsumpcji i bezpieczeństwa socjalnego zawdzięczanego schyłkowi nowoczesności. Pierwsze przestrogi przed groźbami, jakie niesie za soba, pojawiły się już przed ponad czterdziestu laty i raczej ich nie zauważano poza wielkimi Raportami dla Klubu Rzymskiego. Widzimy tu znajomą niekonsekwencję braku przewidywania przyszłości, odwagi w tworzeniu wizji, projektów i planów, jeśli zważymy, że wielkie megatrendy J. Naisbitta pojawiły się w nauce przed wieloma laty, a megatrend zwrotu do społeczeństwa informacyjnego, czy ten, mówiący

${ }^{1}$ J. Hartley, Communication. Cultural and Media Studies, London 2004, s. 6. 
o końcu luksusu w izolowanych systemach ${ }^{2}$, były sygnalizowane przed wspomnianymi Raportami, bo już przez Kahna i Wienera w ich The Year 2000 i inspirowały wciąż niedocenianego A. Tofflera tworzącego teorię i zasady praktyki „trzeciej fali” przed 30 laty. Tymi przestrogami przed radykalnymi skutkami zmian globalizacyjnych przejęli się nieliczni praktycy, nauce zaś przypadło, tak często bezrefleksyjne, opisywanie tego, co już stanowiło realne zagrożenie, choć niektórzy ludzie nauki nie mogą sobie wyrzucać zaniechań, gdyż ich ostrzeżenia, nakłanianie do polityki prewencji przed dwudziestu i więcej laty i tak nie były słuchane przez tych, którzy wtedy mogli coś zmienić. Politycy krajów rozwiniętych byli i pozostaja konsekwentni w swojej niekonsekwencji nie siląc się nawet na zrozumienie istoty zmian, jakby pewni tego, że nie pojmuje tych zmian większość społeczeństw. Taka pewność ma swoje podstawy, jako że studenci drugiego stopnia studiów politologicznych nie wiedzą wiele o zjawiskach wiązanych z globalizacja. Trudno zauważyć w ich wystapieniach, enuncjacjach ślady chęci zrozumienia i wyjaśniania, choć problemy globalizacji sa tak żywe w nauce, a przy tym odcisną się na ich życiu.

Przyglądając się próbom rozpoznań istoty wczesnej globalizacji zauważamy, że, polegając na wiwisekcji tylko tych aspektów, sugerowano, że trzeba zaczać myśleć nad tym jak zaczać zmieniać bieg rzeczy zagrażających i spoistości znanego świata i strukturom społecznym, ale były to próby bardzo anemiczne, nie znajdujące społecznego odze$\mathrm{wu}^{3}$. O kryzysach inspirowanych przez dopiero rozpoznawane procesy pisano zbyt późno, wtedy gdy one prezentowały się w postaci dojrzałej, limitowały system, tworzyły własne prawa, upodmiotowiały systemy korporacyjne. Po czasie zaś, kiedy powstały swoiste paradygmaty globalizacji, rozważania o różnych jej aspektach zamieniło się w mody jej krytyki albo apologii ze szkodą dla prób właściwego jej odczytywania, a takie są konieczne, jeśli chcemy myśleć o w miarę racjonalnym procesie decyzyjnym ${ }^{4}$. Pojawił się tu swoisty ikonoklazm globalizacji majacy maskować jej prawdziwe postaci ${ }^{5}$ i nie wydaje się, że działo się to bez wydatnego udziału korporacji medialnych, których siła także zdaje się niedoceniana, choć czasami bywa także przeceniana. Jesteśmy zdania, że one dysponuja większa władzą niż myślimy, co w praktyce oznacza władzę ich właścicieli, władzę symboliczna, ale, co zauważaliśmy, nie bywa to tożsame z umiejętnością wykorzystania tej władzy ${ }^{6}$. Sami

\footnotetext{
${ }^{2}$ J. Naisbitt, Megatrendy, s. 18.

${ }^{3} \mathrm{~K}$. Lynch, What Time is this Place?, s. 1.

${ }^{4}$ S. Ewen, All Consuming Images, New York 1988, s. 20.

${ }^{5}$ A. Muhammadi, Internet. Communication and Globalization, London 1997, s. 170.

${ }^{6} \mathrm{H}$. Jenkins, Kultura konwergencji. Zderzenie starych i nowych mediów, Warszawa 2007, s. 9.
} 
dziennikarze zaś są symetryczni wobec zjawiska w taki sposób, że ich pozycja społeczna, zależna przede wszystkim od właściciela medium, jest symetryczna do „opinii społecznej” o poszczególnych zjawiskach globalizacji ${ }^{7}$. Medialna, przeznaczona dla masowego odbiorcy, wizja globalizacji, z jaką stykamy się niemal codziennie, to obraz procesu spontanicznego, niezamierzonego przez racjonalne podmioty, symetrycznego, bo w jednaki sposób odnoszącego się do jednostek, grup społecznych, państw, niezależnego od racjonalnych działań politycznych, a nadto, nie uwikłanego w żadne relacje władzy (stosunki nadrzędności i podrzędności). Powiada się metaforycznie, że jest to forma kompresji czasoprzestrzeni, proces „obiektywny”, co nadaje mu już wymiar transcendentny i do pewnego stopnia utrudnia zrozumienie ${ }^{8}$. Przy czym przez takie metafory ma się tu zwykle na myśli globalna przestrzeń informacyjna. Media globalne, wytwory i kreatorzy globalizacji, sprawiły, że wiele idei, przekonań i wierzeń uległo podważeniu, zniekształceniu, przemieszaniu służącym niezrozumieniu - uważał D. Strinati ${ }^{9}$. W jakiejś mierze dzięki nim pojawiły się mity „dobrej” i „złej” globalizacji, mające z natury charakter bezdyskursywny, przeznaczony dla potencjalnych wyznawców. Mocno podkreślały ów „obiektywizm” tych mitów autorytety, jak choćby teoretycy z Uniwersytetu Chicago, wedle których globalizacja, animowana przez ekonomiczne siły, jest niczym siły natury - stała i niezmienna ${ }^{10}$. Z siłami natury walczyć można, owszem, ale zwykle bez nadziei na sukces.

Będący zdecydowaną mniejszościa, twórcy mitów „dobrej” globalizacji, przekonują do wizji tejże globalizacji jako świata homogenicznego, bez konfliktów narodowych, klasowych, kulturowych, oponenci zaś do ich odwrotności i ta rytualizacja przeciwieństw trwa w najlepsze, a wyznawcy nie mają wielkiego wyboru przedmiotu wiary obezwładnieni powaga ,autorytetów”. Samozbawieni beneficjenci w krajach bogatych są oczywiście za globalizacją w takiej postaci, wykluczeni przeciw, a z pozoru z boku stoja elity polityczne - tak widzieli to zwolennicy globalizacji kontrolowanej w formach jej przedstawiania pisząc: „Czystą kpiną trzeba nazwać formułę szefów rządów 7 najbardziej rozwiniętych krajów uprzemysłowionych, którzy w Lyonie w 1996 roku ogłosili: globalizację należy przekształcić w sukces ku pożytkowi wszystkich ${ }^{11}$. Ale wiemy, że zaklinanie rzeczywistości jest zwykle manifestacją bezradności.

\footnotetext{
${ }^{7}$ E. Alterman, What Liberal Media?, New York 2004, s. 21.

${ }^{8}$ D. Held, Prospects for Democracy, London 1994, s. 43.

${ }^{9}$ D. Strinati, Wprowadzenie do kultury popularnej, Poznań 1998, s. 181.

${ }^{10}$ N. Klein, Doktryna szoku, Warszawa 2008, s. 66.

${ }^{11}$ H.P. Martin, H. Schumann, Pułapka globalizacji. Atak na demokrację $i$ dobrobyt, Wrocław 2000, s. 15.
} 
Zdawać się może, że pojawiła się zewnętrzna, „obiektywna” siła, która determinuje zmiany w sposób nieubłagany, na swój sposób konsekwentny i nic nie możemy na to poradzić, skoro jest „obiektywna”. Tak twierdzą zdecydowani zwolennicy globalizacji. My zaś nie mamy najmniejszych watpliwości, że proces ten jest dziełem człowieka zbiorowego, a jako takie daje się moderować, kontrolować, ograniczać, a na pewno rozpowszechniać jako niewattpliwe dobro powszechne. Ponad $60 \%$ Amerykanów jest przekonanych, że Stany powinny aktywnie promować globalizację, bo odczytuje w tym dobro dla siebie i dla innych, pod warunkiem, że będzie tym dobrem ${ }^{12}$. Globalizację w ogóle, która sami Amerykanie utożsamiają z krzewieniem amerykańskich wzorów, bo ich negatywne, ekonomiczne i polityczne konsekwencje sa dla nich tylko zbiorem medialnych mityzacji. Ich nie interesuje to, że inaczej widzi to M. Friedman, zainteresowany ekonomicznymi jej aspektami, zmieniajacy pogląd na kapitalizm, a dla niego globalizacją zarzadzaja ludzie z Davos, to oni stworzyli fast world, oni dokonali rewolucji zwanej globalizacja, która zmienia życie wszystkich, i to radykalnie, tak radykalnie i szybko jak żadna z rewolucji ekonomicznych w przeszłości. Dla zwykłego człowieka te zmiany dokonują się relatywnie powoli (choć są przecież niepojęcie szybkie jak na skalę historii), on adaptuje się jak żaba Handy'ego, a ten, ciagle przypominany, „obiektywizm” zmian paraliżuje, oducza zadawania pytań.

Podobnie jak Amerykanie i my miewamy jednak ogromne kłopoty starając się ją zrozumieć skażeni determinizmem, nieprzyzwyczajeni do myślenia prospektywnego, nie potrafiący ekstrapolować nawet prostych trendów, a bez tego wszystkiego nie można mówić o zrozumieniu, wyjaśnieniu i preparacji działań w imię przyszłości, takich działań, jakie moga ją kształtować w pożądanych kierunkach. Brak umiejętności przewidywania przekłada się na niemoc strategiczna i nietrudno zauważyć, że w teraźniejszości globalizacji dominują działania doraźne, chaotyczne, a takie nie gwarantuja powodzenia, czyli nawet częściowej kontroli procesów i ludzi je animujących. Czynnikiem znaczącym jest także, poza falsyfikowaniem, pomniejszanie, a nawet lekceważenie problemów tworzonych przez globalizację. A są one co najmniej ogromne, czego poświadczeniem sa kryzysy funkcjonalne gospodarek narodowych, które będą się eskalowały i stanowiły coraz to nowe zagrożenia. Globalizacja jest jakby tłem okresu przejściowego, który - zdaniem H. Kissingera - może potrwać znacznie dłużej niż się sądzi, co optymistyczne nie jest, acz Kissinger oparł owo przekonanie tylko o intuicję ${ }^{13}$.

${ }_{12}$ A.D. Handler, B. Mazlish, Leviathans. Multinational Corporations and the New Global History, Cambridge 2005, s. 217.

${ }^{13}$ H. Kissinger, Dyplomacja, Warszawa 1996, s. 896. 
Poza tym ona cały czas generuje Nowe. Oznacza nowe przestrzenie działania, nowe granice, nowe role, zasoby, sprzeczności i konflikty, których nawet nie antycypowaliśmy i teraz czujemy się zagubieni podwójnie poszukując rozwiązań i najczęściej spotykamy takie, jakie sprawdzały się w przeszłości, co nie gwarantuje sukcesu ${ }^{14}$. Ci, którzy stykali się z pogłębionymi, poważnymi dysputami o globalizacji moga czuć strach, spodziewać się nowych, codziennych problemów zamiast spełnienia.

Dzieli się ją z nawyku na kilka postaci, opisuje na wiele sposobów i mityzuje, zwłaszcza w polityce, co z drobiną sarkazmu konstatowali autorzy kontrowersyjnej pracy: „Politycy niczym Humpty-Dumpty wykorzystują to słowo nadając mu takie znaczenie, jakie im aktualnie odpowiada"15. Przez takie postaci rytualizacji globalizacja zdaje się nam tym, co jest tu i teraz i zwykle nie zastanawiamy się nad jej konsekwencjami, jakoś adaptując się do nowych. Pytani o globalizację studenci poprzestaja na ogólnikach bez cienia emocji. Nie wydaje się im, by miała jakikolwiek wpływ na ich przyszłość, a z pewnością mieć będzie niemały. Co smutne, nawet oni nie zmierza się z nia, nie spróbuja jej ukierunkować z tak wykształconymi nawykami. To już wygląda na pokłosie braku nie tylko umiejętności myślenia prospektywnego, ale analizowania i diagnozowania zjawisk i procesów. Umiejętności odwzorowania, jakie zdobywają na studiach to zdecydowanie za mało na czas przemian.

Wedle wielu teoretyków uważających globalizację za konieczny etap rozwoju, który musimy przeżyć, dziś pojawił się czwarty wymiar przestrzeni społecznej w postaci takich uwarunkowań globalnych, które sa pozbawione miejsca, dystansu. Metaforycznie interpretujacy ja teoretycy powiadają z emfaza, że już nie będzie więcej „tam”, a tylko „tu”, co oznacza i wiele i nic ${ }^{16}$. Inni zaś artykułuja przekonanie, że globalizacja jest dobra dla wszystkich, że jest manifestacja ludzkich zdolności tworzenia i chęci konsumpcji, że nie zostanie zatrzymana przez polityków i biurokratów marzacych ponoć o tym, by zahamować przepływ kapitałów, technologii i informacji ${ }^{17}$. Trudno zrozumieć takie insynuacje wyznawców globalizacji, bo ani politycy, ani biurokraci nie sa hamulcowymi ani twórcami globalizacji, a raczej pasażerami na gapę.

Wydaje się im, że szansa moderowania zjawisk globalizacyjnych przed politykami była, ale w odpowiednim czasie rządy państw silnych

${ }^{14}$ U. Beck, Władza i przeciwwładza..., s. 23.

${ }^{15}$ J. Micklethwait, A. Wooldridge, Czas przyszły doskonaty, Poznań 2003, s. 34.

${ }^{16}$ S. Barwell, K. Bowles, Border Crossing, [w:] Cyberculture Reader, New York 2000, s. 702.

${ }^{17}$ Partners in Prosperity, the Report of the Twentieth Century Fund Task Force on the International Coordination of National Economic Policies, New York 1991, s. 35. 
nie chciały kształtować tego procesu w pożądanych kierunkach, a odwrotnie, postawiły na żywiołowość, wolną gre nieznanych sił ${ }^{18}$. Nie jesteśmy tylko pewni, czy taką szansę w ogóle kiedyśs dostrzegano. Jeśli $\mathrm{w}$ literaturze pojawiło się tak niewiele przestróg przed negatywnymi skutkami, to czy możemy mniemać, iż dostrzegali to politycy? W to można co najmniej wątpić, jeżeli nie zauważamy konkretnych działań zapobiegających niepożądanym skutkom. To - zdaniem tych niewielu autorów przestróg - właśnie politycy i biurokraci, przyzwyczajeni do inercji, niekompetentni, nie chcą zamykać drogi do „lepszych światów”, czekających na nas rzekomo za progiem naszego już tysiąclecia dzięki sile, jaka jest globalizacja za sprawa tej naturalnej inercji, niekompetencji, ale tej już nie nazwiemy „naturalna”. Tego nie da się podeprzeć mocnymi argumentami, ale takie właśnie sugestie o nadchodzeniu lepszego świata przesycają także enuncjacje publicystów, co nie może dziwić, gdyż oni w większości sa beneficjentami globalizacji, a poszukując winnych zła, jakie pojawia się wraz z globalizacją odnajdują tam, w strukturach państwa oskarżając je o całe zło. Zwykle przywołuja przykłady ludzi i państw, które wykorzystały szanse stworzone przez globalizację zachwycając się Chinami, Indiami, Brazylią nie chcąc zauważać przegranych, a tych jest więcej niż rzekomych beneficjentów.

Zadeklarowani jej zwolennicy sa skłonni traktować nasz czas jako nową epokę w dziejach człowieka, otwarcie drogi do społeczeństwa globalnego, powszechnego dobrobytu, kultury uniwersalnej. W tym szeregu nie brakło „fałszywego proroka” F. Fukuyamy, który twierdził, że nie ma cywilizacji, która nie korzystałaby z dobrodziejstw procesów globalizacyjnych nie konkretyzując takich sugestii, bo to byłby prawdziwy kłopot ${ }^{19}$. Zdaje się, że tak przejawia się ten narcyzm kulturowy Zachodu, to poczucie wyższości nad innymi cywilizacjami, które każe traktować globalizację i marsz korporacji jak misję cywilizacyjną ${ }^{20}$. Zwłaszcza ci wyznawcy, którzy zwracają uwagę na aspekty ekonomiczne, sądza, że globalizacja jest tożsama z podnoszeniem stopnia efektywności gospodarczej, a także stopnia korzyści, jakie, jeśli nie dziś, to w niedalekiej przyszłości, czekają wszystkie kraje. Globalizacja to dla nich większy rynek, większy asortyment towarów i usług, międzynarodowy podział pracy, a poza tym racjonalny, bo przecież wymuszany argumentami ekonomicznymi.

Racjonalne są dla nich szaleństwa z cenami ropy windowanymi przez traderów reprezentujących kapitał finansowy, zalew rynków eu-

${ }^{18}$ Ch. Greefe, M. Greffrath, M. Schuman, Czego chca krytycy globalizacji. ATTAC, Kraków 2004, s. 35.

${ }^{19}$ F. Fukuyama, Koniec historii, Poznań 1996, s. 190.

${ }^{20}$ M. Janion, Niesamowita Stowiańszczyzna, s. 20. 
ropejskich przez fatalnej jakości towary z Chin i innych krajów-producentów na zlecenia korporacji, ceny na wiele artykułów zbijane poniżej kosztów produkcji w interesie konsumentów krajów bogatych. Z uporem powtarzaja, że to właśnie ta konieczność, zdeterminowana „żelaznymi prawami" ekonomii. Tacy komentatorzy przyjmuja postawy zdecydowanie wyznawcze nie chcąc zauważać choćby i tego, że globalizacja to wir stworzony przez najbogatsze kraje, a właściwie ich elity finansowo-przemysłowe i to one, nie państwa, sa największymi beneficjentami nie zamierzając dzielić się zyskami z innymi powracając do złotych zasad „wilczego kapitalizmu”. Biednym grozi jeszcze większa bieda i jej eskalacja jest czymś, co można ekstrapolować na kilka następnych lat, a może dziesięcioleci. Bogaci co rusz powtarzaja, że globalizacja jest środkiem zbawienia dla krajów biednych, ale gorsety tym biednym przez nich narzucane sa pozbawione zasadności, skrupułów, służą przede wszystkim im samym ${ }^{21}$. Nierzadko powiada się z sarkazmem, że bogaci mają coraz więcej pieniędzy, a biedni coraz więcej dzieci. Za sprawa globalizacji ci drudzy maja także coraz więcej nadziei i coraz więcej złości, gniewu, co rodzi zjawiska będące już poważnymi zagrożeniami asymetrycznymi. Wydaje się, że ten bunt będzie się eskalował i zagraża erupcja, co nie jest niemożliwe.

Traktując globalizację jako koherencję wszystkich dziedzin życia, jej adherenci (którzy zdaja się nam postmodernistami, choć chyba nikt nie wie, czym jest postmodernizm), łącza ją z ideami społeczeństwa informacyjnego i niemal proroczo zapowiadają nadejście Nowej Gospodarki i Końca Pracy, tworząc nowe mity zbawienia skwapliwie rytualizowane nie tylko przez media, ale i część świata nauki. J. Riffkin, A. Schaff, czy E. Roullani głosza, że rozwój technologiczny znosi wszelkie antagonizmy między kapitałem a praca. Te antynomie przezwycięża Nowa Gospodarka, czyli te działy, które sa powiąane z nowymi technologiami informacyjnymi i sa zarazem forpocztami postkapitalizmu.

Wedle tych teoretyków zwycięstwo Nowej Gospodarki spowoduje minimalizację zapotrzebowania na klasyczną siłę roboczą i powstanie nowych proporcji ludzi pracujących i nie za sprawą braku odpowiednich kompetencji. Koniec Pracy ma oznaczać prawdziwy koniec dla nawet 80\% społeczeństwa, dla ludzi zbędnych z ekonomicznego punktu widzenia, choć takie szacunki wyglądają na prowokacje, nierzadkie w naukach społecznych naszego czasu. Tacy obywatele znajdą się na łasce (i niełasce) państwa, które zapewne niedługo odrzuci jakiekolwiek koncepcje państwa dobrobytu i zanosi się na to, że odrzucić musi ze względu na potęgującą się, funkcjonalną słabość. Czasami trudno zrozumieć

${ }^{21}$ J. Stiglitz, Fair trade. Szansa dla wszystkich, Warszawa 2007, s. 35. 
optymizm uczonych głoszących takie koncepcje, widać bowiem, że będąc ludźmi wiary wierzą w to, że niejako automatycznie problem tych ludzi zbędnych rozwiąże się sam, jak tysiące wielkich problemów ludzkości, choć te przecież nigdy nie rozwiązywały się same, choć czasami tak się zdawać może, ale tak się tylko zdaje. Oczywiście, także wedle nich, jest to proces całkowicie „obiektywny” i winnych znowu winniśmy szukać nie w państwie i jego instytucjach, nie w praktyce zachłannych korporacji i banków, ale w transcendencji.

Globalizacja bywa najczęściej postrzegana jako rodząca się dominacja rynku światowego nad sfera polityki i bywa sprowadzana tylko do sfery ekonomii, jakby nie miała przełożenia na politykę, inni zaś orientują się na holistyczne jej ujmowanie powiadając, że jest to proces umiędzynarodowienia wszystkich aspektów życia człowieka i często na tym poprzestają zauważając choćby, że mieliby niejakie problemy $\mathrm{z}$ uzasadnieniem tego umiędzynarodowienia politycznego, a inni jeszcze utrzymuja, że globalizacja to homogenizacja, uniwersalizacja zachodnich struktur, postaw, widząc to w kontekstach kulturowych będących efektami „kreolizacji” (U. Hannerz) lub „hybrydyzacji” (J. Piederse) ${ }^{22}$. Nietrudno zauważyć, że jeszcze nie określono jej istoty i myślimy tu o jej treściach, nie formach, a bez tego nie można mówić nie tyle o terapiach, co o stawianiu choćby pobieżnych diagnoz. Musi budzić zainteresowanie, zwłaszcza jej ekonomiczne aspekty, jeśli zważymy, że już ponad $40 \%$ produktu światowego brutto przypada na transnarodowe podmioty funkcjonujące na rynku światowym, a 60\% światowego produktu brutto jest poddane procesom związanym z globalizacją ekonomiczna. Nadto, w transferze globalnym, zdominowanym przez korporacje, znalazło się około $80 \%$ handlu światowego i w podobnej wielkości finanse światowe. Pomiędzy 100 ekonomikami na świecie ponad połowa jest korporacyjna, nie krajowa i proporcje między nimi z roku na rok zwiększają się na korzyść korporacji ${ }^{23}$. Dla 2 tysięcy największych korporacji pracuje około 350 milionów ludzi ${ }^{24}$. To tylko wyrywkowe dane, ale one choć trochę potwierdzają sugestie, że z roku na rok zwiększa się także ich poczucie siły i bezkarności, co także ma swój wpływ na politykę. Co do tego zaś, że ekonomia determinuje politykę nie musimy się przekonywać.

Globalizacja w takiej postaci, z jaką stykamy się dzisiaj, nie pojawiła się ex nihilo, intensywne procesy globalizacyjne zauważano po

${ }^{22}$ J. Piederse, Globalization as Hybrydization, [w:] Global Modernities, ed. M. Featherstone, London 1995, s. 99.

${ }^{23}$ T. Hartmann, Unequal Protection. The Rise of Corporate Dominance and the Theft of Human Rights, New York 2004, s. 37.

${ }^{24}$ D. Rothkopf, Superclass. The Global Power Elite and the World they are Making, New York 2008, s. 35. 
okresie załamania gospodarczego początku lat 70., choć spotykamy się z sugestiami, że taka globalizacja istniała „od zawsze” albo takimi, których autorzy widza ją już w trzeciej i czwartej dekadzie XX wieku łacząc ją ze śmielszymi próbami usamodzielnienia się korporacji, zwłaszcza w Stanach. Takie „odkrycia” sa swego rodzaju pochodna niemocy w wyjaśnianiu, gdyż analitycy chca podpierać swoje rozpoznania nowymi hipotezami, a o takie najłatwiej i to niepokoi, zwłaszcza gdy wielość hipotez nie owocuje pytaniami badawczymi odsłaniajaccymi przesłanki do ryzykownych nieraz wniosków. Wydaje się jednak, że to kryzys lat 70. wymusił coraz to bardziej agresywne formy konkurencji podmiotów gospodarczych, a rewolucja technologiczna, także będąca swoistym owocem kryzysu, inspirowała radykalną transformację sposobów produkcji i akumulacji kapitału przekładając się na znaczące ograniczenia w stosowaniu klasycznej siły roboczej. To wszystko, przy wzięciu pod uwagę presji kapitału finansowego i inwestycyjnego, wymusiło na Reaganie kroki zmierzające do pełnego uwolnienia korporacji ${ }^{25}$. Zastanawiać może także akceleracja globalizacji po rozpadzie bloku socjalistycznego i stabilizacji politycznej świata na innym poziomie, a o prawdziwym przyspieszeniu procesów możemy mówić po roku 1989.

Nosicielami procesów globalizacyjnych w warunkach świata unipolarnego stały się firmy ponadnarodowe. Uniezależniające się niekiedy daleko od państw, przez naciski polityczno-finansowe, wymuszały nowe postacie konkurencji, tworzyły mechanizmy korupcyjne, posuwały się także do przemocy chcąc ukształtować pożądany przez siebie profil rynku, sposoby konsumpcji, powodując się „korporacyjna mistyka” opieraną na wartościach obcych kulturze Zachodu - zauważał trzeźwy analityk, choć trudno się z takimi uwagami godzić, bo takie działania są emanacją kultury Zachodu ${ }^{26}$. One cały czas dążyły do spełnienia się w pełnej niezależności determinowane logiką zysku, integralną częścia owej „kultury” i uwolnione poczęły tworzyć własny świat oparty na wartościach starego, „wilczego" kapitalizmu inspirując erozję starych wartości demokratycznych, bo te są im tylko zawada. Chyba sporo racji ma D. Korten powiadajaccy, że :,syrena kapitalizmu przywdziewa szaty rynku, demokracji i powszechnego dobrobytu, jest ona jednak ich śmiertelnym wrogiem"27 i mający na myśli postkapitalizm.

Sama struktura przedsiębiorstwa kapitalistycznego wręcz wyklucza formy demokratyczne i starczy spojrzeć na jakąś firmę, by przekonywać się, że ta symbioza kapitalizmu i demokracji w ramach państw narodowych jest wymuszana, była wymuszana od czasu, w którym powstawały

\footnotetext{
${ }_{25}$ J. Hagstrom, Beyond Reagan, New York 1988, s. 17.

${ }^{26}$ Ch. Derber, Corporation Religion, New York 2000, s. 119.

${ }^{27}$ D.C. Korten, Świat po kapitalizmie, Łódź 2002, s. 47.
} 
wielkie molochy kapitalizmu. Dziś one, jako nadnarodowe korporacje nie rzuciły wyzwania państwom narodowym, jak się czasami twierdzi, one toczą z nimi wojnę bez brania jeńców, doprowadzając do sytuacji „rządzenia bez rządu" - jak ze sporą dozą przesady, nazywał politykę korporacji J. Rosenau ${ }^{28}$. Bodaj ostatni apostołowie ingerencji państwa $\mathrm{w}$ ich sprawy próbowali dokonać cudu w czasie prezydentury Clintona, ale to się nie udało nawet w części, nie powtórzyli cząstkowego sukcesu Brandeisa walczacego z korporacjami za prezydentury Wilsona ${ }^{29}$.

Uniezależnienie wielkich korporacji od państw-macierzy (o ile można mówić o takich mając na uwadze ich wielonarodowość) oznaczało przede wszystkim niezależność w działaniach wobec państw eksplorowanych przez nie gospodarczo, łatwo bowiem zauważyć, że rząd amerykański (od Reagana) i brytyjski (od Thatcher) czyniły wiele, by zapewnić korporacjom jak najdalej idącą swobodę na rynkach międzynarodowych nie obawiając się o niekorzystne dla państwa i obywateli efekty ${ }^{30}$, a konsekwencje dla budżetów sa oczywiste, bo dziś to korporacje decydują o tym, czy i gdzie mają lokować inwestycje, gdzie maja płacić podatki, których, rzecz jasna, płacić nie chca nikomu ${ }^{31}$. Wedle starego paradygmatu ekonomia była kluczem do zrozumienia polityki i pozornie tak ja pojmowano, uwolnione korporacje miały być politycznymi forpocztami, strażami przednimi państw-macierzy realizującymi „politykę”. Wychodząc z niego także utrzymywano, że sa to działania zbawcze dla wszystkich, zgodne z liberalnym oglądem świata, co dla przywołanych wyżej teoretyków i zarazem krytyków globalizacji jest „czystą kpina”.

O pogłębiającej się słabości państw doby globalizacji może świadczyć także to, że działalność MFW, Banku Światowego, OECD jest podporządkowana interesom najbogatszych i najsilniejszych i nie służy biednym - konstatuje wielu obserwatorów procesu, a danych potwierdzających takie konstatacje nie brakuje. Nadto, korporacje zdecydowanie usuwaja wszelkie bariery utrudniające ich działalność. Między innymi MFW i Bank Światowy opóźniły i redukowały pomoc dla kilkudziesięciu najbiedniejszych krajów, „opornych” wobec procesów globalizacyjnych, a w praktyce oznaczało to wymuszenia ograniczające drastycznie suwerenność tych państw, a dodajmy, że takich ustaleń dokonano w $1991 \mathrm{roku}^{32}$. One sprawiaja, że globalizacja rozumiana jako

28 S.J. Kobrin, Multinational Corporations. The Protes Movement and the Future of Global Governance /w/ Leviathans. Multinational Corporations and the New Global History, eds A.D. Chandler, B. Mazlish, Cambridge 2005, s. 233.

${ }^{29}$ J.P. Krugman, The Age of Diminshed Expectations, Cambridge 1995, s. 22.

${ }^{30}$ D.C. Korten, When Corporations Rule the World, San Francisco 2001, s. 319.

${ }^{31}$ N. Hertz, The Silent Takeover. Global Capitalism and the Death of Democracy, New York 2003, s. 63.

${ }^{32}$ Nasza wspólna przyszłość, Raport Światowej Komisji do Spraw Środowiska i Rozwoju, Warszawa 1991, s. 39 
wymuszenia przez wielkie korporacje kształtuje marginalizację - tak uważał polski socjolog ${ }^{33}$ idąc za wieloma badaczami nie obawiajacymi się o podejrzenia o alterglobalizm, czy o podobne grzechy.

Siła, ekspansjonizm z jednej i straty społeczne z drugiej strony, biorace się z działalności korporacji rosna z roku na rok. Co rusz spotykamy się z zaburzeniami ekonomicznymi będacymi dziełem korporacji wielkich i małych, zwykle wspierających się na każdym froncie wtedy, kiedy zapewnia to obopólne korzyści. Wspomnieliśmy już o cenach ropy, ale spójrzmy także na praktykę polskich banków, które przy wsparciu rządu rozkręciły budowlany boom windując ceny mieszkań i potęgując uzależnienie milionów kredytobiorców o dziesiątki procent w skali jednego roku. Zdawać się może, że takie machinacje znajdują się daleko od głównych nurtów globalizacji, ale chyba możemy je nazwać forma spekulacji globalizacyjnej, bowiem te właśnie procesy, znacznie osłabiajace państwa, umożliwiły i uprawniły takie zachowania. Przy ich uwzględnieniu marzenia przeciętnych ludzi o stabilizacji na wysokim poziomie pozostana tylko marzeniami, a ryzyko życia na kredyt będzie się potęgowało, bo w starciu $\mathrm{z}$ finansowym molochem szanse pojedynczego obywatela sa znikome. Biorac kredyt na ustalonych warunkach już teraz możemy spodziewać się, że jedna strona ich nie dotrzyma i pozostanie bezkarna, choćby działała poza prawem.

Miał swoje racje L. Thurow, kiedy mówił, że zwycięzca bierze wszystko i tę stara prawdę potwierdzają triumfujące korporacje, które zmieniają nie tylko reguły gry ekonomicznej, ale także struktury normatywne, symboliczne ${ }^{34}$. Maja takie racje ci, którzy, jak N. Chomsky, powiadaja, że w globalizacji profity sa indywidualne, a koszty społeczne, a to musi determinować radykalne zmiany społeczno-polityczne ${ }^{35}$. Przekonują się o tym także najbogatsi. Dla wielu Amerykanów częścią ich życia stały się długi, dłuższy tydzień pracy i brak miejsc pracy ${ }^{36}$, a amerykański sen zaczyna zamieniać się w koszmar po kryzysie z września 2008, choć jest to koszmar bogatych. A jeżeli tak wygląda koszmar bogatych Amerykanów, to jak mogą wyglądać koszmary biedaków?

$\mathrm{Na}$ niewiele zdaja się inicjatywy, choćby ONZ, które przyniosły umowny efekt w postaci Porozumienia Globalnego między Organizacja a 50 wielkimi korporacjami, w tym finansowymi. Przyjęte na szczycie milenijnym we wrześniu 2000 roku pakiety przewidywały m.in. redukcję o połowę zadłużenia krajów najbiedniejszych do roku 2015 oraz działania na rzecz poprawy stanu zdrowotności w krajach biednych.

\footnotetext{
${ }^{33}$ E. Wnuk-Lipiński, Świat międzyepoki, Kraków 2005, s. 247.

${ }^{34}$ L. Thurow, Przyszłość kapitalizmu, s. 36

${ }^{35}$ N. Chomsky, Class Warfare. Interviews with Dawid Barsamian, Monroe 1996, s. 42.

${ }^{36}$ T. Hartmann, Unequal Protection, s. 191.
} 
Wielu uczestników szczytu akcentowało przekonanie, że takie deklaracje służą tylko pacyfikowaniu nastrojów w krajach narażonych na prawdziwa agresję „wilczych” korporacji i podówczas nie brakowało głosów żądających „ucywilizowania” procesów globalizacyjnych przez instytucje międzynarodowe póki jest to jeszcze możliwe. Przy czym warto przypomnieć, iż właściwie powtarzano tylko stare postulaty autorów spod znaku Klubu Rzymskiego z lat 70., a jeszcze wtedy można było myśleć o właściwej prewencji, ale nie ze strony instytucji międzynarodowych, tylko najsilniejszych państw działających wspólnie, bo dziś jest za późno na działania pojedynczych podmiotów, choćby najsilniejszych. Analitycy nie mają wątpliwości, że marzenia U. Hannerza o integracji i komplementarności centrum i peryferii są tylko marzeniami albo wyznaniem wiary. Peryferie świata powoli zamieniają się w pustynie, a centrum staje się twierdza dobrobytu. Animatorzy globalizacji sa pewni wygranej, czyli pełnej dominacji i nie pytaja o to, co będzie z przegranymi ${ }^{37}$.

Ale co może oznaczać ich pełne zwycięstwo? Czym być może to spełnienie korporacji? Pojawiaja się pytania o to, czy stworzą realny global governance i przejma władze wraz z jej atrybutami? Na razie nie wydaje się to ani możliwe, ani pożądane przez nie same, choć dysponuja ogromnymi potencjałami, ale naturalne jest, że nie chca tracić energii i środków na tworzenie nowych ośrodków władzy, a potem, raczej nieuniknioną konfrontację z podmiotami państwowymi, które są przecież ich w miarę posłusznymi narzędziami. Dysponuja siłą polityczna, tą miękką i to im jeszcze wystarcza ${ }^{38}$. Nie wydaje się także, by sprawdziły się profecje L. Thurowa, który swego czasu marzył o odrzuceniu idei wzrostu gospodarczego jako imperatywu i inicjowaniu równowagi między niesymetrycznymi podmiotami gospodarki światowej, co miałoby zaowocować skuteczną walką z nędza, z wykluczeniem słabych. W naszym czasie żadne ograniczenia, etyczne czy prawne nie powstrzymaja korporacji przed eksploatacją wszystkiego i wszystkich w imię bogactwa dla siebie i swoich właścicieli - to zdanie innego analityka ${ }^{39}$. Thurow wspominał o erze globalnych regulacji, ale pojawia się pytanie o to, czy dziś istnieje siła zdolna okiełznać korporacje. Przypominając sobie przegraną walkę z monopolami toczoną przez obu Rooseveltów w Stanach możemy być co najmniej sceptyczni, ale tu sam sceptycyzm nie wystarcza, musimy zadawać sobie pytania o przyszłość. Tu raz jeszcze

${ }^{37}$ R.B. Reich, Praca narodów. Przygotowanie się do kapitalizmu XXI wieku, Toruń 1996, s. 245.

${ }^{38}$ N. Hertz, The Silent Takeover, s. 7.

39 J. Bakan, Korporacja, Patologiczna pogoń za zyskiem i wtadza, Warszawa 2006, s. 132 . 
zauważmy ten obezwładniający recentywizm. Problemy uważane za małe (zwykle jeszcze pomniejszane) sa odsuwane na bok, choć nawet próba prostej ekstrapolacji niektórych trendów wskazuje, iż za jakiś czas staną się ogromne.

Mając na uwadze ich siłę nie wydaje się, by państwa były zdolne do okiełznania samowoli korporacji, nawet przy założeniu dobrej woli wszystkich znaczących podmiotów życia międzynarodowego i zgodzie na wspólne działania. Także ONZ, widziana przez niektórych jako zaczyn rządu globalnego, nie jest i nie będzie tą siłą. Amerykańscy neokonserwatyści z Kristolem na czele swego czasu łudzili się, że moga to być Stany, choć ich projekt „Nowego Amerykańskiego Wieku” miał raczej na celu otoczenie opieka i wspomaganie korporacji z kapitałem amerykańskim, jakby naprawdę potrzebowały takiej opieki ${ }^{40}$. Oni zauważali jednak, że globalizacja ekonomiczna nie tworzy zintegrowanego, samoregulującego się systemu zdolnego do zachowania stabilności i sądzili, że uda się stworzyć sieć sojuszów państw i korporacji, jaka zapewni obopólne korzyści ${ }^{41}$. W takim kształcie globalizacja mnoży zagrożenia dla państw, ale one, przy pomocy korporacji, jeszcze doceniających ich opiekę, jeszcze jakoś sobie z tym radza.

Działajace na wielu rynkach, nastawione na zysk korporacje, z konieczności zmierzają do ich ujednolicania dążąc zwykle do monopolizacji danego rynku, a chwytliwe hasła liberalizmu rynkowego zwykle bywaja sztafażami tworzonymi przez kooperujace $\mathrm{z}$ finansowymi i przemysłowymi korporacje medialne, które skutecznie i nieodpowiedzialnie zmieniaja „kulturową ekologię świata” - jak przed niemal trzydziestu laty konstatował teoretyk ${ }^{42}$. Zasadą naczelną każdej korporacji, medialnych nie w ostatku, jest stara maksyma wczesnego kapitalizmu i maksymalizacja zysku za wszelką cenę odsuwa na plan trzeci koszty społeczne, polityczne, co w naturalny sposób powinno konfliktować je z władzami państw narodowych i wielkimi grupami ludzkimi, a tymczasem te konflikty jakoś się rozmywaja, a dzięki mediom winni sa nie konkretni ludzie a zjawiska wręcz transcendentne, czyli kryzys, transformacja itp. Zwolennik mitu „dobrej” globalizacji twierdzi, że obecność korporacji ponadnarodowych, zwłaszcza w opresyjnych systemach politycznych, prowadzi do ich stopniowej demokratyzacji, a to dlatego, że firmy te sa rzekomo bardzo wrażliwe na krytykę zachodnich konsumentów ${ }^{43}$.

Nie mamy wielu poświadczeń takich zachowań, a korporacje o wiele lepiej czują się w reżimach autorytarnych z prostego względu. W ta-

\footnotetext{
${ }^{40}$ R. Singer, Jeden świat. Etyka globalizacji, Warszawa 2006, s. 9.

${ }^{41}$ J. Staniszkis, Wtadza globalizacji, s. 10.

${ }^{42}$ H. Mowlana, Global Information and World Communication, New York 1986, s. 83.

${ }^{43}$ J. Norberg, Spór o globalizację, s. 248.
} 
kich o wiele łatwiej dogadać się z wąskimi elitami oferując im znacznie mniej niż w demokracjach i w znacznie prostszy sposób. A jeśli już pojawiają się konflikty na tle transferu korupcyjnego, gasi się je przy pomocy większych stawek korupcyjnych, nacisków politycznych i manipulacji opinia publiczna, co nie jest zbyt trudne, jeśli zważymy, że elity polityczno-przemysłowo-finansowe sa właściwie jednią a manipulacja odbiorcami przesłań medialnych nie jest w naszym czasie sprawa skomplikowana. Łatwo manipulować tak zwaną opinią twierdzeniami o koniecznościach ekonomicznych, „obiektywności procesu”, nieodwracalności zmian, a nawet mali beneficjenci globalizacji, w obawie przed utratą statusów, chętnie rytualizują takie przekazy obawiajac się losu zupełnie wykluczonych, którzy w części pogodzili się z końcem marzeń o rajach utraconych nie porzucając marzeń o zbawieniu, spełnieniu w rzeczach.

Wielu obserwatorów zjawisk i procesów ponowoczesności, niekiedy dalekich od postaw alterglobalistycznych, nie ma wątpliwości co do tego, że korporacje są rozsadnikami amoralizmu politycznego na skalę lokalną i globalna, uniemożliwiają bowiem hamowanie ucieczki kapitału, profesjonalistów, uciekaja przed podatkami w krajach, w których inwestują w bezwzględny sposób wykorzystując siłę roboczą. Nie wspominamy już o ich zachowaniach w krajach trzecich, gdzie przyjmowane sa $\mathrm{z}$ otwartymi ramionami przez rządy mające nadzieje na industrializację imitacyjną i transfery korupcyjne. Efektami sa wielkie aukcje własnych obywateli, rosnąca korupcja, uzależnienie władz lokalnych od sponsorów i w efekcie, jak zauważała to z dużą dozą emfazy N. Klein: „walka z nędzą rodzi jeszcze większą nędzę" ${ }^{4}$. Podobne zjawiska możemy zauważyć także w Polsce. Być może nie jesteśmy krajem „trzecim" wedle siebie, ale dla korporacji?

Nie tylko autorzy reagujacy emocjonalnie na zjawiska globalizacji poświadczają rosnące marginesy nędzy zauważając $\mathrm{w}$ tym realne niebezpieczeństwa dla sytego, bogatego, białego świata, o czym jeszcze wspomnimy zbliżając „religie uciśnionych”i poszukujących dróg zbawienia w doczesności. Tego rodzaju supozycje stają się coraz bardziej powszechne, a ukryć ich nie można, bo nie da się ukryć marginesu nędzy, który, według J. Stiglitza, wzrósł w ostatniej dekadzie wieku o około 100 milionów ludzi ${ }^{45}$. Inni komentatorzy, posługując się w miarę dokładnymi kwantyfikatorami, dodają że nigdy jeszcze różnice między biednymi a bogatymi nie były tak wielkie. Jeszcze w roku 1960 przeciętny dochód na głowę mieszkańca 1/5 najbiedniejszych krajów

$\overline{{ }^{44} \text { N. Klein, No logo, Warszawa 2004, s. } 224 .}$

${ }^{45}$ J. Stiglitz, Globalizacja, Warszawa 2005, s. 23. 
był trzydziestokrotnie niższy od dochodu mieszkańca krajów bogatych, a dziś jest niższy o około $80 \mathrm{razy}^{46}$. Taki trend wydaje się stabilny i zapewne będzie źródłem nowych koszmarów.

Konsekwencją tak wielkich dysproporcji jest zauważalna od kilku dekad „rewolucja rosnacych oczekiwań”, która już dziś owocuje zagrożeniami asymetrycznymi i falami imigrantów do krajów bogatych, a masowa imigracja to także spore zagrożenie. Mityzowany przed ponad trzydziestu laty konflikt między Południem a Północa dziś dopiero staje się rzeczywistością i nie jest to ani raczej nie będzie konflikt zbrojny. Biedni nie przestaną marzyć o swoich rajach odzyskanych, a takie marzenia, takie iluzje posybilne rodza kroki desperackie, o czym bogaci nie chca wiedzieć mając swoje iluzje. Poświadczeniem takiego stosunku do biednych jest choćby miejsce nędzarzy w mediach albo raczej jego brak. Setki razy częściej oglądamy rytuały i celebry z życia bogatych niż wstrzasajace obrazy umierajacych z głodu. Ale te media nie moga traktować świata inaczej, jeżeli służą kulturowemu imperializmowi uniwersalizującemu doświadczenia grupy dominującej i ustanawiaja je jako normy. Dość umiejętnie stworzyły społeczeństwo billboardowe, a tylko specjaliści wiedzą o tym, że kulturowe, toczone przez nie wojny, co zauważał jeden z nich, sa brudnymi wojnami, jak partyzantka w dżungli i nie podlegają konwencjom ${ }^{47}$.

Problemy globalne współtworzone przez korporacje, wśród których najważniejsze zdają się: zagrożenie środowiska, ubóstwo, głód i choroby społeczne, dotykaja przede wszystkim kraje biedne. Pokłosiem potęgujących się problemów tych odrzuconych, także w Azji, jest przecież terroryzm międzynarodowy. Na pierwszy rzut oka taki argument zdaje się nadużyciem, ale ideolodzy Al.-Kaidy i innych grup mówią cały czas o obronie wszystkich uciśnionych Azji i Afryki, wszystkim prezentuja stara, millenarystyczną wizję Królestwa Bożego na ziemi po pokonaniu szatana. Tu mamy więcej paradoksów. Szatanem dla niedawnych sojuszników i uczniów są przecież nieodmiennie ewangeliczne, misjonistyczne Stany Zjednoczone, które jeszcze nie tak dawno sympatyzowały z ruchami narodowowyzwoleńczymi i nie budziły wrogości, ale zwykle sympatię w III Świecie ${ }^{48}$. Byłe macierze kolonialne nie są nawet pomocnikami Szatana. To właśnie Amerykanie, nie Europejczycy z tych byłych macierzy kolonialnych sa ucieleśnieniem zła i raczej nie pytaja o to, dlaczego tak jest. Stany wciąż deklaruja przyjaźń wobec tych, którzy kultywuja podobne wartości, ale wiara w takie deklaracje zwątlała

${ }^{46}$ Ch. Greefe, M. Greffrath, M. Schumann, Czego chca krytycy globalizacji, s. 105.

${ }^{47}$ T. Sowell, Is Reality Optional and other Essays, Stanford University 1993, s. 79.

48 J.S. Stoassinger, The Might of Nations. World Politics in out Time, New York 1986, s. 121. 
zupełnie. Pytania o erozję tej wiary prowadzą czasami do odpowiedzi oczywistych, ale nie dla samych Amerykanów. Można sugerować, że Stany jako hipostaza Szatana to także pokłosie amerykanizacji kultury masowej, jej dominacji w krajach najbiedniejszych.

Wspominaliśmy o tym, że bieda rodzi desperację, a niewyobrażalna dla bogatych bieda niepojętą dla nas desperację ocierającą się o chęć unicestwienia tych nieczułych na krzywdę bogaczy. Kiedy pytamy o jej źródła odpowiedzi zdaja się proste. Oto globalne dziś media zbliżaja biednym świat zupełnie dla nich niepojęty z problemami równie niepojętymi, bo jakie maja bohaterowie sitcomów? Ci, którzy codziennie walczą o przeżycie widza, dzięki TV, jakim jest świat gnuśnych sybarytów, tak inny od ich świata, rządzony innymi wartościami, a nade wszystko, niepojęcie dla tych nędzarzy marnotrawny. Zawiść, zazdrość - te motory postępowania, jakich także zdajemy się nie doceniać - połączone $\mathrm{z}$ oczywistym pragnieniem lepszego życia wymagaja skanalizowania w wyobrażeniach zbiorowych. Bogaci stają się coraz bardziej obcy i coraz bardziej znienawidzeni nie tylko dlatego, że sa bogaci, bo pojawiaja się pytania o to, czyim kosztem. Biedni przypominają sobie historię i w wyobrażeniach zbiorowych pojawiają się sądy, że zwykła sprawiedliwość wymaga odpłaty, że bogaci mogą i powinni zrezygnować z części swego bogactwa i podzielić się z potrzebującymi, bo owe bogactwa zawdzięczają biedakom. Dla nich ci terroryści sa często wojownikami o wolność, równość, sprawiedliwość. To, kim są to tylko punkt widzenia ${ }^{49}$.

Nieprawda jest, jak niefrasobliwie powiadają niektórzy, że ci nędzarze nie mają nadziei, mają jej bodaj więcej niż bogaci i taka nadzieja pcha ich do czynów, a są nimi albo próby ucieczki z piekła, albo walka z tymi ciemnymi, niepojętymi siłami, które tworzą ich piekło, a im tak łatwo ukazać postać szatana. Oni, poruszając się w innych kręgach wyobrażeń zbiorowych, po swojemu będą szukać sensu w tym świecie, będą szukać swoich miejsc z nadzieja na to, że je znajdą i takiej nadziei nie zaspokoja płonne obietnice, jakimi szafuja bogaci. Taką walkę umożliwiają ci, którzy są „kapłanami religii uciśnionych”, że użyjemy tu metafory E. Hobsbawma. Nietrudno zauważyć, że przywódcy znaczących organizacji terrorystycznych, organizujący święte wojny, bardzo przypominaja przywódców robotniczych połowy wieku XIX, choć to także może wydać się nadużyciem, a mimo to nasuwa się nieodparcie. Ale i nietrudno jednak zauważyć, że zwykle są idealistami, zwykle $\mathrm{z}$ bogatych rodzin, często intelektualistami nie czującymi bliskich więzi

${ }_{49}$ P. Bayley, Terror in Political Discourse, [w:] Discourse and Contemporary Social Change, eds N. Fairclough, G. Cortese, P. Ardiesone, Bern 2007, s. 53. 
z tymi, o których dobro walcza, bo nie walczą o dobro tych prymitywnych, śmierdzących nędzarzy, ale o Dobro jako wartość, „sprawę” dająca powody do samopoświęcenia będącą dla nich formą spełnienia ${ }^{50}$. A walcząc zapominają często, że kochając Człowieka nienawidzą ludzi, jak mówił B. Russell i w imię tego Dobra sieją zwykle zło najczęściej nie przysługujac się tym, w imieniu których występuja.

Osiagane „sukcesy” w walce z Szatanem jeszcze mocniej determinują fanatycznych idealistów, często oskarżanych o dewiacje psychiczne, ale to tylko poświadcza fakt, iż bardzo niewiele wiemy o psychologii terroryzmu ${ }^{51}$. Niekiedy terrorystyczne epizody bywają traktowane przez media jak wygrane bitwy przez jedna ze stron tej „bitwy dobra ze złem", a samo podniesienie terroryzmu do rangi uniwersalnej siły instytucjonalizuje stan ciagłej wojny w skali globalnej i jest potrzebne politykom w realizacji wielu celów. Stworzeniem szlachetnej genealogii dla tej wojny jest także przeniesienie jej w huntingtonowskie wymiary „zderzenia cywilizacji”, co wydaje się nieporozumieniem, ale publicystom z musu musimy wybaczać wiele.

Nie wydaje się, by te, gromko okrzykiwane wojny z terroryzmem zakończyły się sukcesami państw i nie bardzo wiadomo, co mogłoby być takim sukcesem. To zagrożenie asymetryczne jest generowane nędza, wielkimi nadziejami, a im przepaści między biednymi i bogatymi będa rosły, tym większe ilości desperatów obrócą się tam, gdzie popchną ich organizatorzy ich wyobrażeń zbiorowych, wiedzaccy jak poruszać się w ich przestrzeniach mitycznych. Nienawiść stała się naprawdę globalna i na lata zostanie źródłem buntu, a „ponieważ 95\% światowego przyrostu ludności koncentruje się na najbiedniejszych obszarach globu nie ma już sensu pytać czy będą nowe wojny, ale jakiego rodzaju wojny"52. Takich niebezpieczeństw nie zauważają elity białego świata, które wybrały izolację i sa gotowe płacić za nią wysoką cenę - zauważał Z. Bauman ${ }^{53}$. Dziś dość łatwo izolować się tej większości mieszkańców w miarę sytego i zadowolonego społeczeństwa, ale w przyszłości nie zdołają izolować się od miliardów biedaków poszukujących swego miejsca w świecie.

Te „wojny” z terroryzmem chyba zakończą się tak, jak próby walki z międzynarodową przestępczościa, rozkwitającą właśnie wraz z postępami globalizacji, co powinno zastanawiać i zastanawia tych, którzy utrzymuja, że ta przestępczość jest „ciemną strona globalizacji” ${ }^{54}$. Z jed-

${ }^{50}$ M. Sageman, Sieci terroru, Kraków 2008, s. 120.

${ }^{51}$ J. Horgan, Psychologia terroryzmu, Warszawa 2008, s. 52.

${ }^{52}$ P. Martin, H. Schumann, Putapka globalizacji, s. 35.

${ }^{53}$ Z. Bauman, Globalizacja, Warszawa 2000, s. 29.

${ }^{54}$ P. Wiliams, Organizing Transnational Crime, [w:] Combating Transnational Crime Concepts. Activities and Responces, eds P. Wiliams, D. Vlassis, London 2005, s. 66. 
nej strony taki rozkwit stał się możliwy dzięki postępującemu upadkowi instytucji państwa, idącemu w parze z demoralizacją aparatu państwowego, bowiem jego części (urzędnicy i policja) poszukują zabezpieczeń codziennej egzystencji - zauważał amerykański badacz mający na uwadze państwo amerykańskie ${ }^{55}$. Z drugiej strony przestępczości sprzyjaja inne konsekwencje globalizacji i regionalizacji, czyli brak wielu barier. Taka przestępczość staje się dobrze zorganizowanym biznesem, a tylko nielegalny transport imigrantów to interes wart ponoć rocznie około 7 miliardów dolarów ${ }^{56}$. Ostrożne szacunki wybitnego politologa sprzed dziesięciu lat wskazują na to, iż globalne podziemie zarabiało rocznie około 1,5 biliona dolarów ${ }^{57}$, ale są to tylko szacunki, a w dodatku bardzo ostrożne, a chyba nigdy nie poznamy w miarę pewnych danych.

Wracajac do rozsadników nowego ładu zauważamy, że nie brakuje takich teoretyków, którzy sądza, że korporacje przyczyniają się do rozwoju dualnego, to znaczy inspirują rozwijanie branż będących ich domenami i tworzą przepaści między nimi a pozostałymi częściami gospodarek narodowych i nie sposób wymusić na nich symetrii działań strategicznych w skali jakiegoś państwa. Wniosek o powiększaniu przez nie nierówności w skali globalnej wcale nie jest nieuprawniony, bo wiele państw biednych odniosło jakieś korzyści z kooperacji z nimi, choć nie były to z pewnościa gwarancje zrównoważonego rozwoju, jak twierdzi się przywołując przykłady Brazylii czy Chile. Niektórzy analitycy podkreślają i marzenia i dążenia korporacji do swoistej synergii, ale zdaje się, że tu pokładają wiarę w postmodernistyczne pół-prawdy i pół-kłamstwa wmontowanych w system korporacyjny mediów masowych, choć, zauważając ograniczenia podaży i popytu, zapewne będa musiały myśleć o kooperacji, ale najpierw między sobą, bo nie sądzimy, że zechca szukać pomocy u państw przy rozwiązywaniu ich problemów wewnętrznych. One same próbuja przekonywać, że czują się odpowiedzialne wobec społeczeństw, co zdaje się jednak być potwierdzeniem świadomości siły, a nie deklaracja powinności. Społeczna odpowiedzialność korporacji jest ich nowa religia ${ }^{58}$, ale bez religijności, czyli bez praktyki, jaka mogłaby przekonywać do dobrych intencji. Czasami niektóre korporacje czynią kroki, by poprawiać swój społeczny wizerunek akcjami charytatywnymi, ale jeśli zmierzymy wysiłki i efekty tych działań, będziemy niemile zaskoczeni ich „szlachetnościa”"

\footnotetext{
${ }^{55}$ M. Glenny, McMafia, New York 2008, s. 58.

${ }^{56}$ P. Arlacchi, The Dynamics of Illegal Markets, [w:] Combating Transnational Crime, s. 11.

${ }^{57}$ A. Etzioni, From Empire to Community, New York 2004, s. 146.

${ }^{58}$ J. Bakan, Korporacja, s. 39.

${ }^{59}$ H. Glasbeek, Wealth by Stealth. Corporate Crime, Corporate Law and the Perversion of Democracy, Toronto 2002, s. 213.
} 
Ekstrapolowane w dalszą przyszłość trendy zdają się wskazywać na to, że procesy globalizacyjne już zaowocowały skutkami chyba nie do odwrócenia. Największe korporacje już dysponują potencjałami dorównującymi wielu rozwiniętym państwom i naturalną konsekwencja, a nawet swoistym przymusem wzrostu potęgi będzie poszukiwanie form podmiotowości politycznej, co do tego nie mamy wątpliwości, a przesłanek do takich wniosków dostarcza praktyka „człowieka z Davos”. Takimi mocnymi przesłankami są choćby korporacje wojskowe pozostające od kilku lat w cieniu innych zjawisk naszego czasu. Mówiliśmy o tym, że korporacje gospodarcze wykorzystują struktury państwowe, ale tworząc wojskowe zdaja się przygotowywać do samodzielnych poczynań, innego poziomu upodmiotowienia. Niepokoić może fakt, że nie odnaleziono formuł detekcji, które mogłyby zapobiec wielu negatywnym skutkom globalizacji, niechcianym także przez działające w chaosie korporacje, które, mimo wszystko, wiele tracą na niemożności projektowania się w przyszłości. Być może taki stan rzeczy jest do pewnego stopnia pochodną ilości „wyznawców” globalizacji w środowiskach opiniotwórczych, którzy nie ograniczaja się tylko do dodatniego wartościowania wielu zjawisk, ale falsyfikuja je i mityzują służąc samouspokajaniu się. „Postęp”, kojarzony z procesami globalizacyjnymi, wiąże ręce politykom w sytuacji, w której rzekomo geoekonomia zastapiła geopolitykę, jak widział to C. Jean ${ }^{60}$.

Nierówności między państwami i całymi regionami nie sa jedyna konsekwencją działań korporacji nastawionych przede wszystkim na zysk i zdeterminowanych w osiaganiu największej jego stopy. Raczej bez przekonania, ale mówi się także o tym, że większość zagrożeń stających dziś przed ludzkością to dzieło tych anonimowych sił, które przecież aż tak anonimowe nie sa, choć być takimi chca. Agresja bezdusznych, nie uznających powszechnie akceptowanych wartości, korporacji obraca się przeciw przyrodzie i człowiekowi, niszczy dorobek wielu pokoleń - to argumenty równie niekonkretne, jak i inne podejrzenia i oskarżenia zadeklarowanych przeciwników globalizacji. One jednak profilują kształty wyobrażeń zbiorowych, rodzą zbiorowe psychozy, które czasami uniemożliwiaja przeciwstawianie się złym skutkom globalizacji. Eksperci i politycy zarazem (B. Kouchner) twierdza, że choćby odrzucenie traktatu lizbońskiego przez Irlandczyków było konsekwencja kumulacji strachów przed globalizacją. Nieświadomi tego, nie wierzący, że to właśnie silna Unia może być skuteczną zapora przeciw samowoli korporacji, odrzucili traktat mniemając, że sami poradzą sobie lepiej niż wespół z innymi i okazało się, że sami są bezradni.

${ }^{60}$ C. Jean, Geopolityka, Wrocław 2003, s. 24. 
Krach giełdowy, pamiętany już tylko przez specjalistów, sprawił iż w świecie kapitalistycznej gospodarki doszło do swoistego zamachu stanu i przyspieszenia globalizacji poprzez przekształcenie się gospodarki finansowej w drażek sterowniczy gospodarki światowej - uważa S. Salomon. Lotny, szybko przemieszczający się i z natury reproduktywny kapitał uniezależnił się od produkcji, wyrwał się spod kontroli państw i zaczął przemieszczać się wewnątrz państw i przez granice. Kapitał szukał nowych dróg reprodukcji przy pomocy ludzi zachowując się jak przysłowiowy leming, posłuszny jednak woli człowieka i zmieniał postać świata. Bezpaństwowe pieniądze zaczęły określać zachowania polityczne rządów, zmieniały parametry równowagi ekonomicznej i politycznej, bilanse siły w stosunkach międzynarodowych. Dla Salomona była to rewolucja dorównująca znaczeniem rewolucji przemysłowej i ten prowokacyjny sąd sprzed kilkunastu lat trzeba było w swoim czasie potraktować poważnie ${ }^{61}$. Dla G. Sorosa zaś był to początek jeszcze większego zagrożenia, kiedy mówił jeszcze w 1997 roku: „Chociaż zarobiłem fortunę na rynkach finansowych, teraz boję się intensyfikacji działań kapitału lesseferycznego. Głównym wrogiem społeczeństwa otwartego nie jest już komunizm, a kapitalizm"62.

Konsekwencja tej „rewolucji” - twierdził A. Toffler - był transfer władzy z rąk polityków w ręce ekonomistów i finansistów ${ }^{63}$, nie mających żadnych zobowiązań społecznych i nie chcących ich mieć, dla nich kluczem do wszystkiego jest $z^{2} s^{64} \mathrm{i}$ w takich sądach widzimy zgodę wielu analityków. Coraz więcej kluczowych decyzji podejmowali nie pochodzący z wyboru członkowie klubu bankierów, nie mający żadnego zrozumienia dla konsumentów, biednych czy bogatych, co można było potwierdzać już w początkach kryzysu finansowego. Zakres kompetencji i działań banków centralnych, mogących sterować biegiem strumieni bezpaństwowych pieniędzy sprawił, że powierzano im coraz bardziej rozbudowane uprawnienia $\mathrm{w}$ sferze podejmowania decyzji stricte politycznych tyczących wzrostu i recesji, wartości walut narodowych, regulacji finansowych określających, kto w społeczności zyska i kto straci. Dbający o anonimowość ludzie, selekcjonowani i w znacznej części reprezentujący sektor prywatny, reguluja krwioobieg gospodarki światowej, sprawują nad nią kontrolę, sami niekontrolowani przez niekompetentnych polityków, o których już coraz częściej mówi się, że ich

${ }^{61}$ S. Salomon, Gra o przetrwanie, Warszawa 2000, s. 130.

${ }^{62}$ T. Hartmann, Unequal Protection, s. 245.

${ }^{63}$ A. i H. Toffler, Revolutionary Wealth. How it will be Created and how it will Change our Lives, New York 2006, s. 115.

${ }^{64}$ M. Kelly, The Divine Right of Capital. Dethroning the Corporate Aristocracy, San Francisco 2003, s. 45. 
głównym celem jest tylko zaspokajanie oczekiwań wyborców ${ }^{65}$. Zanik umiejętności rządzenia, tak zauważalny w demokracjach, sprawia, że elity polityczne nie sa w stanie bronić interesów społeczeństw, a bezradne, ubezwłasnowolnione społeczeństwa same nie sa już w stanie ich artykułować. Wiara w to, że będą daż̇yły do społecznego zbawienia, jest tylko wiara, także w to, że społeczności same muszą zaczać myśleć o samoorganizacji i samoobronie, ale tu pojawia się pytanie o to, czy je na to stać i smutna odpowiedź nasuwa się sama.

Nie kwestionuje się tego, że proces globalizacji jest najbardziej zaawansowany właśnie na rynkach finansowych dbajacych o swoista homeostazę. Liberalizacja przepływu kapitałów stworzyła nowe podstawy ich funkcjonowania. Wielkie przepływy kapitałowe, różnorodność transakcji, a także ogromna ilość pośredników (fundusze emerytalne, inwestycyjne) współtworzą ten wyalienowany rynek działający przy pomocy tak kruchego pieniądza elektronicznego ${ }^{66}$. Zarządzający częściami rynku moga swobodnie transferować kapitały, a kierunki ich przepływu bywaja niekiedy niemożliwe do odgadnięcia i przez to umykaja nie tylko fiskusom, co w oczywisty sposób przekłada się na konstrukcje budżetowe i w konsekwencji na nakłady na cele społeczne, a to odsuwa w przeszłość idee państwa dobrobytu w wielu krajach. Nieskoncentrowany rynek cechuje niestabilność i tu pojawiają się groźby kryzysów mogących zagrozić gospodarce światowej, a to za sprawą dominacji w alokacji czynników wytwórczych. Jakakolwiek kontrolę państw czy organizacji międzynarodowych uniemożliwiaja „,́sięte” prawa własności. Rozdrobnienie i umiędzynarodowienie pakietów własnościowych firm sprawia, że tak trudno ustalić właścicieli, a dodatkowym utrudnieniem są międzynarodowe fuzje i przejęcia.

Alienacja umiędzynarodowionego kapitału służącego tylko partykularnym interesom, jest zaledwie jednym z czynników podważających władzę, a co za tym idzie, suwerenność państw narodowych. Ekonomiści zauważaja, że agresja wielonarodowych, bezwzględnych korporacji tworzy destrukcyjne dla rządów napięcia polityczne i nieustannie stawia państwa przed koniecznościami permanentnego ustalania równowagi między instytucjami gospodarczymi i politycznymi, choć wpływ polityków na gospodarkę wydaje się maleć z każdym rokiem, co obserwujemy także w Polsce widząc, jakie problemy zakrzątają uwagę polityków i mediów. Korektorami równoważenia w skali międzynarodowej nie sa już umowy, pakty, układy, ale swoiście interpretowane „prawa rynku”, z którymi państwa często nie próbują walczyć, by nie narazić się

${ }^{65}$ W. Greider, The Betrayal of American Democracy, s. 123.

${ }_{66}$ A. Bógdał-Brzezińska, M.F. Gawrycki, Cyberterroryzm i problemy bezpieczeństwa informacyjnego we wspótczesnym świecie, Warszawa 2003, s. 88. 
na oskarżenia o protekcjonizm - uważają niektórzy teoretycy dodając także, iż kontrola mechanizmów rynkowych przez demokratycznie wybieranych polityków jest w zasadzie niemożliwa przede wszystkim za sprawą wspomnianej niekompetencji. Tak więc, wizje zbawienia przez nich kreowane są tylko sztafażami mającymi pomagać w utrzymaniu władzy elit służących samym sobie. Redystrybucja władzy jest faktem potwierdzanym przez wielu analityków, mających jednak problemy ze wskazaniem jej środków, a sugestie, że transnarodowe regulacje powoli tworza korporacyjne społeczeństwo globalne, że następuje ta wyraźna redystrybucja władzy, zdają się tylko albo sądem nieuprawnionym, albo prowokacja - jak sądzą autorzy ciekawej pracy ${ }^{67}$.

$\mathrm{Na}$ razie korporacje, bezwzględnie i skutecznie, wykorzystuja potencjały państw narodowych, co jest tanie, wygodne i łatwe ze względu na odwieczną koniunkcję pieniądza i władzy, a także naturalne słabości polityków różnych szczebli władzy, co do których nie mamy wątpliwości, że je maja. Chyba nie bezzasadnie oskarża się konglomeraty wojskowo-przemysłowe o inspirowanie krótkich i łatwych rozwiązań militarno-politycznych majacych pobudzać popyt na nowe produkty do zabijania ${ }^{68}$. Jeszcze nie wykorzystuja, jak by można, swoich emanacji - korporacji wojskowych, tej nowej jakości w ich działaniach, jakby zapowiedzi szukania podmiotowości. Na razie te prywatne armie służą tylko dobrze płacacym im państwom przekonując przy tym, że korporacje wojskowe są rozwiązaniem dla biednych. Mając na uwadze koszty wynajęcia jednostek dawnej Blackwater czy Executive Outcomes raczej watpimy w to.

Bezwzględność nowych form gospodarowania mocno akcentuje twórca pojęcia „turbokapotalizm” E. Luttwak. Wedle niego Stany odpowiedziały na własne strachy społeczne i ekonomiczne erupcja kapitalizmu z doładowaniem. Twierdził, że interwencja państwa została radykalnie ograniczona, a niekiedy nawet bywa postrzegana jako zgubna dla gospodarki, choć ograniczenie to jest raczej zgubne dla państwa. Luttwak, przed ponad dziesięciu laty, określał stan dzisiejszego kapitalizmu jako „twórczą destrukcję”, pojmowana jako powrót wolnej konkurencji i zasady maksymalizacji zysku przez innowacje techniczne z braku możliwości stosowania metod ekstensywnych. Był wtedy i kontrowersyjny i niekonsekwentny, bo to nie Stany reagowały, ale korporacje i takie reakcje muszą osłabiać państwo, a dość trudno zakładać, że Stany świadomie działały na własną szkodę, założyć zaś można, że nie przewidywano konsekwencji turbokapitalizmu.

\footnotetext{
${ }^{67}$ R.D. Lipschutz, C. Fogel, Global Civil Society and the Privatization of Transnational Regulation, [w:] The Emergency Authority In Global Governance, eds R.B. Hall, T.J. Bierstacker, Cambridge 2007, s. 122.

${ }^{68}$ G. Schumacher, A Bloody Business, St. Paul Minnesota 2006, s. 25.
} 
Uniezależniony od państwa kapitał począł szukać możliwości ekspansji za granicami wzbogacony o wiele innowacji, w tym komputeryzację. Agresywny, bezwzględny, uznaje tylko te metody, które sa skuteczne, czasami tylko chroniąc się pod skrzydła państwa-macierzy, choć przyznawać się może do wielu „opiekunów”, będąc zjawiskiem transnarodowym. Będąc także emanacją amerykanizmu turbokapitalizm uniezależnia się poszukując dziś form dla w miarę konkretnych treści i muszą być to formy gwarantujące swoiście pojmowaną wolność gospodarcza, a takiej nie zagwarantuja państwa wysoko rozwinięte, które musza myśleć o budżetach. Turbokapitalizm potrzebuje jednak gwarancji stabilności i pojawia się wiele supozycji, że niektóre kroki polityczne Stanów Zjednoczonych znakomicie służą przede wszystkim korporacjom, nie państwu. O wiele mniej społeczności amerykańskiej, łudzonej, oszukiwanej argumentami o potrzebie istnienia gwaranta pokoju i bezpieczeństwa światowego ${ }^{69}$. Prosta obserwacja może dostarczyć wielu przesłanek do wniosku, że interwencja w Iraku znakomicie posłużyła destabilizacji i pokoju i bezpieczeństwa, choć ludzie nauki i publicyści związani z establishmentem uparcie twierdzą co innego.

Mając także przyzwolenie społeczne, będące swoistą konsekwencja kultywowania „wartości purytańskich”, kapitał amerykański wespół z europejskim i japoskim poczał zmieniać nie tylko kształt gospodarki światowej, ale i społeczeństw. Turbokapitalizm - wykwit wielkich megatrendów Naisbitta, promuje tylko kwalifikacje przydatne jemu samemu (w produkcji i usługach), a ponieważ jest formą intensywna, progi kwalifikacji zostały podniesione tak, że tylko niewielka część społeczeństwa może je przekroczyć i tylko ta część interesuje korporacje, reszta jest przydatna tylko jako, ważny albo mniej ważny, segment rynku zbytu, o który trzeba dbać, ale niezbyt pieczołowicie i raczej nie z myśla o jego dobru. Szeroko rozumiana inteligencja, w tym techniczna, raczej nie może liczyć na zajęcie eksponowanych miejsc w nowych warunkach i jej pełna zachwytów fascynacja globalizacją (zwłaszcza kulturowa), jest tylko złudzeniem, wiara tej inteligencji w zachowanie dotychczasowych statusów sukcesywnie przecież obniżanych. Ona jest bardziej mobilna niż inne grupy - zauważał Ch. Handy - ale groźby przed nia stojące wcale nie są mniejsze ${ }^{70}$. Jej także, jak całej „reszcie”, pozostaje degradacja społeczna i materialna, bowiem lotny kapitał przenosi się do rajów siły roboczej, a konsekwencje takich przenosin sa zabójcze dla rynków pracy w krajach rozwiniętych, a także średnich. Ze złudzeń próbuje nas odzierać konsekwentna i prowokacyjna N. Klein, pisząc:

${ }^{69}$ R.A. Coate, The Future of United Nations, [w:] U.S. Policy and the Future of the United Nations, ed. R.A. Coate, New York 1994.

${ }^{70}$ Ch. Handy, Wiek przezwyciężonego rozumu, Warszawa 1996, s. 78. 
„Ściagający kapitał rządy średnich krajów mają nadzieję na miejsca pracy, nowe technologie (...) Kraje te wystawiaja na aukcję własnych obywateli rezygnując z podatków. Walka z nędzą rodzi jeszcze większa nędzę"71. Bogaci biedacy jakoś sobie radzą eksploatując prawdziwych biedaków i Polacy także są w rzędzie tych bogatych biedaków, acz bliżej jego końca.

Konsekwencje takiego korporacyjnego ataku dla państwa i jego instytucji są oczywiste, a zauważa się, że państwa wręcz nie chcą bronić się przed naruszaniem swojej domeny obawiając się o zmasowany atak solidarnych $\mathrm{w}$ takich sytuacjach korporacji. O tym myślacc autorzy ciekawej, prowokujacej pracy stwierdzali, że „polityka zbankrutowała”"2. Nietrudno zauważyć, że proces globalizacji ma wpływ na powstawanie nowych jakości politycznych, a tymi sa ,państwa upadłe” (failed states), będące znaczącym źródłem zagrożeń asymetrycznych, aczkolwiek trudno wyraźniej zarysować te zależności między polityką korporacji i upadłościami i, być może, mamy do czynienia tylko z symetrią w czasie, a być może z implozją państwowości płynąca z innych, jeszcze nierozpoznanych źródeł. Zauważał je epimetejski F. Fukuyama pisząc, że tam, gdzie znika rządzenie, tam natychmiast rodzi się zagrożenie dla bezpieczeństwa i tego nie można tolerować ${ }^{73}$. Mądry poniewczasie jak mityczny Epimeteusz przedstawiciel amerykańskiego establishmentu nie chciał zauważyć, że to korporacje, a także same Stany, uczyniły wiele, by liczba państw upadłych i upadających powiększała się z roku na rok. Ograniczanie mityzowanej przez polityków suwerenności państw słabych jest faktem i sporo racji ma autor powiadajacy, że suwerenność polityczna bez ekonomicznej jest tylko pustą deklaracja, choć zbyt oryginalny nie jest ${ }^{74}$. „Suwerenne” państwa nie są w stanie spełniać swego podstawowego obowiązu, a takim jest ochrona swoich obywateli rozumiana także jako dbanie o ich „dobrostan”, że użyjemy tu określenia J. Czapińskiego. We współczesnym świecie państwa nie próbują ani nie sa w stanie ingerować w działania globalnego kapitalizmu ${ }^{75}$.

Globalizacja w takich kształtach jest wstrzasem dla wszystkich podmiotów państwowych, zaciera różnice między tym, co narodowe a uniwersalne, a czynniki uniwersalne tworza przestrzeń transnarodowa, jeszcze nie wypełnioną treściami - zauważał U.Beck, a za nim

${ }^{71}$ N. Klein, No logo, s. 224.

${ }^{72}$ Ch. Greefe, M. Greffrath, H. Schumann, Czego chca krytycy globalizacji, s. 16.

${ }^{73}$ F. Fukuyama, Budowanie państwa. Władza $i$ tad międzynarodowy $w$ XXI wieku, Poznań 2005, s. 115.

74 A. Marszałek, Ekonomiczne uwarunkowania suwerenności $w$ integrujacej się Europie, [w:] Suwerenność $i$ państwa narodowe w integrujacej się Europie, red.

G. Fiszer, Cz. Mojsiewicz, Poznań 1995, s. 40.

${ }^{75}$ W. Wosińska, Oblicza globalizacji, s. 365. 
A. Giddens ${ }^{76}$. Przestrzeń taka kwestionuje zasadność niektórych, ważkich działań jednostek i grup w kurczącej się jednak przestrzeni narodowej. Nie prowadzi to jednak do nowej postaci konwergencji, jak sądzą niektórzy. Raczej niesie ze sobą nową stratyfikację i państwa wmontowane $\mathrm{w}$ procesy globalizacyjne pozostaja w miarę silne wtedy, kiedy współsterują procesami, kontroluja je w jakiejś mierze, ale takie, które nie mogą liczyć na symbiozę z wielkimi korporacjami, marginalizuja się coraz bardziej i trzeba jak najczęściej pytać o to, ku czemu moga prowadzić takie odczucia w krajach najbiedniejszych ${ }^{77}$. Pytać trzeba, bo nowe postaci desperacji groża eskalacją działań takich, jak 11 września.

Chyba można już twierdzić, iż w pierwszych latach nowego wieku korporacje zauważyły bariery wzrostu, konsekwencje destabilizacji będącej wynikiem chaotycznego, spontanicznego działania w imię zysku $^{78}$. Owocnym interesom i zyskom służy ład, a one jeszcze nie sa w stanie wytworzyć go bez pomocy wypróbowanych struktur państw i chyba jeszcze nie są do tego gotowe. Maksymalizację zysków osiagana przez stałe podnoszenie cen przy jednoczesnym minimalizowaniu kosztów produkcji ograniczaja znacznie bariery popytu tworzone właśnie przez nie, bo o wysokości tej bariery stanowią przecież płace w zakładach produkcyjnych i usługowych, a te czasami (jak Chiny, nazywane przez eksperta XIX-wiecznym krajem wchodzacym w ere ponowoczesną i nie wspominamy tu o Bangladeszu $)^{79}$ sięgają minimów przeżycia i zwykłych pracowników korporacji nie stać na zakup produktów firmy macierzystej, gdy te maja już charakter dóbr statusowych, a istnieja także progi obniżania cen dla biedaków, co widzimy w supermarketach oferujacych surogaty produktów sprzedawanych często poniżej kosztów produkcji. Brak kontroli, synchronizacji i wiele innych braków przesadziło o tym, że na razie nie można ani spowolnić, ani zatrzymać niektórych procesów globalizacyjnych. Po części za sprawą braku rozpoznań zagrożeń, po części za sprawą braku umiejętności przeciwdziałania, ale przede wszystkim braku woli tego działania.

Prawdziwym problemem dla przeciętnych zjadaczy chleba sa rażące opóźnienia w adaptacji struktur państwa wobec nowych wyzwań. Konstatacje wielu obserwatorów to sugestie, że demokracja przedstawicielska nie opierana na kryteriach kompetencji uniemożliwia adaptację tych struktur do nowych warunków. Większość państw nie radzi sobie z szybkimi reakcjami na nowe wyzwania i skutkami takich zaniechań czy zapóźnień sa radykalne ograniczenia autonomiczności państwowych aparatów władzy, tracących np. możliwości skutecznej

\footnotetext{
${ }^{76}$ A. Giddens, Trzecia droga, s. 33.

77 Z. Łomny, Człowiek i edukacja wobec przemian globalnych, Opole 1995, s. 95.

${ }^{78}$ J. Staniszkis, Wtadza globalizacji, s. 8.

${ }^{79}$ D.S. Goodman, G. Segal, China Deconstructed, London 1994, s. 322.
} 
egzekucji prawa wobec podmiotów nadnarodowych, a taką utratę widzimy także w naszym kraju. Czasami wskazuje się na konsekwencje, jakimi sa elementy destruujace podstawy systemów demokratycznych za sprawą pojawiania się lobby wymuszajacych pożądane przez siebie decyzje i determinujących falsyfikacje działań politycznych, które staja się czasami zupełnie niezrozumiałe dla „konsumentów” polityki. Owe lobby są wydatnie wspomagane przez „niezależne” media, które bywaja powiązane silnymi nićmi ze światami finansów i polityki, ich „obiektywizm" zaś trzeba podawać w watpliwość, podobnie jak uzurpacje, że sa wyrazicielami głosu opinii publicznej. Wspomina się także o trendzie przenoszenia procesów decyzyjnych ze sfery polityki do sfery ekonomii, choć to także jest polityka i chyba jednak bardzo skoncentrowana.

Człowiek mityczny przyjmuje globalizację jak jeden z wielu dopustów, nie bożych, ale rozwojowych wierząc $\mathrm{w}$ to, iż to naturalny etap rozwoju, nawet postępowy. Zadeklarowanych, racjonalizujacych swoje postawy przeciwników globalizacji jest niewielu i zwykłym zjadaczom chleba trudno ich zrozumieć, tym trudniej, że sa prezentowani we mediach jak przeciwnicy postępu, stabilizacji, dobrobytu i czego tam jeszcze. Przypominajacy amerykańskich muckrakerów (demaskatorów z czasu T. Roosevelta) rekrutują się jednak ze środowisk intelektualnych, konceptualnie płodnych, inicjatywnych i stą ich sugestie warto zbliżać choć $\mathrm{w}$ zarysie $\mathrm{w}$ pracach przeciwników globalizacji. Proponuja rozwiązania, których nie kwestionuja nawet autorytety. Postuluja choćby nową organizację przemysłu i handlu tak, by umożliwiać zrównoważony rozwój wszystkim, racjonalne rozporządzanie „dobrami globalnymi”, tworzenie nowej etyki. Ich zdaniem bierne, samozadowolone społeczności nie są w stanie, nie tylko sprzeciwić się niektórym trendom globalizacyjnym, ale nawet podjąć się próby zrozumienia zmian, jakie wpływają na ich życie. Te ruchy społeczne stawiają wartości nad pieniądzem i zdaja się przypominać początki tych, które wstrząsnęły światem na początku XX wieku.

Niektórzy alterglobaliści, spragnieni swoiście pojmowanego „czynu", jak biblijni profeci, wyczekują znaku przesilenia, który będzie zwiastował wielką metamorfozę opinii światowej. Zdają się postępować za sugestiami badaczy, którzy powiadaja, że dziś „potrzebujemy rewolucji, by zatrzymać taki rozwój korporacji”"80. Takim znakiem nie był nawet 11 września i zdaniem S. George, ten zamach nie był wystarczajaccy, aby mógł zapoczątkować proces nowego sposobu myślenia, refleksji na temat nowej architektury świata ${ }^{81}$.

${ }^{80}$ M. Kelly, The Divine Right of Capital. Dethroning the Corporate Aristocracy, San Francisco 2003, s. 173.

${ }^{81}$ Ch. Greefe, M. Geffrath, M. Schumann, ATTAC, s. 245. 


\section{1}

\section{KROKI W PRZYSZLOŚĆ}

Zauważamy bez trudu, że, mimo wszystko, pytania o człowieka, spełnienie w jego życiu, ludzką immanencję, o kształty zbiorowości, stały się o wiele bardziej intensywne w ostatnich dziesięcioleciach, kiedy po raz któryś w dziejach zostaliśmy porażeni szokiem przyszłości i nagle znaleźliśmy się w świecie symulakrów Baudrillarda, niepomni choćby ostrzeżeń Ortegi y Gasseta, który mówił o tym, że ciało nie nadąża za rozwojem własnej cywilizacji1. Odkryliśmy dziś, iż mówiący o wielkich strukturach społecznych i ich zbawczych rolach przedstawiciele nauki zapomnieli o elementach tych struktur, o ludziach. Takie traumy nie sa niczym nowym w dziejach człowieka, nieodgadniona przyszłość niosła za sobą wiele wydarzeń porażających przodków chyba bardziej niż nas, a czasami budzących wielkie nadzieje, jakich dzisiaj nie dostrzegamy. Nie rozumiemy tego, nie mogąc, po trosze nie chcąc, rekonstruować psychosfery średniowiecza choćby po „czarnej śmierci” albo później, po wojnie trzydziestoletniej i wiedzac jak jest to trudne, wiedząc także, że dla wielu ludzi nauki jest to i niepotrzebne i niemożliwe, co jest szczególnie smutne, jeśli dotyczy historyków, dla których rzetelna rekonstrukcja przeszłości jest powinnościa, ale oni pojmuja ową powinność po swojemu.

Ta trauma, wiązana z niepojęcie szybkimi zmianami dotknęła nas w czasie końca umownej nowoczesności, kiedy biały świat oswoił się już na dobre ze zwiastunami dostatku dóbr materialnych i niemal nieograniczonego konsumpcjonizmu wybranych, który zawdzięczaliśmy dojrzałemu stadium industrializmu, sile państw narodowych i realizowanym treściom demokracji. Trauma tym większa, iż mniemano, że poradzono sobie z kryzysami, załamaniami i czeka nas epoka dobrobytu. Nowe, energooszczędne, zautomatyzowane formy produkcji umożliwiły

${ }^{1}$ J. Ortega y Gasset, Bunt mas, Warszawa 2002, s. 95. 
takie jej umasowienie i potanienie, jakie nawet wymuszały masowa konsumpcję dla zapewnienia stałości jej poziomów, a wszystko w czasie relatywnie bardzo krótkim. I tak - komentował filozof - żyjemy w wieku, w którym robi się wszystko. Najpierw nie robiono niczego, potem trochę, a teraz wszystko².

Robiąc wszystko, a nawet więcej w sferze materialnej, zapominano o sobie, choć, jak wiemy, nigdy nie dbaliśmy o jednostki zapatrzeni w te wielkie struktury, jako rzekomo ważniejsze. Tłumacząc prawa rozwojowe winniśmy wreszcie baczniej spojrzeć na atomy tych struktur, bo przecież człowiek współczesny jest zdolny do przekształcenia wszystkiego, ale zapomina o własnym rozwoju - powtarzał A. Peccei i nie był jedynym, który dostrzegał asymetrię istnienia przypominając antroposferę romantyzmu, w której jednostka wraz z jej emocjami była planem pierwszym.

Teoretycy ponowoczesności postrzegają nasz czas jako okres zastępowania naturalnych do tej pory więzi międzyludzkich przez sztuczne, ograniczające i skutecznie znoszące, wypracowywane przez tysiące lat więzy wspólnotowe. Jak to w nauce bywa, mają całkiem odmienne spojrzenia na kształty antroposfery naszych dni, czasami chyba zbyt wyrafinowane jak na gust przeciętnego odbiorcy. Według A. Elliota ponowoczesność oznacza aktywny i twórczy proces nieustannego kształtowania samego siebie ${ }^{3}$. Dla F. Toenniesa zaś człowiek współczesny jest już skrajnie zatomizowany, anonimowy, staje się mało znacząca cząstka „samotnego tłumu” i jego „cząstkowość” będzie malała wraz z czasem, wraz z zanikiem empatii rozumianej jako zdolność przyjmowania nowych ról społecznych, co zdaje się tylko pobożnym życzeniem ${ }^{4}$. To oznaczać będzie dla autora atrofię wiary w zbawienie w zbiorowości. Tu obaj autorzy zdają się mieć rację. Elliot zapewne myślał o elitach, Toennies zaś o zwykłych ludziach.

Z kolei N. Postman tworzył pojęcie technopolu wracając do konwencji prowokacji, przypominając w tym autorów Raportów dla Klubu Rzymskiego, ale był bardziej wyrafinowany, intelektualny, przewrotny. Charakteryzując nasza epokę, generalizując i prowokując kreuje technopol jako system, w którym podstawowym celem pracy ludzkiej jest wydajność, język nauk ścisłych jest jedynym przystającym do właściwego opisu świata, subiektywizm jest przekleństwem i istnieje tylko to, co „obiektywne”, kwantyfikowalne. Według Postmana te założenia realizujemy przy pomocy fetyszyzowanej techniki, która już ubezwłasnowolniła jednostkę na tyle, że nie jest ona w stanie zdobyć się na

${ }^{2}$ O. Marquard, Rozstanie..., s. 68.

${ }^{3}$ A. Elliot, Koncepcje ,ja”, s. 98.

${ }^{4}$ M.H. Davies, Empatia. O umiejętności wspótdziałania, Gdańsk 1999, s. 202. 
głębszą refleksję nad sobą. System technopolu odbiera nam koherencję świata, czyni nas skrajnie zewnątrzsterownymi, jakby czesściami jakiejś ogromnej machiny, której istota jest zagadka, jak dla J.L. Godarda w „Alphaville”. W tym filmie człowiek oddaje się maszynie wierząc $\mathrm{w}$ zbawienie przez nią, przy czym częściami innych maszyn stają się inni ludzie, czasami krańcowo bezradni bez technologicznych protez, zapominający o światach symbolicznych, tracacy podstawy kulturowe. Ma sporo racji inny teoretyk zauważający, że wokół mamy nowych luddystów, którzy boją się swojej przyszłości, niezdolni do jej zrozumienia ${ }^{5}$, ale nie sa to racje pełne ani w jednym, ani w drugim przypadku.

Dla zrozumienia, a potem adaptacji w nowym czasie właśnie kultura zdaje się ważniejsza niż się sądzi, ale zainteresowanie nią niektórych nauk społecznych jest wciąż marginalne. Wedle teoretyka przez kulturę rozumie się czasem wszystko i tym sposobem pojęcie traci swoją przydatność jako narzędzie nauki, czego potwierdzenia - zdaniem autora - znajdziemy w kulturoznawstwie ${ }^{6}$. Jeszcze dalej szedł O. Patterson, wedle którego nauka traktuje kulturę jako system symboliczny, który można poddawać wyrafinowanym niekiedy próbom rozumienia, interpretacji, opisu i który wymaga poznawania, kultywowania jako dystynktywny wytwór konkretnej społeczności. Jednak pod żadnym pozorem - stwierdzał z dużą dozą sarkazmu jeszcze jeden „prowokator” - nie wolno wykorzystywać kultury do wyjaśniania problemów związanych z ludźmi, którzy są jej wytwórcami ${ }^{7}$.

W okresie przełomu ponowoczesnego pojawiają się dziesiątki ogólnych rozważań o wielokulturowości, relacjach między kulturami dominujaccymi a podrzędnymi, czy o kulturze wysokiej i formach jej homogenizacji. Niekiedy, choć takie impresje często noszą znamiona naukowości, nie sa nawet trafnymi diagnozami, a daleko im do statusu terapii, choć takich powinniśmy oczekiwać chcąc odnaleźć stabilne podstawy bycia w nowym świecie. „Nauka - pisał z podobnym jak Patterson przekonaniem D. Kerkove myśląc o kulturze - nie wie, dokąd zdążamy, bo pominęła pytanie „dlaczego”, które powinna postawić zdewaluowanym religiom. Nie może znać przyszłości, ponieważ nie jest w stanie ocenić teraźniejszości”.

Być może te dysputy o kulturze wyglądałyby inaczej, gdyby elity zrozumiały prostą dla amerykańskiego kulturoznawcy prawdę, że kul-

\footnotetext{
${ }^{5}$ N. Heap, R. Thomas, Information, Technology and Society, London 1995, s. 68.

${ }^{6}$ B. Bjerke, Kultura a style przywództwa, Kraków 2004, s. 29.

${ }^{7}$ O. Patterson, Kultura na poważnie, [w:] Kultura ma znaczenie, red. L.E. Harrison, S.P. Huntington, Poznań 2003, s. 306.

8 D. de Kerkove, Powtoka kultury. Odkrywanie nowej elektronicznej rzeczywistości, Warszawa 1996, s. 23.
} 
tura i jej instytucje są na samym szczycie listy przyczyn szybkiego wzrostu, czego raczej nie sa w stanie zrozumieć politycy ${ }^{9}$. Kultura kształci, profiluje i decyduje o rozwoju socjo, psycho i antroposfery, przesądza o kształtach społeczności, jej aktywizmie, tworzy kapitał społeczny, ale skutki tego kształcenia, profilowania, pojawiaja się dopiero po latach. Jest ciagłą uprawą światów symbolicznych i normatywnych wielkich grup społecznych przypominająca N. Postmanowi hodowlę storczyków, wymagająca niezwykłej pieczołowitości i konsekwencji ${ }^{10}$. Tego nie jest w stanie zrozumieć wielu przypadkowych teoretyków i praktycznych organizatorów wyobrażeń zbiorowych, ale także tych, którzy mienią się być kulturoznawcami oraz takich, którzy na czas jakiś posiedli cząstkę władzy symbolicznej i z przekonaniem do swoich racji próbuja sadzić w wielkim ogrodzie jakieś egzotyczne rośliny z nadzieją że przyjmą się, a może nawet zakwitną. Takie nadzieje często obumieraja jak te rośliny, bo ten ogród rządzi się swoimi prawami i trzeba zaczać je poznawać odrywając się od zużytych paradygmatów. Choćby polskie światy wyobrażeń zbiorowych pełne są egzotycznych roślin, których obumieranie bywa przyjmowane bez żalu, nawet przez sadzących je. Oni są skłonni uważać, że znajdą roślinki nie wymagające takiej troskliwości.

Wedle wielu teoretyków słabości kultury jakiejś zbiorowości, zwłaszcza normatywnej, przekładają się na brak koherencji społeczności z nowymi jakościami w życiu, choćby technicznymi, które naciskaja, eskalują ryzyko, potęguja poczucie niepewności, a człowiek zwykle późni się z tworzeniem nowych symboli i norm, które mogłyby pozwolić na oswojenie się ze zmianami, na swoistą facylitację, zwykle bywa opóźniony, niekiedy tak, że nie da się tych zapóźnień nadrobić. Przyspieszenie zmian środowiska zewnętrznego nie idzie w parze ze zmianami w sferach wyobrażeń zbiorowych, co zauważał McLuhan powiadajacc, że dziś działania i reakcje następuja prawie jednocześnie przy czym reakcje nie są symetryczne wobec działań, nie są odpowiedzią na nie. W rzeczywistości - dodawał dalej McLuhan - żyjemy mitycznie i integralnie, lecz dalej myślimy wedle starych, pokawałkowanych wzorów czasu i przestrzeni należących do starej epoki ${ }^{11}$.

Żyjemy w technicznej ponowoczesności posługując się symbolami i normami starej epoki, których już nie da się bronić, bo wiele z nich tylko potęguje nasze zagubienie $\mathrm{w}$ czasie, w jakim rzekomo osiagamy progi raju konsumpcyjnego. Jako ludzie - powiadał R. May - jesteśmy bardziej zagubieni, pozbawieni ideałów moralnych, pełni obaw o przyszłość, niepewni tego, co robić, by zmienić zaistniały stan rzeczy lub

\footnotetext{
${ }^{9}$ M. Equal, Divergent Paths, s. VII.

${ }^{10}$ N. Postman, Zabawić się na śmierć, s. 51.

${ }^{11}$ M. McLuhan, Wybór tekstów, Poznań 2001, s. 210.
} 
jak ratować zagrożone życie wewnętrzne ${ }^{12}$. Nie zauważamy jak wiele straciliśmy $\mathrm{w}$ ciagu tak krótkiego czasu, jak bardzo zmieniliśmy się w nurtach III fali, której istoty nie chcieliśmy kiedyś poznawać traktując z takim dystansem prowokacje Tofflera. W odruchu samoobronnym, wymuszonym zmianami stosunków produkcji, usług młodzi nie chca dorastać, dorośli starzeć się, a starzy chcą za wszelką cenę być młodzi, bo młodość jest wartościa gwarantująca choćby pracę - zauważał dawno temu filozof. Zmieniliśmy się bardzo, a nie chcemy tego dostrzegać - dodawał inny teoretyk ${ }^{13}$. Przypisujemy to mityzowanemu postępowi, niekiedy z nadzieja, że życie wróci w stare tory, ale to są tylko nadzieje krótkiego trwania.

Nie potrafimy korygować naszego życia mitycznego posługując się starymi zbitkami symboli w ramach starych wyobrażeń, a zwykle potwierdzeniem tego jest sięganie po coraz to nowe elementy tradycji, jakie rzekomo pomagają nam coś uratować. Zdawać się czasami może, że przyspieszenie objęło tylko światy kultury materialnej i brak tej spójności między człowiekiem a nowym środowiskiem, także politycznym, bierze się z niedorozwoju kultury, zwłaszcza symbolicznej, a dzięki niej możemy choćby określać statusy nowych zjawisk, symbolizować je, czynić pozytywnymi albo negatywnymi. To, być może, pozwoli odnaleźć nam równowagę, wpływać na działania, bo przecież świadome działanie musi poprzedzać świadoma myśl (niekoniecznie racjonalna). Pośrednio takie zależności zauważał autor piszący, iż: „fikcja daje nam wskazówki do nowych celów, inspiruje nowe dążenia, które zmieniaja nas całych"14. Gdybyśmy poszukiwali przykładu fikcji generującej zachowania zbiorowe spójrzmy choćby na wizję IV Rzeczpospolitej czy wizje państwa liberalnego, choć te przykłady z naszego podwórka nie wydają się zbyt dobre, bo w tych przypadkach wizje nie rodzą telosów, pozostają puste.

Wydaje się, że kultura, rozumiana jako kultywowanie norm i symboli łaczacych małe i większe grupy społeczne, zapewnia spoistość społeczna, zrozumienie i aktywizację wobec wyzwań stających przed tymi, którzy sa w stanie poczuć wartość takiego spoiwa, bo nie wszyscy sa jeszcze w stanie ${ }^{15}$. Dostarcza nam wzorów narracyjnych będących dla nas wzorami poszukiwania swego miejsca w świecie, a zdaje się, że tego miejsca nie przestajemy poszukiwać nawet wtedy, kiedy zdaje się

${ }^{12}$ R. May, Btaganie o mit, Poznań 1997, s. 20.

${ }_{13}$ J. Jacobi, Zamaskowanie. Obrazki z psychologii życia codziennego, Warszawa 1979, s. 27.

${ }^{14}$ M.C. Nussbaum, Love's Knowledge. Essays on Philosophy and Literature, Oxford 1990, s. 3.

${ }^{15}$ M. Gladwell, The Tipping Point, Boston 2002, s. 177. 
nam, że już je znaleźliśmy. I nie jest to kultura wysoka, ale raczej zwykłe rytualizacje konglomeratów symbolicznych mieszczących się w jej innych postaciach. Czasami zdaje się, że mityzacje znaczenia „kultury wysokiej" sa nawet szkodliwe, wpędzaja tylko w kompleksy tych, którzy nie są w stanie zrozumieć nie Kafkę czy Joyce'a, ale ludzi o nich mówiących, czyniących wokół tych wielkości niepojęte misteria, rytualizujących wciąż te wielkości na sposoby, które czynią je jeszcze bardziej niepojętymi, dalekimi jak gwiazdy. Nadto, w naszym czasie nie mamy już pewności czy „kultura wysoka” jeszcze istnieje. Jej umowność akcentują medialne „autorytety” wynosząc do jej poziomu swoje wybory i zwykle zgadzając się ze sobą.

Ogromna ilość nowych wyzwań wymaga przemyślanych działań w celu „oswojenia” nowości, gdyż inaczej moga grozić nam niewyobrażalne zaburzenia funkcjonalne. Na razie zachowujemy się jak te wspomniane żaby Handy'ego włożone do garnka z zimną wodą postawionego na ogniu. Żaby robią wszystko, by przystosować się do podnoszącej się temperatury, dyskutują naprawdę gorąco, co mają teraz robić i zamiast myśleć o wyskoczeniu z garnka zostaja w nim, aż zostają zamienione $\mathrm{w}$ żabią zupę. Popełniamy zasadniczy błąd starajac się przystosować do chaotycznie przetwarzanego świata, który niby zmieniamy po to, by się lepiej przystosować, ale powinniśmy wreszcie zaczać przystosowywać świat do naszych potrzeb i dlatego winniśmy zaczać myśleć na opak - sugerował przewrotnie Handy. Zbyt paraliżuje nas strach przed zmianami i zbyt często, zamiast myśleć o ziemskim niebie, myślimy o piekle tworząc samosprawdzające się prognozy. Zbyt często je mityzujemy wyolbrzymiamy zamiast stanąc im naprzeciw, zacząć walczyć o pełnię życia, jaka jest możliwa do osiaggnięcia w tym chaosie dla największych grup ludzkich. Taka walka może pogłębić chaos, ale może go także uporządkować

Wiemy jak wiele w tym ryzyka, ale zawsze istniejące ryzyko może być inspirujące, ekscytujące, o ile tylko postanowimy zmierzyć się z nim mierząc wpierw swoje ograniczone siły. Takie postanowienie może przesądzić nie tylko o bardziej świadomych wyborach alternatyw, ale także umożliwić nam opanowanie nowych form detekcji konfliktów i niebezpieczeństw i może wreszcie wtedy zajmiemy się zapobieganiem im, a nie tylko likwidowaniem skutków. Jeśli nie - powiadał Ch. Handy, to nowy porządek światowy najprawdopodobniej stanie się nieporządkiem ${ }^{16}$, choć można mieć wątpliwości co do tego, że dziś żyjemy w „porządnym” świecie, jeśli nie wiemy jak ten świat powinien wygladać. Handy miał na myśli zbiorową niemoc w kreowaniu przyszłości,

${ }^{16}$ Ch. Handy, Wiek paradoksu, s. 23. 
ale ta zdaje się być emanacją jednostkowych, konsekwencją społecznej atomizacji. Musimy uczyć się myśleć długoterminowo i mieć szerokie wizje, by móc wykreować prawdziwie ludzki ład - dodawali inni, prospektywni teoretycy poprzestajac jednak na takim imperatywie ${ }^{17}$. Ale to może dlatego refleksje na tym polu cechuje to, zastanawiajacce teoretyka, pomieszanie paraliżu i szału, nadaktywności i rezygnacji, czyli anomia. Pytamy o przyszłe miejsce człowieka nie mogac nawet dysponować stabilnymi hierarchiami wartości, zintegrowanymi koncepcjami teoretycznymi, wskazówkami umożliwiającymi orientację kognitywna i moralna ${ }^{18}$.

Zmiany są dla Handy'ego tożsame z uczeniem się, innowacyjnościa, przezwyciężaniem lenistwa, które zatrzymuje naturalny bieg procesu polegajacego na zadawaniu pytania, tworzenia teorii, testu teorii i zadania następnego pytania otwartego. Zatrzymanie biegu procesu ogranicza cechy niezbędne do właściwego uczenia się, tworzy egoizm rozumiany jako branie odpowiedzialności za siebie i za swoje czyny, kreuje zmianę formatu rozumiana jako życie w niestabilnym świecie. „Poszukiwacz"powraca tym sposobem do modelu homo creatora, zdawać by się mogło, przeżytego, ale w takim właśnie modelu człowiek na nowo może odkrywać istotę spełniania się, zbawiania w pracy twórczej, sięgania po treści ukryte w każdym $\mathrm{z}$ nas, a nie do odkrycia innej istoty w warunkach poddania się choćby konsumpcjonizmowi. Wiemy, że człowieka stać na wiele, że „ludzie po krótkim treningu potrafią funkcjonować w zgoła nienaturalnym dla nich rytmie, poddawani niewyobrażalnej przedtem stymulacji”" ${ }^{19}$. Stać na to człowieka jako przedstawiciela gatunku, ale, pocieszając się naszymi niezwykłymi umiejętnościami szybkiej i skutecznej adaptacji, zwykle nie pytamy o to, jakim kosztem tego dokonujemy. Wydaje się, że zdecydowana większość z nas, ledwo przystosowanych sybarytów, nie znalazłaby większość sobie takiej siły jak „niepokonani” z filmu P. Weira albo „zaginieni” z popularnego serialu telewizyjnego - alegoria nas wszystkich zagubionych w ponowoczesności. Tak chyba odczytują to odbiorcy, bo inaczej nie możemy sobie tłumaczyć tej popularności serialu pełnego zdarzeń tak nieprawdopodobnych, że aż bliskich w takim właśnie czasie jak nasz.

Nietrudno zauważyć, że jednak większość ludzi nie szuka siebie, nie wie jak się spełnić, zawierza tym, którzy uczą się, pracują i tworzą za nich, zdaje się na sterowanie $\mathrm{z}$ zewnątrz $\mathrm{z}$ naiwną wiarą $\mathrm{w}$ to, że inni będą działać $w$ ich interesie, co jest jeszcze jedną iluzją epoki

\footnotetext{
${ }_{17}$ T. Ball, R. Dagger, Ideals and Ideologies, New York 2002, s. 405.

${ }^{18} \mathrm{H}$. Boehm, O niewyobrażalności teraźniejszości i o przyszłym miejscu człowieka, [w:]

Kultura techniki, wybór E. Schulz, Poznań 2001, s. 485.

${ }^{19}$ J. Jedlicki, Świat zwyrodniały, s. 50.
} 
paradoksu współtworzoną przez demokrację. Ci, którzy radzą sobie ze zmianami i sobą przede wszystkim myślą o sobie właśnie, także ci dysponujący władza, a państwo - dodawał Mc Rae - wciąż pyta o to, jak zmieniać postępowanie ludzi na sposoby przez nie pożądane ${ }^{20}$. Ono nie jest dla ludzi, a odwrotnie i wiele wskazuje na to, że będzie coraz bardziej wsobne, egoistyczne. My sami musimy zacząć pytać i odpowiadać na pytania o sposoby szukania siebie w świecie, pojawiające się w nowym czasie, zawierać indywidualne kontrakty z przyszłością tworząc kapitał dla następnych generacji, które także będą pragnąć tego, co my, czyli spełnienia w idealnych światach ${ }^{21}$.

Nie za bardzo pomagają nam w tym nauki społeczne. Okazują się może przydatne w analizach, wyjaśnianiu przeszłości, ale nie pomagaja w detekcji, zwalczaniu trudności ani też nie dostarczają wskazówek dla przyszłości ${ }^{22}$. Miał swoje racje E. Bloch, kiedy powiadał, że cała filozofia europejska karygodnie zwracała wzrok ku przeszłości, zaspokajała się interpretacja zastanego świata, miast planować inny, lepszy świat i uczyć ludzi, jak go stworzyć takim, by umożliwiał pełnię życia, a od filozofii tego można wymagać, by tworzyła drogowskazy. Nie pomagaja też ci, którzy powinni to robić - politycy kształceni na starych wzorach. To oni w naszych czasach powinni reprezentować interesy przyszłości wobec teraźniejszości, a robią coś zupełnie przeciwnego i z taką konstatacją L. Thurowa trudno się nie zgodzićn ${ }^{23}$.

W ponowoczesności, chaosie wywołanym zderzeniem dwóch fal cywilizacji, według A. Tofflera, brak jeszcze korektorów niezrównoważenia społecznego i politycznego, jakich potrzebuja bezradne jednostki, co przesądza o jakości człowieka politycznego i strukturach, którym zawierzył stale poszukując swoistego equilibrium między pragnieniem a rzeczywistością. Można mniemać, iż społeczności trzeciej fali brak jednak sił intelektualnych do stworzenia nowych zwieńczeń kultury normatywnej na starych zrębach, ale niewątpliwie będzie zmierzała $\mathrm{w}$ kierunku stworzenia nowej etyki uniwersalnej, bowiem w każdej cywilizacji muszą istnieć wartości, których nie można relatywizować tak, jak czynią to niektórzy postmoderniści ze swoją skłonnością do synkretyzmu i parodii, które nie sa dla nich wyjątkami a regułami ${ }^{24}$. $\mathrm{W}$ takich ramach kulturowych człowiek nie odnajduje tak potrzebnych mu, odwiecznych struktur ładu, a zwykły chaos, który przeraża, obez-

${ }^{20}$ H. Mc Rae, Świat w roku 2020, Warszawa 1996, s. 294.

${ }^{21}$ J. Rawls, Teoria sprawiedliwości, Warszawa 1994, s. 392.

${ }^{22}$ J. Łukasiewicz, Eksplozja ignorancji, Warszawa 2000, s. 8.

${ }^{23}$ L. Thurow, Przyszłość kapitalizmu, s. 29.

${ }^{24}$ P. Novotny, No Future, [w:] Political Scence-Fiction, eds M. Hassler, C. Wilcox, Columbia University 1977, s. 101. 
władnia, rodzi niechęć do aktywizmu. Zaczyna odczuwać, że niemożliwe jest osiaganie pełni intelektualnej, tożsamości nawet, a bez niej nie może właściwie funkcjonować w społeczeństwie, jeśli nie wie, kim jest. I trudno wierzyć teoretykowi, który raczej beztrosko, z jakimś programowym optymizmem, utrzymuje, że wkraczamy w erę przebudzenia ${ }^{25}$. Jeśli już, jest to przebudzenie ze spokojnego snu w miarę stabilnej, przewidywalnej nowoczesności i wejście w rozedrgana, nerwową rzeczywistość ponowoczesności. Budząc się ze spokojnego snu wpadamy $\mathrm{w}$ niepojęty świat przypominajacy ten po drugiej stronie lustra.

Trzeba także zacząć odsuwać na plany dalsze prymat rozumu instrumentalnego, tego rodzaju racjonalności, jaka ekonomizuje nasze działania, zmusza nas do szukania najprostszych środków prowadzących do celu bez oglądania się na innych. Ten prymat powracajacy w postkapitalizmie nie oznacza racjonalności politycznej, bowiem współtworzy tylko kulturę narcyzmu, w której głównym celem jest samorealizacja ograniczana do samego zbieractwa, a oznacza ona egotyzm, zamykanie się w sobie, ucieczkę przed współuczestnictwem w wyborach politycznych. A naszym zdaniem prawie każdy człowiek chce rozumieć politykę i spełniać się przez nia jako część zbiorowości, nawet wtedy, kiedy zbiorowość jest traktowana jako wróg. Taki egotyzm może rodzić osobowości paranoiczne, które cechują się schelerowskimi resentymentami, podejrzliwościa, wsobnościa, wrogością do wszystkiego, lękiem przed utratą niezależności, myśleniem urojeniowym ${ }^{26}$.

Ta trzecia fala, niejako w naturalny sposób, musi przynieść nowa ludzką jakość bliską kształtom tej, o jakiej kiedyś marzył prezes Klubu Rzymskiego A. Peccei. A po to, by odpowiedzieć na pytanie o formy i treść homo futurus winniśmy poszukiwać odpowiedzi na pytania o to, kim jest teraz, w tej międzyepoce. Nietrudno zauważyć, że poszukiwania pełniejszego paradygmatu natury ludzkiej to dopiero ostatnie dekady wieku XX i były to poszukiwania chaotyczne, niekoherentne, owocujące dziesiątkami epitetów od homo faber poczynając, a kończąc na homo concors, bo trudno traktować je jako koherentne, twórcze koncepcje, a prędzej jak naukowe ekstrawagancje. Zdaniem wielu prospektywnie nastawionych antropologów i kulturoznawców człowiek sam musi zdefiniować siebie na nowo pamiętając o tym, iż żadna definicja kreatora nie może być ostateczna, żadna nie może stać się „pocałunkiem śmierci”.

W naszym właśnie czasie trzeba wyzwalać zbiorową wyobraźnię, bo w niej kryją się niepojęte rezerwuary sił sprawczych i społeczeństwa

${ }^{25}$ W. Straus, N. Howie, Generations, s. 348

${ }^{26}$ R.S. Robins, J. Post, Paranoja polityczna, s. 18-24. 
same, bez oglądania się na egotyczne, niekompetentne, wyalienowane elity, winny zajać się tworzeniem swoistej filozofii samoorganizacji, dostosowaniem struktur społecznych i politycznych do nowych warunków, co dla Tofflera czy Morgensterna oznaczało konieczność podnoszenia poziomu podmiotowości jednostek, bo instytucje państwa nie sa tym zainteresowane. Ale tu pojawia się znowu pytanie o to, czy jednostki na to stać, a nadto o siły sprawcze takich przemian, bo trudno zakładać zbiorową iluminację milionów ${ }^{27}$. Instytucje publiczne już czują się spełnione na swój sposób albo ugrzęzły w zbiorowym egotyzmie nie determinowane przez polityków ani zbiorowości. Społeczności zaś muszą zacząć myśleć holistycznie o zbawieniu całej ludzkości, ale po określeniu statusów jednostki.

Inaczej - zauważał inny teoretyk także pomijający pytanie o to, jak to zrobić - jednostkom grozi status „człowieka zastanego”, zaskorupionego w swojej przestrzeni mitycznej, nie potrafiącego racjonalizować postaw i zachowań wynikających z determinacji „nieświadomego”, a taka postawę, wypływająca z głębin świata mitycznego, religii ${ }^{28}$, prezentują ci, którzy skłonni sa obdarzać innych tym, co zwiemy charyzma. Prospektywnie nastawieni badacze utrzymuja, że trzeba inspirować powstawanie nowych regulacji kulturowych, jeżeli przez kulturę rozumiemy wszystkie formy zachowania człowieka na poziomie emocjonalnym i racjonalnym. Wedle nich jednostka powinna postrzegać świat holistycznie, być zdolna do obrony przed alienacją i manipulacja, umieć rozwiązywać konflikty, komunikować się i kooperować, co przecież wymaga ogromnego wysiłku, na jaki jednak stać tylko nielicznych, a po podjęciu takiego wysiłku owe jednostki moga poczuć się wyalienowane nie widząc pożądanych efektów. Rządzącym zaś zależy na tym, by móc swobodnie manipulować zadowolonymi z siebie i świata, w jakim żyja, masami biernych konsumentów znaków rzeczywistości, niezdolnych już do samozbawienia poza materialnym, ciagle poszukujacym tych soterów, którzy rozwiażą ich problemy za nich ${ }^{29}$. I tu także spotykamy się $\mathrm{z}$ piekłem dobrych intencji. Imperatywy, jakich nie szczędzą nam teoretycy, nie zastapia naprawdę dobrych, praktycznych rad.

Może się wydawać, że dziś ma miejsce swoista homeostaza, jakaś leniwa równowaga między rządzącymi a rządzonymi mimo tego powiększającego się dystansu między nimi i to potwierdzają niektórzy teoretycy. Marną jakość polityków z obojętnością przyjmuja „pokolenia, które rosna bez religii” - pisał D. Coupland ${ }^{30}$. Ich ziemska wiara we

\footnotetext{
${ }^{27}$ A. Toffler, Trzecia fala, Warszawa 1986.

${ }^{28}$ D. Aberbach, Charisma in Politics. Religion and the Media, London 1996, s. 3-4.

${ }^{29}$ J.K. Galbraight, The Age of Uncertainity, Boston 1977, s. 327.

${ }^{30}$ D. Coupland, Życie po Bogu, Warszawa 1997, s. 129.
} 
wszystko też zdaje się być bardziej krucha, ale to mogą być tylko pozory, a do takich sugestii skłania zauważalny upadek dawnych systemów wartości. Wydaje się nam, że reakcje na pustkę, deficyt wiary chyba muszą nastapić i być może zauważamy zwiastuny poważnego przełomu obserwujac manifestacje buntu młodych, jak choćby ten w sprawie ACTA, a tego się nie spodziewano. Chyba jednak pokolenia wstępujące przejawiaja mniejsze zainteresowanie zaspokojeniem czysto materialnych potrzeb na rzecz poszukiwania „duchowego spokoju”31. Być może niedaleki jest czas nowego buntu młodych, a przypomnijmy, że nic go nie zapowiadało w latach 60 , że był buntem przeciw niedostatkowi wartości, z pozoru wydawało się, że niekonstruktywnym, ale po latach okazało się, że jednak zmienił wiele.

Próbujacy antycypować kierunki rozwoju antroposfery filozofowie, socjologowie i politolodzy zauważaja, że zmiany społeczne w skali makro nie następują tak szybko, jak w świecie techniki, a niekiedy dochodzi nawet do petryfikacji struktur społecznych, jak widział to E. Fromm. Jego zdaniem pełna, wręcz ostateczna, polaryzacja stanowisk wobec życia nastapiła już przed kilkudziesięciu laty. Jedni wybrali zbawienie przez dobra materialne będące życiem bezwartościowym (non-life), podporządkowane biurokratycznym strukturom, sztywnym ramom zachowań narzucanym przez dobrobyt, inni zaś wyraźnie artykułowali potrzebę prawdziwego życia, konieczność odzyskania kontroli nad życiem społecznym i uczłowieczenia technologii. Fromm, idąc za wieloma krytykami cywilizacji technicznej uważał, że technika ze środka już przekształciła się w cel sam w sobie, w autonomiczną siłę, do której dostosować się musi jej twórca przejawiajacy wiarę w transcendencję. Twierdził, że jako w pełni autonomiczna technika zniewala człowieka, pozbawia go możliwości wyboru, narzuca środki, które musza być stosowane przy osiaganiu celów. Człowiek staje się tylko „pyłem historii” powodowanym siłami, których nie pojmuje i raczej pojmować nie chce zniechęcany szybkością zmian. Łudząc się tym, że osiągnał swoje niebo, wegetuje w czyśćcu.

Krytyczny, maksymalistyczny, prowokacyjny twórca, jak wielu ludzi nauki zdawał się nie wątpić w egzystencjalne dobro natury ludzkiej, w ogromny potencjał tkwiący w każdym z nas i w społecznościach. Wedle niego, przypominającego tu dziesiątki natchnionych rewelatorów wieku XIX, wciąż istnieją ludzie obdarzeni „,charakterem rewolucyjnym”, czyli jednostki wewnętrznie autonomiczne o stabilnych, uniwersalnych systemach wartości, wolne od nienawiści, altruistyczne, potrafiące kultywować prawdziwą sztukę miłości do człowieka. One

${ }^{31}$ B. Brzozowska. Gen X. Pokolenia konsumentów, Kraków 2005, s. 17. 
stanowią mniejszość, ale dzięki tej zdrowej psychicznie mniejszości o „orientacji produktywnej” możliwy jest postęp moralny ${ }^{32}$. Ta zdrowa psychicznie mniejszość nie jest przystosowana do istniejącej kultury, zwłaszcza masowej, nie praktykuje fałszywych z punktu widzenia natury ludzkiej wartości i jest potencjalnie siłą wiodąca ludzkości, prawdziwym soterem. Ale jeśli poszukujemy takiej mniejszości idąc śladem Fromma możemy poczuć spory zawód. Jej właściwie nie ma, bo nie tworza jej jednostki porozrzucane w zbiorowości, często nie potrafiące się porozumieć mimo podkreślania pokrewieństwa, choć ich obecność jest zauważalna. Trudno także dostrzec możliwość dotarcia tych jednostek do społeczności.

Inni analitycy i diagności, poszukujący dróg powrotu do starych, stabilnych i zrozumiałych form życia w niepojętej ponowoczesności dodaja, że śmielsze spojrzenie w przyszłość może zmienić wiele, inspirować zarówno polityków, jak i zwykłych zjadaczy chleba, że jednostka powinna być fundamentem wszelkiego projektowania czy wizjonerstwa, bo przecież chcące ego żyje dla przyszłości ${ }^{33}$. Przypomnijmy, że wizje przyszłości - jak utrzymywał G. Therborn - to nowe horyzonty naszych dążeń, pełne miejsc, których nigdy jeszcze nie oglądało ludzkie oko i z tym nie można się nie godzićc ${ }^{34}$. R. Jungk zaś powiadał, że żadna wizja przyszłości nie może aktywizować ani preparować działań dla jutra, jeżeli nie będziemy potrafili implantować w nią zwykłego, konkretnego człowieka z jego obawami i pragnieniami lepszego życia, jego strachami i nadziejami na spełnienie. Jednostka, z jej wydolnościa, kwalifikacjami, tożsamościa, orientacjami, zachowaniami, jest w stanie przesądzić o skutecznej realizacji predykcji społecznej, ekonomicznej czy politycznej rozumianej jednak tylko jako swoista rekomendacja działań mających prowadzić do pożądanych celów.

Nie musimy przekonywać się do tego, że chyba każda, nawet drobna dyspozycja, każda decyzja, niekoniecznie polityczna, jest forma zarządzania przyszłościa, poszukiwania w niej dobra swojego i innych. Projektowanie jej w skali mikro jest zauważalną przez każdego, codzienna koniecznościa, jest zarazem sumą działań człowieka oparta $\mathrm{w}$ jakimś stopniu na procedurach myślenia racjonalnego, w jakimś mitycznego, tworzy swoiste opozycje ideologii, religii, propagandy, które legitymizuja w jednakim stopniu działania dla przyszłości. Naszym zdaniem możliwe jest stworzenie mechanizmów mających wspomagać jednostki i zbiorowości w kreacji jutra, choć bywa to niekiedy traktowane z dystansem, bo świadoma kreacja jutra jest tożsama z wyborem

${ }^{32}$ E. Fromm, Niech się stanie człowiek, Wrocław 1994, s. 82.

${ }^{33}$ H. Arendt, Wola, s. 69.

${ }^{34}$ G. Therborn, Drogi do nowoczesnej Europy, Warszawa 1998, s. 508. 
i określaniem celów. Zauważamy, że człowiek z konieczności, na bieżąco projektuje siebie w przyszłości wspierając się najczęściej o modele recentywne, tworzone dla umownej teraźniejszości i tracące na znaczeniu wraz z nia, co czyni projektowanie co najmniej mało skutecznym. Natomiast skierowany w przyszłość staje się nie tylko twórcą kultury, ale jej świadomym interpretatorem i konsumentem starającym się wyprzedzać czas. To jednostka, cały czas działajacca w i dla przyszłości, jest kreatorem obszaru kultury normatywnej i idealnej, których jakość determinuje w efekcie kształty kultury materialnej, gdyż, jak powiadał J. Bronowski: „Nasz obraz świata zawsze zależy od metafor, które doń wprowadzamy. Metafory rodzą algorytmy, a one znów metafory" ${ }^{35}$.

Umocowanie tylko w przeszłości „metafory dominującej” Ricoeura, czy tego, co Eliade nazywa archetypem, zmusza nas do wiązania tej ulotnej teraźniejszości z tym, co było, rodzi niemożność zdecydowanej, szybkiej akceptacji tego, co jest już przyszłościa, co staje się tu i teraz. Tam, za progiem umownego jutra, mogą kryć się raje odzyskane, tam powinny znaleźć się potwierdzenia i przesłanki nowych nadziei, choć nie brak i takich, które zrodzą nowe strachy. Przez korzenienie w jutrze nowych jakościowo nadziei jednostkowych i zbiorowych możemy myśleć może nie o ideale, ale o nowych strukturach władzy, życia zbiorowego, zależności, systemach aksjonormatywnych, bo przecież one przeżywaja się. Wszystko to mieści się w nieobjętym Królestwie Możliwości, tuż za progiem teraźniejszości. Musimy zaczać myśleć o nim inaczej, a nietrudno chyba zgodzić się z filozofem, który powiadał, że jak długo myślenie o jutrze nie wywołuje w nas żadnych reakcji afektywnych, tak długo bezskuteczne są nasze działania w teraźniejszości ${ }^{36}$.

Za takim myśleniem - dodają inni, nie pytajacy o to, czy jest to możliwe - iść musi nacisk świadomej swych ról opinii społecznej, gdyż politycy zbyt często traktuja jednostki i grupy przede wszystkim jako obiekty politycznej manipulacji, pod warunkiem, że taka opinia powstanie, bo jednak wattpimy $\mathrm{w}$ to, że istnieje, autentyczna i autonomiczna. Zdaniem wielu kreatorów antroposfery jutra zorientowanych na rozwiązania globalne, niezbędne jest świadome tworzenie nowych regulatorów cywilizacyjnych, które pomagaja w organizowaniu społeczności do rozwiązywania problemów, które pojawią się w niedalekiej przyszłości, zneutralizuja syndrom zachowań określany mianem „niezadowolenia kulturowego”, a oznaczajacego odczuwana bezsiłę jednostek jako obywateli i „konsumentów” demokracji wobec tego, co „obiektywne” i „subiektywne” w życiu społecznym. Tu także nie bardzo

${ }_{35}$ J. Bronowski, Źródta wiedzy i wyobraźni, Warszawa 1984, s. 67.

${ }^{36}$ D. Birnbacher, Odpowiedzialność za przyszłe pokolenia, Warszawa 1999, s. 6. 
wiemy, co znaczy świadome tworzenie, czy spontaniczne, czy odgórne. Czujemy tylko intencje zawarte $\mathrm{w}$ takich opiniach.

Wedle autorów podobnych koncepcji występowanie tego syndromu jest szczególnie widoczne w tym, że każdy z osobna chce robić zupełnie co innego niż zbiorowość i wydaje się, że jest to problem w części inicjowany, a na pewno akceptowany przez rządzących. Tak przynajmniej utrzymywał G. Picht, zauważający z gorycza, że nawet przeraźliwe obrazy naszkicowane przez Orwella zdaja się być idyllą w porównaniu z tym, co przeżywamy w rzeczywistości choć w innych formach i w innej skali $^{37}$. Wspomniane regulatory cywilizacyjne powinny przede wszystkim w znaczący sposób eliminować wyrosłe z podłoża indywidualizmu postawy kratyczne (władcze), które destabilizują struktury społeczne, a sa pojmowane na niezwykle prosty sposób przez Fromma. Wedle niego człowiek ogarnięty żądzą władzy, nie tylko w politycznej mikroskali, poddaje się tym, którzy rządzą i chce rządzić tymi, którzy są słabsi. Takim sposobem spełnia się on, ale to nie oznacza spełnienia dla innych

Taka ludzka jakość jest właśnie swoistym owocem dominującego w kulturze europejskiej indywidualizmu - sugerował Ch. Taylor. Według niego indywidualizm to zawężenie horyzontów do własnych problemów. Mając na uwadze tylko jednostkowe cele indywidualiści dopasowuja do nich odpowiednie środki, a niekiedy sa to środki minimalne, dysponowane przez rozum instrumentalny. Jego zdaniem indywidualista poszukuje najbardziej ekonomicznych form, by osiagnąc osobiste cele i cały czas ewoluuje w kierunku narcyzmu skłonny mniemać, że samorealizacja to najważniejszy cel życia i jeśli system mu to umożliwia, jest dla niego dobry ${ }^{38}$. Jest bardzo podatny na wiarę w dynamiczny mit „pełni życia”, swoistą wizję zbawienia proponowana przez kulturę masowa, która w przaśna codzienność wnosi poczucie kompensacji przez posiadanie dóbr statusowych, ale także możliwość identyfikacji z cierpiącymi, kochającymi bohaterami filmów i seriali, co desublimuje pragnienie dobra, szlachetności. Tu warto dodać, iż socjologowie zauważają dużą łatwość utożsamiania się z powieściowymi i filmowymi postaciami prowadzacca do tego, że sztuczne problemy tych postaci staja się często ważniejsze niż ich własne, a konsekwencje takich identyfikacji bywają zabójcze dla codziennych więzi i zależności, choć taka postać indywidualizmu nie odpowiada formie „klasycznej”, o ile taka istnieje. Pomijając częsty amoralizm indywidualisty zauważamy i to, że w jego przypadku poszukiwania pełni idą w dwóch kierunkach. Ważniejszym zdaje się spełnienie przez dobra materialne, ale symetrycznie indywidualista za wszelką cenę chce dowieść, że jest prawdziwie upodmioto-

${ }^{37}$ G. Picht, Odwaga utopii, s. 191.

${ }^{38}$ Ch. Taylor, Etyka autentyczności, Kraków 1996, s. 11. 
wiony, wie wiele, a może nawet wszystko, że spełnia się w emocjach, choćby były to złe emocje, takie jak radość górowania nad innymi.

Liczni krytycy cywilizacji technicznej na jej etapie informacyjnym zgodnie i od dawna suponuja, że człowiek staje się duchowym kaleka, strach zaś, lęk przez głębszymi uczuciami, powinnościami rodzinnymi, bierność, brak spontanicznej radości to najwidoczniejsze symptomy wewnętrznego obumierania jednostki, które determinuje rosnący pasywizm społeczny, a jest to dla nich swoiste sprzężenie zwrotne. Coraz częściej i głośniej mówi się o dysjunktywnej, destruktywnej roli strachu, zwłaszcza przed degradacją społeczna, a wiemy już, że strach właśnie przesądza o zamykaniu się człowieka najpierw w jego twierdzy - mieszkaniu, a potem w sobie. Człowiek porażony strachem staje się jednostka postawiona poza społecznościa, a winę za to ponosi przede wszystkim system polityczny i sami politycy, dla których często strach jest skuteczna bronią w podporządkowywaniu ludzi. W takim stanie człowiek staje się dysfunkcjonalny. Takich, pełnych strachu jednostek nie przejma konceptualizacje nasycone podejrzanym altruizmem, tak często artykułowane przez polityków. Nie mogacc osiagnąc indywidualnego spełnienia nie będa zdolne uczynić niczego dla dobra wspólnego, choć będą dysponowały takimi możliwościami, a one są tylko drobinami, czastkami „samotnego tłumu”.

Nawet jeśli za progiem nowego millenium, który przekroczyliśmy z ogromnymi nadziejami na potocznie rozumiany postęp, pojawią się nowe, rewelacyjne i rewolucyjne rozwiązania tyczące jednostek, to i tak czeka je tysiąc jeszcze niewiadomych, nowych zagrożeń, a z wieloma starymi nie zdołamy uporać się tak szybko, jak choćby z tymi, które za sprawą niespełnień wciąż są zmorami naszego czasu, a między nimi z gwałtem, przemoca, brakiem wartości, który to brak widać zwłaszcza w doborze celów implikujących działania. Tymczasowość, modularyzm, konformizm i fanatyzm stają się zagrożeniami, które trzeba postrzegać jako poważne i rzeczywiste, zauważajacc i to, jak lekceważono je przed jeszcze niewielu laty, kiedy jednostka wraz z takimi cechami znajdowała się na drugim planie zainteresowania polityków i badaczy. Załamało się społeczeństwo drugiej fali - alarmował swego czasu tak niedoceniany A. Toffler, który utrzymywał, że poczyna nam brakować wyraźnych odniesień do struktury świata, jakimi w społeczeństwie drugiej fali były: rodzina, obyczaje, hierarchie statusu, zrozumiałe stosunki władzy i zależności. A my nie zauważamy tego, że na naszych oczach rodzi się nowa cywilizacja z nowymi kształtami życia gospodarczego, politycznego, a nie chcemy, nie potrafimy jej konstruować, fatalistyczni od setek lat ${ }^{39}$.

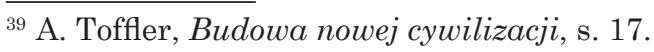


W zasadzie dysputa o antroposferze, czy psychosferze to polemika wokół statusu człowieka dnia dzisiejszego, ale żadnemu z dyskutujacych nie mogło udać się pominięcie projekcji w jutro. Choć pojawiło się wiele interesujących sugestii traktujących o jutrze, to żaden $\mathrm{z}$ teoretyków nie pokusił się o próbę naszkicowania portretu człowieka naszego już tysiąclecia, choć nader często, ale ogólnikowo, sygnalizowano taką konieczność i stąd nie wiadomo, kogo sytuuje się w tym „jutrze”. O wiele łatwiej nam iść, kiedy widzimy pożądany, akceptowany punkt dojścia, tak więc zdrowy rozsądek nakazuje kreowanie takich modeli człowieka, z którymi moglibyśmy się, nie tyle utożsamiać, co porównywać, modeli dynamicznych, bo dualny człowiek jest zmienny, do czego nie musimy się przekonywać. Orientacja prospektywna jest możliwościa wbudowania w nowy świat mąrych, przemyślanych innowacji, a wymaga umiejętności alternatywnego, probabilistycznego, holistycznego myślenia i są to sugestie zdające się być koniecznością dla polityki społecznej naszego czasu. W jakiejś mierze są już nimi dla ludzi nauki, ale już nie dla polityków. Ci potrafią nawet dekretować takie rozwiązania, ale bez wyrazistej woli działania.

Postulaty takich zmian zdają się bezdyskursywne, ale wychowanie takiego człowieka, który, myśląc o samozbawieniu, będzie chciał także zbawiać świat, wymaga wręcz rewolucji i o takiej od lat mówili i mówia uczestnicy prac Klubu Rzymskiego. Autorzy jednego z głośnych Raportów przed trzydziestu laty alarmowali zauważając powiększanie się „luki ludzkiej” ${ }^{40}$. Wedle nich człowiek, nie potrafiąc zrozumieć zmian świata, coraz bardziej oddala się od niego, staje się przedmiotem, a przedmioty nie dokonują rewolucji. Zjawiskiem przybierającym postać kataklizmu jest dyfuzja tożsamości i tożsamość lustrzana, a bardzo niepokoić moga preferowane dziś hierarchie wartości kultywowane przez środki masowego przekazu i upowszechniajace się bardzo szybko za sprawa rytualizacji. Zanikaja hierarchie kreatywne: sokratejska, prometejska, apollińska, a wszechobecne stają się te nastawione na wygodne życie, konsumpcjonizm, żądzę panowania nad innymi, czyli dionizyjska i heraklejska. Istotne jest także powiększanie się luk między umownymi Północą i Południem czyniące wzajemne zrozumienie co najmniej bardzo trudnym, o ile już nie niemożliwym, a takim się zdaje, jeśli konfrontujemy poziomy spełnienia i światy wyobrażeń zbiorowych.

Z pewnością takie alarmy ostrzegające przed tym, co potocznie zwie się dehumanizacja, są potrzebne, choć w tym przypadku przywołuje się groźby, które stawały przed dualnym człowiekiem chyba od „zawsze”.

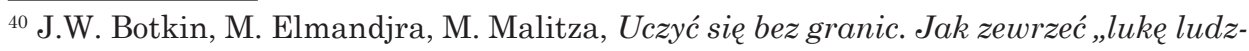
$k a$, Warszawa 1982. 
Poszukujący pełnego spełnienia ludzie obierali te drogi trwając na nich w opozycji do obierających inne i przez wieki zdaje się utrzymywać stan równowagi, jakaś naturalna homeostaza. Nie znaczy to, że nie powinniśmy wspierać te najbardziej pożądane wzory. A. Peccei, długoletni prezes Klubu Rzymskiego twierdził z całym przekonaniem, że tak i chyba nie bardzo grzeszył idealizmem. Wedle niego powinniśmy korygować ramy antroposfery przez tworzenie swoistych imperatywów, a oto one:

- jakość populacji jest ważniejsza od wielkości;

- obowiąziem każdego pokolenia jest zostawianie lepszego świata następcom;

- świadomość gatunkowa powinna zyskać prymat nad narodowa, klasowa;

- odpowiednia ilość rozstrzygnięć ponadnarodowych tyczących antroposfery jest konieczna dla dalszego rozwoju;

- rozwój człowieka powinien mieć charakter antycypujący i przygotowujący do przyszłości, w przeciwieństwie do ewolucji, która dokonuje się przez reakcje i adaptacje ${ }^{41}$.

Nieżyjący już prezes Klubu Rzymskiego kreślił szerokie ramy, które wypełniać mieli socjologowie, psychologowie, historycy, a owe ramy w jakimśs stopniu oznaczały dyrektywy i propozycje nowego holizmu, immanentyzmu, naturalizmu - sugerowanych w jego Human Quality. Wedle niego człowiek przyszłości powinien postrzegać świat jako system naczyń połączonych, zdawać sobie sprawę z tego, że nie wolno mu lekceważyć symptomów niekorzystnych zjawisk, gdziekolwiek by się pojawiły. Powinien wreszcie poczuć się mieszkańcem ziemi i wziąć na siebie odpowiedzialność za jej losy, spełniać się w wielkiej, ziemskiej wspólnocie i dopiero potem myśleć o sobie. Poza tak rozumianym holizmem Peccei postulował także konieczność propagowania nowego naturalizmu nawiązując do klasyków tego nurtu pedagogiki, zwłaszcza Pestalozziego. Nowy immanentyzm zaś to swoista reinterpretacja arystotelesowskiego hylemorfizmu, podkreślanie konieczności autokreacji człowieka naszej doby, człowieka który sam czyni wszystko, by odkryć w sobie to, co jest jego treścią i tym sposobem spełnić się w życiu. Takie rozwiązania propagował także M. Foucault nazywając je hermeneutyka „technik siebie” ${ }^{2}$. Obie propozycje, nie dość, że nieznane szerokim grupom, to wymagające dużego wysiłku intelektualnego, emocjonalnego i raczej nie rokujace spełnienia w takich wymiarach.

Poprzez idee „rewolucji ludzkiej”, „nowego humanizmu” poczęto propagować przekonanie, że pierwszym krokiem prowadzącym do wyj-

\footnotetext{
${ }^{41}$ A. Peccei, Przyszłość jest w naszych rękach, s. 204-205.

${ }^{42}$ M. Foucault, Filozofia, historia, polityka, Warszawa 2000, s. 248.
} 
ścia z wyobcowania, zagubienia, jest inspirowanie rozwoju „krytycznej świadomości jednostki”. By zajać jakąolwiek postawę wobec własnego losu człowiek współczesny musi wpierw osiagnać pełną świadomość sytuacji, w jakiej się znalazł. Dopiero na tym gruncie może podjąc próbę jej przekroczenia, pod warunkiem, że będzie w stanie znaleźć i określić nowe jakościowo cele i potrzeby. To swoisty imperatyw dla tych idealistów, którzy suponuja, że społeczne i polityczne życie Zachodu musi zostać zmienione przez rewolucję nowych nadziei ${ }^{43}$. Inaczej grozi destrukcja zaufania w system społeczny, upadek istniejacych zawiąków społeczeństwa obywatelskiego, co oznaczać może także utratę nadziei na zbawienie w społeczności i poddanie się politycznym traderom. Konsekwencją takiej utraty będzie społeczna atomizacja i zmiana form władzy - mówiono przed laty i te konsekwencje widzimy dziś w formach i treściach demokracji sterującej dziś w kierunku tego „wodnistego cezaryzmu”. Ale jak można sobie wyobrazić propagowanie takiej „krytycznej” świadomości? Kto ma to robić? Pytając o to, zauważymy, że tu znowu mamy zamknięte koło. Goethe powiedział, że mielibyśmy dobrze wychowane dzieci, gdyby ich rodzice byli dobrze wychowani. A tu?

Można mieć wątpliwości do niektórych z powyższych propozycji, ale chyba jednak nowa psychosfera, jej dyskutowanie i próby tworzenia sa koniecznościa, jeżeli zważymy rosnącą podatność na hasła populistyczne, fundamentalizmy, rosnący chaos w stosunkach międzynarodowych, irytujące formy poprawności politycznej i rozszerzenie rzekomo demokratycznych wolności sięgających - zdaniem niektórych - homodyktatury. Początki tych zjawisk bywały zwykle lekceważone przez wielu ludzi nauki traktujących je jako akcydensy, czasami jako przejawy i objawy „dziecięcych chorób”. Nie dostrzegano w tym rosnacych dysproporcji między zanikająca racjonalnością a rosnąca wiara immanentna. Człowiek wiary, powodowany, sterowany z zewnątrz jest jednak tylko z pozoru powolnym, potulnym przedmiotem rządzenia. Jego wiara, zawsze generowana wizjami lepszego jutra, może pchać go do zachowań nieprzewidywalnych, jeśli znajdą się organizatorzy wyobrażeń zbiorowych, którzy wskażą mu drogę, jaką on uzna za swoja. Jest nieobliczalny, nawet fanatyczny wtedy, kiedy uwierzy, że o jego tożsamości przesądza głęboka wiara w jakieś ideały i kiedy znajdą się umiejętni organizatorzy jego wyobrażeń zbiorowych. O takiej nieobliczalności przekonuja wielkie rewolucje - dzieła ludzi z pozoru uprzedmiotowionych.

Póki co pojawiły się ledwie wstępy do terapii obejmujących tylko fragmenty antroposfery, ale nie mogły być bardziej konkretne od dia-

${ }^{43}$ R. Rorty, Contingency, Irony and Solidarity, Cambridge 1989, s. 64. 
gnoz, których spotykaliśmy i spotykamy setki, a tyczą one tylko one człowieka białego, sytego świata i są propozycjami mówiącymi tylko o treściach, nie formach akulturacji i socjalizacji, a to jednak zbyt mało. Różnią się, choć można zauważyć zgodność teoretyków, co do tego, że zastane warunki społeczne są wręcz nieludzkie, że etyka zakładająca że to, co jest dobre dla społeczeństwa, jest też dobre dla jednostki, przeżyła się nieodwołalnie. Nieludzkie nie w tym sensie, że nie odpowiada wiecznej, niezmiennej naturze człowieka, ale w tym, że ramy, jeszcze nowoczesnych, społeczeństw stały się zbyt ciasne dla wszechstronnego rozwoju jednostek, że systemy polityczne nie stwarzaja dostatecznej przestrzeni dla ogromnych potencjałów jednostkowych, a indywidualność ma niezbywalne prawa do rozwoju tych potencjałów.

Diagności krytykujący zastany świat nie szukali zbyt często leków dla dnia dzisiejszego i zdecydowanie woleli rzutować w przyszłość konieczność opracowania np. nowej etyki globalnej i modelu człowieka prometejskiego, przewidującego, tworzącego i świadomego aktu tworzenia, obdarzonego wyobraźnia polityczna - człowieka wtórnego renesansu, a ten ma się pojawić ex nihilo. Wedle idealistów taki człowiek powinien przedkładać bycie nad posiadanie i przejawiać wielostronny aktywizm wynikający z wewnętrznej, nie narzuconej potrzeby. Humanizm, który był spoiwem zachodniego świata, który ukształtował jego polityczne kształty, musi znowu wypełnić umysły po to, by zachód znowu stał się stwórczy - sugerował dawno temu M. Foucault, idealizując jak wielu podobnych mu diagnostów ${ }^{44}$. I nietrudno zauważyć, iż owego humanizmu jest coraz mniej i mniej.

Foucault należał do grona kreatywnych optymistów, a tacy stanowili jednak zdecydowana mniejszość w ostatnich dekadach, choć dawne koncepcje P. L. Bergera z jego Homeless Mind były ciekawą próbą odkrywania możliwości stojących przed człowiekiem przyszłości w okresie intuicyjnie pojmowanego, wyczuwanego przełomu. W późnych latach 70. autor optymistycznie sugerował, że człowiek epoki postindustrialnej będzie spełniał się w pracy dla społeczności, że będzie cechował się otwartością oznaczająca stała gotowość na zmiany, na adaptację w nowych warunkach, a widzimy że jest gotowy na zmiany jak te żaby Handy'ego. Nadto, będzie refleksyjny, stale analizujący siebie, swój stosunek do innych oraz osiagnie pełna, dojrzała tożsamość, która przełoży się na owocną partycypację polityczną. Być może taka możliwość była wówczas, po rewolcie kontrkulturowej lat 60. otwarta, ale dziś widzimy ją jako jeszcze jedna niewykorzystana, a sugestie Bergera jako przejaw idealizmu człowieka jednak mocno oderwanego od życia. Podobnie wy-

${ }^{44}$ M. Foucault, Language, Counter-Memory, Practice, Cornell University 1977, s. 221. 
glądały wysiłki uniwersalistów kreujących etykę globalną której założenia prezentujemy:

- każda istota ludzka posiada niezaprzeczalna i nienaruszalna godność: poszczególne państwa i osoby są zobowiązane do poszanowania i ochrony godności każdej istoty ludzkiej;

- żadna osoba ani organizacja społeczna nie może być wyłaczona spod praw i obowiązków moralnych; wszyscy - osoby i twory społeczne - sa zobowiązane do czynienia dobra i unikania zła;

- istoty ludzkie zostały wyposażone w rozum i sumienie - wielkim wyzwaniem dla człowieka jest działanie zgodne z głosem sumienia; wspólnoty ludzkie, państwa i inne twory społeczne są zobowiązane do ochrony i podtrzymywania swoich zdolności w tym względzie;

- wspólnoty ludzkie, państwa i inne twory społeczne, które przyczyniają się dla dobra ludzkości i świata, maja prawo do istnienia i rozwoju; wszyscy winni przestrzegać tego elementarnego prawa;

- ludzie sa częścią natury, nie żyją obok; zasady etyczne dotyczą również wszystkich innych istnien, całej reszty świata na ziemi, a nawet w kosmosie. Krótko mówiąc, niniejsza Deklaracja, stosownie do rzeczywistości, nie jest antropocentryczna, lecz kosmoantropocentryczna ${ }^{45}$.

Zdawać się może, że takie supozycje także grzeszą nadmiernym idealizmem, ale ów idealizm zaczyna prezentować się całkiem inaczej, jeśli przyjrzymy się nazwiskom firmującym idee takiego uniwersalizmu i pod nazwiskami Jana Pawła II odnajdziemy Dalaj Lamę, V. Havla, J. Habermasa, jeśli zauważymy synchronię z imperatywami autorów spod znaku Klubu Rzymskiego i wszystkimi propozycjami rewolucji ludzkiej i nowego humanizmu, zgodnymi co do konieczności przebudowy całej antroposfery XXI wieku. Autorzy Deklaracji zauważali konieczność metanoi, czyli radykalnej zmiany sposobu myślenia. Nowy człowiek musi zaczać myśleć o świecie jako całości i zacząć tworzyć dom dla wszystkich - królestwo człowieka dla człowieka, co już nieco przypomina wizje millenarystów. To już poważna „oferta” dla poszukujacych innych, lepszych światów, a takich poszukiwaczy nie brakuje, zwłaszcza wśród ludzi młodych. Ta, przedłożona na rynku idei, oferta nie znalazła jednak nabywców w świecie polityki, a bez aktywnego udziału ludzi z tego świata radykalne przemiany są tylko idealistyczna mrzonka, choć pewnie wielu młodych ludzi przyjęło takie sugestie.

$\mathrm{W}$ ujęciu ogólnym ta interpretacja uniwersalizmu obejmuje soba kategorie nadczasowe, towarzyszace człowiekowi od zarania dziejów. Owe kategorie mieszczą się w pracy, rodzinie, moralności, religii, sztu-

${ }_{45}$ Powszechna Deklaracja Światowych Zasad Etycznych, [w:] Szkoła przeżycia cywilizacyjnego, Warszawa 1997, s. 175. 
ce, edukacji, ekonomii i dają się konkretyzować. Uniwersaliści podkreślają to, że historia gatunku i kultury potwierdza istnienie wielu dominacji w nie stykających się ze sobą kulturach wyrażających się w powszechnie akceptowanych postawach, zachowaniach, co podkreślają katalogi zakazów i nakazów spotykanych we wszystkich niemal kulturach. Na takich podstawach - ich zdaniem - można zbudować świadomość uniwersalną i dla zwolenników w dobie państw narodowych, eskalacji różnej maści fundamentalizmów. Uniwersalizm jest idea scalająca, wizją permanentnego potwierdzania poczucia wspólnoty ludzkiej. Nie może to oznaczać unifikacji na wzór globalizmu ani odrzucania inności, ale jedność ponad różnicami z jak najdalej posunięta tolerancją i otwarciem na innych.

Była to próba stworzenia, a właściwie odtworzenia depozytu, na straży którego stali i stoją intelektualiści, a już teraz są nam potrzebne przemyślane i skuteczne terapie - wołał przed prawie trzydziestu laty Toffler - bo jeżeli ich nie znajdziemy, to za kilkadziesiąt lat wszyscy będziemy chorzy psychicznie i z pewnością nie uleczą nas chorzy psychiatrzy radzacy wybrać czerwona pigułkę. Radykalnie i niezmiennie prowokujacy inspirował dyskusje nad egzystencją i esencją człowieka współczesnego, nad stanami jego świadomości i postawami determinujacymi charakter i twory jego działań. Nie tylko, gdyż jego uwagi o ,adhokracji”, elitach przypadkowych, zwłaszcza w polityce, zdają się być stale potwierdzane obserwacjami. Jeśli zatracimy cele, jakie stanowia o naszym człowieczeństwie, możemy stracić także szanse zbawienia w „byciu” i pozostanie nam tylko posiadanie, które nie czyni nas szczęśliwymi, bo ono jest nienasyceniem.

Groźby stojące przed człowiekiem naszego czasu są w dużej mierze efektem kształcenia rodzącego u młodych ludzi prezentyzm i recentywizm. Przypomnijmy, że prezentyzm to przekonanie o tym, że porządek świata jest względnie niezmienny i wystarczy nam, niewyobrażalna przecież, wiedza o przeszłości będąca podstawą sądów o i w teraźniejszości. Pełni wiedzy natomiast niej jako o dobrej i złej nauczycielce życia nie maja nawet profesjonalni historycy, a zwykłym zjadaczom chleba starczyć muszę jej niewielkie ułamki. Recentywiści natomiast sa przekonani, że odpowiedzi na wszystkie pytania teraźniejszości i o teraźniejszości tkwią w właśnie w niej i rozwiązując problemy dnia dzisiejszego szukaja nowych, natychmiastowych rozwiązań, choć nie unikają takich, jakie już stosowano. Według E.T. Halla niebezpieczeństwo polega i na tym, że problemy realnego życia bywają w nauce usuwane na plan drugi, a na pierwszym pojawiaja się dalekie od praktyki rozważania filozoficzne i teoretyczne, a tym sposobem zanikają drogowskazy dla tych, którzy wciąż poszukują siebie. 
Przyglądając się swoim studentom zauważał, że w większości bywają bezradni w zetknięciu z prawdziwym życiem, ponieważ wpierw muszą wiedzieć, co zamierzają odkryć i muszą dysponować teorią lub hipoteza do sprawdzenia ${ }^{46}$. Jego zdaniem kultury z kręgu tradycji europejskiej zinstytucjonalizowały procesy uczenia się do niedopuszczalnych granic, a czyniąc to lekceważyły podstawowe atrybuty natury człowieka, wręcz naruszyły jego homeostazę uniemożliwiając mu poszukiwanie siebie w społeczeństwie.

Niezdolność do stałych, przemyślanych transgresji, do przekraczania samego siebie, zmieniania się, zdaje się być przymiotem człowieka współczesnego, choć akurat takie generalizacje najczęściej mają charakter prowokacji intelektualnej. Ale można kusić się o konstatacje, że człowiek naszego czasu nie radzi sobie nawet z działaniami obronnymi, czyli takimi, które utrzymują na stałych poziomach wartości niezbędne w codzienności. Działania obronne, zwykle powszechne, rutynowe, są nakierowane przede wszystkim na obronę sfery intymnej, osobistej, towarzyskiej, ale poza nie już nie wykraczają zbyt często. Owszem, człowiek powinien bronić swej małej stabilizacji i zwykle gotów jest na duże poświęcenie, by nie naruszano tych rewirów, ale przecież żyje $\mathrm{w}$ społeczeństwie. Czasami, koncentrując się na nieudolnej obronie, zapomina o innych koniecznościach, koniecznościach samorealizacji zmuszających do stałej konfrontacji ze światem i innymi ludźmi. Zapominajac o przekraczaniu siebie za sprawą nowych wyzwań często przyzwala na regres, a niekiedy nawet na utratę osobowości za cenę pracy, stabilizacji, małych przyjemności. Symptomy takiego regresu bez trudu zauważy u siebie większość absolwentów studiów wyższych, którzy mniemaja, że zdobyli swoje statusy na zawsze i one zapewniaja miejsce w społeczeństwie odpowiednie do ich kwalifikacji. Natomiast uświadomienie sobie konieczności stałych, kontrolowanych transgresji czyni jednostkę aktywna, zmusza do podejmowania działań, myślenia prospektywnego, zarówno w przestrzeni jednostkowej, jak i społecznej.

Komentując wysiłki antropologów, socjologów, psychologów i demografów wielu teoretyków utrzymuje, że obiektem szczególnej troski powinien stać się człowiek i myśla przede wszystkim o obywatelach „pierwszego świata”. Wedle nich brak koherentnych, racjonalnych projekcji antroposfery w skali globalnej może prowadzić w kierunku światów przeludnionych, głodnych, z nieodłącznymi od tych obrazów autorytarnymi formami władzy, pełna kontrola nad poczynaniami obywateli. Jednostki w takich państwach znów moga stać się nawet nie racjami istnienia państwa, a tylko zawadą w realizacji „wyższych ce-

${ }^{46}$ E.T. Hall, Poza kultura, s. 79. 
lów" a to dlatego, że nie są częściami zbiorowości mających swoje cele zagrożeń i je realizować.

Ilość zagrożeń stojących przed człowiekiem tego tysiąclecia zagraża prawdziwym regresem „człowieczeństwa” dla wielu myślicieli. Światu obecnemu, zdominowanemu przez hiperorganizację, grozi utrata podstawowych praw jednostki - powtarzał w swoich pracach K. Lorentz, przechodząc od śmiertelnych grzechów cywilizacji do poszukiwania prób obrony przed presja zjawisk nowej epoki wymuszających bezkrytyczne podporządkowanie się, bezmyślny konformizm, lenistwo myślowe posunięte aż po brak elementarnych pytań egzystencjalnych, poczynając od pytania o to, po co istniejemy ${ }^{47}$. Nie zadajemy już tak wielu pytań o to, czym jest szczęście przyjmując jego reglamentowane miary, zwłaszcza w wymiarze materialnym.

Wedle Lorentza jednym z największych niebezpieczeństw stających przed człowiekiem naszego czasu jest obecny charakter wrodzonych i tradycyjnych form zachowania się człowieka. Zdaniem filozofa wiele norm zachowania się człowieka jest programowane filogenetycznie, czyli sa to normy będące wrodzonymi, teleonomicznymi (sprzyjającymi zachowaniu gatunku) formami doświadczenia. Te normy sterowane sa emocjami, które Lorentz określał jako nerwowe i zmysłowe systemy powstałe przez filogeneze i utrwalone genetycznie. W naszym czasie zauważyć można, że filogenetyczne przystosowanie do nowych warunków nie nadąża za szybkimi zmianami kulturowymi. I tu pojawia się nieprzystawalność naturalnych predyspozycji człowieka do warunków kreowanych przez zmieniająca się kulturę. Owe naturalne predyspozycje, z czym nie do końca można się zgodzić, to: zamiłowanie do ładu, radość z posiadania, żądza władzy, dążenie do zajmowania coraz wyższych pozycji w hierarchii społecznej, wyczucie nadmiaru i braku, odczucie piękna i brzydoty, dobra i zła. W warunkach niemożności ich realizacji pojawiać się musi poczucie niespełnienia, obcości i człowiek sam nie jest $\mathrm{w}$ stanie rozpoznać istoty takiej alienacji, a nie mogac popada w różnego rodzaju neurozy.

Wzrastająca rozbieżność między uformowanym przez kulturę i cywilizację porządkiem społecznym a naturalnymi skłonnościami człowieka ma swoje odpowiedniki w nim samym, jest to sprzeczność duszy i umysłu - powiada Lorentz. Dusza (rozwój filogenetyczny) jakby zatrzymała się w rozwoju, podczas gdy umysł otrzymuje setki nowych bodźców z coraz szybciej zmieniającego się środowiska i nie potrafi sobie radzić $\mathrm{z}$ ich nadmiarem. W takim świecie umysł podporządkował sobie duszę traktując ją jak przeciwnika. Przyrodzona natura ludzka

${ }^{47}$ K. Lorentz, Regres człowieczeństwa, Warszawa 1986. 
została skrępowana kulturowym kaftanem bezpieczeństwa sztucznego środowiska technicznego. Wywodzące się z kultury zakazy i nakazy wręcz gwałca wrodzone programy zachowania i ten przymus eskaluje się jeszcze potęgując poczucie zagubienia. Wielkie nadzieje na przezwyciężenie filogenetycznie zaprogramowanych tendencji widział Lorentz w moralności i suponował, że przy jej pomocy można wygrać prawdziwa bitwę o przetrwanie człowieczeństwa w człowieku. Daleki od optymizmu w oglądzie przyszłości gatunku proponował powrót do niektórych, zapomnianych zwyczajów, reorientację wychowania i inne remedia,, które pozwolą na w miarę pełną homeostazę społeczności. Nie można chyba jednak odmówić zasadności jego sugestii, że mechanizmy samoobronne człowieka można generować tylko w zbiorowościach składajacych się z jednostek świadomych swego statusu.

Człowieka wciąż nazywa się zwierzęciem społecznym i bez społeczeństwa jest tylko struktura biologiczna. Aby być częścią społeczeństwa jego więzi społeczne muszą być wielorakie, bo inaczej staje się tylko cząstką stada doznająca atawistycznych emocji, zdecydowanie innych od wyobrażeń o nich konstruktywistów kulturowych ${ }^{48}$. A powracając do zwierzęcości w świecie wyrafinowanej techniki, człowiek daje łatwo soba powodować, przyjmować implantowane w świat wyobrażeń takie, z którymi utożsamiaja go inni. Jako zewnątrzsterowny przedmiot oczekuje, poszukuje z pomoca innych nowych źródeł zmutowanych norm i zwykle odnajduje je w środkach masowego przekazu, staje się kibicem, a kibica nie interesuja diagnozy i terapie, bo tymi zajmuja się prawdziwi aktorzy wielkiego show. Staje się indyferentny moralnie, religijnie, politycznie, a indyferentyzm przekreśla tkwiące w nim możliwości, a nawet gorzej, bo nie pozwala na ich odkrycie, po części za sprawą sublimacji obcości w sobie ${ }^{49}$. Człowiek rodzi się i umiera jako forma, która zbyt często nie wypełnia się żadną treścia - takie konstatacje słyszymy dziś zbyt często, by traktować je tylko jako ozdobniki. $\mathrm{Z}$ lenistwa w poszukiwaniach tego, co w nas właściwe pozostajemy soba takimi, jakimi nie powinniśmy być.

Jedna z form współczesnego spełniania się w dobrach jest marketing personality, której reprezentacje charakteryzują się traktowaniem własnego życia jako towaru, który cały czas prezentuje się na rynku życia, w niemal wszystkich sytuacjach życiowych. Marketing personality traktuje swoją towarowość nader poważnie i jest uwrażliwiony na każde drgnienie rynku. Jego gotowość ulegania różnym konformizmem, modom i fascynacjom jest ogromna, jak wielka jest umiejętność mimi-

${ }^{48}$ K. Oatley, J.M. Jenkins, Zrozumieć emocje, Warszawa 2003, s. 55.

${ }^{49}$ B. Waldenfels, Topografia obcego, Warszawa 2002, s. 27. 
kry. Taka osobowość nie na własnych przekonań ani tożsamości, nawet nie potrafi kochać ani nienawidzić - zauważał Fromm opisując całkiem trafnie „charakter merkantylny” ${ }^{50}$.

Chcąc zmienić, wzbogacać postaci zbawienia w doczesności powinniśmy przyjąć, że żyjemy w świecie, w którym cały czas wyłania się Nowe - mówił J. Habermas ${ }^{51}$ a także posiasść umiejętność mierzenia się z wyzwaniami przyszłości. Można bez końca analizować przeszłość, jak czynimy to teraz przekonani do takich zabiegów, ale prawie każda przyszłość można zaprojektować w Królestwie Możliwości i na tym polega różnica między znoszeniem przyszłości a cieszeniem się nią - dodawał E. de Bono, zapominając o tym, że takie próby projektowania muszą brać pod uwagę wszystko, co niesie nieprzewidywalne jutro. Ale przyszłość należy do tych, którzy potrafia ją sobie wyobrazić i to w setkach kształtów, kształtów, z których nie wszystkie staną się realnościa. Pamiętając o tym chyba powinniśmy przypominać sobie motto z książki S. Levitta - jeżeli żaden z nas nie potrafi przewidzieć przyszłości, najlepsze, co możemy zrobić, to przygotować się na to, by odpowiedzieć na wszystko, co przyniesie nam przyszłośćc ${ }^{52}$.

Ta przyszłość nie budzi wielkich nadziei, jakie spotykaliśmy $\mathrm{w}$ okresie choćby fine de siecle. Niepewność, jaka jest miara naszego czasu, znowu wpływa na pojawienie się w wyobrażeniach zbiorowych wojny - najstarszej ikony ludzkości, wraz z przekonaniem, że tylko taki kataklizm znowu przywróci homeostazę. Dla jednych będzie to nic innego jak walka o przetrwanie, jeśli wszystkie konflikty końca wieku były konfliktami o energie $e^{53}$. Dla innych zaś hiperkonflikt, który ogarnie cały świat, a będzie swego rodzaju koniecznością dziejową ${ }^{54}$. Taka postać wiary, przy przypomnieniu niespełnionego proroctwa Majów o końcu świata z 2012 roku jest wyrazem bezradności i z takiego stanu może nas wyrwać tylko wielkie wyzwanie. Jakie?

${ }^{50}$ E. Fromm, Mieć czy być?, Poznań 2003, s. 226.

51 J. Habermas, Filozoficzny dyskurs nowoczesności, Kraków 2000, s. 15.

${ }^{52}$ S. Levitt, Quality is just a Beginning, New York 1994.

${ }^{53}$ M. Harris, Energy and Security, [w:] Grave New World. Security, Challenges in the $21^{\text {st }}$ Century, ed. M.E. Brown, Washington 2003, s. 159.

${ }^{54}$ J. Attali, Krótka historia przyszłości, Warszawa 2008, s. 214. 



\section{Bibliografia}

Aberbach D., Charisma in Politics. Religion and the Media, London 1996.

Aldridge A., Konsumpcja, Warszawa 2006.

Alexander D., White R.S., Nauka blisko wiary, Warszawa 2006.

Alfaro J., Teologia postepu ludzkiego, Warszawa 1971.

Alger D.E., The Media and the Politics, Belmont 1996.

Allen S., Kultura newsów, Kraków 2006.

Alterman E., What Liberal Media?, New York 2004.

Andersen B., Wspólnoty wyobrażone, Kraków 1997.

Appadurai A., Nowoczesność bez granic. Kulturowe wymiary globalizacji, Kraków 2005.

Arendt H., The Life of the Mind, New York 1978.

Arendt H., Wola, Warszawa 2002.

Argyle M., Psychologia szczęścia, Wrocław 2004.

Ariely D., Potęga racjonalności. Ukryte sity, które wptywaja na nasze decyzje, Wrocław 2009.

Aron R., Opium intelektualistów, Warszawa 2000.

Aronson E., Człowiek istota społeczna, Warszawa 2002.

Ash T.G., The Polish Revolution. Solidarity, New York 1999.

Ash T.G., Free World, New York 2005.

Ashcroft J., Making a Killing, London 2006.

Atkins J.B., Journalism as a Mission, [w:] The Mission. Journalism, Ethics and the World, ed. J.B. Atkins, Iowa State University 2002.

Attali J., Krótka historia przyszłości, Warszawa 2008.

Aveni A., Poza kryształowa kula, Poznań 2001.

Baader R., Śmiercionośne myśli. Dlaczego intelektualiści niszcza nasz świat, Wrocław 2009.

Bacon F., Eseje, Warszawa 1958

Baczko B., Wyobrażenia społeczne. Szkice o nadziei i pamięci zbiorowej, Warszawa 1994.

Balibar E., Trwoga mas. Polityka i filozofia przed Marksem i po Marksie, Warszawa 2007.

Bakan J., Korporacja. Patologiczna pogoń za zyskiem i władza, Warszawa 2006. 
Ball T., Dagger R., Ideals and Ideologies, New York 2002.

Bańka J., Przeciw szokowi przyszłości, Katowice 1977.

Bańka J., Ja, teraz, Katowice 1983.

Baring A., Czy Niemcom się uda? Pożegnanie złudzeń, Wrocław 2000.

Barker D.C., Rushed to Judgement, New York 2002.

Basarir Y., Text of Tension and Dissociation, [w:] Culture Agonistes. Debating Culture, Rereading Texts, eds T. Tsimpsouki, A. Spiropoulu, Bern 2002.

Baudrillard J., Ameryka, Warszawa 1998.

Baudrillard J., Procesja symulakrów, [w:] Nowe media w komunikacji społecznej w XX wieku, Warszawa 2002.

Baudrillard J., Społeczeństwo konsumpcyjne. Jego mity i struktury, Warszawa 2006.

Bauman Z., Wolność, Kraków 1995.

Bauman Z., Wieloznaczność nowoczesna - nowoczesna wieloznaczność, Warszawa 1995.

Bauman Z., Etyka ponowoczesna, Warszawa 1996.

Bauman Z., Pracodawcy i ttumacze, Warszawa 1998.

Bauman Z., Ponowoczesność jako źródto cierpień, Wrocław 2000.

Bauman Z., Globalizacja, Warszawa 2000.

Bauman Z., Praca, konsumpcjonizm i nowi ubodzy, Kraków 2006.

Barwell S., Bowles K., Border Crossing, [w:] The Cyberculture Reader, ed. D. Bell, New York 2000.

Beard Ch., The American Spirit. A Study of the Idea of Civilization in the United States, New York 1942.

Beck U., Społeczeństwo ryzyka, Warszawa 2002.

Beck U., Wtadza i przeciwwładza w epoce globalnej. Nowa ekonomia polityki światowej, Warszawa 2005.

Bell D., The Cultural Contradiction of Capitalism, London 1979.

Bellah R.N., Beyond Belief, California University 1991.

Bellamy E., W roku 2000, Warszawa 1890.

Bellamy E., Equality, London 1910.

Bender T., Intellectual and Cultural History, New York 1997.

Benedict M., Cyberspasm. First Steps, [w:] The Cyberculture Reader, ed. D. Bell, New York 2000.

Bennet W.L., The Politics of Illusion, Washington 1996.

Bercovitch S., The Puritan Origins of the American Self, New Haven 1975.

Bercovitch S., The American Jeremiad, Wisconsin 1878.

Berger P.L., Rewolucja kapitalistyczna, Warszawa 1995.

Bergson H., Dwa źródta moralności i religii, Kraków 1993.

Berlin I., Zmyst rzeczywistości, Poznań 2002.

Berry A., Nastepne 500 lat, Warszawa 1997.

Besancon A., Przekleństwo wieku, Warszawa 2000.

Birnbacher D., Odpowiedzialność za przyszłe pokolenia, Warszawa 1999.

Bjerke B., Kultura a style przywództwa, Kraków 2004.

Bloch R., Visionary Republic. Millenial Themes in American Thought, Cambridge 1985.

Blumhofer E.L., Restoring the Faith, Chicago 1993.

Boaz D., Libertarianizm, Poznań 2005.

Bocheński J.M., Lewica, religia, sowietologa, Warszawa 1996.

Bogunia-Borowska M., Śleboda M., Globalizacja i konsumpcja. Dwa dylematy wspótczesności, Kraków 2003.

Bohme H., O niewyobrażalności teraźniejszości i o przyszłym miejscu człowieka, [w:] Kultura techniki, wybór E. Schulz, Poznań 2001. 
Boorstin D.J., Poszukiwacze. Dzieje ludzkich poszukiwań sensu świata, Warszawa 1998.

Boxel M. von, Encyklopedia głupoty, Warszawa 2005.

Boyes R., Cywiński B., Sezon na Europę, Warszawa 2003.

Bógdał-Brzeińska A., Gawrycki M.F., Cyberterroryzm i problemy bezpieczeństwa informacyjnego we wspótczesnym świecie, Warszawa 2003.

Braidotti R., Transpositions, Cambridge 2007.

Brighthouse H., Sprawiedliwość, Warszawa 2007.

Bronowski J., Źródta wiedzy i wyobraźni, Warszawa 1984.

Brooks S.G., Producing Security. Multinational Corporations, Globalization and the Changing Calculus of Conflict, Princeton 2005.

Brumlik M., Gnostycy. Marzenia o samozbawieniu człowieka, Gdynia 1999.

Brzeziński Z., Plan gry USA-ZSRR, Warszawa 1990.

Brzeziński Z., Polska scena obrotowa, [w:] Wizje Polski, red. A. Targowski, Warszawa 1995.

Brzeziński Z., Wybór. Dominacja czy przywództwo, Kraków 2004.

Brzozowska B., Gen X. Pokolenie konsumentów, Kraków 2005.

Buel R., Freedom and Press in Revolutionary America, [w:] The Press and the American Revolution, eds B. Boilyn, J.B. Hench, Boston 1981.

Burke J., Ornstein R., Ostrze geniuszu, Warszawa 1999.

Burke K., Language as Symbolic Action, Berekeley 1966.

Burszta W., Dwie Europy, [w:] Dylematy tożsamości europejskich pod koniec drugiego tysiaclecia, red. J. Mucha, W. Olszewski, Torun 1997.

Butler J., Awash in the Sea of Faith. Christianizing the American People, Harvard 1990.

Cameron R., Historia gospodarcza świata, Warszawa 2001.

Cameron F., US Foreign Policy after the Cold War, New York 2002.

Campbell J., The Community Reconstruct. The Meaning of Pragmatic Thought, Chicago 1992.

Canetti E., Masa i władza, Warszawa 1996.

Capra F., Punkt zwrotny, Warszawa 1987.

Carnap R., Wprowadzenie do filozofii nauki, Warszawa 2000.

Carrithers M., Dlaczego ludzie maja kultury, Warszawa 1994.

Carroll P.N., Noble D.W., The Free and the Unfree, New York 1988.

Cassirer E., Esej o człowieku, Warszawa 1977.

Castells M., Społeczeństwo sieci, Warszawa 2007.

Castoriadis C., The Imaginery Institutions of Society, [w:] Literature and the Political Imagination, ed. J. Horton, London 1996.

Cavell C., The Seanse of Walden, Chicago 1992.

Chardin, T. de, The Future of Man, New York 2004.

Charon J.M., Ten Questions. A Sociological Perspective, Minnesota State University 2001.

Chaunu P., Cywilizacja Oświecenia, Warszawa 1989.

Chełpa S., Witkowski T., Psychologia konfliktów, Warszawa 1999.

Chesterton G.K., Ortodoksja, Warszawa 1998.

Chilton P.A., Schaffner Ch., Politics as Text, Amsterdam 2002.

Chomsky N., Class Warfare. Interviews with David Barsamian, Monroe 1996

Chomsky N., Media Control, New York 2002.

Chomsky N., Language and Politics, London 2004. 
Cialdini R.B., Wywieranie wptywu na ludzi. Teoria i praktyka, Gdańsk 2003.

Cioran E., Historia i utopia, Warszawa 1997.

Cioran E., Księga złudzeń, Warszawa 2004.

Cioran E., Upadek w czas, Warszawa 2008

Clecak P., America's Quest of the Ideal State, New York 1983.

Clifford P., Krótka historia końca czasów, Warszawa 1999.

Coate R.A., The Future of United Nations, [w:] U.S. Policy and the Future of the United

Nations, ed. R.A. Coate, New York 1994.

Coil H.W., The History of Liberty, New York 1965.

Condillac E.B. de, Traktat o wrażeniach, Warszawa 1958.

Coniff R., Korporacyjne zwierze, Warszawa 2006.

Conquest R., Uwagi o spustoszonym stuleciu, Poznań 2002.

Conrad J., Człowiek, rasa, kultura, Warszawa 1971.

Corm R., Religia i polityka w XXI wieku, Warszawa 2007.

Corner J. Harvey S., Television Times, London 1996.

Crick B., Wobronie polityki, Warszawa 2004.

Cullen J., The American Dream, Oxford 2003.

Cuomo F., Wielkie proroctwa, Kraków 2004.

Cutler H.C., Sztuka szczęścia, Poznań 2005.

Czapiński J., Makropsychologia czyli psychologia zmiany społecznej, [w:] Jednostka $i$ społeczeństwo, red. M. Lewicka, J. Grzelak, Gdańsk 2002.

Dahl R.A., A Preface to Democratic Theory, Chicago 1956.

Dahl R.A., Dillemas of Pluralist Democracy, London 1982.

Dahl R.A., O demokracji, Kraków 2000.

Dahl R.A., On Political Equality, Yale University 2006.

Dahrendorf R., Reflections on the Revolution in Europe, London 1990.

Damasio A.R., Tajemnice świadomości, Poznań 2000.

Danielewicz Z., Między kościołem a sekta, Warszawa 1999.

Davies M.H., Empatia. O umiejętności wspótdziałania, Gdańsk 1999.

Davis E., Techgnoza, Poznań 2002.

Davis M.H., Empatia. O umiejętności współdziałania, Gdańsk 1999.

Dawkins R., Bóg urojony, Warszawa 2008.

Dawson Ch., Postep i religia, Warszawa 1958.

Dayan D., Katz G., Media Events. The Live Broadcasting of History, Cambridge 1994.

Debord G., Społeczeństwo spektaklu, Warszawa 2006.

Delbanco O., The Puritan Ordeal, Harvard 1989.

Delpech T., Powrót barbarzyństwa, Warszawa 2008.

Delumeau J., Cywilizacja Odrodzenia, Warszawa 1987.

Demerath N.J., Crossing the God. World Religions and Worldly Politics, London 2001.

Dennet D.C., Natura umystów, Warszawa 1997.

Dennet D.C., Odczarowanie. Religia jako zjawisko naturalne, Warszawa 2008.

Derber Ch., Corporation Nation, New York 2000.

Dewey J., Democracy and Education, New York 1966.

Dijk T. van, Ideology. A Mutlidisciplinary Approach, London 2000.

Dijk T. van, Elite Discourse and Racism, Newbury Park 1993.

Disch L.J., The Tyranny of Two Party System, Cambridge 2002.

Donhof M.G., Ucywilizujmy kapitalizm. Granice wolności, Warszawa 2000.

Drakulic S., How we Survived Communism and even Laughed, New York 1992.

Drucker P.F., Społeczeństwo pokapitalistyczne, Warszawa 2001. 
Duffield M., Global Governance and the New Wars, London 2007.

Duignan P., Sann L.H., The USA and the New Europe, Oxford 1994

Dymkowski M., Wprowadzenie do psychologii historycznej, Gdańsk 2003.

Dziak W.J., Kim Ir Sen, Warszawa 2001.

Easterbrook N., State Heterotopia, [w:] Political Scence-Fiction, eds D.M. Hassler, C. Wilcox, Columbia University 1977.

Eatwell R., Faszyzm. Historia, Poznań 1999.

Eberlein B., Reconstituting Political Authority in Europe, [w:] Complex Sovereignity, eds E. Grande, L.W. Pauly, Toronto 2005.

Eckholm E.P., Człowiek $i$ środowisko, Warszawa 1987.

Eco U., Nieobecna struktura, Warszawa 1996.

Eco U., Semiologia życia codziennego, Warszawa 1998.

Eco U., Dzieło otwarte. Forma i nieokreśloność w poetykach wspótczesnych, Warszawa 1994.

Edelman M., Constructing the Political Spectacle, Chicago 1988.

Elasmar M.C., The Impact of International Television. A Paradigm Shift, London 2003.

Eliade M., Traktat o historii religii, Warszawa 2000.

Eliade M., Sacrum i profanum, Warszawa 1999.

Elliott A., Koncepcje ,ja “, Warszawa 2007.

Ellul J., The Technological Society, New York 1964.

Equal M., Divergent Paths, How Culture and Institutions have Shaped North American Growth, New York 1996.

Erazm z Rotterdamu, Trzy rozprawy, Warszawa 1960.

Erickson E.H., Dopetniony cykl życia, Poznań 2002.

Ernest J., „Ideology” and the Economic Interpretation of the Revolution, [w:] The American Revolution, ed. A.F. Young, Illinois University 1979.

Etzioni A., From Empire to Community, New York 2004.

Ewen S., All Consuming Images, New York 1988.

Falk R.A., A Study of Future Worlds, Amstardam 1975.

Fath S., Religia w Biatym Domu, Warszawa 2007.

Fenton S., Etniczność, Warszawa 2007.

Filipiak M., Homo communicans, Lublin 2004.

Finkielkraut A., Zagubione człowieczeństwo, Warszawa 1999.

Fisze J., Understanding Popular Culture, New York 2007.

Fitoussi J., Rosanvalon P., Czas nowych nierówności, Kraków 2000.

Flanigan W.H., Zingale N.H., Political Behavior of American Electorate, Boston 1979.

Fogler J.P., Pode M.S,, Konflikt i interakcja, [w:] Mosty zamiast murów. O komunikowaniu się między ludźmi, red. J. Stewart, Warszawa 2002.

Foster J.B., In Defense of History, [w:] In Defense of History. Marxism and Postmodern Agenda, eds E.M. Wood, J.B. Foster, New York 1997.

Foucault M., Language, Counter-Memory, Practice, Cornell University 1977.

Foucault M., Nadzorować i karać. Narodziny więzienia, Warszawa 1998.

Foucault M., Historia seksualności, Warszawa 1995.

Foucault M., Filozofia, historia, polityka, Warszawa 2000.

Foucault M., Stowa i rzeczy. Archeologia nauk humanistycznych, Gdańsk 2006.

Foucault M., Security, Territory, Population, New York 2007.

Frank M., Świadomość siebie i poznanie siebie, Warszawa 2002.

Frazer J.G., Złota gałaź, Warszawa 1969.

Friedrich C.J., Europe: An Emergent Nation?, New York 1969. 
Friedman M., Capitalism and Freedom, Chicago 1982.

Friedman M., Tyrania status quo, Sosnowiec 1997.

Fries F., Spór o Europę, Warszawa 1998.

Fromm E., Ucieczka od wolności, Warszawa 1978.

Fromm E., Niech się stanie człowiek, Wrocław 1994.

Fromm E., Zdrowe społeczeństwo, Warszawa 1996.

Fromm E., Psychoanaliza a religia, Poznań 2000.

Fromm E., Kryzys psychoanalizy, Poznań 2000.

Fromm E., Mieć czy być?, Poznań 2003.

Fromm E., Rewolucja nadziei, Poznań 1996.

Fukuyama F., Koniec historii, Poznań 1996.

Fukuyama F., Budowanie państwa. Władza i ład międzynarodowy w XXI wieku, Poznań 2005.

Furet F., Przeszłość pewnego złudzenia. Esej o idei komunistycznej w XX wieku, Warszawa 1996.

Gabor D., Inventing the Future, New York 1964.

Gadamer H.G., Prawda i metoda, Warszawa 2004.

Galbraight J.K., The Age of Uncertainity, Boston 1977.

Galbraight J.K., The Anatomy of Power, Boston 1983.

Gamson J., Freaks Talk Back, Chicago 1998.

Geertz C., Interpretacja kultur, Kraków 2005.

Gibb H.A.R., Mahometanizm, Warszawa 1965.

Giddens A., Trzecia droga. Odnowa socjaldemokracji, Warszawa 1999.

Giddens A., Nowoczesność i tożsamość, Warszawa 2002.

Giddens A., Stanowienie społeczeństwa, Poznań 2003.

Ginsberg B., Lowi T.J., Weir M., We the People, New York 1997.

Gladwell M., The Tipping Paint, Boston 2002.

Glasbeek H., Wealth by Stealth. Corporate Crime, Corporate Law and the Perversion of Democracy, Toronto 2002.

Glenny M., McMafia, New York 2008.

Goldfarb J.C., The Cynical Society. The Culture of Politics and the Politics of Culture in American Life, Chicago 1991.

Goodman D.S., Segal G., China Deconstructed, London 1994.

Goodrick-Clarke N., Okultystyczne źródta nazizmu, Warszawa 2001.

Goodwyn L., The Populist Moment. A Short History of the Agrarian Revolt in America, Oxford 1978.

Gould J., Skaty wieków, Poznań 2002.

Graber D.A., Mass Media and American Politics, Washington 2006.

Graber D.A., Media Power in Politics, Washington 2007.

Grabowska M., Szawiel T., Budowanie demokracji, Warszawa 2003.

Gray J., Po liberalizmie, Warszawa 2001.

Gray J., Czarna msza. Apokaliptyczna religia i śmierć utopii, Kraków 2009.

Gray M., Sity życia, Warszawa 1988.

Greefe Ch., Greffrath M., Schumann M., Czego chca krytycy globalizacji. ATTAC, Kraków 2004.

Greider W., The Betrayal of American Democracy. Who will tell the People?, New York 1998.

Gross F., Federacje i konfederacje europejskie, Warszawa 1994.

Guitton J., Sens czasu ludzkiego, Warszawa 1999. 
Habermas J., Legitimated Crisis, [w:] Comparative Politics, eds B.E. Brown, R.C. Macridis, Belmont 1996.

Habermas J., Democratic Theory, [w:] Democracy and Difference, ed. S. Benhabib, Princeton 1996.

Habermas J., Filozoficzny dyskurs nowoczesności, Kraków 2000.

Hadden J.K., Swann Ch.E., Prime Time Preachers. The Rising Power of Teleevangelicism, Reading 1991.

Hagstrom J., Beyond Reagan. The New Landscape of American Politics, New York 1988.

Hall E.T., Poza kultura, Warszawa 1984.

Hall K., Jamieson K., Campbell K., The Interplay of Influence, Belmont 2001.

Halpern P., Na tropach przeznaczenia, Warszawa 2004.

Handy Ch., Wiek paradoksu. W poszukiwaniu sensu przyszłości, Warszawa 1996.

Handy Ch., Głód ducha. Poza kapitalizmem, Wrocław 1998.

Handy Ch., Wiek przezwyciężonego rozumu, Warszawa 1998.

Hannerz U., Powiazania międzynarodowe. Kultura, ludzie, miejsca, Kraków 2006.

Hannerz U., Odkrywanie miasta, Warszawa 2008.

Hardt M., Negri A., Imperium, Warszawa 2005.

Hardt M., Negri A., Multitude. War and Bureaucracy in the Age of Empire, New York 2004.

Harman E.S.,Chesnay R.W., The Global Media. The New missionaries of Corporate Capitalism, London 1999.

Harris M., America Now. The Anthropology of Changing Culture, New York 1981.

Hartley J., Communication, Cultural and Media Studies, London 2004.

Hartmann T., Unequal Protection. The Rise of Corporate Dominance and the Theft of Human Rights, New York 2004.

Hassler R.A., Księga zagtady, Kraków 1999.

Hatch N.O., The Democratization of American Christianity, New Haven 1988.

Hayek F.A, Konstytucja wolności, Warszawa 2006.

Haynes J., Religion in Global Politics, London 1998.

Hawkins B., Ideology, Metaphor and Iconographic Reference, [w:] Language and Ideology, eds R. Dirren, R. Frank, Amsterdam 2001.

Hawrylyshyn B., Drogi do przyszłości, Warszawa 1990.

Heap N., Thomas R., Information, Technology and Society, London 1995.

Held D., The Prospects for Democracy, London 1994.

Held D., Global Government, Cambridge 2007.

Herder J.G., Myśli o filozofii dziejów, Warszawa 1962.

Herring P., The Politics of Democracy. American Parties in Action, New York 1968.

Hertz N., The Silent Takeover. Global Capitalism and the Death of Democracy, New York 2003.

Hesse H., Moja wiara, Warszawa 1993.

Hiley D.R., Doubt and the Demand of Democratic Citizenship, Cambridge 2006.

Himmelfarb G., Jeden naród, dwie kultury, Warszawa 2007.

Hirsz Z.I., Historia polityczna Polski, Białystok 1998, t. I-V.

Hofstede G., Kultury i organizacje. Zaprogramowanie umystu, Warszawa 2000.

Honderich T., Ile mamy wolności?, Poznań 2001.

Hook S., Marxism and Beyond, New Jersey 1983.

Hook S., The Quest of Being, New York 1991.

Horgan J., Psychologia terroryzmu, Warszawa 2008. 
Horkheimer M., Społeczne funkcje filozofii, Warszawa 1987.

Horkheimer M., Krytyka instrumentalnego rozumu, Warszawa 2007.

Hormon J., Baumeister A.T., Literature and the Political Imagination, [w:] Literature and the Political Imagination, ed J. Horton, London 1996.

Horney K., Wyklady ostatnie, Poznań 2000.

Horowitz D., The Morality of Spending. Attitudes toward the Consumer Society in America 1875-1940, Chicago 1992.

Hudson R., Wiliams .N.M., Re-shaping Europe, [w:] Rethinking European Welfare, eds J. Fink, G. Lewis, London 2001.

Huizinga J., Homo ludens. Zabawa jako źródto kultury, Warszawa 1998.

Huntington S.P., Trzecia fala demokratyzacji, Warszawa 1995.

Huxley A., Nowy, wspaniały świat, Kraków 1988.

Imos R., Wiara człowieka radzieckiego, Kraków 2006.

Jacob F., Gra możliwości, Warszawa 1987.

Jacobi J., Zamaskowanie. Obrazki z psychologii życia codziennego, Warszawa 1979.

Jacyno M., Kultura indywidualizmu, Warszawa 2007.

Jan Paweł II, Przekroczyć próg nadziei, Lublin 1994.

Jan Paweł II, Wiara i kultura, wybór M. Radwan, S. Wylężałek, T. Gorzkula, RzymLublin 1988.

Janicka J., Obraz transformacji polskiej i relacji polsko-niemieckich w prasie niemieckiej w latach 1980-1998, Toruń 2002.

Janion M., Niesamowita Stowiańszczyzna, Kraków 2007.

Jasiński B., Lukacs, Warszawa 1985.

Jean C., Geopolityka, Wrocław 2003.

Jedlicki J., Świat zwyrodniały. Lęki i wyroki krytyków nowoczesności, Warszawa 2000.

Jenkins H., Kultura konwergencji. Zderzenie starych $i$ nowych mediów, Warszawa 2007.

Johnson H., Sleepwalking through History. America in the Reagan Years, New York 2003.

Johnson-Cartree K.S., Copeland G.A., Manipulation of the American Voter, Westport 1997.

Jones H., Religia gnozy, Warszawa 1994.

Jung C.G., Wspomnienia, sny, myśli, Warszawa 1993.

Jungk R., Człowiek tysiaclecia, Warszawa 1981.

Kaider A., Spojrzenie na przemiany ustrojowe $w$ Polsce $w$ latach 1989-1997, [w:] Imponderabilia wielkiej zmiany, red. P. Sztompka, Kraków 1999.

Kane H., Starke L., Time for Change, Washington 1992.

Karwat M., Miernoty i figuranci, Torun 1999.

Kastoryano R., Transnational Nationalism, [w:] Identities, Affiliations and Allegiances, eds S. Benhabib, I. Shapiro, Cambridge 2007.

Kelly M., The Divine Right of Capital. Dethroning the Corporate Aristocracy, San Francisco 2003.

Kelman S., Why Public Ideas Matter, [w:] The Power of Public Ideas, ed. R.B. Reich, Harvard 1990.

Kerkove D. de, Powtoka kultury. Odkrywanie nowej elektronicznej rzeczywistości, Warszawa 1996.

Kępiński A., Lęk, Warszawa 1977.

Kilanowski M., Individual and Community, [w:] Deconstruction and Reconstruction, red. J. Ryder, K. Wilkanowska, Amsterdam 2004. 
Kim Ir Sen, Odpowiedzi na pytania dziennikarzy zagranicznych, Phenian 1975.

King A., Schneider B., Pierwsza rewolucja globalna. Jak przetrwać? Raport dla Klubu Rzymskiego, Warszawa 1982.

Kirk R., The Politics of Prudence, New York 1994

Klein N., No logo, Warszawa 2004.

Klein N., Doktryna szoku, Warszawa 2008.

Kobrin S.J., Multinational Corporations. The Protest Movement and the Future of Global Governance, [w:] Leviathans. Multinational Corporations and the New Global History, eds A.D. Chandler, B. Mazlish, Cambridge 2005.

Kochan M., Slogany w reklamie i polityce, Warszawa 2003.

Kolczyński M., Mazur M., Wojna na wrażenia, Warszawa 2007.

Kołakowski L., Główne nurty marksizmu, Poznań 2002.

Korten D., Świat po kapitalizmie, Łódź 2002.

Korten D., When Corporations Rule the World, San Francisco 2001.

Korten D., The Great Turning. From Empire to Earth Community, San Francisco 2006.

Kothari R., Footsteps into the Future, Stockholm 1978.

Kozielecki J., Transgresyjne koncepcje człowieka, Warszawa 1987.

Kozielecki J., O człowieku wielowymiarowym, Warszawa 1988.

Krapiec M.A., Dzieła, t. X, Lublin 1993.

Kreft P., Ekumeniczny dzihad. Ekumenizm i wojna kultur, Warszawa 2005.

Kristol I., Neokonserwatywne przekonania, [w:] Neokonserwatyzm, red. I. Steltzer, Warszawa 2007.

Krocker A. i M., Code Warriors, [w:] The Cyberculture Reader, ed. D. Bell, New York 2000.

Kroes R., The Commodification of America's Icons of Freedom, [w:] „Here, There and Everywhere". The Foreign Politics of American Popular Culture, eds R. Wagneleitner, E.T. May, London 2000.

Król E.C., Propaganda i indoktrynacja narodowego socjalizmu w Niemczech 19191945, Warszawa 1999.

Krugman R., The Age of Diminished Expectations, Cambridge 1995.

Kumor B., Historia Kościoła. Czasy wspótczesne, Lublin 2001.

La Feber W., The American Age, New York 1989

Landes D.S., Bogactwo i nędza narodów, Warszawa 2007.

Langer S., Nowy sens filozofii, Warszawa 1976.

Lapennies W., Niebezpieczne powinowactwa z wyboru, Warszawa 1996.

Lasch Ch., The Culture of Narcissism, New York 1991.

Lasch J., The Relevance of Philosophy to Life, Nashville 1995.

Le Bon G., Psychologia ttumu, Warszawa 1983.

Leary M., Wywieranie wrażenia na innych. O sztuce autoprezentacji, Gdańsk 2003.

Lenin W.I., Rewolucja proletariacka a renegat Kautsky, Dzieła, t. 28.

Lenski G., Lenski J., Nolan P., Human Societies. An Introduction to Macrosociology, New York 1991.

Leuw G. van der, Fenomenologia religii, Warszawa 1997.

Levin N.G., Woodrow Wilson and World Politics, London 1970.

Levine B., The Migration of Ideology and the Contested Meaning of Freedom, Washington 1992.

Levinson H., Psychologia przywództwa, Gliwice 2007.

Levitt S., Quality is just a Beginning, New York 1994.

Lewandowski E., Pejzaż etnicznej Europy, Warszawa 2005. 
Lewis P.G., Democracy and it's Future in Eastern Europe, [w:] Prospects for Democracy, ed. D. Held, London 1994.

Lippman W., Public Opinion, New York 1996.

Lipschutz R.D., Global Civil Society and the Privatization of Transnational Regulation, [w:] The Emergence of Private Authority in Global Governance, eds R.B. Hall, T.J. Bierstacker, Cambridge 2007.

Lipset S.M., Homo politicus. Społeczne podstawy polityki, Warszawa 1998.

Lipset S.M., Schneider W., The Confidence Gap. Business. Labour and Government in the Public Mind, Balrtimore 1987.

Lister R., Bieda, Warszawa 2007.

Liszka J., Ojczyzna, naród, państwo, region w procesie integrracji europejskiej, [w:] Społeczeństwo wobec problemów transformacji i integracji, red. J. Liszka, Ustroń 2001.

Lobkowitz N., Czas kryzysu, czas przełomu, Kraków 1996.

Lorentz K., Regres człowieczeństwa, Warszawa 1986.

Lott E., Love and Theft, Oxford 1995.

Luhmann N., Funkcje religii, Warszawa 1998.

Luttwak E., Turbokapitalizm, Wrocław 2000.

Lynch K., What Time is this Place?, Cambridge 1990.

Łomny, Człowiek i edukacja wobec przemian globalnych, Opole 1995.

Łukasiewicz J., Eksplozja ignorancji, Warszawa 2000.

Mandelbaum M., The Case of Goliath, New York 2005.

Mannheim K., Ideologia i utopia, Lublin 1992.

Manovich L., Język nowych mediów, Warszawa 2006.

Manteufel T., Narodziny herezji, Warszawa 1964.

Marcel G., Homo viator, Warszawa 1959.

Marchand R., Advertising the American Dream, Berkeley 1985.

Marczewska-Rytko M., Demokracja bezpośrednia, Lublin 2001.

Marquard O., Apologia przypadkowości, Warszawa 1994.

Marquard O., Rozstanie z filozofia pierwszych zasad, Warszawa 1994.

Marquard O., Szczęście w nieszczęściu, Warszawa 2001.

Marszałek A., Ekonomiczne uwarunkowania suwerenności w integrujacej się Europie, [w:] Suwerenność i państwa narodowe w integrujacej się Europie - Przeżytek czy przyszłość, red. G. Fiszer, Cz. Mojsiewicz, Poznań 1995.

Martin P., Schumann H., Pułapka globalizacji. Atak na demokrację $i$ dobrobyt, Wrocław 2000.

May R., Btaganie o mit, Poznań 1997.

May R., Mitość i wola, Poznań 1998.

Major F., Memory of the Future, Paris 1995.

Mazur J., Od kerygmatu do ewangelii życia, Radom 2003.

McDougall W.A., Promised Land. The American Encounter with the World since 1776. Crusader State, Boston 1997.

McGinnis A.L., Potega optymizmu, Warszawa 1993.

McGregor Burns J., Roosevelt. The Lion and the Fox, San Diego 1984.

McLuhan M., Wybór tekstów, Poznań 2001.

Mc Manus J., Market - Driven Journalism. Let the Citizen Beware?, Thousand Oaks 1994.

McPherson C.B., The Real World of Democracy, Oxford 1996.

Mc Rae H., Świat w roku 2020, Warszawa 1996. 
Meckelburg G., Agenci PSI. Manipulacje naszq świadomościa, Gdynia 1997.

Melsen A.G. van, Filozofia przyrody, Warszawa 1968.

Melsen A.G van., Nauka i technologia a kultura, Warszawa 1969.

Merlau-Ponty M., Proza świata, Warszawa 1976.

Mettrie de la J.O., Człowiek-maszyna, Warszawa 1984, s. 39

Michna E., Etyczny wymiar tożsamości etnicznej, [w:] Etyczny wymiar tożsamości kulturowej. Studia o antropologii społecznej, red. M. Flis, Kraków 2004.

Micklethwait J., Wooldridge A., Czas przeszły doskonaty, Poznań 2003.

Mikołowski-Pomorski J., Jak narody porozumiewaja się ze soba w komunikacji międzykulturowej i komunikowaniu medialnym, Kraków 2007.

Miller D.C. American Iconology, New Haven 1993.

Miłosz Cz., Zniewolony umyst, Kraków 1989.

Minois G., Diabet, Warszawa 2001.

Misses K. von, Planowany chaos, Lublin 2005.

Morin E., O naturze Zwiazku Radzieckiego, Warszawa 1990.

Morone J.M., The Democratic Wish. Popular Participation and the Limits if American Government, New York 1990.

Morris D., Ludzkie zoo, Warszawa 2005.

Morris D., Naga matpa, Warszawa 2005.

Motycka A., Rozum i intuicja w nauce, Warszawa 2005.

Mowlana H., Global Information and World Communication, New York 1986.

Muhammadi A., International Communication and Globalization, London 1997.

Muszyński J., Polskie Państwo Partyjne, Warszawa 2002.

Nage T., Gangi Ameryki. Współczesne korporacje w demokracji, Warszawa 2004.

Naisbitt J., Megatrendy, Poznań 1997.

Nasza wspólna przyszłość, Raport Światowej Komisji do Spraw Środowiska i Rozwoju, Warszawa 1991.

Nelson M., The Presidency and the Political System, Washington 1995.

Norberg J., Spór o globalizację. Kto zyskuje a kto traci i dlaczego, Warszawa 2006.

Novotny P., No Future, [w:] Political Science-Fiction, eds. M. Hassler, C. Wilcox, Columbia University 1977.

Nussbaum M.C., Love's Knowledge. Essays on Philosophy and Literature, Oxford 1990.

Oatley K., Jenkins J.M., Zrozumieć emocje, Warszawa 2003.

Offe C., Zmieniajaca się Europa, Warszawa 1999.

Olson T., Millenarism, Utopianism and Progress, London 1992.

Ortega y Gasset J., Bunt mas, Warszawa 2002.

Ortega y Gasset J., Szkice o miłości, Warszawa 1989.

Pangle T.L., Uszlachetnianie demokracji, Kraków 1994.

Pannenberg W., Człowiek, wolność, Bóg, Kraków 1995.

Pańków I., Filozofia utopii, Warszawa 1990.

Pareto V., Uczucia i działania. Fragmenty socjologiczne, Warszawa 1994.

Partners in Prosperity, the Report of the Twentieth Century Fund Task on the International Coordination of National Economic Policies, New York 1991.

Pascal B., Myśli, Warszawa 1983.

Patterson O., Kultura na poważnie, [w:] Kultura ma znaczenie, red. L.E. Harrison, S.P. Huntington, Poznań 2003.

Patterson T.E., The American Democracy, New York 1993.

Peccei A., Przyszłość jest w naszych rękach, Warszawa 1987.

Peck A., Teleewangelizm, apokalipsa i polityka, Tyczyn 2005. 
Pennock J.R., Democratic Political Theory, Princeton University 1979.

Pervin L.A., Psychologia osobowości, Gdańsk 2002.

Philips A., Przestrzeń publiczna, życie prywatne, [w:] Aktorzy życia publicznego. Pteć jako czynnik rozróżniajacy, red. R. Siemieńska, Warszawa 2003.

Philips P., Meda Democracy in Action. Censored 2004, New York 2003.

Pichaske D., Poland in Transition 1989-1991, Southwest State University 1994

Picht G., Odwaga utopii, Warszawa 1981.

Piederse J., Globalization as Hybrydyzation, [w:] Global Modernities, ed. M. Featherstone, London 1995.

Pieper J., Nadzieja a historia, Warszawa 1981.

Pipes R., Wtasność a wolność, Warszawa 2000.

Pirsig R.M., Lila czyli rozprawa o moralności, Poznań 1995.

Plano J.C., Greenberg M., The American Political Dictionary, New York 1993.

Pollack Sadker M., Sadker D.M., Teachers, Schools and Society, New York 1991.

Popper K., W poszukiwaniu lepszego świata, Warszawa 1997.

Popper K., Wiedza obiektywna. Ewolucyjna teoria epistemologiczna, Warszawa 2002.

Posner R.A., The Economic of Justice, Harvard University 1983.

Possenti V., Religia $i$ życie publiczne. Chrześcijaństwo $w$ dobie ponowożytnej, Warszawa 2005.

Postman N., Technopol. Triumf kultury nad technika, Warszawa 1995.

Postman N., W strone XVIII wieku, Warszawa 1999.

Postman N., Zabawić się na śmierć, Warszawa 2003.

Pratkanis A., Aronson E., Wiek propagandy, Warszawa 2003.

Preece J.J., Prawa mniejszości, Warszawa 2007.

Prognozy. Trzydziestu myślicieli o przyszłości, red. G. Griffith, Poznań 2006.

Proudhon P., Wybór pism, Warszawa 1974.

Purcell C., The Machine in America. A Social History of Technology, Baltimore 1995. 460

Ramphal S., Our Country. The Planet, Washington 1992.

Rand A., Powrót człowieka pierwotnego, Poznań 2003.

Raport o stanie wiary. $Z$ księdzem kardynałem J. Ratzingerem rozmawia V. Messori, Kraków 1986.

Ratzinger J.M., Sól ziemi, Kraków 1997.

Rawls J., Teoria sprawiedliwości, Warszawa 1994.

Reeves B., Media i ludzie, Warszawa 2000.

Reich R.B., Praca narodów. Przygotowanie się do kapitalizmu XXI wieku, Torun 1996.

Renaut A., Era jednostki. Przyczynek do historii podmiotowości, Wrocław 2001.

Ricoeur P., Krytyka i przekonanie, Warszawa 2003.

Ricoeur P., O sobie samym jako innym, Warszawa 2005.

Ridley M., O pochodzeniu cnoty, Poznań 2000.

Riffkin J., The Age of Access, New York 2000.

Ritzer G., Makdonaldyzacja społeczeństwa, Warszawa 2002.

Ritzer G., Magiczny świat konsumpcji, Warszawa 2004.

Ritzer G., M.Kammeyer K.C., Experiencing a Changing Society, Boston 1982.

Robins R.S., Post J., Paranoja polityczna. Psychopatologia nienawiści, Warszawa 1999. Robins K., Cyberspace and the World we Live in, [w:] Cyber Space. Cyber Bodies. Cyber Punk, eds M. Featherstone, R. Burrows, London 1995.

Rogers M.F., Barbie jako ikona kultury, Warszawa 2003.

Rorty R., Contingency, Irony and Solidarity, Cambridge 1989. 
Rorty R., Filozofia a zwierciadto natury, Warszawa 1994.

Rothenbuhler E.W., Komunikacja rytualna, Kraków 2003.

Rothkopf D., Superclass. The Global Power Elite and the World they are Making, New York 2008.

Rougemont D. de, List otwarty do Europejczyków, Warszawa 1995.

Rozmowy o końcu czasów, Wrocław 2000.

Russel B., Paer Aspera ad Astra, [w:] Science and Future of Mankind, New York 1964

Russel Hochschild A., The Managed Heart, Commercialization of Human Feelings, Berkeley 1983.

Ryn C.G., Democracy and the Ethical Life. A Philosophy of Politics and Community, London 1979.

Rytel J., Tezy o świadomości narodowej Polaków, [w:] Patriotyzm, nacjonalizm. Stereotypy narodowe w edukacji historycznej, red K. Zaufal, H. Wesołowska, Kraków 1995.

Safronow J., Wnuki naszych wnukow, Moskwa 1949.

Sageman M., Sieci terroru, Kraków 2008.

Salomon S., Gra o zaufanie, Warszawa 2000.

Sand P.H., Lessons Learned in Global Environmental Governance, New York 1990.

Sartori G, Teoria demokracji, Warszawa 1994.

Sartori G., Rethinking Democracy. Bad Polity and Bad Politics, [w:] Comparative Politics, eds B.E. Brown, R. Macridis, Belmont 1996.

Schaeffer R., Filozofia religii, Częstochowa 1989.

Scheler M., Resentyment a moralność, Warszawa 1977.

Schell J., The Time of Illusion, New York 1976.

Schelling C., Choice and Consequence. Perspective of an Errant Economist, Cambridge 1984.

Schierup C.U., Hansen P., Castles S., Migration,Citizenship and the European Welfare State, Oxford 2006.

Schiffer I., Charisma. A Psychoanalytic Look at Mass Society, New York 1973.

Schlesinger A.M., jr., The Politics of Upheaval, Boston 1988.

Schmidt A.J., Under the Influence. How Christianity Transformed Civilization, Grand Rapids 2001.

Schnedelbach H., Próba rehabilitacji animal rationale, Warszawa 2001.

Schnedelbach H., Rozum i historia, Warszawa 2001.

Schneider H., Laboratorium Ziemia, Warszawa 1998.

Schumacher G., A Bloody Business, St. Paul 2006.

Schumpeter J.A., Kapitalizm. Socjalizm. Demokracja, Warszawa 1995.

Scruton R., Intelektualiści nowej lewicy, Poznań 1999.

Scruton R., Zachód i cała reszta, Poznań 2003.

Sen A., Rozwój i wolność, Poznań 2002.

Sepkowski A., Człowiek a przyszłość, Torun 2005.

Sepkowski A., Poczatki misji. Narodziny amerykańskiej „religii obywatelskiej”, Toruń 2008.

Sepkowski A., Millenialne marzenia, „Przegląd Humanistyczny” 2008, nr 3.

Sesboue B., Wierze, Warszawa 2000.

Shahen I.G., Reel Bad Arabs, New York 2001.

Shively W.P., Power and Choice, New York 1991.

Sikorski W., Przyszłe wojny, Warszawa 1984.

Simon K., Cywilizacja wczesnego chrześcijaństwa, Warszawa 1979. 
Singer P., Jeden świat. Etyka globalizacji, Warszawa 2006.

Skarga B., Kłopoty intelektu, Warszawa 1975.

Skeggs B., Class, Self, Culture, London 2004.

Slaughter A.M., A New World Order, Princeton 2005.

Smith A.D., Nacjonalizm, Warszawa 2007.

Smith H.N., Virgin Land, Harvard 1995.

Smith J.E., The Spirit of American Philosophy, New York 1983.

Sobel R., The Age of Giant Corporations, London 1993.

Sommer M., Zbieranie. Próba filozoficznego ujęcia, Warszawa 2003.

Sorel J., Złudzenia postępu, Kraków 1912.

Sorensen G., Democracy and Democratization, Oxford 1993.

Soros G., Nowy, okropny świat. Era omylności, Warszawa 2006.

Sowell T., Is Reality Optional and the other Essays, Stanford University 1993.

Spaeman R., Osoby. O różnicy między kimś a kimś, Warszawa 2001.

Spengler O., Zmierzch Zachodu. Zarys morfologii historii uniwersalnej, Warszawa 2001.

Staniszkis J., Wtadza globalizacji, Warszawa 2003.

Staples Lewis C., Listy o modlitwie i moralności, Warszawa 1980.

Stearns P.N., Ksiadz Lamennais, Warszawa 1970.

Steffens L., Letters, New York 1939.

Stevenson N., Understanding Media Culture, London 1995.

Stevenson N., Cultural Citizenship, Berkshire 2003.

Stiglitz J., Globalizacja, Warszawa 2005.

Stiglitz J., Charlton A., Fair trade. Szansa dla wszystkich, Warszawa 2007.

Stirner M., Jedyny i jego własność, Warszawa 1995.

Stoassinger J.G., The Might of Nations. World Politics in our Time, New York 1986.

Storey J., Studia kulturowe I badania kultury popularnej. Teorie i metody, Kraków 2003.

Strange S., The Future of American Empire, [w:] The United States in the World Political Economy, ed. T. Rueter, New York 1994,

Strauss W., Howie N., Generations. The History of America's Future, New York 1991.

Strinati D., Wprowadzenie do kultyru popularnej, Poznań 1998.

Stróżewski W., W kręgu wartości, Kraków 1992.

Strugaccy A. i B., Przenicowany świat, Warszawa 1971.

Suchoński A., Opinie o Polsce i Polakach w podręcznikach do nauczania historii, [w:] Kultura polityczna w Polsce. Swoi i obcy, Poznań 2005, t. IV.

Szachnazarow G., Socjalisticzieskaja sudba cziełowieka, Moskwa 1978.

Szacki J., Dylematy historiografii $i$ inne studia $i$ szkice, Warszawa 1991.

Szahaj A., Niesprawiedliwość a demoralizacja, [w:] Demokracja spektaklu, red. P. Żuk, Warszawa 2004.

Szczepański J., Społeczne konteksty polityki, [w:] Homo politicus, red. S. Filipowicz, Warszawa 1993.

Szczęsna E., Poetyka reklamy, Warszawa 2001.

Szczurowski J., Surdykowski J., Nasza Ameryka, Toruń 2002.

Szestow L., Ateny i Jerozolima, Kraków 1993.

Szmyd J., Religijność $i$ transcendencja, Kraków 2000.

Sztompka P., Zaufani: warunek podmiotowości, [w:] Oblicza społeczeństwa, red. K. Gorlach, Z. Saręga, Kraków 1996.

Świętochowska U., Stosunek Polaków do integracji z Uniq Europejska, „Cywilizacja w czasie i przestrzeni” 2002, t. 8. 
Świętochowski A., Utopie w rozwoju historycznym, Warszawa 1910.

Takaki R., Strangers from a Different Shore, New York 1989.

Takaki R., A Different Mirror. A History of Multicultural America, Boston 1993.

Taleb N.N., The Black Swan, The Impact of the Highly Improbable, New York 2007.

Tannen D., Cywilizacja kłótni, Poznań 2003.

Tatarkiewicz W., Droga do filozofii i inne rozprawy filozoficzne, Warszawa 1971, t. I.

Taylor P.J., The Way the Modern World Works, New York 1996.

Teilhard de Chardin P., Pisma wybrane, Warszawa 1967.

Therborn G., Drogi do nowoczesnej Europy, Warszawa 1998.

Thompson J.B., Media i nowoczesność. Społeczna teoria mediów, Wrocław 2001.

Thomson O., Historia propagandy, Warszawa 2001.

Thoreau H.D., Obywatelskie niepostuszeństwo, Poznań 2006.

Thurow L., Przyszłość kapitalizmu. Jak dzisiejsze siły ekonomiczne ksztattuja świat jutra, Wrocław 1999.

Timoszyk-Tomczyk C., Konstruowanie własnej przyszłości w kontekście zmian we wspótczesnym świecie, [w:] Psychologia wspótczesna. Oczekiwania i rzeczywistość, red. M. Ledzińska, S. Rudkowska, L. Wrona, Kraków 2005.

Tender G., Myślenie polityczne, Warszawa 2003.

Tischner J., Etyka solidarności i Homo sovieticus, Kraków 1992.

Tocqueville A. de, Dawny ustrój i rewolucja, Warszawa 2005.

Todd E., Schytek imperium. Rozważania o rozkładzie systemu amerykańskiego, Warszawa 2003.

Toffler A., Szok przyszłości, Warszawa 1974.

Toffler H. i A., Budowa nowej cywilizacji. Polityka trzeciej fali, Poznań 1996.

Toffler H. i A., Revolutionary Wealth. How it will be Created and how it will Change our Lives, New York 2006.

Tonkin P.K., Puritans and Pragmatists, New York 1976.

Trutkowski C., Społeczna reprezentacja polityki, Warszawa 2000.

Tugenhand E., Bycie. Prawda. Rozprawy filozoficzne, Warszawa 1999.

Turner B.S., Mc Citizens, [w:] Resisting Mc Donaldization, ed. B. Smart, London 1999.

Turner J.H. Stets J.E., Socjologia emocji, Warszawa 2009.

Turner V., Gry społeczne, pola i metafory, Kraków 2005.

Vattimo, Koniec nowoczesności, Kraków 2006.

Venter A.J., War Dog. Fighting other People's Wars, New York 2006.

Vile M.J., Politics in USA, New York 2007.

Viraq I., The all Consuming Lifestyle, [w:] Rush to Burn. America's Garbage Crisis, Washington 1989.

Virillo P., Bomba informacyjna, Warszawa 2006.

Voegelin E., Nowa nauka polityki, Warszawa 1992.

Waldenberg M., Narody zależne i mniejszości narodowe w Europie Środkowo-Wschodniej, Warszawa 2000.

Waldenfels B., Topografia obcego, Warszawa 2002

Wallerstein I., Koniec świata, jaki znamy, Warszawa 2004.

Wallerstein I., Analiza systemów-światów, Warszawa 2007.

Wallerstein I., Utopistic, New York 1999.

Walzer M., Polityka i namiętności. O bardziej egalitarny liberalizm, Warszawa 2006.

Wasilewski J., Moralność elit politycznych, [w:] Kondycja moralna społeczeństwa polskiego, red. J. Mariański, Kraków 2002.

Weber D., Rhetoric and History in Revolutionary New England, Oxford 1988. 
Weber M., Gospodarka i społeczeństwo. Zarys socjologii rozumiejacej, Warszawa 2002. Weizsacker C.F. von, Jedność przyrody, Warszawa 1978.

Wells H.G., Jutro ludzkości, Łódź 1946.

Welsch, Sztuczne raje, [w:] Nowe media w komunikacji społecznej w XX wieku, Warszawa 2002.

Wickler W., Biologia dziesięciu przykazań, Poznań 2001.

Wiener N., God \& Golem Inc., Cambridge 2007.

Wilber K., Krótka historia wszystkiego, Warszawa 1997.

Wilber K., Integralna teoria wszystkiego, Poznań 2006.

Wiliams B., Lenin, Wrocław 2002.

Wills G., Inventing America. Jeffersonian's Declaration of Independence, New York 1979 .

Wilson E.O., Przyszłość życia, Poznań 2003.

Winthrop J., A Model of Christian Charity, [w:] American Religious History, ed. E. Potterfield, Oxford 2002.

Winn D., Manipulowanie umystem, Warszawa 2003.

Witkowski T., Psycho-manipulacja, Taszów 2006.

Wittfogel K.A., Wtadza totalna, Torun 2002.

Wnuk-Lipiński E., Świat międzyepoki, Kraków 2005.

Wojtyła K., U podstaw odnowy, Kraków 1972.

Wolfowitz P., The New Defense Strategy, [w:] Rethinking America's Security

Woll P. Zimmerman S.E., American Government, New York 1987.

Wood E.M., What is „Postmodern” Agenda, [w:] In Defense of History. Marxism and Postmodern Agenda, eds E.M. Wood, J.B. Foster, New York 1997.

Wosińska W., Oblicza globalizacji, Sopot 2008.

Young C.M., Portrait of an Age, London 2002.

Zadencki J., Wobec despotyzmu wolności, Kraków 1995.

Zdybel L., Idee spisku $i$ teorie spiskowe $w$ świetle analiz krytycznych $i$ badań historycznych, Lublin 2002.

Zeldin T., Intymna historia ludzkości, Warszawa 1998.

Znaniecki F., Ludzie teraźniejsi i cywilizacja przyszłości, Warszawa 1974.

Zonis M., Scheler D., The East European Opportunity, New York 1992.

Żelazny W., Etniczność. Ead - konflikt - sprawiedliwość, Poznań 2006.

Życiński J., Europejska wspólnota ducha, Warszawa 1998. 